Centrum Studiów Antymonopolowych i Regulacyjnych

Agata Jurkowska-Gomułka

\title{
Publiczne i prywatne egzekwowanie zakazów praktyk ograniczających konkurencję
}

Warszawa 2013

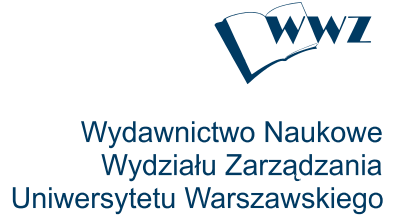

Podręczniki i Monografie 


\section{Publiczne i prywatne egzekwowanie zakazów praktyk ograniczających konkurencję}




\title{
$\overline{\mathrm{CAR}} \mathrm{S}$
}

\section{Centrum Studiów Antymonopolowych i Regulacyjnych Wydziału Zarządzania Uniwersytetu Warszawskiego}

\section{Trzydziesta druga publikacja Programu Wydawniczego CARS}

Seria: Podręczniki i Monografie (12)

\author{
Redaktor serii: dr hab. Tadeusz Skoczny, prof. UW
}

\section{Centrum Studiów Antymonopolowych i Regulacyjnych (CARS) www.cars.wZ.uw.edu.pl}

Centrum Studiów Antymonopolowych i Regulacyjnych (CARS) zostało utworzone uchwałą Rady Wydziału Zarządzania Uniwersytetu Warszawskiego z dnia 21 lutego 2007 r. jako ,inna wymieniona w regulaminie wydziału jednostka, niezbędna do realizacji zadań wydziału" w rozumieniu § 20 Statutu Uniwersytetu Warszawskiego z dnia 21 czerwca 2006 r.

CARS prowadzi między- i interdyscyplinarne badania naukowe oraz prace rozwojowe i wdrożeniowe w zakresie ochrony konkurencji i regulacji sektorowych w gospodarce rynkowej, ale także przygotowuje wydawnictwa zwarte i periodyczne, organizuje lub współorganizuje konferencje, seminaria, warsztaty i szkolenia, a w przyszłości będzie także patronować studiom podyplomowym.

W skład CARS wchodzą Członkowie Zwyczajni (pracownicy naukowi Wydziału Zarządzania UW), Członkowie Stowarzyszeni (pracownicy naukowi innych wydziałów UW, w tym głównie Wydziału Prawa i Administracji i Wydziału Nauk Ekonomicznych, a także innych krajowych i zagranicznych uczelni i jednostek badawczych) oraz Stali Wspólpracownicy (w tym osoby zatrudnione w polskich i zagranicznych firmach i instytucjach publicznych i prywatnych). 


\section{Publiczne i prywatne egzekwowanie zakazów praktyk ograniczających konkurencje: w poszukiwaniu zrównoważonego modelu wspótistnienia}

"Neither public or private enforcement should 'monopolize' competition law, but must work together to deter, detect, punish, and compensate victims of unlawful anticompetitive conduct. Only then is a consumer friendly competitive economy possible"

Spencer Weber Waller,

Towards a Constructive Public-Private Partnership to Enforce Competition Law, World Competition 2006, vol. 29(3)

Warszawa 2013

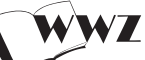

Wydawnictwo Naukowe

Wydziału Zarządzania Uniwersytetu Warszawskiego 
Recenzenci:

Prof. INP PAN dr hab. Dawid Miąsik

Zakład Prawa Konkurencji, Instytut Nauk Prawnych PAN

Prof. UW dr hab. Tadeusz Skoczny

Samodzielny Zakład Europejskiego Prawa Gospodarczego Wydziału Zarządzania Uniwersytetu Warszawskiego

Korekta i redakcja: Anna Miler

Projekt okładki: Dariusz Kondefer

(C) Copyright by Wydawnictwo Naukowe Wydziału Zarządzania Uniwersytetu Warszawskiego and Agata Jurkowska-Gomułka

ISBN: 978-83-63962-23-4

978-83-63962-24-1 (e-book)

DOI: $10.7172 / 3013.6$

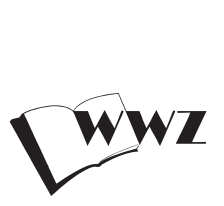

Wydawnictwo Naukowe Wydziału Zarządzania

Uniwersytetu Warszawskiego

02-678 Warszawa, ul. Szturmowa 1/3

Tel. $(+48-22)$ 55-34-164

E-mail: jjagodzinski@mail.wz.uw.edu.pl

www.wz.uw.edu.pl

SKLAD I LAMANIE:

Dom Wydawniczy ELIPSA,

00-189 Warszawa, ul. Inflancka 15/198

Tel./faks (+48-22) 635-03-01; (+48-22) 635-17-85

E-mail: elipsa@elipsa.pl; www.elipsa.pl

DYSTRYBUCJA

Księgarnia Ekonomiczna

02-094 Warszawa, ul. Grójecka 67

Tel. (+48-22) 822-90-42; faks (+48-22) 823-64-67

E-mail: info@ksiegarnia-ekonomiczna.com.pl 


\section{Spis treści}

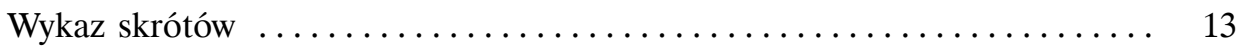

Wstęp......................................... 17

Rozdział I. Zrównoważony model egzekwowania prawa ochrony konkurencji:

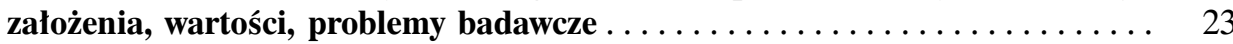

1.1. Rozstrzygnięcia terminologiczne ................... 23

1.2. Elementy modelu egzekwowania prawa ochrony konkurencji ...... 27

1.3. Dychotomia systemu prawa jako kontekst dla rozróżnienia modelu publicznego i prywatnego egzekwowania prawa ochrony konkurencji... 30

1.4. Współistnienie publicznego i prywatnego trybu egzekwowania prawa ochrony konkurencji jako problem badawczy .............. 35

1.4.1. Zasady kształtowania relacji między trybami: subsydiarność, komplementarność, dekomplementarność ............

1.4.2. Obszary wzajemnego oddziaływania publicznego i prywatnego trybu egzekwowania prawa ochrony konkurencji: inicjacja, przebieg, zakończenie postępowania..............

1.4.3. Wymiar aksjologiczny kompleksowego modelu egzekwowania prawa ochrony konkurencji: efektywność, spójność, równość...

1.5. W poszukiwaniu nie tylko zintegrowanego, ale także zrównoważonego modelu egzekwowania reguł konkurencji...............

Rozdział II. Publicznoprawny tryb egzekwowania zakazów praktyk

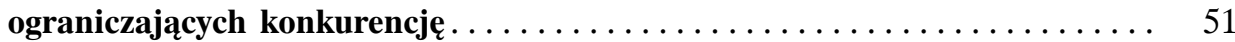

2.1. Uwagi wstępne .......................... 51

2.2. Administracyjnoprawny tryb egzekwowania prawa ochrony

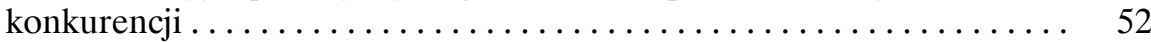

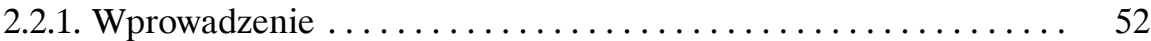

2.2.2. Otoczenie prawne administracyjnego trybu egzekwowania zakazów praktyk ograniczających konkurencję......... 54 2.2.2.1. Regulacje Unii Europejskiej................ 54 2.2.2.2. Regulacje polskie ................... 59

2.2.3. Charakterystyka administracyjnoprawnego trybu egzekwowania prawa ochrony konkurencji .................. 61

2.2.4. Wymiar instytucjonalny administracyjnego egzekwowania prawa ochrony konkurencji ..................... 66 
2.3. Prawnokarny tryb egzekwowania zakazów praktyk ograniczających

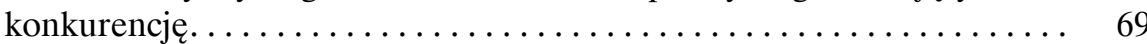

2.3.1. Przesłanki kryminalizacji prawa ochrony konkurencji ........ 69

2.3.2. Problem odpowiedzialności karnej podmiotów abstrakcyjnych (zbiorowych) ............................ 73

2.3.3. Definicja przestępstwa monopolizacji rynku (przestępstwa

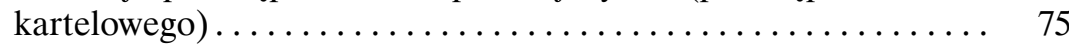

2.3.4. Prawnokarne aspekty administracyjnego trybu egzekwowania prawa ochrony konkurencji ................... 79

2.3.5. Stan zaawansowania kryminalizacji prawa ochrony konkurencji . 83

2.3.6. Aktualne możliwości kwestionowania praktyk antykonkurencyjnych w świetle polskiego prawa karnego w Polsce.................................. 88

2.3.6.1. Przestępstwo zmowy przetargowej............. 88

2.3.6.2. Przestępstwo nadużycia zaufania ............... 91

2.3.6.3. Odpowiedzialność karna podmiotów zbiorowych ...... 96

2.3.7. Współistnienie prawnokarnego trybu egzekwowania zakazów antykonkurencyjnych praktyk $\mathrm{z}$ innymi trybami ........... 99

2.3.7.1. Tryb prawnokarny a tryb administracyjnoprawny ...... 99

2.3.7.2. Tryb prawnokarny a tryb prywatnoprawny.......... 102

2.4. Uwagi końcowe ................................... 103

Rozdział III. Prywatnoprawny tryb egzekwowania zakazów praktyk ograniczających konkurencje............................... 105

3.1. Uwagi wstępne .................................. 105

3.2. Prywatne egzekwowanie wspólnych reguł konkurencji

Unii Europejskiej................................. 107

3.2.1. Źródła uprawnień jednostek do dochodzenia roszczeń z tytułu naruszenia art. 101 i 102 Traktatu o funkcjonowaniu Unii Europejskiej ..............................

3.2.2. Ramy proceduralne dla dochodzenia roszczeń wynikających z naruszenia wspólnych reguł konkurencji Unii Europejskiej ...

3.2.3. Prywatne egzekwowanie prawa ochrony konkurencji w unijnych inicjatywach legislacyjnych i orzecznictwie.............. 116

3.2.3.1. Akty prawne odnoszące się do sądowego dochodzenia roszczeń z tytułu naruszenia art. 101 i 102 TFUE..... 116

3.2.3.2. Orzecznictwo sądów Unii Europejskiej dotyczące prywatnego egzekwowania art. 101 i 102 TFUE....... 122

3.2.4. Podsumowanie ............................. 126

3.3. Prywatne egzekwowanie prawa ochrony konkurencji w Polsce........ 128

3.3.1. Możliwości wykorzystania obowiązujących regulacji jako podstawy roszczeń z tytułu naruszenia art. 6 i 9 uokik........ 128 3.3.1.1. Wprowadzenie .......................... 128 3.3.1.2. Kodeks cywilny ........................ 131 
3.3.1.3. Ustawa o zwalczaniu nieuczciwej konkurencji........ 132

3.3.1.4. Ustawa o przeciwdziałaniu nieuczciwym praktykom

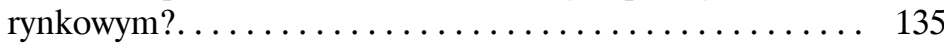

3.3.1.5. Uwagi końcowe. .................... 138

3.3.2. Proceduralne i instytucjonalne aspekty prywatnego

egzekwowania prawa ochrony konkurencji - zarys zagadnienia. .

3.3.2.1. Postępowanie przed sądem powszechnym (zwykłe postępowanie sądowe $) \ldots \ldots \ldots \ldots \ldots \ldots \ldots \ldots$

3.3.2.2. Postępowanie przed sądem polubownym (postępowanie arbitrażowe)

3.3.2.3. Sądy zaangażowane $\mathrm{w}$ prywatne egzekwowanie prawa ochrony konkurencji ..................... 144

3.4. Uwagi końcowe ........................... 146

Rozdział IV. Interes publiczny i prywatny w egzekwowaniu zakazów praktyk ograniczających konkurencje . . . . . . . . . . . . . . . . . . . 149

4.1. Uwagi wstępne ............................. 149

4.2. Interes publiczny realizowany przez prawo ochrony konkurencji. . . . . 151

4.3. Interes publiczny a interes prywatny w publicznym trybie egzekwowania zakazów praktyk ograniczających konkurencję ....... 156

4.4. Interes prywatny w egzekwowaniu zakazów antykonkurencyjnych

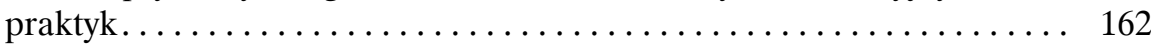

4.4.1. Zarzut naruszenia prawa ochrony konkurencji jako „tarcza” i „miecz" .............................. 162

4.4.2. Locus standi w sądowym dochodzeniu roszczeń z tytułu naruszenia zakazów praktyk ograniczających konkurencję ..... 164 4.4.2.1. Uwagi wstępne . . . . . . . . . . . . . . . . . . . 164 4.4.2.2. Kontrahenci (nabywcy i dostawcy) . . . . . . . . . . . 171 4.4.2.3. Konkurenci ......................... 180 4.4.2.4. Konkurenci i kontrahenci będący stronami zakazanych porozumień ograniczających konkurencję ......... 182

4.4.2.5. Konsumenci. . . . . . . . . . . . . . . . . . . . . . . . . . . . 185

4.4.2.6. Inne podmioty. . . . . . . . . . . . . . . 189

4.4.3. Pozwy zbiowe jako szczególna forma realizacji interesu prywatnego .............................. 193

4.4.3.1. Istota pozwów zbiorowych w kontekście prywatnego egzekwowania prawa konkurencji .............

4.4.3.2. Pozwy zbiorowe $\mathrm{w}$ inicjatywach legislacyjnych Unii Europejskiej ........................ 195

4.4.3.3. Możliwość zbiorowego dochodzenia roszczeń z tytułu naruszenia zakazów antykonkurencyjnych praktyk w Polsce............................. 
Rozdział V. Dostępność dowodów dla celów prywatnego egzekwowania zakazów praktyk ograniczających konkurencję ............... 213

5.1. Uwagi wstępne ........................... 213

5.2. Ważenie interesów: „za” i „przeciw” udostępnianiu dowodów pozyskanych w innym trybie egzekwowania zakazów praktyk ograniczających konkurencję .................... 216

5.3. Wzajemne wykorzystanie dowodów zgromadzonych w postępowaniu przed organem ochrony konkurencji oraz w postępowaniu sądowym. . 218 5.3.1. Udostępnianie dowodów zgromadzonych w postępowaniu antymonopolowym .............................. 218

5.3.2. Potencjalny status dowodów zgromadzonych w postępowaniu antymonopolowym w postępowaniu przed sądem powszechnym 224

5.3.3. Udostępnianie dowodów zgromadzonych w postępowaniu sądowym na rzecz postępowania antymonopolowego ........

5.3.4. Zakres przedmiotowy zastosowania mechanizmu ujawniania dowodów .............................. 228

5.3.4.1. Uwagi wstępne ..................... 228

5.3.4.2. Wyłączenie ujawniania dla dowodów stanowiących tajemnice przedsiębiorstwa . ...............

5.3.4.3. Wyłączenie ujawniania dla dowodów związanych z programem darowania i łagodzenia kar (leniency) ....

5.3.4.4. Problem ochrony poufności informacji zgromadzonych w postępowaniu ugodowym ...............

5.4. Możliwość dostępu do informacji i dowodów gromadzonych przez organy ochrony konkurencji na podstawie regulacji o dostępie do informacji publicznej ......................

5.4.1. Stosowanie unijnego rozporządzenia o przejrzystości

w celu uzyskania dostępu do dokumentów zgromadzonych

$\mathrm{w}$ postępowaniu antymonopolowym $\ldots \ldots \ldots \ldots \ldots \ldots$

5.4.1.1. Zasady realizacji prawa dostępu do dokumentów Komisji w świetle orzecznictwa .............. 247

5.4.1.2. Przesłanki odmowy dostępu do dokumentów Komisji w świetle orzecznictwa................. 250

5.4.1.3. Uwagi końcowe. .................... 254

5.4.2. Stosowanie ustawy o dostępie do informacji publicznej w celu uzyskania dostępu do informacji zgromadzonych w postępowaniu przed Prezesem UOKiK ............. 255

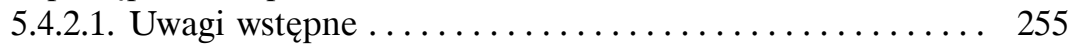

5.4.2.2. Zakres przedmiotowy ustawy o dostępie do informacji publicznej a akta postępowania antymonopolowego .... 256

5.4.2.3. Zakres podmiotowy ustawy o dostępie do informacji publicznej a podmioty legitymowane do wystąpienia z roszczeniami z tytułu naruszenia zakazów praktyk ograniczających konkurencję ............. 
5.4.2.4. Ustawowe przesłanki ograniczenia dostępu do informacji publicznej a ograniczenia dostępu do informacji zgromadzonych w postępowaniu antymonopolowym ..................... 264

5.4.2.5. Tryb udostępniania informacji publicznej przez Prezesa

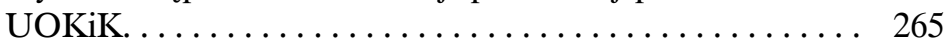

5.4.2.6. Uwagi końcowe. ................... 267

5.5. Ujawnianie dowodów między stronami ................. 269

5.6. Możliwość ujawniania dowodów w polskim postępowaniu cywilnym. . 273

5.6.1. Zarządzanie ujawnienia dowodu przez sąd ............ 273

5.6.2. Dopuszczanie dowodów z urzędu . . . . . . . . . . . . 277

5.7. Prawo do informacji w polskim prawie własności przemysłowej

i prawie autorskim - wzorzec dla prywatnego egzekwowania zakazów praktyk ograniczających konkurencję? ................ 282

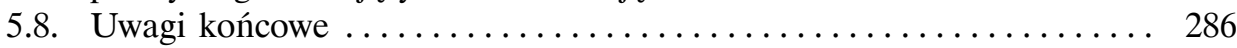

Rozdział VI. Wzajemne oddziaływanie rozstrzygnięć publicznego i prywatnego trybu egzekwowania zakazów praktyk ograniczających konkurencję........ 289

6.1. Uwagi wstępne . . ........................... 289

6.2. Dostępność drogi sądowej a rozstrzygnięcia w trybie publicznym . . . . 291

6.3. Istniejące decyzje organów ochrony konkurencji a rozstrzygnięcia sądowe . . . . . . . . . . . . . . . . . . . . . . . . . . . . . . . . . . . . 294

6.3.1. Reguła Masterfoods w prawie Unii Europejskiej ............ . 294

6.3.2. Związanie decyzją administracyjną w postępowaniu sądowym w Polsce..................................... 298

6.3.2.1. Uwagi wstępne . . . . . . . . . . . . . . . . . . . 298

6.3.2.2. Związanie sądu cywilnego decyzją Prezesa UOKiK. . . . 303

6.4. Brak decyzji administracyjnej w sprawie praktyki ograniczającej konkurencję a przebieg postępowania sądowego . . . . . . . . . . 310

6.5. Inne możliwości oddziaływania organów ochrony konkurencji na rozstrzygnięcia sądowe . ....................... 313

6.6. Związanie organów ochrony konkurencji wyrokiem sądu cywilnego... 317

6.7. Uwagi końcowe .......................... 319

Rozdział VII. Sankcje i środki ochrony prawnej w postępowaniu przed organami ochrony konkurencji i przed sądami cywilnymi . . . . . . . . .

7.1. Sankcje w publicznoprawnym trybie egzekwowania zakazów praktyk ograniczających konkurencję - uwagi wstępne ............. 323

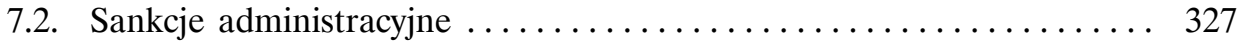

7.2.1. Nakaz zaniechania praktyki ograniczającej konkurencję. Środki

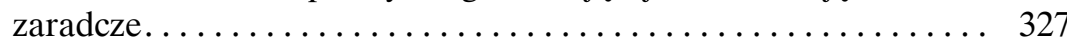

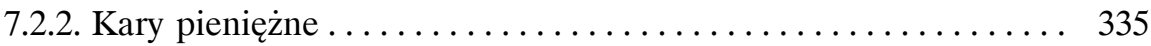

7.3. Antymonopolowe sankcje karne .................... 340

7.3.1. Uwagi wstępne ... . . . . . . . . . . . . . . . . . . . 340 
7.3.2. Rodzaje antymonopolowych sankcji karnych. . . . . . . . . . . . 342

7.3.2.1. Kary właściwe dla przestępstw antymonopolowych. . . . . 342

7.3.2.2. Środki karne właściwe dla przestępstw

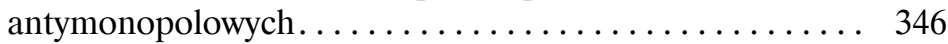

7.3.2.2.1. „Dyskwalifikacja zawodowa” ........... 346

7.3.2.2.2. Obowiązek naprawienia szkody przez sprawcę. . 348

7.4. Wzajemne oddziaływanie sankcji antymonopolowych nakładanych w trybie administracyjnoprawnego i karnoprawnego egzekwowania reguł ochrony konkurencji . . . . . . . . . . . . . . . . . . . 351

7.5. Sankcje w prywatnoprawnym trybie egzekwowania zakazów praktyk ograniczających konkurencję - uwagi wstępne .............. 354

7.6. Nieważność czynności prawnych naruszających zakazy praktyk

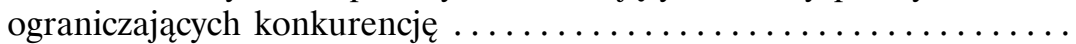

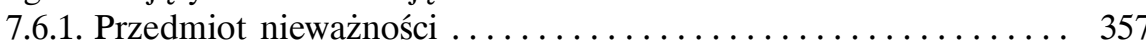

7.6.2. Charakter nieważności ....................... 360

7.6.3. Zakres nieważności ......................... 366

7.6.4. Roszczenia o ustalenie istnienia lub nieistnienia stosunku

prawnego.

7.7. Roszczenie odszkodowawcze $\mathrm{z}$ tytułu naruszenia zakazów praktyk ograniczających konkurencję ...................

7.7.1. Uwagi wstępne ......................

7.7.2. Odpowiedzialności kontraktowa uczestników porozumienia....

7.7.3. Odpowiedzialność deliktowa z tytułu naruszenia zakazów praktyk ograniczających konkurencję ................. 372

7.7.3.1. Wina jako przesłanka odpowiedzialności z tytułu czynów niedozwolonych w kontekście naruszeń zakazów antykonkurencyjnych praktyk .............

7.7.3.2. Związek przyczynowy jako przesłanka odpowiedzialności z tytułu czynów niedozwolonych w kontekście naruszeń zakazów antykonkurencyjnych praktyk ......... 375

7.7.3.3. Szkoda antymonopolowa................. 376

7.7.3.3.1. Pojęcie szkody antymonopolowej ......... 376

7.7.3.3.2. Zakres szkody antymonopolowej. ......... 379

7.7.3.3.3. Uwagi ogólne o sposobach naprawienia

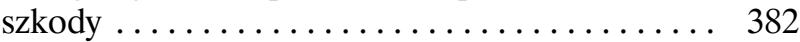

7.7.3.3.4. Ustalanie wysokości szkody antymonopolowej . . 384

7.7.3.3.5. Okoliczności modyfikujące wysokość odszkodowania ................... 390

7.7.3.3.6. Rodzaje odszkodowań............... 394

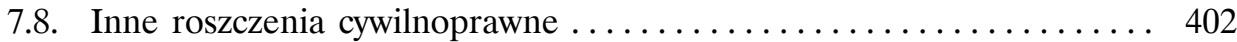

7.8.1. Uwagi wstępne .......................... 402

7.8.2. Roszczenie o zaniechanie . . . . . . . . . . . . . . . . . . . . 404

7.8.3. Roszczenie o przywrócenie stanu poprzedniego. Roszczenie o usunięcie skutków naruszenia................ 
7.8.4. Roszczenie z tytułu bezpodstawnego wzbogacenia.......... 410

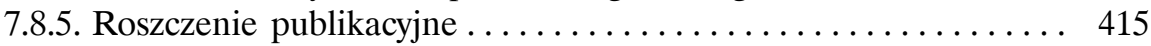

7.8.6. Roszczenie o zasądzenie odpowiedniej kwoty na cel społeczny związany ze wspieraniem kultury polskiej lub ochroną dziedzictwa narodowego .................... 418

7.9. Wzajemna „zaliczalność” sankcji nałożonych w ramach publicznego i prywatnego trybu egzekwowania zakazów praktyk ograniczających konkurencję............................... 419

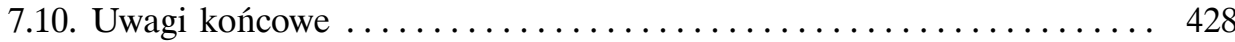

Rozdział VIII. W kierunku zrównoważonego publiczno-prywatnego modelu egzekwowania zakazów praktyk ograniczających konkurencję w Polsce . . . 431

8.1. Aktualny model egzekwowania zakazów antykonkurencyjnych praktyk w Polsce. .

8.2. Potrzeba regulacji prywatnego egzekwowania zakazów antykonkurencyjnych praktyk?

8.3. Najważniejsze rozwiązania legislacyjne zmierzające do budowy zrównoważonego modelu egzekwowania zakazów antykonkurencyjnych praktyk (postulaty de lege ferenda) . . . . . . . . . . . . . . . . . 434

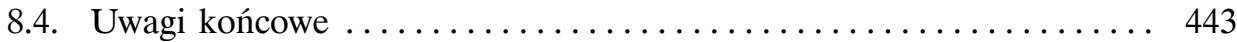

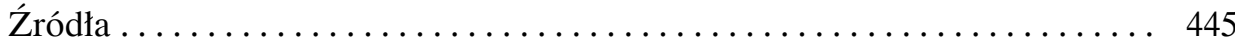

Literatura ............................ 445

Akty prawne i dokumenty towarzyszące (w tym akty niewiążace

i projekty aktów prawnych) ................... 470

Orzecznictwo................................ 475 



\section{Wykaz skrótów}

\section{Wykaz skrótów}

CAT - Competition Appeal Tribunal

CMLR - Common Market Law Review

DoJ - Department of Justice

E.C.L.R. - European Competition Law Review

ECN - Europejska Sieć Konkurencji (European Competition Network)

EKES - Europejski Komitet Ekonomiczno-Społeczny

EKPC - Europejska Konwencja Praw Człowieka

EPS - Europejski Przegląd Sądowy

ERPL - European Review of Private Law

ETPC - Europejski Trybunał Praw Człowieka

G.C.L.R. - Global Competition Litigation Review

iKAR - internetowy Kwartalnik Antymonopolowy i Regulacyjny

kc $\quad-$ Kodeks cywilny

ke $\quad-$ Komisja Europejska

kk $\quad-$ Kodeks karny

k.p.a. $\quad-$ Kodeks postępowania administracyjnego

kpc $\quad-$ Kodeks postępowania cywilnego

KPP - Karta praw podstawowych

KPP - Kwartalnik Prawa Prywatnego

KPPubl. - Kwartalnik Prawa Publicznego

ksh $\quad-$ Kodeks spółek handlowych

NCA - National Competition Authority

MoP - Monitor Prawniczy

NSA - Naczelny Sąd Administracyjny

OECD - Europejska Organizacja Współpracy i Rozwoju (European Organization of Cooperation and Development) 


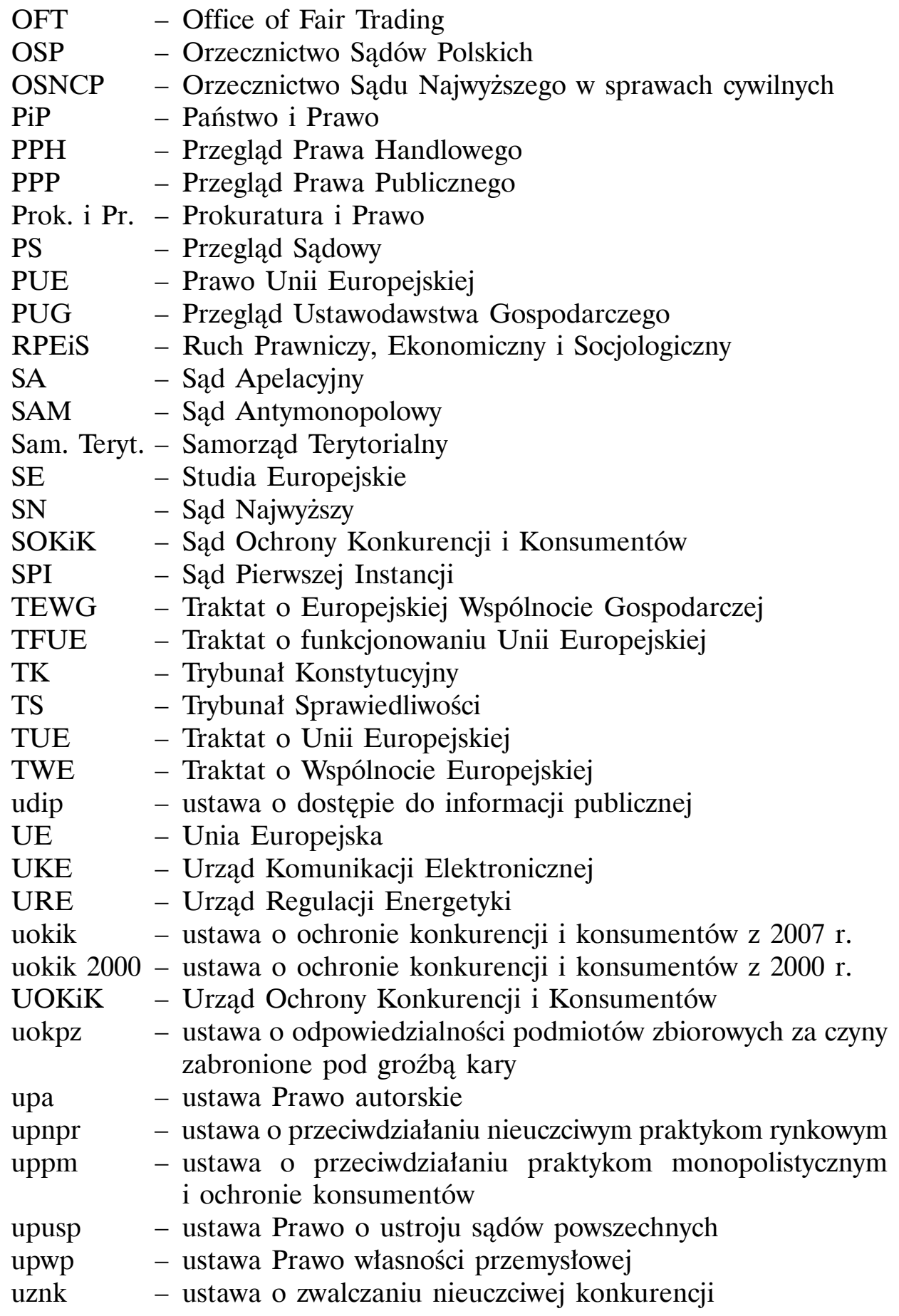


WE - Wspólnota Europejska

WSA - Wojewódzki Sąd Administracyjny

YARS - Yearbook of Antitrust and Regulatory Studies 



\section{Wstęp}

Książka „Publiczne i prywatne egzekwowanie zakazów praktyk ograniczających konkurencję: w poszukiwaniu zrównoważonego modelu współistnienia" stanowi podsumowanie moich długoletnich badań nad zagadnieniem sądowego dochodzenia roszczeń z tytułu naruszenia reguł konkurencji. Badania te prowadzone były przede wszystkim z perspektywy prawnika wywodzącego się $\mathrm{z}$ domeny prawa publicznego (publicznego prawa ochrony konkurencji). Naturalnie zatem podążyły one ku wzajemnym relacjom publicznego i prywatnego egzekwowania reguł konkurencji, zaś za główny cel obrane zostało określenie ramowych założeń takiego modelu egzekwowania reguł konkurencji, na który będzie składał się zarówno (publiczny) tryb postępowania przed organem ochrony konkurencji, jak i (prywatny) tryb dochodzenia roszczeń przed sądami powszechnymi. Taki dwufilarowy model określony został jako kompleksowy lub zintegrowany. Badania koncentrowały się jednak nie tyle na samym fakcie współistnienia dwóch trybów egzekwowania reguł konkurencji, ile na ich współoddziaływaniu. U podstaw rozważań zawartych w prezentowanej książce leży założenie, że współczesny zintegrowany model egzekwowania reguł konkurencji powinien być modelem zrównoważonym. Tym samym absolutnie porzuciłam początkową tezę badań ukierunkowaną na przeciwstawienie (a nie korelację) publicznego i prywatnego egzekwowania reguł konkurencji, wyrażaną niekiedy w piśmiennictwie formułą versus (public versus private enforcement).

Wychodząc od określenia „modelu zrównoważonego” zarówno w sensie przedmiotowym (elementy modelu), jak i aksjologicznym (wartości tworzące postulowaną „równowagę”), analizuję wybrane aspekty publicznego i prywatnego egzekwowania reguł konkurencji w celu zdefiniowania ich pożądanych wzajemnych relacji. W odniesieniu do wybranych (w moim przekonaniu - najistotniejszych) elementów modelu egzekwowania prawa 
ochrony konkurencji formułuję również postulaty de lege ferenda, ukierunkowane na budowanie modelu zrównoważonego.

Książka nie stanowi wyczerpującego omówienia regulacji prawnych dla obydwu trybów egzekwowania reguł ochrony konkurencji; nie jest jej celem prezentowanie ani korzyści istnienia zintegrowanego modelu egzekwowania reguł konkurencji, ani też barier dla prywatnego egzekwowania reguł konkurencji. Przepisy stanowiące podstawę publicznego egzekwowania reguł konkurencji są przedmiotem kilku komentarzy do ustawy o ochronie konkurencji i konsumentów; regulacje możliwe do wykorzystania w związku z sądowym dochodzeniem roszczeń zostały omówione bądź to w publikowanych przez różne międzynarodowe instytucje i wydawców zbiorach raportów krajowych poświęconych prywatnemu egzekwowaniu reguł konkurencji, bądź to - bardziej skrótowo - w artykułach podejmujących problematykę dochodzenia roszczeń z tytułu naruszenia reguł konkurencji na drodze sądowej przez podmioty prywatne.

Problematyka korelacji publicznego i prywatnego egzekwowania reguł konkurencji nie była jak dotąd przedmiotem znaczącego zainteresowania polskiej doktryny - wybrane kwestie z tego zakresu analizowane były co najwyżej na marginesie ogólnych rozważań nad prywatnym egzekwowaniem reguł konkurencji. Polskie piśmiennictwo odnoszące się do sądowego dochodzenia roszczeń z tytułu naruszenia reguł konkurencji nie jest jednak bardzo bogate - do najobszerniejszych opracowań, podejmujących również tematykę związków między publicznym i prywatnym egzekwowaniem prawa ochrony konkurencji, należą przede wszystkim rozprawy (książki) autorstwa P. Podreckiego i M. Sieradzkiej; ponadto problematyka ta - aczkolwiek wyłącznie w odniesieniu do unijnego prawa konkurencji - była przedmiotem rozważań w rozprawach M. Szpunara i M. Adamczak-Reteckiej. Prywatne egzekwowanie reguł konkurencji stanowiło również przedmiot badań i publikacji M. Bernatta, M. K. Kolasińskiego, K. Kowalik-Bańczyk, O. Kopiczko, M. Kozak, R. Molskiego, A. Piszcz, R. Stefanickiego, przy czym $\mathrm{w}$ przypadku niektórych $\mathrm{z}$ wymienionych autorów mieliśmy do czynienia z pojedynczymi artykułami. Problematyka prywatnego egzekwowania reguł konkurencji pojawiła się również wpadkowo we wszystkich dostępnych na rynku komentarzach do ustawy o ochronie konkurencji i konsumentów.

Piśmiennictwo zagraniczne, zwłaszcza amerykańskie, obfituje w prezentacje badań poświęconych współfunkcjonowaniu publicznego i prywatnego trybu egzekwowania reguł konkurencji - są to badania prowadzone zarówno przez prawników, jak i ekonomistów. W literaturze europejskiej problematyka relacji między obydwoma submodelami egzekwowania prawa ochrony konkurencji podejmowana była przez wielu autorów, jednak naj- 
większe znaczenie dla rozwoju doktryny wydają się mieć prace W. P. Wilsa, A. P. Komninosa i C.A. Jonesa.

Rozważania prowadzone są w ośmiu rozdziałach. Pierwszy z nich precyzuje przyjętą optykę badawczą (w tym kwestie terminologiczne) i wyjściowe tezy (rozdział I: Zrównoważony model egzekwowania prawa ochrony konkurencji: założenia, wartości, problemy badawcze). Kolejne dwa rozdziały poświęcone są prezentacji generalnych założeń publicznego i prywatnego trybu egzekwowania reguł konkurencji w wymiarze krajowym i unijnym (rozdział II: Publicznoprawny tryb egzekwowania zakazów praktyk ograniczających konkurencję; rozdział III: Prywatnoprawny tryb egzekwowania zakazów praktyk ograniczających konkurencję). Następne rozdziały koncentrują się na wybranych aspektach korelacji publicznego i prywatnego trybu egzekwowania reguł konkurencji w fazie inicjowania postępowania (rozdział IV: Interes publiczny i prywatny w egzekwowaniu zakazów praktyk ograniczających konkurencję), jego przebiegu (rozdział V: Dostępność dowodów dla celów prywatnego egzekwowania zakazów praktyk ograniczających konkurencję; rozdział VI: Wzajemne oddziaływanie rozstrzygnięć publicznego i prywatnego trybu egzekwowania zakazów praktyk ograniczających konkurencję) i zakończenia (rozdział VII: Sankcje i środki ochrony prawnej w postępowaniu przed organami ochrony konkurencji i przed sądami cywilnymi). Rozważania podsumowane są prezentacją postulatów de lege ferenda odnoszących się do współfunkcjonowania publicznego i prywatnego trybu egzekwowania reguł konkurencji (rozdział VIII: W kierunku zrównoważonego publiczno-prywatnego modelu egzekwowania zakazów praktyk ograniczających konkurencję w Polsce).

Sformułowanie postulatów i wytycznych służących stworzeniu zrównoważonego modelu egzekwowania reguł konkurencji jest możliwe tylko po przeprowadzeniu analiz różnych aspektów obydwu trybów egzekwowania reguł konkurencji i wzajemnych zależności między nimi. W tym celu analizie poddane zostaną trzy elementy modelu wdrażania prawa, tj. podmioty, procedury oraz sankcje. Analiza nie będzie natomiast obejmowała wymiaru przedmiotowego modelu egzekwowania prawa tj. materialnoprawnych reguł konkurencji ${ }^{1}$.

Na potrzeby prowadzonych rozważań za przedmiot wdrażania przyjęty został zakaz praktyk ograniczających konkurencję zarówno wielostronnych

1 Analizom materialnych aspektów zakazów praktyk ograniczających konkurencję poświęciłam wiele swoich publikacji, wśród których na szczególną uwagę zasługuje komentarz do art. 6 i komentarze do wybranych fragmentów art. 9 uokik, wchodzące w skład pracy zbiorowej: T. Skoczny, A. Jurkowska, D. Miąsik (red.), Ustawa o ochronie konkurencji i konsumentów. Komentarz, C. H. Beck, Warszawa 2009. 
(zakaz porozumień ograniczających konkurencję), jak i jednostronnych (zakaz nadużywania pozycji dominującej). Mimo że polski ustawodawca, tytułując dział II ustawy o ochronie konkurencji konsumentów wskazuje na jeden zakaz obejmujący dwa rodzaje praktyk ograniczających konkurencję, posługiwanie się pojęciem zakazu w liczbie mnogiej wydaje mi się bardziej precyzyjne i adekwatne $\mathrm{z}$ dwóch powodów: po pierwsze $\mathrm{w}$ ten sposób podkreśla się pewną odrębność obydwu rodzajów praktyk ograniczających konkurencję, po drugie zaś treść rozważań odnosi się zarówno do zakazu (zakazów) wyrażonych w prawie krajowym, jak i zakazów formułowanych w prawie Unii Europejskiej.

Istotą rozważań pozostaje egzekwowanie głównie krajowych reguły konkurencji (tzn. art. 6 i 9 ustawy o ochronie konkurencji i konsumentów), jednak charakter relacji między krajowym prawem konkurencji a wspólnymi regułami konkurencji Unii Europejskiej, a w szczególności obowiązek stosowania tych ostatnich przez krajowe organy ochrony konkurencji, wymaga uwzględnienia w tych analizach także art. 101 i 102 TFUE. Prywatne egzekwowanie prawa ochrony konkurencji przed sądami państw członkowskich Unii Europejskiej dotyczy zarówno krajowych, jak i unijnych reguł konkurencji.

Mimo że o prywatnym egzekwowaniu reguł ochrony konkurencji najczęściej mówi się w kontekście zakazów antykonkurencyjnych praktyk, to wiele uwag poczynionych w związku z publicznym i prywatnym egzekwowaniem tych zakazów może znaleźć zastosowanie w innych obszarach ochrony konkurencji (pomoc publiczna, kontrola koncentracji).

Należy równocześnie podkreślić, że proponowany zintegrowany i zrównoważony model egzekwowania reguł konkurencji, choć wypracowany w odniesieniu do konkretnego porządku prawnego, sam w sobie posiada charakter uniwersalny i może znaleźć zastosowanie także w innych - krajowych, ale i międzynarodowych - systemach prawnych.

W prowadzeniu analiz wykorzystana została zarówno metoda dogmatycznoprawna, jak i - w niewielkim zakresie - prawnoporównawcza. Warto zaznaczyć, że dorobek światowej doktryny w obszarze modelu egzekwowania prawa ochrony konkurencji (zwłaszcza prywatnego egzekwowania) jest bardzo znaczący, stąd rozważania prowadzone w książce opierają się na najbardziej ugruntowanych pozycjach literatury światowej (głównie zachodnioeuropejskiej i amerykańskiej) ${ }^{2}$. Polski dorobek doktrynalny w tej dzie-

2 O ogromnym zakresie piśmiennictwa może świadczyć fakt, że obok uznanych periodyków poświęconych generalnie prawu konkurencji (zarówno regułom materialnym, jak i proceduralnym) od 2008 publikowane jest czasopismo odnoszące się wyłącznie do zagadnień związanych z prywatnym egzekwowaniem reguł konkurencji (Global Competition Litigation Review), w 2013 r. pojawi się czasopismo koncentrujące się na wszelkich aspektach egzekwowania reguł konkurencji (Journal of Antitrust Enforcement). 
dzinie, choć niezbyt imponujący, został natomiast uwzględniony w możliwie największym (według najlepszej wiedzy autorki) stopniu. Analogicznie, kompleksowej analizie poddany został dorobek orzeczniczy sądów polskich oraz sądów Unii Europejskiej, w znacznie mniejszym zakresie uwzględnione zostało natomiast orzecznictwo amerykańskie, incydentalnie działalność orzecznicza sądów w innych państwach członkowskich Unii Europejskiej.

Prezentowana książka, poszerzając spektrum piśmiennictwa poświęconego egzekwowaniu (enforcement) prawa konkurencji, pozostaje - ze względu na ujęcie tematyki prywatnego i publicznego egzekwowania reguł konkurencji - pracą stosunkowo oryginalną. Mam nadzieję, że będzie ona stanowiła przyczynek do jakże potrzebnej dyskusji doktrynalnej nad kompleksowym modelem egzekwowania reguł konkurencji.

Książka uwzględnia stan prawny i stan badań na dzień 1 stycznia 2013 r., w tym datowany na 21 listopada 2012 r. projekt ustawy nowelizującej ustawę o ochronie konkurencji i konsumentów. 



\section{Zrównoważony model egzekwowania prawa ochrony konkurencji: założenia, wartości, problemy badawcze}

\subsection{Rozstrzygnięcia terminologiczne}

Rozważania nad korelacją publicznego i prywatnego trybu egzekwowania prawa ochrony konkurencji należy rozpocząć od kilku uwag definicyjnych (i zarazem porządkowych) odnoszących się do samego pojęcia „egzekwowania”. Źródłem pewnych trudności terminologicznych jest fakt, że zasadnicze kwestie doktrynalne dotyczące publicznego i prywatnego trybu egzekwowania prawa ochrony konkurencji (public and private enforcement of competition law) wypracowane zostały w piśmiennictwie anglojęzycznym i stanowią one naturalny punkt odniesienia także dla polskich badań. Punktem wyjścia rozważań terminologicznych pozostaje okoliczność posługiwania się autorów w polskim piśmiennictwie, w odniesieniu do problemu stanowiącego przedmiot niniejszej pracy, zarówno sformułowaniem publicznego bądź prywatnego „wdrażania”, jak i „stosowania” czy „egzekwowania” prawa ochrony konkurencji ${ }^{1}$. Przygotowanie monografii poświęconej współzależ-

1 Pojęcia „wdrażanie prawa konkurencji” używałam we wcześniejszych swoich publikacjach - por. np. A. Jurkowska, Prywatnoprawne wdrażanie wspólnotowego prawa konkurencji, Zeszyty CEN (Zeszyt 19), Centrum Europejskie Natolin, Warszawa 2005; tak również - M. Będkowski-Kozioł, Prywatne wdrażanie prawa antymonopolowego w RFN - uwagi na tle regulacji siódmej noweli kartelowej, PUG 2007, nr 12. Z kolei pojęcie „stosowanie prawa konkurencji” używane jest m.in. przez: M. Sieradzka, Dochodzenie roszczeń odszkodowawczych z tytutu naruszenia unijnego i krajowego prawa konkurencji (część I), PUG 2012, nr 1, s. 17, 18. Natomiast M. Szpunar konsekwentnie tłumaczy private enforcement of competition law jako „dochodzenie roszczeń prywatnoprawnych wynikających z naruszenia prawa konkurencji” - M. Szpunar, Odpowiedzialność podmiotu prywatnego $z$ tytułu naruszenia prawa wspólnotowego, Oficyna a Wolters Kluwer Business, Warsza- 
ności obydwu trybów egzekwowania prawa ochrony konkurencji stanowi znakomitą okazję do podjęcia refleksji terminologicznych i ewentualnej rewizji stosowanych dotychczas rozwiązań.

Lektura dostępnych polsko-angielskich słowników terminologii prawniczej dowodzi, że czasownik enforce (w kontekście np. to enforce antitrust law) tłumaczony jest na język polski jako „egzekwować”, „wprowadzać w życie”, „dochodzić (roszczeń)”2, pojęcie enforcement przekłada się natomiast w pierwszej kolejności jako „wykonywanie, egzekwowanie"3 lub tylko jako „egzekwowanie prawa”4, podczas gdy termin application (w kontekście application of law) wyjaśniany jest jako „zastosowanie (stosowanie) pra-

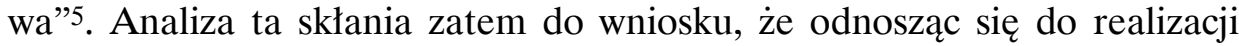
prawa ochrony konkurencji w drodze publiczno- lub prywatnoprawnej należy rozważyć przynajmniej trzy pojęcia: „stosowanie prawa”, „egzekwowanie prawa” oraz - tradycyjnie używane dotychczas - „wdrażanie prawa”. Warto zaznaczyć, że w niemieckiej literaturze prawniczej używa się pojęć Rechtsanwendung oraz Rechtsapplikation, to ostatnie R. Sarkowicz i J. Stelmach sprowadzają do polskiego pojęcia „stosowania prawa"6.

Słownik języka polskiego definiuje czasownik „egzekwować” (łac. exsequi) jako „wymagać wykonania, spełnienia czegoś; wykonywać, realizować” oraz jako „stosować środki przymusu w celu wykonania orzeczeń władz,

wa 2008, s. 293. Większość autorów posługuje się pojęciem prywatnego egzekwowania prawa ochrony konkurencji (reguł konkurencji) - por. m.in.: M. Adamczak-Retecka, Odpowiedzialność odszkodowawcza jednostki za naruszenie prawa wspólnotowego, IWEP, Warszawa 2010, s. 23; M. K. Kolasiński, Odpowiedzialność cywilna za szkody powstate $w$ wyniku naruszenia wspólnotowych zakazów stosowania praktyk ograniczających konkurencję i nadużywania pozycji dominującej, PPH 2007, nr 11, s. 16; R. Molski, Prywatnoprawna ochrona konkurencji $w$ amerykańskim prawie antytrustowym, KPP 2005, z. 3, s. 765 i d.; T. Skoczny, Stosowanie wspólnotowych regut konkurencji - także w Polsce - po 1 maja 2004 r., KPPubl. 2004, z. 2, s. 173.

2 Por. J. Gordon, Stownik terminologii prawniczej i gospodarczej (polsko-angielski, angielskopolski), Wyd. Potext, Warszawa 2008, s. 575.

3 Tak E. Ożga, The Great Dictionary of Law and Economics, Vol. I. English-Polsih, C. H. Beck, Warszawa 2006, s. 216. Por. także J. Pieńkoś, Polsko-angielski stownik prawniczy, Zakamycze, Kraków 2002, s. 71.

4 Tak E. Ożga, Stownik terminologii prawniczej. Część 2 angielsko-polska, Oficyna Wydawnicza Branta, Bydgoszcz 2002, s. 245-246. Tak również: P. H. Collin, K. Bartnicki, Stownik prawa (angielsko-polski, z indeksem polsko-angielskim), Wyd. Wilga, Warszawa 2001, s. 125; E. Myrczek, Dictionary of Law Terms. English-Polish. Polish-English, C. H. Beck, Warszawa 2005, s. 59.

5 E. Ożga, Stownik terminologii prawniczej..., s. 51-52. Por. także: Stownik prawniczy polskoangielski, Wyd. Polskiej Akademii Nauk, Ossolineum, Wrocław 1986, s. 111; J. Gordon, Stownik terminologii..., s. 464-465.

6 R. Sarkowicz, J. Stelmach, Teoria prawa, Wyd. UJ, Kraków 1998, s. 95. 
w szczególności sądowych”7. Z kolei czasownik „wdrażać” definiowany jest - w znaczeniu prawniczym - jako „zacząć oficjalne śledztwo, rozpocząć urzędowo postępowanie sądowe" 8 , natomiast w znaczeniu pozaprawniczym „wdrażać” oznacza „wprowadzać w życie” (w polskim systemie prawnym pojęcia wdrażania od wielu lat używa się głównie w kontekście recepcji prawa Unii Europejskiej do prawa krajowego - przede wszystkim mówi się o „wdrażaniu” dyrektyw, przy czym słowo „wdrażanie” stanowi w tym przypadku translację angielskiego terminu implement, a nie enforce).

Żadne z rozważanych pojęć („stosowanie”, „wdrażanie”, „egzekwowanie prawa") nie jest terminem prawnym. W polskim piśmiennictwie prawniczym (w tym przede wszystkim $\mathrm{w}$ obszarze teorii prawa) najczęściej spotykanym pojęciem jest „stosowanie prawa”. R. Sarkowicz i J. Stelmach postrzegają je jako element szerszego zjawiska określanego - za doktryną niemiecką - jako „urzeczywistnianie prawa” (niem. Rechtsverwirklichung). Autorzy ci, sceptycznie zresztą odnoszący się do tradycyjnych, zorientowanych pozytywistycznie definicji „stosowania prawa”, obejmują pojęciem „urzeczywistniania prawa” „nie tylko procesy stosowania prawa, lecz również procesy wykładni i uzasadniania prawa, a nawet do pewnego przynajmniej stopnia, procesy tworzenia prawa"9.

Szerokie ujęcie pojęcia „stosowania prawa” zaproponował także J. Wróblewski, który podkreślał, że nie ma ono sprecyzowanego znaczenia ani $\mathrm{w}$ języku prawnym, ani w językach prawniczych ${ }^{10}$. Autor ten wyróżniał wiele elementów składowych znaczenia pojęcia „stosowanie prawa”. Element podmiotowy wskazuje, że podmiotem stosowania prawa jest organ państwa, organy osób prawnych lub inne podmioty wykorzystujące swe uprawnienia. Element aktywności określanej jako stosowanie prawa odnosi się do wiążącego ustalania praw lub obowiązków osób albo stanu prawnego w decyzji stosowania prawa bądź do wykorzystania kompetencji do działań innych niż wydawanie decyzji stosowania prawa, czy wreszcie do wykonywania uprawnień i spełniania obowiązków nałożonych przez normy prawne. Stosowanie prawa określane jest też według J. Wróblewskiego poprzez skutek, którym może być ustalenie praw i obowiązków, określenie stanu prawnego, czy też np. realizacja kary. Wreszcie, stosowanie prawa może być „zrelatywizowane

7 S. Dubisz (red.), Uniwersalny stownik języka polskiego. Tom 1, Wyd. Naukowe PWN, Warszawa 2003, s. 792. Por. także M. Jarosz, Stownik wyrazów obcych, Wyd. Europa, Wrocław 2001, s. 179.

8 S. Dubisz (red.), Stownik języka polskiego. Tom V, Wyd. Naukowe PWN, Warszawa 2003, s. 48.

9 R. Sarkowicz, J. Stelmach, Teoria prawa, s. 96.

10 J. Wróblewski, Sadowe stosowanie prawa, Państwowe Wydawnictwa Naukowe, Warszawa 1972, s. 7. 
do systemu prawnego lub jego części” i wówczas jest ono zbieżne z tworzeniem prawa ${ }^{11}$. Najczęstsze jednak teoretyczne ujęcie pojęcia „stosowania prawa”, określane przez J. Wróblewskiego jako węższe jego znaczenie, sprowadza je do „działalności organów państwa, które podejmują decyzje na podstawie norm obowiązujących"12.

L. Morawski definiuje „stosowanie prawa” jako „władczą działalność organów państwa polegającą na wydawaniu decyzji indywidualno-konkretnych (akty stosowania prawa) na podstawie norm prawnych (akty tworzenia prawa)"13.

Z kolei A. Redelbach, S. Wronkowska i Z. Ziembiński podstawowe znaczenie terminu „stosowanie prawa” odnajdują w „korzystaniu z upoważnień, których określona norma prawna udziela jakiemuś podmiotowi”"14.

Wskazane definicje stosowania prawa wydają się koncentrować na aspekcie kompetencyjnym, odnosząc stosowanie prawa do działalności organów państwa, o czym świadczą wyróżniane w doktrynie typy stosowania prawa: sądowe lub administracyjne (A. Korybski, L. Leszczyński, A. Pieniążek ${ }^{15}$ ), poszerzone o quasi-sądowe i quasi-administracyjne stosowanie prawa (L. Morawski16) albo też stosowanie kierownicze lub sądowe (A. Redelbach, S. Wronkowska, Z. Ziembiński ${ }^{17}$ ).

Aby właściwie określić przedmiot niniejszej pracy, „odpowiednie dać rzeczy słowo", przydatne będzie odwołanie się w tym miejscu do poglądów L. Leszczyńskiego, który odróżnia pojęcie „stosowania prawa”, rozumianego jako „proces decyzyjny podejmowany przez kompetentny organ państwowy (lub inny podmiot upoważniony), prowadzący do wydania wiążącej decy-

11 J. Wróblewski, Sądowe stosowanie..., s. 7-9.

12 J. Wróblewski, Wstęp do prawoznawstwa (wyd. IV rozszerzone), Wyd. Uniwersytetu Łódzkiego, Łódź 1984, s. 122. Tak również: A. Korybski, L. Leszczyński, A. Pieniążek, Wstęp do prawoznawstwa, Morpol, Lublin 2000, s. 127; T. Stawecki, P. Winczorek, Wstęp do prawoznawstwa, C. H. Beck, Warszawa 1996, s. 133.

13 L. Morawski, Wstęp do prawoznawstwa, TNOiK, Toruń 2005, s. 149. Tak również A. Jamróz, Wprowadzenie do prawoznawstwa, Wyd. Prawnicze LexisNexis, Warszawa 2008, s. 168.

14 A. Redelbach, S. Wronkowska, Z. Ziembiński, Zarys teorii państwa i prawa, Wydawnictwo Naukowe PWN, Warszawa 1992, s. 250.

15 A. Korybski, L. Leszczyński, A. Pieniążek, Wstęp do prawoznawstwa, s. 129.

16 L. Morawski, Wstęp..., s. 150-151.

17 A. Redelbach, S. Wronkowska, Z. Ziembiński, Zarys teorii..., s. 253. Stosowanie prawa typu sądowego oznacza, że „treść aktu organu państwa jest wyznaczona przez treść przepisów prawa materialnego, ale organ państwa jest upoważniony do ustanowienia określonego rodzaju normy indywidualnej i konkretnej w odniesieniu do danej sprawy”. Z kolei stosowanie prawa typu kierowniczego występuje w tych przypadkach, „gdy organ uzyskuje kompetencję do wydania aktów o treści w ogólnym tylko zarysie wyznaczonej przez normy prawa materialnego". 
zji o charakterze jednostkowym (indywidualnym i konkretnym)”, od pojęć „realizowania prawa” oraz „wykonywania prawa”18. „Realizowanie prawa” polega na „zachowaniu się zgodnym z dyspozycją normy prawnej, realizującym zgodny z prawem cel działającego podmiotu”. Natomiast „wykonywanie prawa" obejmuje w szerokim sensie realizowanie, przestrzeganie oraz stosowanie prawa.

Biorąc pod uwagę fakt, iż przedmiotem niniejszej rozprawy jest model wspólistnienia dwóch z pozoru nie przystających do siebie trybów wdrażania/egzekwowania/stosowania (?) prawa ochrony konkurencji, przyjęcie dla określenia tego przedmiotu pojęcia „stosowania prawa” w tradycyjnym ujęciu wydaje się nazbyt wąskie. Nie uwzględnia ono dostatecznie pozaproceduralnych aspektów wspólistnienia obu trybów, takich jak: charakter i istota sankcji oraz ich wzajemne oddziaływanie. $\mathrm{Z}$ tego powodu bardziej adekwatne wydaje się skorzystanie z pojęcia „wykonywania” prawa konkurencji w ujęciu zbliżonym do zaproponowanego przez L. Leszczyńskiego. Jednak ze względu na to, że w języku prawniczym pojęcie „wykonywania prawa” występuje zazwyczaj w węższym sensie i oznacza wówczas „działania organów państwowych”, zbliżając się przez to do „stosowania prawa"19, dla omawianej problematyki przyjmę pojęcie „egzekwowania prawa”, stanowiące synonim dla „wykonywania prawa”, ale wolne od wskazanych obciążeń praktyki języka prawniczego. Nie bez znaczenia dla tego wyboru terminologicznego pozostaje również anglojęzyczny pierwowzór siatki pojęciowej (bliższy pojęciu „egzekwowania” niż „stosowania prawa”). Wybór pojęcia „egzekwowanie” podyktowany został także tym, że w piśmiennictwie z zakresu prawa ochrony konkurencji pojęciem „wdrażania” obejmuje się nie tylko aspekty proceduralne, ale także instytucjonalne (ustrojowe) stosowania reguł konkurencji ${ }^{20}$ - te ostatni pozostaną zaś w zasadzie poza zakresem mojego zainteresowania.

\subsection{Elementy modelu egzekwowania prawa ochrony konkurencji}

Teoretycy prawa zwykli konstruować różnorodne modele stosowania prawa; znane są choćby decyzyjne czy informacyjne modele jego stosowania. Odróżnienie pojęć „wdrażania”, „stosowania” i „egzekwowania” prawa, dokonane na potrzeby niniejszej publikacji, nie pozwala na proste

18 L. Leszczyński, Zagadnienia teorii stosowania prawa. Doktryna i tezy orzecznictwa, Zakamycze, Kraków 2004, s. 15-16.

19 Ibidem, s. 16.

20 Por. T. Skoczny, Instytucjonalne modele wdrażania regut konkurencji na świecie - wnioski dla Polski, RPEiS 2011, z. 2, s. 77-78. 
zaadaptowanie wybranego modelu stosowania prawa na potrzeby modelu egzekwowania prawa ochrony konkurencji. Niezbędne jest zatem nakreślenie takiego autonomicznego modelu. Jeśli model egzekwowania prawa ochrony konkurencji zostanie zbudowany w oparciu o kryteria przedmiotowe, wskazujące na elementy (instytucje) składowe, będzie on miał charakter modelu statycznego. Jeśli natomiast model ten zostanie oparty na kryteriach czasowych, wskazujących na poszczególne etapy (czynności) postępowania $\mathrm{w}$ trybie publicznym i prywatnym, będzie to model w ujęciu dynamicznym.

Przyjmując, że instytucja prawna może być definiowana jako „mechanizm będący wiązką reguł prawnych rządzących pewną instytucją-organem lub określoną sytuacją prawną" 21 , wśród elementów konstytuujących model egzekwowania prawa ochrony konkurencji w ujęciu statycznym należy wyróżnić zbiory norm prawnych odnoszące się do:

- przedmiotu podlegającego egzekwowaniu;

Przedmiot ten stanowią materialnoprawne reguły ochrony konkurencji, zawarte w aktach $\mathrm{z}$ zakresu prawa publicznego ${ }^{22}$. Prywatnoprawne egzekwowanie prawa ochrony konkurencji odnosi się w większości przypadków - i taki jest zakres analiz prowadzonych w niniejszej książce - do zakazów praktyk ograniczających konkurencję, tj. do zakazu porozumień ograniczających konkurencję (wyrażonego w art. 6 ustawy o ochronie konkurencji i konsumentów oraz w art. 101 TFUE) i zakazu nadużywania pozycji dominującej (wyrażonego w art. 9 ustawy oraz w art. 102 TFUE). Prywatne dochodzenie roszczeń wynikających z naruszenia prawa ochrony konkurencji może dotyczyć również norm w zakresie antykonkurencyjnej pomocy publicznej ${ }^{23}$ oraz prewencyjnej kontroli koncentracji.

21 Taką definicję instytucji prawnej akceptują B. Adamiak i J. Borkowski w: tychże, Postępowanie administracyjne i sq̨dowoadministracyjne, Warszawa 2008, s. 102. Autorzy powołują się tu na definicję sformułowaną w: R. Guilllien, J. Vincent, Lexiques de termes juridiques, Paryż 1972, s. 188.

22 W Polsce reguły te ustanowione są w Ustawie z dnia 16 lutego 2007 r. o ochronie konkurencji i konsumentów (Dz. U. 2007 Nr 50, poz. 331 ze zm.), na poziomie Unii Europejskiej - w Traktacie o funkcjonowaniu Unii Europejskiej (wersja skonsolidowana: Dz. Urz. 2012 C 326).

23 Por. Komunikat Komisji w sprawie egzekwowania prawa dotyczącego pomocy państwa przez sądy krajowe (Dz. Urz. UE 2009 C 85/01). Zob. także T. Jestaedt, J. Derenne, T. Ottervanger, Study on the enforcement of State aid law at national level, Publications Office, Luxembourg 2006 (Part I. Application of EC State Aid rules by national courts) oraz dokument zatytułowany 2009 update of the 2006 Study on the enforcement of State aid law at national level (dostępny pod adresem: http://ec.europa.eu/competition/state_aid/ studies_reports/enforcement_study_2009.pdf). 
- podmiotów egzekwujących normy materialne;

Swoje role w egzekwowaniu prawa ochrony konkurencji odgrywają następujące kategorie podmiotów: 1) organy publiczne (organy ochrony konkurencji i sądy), 2) podmioty pozostające w bezpośrednich lub pośrednich relacjach gospodarczych z podmiotami dopuszczającymi się naruszeń zakazów praktyk ograniczających konkurencję (są to konkurenci, kontrahenci i konsumenci), 3) inne podmioty wykazujące interes w dowodzeniu naruszeń prawa konkurencji (np. akcjonariusze podmiotów poszkodowanych wskutek antykonkurencyjnych praktyk).

- procedur egzekwowania norm materialnych przez uprawnione podmioty;

Element ten obejmuje procedurę administracyjną (przepisy postępowania administracyjnego) lub karną (przepisy postępowania karnego) w ramach publicznego egzekwowania prawa ochrony konkurencji oraz procedurę cywilną (przepisy postępowania cywilnego) - w ramach prywatnego egzekwowania prawa ochrony konkurencji. Ze względu na fakt, że postępowanie antymonopolowe nie jest „czystym” postępowaniem administracyjnym, procedura administracyjna może być uzupełniana przepisami z zakresu procedury cywilnej, a nawet karnej.

- sankcji za naruszenie egzekwowanych norm materialnych.

Publiczne egzekwowanie prawa ochrony konkurencji opiera się na wykorzystaniu sankcji administracyjnych lub/i karnych, zaś prywatne wdrażanie - sankcji cywilnoprawnych.

Pierwszy z wymienionych powyżej elementów (normy stanowiące przedmiot egzekwowania, tj. zakaz normatywny) jest wspólny dla obydwu submodeli egzekwowania prawa ochrony konkurencji - publicznego i prywatnego - natomiast pozostałe elementy (zbiory norm odnoszące się do podmiotów, procedur i sankcji) różnicują te modele.

Model egzekwowania prawa ochrony konkurencji w ujęciu dynamicznym wyznaczają elementy składowe definiujące czynności podejmowane $\mathrm{w}$ celu egzekwowania prawa przez podmioty prywatne lub organy publiczne. W takim ujęciu model składa się z następujących elementów:

- identyfikacja zachowań uruchamiających proces egzekwowania prawa ochrony konkurencji;

Chodzi tu o identyfikację naruszeń materialnoprawnych zakazów praktyk ograniczających konkurencję. Aktualność zachowują uwagi poczynione dla modelu w ujęciu statycznym, a dotyczące przedmiotu podlegającego egzekwowaniu.

- podjęcie czynności zmierzających do wykrycia i dowiedzenia naruszenia materialnych reguł konkurencji; 
Czynności te obejmują inicjowanie postępowania przed publicznym organem ochrony konkurencji (postępowania administracyjnego lub o zbliżonym, aczkolwiek „hybrydowym” charakterze, bądź postępowania karnego) bądź przed sądem cywilnym oraz czynności dowodowe, charakterystyczne dla postępowania administracyjnego (lub zbliżonego), karnego bądź sądowego.

- zastosowanie sankcji za naruszenie reguł materialnoprawnych.

Podobnie jak w przypadku modelu egzekwowania prawa ochrony konkurencji w ujęciu statycznym, również i w modelu w ujęciu dynamiczny pierwszy element jest identyczny dla trybu prywatnego i publicznego egzekwowania reguł konkurencji, zróżnicowanie następuje natomiast w zakresie drugiego i trzeciego elementu.

\subsection{Dychotomia systemu prawa jako kontekst dla rozróżnienia modelu publicznego i prywatnego egzekwowania prawa ochrony konkurencji}

Rozważania nad publicznym i prywatnym modelem egzekwowania prawa ochrony konkurencji naturalnie wiążą się z dychotomią systemu prawa tworzonego przez prawo publiczne i prawo prywatne, choć należy zaznaczyć, że niekiedy współcześnie coraz częściej wyróżnia się także „dodatkowo zbiorczą kategorię unormowań mieszanych, tzw. amfibijnych: prywatnoprawnych i publicznoprawnych" 24 . W pierwszej ze wskazanych sfer jednostka podlega zwierzchnictwu organów państwowych, w drugiej - przeciwnie, nie podlega ona poleceniom (zakazom, nakazom) władzy publicznej. H. Woolf stawia przed prawem publicznym zadanie właściwego wykonywania przez organy publiczne obowiązków wobec ogółu („ochronę państwa i utrzymywanie porządku"), natomiast przed prawem prywatnym - ochronę jednostek przed negatywnymi działaniami innych jednostek (w większości przypadków sprowadza się to do ochrony własności i rozstrzygania związanych z tym sporów) ${ }^{25}$. J. Łętowski wskazywał na cztery teorie stanowiące „podstawowe drogi oddzielania sfery publicznej od sfery prywatnej”: teorię fiskusa (,stosunki mające za przedmiot majątek należą lub co najmniej powinny należeć do prawa prywatnego”), teorię testu („tam, gdzie mamy do czynienia z interesem publicznym, dominuje prawo publiczne, tam gdzie sprawa dotyczy

24 Z. Duniewska, [w:] R. Hauser, Z. Niewiadomski, A. Wróbel (red.), System prawa administracyjnego. Instytucje prawa administracyjnego. Tom 1, C. H. Beck, Warszawa 2010, s. 152.

25 H. Woolf, Public Law - Private Law. Why the Divide? Personal View, Public Law 1986, s. 221. 
ochrony interesu prywatnego - prawo prywatne”), teorię podmiotową („,ze stosunkiem prawa publicznego mamy do czynienia wówczas, gdy jedną ze stron jest państwo lub organ państwa”), teorię podporządkowania („władcze uprawnienia administracji w sferze prawa publicznego, a równość stron w sferze prawa prywatnego") ${ }^{26}$.

W piśmiennictwie wyróżnia się wiele kryteriów podziału na prawo publiczne i prawo prywatne, m.in.: kryterium podmiotowe (prawo publiczne reguluje stosunki między organami państwami oraz między organami państwa i obywatelami), kryterium przedmiotowe zwane również kryterium interesu (prawo publiczne odnosi się do stosunków władczych, w których jeden podmiot jest podporządkowany drugiemu, natomiast prawo prywatne reguluje stosunki równorzędne), czy wreszcie - kryterium dochodzenia roszczeń, określane także jako kryterium ochrony prawa (roszczenia publicznoprawne są dochodzone $\mathrm{z}$ urzędu, roszczenia prywatnoprawne - na wniosek stron $)^{27}$. W zestawieniu tym można umieścić także kryterium proceduralne (wyłączności proceduralnej) - uprawnienia wynikające z prawa publicznego chronione są tylko poprzez sądową kontrolę aktów administracyjnych, natomiast uprawnienia wywodzące się z prawa prywatnego - poprzez sądowe dochodzenie prywatnych roszczeń28. W nowszych opracowaniach jako kryterium rozróżnienia ius publicum i ius privatum przyjmuje się często metodę regulacji rozumianą jako sposób kształtowania sytuacji prawnej i stosunków prawnych ${ }^{29}$. Uzasadnione wydaje się również wskazanie jako kryterium różnicujące prawo publiczne i prawo prywatne rodzaju sankcji nakładanych na podmioty dopuszczające się naruszenia prawa (w prawie publicznym - sankcje w postaci administracyjnych kar pieniężnych, administracyjnych nakazów/zakazów, a także sankcje typowe dla prawa karnego: grzywna, pozbawienie/ograniczenie wolności; w prawie prywatnym - sankcja nieważności, odszkodowania, realizacja innych świadczeń na rzecz podmiotów prywatnych).

26 J. Łętowski, $W$ sprawie granicy między prawem publicznym a prywatnym, [w:] B. Kordasiewicz, E. Łętowska (red.), Prace z prawa cywilnego wydane dla uczczenia pracy naukowej Profesora Józefa Stanistawa Piatowskiego, Ossolineum, Wrocław 1985, s. 354-355.

27 Por. A. Jamróz, Wprowadzenie do prawoznawstwa, s. 68-69; L. Morawski, Wstęp do prawoznawstwa, TNOiK, Toruń 2005, s. 92; G. L. Seidler, H. Groszyk, J. Malarczyk, A. Pieniążek, Wstęp do nauki o państwie i prawie, Morpol, Lublin 2000, s. 164-165.

28 G. Anthony, UK Public Law and European Law, Hart Publishing, Oxford and Portland, Oregon 2002, s. 36; J. Beatson, "Public" and "Private" in English Administrative Law, Law Quaterly Review 1987103 34, s. 35.

29 Z. Duniewska, [w:] R. Hauser, Z. Niewiadomski, A. Wróbel (red.), System prawa administracyjnego..., s. 159. 
Biorąc pod uwagę wyodrębnione powyżej (choć zapewne niewyczerpujące) kryteria, można podjąć próbę scharakteryzowania istoty publicznego (publicznoprawnego) i prywatnego (prywatnoprawnego) modelu egzekwowania reguł konkurencji (póki co jako modeli rozłącznych, autonomicznych) ${ }^{30}$. Publiczne egzekwowanie prawa ochrony konkurencji może być definiowane jako działanie instytucji (organu) administracji publicznej dla wykrycia naruszeń prawa materialnego (zorientowanego na realizację interesu publicznego polegającego na ochronie mechanizmu konkurencji na rynku) i nałożenia (publicznoprawnych) sankcji za nie ${ }^{31}$. Interwencja organu administracyjnego podejmowana jest władczo, na podstawie przepisów proceduralnych regulujących postępowanie organów administracji publicznej w sprawach indywidualnych ${ }^{32}$. Decyzje organów administracji publicznej, w których stwierdza się naruszenie prawa oraz nakłada sankcje za naruszenie prawa ochrony konkurencji, podlegają kontroli sądowej, jednak podkreślenia wymaga okoliczność, że w wielu porządkach prawnych (w tym w Polsce) kontrola sądowa decyzji organu ochrony konkurencji odbiega od „czystego" modelu kontroli wykonywanej przez sądy administracyjne (nie jest to kontrola ograniczona do legalności rozstrzygnięcia organu administracji). Europejski (unijny) i polski model egzekwowania reguł konkurencji uprawnia do utożsamiania publicznego trybu egzekwowania prawa ochrony konkurencji z działalnością organów administracji publicznej - w pewnym uproszczeniu publiczny model egzekwowania prawa ochrony konkurencji mógłby być określany jako model administracyjny (administracyjnoprawny), niemniej jednak należy pamiętać o tym, że model publiczny może być również modelem karnoprawnym. Kluczowe elementy modelu publicznego egzekwowania prawa ochrony konkurencji pozostają dla obydwu podtypów (administracyjnoprawnego i karnoprawnego) takie same.

Prywatne egzekwowanie prawa ochrony konkurencji również polega na dowiedzeniu naruszenia materialnoprawnych reguł konkurencji i nałożeniu sankcji (cywilnoprawnych), przy czym działanie to podejmowane jest w celu ochrony indywidualnych (prywatnych) interesów ekonomicznych przed anty-

30 S. Shavell twierdzi, że publiczne i prywatne egzekwowanie reguł konkurencji stanowi jeden $\mathrm{z}$ wymiarów interwencji prawa, przy czym autor ten przeciwstawia prywatną metodę egzekwowania prawa metodzie publicznej - tenże, The Optimal Structure of Law Enforcement, Journal of Law and Economics 1993, vol. XXXVI, s. 258-259.

31 Por. A. Mitchell Polinsky, S. Schavell, The Theory of Public Enforcement of Law, Discussion Paper No. 529, Harvard Law School, 10/2005, s. 1 [z:] http://lsr.nellco.org/cgi/ viewcontent.cgi? article $=1317 \&$ context $=$ harvard_olin.

32 Por. art. 1 pkt 1 ustawy z dnia 14 czerwca 1960 r. - Kodeks postępowania administracyjnego (tekst jedn. Dz. U. 2000 Nr 98, poz. 1071 ze zm.). 
konkurencyjnymi działaniami innych podmiotów na rynku. Sama inicjacja tego procesu (i w znacznej mierze jego przebieg) zależy od aktywności podmiotów prywatnych, które doznały szkody wskutek zakazanych (sprzecznych z prawem) działań. Realizacja ochrony prawnej odbywa się z pomocą instytucji publicznej (sądu), w oparciu o reguły proceduralne przewidziane dla rozstrzygania sporów ze stosunków z zakresu prawa cywilnego ${ }^{33}$. Prywatne egzekwowanie prawa ochrony konkurencji określa się często również jako egzekwowanie sądowe lub sądowe dochodzenie roszczeń.

Prowadzone w dalszej części niniejszej książki rozważania opierają się na założeniu, że współcześnie mamy do czynienia z kompleksowym modelem egzekwowania prawa ochrony konkurencji, na który składają się dwa submodele (tryby) 34 : publicznego i prywatnego egzekwowania reguł konkurencji. Publiczny i prywatny submodel egzekwowania prawa mogą, choć nie muszą ze sobą koegzystować, w różny sposób mogą kształtować się relacje między nimi. Za współfunkcjonowaniem dwóch trybów egzekwowania reguł konkurencji przemawia okoliczność, że w każdym z nich można realizować funkcje (cele) procesu (mechanizmu) egzekwowania prawa ochrony konkurencji, do których należy zaliczyć: funkcję polegającą na doprowadzeniu do zakończenia naruszenia, funkcję karania (punishment) i odstraszania (prewencji; deterrence) oraz funkcję kompensacyjną ${ }^{35}$; dodatkowo egzekwowaniu przypisuje się również funkcję w postaci „rozwijania i wyjaśniania” (development, clarification) prawa ochrony konkurencji ${ }^{36}$ oraz - pokrewną funkcji kompensacyjnej - funkcję zapobiegania transferowi zasobów między podmiotami poszkodowanymi wskutek naruszenia reguł konkurencji a przedsiębiorcami dopuszczającymi się tych naruszen ${ }^{37}$. Realizacja poszczególnych funkcji odbywa się jednak w każdym z trybów z różnym natężeniem: publicznoprawna metoda egzekwowania reguł konkurencji kojarzona jest

33 Por. art. 1 ustawy z dnia 17 listopada 1964 r. - Kodeks postępowania cywilnego (Dz. U. $1964 \mathrm{Nr}$ 43, poz. 296 ze zm.).

34 Pojęcia „submodelu” i „trybu” egzekwowania prawa traktuję na potrzeby prowadzonych rozważań zamiennie i równoważnie.

35 Tak A. P. Komninos, Relationship between Public and Private Enforcement: quod Dei Deo, quod Caesaris Caesari (referat wygłoszony na konferencji Integrating public and private enforcement of competition law: Implications for courts and agencies, Florencja, 17-18 czerwca 2011 r.), dostępny pod adresem: http://papers.ssrn.com/sol3/papers. cfm?abstract_id=1870723, s. 2.

36 Tak W. P. J. Wils, The Relationship Between Public Antitrust Enforcement and Private Actions for Damages, World Competition 2009, vol. 32(1); dostępny także pod adresem: http://papers.ssrn.com/sol3/papers.cfm?abstract_id=1296458, s. 6 i n.

37 Tak R. H. Lande, J. P. Davis, Benefits from Private Antitrust Enforcement: An Analysis of Forty Cases, University of San Franciso Law Review 2008, vol. 42, s. 882. 
przede wszystkim z karaniem i odstraszaniem, prywatnoprawna - z kompensowaniem.

Bardziej szczegółowa charakterystyka poszczególnych trybów egzekwowania prawa ochrony konkurencji przedstawiona zostanie w kolejnych rozdziałach, ramowe określenie istoty obydwu submodeli w tym miejscu stanowi jedynie punkt wyjścia dla zdefiniowania podstawowych problemów budowy owego kompleksowego modelu egzekwowania prawa ochrony konkurencji, złożonego z obydwu trybów i charakteryzowanego jako model zrównoważony.

L. Morawski stwierdza, że „nie da się wskazać żadnych ostrych kryteriów, które by rozdzielały sferę prawa publicznego i prywatnego. Dzieje się tak $\mathrm{z}$ tego powodu, że w praktyce te dwie sfery są ze sobą bardzo ściśle powiązane". Za jedno z podstawowych kryteriów tego powiązania autor wskazuje „fakt, iż większość uprawnień prywatno-prawnych jest chroniona za pomocą instrumentów publiczno-prawnych i może być ze względu na interes publiczny w taki, czy inny sposób ograniczona" 38 . W przypadku prywatnego egzekwowania prawa ochrony konkurencji mamy do czynienia z sytuacją odwrotną, tzn. normy o rodowodzie publicznoprawnym mogą być chronione w drodze prywatnoprawnej, co samo w sobie stanowi przejaw prywatyzacji prawa publicznego, mimo że w literaturze wskazuje się raczej na dominację zjawiska przeciwstawnego, tj. publicyzacji prawa prywatnego ${ }^{39}$. Wyraża się nawet obawy, że „działanie pod szyldem ochrony jednostek słabszych czy zapewnienia prawidłowego funkcjonowania konkurencji, dostarczające przykładowych uzasadnień ingerencji władczych w sferę prawa prywatnego, mogą (...) przejść niepostrzeżenie w działania, których celem będzie infiltracja społeczeństwa dla partykularnych celów władzy" 40 . Pogląd tego rodzaju może skłaniać do wniosku o konieczności wzmocnienia prywatnego trybu egzekwowania zakazów praktyk ograniczających konkurencję jako trybu bardziej odpowiedniego dla demokratycznego państwa prawa.

Już w połowie lat osiemdziesiątych J. Łętowski podkreślał, że „są podstawy do stwierdzenia, iż zarówno prawo administracyjne, jak i prawo cywilne rozumiane jako dwa antagonistyczne systemy zamkniętych reguł, rządzące się sobie tylko właściwymi zasadami, niepodatne na naciski z zewnątrz prze-

38 L. Morawski, Wstęp..., s. 91.

39 L. Morawski, Wstęp..., s. 93. Problem „prywatyzacji” prawa publicznego podnoszony jest w piśmiennictwie przede wszystkim w kontekście rosnącej liczby norm o charakterze prywatnoprawnym przyjmowanych w prawie Unii Europejskiej - piszę o tym szerzej w: O „prywatyzacji” prawa wspólnotowego i jej skutkach, EPS 2006, nr 9.

40 A. Żurawik, Problem publicyzacji prawa prywatnego $w$ kontekście ustrojowym, PiP 2010, nr 5, s. 41. 
stały chyba pełnić podstawową twórczą rolę dla rozwoju rozumianej jako całość teorii systemu prawa" ${ }^{41}$. Warto w tym kontekście zwrócić uwagę na fakt, że prywatne egzekwowanie reguł konkurencji najdynamiczniej i najłatwiej rozwija się w kulturze prawnej common law, której przedstawiciele często kontestują charakterystyczny dla kontynentalnych porządków prawnych podział na prawo publiczne i prawo prywatne ${ }^{42}$. C. Harlow już na początku lat osiemdziesiątych XX w. określiła próby wprowadzenia do angielskiego systemu prawnego podziału na prawo publiczne i prywatne jako „staromodne" (old-fashioned) i niepożądane (undesirable) ${ }^{43}$. Nawet jeśli w porządkach prawnych Europy kontynentalnej podział na prawo publiczne i prywatne jest dobrze zakorzeniony i spotyka się ze znacznie mniejszą krytyką, to coraz widoczniejsze wzajemne przenikanie się prawa publicznego i prywatnego, skutkujące mniej „oczywistą” dychotomią systemu prawa, skłania do tworzenia zintegrowanego (publiczno-prywatnego) zrównoważonego modelu egzekwowania prawa konkurencji.

\subsection{Wspótistnienie publicznego i prywatnego trybu egzekwowania prawa ochrony konkurencji jako problem badawczy}

\subsubsection{Zasady kształtowania relacji między trybami: subsydiarność, komplementarność, dekomplementarność}

Punkt wyjścia dla rozważań podjętych w niniejszej publikacji stanowi teza, że współcześnie prawo ochrony konkurencji może (i powinno) być egzekwowane zarówno w submodelu publicznym, jak i submodelu prywatnym, wspólnie konstytuujących model egzekwowania reguł konkurencji. S. W. Waller kwalifikuje to wspólistnienie jako „partnerstwo"44, więk-

41 J. Łętowski, $W$ sprawie granicy między prawem publicznym a prywatnym, [w:] B. Kordasiewicz, E. Lętowska (red.), Prace z prawa cywilnego..., s. 362.

42 Por. m.in.: O. Dawn, Common Values and the Public-Private Divide, Butterworths, London, Edinburgh, Dublin 1999, s. 248-266; M. Taggart, 'The Peculiarities of the English': Resisting the Public/Private Law Distinction, [w:] P. Craig, R. Rawlings (red.), Law and Administration in Europe. Essays in Honour of Carol Harlow, Oxford University Press 2003, s. 107-121.

43 C. Harlow, "Public" and "Private" Law: Definition Without Distinction, Modern Law Review 1980, vol. 43(3), s. 242. Krytyczny wobec poglądów C. Harlow był G. Samuel, Public and Private Law: A Private Lawyer's Response, Modern Law Review 1983, vol. 46(5), s. $558-583$.

44 S.W. Waller, Towards a Constructive Public-Private Partnership to Enforce Competition Law, World Competition 2006, vol. 29(3), s. 67-81; dostępny także pod adresem: http:// papers.ssrn.com/sol3/papers.cfm?abstract_id $=905604$. 
szość autorów postrzega je raczej jako relację „uzupełniania” publicznego trybu egzekwowania reguł konkurencji trybem prywatnym ${ }^{45}$. Przekonanie o potrzebie (a nawet konieczności) współistnienia (współfunkcjonowania) publicznego i prywatnego trybu egzekwowania prawa ochrony konkurencji wywodzi się, po pierwsze $\mathrm{z}$ zauważalnej zmiany charakteru relacji między prawem publicznym i prawem prywatnym (coraz silniejsze wzajemne oddziaływanie dwóch segmentów prawa), a po drugie z postrzegania prawa ochrony konkurencji jako „dojrzałej” dziedziny prawa, której stosowanie może być powierzone nie tylko organom administracji publicznej (względnie organom ścigania), ale także sądom powszechnym.

Współfunkcjonowanie publicznego i prywatnego trybu egzekwowania prawa ochrony konkurencji może być ukształtowane na zasadach definiowanych przeze mnie jako: 1) zasada subsydiarności, 2) zasada komplementarności lub 3) zasada dekomplementarności. Relacjom między obydwoma modelami egzekwowania reguł ochrony konkurencji można przypisać charakter subsydiarny wówczas, gdy jeden $\mathrm{z}$ nich pozostaje $\mathrm{w}$ bezpośredniej zależności od drugiego, tj. gdy skorzystanie z jednego trybu egzekwowania reguł konkurencji warunkuje korzystanie $\mathrm{z}$ drugiego trybu. Warunkowanie może mieć charakter bezwzględny (formalny) - z sytuacją taką będziemy mieć do czynienia np. wówczas, gdy obowiązujące regulacje prawnie nie zezwalają na „uruchomienie” prywatnego trybu egzekwowania prawa ochrony konkurencji bez uprzedniego zamknięcia ścieżki egzekwowania reguł konkurencji na drodze publicznoprawnej. Warunkowanie może mieć także charakter względny (pozaformalny) - będzie to dotyczyło sytuacji, w której co prawda brak regulacji wskazujących na obligatoryjne formalne uzależnienie jednego trybu egzekwowania prawa ochrony konkurencji od drugiego, ale potencjalni beneficjenci jednego z trybów są przekonani o niemożności skutecznego skorzystania $\mathrm{z}$ niego bez uprzedniej realizacji drugiego trybu (sytuacja taka będzie miała miejsce wtedy, gdy potencjalni zainteresowani sądowym dochodzeniem roszczeń z tytułu naruszenia zakazów praktyk ograniczających konkurencję są przekonani - bo wskazuje na to orzecznictwo - o braku sensu podejmowanych działań, jeśli organ ochrony konkurencji nie wydał wcześniej decyzji stwierdzającej naruszenie reguł materialnoprawnych). W założeniach czysto teoretycznych subsydiarność może być realizowana w obydwu kierunkach - tryb publicznego egzekwo-

45 R. Van Den Bergh, S. Keske, Private Enforcement of European Competition Law: Quo Vadis?, European Review of Contract Law 2007, nr 4, s. 473-476; A. P. Komninos, Relationship between Public and Private Enforcement..., s. 9; R. H. Lande, J. P. Davis, Benefits from Private Antitrust Enforcement..., s. 905-906. W polskim piśmiennictwie tak: R. Molski, Prywatnoprawna ochrona konkurencji..., s. 809. 
wania prawa ochrony konkurencji może warunkować korzystanie z trybu prywatnego i odwrotnie. W praktyce jednak to zazwyczaj submodel publicznego egzekwowania reguł konkurencji warunkuje (przynajmniej formalnie) realizację submodelu prywatnego: trudno bowiem wyobrazić sobie, że aktywność publicznych organów ochrony konkurencji miałaby być uzależniona od uprzedniej inicjatywy podmiotów prywatnych wstępujących na ścieżkę sądowego dochodzenia roszczeń. Możliwe, choć zapewne rzadkie, jest co najwyżej warunkowanie publicznego trybu egzekwowania reguł konkurencji przez tryb prywatnoprawny w sposób nieformalny - informacja o postępowaniu sądowym w sprawie roszczeń związanych z praktyką ograniczającą konkurencję może skłonić organ ochrony konkurencji do wszczęcia własnego postępowania dotyczącego danej praktyki.

Komplementarność trybów egzekwowania reguł konkurencji polega - w moim przekonaniu - na tym, że co prawda decyzja o zainicjowaniu publicznoprawnego lub prywatnoprawnego trybu przez uprawnione podmioty pozostaje całkowicie autonomiczna, jednak jeśli postępowania takie już się toczą lub toczyły, poszczególne ich aspekty oddziałują na siebie (np. istnieją regulacje pozwalające na udostępnianie materiału dowodowego zebranego $\mathrm{w}$ postępowaniu publicznoprawnym na potrzeby postępowania prywatnoprawnego ${ }^{46}$. Aktualność zachowują przy tym uwagi poczynione w odniesieniu do zasady subsydiarności co do kierunku oddziaływania na siebie obydwu trybów: teoretycznie oddziaływanie może być wzajemne (w obydwu kierunkach), w praktyce to głównie różne aspekty postępowania prowadzonego przed organem ochrony konkurencji oddziałują na (prywatne) postępowania sądowe.

Poprzez dekomplementarność submodeli egzekwowania reguł konkurencji rozumiem sytuację, w której obydwa tryby pozostają całkowicie (formalnie i pozaformalnie, bezwzględnie i względnie) niezależne od siebie ${ }^{47}$ w każdym stadium postępowania i w każdym jego aspekcie. W rzeczywistości dekomplementarność submodeli egzekwowania reguł konkurencji występuje jedynie w przypadku, gdy egzekwowanie prawa ochrony konkurencji odbywa się tylko w ramach jednego z trybów: publicznego lub prywatnego, bądź wówczas, gdy nie istnieją żadne regulacje prawne ani traktowane w praktyce

46 W polskiej doktrynie funkcjonowanie modelu komplementarnego ochrony konkurencji postuluje R. Molski - por. tenże, Prywatnoprawna ochrona konkurencji..., s. 807. Jednak zaproponowana przez tego autora definicja komplementarności bliższa jest sformułowanej poniżej definicji modelu zrównoważonego ochrony konkurencji.

47 A. P. Komninos właściwie definiuje niezależność publicznego i prywatnego trybu egzekwowania reguł konkurencji jako brak relacji hierarchicznych między nimi - A. P. Komninos, Relationship between Public and Private Enforcement..., s. 1. 
jako precedensowe orzecznictwo pozwalające na przenikanie się różnych aspektów dwóch trybów postępowań. Relacje oparte na zasadzie dekomplementarności w najbardziej dogmatyczny sposób oddają podział na prawo publiczne i prawo prywatne.

Fakt, że relacje (współzależności) między publicznym a prywatnym egzekwowaniem reguł konkurencji mogą być charakteryzowane przez jedną ze wskazanych powyżej zasad, jest albo wynikiem świadomej decyzji ustawodawcy (np. w przypadku zasady subsydiarności, gdy regulacje prawne uzależniają wszczęcie postępowania w jednym trybie od uprzedniego zakończenia postępowania $\mathrm{w}$ drugim trybie) albo rezultatem bierności ustawodawcy (w przypadku zasady dekomplementarności). W braku odpowiednich uregulowań ustawowych niektóre aspekty współzależności obydwu submodeli egzekwowania reguł konkurencji mogą być kształtowane - według jednej ze wskazanych powyżej zasad - w orzecznictwie.

Nie wykluczam również tego, że relacje między publicznym a prywatnym egzekwowaniem reguł konkurencji mogą kształtować się częściowo według zasady subsydiarności, częściowo według zasady komplementarności. Należy jednak podkreślić, że zasada subsydiarności, zwłaszcza w wersji przewidującej formalne uzależnienie inicjacji jednego trybu od drugiego, może hamować rozwój jednego z submodeli egzekwowania reguł konkurencji (zazwyczaj trybu prywatnego). Zasadzie komplementarności postępowań można natomiast przypisać generowanie efektów synergii wspólistnienia dwóch trybów egzekwowania reguł konkurencji, co uznaję za pożądany (a nawet docelowy) rezultat funkcjonowania kompleksowego (zintegrowanego $)^{48}$ modelu egzekwowania prawa ochrony konkurencji.

Przyjęcie komplementarności jako podstawowej zasady rządzącej relacjami między publicznym a prywatnym trybem egzekwowania prawa ochrony konkurencji skutkuje koniecznością podjęcia szczegółowych badań nad poszczególnymi aspektami powiązań między jednym a drugim trybem. Badania takie wymagają: po pierwsze identyfikacji obszarów (problemów) zazębiania się (punktów styczności) publicznego i prywatnego egzekwowania prawa ochrony konkurencji, po drugie identyfikacji aktualnego stanu prawnego bądź stanu orzecznictwa, odnoszącego się do wyodrębnionych

48 Zintegrowany model publicznego i prywatnego trybu egzekwowania reguł konkurencji określany jest również jako: „holistyczny” (por. J. Kloub, White Paper on Damage Actions For Breach of the EC Antitrust Rules: Plea For a More Holistic Approach to Antitrust Enforcement, European Competition Journal 2009, vol. 5(2), s. 515-547), „hybrydowy” (por. J. P. Terhechte, Enforcing European Competition Law - Harmonizing Private and Public Approaches in a More Differentitated Enforcement Model, [w:] J. Basedow, J. P. Terhechte, L. Tichy (red.), Private enforcement of competition law, Nomos, 2010). 
punktów styczności obydwu trybów. Dopiero wyniki tych dwóch etapów badań pozwalają na formułowanie wniosków co do obecnych relacji między publicznym a prywatnym egzekwowaniem reguł konkurencji oraz postulatów co do zmian stanu prawnego (postulatów de lege ferenda) i/lub praktyki orzeczniczej w celu zbudowania zintegrowanego modelu egzekwowania reguł konkurencji, w którym relacje między obydwoma składowymi oparte są na zasadzie komplementarności.

\subsubsection{Obszary wzajemnego oddziaływania publicznego i prywatnego trybu egzekwowania prawa ochrony konkurencji: inicjacja, przebieg, zakończenie postępowania}

Określenie relacji między prywatnym a publicznym egzekwowaniem prawa konkurencji powinno nastąpić w trzech wymiarach: inicjacji postępowań, przebiegu postępowań oraz zakończenia postępowania.

W pierwszym wymiarze dla określenia relacji między obydwoma trybami egzekwowania prawa konkurencji konieczne jest, w moim przekonaniu, zidentyfikowanie rodzaju (charakteru) interesów, jakie są lub powinny być realizowane przez publiczne i prywatne egzekwowanie prawa ochrony konkurencji, oraz określenie stopnia i zakresu ich współoddziaływania. Pośrednio prowadzi to również do wyznaczenia kręgu podmiotów zainteresowanych zainicjowaniem i przeprowadzeniem postępowania związanego $\mathrm{z}$ naruszeniem reguł konkurencji w postępowaniu przed organem ochrony konkurencji lub przed sądem powszechnym. W tym kontekście pojawia się pytanie o dostępność obydwu trybów dla podmiotów prywatnych oraz ich rolę w każdym z postępowań.

Relacje między dwoma trybami egzekwowania prawa ochrony konkurencji w wymiarze inicjacji postępowań charakteryzowane są także poprzez rozstrzygnięcia dotyczące możliwości wszczęcia postępowania w jednym z trybów (publicznym lub prywatnym) bez uprzedniego wszczęcia lub zakończenia postępowania $\mathrm{w}$ drugim trybie. W tym kontekście pojawia się pytanie, czy możliwe jest wystąpienie z powództwem cywilnym z tytułu naruszenia zakazu porozumień ograniczających konkurencję w sytuacji braku (uprzedniego) rozstrzygnięcia wydanego przez administracyjny organ ochrony konkurencji. Pytanie to można odwrócić (pytając o możliwość wszczynania postępowań administracyjnych bez uprzedniego rozstrzygnięcia cywilnoprawnego) - ustawy o ochronie konkurencji (antymonopolowe) są jednak aktami z obszaru prawa publicznego i mało prawdopodobnym jest, aby rozstrzygnięcie sądu cywilnego warunkowało podjęcie interwencji przez 
organ administracyjny. Wreszcie, w obszarze inicjacji postępowań relacje między obydwoma trybami mogą być charakteryzowane poprzez oddziaływanie terminów przedawnienia przewidzianych dla spraw antymonopolowych $\mathrm{w}$ postępowaniu przed organem ochrony konkurencji oraz przed sądami powszechnymi.

W wymiarze przebiegu postępowań analiza relacji między prywatnym i publicznym egzekwowaniem prawa ochrony konkurencji wymaga przede wszystkim odpowiedzi na pytanie o dostępność i możliwość wykorzystania dowodów pozyskiwanych w postępowaniu w jednym trybie (głównie publicznoprawnym) w postępowaniu w drugim trybie (prywatnoprawnym). Za punkt styczności między trybami egzekwowania reguł konkurencji w obszarze przebiegu postępowania należy uznać także możliwość występowania przez organ ochrony konkurencji do sądu, przed którym toczy się postępowanie w sprawie związanej z naruszeniem zakazów praktyk ograniczających konkurencję, w roli amicus curiae (lub zbliżonej).

Jeśli chodzi o zakończenie postępowania, to relacja między trybami egzekwowania prawa ochrony konkurencji przejawia się w (ewentualnym) oddziaływaniu sankcji nałożonych w ramach jednego trybu egzekwowania reguł konkurencji na sankcje nakładane $\mathrm{w}$ drugim trybie (relacja ta obrazowana jest np. przez problem dopuszczalności zmniejszania odszkodowań, do których w procesach cywilnych są zobowiązani uczestnicy karteli, którzy przystąpili do programu leniency).

\subsubsection{Wymiar aksjologiczny kompleksowego modelu egzekwowania prawa ochrony konkurencji: efektywność, spójność, równość}

Zdefiniowanie opartych na zasadzie komplementarności relacji między publicznym i prywatnym trybem egzekwowania reguł konkurencji dla celów ukształtowania kompleksowego modelu egzekwowania prawa ochrony konkurencji wymaga określenia pożądanej aksjologii takiego modelu. Wybór wartości, na jakich oparte będzie egzekwowanie prawa w ramach określonego modelu egzekwowania, naznaczony jest pewną dozą subiektywizmu, niemniej jednak możliwy jest dobór takich wartości, których obecność w procesie egzekwowania reguł konkurencji (bez względu na tryb) wydaje się mało kontrowersyjna i dość powszechnie akceptowana, tak w doktrynie, jak i w orzecznictwie. Istotny wydaje się również dobór takich wartości, które należy postrzegać jako kluczowe dla funkcjonowania modelu egzekwowania prawa.

Kierując się takim założeniem proponuję, aby kompleksowy model egzekwowania prawa ochrony konkurencji opierał się na następującej triadzie 
wartości: efektywność - spójność - równość. Efektywność (skuteczność) należy odnosić do „ścigania” naruszeń reguł konkurencji (a pośrednio do efektywności samych norm materialnoprawnych), przez spójność stosowania prawa ochrony konkurencji rozumiem jednolite stosowanie reguł konkurencji przez publiczne organy ochrony konkurencji i przez sądy, natomiast równość dotyczy przypisania równoważnej roli obydwu trybom egzekwowania reguł konkurencji (braku uprzywilejowania jednego z trybów kosztem drugiego).

Efektywność (skuteczność) egzekwowania prawa ma wiele wymiarów, tak prawnych, jak i pozaprawnych. Ma ona na celu wspomaganie realizacji celów prawodawczych (skuteczność finistyczna), powinna ona prowadzić do realizacji przez adresatów konkretnych wzorów zachowań oraz wymaga kontroli tego procesu przez aparat wykonawczy (skuteczność behawioralna). W konsekwencji tych działań osiągnięta zostaje skuteczność psychologiczna poprzez powstanie przekonania o nieuchronności działania prawa i aktów jego stosowania 49 .

A. M. Polinsky i S. Schavell jako główny argument przemawiający za zastosowaniem jednego z trybów egzekwowania prawa - publicznego lub prywatnego - wskazują możliwość identyfikacji naruszyciela - jeśli jest ona możliwa, podmioty prywatne będą bardziej skłonne do podejmowania ochrony (oczywiście w trybie prywatnoprawnym); jeżeli natomiast wskazanie naruszyciela nie jest możliwe, ,uprzywilejowana” będzie zapewne publiczna metoda wdrażania prawa ${ }^{50}$. Argument ten ma jednak ograniczone znaczenie praktyczne na gruncie egzekwowania prawa ochrony konkurencji - naruszenia zakazów praktyk ograniczających konkurencję są bowiem z reguły „spersonalizowane” (łatwo zidentyfikować przedsiębiorców naruszających te zakazy). Problem braku identyfikacji naruszyciela najszybciej mógłby dotyczyć konsumentów odczuwających niekorzystne dla nich skutki rynkowe zachowań niezidentyfikowanych przedsiębiorców (np. sytuacja braku wiedzy o pozycji dominującej przedsiębiorcy działającego na zasadzie holdingu - z punktu widzenia konsumentów na rynku widoczna jest aktywność kilku odrębnych przedsiębiorców, tworzących jednak w sensie kapitałowym grupę). W przypadku egzekwowania reguł konkurencji istotniejszy wydaje się raczej problem dowodzenia potencjalnych naruszeń - jeśli pozyskanie i ocena dowodów jest stosunkowo łatwa lub gdy istnieją mechanizmy zapewniające dostęp do materiału dowodowego zgromadzonego przez organ publiczny, podmioty prywatne będą bardziej skłonne do występowania na

49 L. Leszczyński, Zagadnienia teorii..., s. 51.

50 A. M. Polinsky i S. Schavell, The Theory..., s. 4-5. 
drogę sądową, co ostatecznie może decydować o zwiększonym poziomie efektywności egzekwowania prawa ochrony konkurencji, jak i jego materialnych norm.

O efektywności egzekwowania prawa ochrony konkurencji przesądzają również sankcje stosowane w obydwu trybach. Efektywne postępowanie w sprawach naruszenia reguł konkurencji powinno - niezależnie od trybu egzekwowania - w pierwszej kolejności zmierzać do zaprzestania naruszenia i zapewnienia powrotu do zasad „zdrowego" konkurowania. Skutek powrotu do stanu sprzed naruszenia jest $\mathrm{z}$ pewnością skutkiem pożądanym zarówno w ramach publicznego, jak i prywatnego egzekwowania reguł ochrony konkurencji. Pogląd ten wydaje się bezsporny. Dużo więcej kontrowersji wzbudza natomiast kwestia tego, czy efektywność egzekwowania reguł konkurencji jest (może być) osiągnięta także poprzez penalizowanie zachowań naruszających reguły konkurencji - na płaszczyźnie publicznego egzekwowania prawa efekt ten jest osiaggany poprzez sankcje karne lub poprzez administracyjne sankcje finansowe (którym często przypisuje się charakter sankcji prawnokarnych), zaś w obszarze prywatnego egzekwowania prawa - poprzez odszkodowania o charakterze karnym (punitive damages). O ile jednak sankcje o charakterze penalizującym i odstraszającym są dość powszechnie akceptowane w publicznym egzekwowaniu prawa ochrony konkurencji, o tyle koncepcja odszkodowań o charakterze karnym jest odrzucana przez część doktryny i orzecznictwa (nie tylko kontynentalnego, ale także sądów działających w systemie common law). W publicznym trybie egzekwowania prawa nie występuje natomiast ten wymiar efektywności stosowania prawa, który polega na naprawieniu szkody i stanowi najistotniejszy element efektywności prywatnego (sądowego) egzekwowania reguł konkurencji.

Efektywność prawa konkurencji nie może być jedyną miarą rozwiązań przyjmowanych dla obydwu trybów egzekwowania reguł konkurencji, jednak konieczność zapewnienia efektywności prawu konkurencji powoduje, że proponowane rozwiązania współistnienia prywatnego i publicznego trybu egzekwowania zakazów antykonkurencyjnych praktyk muszą wykraczać poza klasyczną koncepcję podziału kompetencji między władzę wykonawczą i sądowniczą ${ }^{51}$.

Różny charakter efektywności dla prywatnego i publicznego trybu egzekwowania reguł konkurencji musi oddziaływać na kształtowanie relacji między nimi. Problemem w tych relacjach $-\mathrm{z}$ punktu widzenia efektywności

51 Por. K. Boskovits, Modernization and the Role of National Courts: Institutional Choices, Power Relations, and Substantive Implications, [w:] I. Kokkoris, I. Lianos (red.), The reform of EC competition law: new challenges, Kluwer Law International 2009, s. 107. 
- może okazać się zaliczanie sankcji nałożonych w ramach jednego trybu na rzecz sankcji stosowanych w drugim trybie: zabieg taki może podnosić skuteczność egzekwowania w jednym trybie, osłabiać natomiast efektywność drugiego trybu - rozważenia wymaga wówczas ostateczny wynik „równania efektywnościowego" całego modelu egzekwowania reguł konkurencji. Przyjęcie rozwiązań pozwalających na „zaliczalność” sankcji jednego trybu na poczet wyników postępowania w drugim może prowadzić do ukształtowania relacji między obydwoma trybami raczej na zasadzie subsydiarności niż komplementarności.

Należy zaznaczyć, że w obszarze prawa Unii Europejskiej efektywność jako wartość modelu egzekwowania prawa ma charakter nieco bardziej złożony - chodzi bowiem nie tylko o efektywność reguł konkurencji, ale także o skuteczność prawa unijnego w ogóle.

Spójność (jednolitość) stosowania reguł konkurencji w trybie prywatnoi publicznoprawnym, oznaczająca konsekwentne stosowania prawa w określony sposób, może być postrzegana zarówno jako samodzielna wartość rządząca modelem egzekwowania reguł konkurencji, jak i element składowy, jeden $\mathrm{z}$ gwarantów efektywności ścigania naruszeń oraz pewności prawa (pewności treści rozstrzygnięć) ${ }^{52}$. Bez względu na tryb egzekwowania prawa ochrony konkurencji, ściśle powiązany z celami tej dziedziny prawa, istota materialnych reguł konkurencji pozostaje taka sama i musi być ona zachowana zarówno w postępowaniu przed administracyjnym organem ochrony konkurencji, jak i przed sądami cywilnymi. Jednolitość stosowania prawa może być zapewniona przez formalne związanie rozstrzygnięciami organów (np. prejudycjalny charakter decyzji organu antymonopolowego), jak i związanie nieformalne („orzecznicze”), przejawiające się w „argumentach i prestiżu podmiotów (np. zasady SN) (...)"53. Jak słusznie zauważa L. Leszczyński, „najważniejsze znaczenie dla osiągania jednolitości decydowania ma jednak postawa praktyki prawniczej" 54 . Z taką sytuacją co do statusu decyzji organu ochrony konkurencji (opartych na prawie krajowym) mamy do czynienia w ramach aktualnych relacji między publicznym a prywatnym egzekwowaniem reguł ochrony konkurencji w Polsce.

Spójność wdrażania reguł konkurencji winna być zapewniona zarówno w ujęciu horyzontalnym (spójność rozstrzygnięć organów administracyjnych i sądowych), jak i w ujęciu wertykalnym (spójność rozstrzygnięć organów

\footnotetext{
52 L. Leszczyński, Zagadnienia teorii..., s. 50.

53 Ibidem.

54 Ibidem.
} 
krajowych i instytucji UE) $)^{55}$ - ta ostatnia dotyczy wyłącznie państw członkowskich UE. Jednolitość horyzontalna podyktowana jest względami efektywności, spójność pionowa wynika z zasady pierwszeństwa prawa UE przed prawem krajowym.

Ostatnią, ale równie ważną wartością, na jakiej powinien opierać się zintegrowany model egzekwowania prawa ochrony konkurencji jest równość (równorzędność) publicznego i prywatnego trybu egzekwowania regut konkurencji.

Źródła równości jako wartości konstytuującej pożądany model egzekwowania reguł konkurencji można upatrywać wprost w przepisach odnoszących się do ustroju gospodarczego. Regulacje odnoszące się do mechanizmów ochrony konkurencji pośrednio wypełniają dyspozycję przepisów konstytucyjnych (lub w przypadku prawa Unii Europejskiej - przepisów, którym taką rangę można przyznać) ustanawiających ustrojową zasadę społecznej gospodarki rynkowej (art. 20 Konstytucji RP ${ }^{56}$; art. 3 TUE ${ }^{57}$ ) lub otwartej gospodarki rynkowej (art. 119 ust. 1 i ust. 2 TFUE oraz art. 16 Karty Praw Podstawowych), której część składową stanowi wolność gospodarcza (wolność działalności gospodarczej).

Artykuł 20 Konstytucji RP ustanawia jako podstawę ustroju gospodarczego model społecznej gospodarki rynkowej oparty na wolności działalności gospodarczej, własności prywatnej oraz solidarności, dialogu i współpracy partnerów społecznych.

Konkurencja (wolność konkurowania) postrzegana jest (obok wolności prowadzenia działalności gospodarczej) jako jeden z filarów wolności gospodarczej58, niekiedy wskazuje się wręcz na tożsamość wolności gospodarczej i konkurencji ${ }^{59}$. Przyjęcie wolności działalności gospodarczej, wraz z wolnością konkurowania, jako zasady ustrojowej skutkuje obowiązkiem

55 Konieczność zapewnienia spójności horyzontalnej i wertykalnej stosowania prawa ochrony konkurencji postulowałam w: Glosa do uchwaty SN z 23.07.2008 r., III CZP 52/08, EPS 2010, nr 5.

56 Konstytucja Rzeczypospolitej Polskiej z dnia 2 kwietnia 1997 r. (Dz. U. Nr 78, poz. 483, zm.: Dz. U. 2006 Nr 200, poz. 1471; Dz. U. 2009 Nr 114, poz. 946).

57 Art. 3 ust. 3. TUE nawiązuje do społecznej gospodarki rynkowej, czyniąc z niej podstawę „trwałego rozwoju Europy” (pozostałe elementy tego rozwoju to zrównoważony wzrost gospodarczy, stabilność cen oraz wysoki poziom ochrony i poprawy jakości środowiska).

58 Por. m.in. M. Szydło, Swoboda działalności gospodarczej, C. H. Beck, Warszawa 2005, s. $11-12$.

59 M. Floriańczyk, Wolność gospodarcza a konkurencja, [w:] W. Szwajdler, H. Nowicki (red.), Konstytucyjna zasada wolności gospodarczej, TNOiK, Toruń 2009, s. 79. Już u progu transformacji ustrojowej w piśmiennictwie zauważano, że „tworzenie systemu rynkowego bez ochrony antymonopolowej nie jest możliwe" - K. Sobczak, Prawne instrumenty polityki antymonopolowej, PUG 1989, nr 4, s. 109. 
zapewnienia przez państwo instytucji i mechanizmów ochrony konkurencji jak słusznie wskazuje C. Kosikowski „w sensie legislacyjnym wolność gospodarcza stanowi kategorię wolności prawnie chronionej”60. Rola państwa $\mathrm{w}$ ochronie konkurencji przejawia się w pierwszej kolejności w tworzeniu prawa ochrony konkurencji, czy nawet szerzej - polityki antymonopolowej61 obejmującej nie tylko działalność prawodawczą, ale także egzekwowanie reguł konkurencji. W tym ostatnim obszarze działalność państwa nie musi być jednak bezpośrednia, oparta na interwencji organów administracji publicznej - jest to tylko jedna z możliwych metod zapewnienia poszanowania konkurencji. Ochrona konkurencji może być równie dobrze (a nawet powinna być) realizowana poprzez aktywność podmiotów prywatnych, wspieraną poprzez właściwą (efektywną, racjonalną czasowo i kosztowo) działalność organów publicznych (organów ochrony konkurencji, sądów powszechnych). Za stanowiskiem, w którym ciężar ochrony konkurencji spoczywa zarówno na instytucjach publicznych, jak i podmiotach prywatnych, przemawia sama koncepcja społecznej gospodarki rynkowej, rozumianej nie tylko jako „określony model ekonomiczny, ale jako konstytucyjny obraz ładu społecznego" 62 , przy czym „określenie ustroju gospodarczego RP mianem społecznej gospodarki rynkowej daje (...) ustawodawcy dosyć dużą swobodę w zakresie kształtowania porządku prawnego w gospodarce"63.

W orzecznictwie Trybunału Konstytucyjnego ugruntowany jest pogląd o dwojakiej naturze art. 20 Konstytucji, który należy postrzegać zarówno jako „normę prawa przedmiotowego i zasadę ustroju gospodarczego państwa, ale i podstawę konstytucyjnego prawa podmiotowego - podjęcia oraz wykonywania działalności gospodarczej" 64 . W moim przekonaniu w tak określonym prawie podmiotowym mieści się uprawnienie przedsiębiorców do przeciwdziałania ograniczaniu ich wolności gospodarczej wskutek antykonkurencyjnych praktyk innych uczestników rynku65. Można przyjąć,

60 C. Kosikowski, Publiczne prawo gospodarcze Polski i Unii Europejskiej, LexisNexis, Warszawa 2005, s. 61.

61 C. Kosikowski, Polskie publiczne prawo gospodarcze, PWN, Warszawa 1998, s. 72.

62 C. Banasiński, Konstytucyjne podstawy ustroju gospodarczego, [w:] C. Banasiński, H. Gronkiewicz-Waltz, K. Pawłowicz, D. Szafrański, M. Wierzbowski, M. Wyrzykowski, Prawo gospodarcze. Zagadnienia administracyjnoprawne, Warszawa 2003, s. 48.

63 M. Szydło, Swoboda działalności..., s. 7-8.

64 Wyrok TK z dnia 19 stycznia 2010 r., SK 35/08, OTK ZU 1/A/2010 poz. 2. W wyroku tym TK powtórzył tezy sformułowane we wcześniejszych wyrokach, m.in.: z dnia 27 lipca 2004 r., SK 9/03, OTK ZU 7/A/2004 poz. 71; z dnia 14 czerwca 2004 r., SK 21/03, OTK ZU 6/A/2004 poz. 56; z dnia z 29 kwietnia 2003 r., SK 24/02 OTK ZU 4/A/2003 poz. 33.

65 Na bezpośrednie odniesienie art. 20 do jednostek wskazuje się również w piśmiennictwie - por. m.in. S. Jarosz-Żukowska, Charakter i znaczenie wolności i praw jednostki wyrażo- 
że korelatem tego prawa podmiotowego jest obowiązek państwa (władz publicznych) - określony pozytywnie - jako obowiązek stworzenia mechanizmów zapewniających poszanowanie wolności gospodarczej lub - określony negatywnie - jako obowiązek powstrzymywania się od takich działań, które uniemożliwiałyby podmiotom prywatnym ochronę własnej wolności gospodarczej przed nadużyciami. Obowiązek ten sformułowany został w art. 76 Konstytucji, stanowiącym, że władze publiczne „chronią konsumentów, użytkowników i najemców przed działaniami zagrażającymi ich zdrowiu, prywatności i bezpieczeństwu oraz przed nieuczciwymi praktykami rynkowymi”.

Równorzędny charakter obydwu trybów egzekwowania reguł konkurencji ma - w moim przekonaniu - swoje źródła także w art. 2 Konstytucji RP, zawierającym zasadę demokratycznego państwa prawa, która „wyraża koncepcję równowagi interesu rynku i zarazem poszanowanie ich autonomii, tworząc konstytucyjną gwarancję negocjacyjnego sposobu rozwiązywania pojawiających się na tle funkcjonowania rynku konfliktów społecznych"66. $\mathrm{Z}$ zasady państwa prawa wywodzono m.in. prawo każdego do sądu i prawo do uczciwego oraz bezstronnego procesu ${ }^{67}$, stanowiące istotę prywatnego egzekwowania reguł konkurencji.

Biorąc pod uwagę okoliczność, że punktem wyjścia dla tworzenia kompleksowego modelu egzekwowania reguł ochrony konkurencji jest „dominacja” trybu publicznego, w celu zapewnienia równorzędności obydwu ścieżek zasadne wydaje się również odwołanie do przepisów konstytucyjnych odnoszących się do roli i uprawnień jednostek w zakresie zapewnienia wdrażania podstawowych zasad ustrojowych, w tym koncepcji gospodarki wolnorynkowej. Za własny przyjmuję pogląd, że w istocie współistnienie publicznego i prywatnego egzekwowania prawa (nie tylko prawa ochrony konkurencji) odzwierciedla „fundamentalne idee dotyczące relacji między państwem a obywatelami i ich rolę w egzekwowaniu prawa"68. W tym kontekście, w moim przekonaniu, należy odwołać się do art. 1 Konstytucji, stanowiącego, że Rzeczpospolita Polska (a zatem i jej ustrój, także gospodarczy) jest dobrem wspólnym wszystkich obywateli oraz do art. 45 ust. 1 Konstytucji gwarantującego każdemu prawo do sądu (wymiaru sprawiedliwości).

nych w Rozdziale I Konstytucji RP, [w:] M. Jabłoński (red.), Wolności i prawa jednostki w Konstytucji RP. Tom 1 (Idee i zasady przewodnie konstytucyjnej regulacji wolności i praw jednostki w RP), C. H. Beck, Warszawa 2010, s. 109, 131-132.

66 C. Banasiński, Konstytucyjne podstawy..., s. 49-50.

67 P. Winczorek, Komentarz do Konstytucji Rzeczpospolitej Polskiej z dnia 2 kwietnia 1997 r. Liber, Warszawa 2000, s. 15.

68 A. P. Komninos, Relationship between Public and Private Enforcement..., s. 1. 


\subsection{W poszukiwaniu nie tylko zintegrowanego, ale także zrównoważonego modelu egzekwowania reguł konkurencji}

Prowadzone w dalszych częściach niniejszej publikacji rozważania mają na celu określenie relacji między prywatnym i publicznym egzekwowaniem reguł konkurencji, tworzących taki model, który będzie można określić nie tylko jako kompleksowy lub zintegrowany (tj. taki, na który składają się obydwa tryby egzekwowania prawa), ale także jako zrównoważony (tj. taki, który w relacjach między publicznym i prywatnym trybem egzekwowania reguł konkurencji uwzględnia efektywność i spójność stosowania prawa ochrony konkurencji oraz równorzędność [równoważność] ścieżek egzekwowania przepisów). Zrównoważony model definiuję jako model, w ramach którego wzajemny wpływ obydwu trybów egzekwowania reguł konkurencji zmierza do ułatwienia prowadzenia postępowań w ramach każdego z trybów tak, aby w możliwie najszerszym zakresie tryb publiczny i prywatny osiągały właściwe dla siebie cele. Model zrównoważony egzekwowania reguł konkurencji to także taki, który - jak trafnie ujął to R. Molski (choć autor ten określa rzeczony model nie jako „zrównoważony”, ale „komplementarny”) - łączy obie metody egzekwowania prawa ochrony konkurencji „w sposób pozwalający możliwie najefektywniej wykorzystywać ich zalety, a zarazem minimalizować wady" 69. W literaturze relacje tego rodzaju między prywatnym i publicznym egzekwowaniem reguł konkurencji określane są jako „konstruktywne” (constructive $^{70}$, „zharmonizowane" i oparte na „wzajemnym zachęcaniu” (mutual encouragment) $^{71}$, używa się również pojęcia „synergii”72. Koncepcja „równoważących tendencji” (equilibrating tendencies) ${ }^{73} \mathrm{w}$ egzekwowaniu reguł konkurencji zaistniała w piśmiennictwie amerykańskim - jest ona tam rozumiana jako „takie korzystanie z dostępnych środków i instrumentów prawnych, które pozwala na naprawienie istniejących nierówności w systemie ochrony konkurencji" 74 : w realiach amerykańskich chodzi przede

69 R. Molski, Prywatnoprawna ochrona konkurencji..., s. 807.

70 S. W. Waller, Towards a Constructive Public-Private Partnership...

71 J. P. Terhechte, Enforcing European Competition Law..., s. 8, 12.

72 Tak R. Stefanicki, Ochrona konsumenta w prawie konkurencji (wybrane zagadnienia), [w:] M.B. Król (red.), Wzmocnienie roli obywateli. Polityka Unii Europejskiej dotyczaca ochrony konsumentów, Fundacja dla Uniwersytetu Jagiellońskiego, Kraków 2012, s. 18-19. Autor analizuje ,problem synergii w procesie równoległego stosowania reguł ochrony konkurencji za pomocą środków prawa publicznego i instrumentów prawa cywilnego".

73 Por. S. Calkins, Summary Judgment, Motions to Dismiss and Other Examples of Equilibrating Tendencies in the Antitrust System, Georgetown Law Journal 1986, vol. 74, s. 1065.

74 W. E. Kovacic, Private Participation in the Enforcement of Public Competition Law (referat wygłoszony na: British Institution of International \& Comparative Law Third Annual 
wszystkim o niedopuszczanie do zjawiska nadużywania prywatnego trybu egzekwowania reguł konkurencji.

Relacje między submodelami egzekwowania reguł konkurencji w modelu zrównoważonym mogą być charakteryzowane poprzez komplementarność lub subsydiarność - zakładam bowiem, że zrównoważona natura kompleksowego modelu egzekwowania reguł konkurencji przejawia się we wzajemnym oddziaływaniu obydwu submodeli. Relacje między prywatnym i publicznym trybem egzekwowania reguł konkurencji, które charakteryzuje dekomplementarność, mogą być również postrzegane jako konstytuujące model „zrównoważony” - w tym wypadku owa „równowaga” ma jednak wymiar negatywny, przejawia się w całkowitej niezależności obydwu submodeli, zatem należy jeszcze raz podkreślić, że pojęciem „zrównoważonego modelu egzekwowania reguł konkurencji” obejmuję pozytywne wzajemne oddziaływanie prywatnego i publicznego trybu egzekwowania reguł konkurencji.

Jak się wydaje, konieczność koegzystencji publicznego i prywatnego egzekwowania reguł konkurencji jest bezdyskusyjna i stąd nie będzie ona przedmiotem dalszych rozważań. Na podwójny - cywilno- i administracyjnoprawny (prywatno- i publicznoprawny) - charakter spraw związanych z naruszeniem reguł konkurencji zwraca się uwagę w polskim orzecznictwie ${ }^{75}$ i doktrynie. O możliwości funkcjonowania kompleksowego modelu ochrony konkurencji pisał m.in. M. Sachajko, wskazując, że „system prawny ochrony konkurencji może posiadać również charakter mieszany, polegający na tym, że zachowania objęte zakresem normowania poddane zostały, łącznie lub rozdzielnie, regulacji administracyjnej, jak też odpowiedzialności karno-prawnej, czy też cywilno-prawnej"76. M. Sieradzka definiuje prywatny model ochrony konkurencji jako „płaszczyznę przenikania się regulacji publicznoprawnych w zakresie materialnoprawnych przepisów ustanawiających zakaz stosowania porozumień ograniczających konkurencję oraz zakaz nadużywania pozycji dominującej na rynku przepisami procesowymi zawartymi w prawie prywatnym, które umożliwiają egzekwowanie naruszeń (...)”77.

Wobec powszechnej zgody na zintegrowany model egzekwowania reguł konkurencji, dalsze rozważania skoncentrują się na potrzebie takiego

Conference on International and Comparative Competition Law: The Transatlantic Antitrust Dialogue, Londyn, maj 2003); tekst dostępny pod adresem: http://www.ftc. gov/speeches/other/030514biicl.shtm.

75 Por. np. wyrok SN z dnia 29 maja 1991 r., III CRN 120/91, OSNCP 1992, z. 5, poz. 87.

76 M. Sachajko, Istota i charakterystyka prawna antymonopolowych kar pieniężnych, RPEiS 2002, nr 1, s. 58.

77 Por. m.in. M. Sieradzka, Dochodzenie roszczeń odszkodowawczych z tytułu naruszenia unijnego i krajowego prawa konkurencji (czesść I), PUG 2012, nr 1, s. 20. 
ukształtowania relacji między prywatnym i publicznym egzekwowaniem reguł konkurencji, które będzie można określić jako zrównoważone, zgodnie z przyjętą triadą wartości. Należy przy tym zaznaczyć, że żadna ze wskazanych powyżej wartości nie może być traktowana jako wartość absolutna, bezwzględnie wymagana w projektowanym modelu egzekwowania prawa ochrony konkurencji. Przeciwnie, funkcjonowanie modelu o charakterze zrównoważonym wymaga niekiedy przyznania prymatu określonej wartości kosztem innej - np. równość obydwu trybów egzekwowania reguł konkurencji może ustąpić miejsca efektywności egzekwowania prawa ochrony konkurencji.

Założenia modelu zrównoważonego egzekwowania reguł konkurencji zostaną przedstawione przed wszystkim w formie postulatów de lege ferenda kierowanych do polskiego ustawodawcy, jak również w formie wskazówek odnoszących się do sposobu wykorzystania aktualnego stanu prawnego i dorobku orzeczniczego, a adresowanych do organów stosujących prawo. 



\section{Publicznoprawny tryb egzekwowania zakazów praktyk ograniczających konkurencję}

\subsection{Uwagi wstępne}

Próba projektowania zintegrowanego i zrównoważonego modelu egzekwowania prawa ochrony konkurencji wymaga w pierwszej kolejności odtworzenia głównych założeń i identyfikacji zasadniczych cech każdego z submodeli egzekwowania reguł konkurencji. Celowi temu służy przede wszystkim prezentacja regulacji ustanawiających podstawy prawne dla funkcjonowania submodeli jako całości i ich wybranych elementów. Prowadzone w tym (i kolejnym) rozdziale rozważania nad istotą jednego z dwóch trybów egzekwowania reguł konkurencji nie są jednak ukierunkowane na szczegółową analizę rozwiązań prawnych, ale na wskazanie tych specyficznych aspektów obydwu submodeli, które mogą rzutować na ich współfunkcjonowanie.

Jako pierwszy prezentowany jest publicznoprawny tryb egzekwowania prawa ochrony konkurencji. Nie ma bowiem wątpliwości, że choćby ze względu na stan zaawansowania rozwoju tego submodelu egzekwowania reguł konkurencji stanowi on punkt odniesienia dla tworzenia zintegrowanego i zrównoważonego modelu egzekwowania zakazów praktyk ograniczających konkurencji.

Analiza publicznoprawnego trybu egzekwowania prawa ochrony konkurencji prowadzi do wniosku, że publicznoprawny tryb egzekwowania prawa ochrony konkurencji nie stanowi spójnej, jednolitej kategorii instytucji i regulacji prawnych; w istocie składają się na niego dwie ścieżki egzekwowania zakazów praktyk ograniczających konkurencję: administracyjnoprawna i prawnokarna. Obecnie ścieżka administracyjnoprawna może być z powodzeniem uznana za podstawowy sposób egzekwowania zakazów antykon- 
kurencyjnych praktyk, jednak w procesie budowania modelu koegzystencji publicznego i prywatnego trybu egzekwowania prawa ochrony konkurencji nie sposób nie uwzględnić intensyfikujących się tendencji do wprowadzania do systemu ochrony konkurencji przepisów prawa karnego.

Uznanie podwójnego charakteru publicznego trybu egzekwowania prawa ochrony konkurencji wymaga jednocześnie określenia relacji nie tylko między publicznym a prywatnym trybem egzekwowania zakazów praktyk ograniczających konkurencję, ale także relacji administracyjnoprawnego i karnoprawnego egzekwowania tych zakazów.

\subsection{Administracyjnoprawny tryb egzekwowania prawa ochrony konkurencji}

\subsubsection{Wprowadzenie}

Administracyjnoprawny model egzekwowania prawa ochrony konkurencji stał się podstawowym narzędziem realizacji polityki konkurencji w samej UE i jej państwach członkowskich, mimo że korzenie prawa antymonopolowego - tak w Stanach Zjednoczonych, jak również w części krajów europejskich - miały charakter regulacji prawnokarnych. Dotyczyło to jednak czasów przed II wojną światową, powstanie Europejskiej Wspólnoty Gospodarczej w 1957 r., a wraz z nią - administracyjnego systemu ochrony konkurencji na wspólnym rynku - zmieniło trajektorię rozwoju modeli ochrony konkurencji w państwach członkowskich Wspólnoty. Wraz z rozszerzaniem się Wspólnoty model polityki konkurencji wypracowany w Traktacie ustanawiającym Europejską Wspólnotę Gospodarczą oraz prawie wtórnym był recypowany w kolejnych państwach członkowskich, zaś wraz ze wzrostem znaczenia Wspólnoty - także w państwach, na które Wspólnota (a dziś - Unia Europejska) silnie oddziałuje politycznie i/lub gospodarczo - w pierwszej kolejności dotyczyło to państw aspirujących do członkowstwa w UE. Pod wpływem porządku wspólnotowego ukształtowany został model egzekwowania prawa ochrony konkurencji także w Polsce. Bez względu na instytucjonalne różnice, jakie występują w poszczególnych państwach, należy przyjąć, że istota administracyjnoprawnego trybu egzekwowania prawa ochrony konkurencji jest wszędzie zbliżona - uzasadniona jest zatem „zgeneralizowana” charakterystyka tego trybu. Należy przy tym zastrzec, że charakteryzowanie podstawowego dla większości państw trybu egzekwowania zakazów praktyk ograniczających konkurencję jako administracyjnoprawnego (administracyjnego) stanowi pewne uproszczenie terminologiczne, jako że sposób instytucjonalnego ukształtowania tego trybu 
w niektórych państwach członkowskich niekoniecznie powinien być charakteryzowany jako stricte administracyjny. Niemniej jednak założenie, że ciężar rozważań niniejszej rozprawy koncentruje się na polskim modelu egzekwowania prawa ochrony konkurencji (z koniecznymi odniesieniami do prawa unijnego) uzasadnia przyjęcie takiego uproszczenia, choć i w polskiej doktrynie nie ma całkowitej zgody co do kwalifikacji postępowania przed Prezesem UOKiK (postępowanie to jest charakteryzowane jako postępowanie administracyjne ${ }^{1}$, szczególne postępowanie administracyjne ${ }^{2}$ lub jako tzw. procedura hybrydowa ${ }^{3}$ ).

Na tle charakterystyki administracyjnego modelu egzekwowania zakazów praktyk ograniczających konkurencję warto wskazać na specyfikę amerykańskiego systemu ochrony konkurencji - postępowanie wstępne (ang. preliminary investigation) prowadzone przez Antitrust Division przy Departamencie Sprawiedliwości wykazuje pewne cechy postępowania administracyjnego nie jest ono bowiem w swej istocie ani cywilne, ani karne ${ }^{4}$, jego efektem pozostaje natomiast - w zależności od wyników - złożenie pozwu cywilnego lub oskarżenie karne.

1 C. Kosikowski, Publiczne prawo gospodarcze Polski i Unii Europejskiej, LexisNexis, Warszawa 2005, s. 331 i d.; M. Bernatt, Sprawiedliwość proceduralna w postępowaniu przed organem ochrony konkurencji, Wyd. Naukowe WZ, Warszawa 2011, s. 84-91.

2 Por. T. Skoczny, R. Janusz, Postępowanie antymonopolowe jako szczególne postępowanie administracyjne, [w:] Instytucje wspótczesnego prawa administracyjnego. Księga jubileuszowa prof. zw. dra hab. Józefa Filipka, Kraków 2001. Tak również m.in.: K. Strzyczkowski, Nowe prawo konkurencji. Uwagi o projekcie ustawy o ochronie konkurencji i konsumentów, PUG 2000, nr 9, s. 7-8; C. Banasiński, Publicznoprawne aspekty ochrony konkurencji, [w:] C. Banasiński, H. Gronkiewicz-Waltz, K. Pawłowicz, D. Szafrański, M. Wierzbowski, M. Wyrzykowski, Prawo gospodarcze. Zagadnienia administracyjnoprawne, LexisNexis, Warszawa 2003, s. 281; R. Stankiewicz, Likwidacja procedur hybrydowych - krok $w$ dobrym kierunku czy szkodliwy dogmatyzm?, [w:] M. Błachucki, T. Górzyńska (red.), Aktualne problemy rozgraniczenia wtaściwości sąów administracyjnych i powszechnych, Naczelny Sąd Administracyjny, Warszawa 2011, s. 161; D. Sylwestrzak, Postępowanie przed Prezesem Urzędu Ochrony Konkurencji i Konsumentów, PUG 2002, nr 9, s. 23 (autorka nazywa, dookreśla szczególny typ postępowania przed Prezesem UOKiK jako „antymonopolowe postępowanie administracyjne").

3 Z. Kmieciak, Postępowanie w sprawach ochrony konkurencji a koncepcja procedury hybrydowej, PiP 2002, nr 4. Tak również m.in.: J. Krüger, [w:] A. Stawicki, E. Stawicki (red.), Ustawa o ochronie konkurencji i konsumentów. Komentarz, LEX a Wolters Kluwer business, Warszawa 2011, s. 740; K. Róziewicz-Ładon, Postępowanie przed Prezesem Urzędu Ochrony Konkurencji i Konsumentów w zakresie przeciwdziatania praktykom ograniczającym konkurencje, LEX a Wolters Kluwer business, Warszawa 2011, s. 41.

4 Antitrust Division Manual, 4th edition, September 2008, s. III-7. 


\subsubsection{Otoczenie prawne administracyjnego trybu egzekwowania zakazów praktyk ograniczających konkurencję}

\subsubsection{Regulacje Unii Europejskiej}

Materialne reguły prawa ochrony konkurencji zawarte są w przepisach Traktatu o funkcjonowaniu UE (art. 101-109 TFUE). Traktat jedynie marginalnie reguluje natomiast kwestie systemowego wdrażania tych reguł istniejące w nim przepisy mają głównie charakter norm kompetencyjnych. $\mathrm{Na}$ mocy art. 103 ust. 1 TFUE Radzie powierzony został obowiązek wydawania dyrektyw lub rozporządzeń w celu zastosowania zasad ustanowionych w art. 101 i 102, w szczególności chodzi tutaj o przepisy ukierunkowane na zapewnienie poszanowania zakazów praktyk ograniczających konkurencję „przez wprowadzenie grzywien i okresowych kar pieniężnych” [art. 103 ust. 2 lit. a)], ustanowienie szczegółowych zasad stosowania wyłączeń spod zakazu porozumień ograniczających konkurencję [art. 103 ust. 2 lit. b)], określenie roli Komisji i Trybunału Sprawiedliwości UE w stosowaniu postanowień prawa wtórnego przyjętych w realizacji dyspozycji art. 103 ust. 2 [art. 103 ust. 2 lit. d)], określenie relacji między ustawodawstwami krajowymi a regułami konkurencji UE i przepisami zapewniającymi ich wdrożenie [art. 103 ust. 2 lit. e)]. Ponadto art. 105 TFUE gwarantuje Komisji kompetencje w zakresie czuwania nad stosowaniem zakazów praktyk ograniczających konkurencję. Podstawowymi narzędziami, w jakie Traktat wyposaża Komisję, jest wszczęcie postępowania w przypadkach podejrzenia naruszenia tych zasad (z urzędu lub na wniosek państwa członkowskiego), we współpracy $\mathrm{z}$ właściwymi władzami państw członkowskich, oraz - w przypadku potwierdzenia zarzutu naruszenia art. 101 lub 102 TFUE - proponowanie środków właściwych do zaprzestania naruszenia (art. 105 ust. 1 TFUE) lub upoważnienie państw członkowskich do przyjęcia środków niezbędnych w celu zaradzenia sytuacji, których warunki i szczegóły określa art. 105 ust. 2 TFUE.

Rozwinięcie ramowych przepisów Traktatu nastąpiło w aktach prawa wtórnego, którym towarzyszą liczne akty niewiążące (soft law). Najważniejszą regulacją prawa wtórnego pozostaje rozporządzenie Rady (WE) nr 1/2003 z dnia 16 grudnia 2002 r. w sprawie wprowadzenia w życie reguł konkurencji ustanowionych w art. 81 i 82 Traktatu $^{5}$. Akt ten zastąpił pierwsze rozpo-

5 Niniejsza praca dotyczy egzekwowania generalnych reguł ochrony konkurencji, nie ma zatem potrzeby analizowania specjalnych zasad stosowania art. 101 i 102 TFUE w sektorach - por. m.in. rozporządzenie Rady (WE) nr 411/2004 z dnia 26 lutego 2004 r. uchylające rozporządzenie (EWG) nr 3975/87 oraz zmieniające rozporządzenia (EWG) 
rządzenie wdrażające reguły konkurencji - rozporządzenie Rady nr 17/62, które obowiązywało przez ponad czterdzieści lat, do 30 kwietnia 2004 r. Potrzeba zmiany rozporządzenia nr 17/62 związana była przede wszystkim z koniecznością modyfikacji systemu stosowania art. 101 ust. 3 TFUE (wcześniej art. 81 ust. 3 TWE): przekształcenia go z systemu wyłączeń indywidualnych na system legalnego wyjątku na zasadzie samooceny6. W związku $\mathrm{z}$ tą zmianą krajowe organy ochrony konkurencji państw członkowskich uzyskały możliwość bezpośredniego stosowania całego art. 101 TFUE (łącznie z ust. 3). Rozporządzenie $1 / 2003$ ustanawia zasady interwencji publicznej podejmowanej przez Komisję lub organy ochrony konkurencji państw członkowskich UE w przypadku podejrzenia naruszenia zakazów praktyk ograniczających konkurencję z art. 101 i 102 TFUE. W obszarze publicznego wdrażania reguł konkurencji rozporządzenie wskazuje uprawnienia Komisji i organów ochrony konkurencji państw członkowskich w zakresie stosowania reguł konkurencji UE dotyczących praktyk ograniczających konkurencję (art. 4-6), rodzaje decyzji wydawanych w postępowaniu antymonopolowym (art. 7-10), zasady współpracy między państwami członkowskimi i Komisją (art. 11-13), uprawnienia dochodzeniowe Komisji (art. 17-22), kary finansowe za naruszenie zakazów (art. 23-24), terminy przedawnienia naruszeń (art. 25-26), procedury wysłuchania stron i ochrony tajemnicy służbowej (art. 27-29) oraz przepisy odnoszące się do wycofania wyłączenia grupowego (art. 29). Rozporządzenie 1/2003 ustanawia również sankcje za naruszenie art. 101 i 102 TFUE [(art. 23 ust. 2 lit. a) i b)] oraz za niedopełnienie przez przedsiębiorstwa formalnych obowiązków nakładanych na nie w toku postępowania prowadzonego przez Komisję [(art. 23 ust. 1 i ust. 2 lit. c)].

nr 3976/87 i (WE) nr 1/2003 w związku z transportem lotniczym między Wspólnotą a państwami trzecim (Dz. Urz. UE L 68, s. 1); rozporządzenie Rady (WE) nr 1419/2006 z dnia 25 września 2006 r. uchylające rozporządzenie (EWG) nr 4056/86 określające szczegółowe zasady stosowania art. 85 i 86 Traktatu do transportu morskiego oraz zmieniające rozporządzenie (WE) $\mathrm{nr} 1 / 2003 \mathrm{w}$ zakresie rozszerzenia jego zakresu na usługi kabotażu i międzynarodowe usługi trampowe (Dz. Urz. UE L 269, s. 1). Zagadnienia te prezentuję szerzej wraz z T. Skocznym w rozdziale Sektorowe reguty konkurencji, [w:] A. Jurkowska-Gomułka, T. Skoczny, Wspólne reguly konkurencji Unii Europejskiej, IWEP, Warszawa 2010, s. 338-421.

6 Por. pkt 4 preambuły rozporządzenia 1/2003. Problematykę zmian w systemie wyłączeń spod zakazu porozumień ograniczających konkurencję prezentuję szerzej wraz z T. Skocznym w: A. Jurkowska, T. Skoczny, Wytaczenia grupowe spod zakazu porozumień ograniczajacych konkurencję we wspólnotowym i polskim prawie ochrony konkurencji, [w:] A. Jurkowska, T. Skoczny (red.), Wytaczenia grupowe spod zakazu porozumień ograniczających konkurencję we Wspólnocie Europejskiej $i$ w Polsce, Wyd. Naukowe WZ UW, Warszawa 2008, s. 27-74. 
Rozwiązania przyjęte $\mathrm{w}$ rozporządzeniu mają realizować cel w postaci skutecznego i jednolitego stosowania wspólnych reguł konkurencji $\mathrm{UE}^{7}$ przy zachowaniu wartości, jaką jest przestrzeganie podstawowych praw do obrony8. Po pięciu latach obowiązywania rozporządzenia 1/2003 Komisja oceniła, że „zasadniczo poprawiło zdolność Komisji do egzekwowania art. 81 i 82 Traktatu WE [obecnie art. 101 i 102 TFUE - przyp. aut.]. Komisja jest w stanie działać w sposób bardziej aktywny i zdecydowanie przeciwdziałać nieprawidłowościom w konkurencyjności kluczowych sektorów gospodarki”9.

Rozporządzenie 1/2003 stało się podstawą wydania rozporządzenia Komisji nr 773/2004 z dnia 7 kwietnia 2004 r. odnoszącego się do prowadzenia przez Komisję postępowań zgodnie z art. 81 i art. 82 Traktatu WE10; rozporządzenie 773/2004 weszło w życie również w dniu 1 maja 2004 r., zastępując obowiązujące uprzednio rozporządzenia nr 2842/9811, nr 2843/9812 oraz $\mathrm{nr} 3385 / 94^{13}$. Regulacja ta ustanawia szczególowe zasady wszczynania postępowań (art. 2), dochodzeń prowadzonych przez Komisję (art. 3-4), rozpatrywania wniosków (art. 5-9), wykonywania prawa do wysłuchania (art. 10-14), ugody w sprawach kartelowych (art. 10a) ${ }^{14}$, dostępu do akt i ochrony informacji poufnych (art. 15-16).

Dla praktyki wdrażania art. 101 i 102 TFUE niezmiernie ważne pozostają także akty niewiążące Komisji ${ }^{15}$. W zakresie przebiegu postępowania antymonopolowego istotne znaczenie ma obwieszczenie Komisji o postę-

7 Por. pkt 1 preambuly rozporządzenia $1 / 2003$.

8 Por. pkt 5 preambuły rozporządzenia 1/2003.

9 Komunikat Komisji do Parlamentu Europejskiego i Rady: Sprawozdanie z funkcjonowania rozporządzenia $\mathrm{nr}$ 1/2003 (SEK(2009)574), Bruksela, dnia 29 kwietnia 2009, $\operatorname{KOM}(2009) 206$ wersja ostateczna.

10 Dz. Urz. UE L 123, s. 18.

11 Rozporządzenie Komisji (WE) nr 2842/98 z dnia 22 grudnia 1998 r. w sprawie przesłuchania stron w określonych procedurach na podstawie art. 85 i art. 86 Traktatu WE (Dz. Urz. EWG L 354, s. 18).

12 Rozporządzenie Komisji (WE) nr 2843/98 z dnia 22 grudnia 1998 r. w sprawie formy, treści oraz innych szczegółów wniosków i zgłoszeń przewidzianych w rozporządzeniu Rady (EWG) nr 1017/68, (EWG) nr 4056/86 oraz (EWG) nr 3975/87 wprowadzające reguły konkurencji do sektora transportu (Dz. Urz. EWG L 354, s. 22).

13 Rozporządzenie Komisji (WE) nr 3385/94 z dnia 21 grudnia 1994 r. w sprawie formy, treści oraz innych szczegółów wniosków i zgłoszeń przewidzianych w rozporządzeniu Rady nr 17 (Dz. Urz. EWG L 377, s. 28).

14 Regulacja dotycząca ugody (art. 10a) została wprowadzona do rozporządzenia 773/2004 na mocy rozporządzenia Komisji (WE) nr 622/2008 z dnia 30 czerwca 2008 r. zmieniającego rozporządzenie $\mathrm{nr}$ 773/2004 w odniesieniu do prowadzenia postępowań ugodowych w sprawach kartelowych (Dz. Urz. UE 2008 L 171, s. 3).

15 Poza zakresem zainteresowania na potrzeby niniejszej pracy pozostają akty niewiążące dotyczące materialnoprawnych aspektów wdrażania art. 101 i 102 TFUE. 
powaniu w sprawie skarg na naruszenie art. 81 i 82 TWE $^{16}$. Jego celem jest dostarczenie obywatelom UE oraz przedsiębiorstwom wskazówek co do tego, w jaki sposób zainteresować organy ochrony konkurencji naruszeniami reguł konkurencji dotykającymi potencjalnych skarżących ${ }^{17}$. Pierwsza część obwieszczenia poświęcona jest problemowi wyboru między publicznym a prywatnym trybem „ścigania” naruszeń zakazów praktyk ograniczających konkurencję oraz podziałowi kompetencji między krajowymi organami ochrony konkurencji a Komisją. W części drugiej obwieszczenia omówione zostały zasady postępowania ze skargami (wnioskami) wniesionymi na podstawie art. 7 ust. 2 rozporządzenia 1/2003.

W obszarze realizacji zasady równości stron oraz prawa do obrony $\mathrm{w}$ ramach postępowania antymonopolowego istotnym dokumentem jest obwieszczenie Komisji dotyczące zasad dostępu do akt Komisji w sprawach na mocy art. 81 i 82 Traktatu WE, art. 53, 54 i 57 Porozumienia EOG oraz rozporządzenia Rady (WE) nr 139/200418. Obwieszczenie to wskazuje na zasady, na jakich Komisja „powinna umożliwić osobom, przedsiębiorstwom lub związkom przedsiębiorców wyrażenie opinii na temat skierowanych przeciwko nim zastrzeżeń oraz powinna umożliwić dostęp do akt"19.

Określeniu szczegółowych zasad działalności rzecznika ds. wysłuchań poświęcona została decyzja Przewodniczącego Komisji Europejskiej 2011/695/UE z dnia 13 października 2011 r. w sprawie funkcji i zakresu uprawnień urzędnika przeprowadzającego spotkanie wyjaśniające w niektórych postępowaniach z zakresu konkurencji ${ }^{20}$. Celem decyzji jest zapewnienie skutecznego wykonywania praw procesowych zainteresowanych stron i innych osób zainteresowanych postępowaniem antymonopolowym prowadzonym przez Komisję.

„Przedstawieniu praktycznych wskazówek w zakresie prowadzenia postępowań przed Komisją Europejską”, jak również „lepszemu zrozumieniu przebiegu postępowań wyjaśniających prowadzonych przez Komisję" wszystko to zaś w celu „zwiększenia efektywności, jak i zapewnienia wysokiego stopnia przejrzystości i przewidywalności” - służy wydane w 2011 r.

16 Tekst tego komunikatu nie jest publikowany w języku polskim. Commission Notice on the handling of complaints by the Commission under Articles 81 and 82 of the EC Treaty (Dz. Urz. UE 2004 C 101, s. 65).

17 Pkt 5 komunikatu.

18 Dz. Urz. UE 2005 C 325, s. 7.

19 Pkt 1 komunikatu.

20 Dz. Urz. UE 2011 L 275, s. 29. 
zawiadomienie Komisji w sprawie najlepszych praktyk w zakresie prowadzenia postępowań w związku z art. 101 i 102 TFUE21.

Relacjom między krajowymi organami ochrony konkurencji w zakresie wdrażania art. 101 i 102 TFUE poświęcone jest obwieszczenie Komisji o współpracy w ramach Sieci Organów Ochrony Konkurencji22. Dokument precyzuje zasady alokacji spraw dotyczących naruszenia wspólnych reguł konkurencji UE oraz wzajemnej pomocy w prowadzeniu postępowań antymonopolowych. Obwieszczenie ustanawia także szczegółowe zasady zapewniania spójności stosowania art. 101 i 102 TFUE zgodnie z art. 3 ust. 2 rozporządzenia 1/2003. Dokument odnosi się również do sytuacji przedsiębiorstw w przypadku alokowania spraw. Ponadto obwieszczenie ustanawia (nowe) zasady funkcjonowania komitetu doradczego ds. praktyk ograniczających konkurencję (Advisory Commitee).

Obwieszczenie Komisji w sprawie współpracy z sądami krajowymi państw członkowskich w zakresie wdrażania art. 81 i 82 TWE $^{23}$ dotyczy w większym zakresie prywatnego trybu egzekwowania reguł konkurencji i zostanie ono omówione w rozdziale III.

Dodatkowo Komisja upubliczniła (poprzez własną stronę internetową) notę wyjaśniającą na temat swoich kompetencji kontrolnych w zakresie egzekucji wykonania decyzji na podstawie art. 20 ust. 4 rozporządzenia 1/200324.

Jako że elementem modelu egzekwowania prawa pozostają sankcje, należy wspomnieć również o tych aktach niewiążących, które kształtują politykę karania Komisji. Należą do nich: wytyczne z 2006 r. w sprawie metody ustalania grzywien nakładanych na mocy art. 23 ust. 2 lit. a) i b) rozporządzenia $1 / 2003^{25}$ oraz obwieszczenie Komisji z 2006 r. w sprawie zwalniania $\mathrm{z}$ grzywien i zmniejszania grzywien w sprawach kartelowych (tzw. obwieszczenie leniency) ${ }^{26}$.

21 Dz. Urz. UE 2011 C 308, s. 6.

22 Tekst tego komunikatu nie jest publikowany w języku polskim. Commission Notice on cooperation within the Network of Competition Authorities (Dz. Urz. UE 2004 C 101, s. 3).

23 Tekst tego komunikatu nie jest publikowany w języku polskim. Commission Notice on the co-operation between the Commission and the courts of the EU Member States in the application of Articles 81 and 82 EC (Dz. Urz. UE 2004 C 101, s. 54).

24 Explanatory note to an authorisation to conduct an inspection in execution of a Commission decision under Article 20(4) of Council Regulation No 1/2003 [z:] http://ec.europa. eu/competition/antitrust/legislation/explanatory_note.pdf.

25 Dz. Urz. UE 2006 C 210, s. 2.

26 Dz. Urz. UE 2006 C 298, s. 11. 


\subsubsection{Regulacje polskie}

Administracyjne egzekwowanie zakazów praktyk ograniczających konkurencję odbywa się z reguły na podstawie tych samych ustaw, które zawierają materialnoprawne reguły konkurencji. Materialne i formalne zasady prawnej ochrony konkurencji są zazwyczaj zgromadzone w aktach prawnych poświęconych wyłącznie tym zagadnieniom, zdarza się jednak, że są one częścią składową obszerniejszej regulacji 27 . Warto zaznaczyć, że polska ustawa łącząca regulację ochrony konkurencji i ochrony konsumentów jest - jeśli chodzi o stronę przedmiotową - unikatowa, obecnie ustawodawcy rzadko łączą te zagadnienia w jednym akcie. Ustawom o ochronie konkurencji towarzyszą ewentualnie szczegółowe akty wykonawcze dotyczące poszczególnych aspektów proceduralnych postępowania antymonopolowego oraz - w zakresie reguł materialnych - akty odnoszące się do wyłączeń pod zakazu porozumień ograniczających konkurencję.

Wiele państw członkowskich UE ukształtowało procedury antymonopolowe na wzór rozwiązań przyjętych w UE, najpierw w rozporządzeniu nr 17/62, a obecnie w rozporządzeniu 1/2003. Taki model regulacji administracyjnego trybu egzekwowania prawa ochrony konkurencji przyjęty został również w Polsce. Już pierwsza „nowoczesna” ustawa antymonopolowa z 1990 r., zawierała zarówno materialne reguły konkurencji, jak i przepisy proceduralne ${ }^{28}$. W taki sam sposób ukształtowana została również ustawa o ochronie konkurencji i konsumentów z 2000 r. ${ }^{29}$ oraz - stanowiąca jej kolejną emanację - obecnie obowiązująca ustawa o ochronie konkurencji i konsumentów z 2007 r..$^{30}$.

Zakazowi praktyk ograniczających konkurencję poświęcony jest dział II ustawy - jak wynika z jego tytułu polski ustawodawca ustanowił co prawda jeden zakaz antykonkurencyjnych praktyk, jednak poszczególne rozdziały w ramach tego działu ustanawiają zakazy dwóch typów praktyk: porozumień ograniczających konkurencję (rozdział 1, art. 6-8) oraz nadużywania pozycji dominującej (rozdział 2, art. 9). Ustawa zawiera również katalog decyzji, jakie mogą być wydawane w sprawach praktyk ograniczających

27 Na przykład we Francji zagadnienia z zakresu ochrony konkurencji stanowią przedmiot regulacji Kodeksu handlowego (Code de Commerce).

28 Wskazując na pierwszeństwo ustawy z 1990 r. pomijam oczywiście regulacje przyjęte przed II wojną światową oraz ustawę z 1987 r., którą trudno uznać za regulację z zakresu ochrony konkurencji we współczesnym rozumieniu.

29 Ustawa z dnia 15 grudnia 2000 r. o ochronie konkurencji i konsumentów (tekst jedn. Dz. U. $2005 \mathrm{Nr}$ 244, poz. 2080 ze zm.), dalej jako uokik 2000.

30 Ustawa z dnia 16 lutego 2007 r. o ochronie konkurencji i konsumentów (Dz. U. 2007 $\mathrm{Nr} 50$, poz. $331 \mathrm{ze}$ zm.), dalej jako uokik. 
konkurencję (rozdział 3 działu II, art. 10-12). W obszarze uregulowań instytucjonalno-proceduralnych zawartych $\mathrm{w}$ ustawie znalazły się przepisy poświęcone organizacji ochrony konkurencji i konsumentów (dział V, art. 29-46) oraz przepisy ustanawiające zasady postępowania przed Prezesem UOKiK (dział VI, art. 47-1051). W odniesieniu do praktyk ograniczających konkurencję zastosowanie znajdują ogólne przepisy proceduralne, zawarte w rozdziale 1 działu VI ustawy (art. 47-85) oraz przepisy szczególne normujące postępowanie w sprawach antykonkurencyjnych praktyk, zawarte w rozdziale 2 tego działu (art. 86-93). Przepisy ustanawiające sankcje za naruszenie przepisów ustawy, w tym reguł materialnoprawnych, usytuowane są częśsiowo (jeśli chodzi o sankcje niepieniężne) w normach dotyczących decyzji wydawanych $\mathrm{w}$ sprawach praktyk ograniczających konkurencję (art. 10), częściowo zaś (jeśli chodzi o sankcje pieniężne) w dziale VII ustawy poświęconym karom pieniężnym (art. 106-113). Przepisy o karach pieniężnych uzupełnione są tzw. rozporządzeniem o leniency ${ }^{31}$, a także rzadko spotykanym w polskiej praktyce - aktem niewiążącym w postaci wyjaśnień w sprawie ustalania wysokości kar pieniężnych za stosowanie praktyk ograniczających konkurencję ${ }^{32}$. Prezes UOKiK wydał również wyjaśnienia odnoszące się do decyzji zobowiązujących, adresowanych do przedsiębiorców, co do których uprawdopodobnione zostało, że dopuścili się praktyk ograniczających konkurencję 33 .

Rozporządzenia towarzyszące ustawie o ochronie konkurencji i konsumentów są w znacznej części rozporządzeniami wyłączającymi niektóre kategorie porozumień spod zakazu porozumień ograniczających konkurencję, wydanymi na podstawie art. 8. Rozporządzenia te muszą być stosowane również w trybie prywatnoprawnego egzekwowania zakazów

31 Rozporządzenie Rady Ministrów z dnia 26 stycznia 2009 r. w sprawie trybu postępowania w przypadku wystąpienia przedsiębiorców do Prezesa Urzędu Ochrony Konkurencji i Konsumentów o odstąpienie od wymierzania kary pieniężnej lub jej obniżenie (Dz. U. Nr 20, poz. 109).

32 Wyjaśnienia zostały wydane w grudniu 2008 r., opublikowane w Dz. Urz. UOKiK 2009 $\mathrm{Nr}$ 1, poz. 1. M. Stefaniuk kwalifikował wyjaśnienia do kategorii aktów generalnych stosowania prawa - tenże, Zasady wymierzania kar pieniężnych $w$ polskim prawie antymonopolowym, [w:] M. Stahl, R. Lewicka, M. Lewicki (red.), Sankcje administracyjne, LEX a Wolters Kluwer business, Warszawa 2011, s. 330. Krytycznie o wyjaśnieniach jako sposobie kształtowania polityki karania w prawie ochrony konkurencji - M. Król-Bogomilska, Kary pieniężne - gtówne kierunki ewolucji w okresie 20 lat rozwoju polskiego prawa antymonopolowego, EPS 2010, nr 5, s. 11-12.

33 Wyjaśnienia w sprawie wydawania decyzji zobowiązującej w sprawach praktyk ograniczających konkurencję oraz praktyk naruszających zbiorowe interesy konsumentów (Dz. Urz. UOKiK $2012 \mathrm{Nr}$ 1, poz. 2). 
praktyk ograniczających konkurencję. Ponadto obowiązują dwa rozporządzenia normujące organizację systemu ochrony konkurencji, tj. właściwość miejscową i rzeczową delegatur UOKiK oraz kwestię utworzenia sądu antymonopolowego ${ }^{34}$. Poza zakresem zainteresowania niniejszej rozprawy pozostają akty wykonawcze do ustawy i wyjaśnienia odnoszące się do kontroli koncentracji.

\subsubsection{Charakterystyka administracyjnoprawnego trybu egzekwowania prawa ochrony konkurencji}

Naturalne tło dla rozważań nad charakterystyką administracyjnoprawnego trybu egzekwowania prawa ochrony konkurencji stanowi charakterystyka „ogólnego" postępowania administracyjnego. Normy prawa formalnego w zakresie administracyjnego prawa procesowego „regulują tryb powstawania zewnętrznych indywidualnych aktów administracyjnych ustalających lub tworzących pewne uprawnienia czy obowiązki”35. Postępowanie administracyjne jest definiowane jako „regulowany przez prawo ciąg czynności procesowych podejmowanych przez organy administracji publicznej oraz inne podmioty postępowania w celu rozstrzygnięcia sprawy administracyjnej w formie decyzji administracyjnej, jak i ciąg czynności procesowych podjętych w celu weryfikacji decyzji administracyjnej"36. Decyzja administracyjna stanowi „zewnętrzny akt władczy (działanie władcze organu administracji publicznej) skierowany na wywołanie określonych skutków prawnych, określających sytuację prawną konkretnie oznaczonego podmiotu, w konkretnie oznaczonej sprawie (sytuacji)"37. Postępowanie administracyjne ukierunkowane jest na wydanie rozstrzygnięcia w sprawie administracyjnej, tj. sprawie indywidualnie oznaczonego adresata, w której przewidziane jest wydanie decyzji administracyjnej, ma ono charakter służebny wobec materialnego prawa administracyjnego. Postępowanie antymonopolowe wykazuje wymienione cechy charakterystyczne postępowania administracyjnego.

34 Rozporządzenie Ministra Sprawiedliwości z dnia 30 grudnia 1998 r. w sprawie utworzenia sądu antymonopolowego (Dz. U. Nr 166, poz. 1254).

35 E. Ochendowski, Postępowanie administracyjne ogólne, egzekucyjne i sq̨dowoadministracyjne, Toruń 2005, s. 20.

36 B. Adamiak, J. Borkowski, Postępowanie administracyjne i sqdowoadministracyjne, Warszawa 2008, s. 98.

37 E. Ochendowski, Postępowanie administracyjne..., s. 31. 
Przypisując postępowaniu antymonopolowemu charakter postępowania administracyjnego, należy zwrócić uwagę na to, czy regulacje postępowania przed organami ochrony konkurencji realizują funkcje zastrzeżone dla regulacji postępowania administracyjnego. W doktrynie wskazuje się na trzy funkcje prawa o postępowaniu administracyjnym: ochronną, porządkującą, instrumentalną. Funkcja ochronna przewiduje ochronę interesu indywidualnego oraz ochronę interesu społecznego (publicznego) ${ }^{38}$. Ten ostatni jest niejako „wbudowany” w normy materialne prawa administracyjnego, w tym także w regulacje ochrony konkurencji - istnienie ,interesu publicznego" w ochronie konkurencji stanowi podstawową przesłankę podjęcia interwencji przez organy ochrony konkurencji, akcentowaną w art. 1 uokik ${ }^{39}$. Ochrona interesu indywidualnego w ramach postępowania administracyjnego odnosi się przede wszystkim do określenia praw i obowiązków podmiotów prywatnych w toku postępowania oraz zapewnienia gwarancji praworządności działania organów publicznych. W doktrynie podkreśla się również obowiązek uwzględniania przez organy administracyjne interesu indywidualnego $\mathrm{z}$ urzędu, obowiązek ten jest wywodzony m.in. z zasady prawdy obiektywnej nakładającej na organ publiczny, a nie na strony postępowania, obowiązek ustalenia stanu faktycznego sprawy ${ }^{40}$. Pogląd ten znajduje również zastosowanie na gruncie postępowania antymonopolowego.

Funkcja porządkująca norm proceduralnych polega na wyznaczeniu ciągu czynności podejmowanych $\mathrm{w}$ toku postępowania, co gwarantuje nie tylko właściwą organizację procesu, ale także jednolitość działania organów ${ }^{41}$. $\mathrm{Z}$ kolei funkcja instrumentalna prawa o postępowaniu służy takiemu kształtowaniu procesu, aby „stał się on sprawnym narzędziem działania organów orzekających w osiągnięciu celu procesu" 42 . Można przyjąć, że nie tylko tradycyjne instytucje postępowania administracyjnego, ale również pewne odrębności procedury antymonopolowej w stosunku do procedury ogólnej, stanowią, że regulacje postępowania antymonopolowego (czy to na szczeblu krajowym, czy unijnym) realizują zdefiniowane powyżej funkcje: porządkującą i instrumentalną.

38 Art. 7 k.p.a. posługuje się pojęciem „interesu społecznego”, art. 1 uokik mówi natomiast o „interesie publicznym”.

39 Szerzej na temat ochrony interesu publicznego jako celu interwencji administracyjnej zob. rozdział IV.

40 B. Adamiak, J. Borkowski, Postępowanie administracyjne..., s. 25-26.

41 Ibidem, s. 29.

42 Ibidem. 
Wzorcowy administracyjny tryb egzekwowania prawa ochrony konkurencji miałby polegać na powierzeniu sprawy indywidualnego podmiotu powiązanej z materialnymi regułami prawa ochrony konkurencji orzekaniu organu administracyjnego, działającego w oparciu o procedurę przewidzianą dla postępowań administracyjnych i stosującego sankcje charakterystyczne dla regulacji administratywistycznej, przy czym rozstrzygnięcia podjęte przez ten organ podlegają kontroli sądowo-administracyjnej.

Specyfika prawa ochrony konkurencji sprawia, że ta dziedzina wymyka się owemu wzorcowemu trybowi i w ramach administracyjnej - co do zasady - metody egzekwowania zakazów praktyk ograniczających konkurencję pojawiają się elementy charakterystyczne dla innych trybów egzekwowania prawa. Dotyczy to uregulowań proceduralnych postępowań w sprawach praktyk ograniczających konkurencję, w ramach których mogą pojawiać się odwołania do regulacji procedury cywilnej i/lub karnej. Również sankcje stosowane $\mathrm{w}$ prawie antymonopolowym wykazują (lub przypisuje się im) niekiedy inne niż czysto administracyjne cechy ${ }^{43}$. W wielu ustawodawstwach, w tym w polskim, tryb weryfikacji decyzji administracji w sprawach z zakresu ochrony konkurencji, traci czysto administracyjny charakter. Organy egzekwujące prawo ochrony konkurencji w zdecydowanej większości porządków prawnych mają co prawda status organów administracji publicznej, ale są one zróżnicowane pod względem wewnętrznej struktury oraz sposobu działania ${ }^{44}$.

Postępowanie w sprawach praktyk ograniczających konkurencję może być prowadzone na podstawie ogólnych przepisów postępowania administracyjnego, zwykle zawartych w akcie o randze kodeksu, bądź na podstawie szczególnych przepisów proceduralnych włączonych do ustawy o ochronie konkurencji. W tym ostatnim przypadku możliwe jest stosowanie odesłań zewnętrznych do ogólnych przepisów procedury administracyjnej lub nawet do innych procedur (cywilnej, karnej).

Bez względu na odesłania do innych procedur, przepisy regulujące postępowanie antymonopolowe odnoszą się do etapów postępowania i instytucji charakterystycznych dla postępowania administracyjnego, tj.: wszczęcie postępowania, prowadzenie postępowania dowodowego, rozprawy, współdziałanie z innymi organami administracji publicznej, zawieszenia postępowania, umorzenie postępowania i wreszcie - merytoryczne rozstrzygnięcia w postępowaniu (decyzje, ugody).

43 Por. pkt 2.2.4. w niniejszym rozdziale.

44 Por. pkt 2.1.4. w niniejszym rozdziale. 
Wszczęcie postępowania może być dokonywane z urzędu i/lub na wniosek zainteresowanych podmiotów. Według mojej najlepszej wiedzy, nie istnieją systemy ochrony konkurencji z postępowaniem wyłącznie wnioskowym tego rodzaju rozwiązanie podważałoby istotę władczej działalności administracyjnych (publicznych) organów ochrony konkurencji i stanowiłoby przejaw prywatnej ochrony konkurencji. Istnieją natomiast takie modele (systemy) ochrony konkurencji, w których postępowanie ma charakter czysto inkwizycyjny - do takich zalicza się polska procedura antymonopolowa w kształcie przyjętym w ustawie o ochronie konkurencji i konsumentów z 2007 r.

Postępowanie dowodowe dopuszcza z reguły wykorzystanie szeregu środków dowodowych, takich jak dowody z dokumentów, od świadków, z opinii biegłego, z opinii jednostki naukowej, z przesłuchania stron. Wyjątkowo wykorzystywane są inne - charakterystyczne dla procedury karnej - środki, takie jak przeszukanie. Dopuszczalność tych środków stanowi wynik bezpośredniego wpływu regulacji unijnych na prawodawstwo krajowe.

Rozprawy administracyjne stosowane są - przynajmniej w Polsce - bardzo rzadko ${ }^{45}$.

Regulacje dotyczące współdziałania z innymi organami mogą dotyczyć współpracy z organami administracyjnymi lub sądowymi. W sytuacji bezpośredniego stosowania art. 101 i 102 TFUE przez krajowy organ ochrony konkurencji istotne znaczenie zyskała także współpraca międzynarodowa z Komisją Europejską oraz organami (administracyjnymi i sądowymi) z innych państw członkowskich UE. Obowiązek współpracy - w określonych sytuacjach polegający nawet na obowiązku przekazania sprawy (Komisji) - determinuje także treść niektórych przepisów krajowych dotyczących zawieszania i umarzania postępowań antymonopolowych.

Postępowanie administracyjne może kończyć się wydaniem decyzji merytorycznej, ugodą lub umorzeniem. Przez decyzję merytoryczną w ramach postępowania antymonopolowego należy rozumieć decyzję stwierdzającą naruszenie zakazu praktyki ograniczającej konkurencję, decyzję stwierdzającą brak naruszenia zakazu praktyki ograniczającej konkurencję oraz decyzję zobowiązującą. Umorzenie postępowania następuje zazwyczaj w przypadku uznania postępowania za bezprzedmiotowe lub w sytuacji przekazania sprawy do rozpoznania Komisji Europejskiej (organowi ochrony konkurencji w innym państwie członkowskim). Do kuriozalnych rozwiązań

45 Krytycznie o znikomym korzystaniu z rozpraw w postępowaniu przed Prezesem UOKiK - M. Bernatt, Sprawiedliwość proceduralna..., s. 138-140. 
należy zaliczyć praktykowane przez Prezesa UOKiK rozwiązanie ${ }^{46}$, zgodnie z którym umorzenie postępowania - jako bezprzedmiotowego - następuje także wówczas, gdy organ ochrony konkurencji nie potwierdził w postępowaniu faktu naruszenia zakazu praktyk ograniczających konkurencję.

Wśród decyzji kończących postępowanie antymonopolowe na uwagę zasługuje decyzja zobowiązująca (ang. commitment decision), na podstawie której - w przypadku znaczącego uprawdopodobnienia naruszenia zakazu antykonkurencyjnych praktyk - przedsiębiorca (przedsiębiorcy), któremu zarzucana jest praktyka podejmuje wobec organu administracyjnego zobowiązanie do zachowania w określony sposób. Decyzje zobowiązujące nie stanowią co prawda rozstrzygnięcia sprawy co do istoty, ale kończą postępowanie antymonopolowe (aczkolwiek może być ono wznowione, jeśli zobowiązania nie zostaną zrealizowane). Instytucją zbliżoną do decyzji zobowiązującej jest ugoda antymonopolowa ${ }^{47}$. Decyzje zobowiązujące oraz ugody są instytucjami postępowania antymonopolowego, które szczególnie promują efektywność postępowania.

W postępowaniu antymonopolowym stosowane są dwa rodzaje sankcji: nakaz zaniechania praktyki ograniczającej konkurencję oraz kary pieniężne. Co do sankcji pierwszego rodzaju - nakaz zaniechania praktyki ograniczającej konkurencję może wiązać się z zastosowaniem środków zaradczych o charakterze behawioralnym lub strukturalnym. $\mathrm{Z}$ kolei sankcjom pieniężnym, mimo że stosowane są one $\mathrm{w}$ ramach postępowania administracyjnego, przyznaje się $\mathrm{w}$ doktrynie niekiedy charakter sankcji prawnokarnych ${ }^{48}$.

Decyzje wydawane w toku postępowania antymonopolowego podlegają kontroli sądowej. Może ona być realizowana w ramach typowego sądownictwa administracyjnego, może też - tak jak ma to miejsce w Polsce - opierać się na zupełnie odrębnym modelu kontroli, realizowanym poza strukturami sądownictwa administracyjnego ${ }^{49}$.

46 Rozwiązanie to zostało właściwie wymuszone przez ustawodawcę, który w ustawie o ochronie konkurencji i konsumentów z 2007 r. nie przewidział decyzji o niestwierdzeniu praktyki ograniczającej konkurencję (decyzje takie organ mógł wydawać pod rządami uokik z 2000 r.).

47 Por. rozdział V, pkt 5.3.4.4. Instytucja ta nie występuje obecnie w polskim prawie antymonopolowym - przewiduje ją jednak (pod nazwą „dobrowolnego poddania się karze”) projekt nowelizacji ustawy o ochronie konkurencji i konsumentów z dnia 21 listopada 2012 r. (por. art. 1 pkt 6 projektu).

48 Por. pkt 2.2.4.

49 Por. pkt 2.1.4. 


\subsubsection{Wymiar instytucjonalny administracyjnego egzekwowania prawa ochrony konkurencji}

Analiza instytucjonalnych systemów egzekwowania prawa ochrony konkurencji pozwala na wyodrębnienie trzech podstawowych typów 50 :

1) system jednego organu administracyjnego (ang. single administrative authority), w którym organ administracyjny łączy funkcje inkwizycyjne i decyzyjne (orzecznicze) ${ }^{51}$;

2) system dualistycznych organów administracyjnych (ang. dual administrative system), polegający na rozdzieleniu funkcji inkwizycyjnych i orzeczniczych między różne organy administracyjne ${ }^{52}$. Za odmianę tego systemu uznaje się także model, gdzie funkcje inkwizycyjne i orzecznicze realizowane są co prawda w ramach jednego organu administracyjnego, ale przez jego różne, niezależne od siebie komórki organizacyjne - model taki realizuje m.in. niemiecki urząd kartelowy;

3) mieszany system administracyjno-sądowy, polegający na tym, że funkcje inkwizycyjne w postępowaniu antymonopolowym realizuje organ administracyjny, zaś funkcje orzecznicze - organ sądowy 53 .

Organy ochrony konkurencji w państwach członkowskich Unii Europejskiej pełnią podwójną rolę - są one właściwe do egzekwowania zarówno krajowych, jak i traktatowych zakazów praktyk ograniczających konkurencję. Zdecentralizowany system stosowania art. 101 i 102 TFUE nie pozbawia bynajmniej kompetencji do egzekwowania tych zakazów samej Komisji Europejskiej. Komisja jest instytucją UE (art. 13 ust. 1 TUE) powołaną do czuwania nad stosowaniem traktatów i środków przyjmowanych przez instytucje na ich podstawie, nadzoruje ona również stosowanie prawa Unii (art. 17 ust. 1 TUE). Kompetencje Komisji w zakresie wdrażania art. 101

50 Por. pkt 2 obwieszczenia o współpracy w ramach Sieci Organów Ochrony Konkurencji. Szczegółową charakterystykę tych modeli - z odniesieniami do konkretnych porządków prawnych - prezentuje T. Skoczny, Instytucjonalne modele wdrażania regut konkurencji na świecie - wnioski dla Polski, RPEiS 2011, z. 2, s. 77-98.

51 System taki istnieje w następujących państwach członkowskich: Bułgaria, Czechy, Dania, Niemcy, Estonia, Grecja, Włochy, Cypr, Lotwa, Litwa, Węgry, Holandia, Polska, Portugalia, Rumunia, Słowenia, Słowacja, Finlandia, Szwecja, Wielka Brytania - podaję za: pkt 192 Commission Staff Working Papier accompanying the Communication from the Commission to the European Parliament and Council - Report on the functioning of Regulation 1/2003, COM(2009)206 final; dalej jako: raport o stosowaniu rozporządzenia 1/2003.

52 System ten funkcjonuje w Belgii i Luksemburgu - podaję za: pkt 193 raportu o stosowaniu rozporządzenia $1 / 2003$.

53 System taki funkcjonuje w Austrii i Irlandii - podaję za: ibidem. 
i 102 TFUE potwierdzone są dodatkowo przez art. 105 ust. 1 zd. 1 TFUE - z przepisu tego wywodzi się uprawnienia Komisji do bezpośredniego (tj. nie wymagającego regulacji wdrażającej) stosowania traktatowych zakazów praktyk ograniczających konkurencję 54 .

Rozporządzenie 1/2003, ustanawiając kompetencje organów krajowych do egzekwowania prawa ochrony konkurencji, nie zawiera jednak żadnych szczegółowych wytycznych co do ustroju organów ani ich pozycji w systemie krajowej administracji publicznej. Prawodawca nałożył na państwa członkowskie UE obowiązek wyznaczenia jednego lub kilku organów ochrony konkurencji odpowiedzialnych za stosowanie art. 101 i 102 TFUE „w sposób, który zapewnia skuteczne wykonanie przepisów rozporządzenia [1/2003 przyp. aut.]" (art. 35 ust. 1 zd. 1 rozporządzenia 1/2003). Należy podkreślić, że państwom członkowskim pozostawiona została swoboda wyboru co do tego, czy krajowe organy ochrony konkurencji mają status organów administracyjnych, czy sądowych (por. art. 35 ust. $1 \mathrm{zd} .2$ rozporządzenia $1 / 2003)$. W sytuacji, gdy system instytucjonalny ochrony konkurencji obejmuje zarówno organy administracyjne, jak i sądowe, organy te mogą mieć różne uprawnienia i funkcje (art. 35 ust. 2 rozporządzenia 1/2003).

Niemal wszystkie państwa członkowskie UE wyznaczyły jako krajowe organy ochrony konkurencji w rozumieniu rozporządzenia 1/2003 organy administracyjne, przy czym - zdaniem Komisji - dominującym modelem instytucjonalnym ochrony konkurencji pozostaje system jednego organu administracyjnego ${ }^{55}$. W raporcie na temat stosowania rozporządzenia 1/2003 znalazło się nawet stwierdzenie, że także system egzekwowania reguł konkurencji na poziomie Unii Europejskiej (kompetencje inkwizycyjne i decyzyjne przyznane Komisji) „odpowiada wyborowi instytucjonalnemu w większości państw członkowskich" 56 .

Nawet jeśli państwa członkowskie UE wyznaczyły do stosowania rozporządzenia $1 / 2003$ organy administracyjne, to sposób organizacji i działania tych organów w poszczególnych państwach członkowskich pozostaje jednak bardzo zróżnicowany. Organy ochrony konkurencji mają charakter monokratyczny (np. polski organ) lub kolektywny (np. Komisja Europejska).

W zakresie administracyjnego egzekwowania reguł konkurencji duże znaczenie ma współpraca organów ochrony konkurencji, do czego skłania - na poziomie międzynarodowym - zasada eksterytorialnego stosowania prawa

54 Por. wyrok Trybunału z dnia 14 grudnia 2000 r. w sprawie C-344/98 Masterfoods Ltd i HB Ice Cream Ltd oraz Ice Cream Ltd i Masterfoods Ltd (Zb. Orz. 2000, s. I-11369), pkt 46.

55 Pkt 192 raportu o stosowaniu rozporządzenia 1/2003.

56 Pkt 54 raportu o stosowaniu rozporządzenia 1/2003. 
antymonopolowego, zaś na poziomie UE - model zdecentralizowanego stosowania wspólnych reguł konkurencji UE. Międzynarodowa współpraca organów ochrony konkurencji realizowana jest $\mathrm{z}$ reguły w trzech wymiarach: (1) informacyjnym, (2) konsultacyjnym, (3) koordynacyjnym.

Na poziomie międzynarodowym (pozaunijnym) współpraca w dziedzinie wdrażania reguł konkurencji odbywa się w ramach Międzynarodowej Sieci Konkurencji (ang. International Competition Network, ICN) ${ }^{57}$, Komitetu Konkurencji Organizacji Współpracy Gospodarczej i Rozwoju (ang. Competition Committee of Organisation of Economic Co-operation and Development $)^{58}$, Światowej Organizacji Handlu (ang. World Trade Organization).

Obowiązek współpracy między Komisją a państwami członkowskimi UE (organami ochrony konkurencji w tych państwach) w zakresie egzekwowania traktatowych reguł konkurencji ustanawia art. 105 ust. 1 zd. 2 TFUE, zaś precyzuje (jako zasadę „ścisłej współpracy”) - art. 11 ust. 1 rozporządzenia $1 / 2003^{59}$. Postanowienia o współpracy organów ochrony konkurencji, realizującej się w sferze wymiany informacji (art. 11 ust. 2-4 oraz art. 12), konsultacji (art. 11 ust. 5) ${ }^{60}$ oraz alokacji spraw (art. 11 ust. 6) ${ }^{61}$ znalazły rozwinięcie w obwieszczeniu Komisji o współpracy w ramach Sieci Organów Ochrony Konkurencji. Współpraca ta została zinstytucjonalizowana w postaci Europejskiej Sieci Konkurencji (ang. European Competition Network, ECN). Współpraca w ramach ECN „przewyższyła oczekiwania i dała «strukturalny impuls» do wdrażania wspólnotowych reguł konkurencji”'62.

Bez względu na przyjęty model instytucjonalny administracyjnego egzekwowania reguł konkurencji, zasada państwa prawa wymaga zapewnienia możliwości sądowej weryfikacji decyzji organów administracyjnych, w tym także organów ochrony konkurencji. Po pierwsze możliwa jest tradycyjna kontrola sądowo-administracyjna, ograniczona do aspektów formalnych (proceduralnych) decyzji. Po drugie kontrola sądowa może mieć charakter merytoryczny i wówczas wykonywana jest przez sądy cywilne. Ten ostatni

57 http://www.internationalcompetitionnetwork.org/.

58 www.oecd.org/competition.

59 Por. także pkt 15 preambuły do rozporządzenia 1/2003.

60 Por. pkt 43-49 obwieszczenia Komisji o współpracy w ramach Sieci Organów Ochrony Konkurencji.

61 Por. pkt 5-30 oraz pkt 50-57 obwieszczenia Komisji o współpracy w ramach Sieci Organów Ochrony Konkurencji.

62 Pkt 183 raportu o stosowaniu rozporządzenia 1/2003 oraz powołany w nim referat E. Paulisa i E. de Smijtera, Enhanced enforcement of the EC competition rules since 1 May 2004 by the Commission and the NCA's. The Commission's view (paper for the IBA Conference on the Antitrust Reform in Europe, 9-11 March 2005). 
model jest pożądany szczególnie tam, gdzie (jak w polskim systemie ochrony konkurencji) monokratyczny organ ochrony konkurencji łączy funkcje inkwizycyjne i orzecznicze - wówczas decyzja administracyjna pełni funkcje swego rodzaju ,aktu oskarżenia” rozpatrywanego przez sąd. Co prawda w raporcie ze stosowania rozporządzenia nr 1/2003 system niezależnej kontroli sądowej decyzji podejmowanych przez organ administracyjny łączący funkcje inkwizycyjne i orzecznicze został oceniony jako „w pełni zgodny z orzecznictwem zarówno sądów wspólnotowych, jak i Europejskiego Trybunału Praw Człowieka"63, jednak model ten obarczony jest wadą - koncentrując się na ocenie merytorycznej sprawy - sąd cywilny ignoruje w zasadzie uchybienia proceduralne powstałe w postępowaniu antymonopolowym przed organem administracyjnym, w efekcie czego błędy te pozostają poza jakąkolwiek kontrolą sądową ${ }^{64}$.

\subsection{Prawnokarny tryb egzekwowania zakazów praktyk ograniczających konkurencję}

\subsubsection{Przesłanki kryminalizacji prawa ochrony konkurencji}

Kryminalizacja praktyk antykonkurencyjnych rozumiana jako obwarowanie zakazów takich praktyk sankcjami (stricte) karnymi (zwłaszcza karą pozbawienia wolności), realizuje podstawową funkcję prawa karnego gospodarczego, tj. funkcję ochronną wobec obrotu gospodarczego, czyli stosunków gospodarczych polegających na wytwarzaniu i wymianie usług i dóbr materialnych. W piśmiennictwie podkreśla się, że ochroną taką objęci są wszyscy uczestnicy obrotu, zarówno podmioty profesjonalne (przedsiębiorcy), jak i podmioty nieprofesjonalne (konsumenci) ${ }^{65}$. W nieco węższym ujęciu można przyjąć, że kryminalizacja zachowań antykonkurencyjnych należy do prawa karnego przedsiębiorstw (prawa karnego biznesu), które to pojęcie

63 Pkt 55 raportu o stosowaniu rozporządzenia 1/2003.

64 Problematyka ta jest w ostatnich latach przedmiotem żywej dyskusji w polskim piśmiennictwie - por. m.in. B. Turno, Model sq̨dowej kontroli decyzji Prezesa Urzędu Ochrony Konkurencji i Konsumentów, PiP 2012, nr 10, s. 33-47; A. Stawicki, Competence of Common Courts in Poland in Competition Matters, YARS 2012, vol. 5(6), s. 57-71; M. Bernatt, T. Skoczny, Publicznoprawne wdrażanie regut konkurencji w Polsce. Czas na zmiany?, [w:] H. Gronkiewicz-Waltz, K. Jaroszyński (red.), Europeizacja publicznego prawa gospodarczego, C. H. Beck, Warszawa 2011, s. 1-14.

65 Tak A. Zientara, Przestęstwo nadużcia zaufania z art. 296 kodeksu karnego, Oficyna a Wolters Kluwer business, Warszawa 2010, s. 37. 
„odnosi się do przestępstw popełnianych przy wykonywaniu działalności przedsiębiorstw prywatnych i publicznych"66.

W piśmiennictwie podkreśla się, że regulacje karne w ramach systemu ochrony konkurencji powinny realizować kilka podstawowych wytycznych: po pierwsze regulacje te powinny być skutecznym mechanizmem maksymalizacji dobrobytu społecznego (zasada efektywności), po drugie sankcje karne powinny być orzekane tylko za te działanie, za które sprawca jest odpowiedzialny (zasada odpowiedzialności), po trzecie kary powinny być proporcjonalne i sprawiedliwe ${ }^{67}$.

Należy zaznaczyć, że kryminalizacja prawa ochrony konkurencji może następować w dwóch nurtach: pierwszym $\mathrm{z}$ nich jest odpowiedzialność osób fizycznych zaangażowanych w określony sposób w zakazane praktyki (jest to nadal dominujący prawnokarny aspekt ochrony konkurencji), drugim odpowiedzialność karna podmiotów zbiorowych ${ }^{68}$. Rozważania niniejszego podrozdziału koncentrują się na pierwszym nurcie.

W. P. J. Wils przedstawia pięć argumentów przemawiających za stosowaniem kary pozbawienia wolności wobec jednostek w związku z przyczynieniem się przez nie do podjęcia i realizacji antykonkurencyjnych praktyk przez firmy; argumenty te nie są jednak oryginalne w tym sensie, że pojawiają się również u wielu innych autorów. Pierwszym z argumentów najczęściej przewijającym się w piśmiennictwie jest niedostateczny efekt odstraszający kar nakładanych w ramach administracyjnego trybu egzekwowania prawa ochrony konkurencji. W. P. J. Wils obliczył, że rzeczywiście odstraszający efekt miałyby kary administracyjne wynoszące ok. $150 \%$ rocznego obrotu produktami należącymi do rynku właściwego, na którym funkcjonowała antykonkurencyjna praktyka ${ }^{69}$. Maksymalne wielkości kar przewidziane w poszczególnych ustawodawstwach antymonopolowych nie tylko nie realizują takiego postulatu (choć zmiana ustawowych progów wydaje się stosunkowo niewielkim problemem), ale i realizować nie mogą, gdyż wielu przedsiębiorców nie byłoby w stanie unieść ciężaru takiej kary, co spowodowałoby poważne „skutki uboczne” zastosowania sankcji właściwych dla

66 O. Górniok, Pojęcie karnego prawa gospodarczego i jego szczególne problemy, [w:] O. Górniok (red.), Prawo karne gospodarcze, C. H. Beck, Warszawa 2003, s. 3.

67 P. Whelan, A Principled Argument for Personal Criminal Sanctions As Punishment under EC Cartel Law, The Competition Law Review 2007, vol. 4(1), s. 19-20.

68 Por. pkt 2.2.2. w niniejszym rozdziale.

69 Szczegółowe wyliczenia przedstawione są w: W. P. J. Wils, The Optimal Enforcement of EC Antitrust Law, Kluwer Law International, 2002, s. 188-237. W piśmiennictwie europejskim zastrzega się, że wyliczenia W. P. J. Wilsa zostały przeprowadzone głównie w oparciu o doświadczenia amerykańskie, które niekoniecznie odpowiadają realiom europejskim - por. P. Whelan, A Principled Argument..., s. 26. 
trybu administracyjnego ${ }^{70}$. Co więcej poniesienie dotkliwych kar pieniężnych osłabi przedsiębiorcę, a przez to prawdopodobnie osłabi konkurencję ${ }^{71}$. Słusznie wskazuje się również, że w wielu przypadkach kara zostanie niejako „spłacona” przedsiębiorcy przez konsumentów w przyszłości ${ }^{72}$.

Za stosowaniem kary pozbawienia wolności wobec jednostek według W. P. J. Wilsa przemawia również fakt, że nałożenie kary na przedsiębiorcę niekoniecznie zniechęci osoby fizyczne do podejmowania antykonkurencyjnych praktyk w przyszłości, zwłaszcza wówczas, gdy wykrycie zakazanej praktyki nastąpi już po tym, gdy pracownik opuści określone miejsce pracy. Również inni autorzy wskazują na bardzo ograniczony wybór środków umożliwiających przedsiębiorcom wpływ na pracowników w celu zapobiegania angażowania firmy w antykonkurencyjne praktyki ${ }^{73}$.

Zdaniem W. P. J. Wilsa istnienie kary pozbawienia wolności sprzyja rozwojowi programów leniency, gdyż w warunkach zagrożenia taką sankcją osoby fizyczne są znacznie bardziej chętne do kooperowania $z$ organami ochrony konkurencji co do wykrywania zakazanych praktyk, nawet jeśli wspólpraca ta jest sprzeczna $z$ interesem ich pracodawcy ${ }^{74}$. D. I. Baker uważa przy tym, że chęć współpracy motywowana jest zarówno strachem przez więzieniem, jak i chęcią zemsty, np. wobec byłego pracodawcy ${ }^{75}$. Dobrowolna współpraca pozostaje zresztą szczególnie istotna w świetle tego, że standardem postępowania karnego jest wolność od samooskarżenia.

Czwarty wskazany przez W. P. J. Wilsa argument sprowadza się do stwierdzenia, że kara pozbawienia wolności stanowi po prostu jedną z najbardziej efektywnych sankcji odstraszających. Świadczyć o tym ma chociażby fakt, że uczestnicy międzynarodowych karteli rezygnowali z operowania na rynku amerykańskim właśnie w obawie przed realnym zagrożeniem karą pozbawienia wolności ${ }^{76}$.

70 W. P. J. Wils, Is Criminalization of EU Law The Answer, World Competition 2005, vol. 28(2), s. 117-159.

71 G. J. Werden, S. D. Hammond, B. A. Barnett, Deterrence and detection of cartels: using all the tools and sanctions, Antitrust Bulletin 2011, vol. 56(2), s. 212.

72 T. Calvani, T. H. Calvani, Cartel sanctions and deterrence, Antitrust Bulletin 2011, vol. 56(2), s. 193.

73 Por. P. Whelan, A Principled Argument..., s. 23-24.

74 Tak również G. J. Werden, S. D. Hammond, B. A. Barnett, Deterrence and detection..., s. 215.

75 D. I. Baker, The Use of Criminal Law Remedies to Deter and Punish Cartels and Bid-Rigging, George Washington Law Review 2001, vol. 69.

76 Opinia ta jest często powtarzana przez amerykańskich urzędników - por. m.in. wystąpienie T. O. Barnetta (Assistant Attorney General, Antitrust Division, U.S. Department of Justice), Criminal Enforcement of Antitrust Laws: The U.S. Model, Fordham Compe- 
Piąty argument prezentowany przez W. P. J. Wilsa odnosi się do silnego, negatywnego moralnie nacechowania kary pozbawienia wolności, co wzmacnia efekt odstraszający sankcji. Ta przesłanka kryminalizacji w zasadzie nie może leżeć u podstaw sankcji nakładanych na przedsiębiorców jako jednostki organizacyjne (podmioty zbiorowe), jednak zbliżonej motywacji w przypadku sankcji korporacyjnych należy upatrywać w obawie przed „czarnym PR-em” firm, przeciwko którym toczy się postępowanie karne (w mniejszym stopniu „Zwykłe” administracyjne postępowanie antymonopolowe). Wskazując na negatywny wymiar moralny naruszeń prawa ochrony konkurencji w piśmiennictwie podkreśla się, że kartele uderzają w kluczowe wartości gospodarki wolnorynkowej ${ }^{77}$. Moralne potępienie dla karteli jest szczególnie widoczne w piśmiennictwie amerykańskim, gdzie wskazuje się na przykład, że „kartele służą wyłącznie obrabowaniu konsumentów z odczuwalnych błogosławieństw konkurencji" 78 . Inne są natomiast odczucia opinii publicznej co do naganności karteli np. w Wielkiej Brytanii czy Australii. Dotychczasowe europejskie doświadczenia w orzekaniu kar pozbawienia wolności (kary stosunkowo niskie, zazwyczaj w zawieszeniu) skłaniają niektórych autorów do wniosku, że przestępstwa monopolizacji rynku jako przestępstwa „białych kołnierzyków" są jednak traktowane znacznie łagodniej niż klasyczne „przestępstwa ulicy”79, co - w moim przekonaniu - może nieco osłabiać argumenty prokryminalizacyjne odwołujące się do moralności.

Należy jeszcze wspomnieć o jednym argumencie przemawiającym za kryminalizacją prawa ochrony konkurencji, a właściwym dla państw europejskich: jest nim chęć (i konieczność) zapewnienia zgodności procedur publicznego egzekwowania zakazów praktyk ograniczających konkurencję ze standardami ustanowionymi w art. 6 ust. 1 EKPC ${ }^{80}$.

Równie uzasadniony wydaje mi się argument prawnoporównawczy, odwołujący się do istniejących regulacji karnego prawa gospodarczego: skoro w systemie prawnym przewidziana jest odpowiedzialność karna za czyny

tition Law Institute's Annual Conference on International Antitrust Law and Policy, New York, 14 września 2006 r., dostępne pod adresem: http://www.justice.gov/atr/public/ speeches/218336.htm. T. Calvani i T. H. Calvani wskazują jednak, że opinia ta nie znalazła potwierdzenia w żadnych oficjalnych danych, choć jednocześnie autorzy ci podkreślają, że są świadomi poufności danych konstytuujących tę informację - por. T. Calvani, T. H. Calvani, Cartel sanctions..., s. 193.

77 P. Whelan, A Principled Argument..., s. 29.

78 G. J. Werden, S. D. Hammond, B.A. Barnett, Deterrence and detection..., s. 208.

79 M. E. Curtis, J. McNally, The Classic Cartel - Hatchback Sentence, The Competition Law Review 2007, vol. 4(1), s. 41-50.

80 W. Moshel, Fines in European competition law, E.C.L.R. 2011, vol. 32(7), s. 374. Por. także pkt 2.2.4. w niniejszym rozdziale. 
o skutkach zbliżonych lub nawet mniej poważnych niż (przynajmniej niektóre) praktyki antykonkurencyjne, tym ostatnim należy przypisać porównywalne sankcje penalne ${ }^{81}$.

Kryminalizacji prawa ochrony konkurencji ma również swoich przeciwników. Wskazują oni m.in., że standardy dowodowe w postępowaniu karnym uczynią niemożliwym dowiedzenie popełnienia przestępstwa, którego istotą jest antykonkurencyjna praktyka ${ }^{82}$ - ten argument wydaje się mniej istotny w przypadku przestępstw kartelowych, natomiast znajduje on - w moim przekonaniu - swoje potwierdzenie w odniesieniu do praktyk nadużywania pozycji dominującej. Innym argumentem przeciwko kryminalizacji prawa ochrony konkurencji pozostają wysokie koszty realizacji karnych aspektów polityki konkurencji.

\subsubsection{Problem odpowiedzialności karnej podmiotów abstrakcyjnych (zbiorowych)}

W nurcie kryminalizacji prawa ochrony konkurencji zagadnieniem kontrowersyjnym pozostaje prawnokarna odpowiedzialność abstrakcyjnych podmiotów prawnych, tj. zarówno osób prawnych, jak i jednostek organizacyjnych pozbawionych osobowości prawnej, ale występujących (aktywnych) w obrocie. W polskim języku prawniczym i prawnym odpowiedzialność takich podmiotów określana jest jako odpowiedzialność podmiotów zbiorowych, natomiast w literaturze anglosaskiej - jako korporacyjna odpowiedzialność karna (corporate criminal liability). Na potrzeby ogólnych rozważań nad kryminalizacją prawa ochrony konkurencji będę posługiwała się zamiennie wszystkimi wskazanymi terminami, zdając sobie jednocześnie sprawę z tego, że żaden $\mathrm{z}$ nich nie jest idealnym, choćby ze względu na to, że na poziomie werbalnym wydaje się nie uwzględniać, że odpowiedzialność karna, o jakiej mowa, może być ponoszona również przez przedsiębiorcę działającego w formie jednoosobowej działalności gospodarczej (samozatrudnienia).

Co prawda prawo rzymskie hołdowało zasadzie societas delinquere non potest, jednak z odpowiedzialnością podmiotów zbiorowych (takich jak miasta) mieliśmy do czynienia już w średniowieczu. Następnie ten typ odpowiedzialność zniknął, przynajmniej w Europie, ok. XVIII w., aby pojawić we

81 Tak m.in. M. Król-Bogomilska, Kary pieniężne w prawie antymonopolowym, KiK, Warszawa 2001, s. 257-258. Autorka słusznie porównuje praktyki antykonkurencyjne, zakazane prawem antymonopolowym, m.in. z czynami nieuczciwej konkurencji, które na mocy ustawy o zwalczaniu nieuczciwej konkurencji są przestępstwami.

82 P. Massey, Criminal Sanctions for Competition Law: A Review of Irish Experiences, The Competition Law Review 2004, vol. 1(1), s. 30. 
współczesnej formie na powrót w wieku XX. U podstaw odpowiedzialności podmiotów zbiorowych leży przekonanie, że dla zapobiegania przestępczości konieczna jest nie tylko odpowiedzialność osób indywidualnych, ale także podmiotów współtworzących „kryminogenny kontekst społeczny”, który przyczynił się do inkryminowanych zachowañ ${ }^{83}$. Aby uczynić zadość potrzebie rozszerzenia kręgu podmiotów, na których spoczywa odpowiedzialność karna, przyjmuje się jeden z trzech zasadniczych modeli korporacyjnej odpowiedzialności karnej: model odpowiedzialności zastępczej (vicarious liability), model odpowiedzialności identyfikacyjnej (określany również jako model alter ego) oraz model bezpośredniej odpowiedzialności karnej podmiotów zbiorowych (odpowiedzialność za czyny własne). Współcześnie coraz częściej pojawiają się regulacje ustanawiające odpowiedzialność podmiotów zbiorowych, zwłaszcza w takich dziedzinach prawa, jak: prawo ochrony środowiska, prawo o publicznym obrocie papierami wartościowymi czy prawo finansowe ${ }^{84}$. Problem przypisywania odpowiedzialności karnej podmiotom abstrakcyjnym doskonale obrazuje tytuł artykułu autorstwa J. C. Coffee, wskazujący, że jednostki organizacyjne „nie mają duszy, którą można potępić, ani ciała, które można kopać" 85 . Podmioty abstrakcyjne nie mogą być w zasadzie obarczone ani złym zamiarem (mens rea), ani świadomością bezprawności czynu ${ }^{86}$.

Korporacyjna odpowiedzialność karna za naruszenia prawa konkurencji ma zarówno swoich zwolenników, jak i przeciwników. Ci pierwsi wskazują, że korporacyjna odpowiedzialność karna różni się od „zwykłej” odpowiedzialności finansowej, ponieważ odpowiedzialność karna „stygmatyzuje” przedsiębiorcę ${ }^{87}$. Obecnie karna odpowiedzialność korporacyjna przewidziana jest m.in. w prawie ochrony konkurencji Australiii ${ }^{88}$ i Danii ${ }^{89}$. W polskiej dok-

83 R. Molski, Sankcje penalne w prawie kartelowym, [w:] Z. Ofiarski (red.), Księga jubileuszowa z okazji 15-lecia Wydziału Prawa i Administracji Uniwersytetu Szczecińskiego, Wyd. Naukowe USz, Szczecin 2004, s. 520-521.

84 W wielu państwach członkowskich Unii Europejskiej, w tym także w Polsce, regulacje dotyczące odpowiedzialności karnej podmiotów zbiorowych przyjęte zostały w wykonaniu obowiązków nałożonych na państwa przez Konwencję o ochronie interesów finansowych Wspólnot Europejskich, przyjętą w 1995 r. oraz przez Protokoły nr I i II do tej Konwencji.

85 J. C. Coffee, "No Soul To Damn: No Body To Kick": An Unscandalized Inquiry into the Problem of Corporate Punishment, Michigan Law Review 1981, vol. 79, s. 386.

86 R. Molski, Sankcje penalne..., [w:] Z. Ofierski (red.), Księga jubileuszowa..., s. 518-519.

87 G. J. Werden, S.D. Hammond, B.A. Barnett, Deterrence and detection..., s. 217.

88 Por. sekcja 44ZZRF, 44ZZRG, 44ZZRH Competition and Consumer Act 2010.

89 Por. sekcja 23(3) duńskiej ustawy o ochronie konkurencji (ustawa nr 1027 z dnia 21 sierpnia 2007 ze zm.). 
trynie wprowadzenie odpowiedzialności karnej osób prawnych za praktyki antykonkurencyjne postulowała już kilka lat temu M. Król-Bogomilska ${ }^{90}$ : dla relacji publicznego i prywatnego trybu egzekwowania prawa ochrony konkurencji szczególne znaczenie ma powołany przez tę autorkę argument, iż „zastosowanie w polskim systemie prawnym odpowiedzialności karnej osób prawnych sprzyjałoby również lepszemu zabezpieczeniu praw przedsiębiorców pokrzywdzonych w wyniku praktyk ograniczających konkurencję" ${ }^{91}$ (co miałoby nastąpić choćby dzięki nawiązce uiszczanej przez sprawcę praktyki antykonkurencyjnej na rzecz pokrzywdzonego ${ }^{92}$ ).

Przeciwnicy odpowiedzialności korporacyjnej podnoszą z kolei argument, że praktyki antykonkurencyjne wynikają z działalności jednostek i to one powinny podlegać sankcjom.

Obserwowany nurt współczesnej kryminalizacji prawa ochrony konkurencji wydaje się koncentrować raczej na odpowiedzialności osób fizycznych - częściowo wynika to z trudności, także „mentalnościowych”, w akceptacji odpowiedzialności karnej podmiotów abstrakcyjnych, częściowo zaś - w moim przekonaniu - z faktu, że kary pieniężne nakładane w postępowaniu przed organami ochrony konkurencji pełnią w większości systemów funkcje quasi-karne; obecnie do rzadkości należą poglądy odmawiające karom antymonopolowym funkcji represyjnej.

\subsubsection{Definicja przestępstwa monopolizacji rynku (przestępstwa kartelowego)}

Egzekwowanie prawa konkurencji za pomocą norm stricte prawnokarnych wymaga ukonstytuowania pojęcia przestępstwa, którego istotą jest naruszenie zakazów antykonkurencyjnych praktyk. Wybory legislacyjne dokonane przez państwa, które zdecydowały się na kryminalizację prawa ochrony konkurencji, jak również poglądy doktryny ${ }^{93}$, wskazują na to, że odpowiedzialność prawnokarna jest realizowana głównie wobec najpoważniejszych antykonkurencyjnych porozumień - stąd w różnych porządkach prawnych definiowane jest przede wszystkim przestępstwo kartelowe, którego przedmiotem są porozumienia ograniczające konkurencję w „najpoważniejszy”, „najtwardszy” sposób. Za takim wyborem przemawia również fundamentalna dla prawa karnego zasada nullum crimen sine lege - nawet, jeśli pojęcie kartelu nie jest jednoznacznie zdefiniowane, to ocena negatywnych anty-

\footnotetext{
90 M. Król-Bogomilska, Kary pieniężne..., s. 258-260.

91 Ibidem, s. 259.

92 Ibidem, s. 260.

93 Por. pkt 2.2.5. w niniejszym rozdziale.
} 
konkurencyjnych skutków porozumień horyzontalnych jest jednoznaczna i nie budzi takich kontrowersji, jak ocena wpływu na konkurencję praktyk jednostronnych (nadużywania pozycji dominującej), czy nawet porozumień wertykalnych. Przepisy ustanawiające zakazy praktyk ograniczających konkurencję nie są szczególnie precyzyjne, a ocenę antykonkurencyjnych praktyk, zwłaszcza nadużywania pozycji dominującej, w znacznym zakresie kształtuje orzecznictwo, które w wielu porządkach prawnych, również w Polsce, nie może być - w myśl art. 87 ust. 1 Konstytucji RP - źródłem prawa powszechnie obowiązującego, nie może zatem konstytuować znamion przestępstwa ${ }^{94}$.

Kategoria najpoważniejszych porozumień ograniczających konkurencję (hardcore cartels) ma swoje ugruntowane miejsce w doktrynie antymonopolowej, odwołuje się do niej również orzecznictwo. Kategoria ta stała się ważnym kryterium stosowania wielu narzędzi polityki konkurencji (np. programów leniency $)^{95}$, czy wreszcie - kształtowania nurtu ekonomizacji prawa konkurencji. Mimo tego, praktycznie żaden ustawodawca nie zdecydował się na definiowanie „najtwardszych” karteli jako specyficznej podgrupy porozumień ograniczających konkurencję. Kryminalizacja prawa ochrony konkurencji stawia w tym zakresie nowe wyzwania, ponieważ ustanowienie odpowiedzialności karnej wymaga stypizowania przestępstwa kartelu i określenia jego znamion.

Jak pokazują doświadczenia brytyjskie ${ }^{96}$, punktem odniesienia dla wyznaczenia sposobu zachowania potencjalnego sprawcy przestępstwa kartelowego, może być definicja kartelu wypracowana w 1998 r. na forum OECD, zgodnie z którą kartelem jest „antykonkurencyjne porozumienie, antykonkurencyjna uzgodniona praktyka lub antykonkurencyjne ustalenie podjęte przez konkurentów w celu ustalania cen, uzgadniania ofert przetargowych (zmowy przetargowe), wprowadzania ograniczeń produkcji lub sprzedaży bądź podziału rynków poprzez alokację klientów, dostawców, terytoriów lub szczebla obrotu (...), a zawierające najbardziej skandaliczne (egregious) naruszenia prawa konkurencji”97.

94 Tak A. Stawicki, B. Turno, [w:] Proponowane przez UOKiK $i$ inne pożadane zmiany w ustawie o ochronie konkurencji z 2007 r. Opinia Grupy Roboczej ds. nowelizacji uokik z 2007 r. przy Centrum Studiów Antymonopolowych i Regulacyjnych (CARS UW), Warszawa, czerwiec 2012, s. 51-52 (dokument dostępny pod adresem: http://www.cars.wz.uw.edu. pl/doradztwo/pdf/Opinia_GR_CARS-fin.pdf).

95 Nie dotyczy to polskiego systemu ochrony konkurencji, gdzie program leniency stosowany jest wobec wszystkich porozumień.

96 Por. § 188 Enterprise Act 2002.

97 Recomendation Concerning Effective Action Against Hard Core Cartels, OECD Council 1998, part A2(a). 
Definicją przestępstwa kartelowego może być objęte zarówno samo zawarcie, jak i wykonanie (organizacja) kartelu (czynności, które mogą być kwalifikowane jako sprawstwo) oraz przyczynienie się do zawarcia lub wykonania kartelu (które może być postrzegane jako podżeganie lub pomocnictwo). Taki model przestępstwa kartelu został przyjęty w Wielkiej Brytanii. Z kolei ustawodawca australijski ustanowił odpowiedzialność karną m.in. za zawarcie i wdrożenie umów lub postanowień kartelowych ${ }^{98}$. Ustawodawca francuski penalizuje już samą konceptualizację zakazanych praktyk kartelowych.

Immanentnym elementem definicji przestępstwa kartelowego jest wskazanie postaci i stopnia winy. Ustawodawca australijski w odniesieniu do karnej odpowiedzialności korporacyjnej wskazał, że wystarczająca jest wiedza (knowledge) lub belief99; z kolei ustawodawca francuski wymaga od oskarżonego osobistego i decyzyjnego zaangażowania w zakazaną praktykę. W interpretacji francuskiego organu ochrony konkurencji, przedstawionej w decyzji wnioskującej do prokuratora o wszczęcie postępowania karnego, zaangażowanie osobiste oznacza działania faktyczne, nie jest wystarczającym jedynie zajmowanie określonej funkcji (np. dyrektora), natomiast zaangażowanie decyzyjne wymaga dowiedzenia związku przyczynowego między działaniami oskarżonego a wdrożeniem praktyki ${ }^{100}$.

$\mathrm{Na}$ uwagę zasługują również rozwiązania legislacyjne, polegające na włączeniu w definicję przestępstwa kartelowego pojęcia „nieuczciwości sprawcy” - winnym przestępstwa kartelu jest ten, kto - jak stanowi prawo brytyjskie - „nieuczciwie godzi się” (dishonestly agree) na zawarcie, wdrożenie lub przyczynienie się do zawarcia lub wdrożenia kartelu. Jednocześnie nie wprowadzono legalnej definicji nieuczciwego postępowania, w tym zakresie obowiązuje zatem standard orzeczniczy wypracowany w latach osiemdziesiątych XX w. w sprawie Ghosh ${ }^{101}$. Test ten oparty jest na dwóch elementach: obiektywnym, zmierzającym do odpowiedzi na pytanie, czy określone zachowanie jest nieuczciwe według standardów zwykłych ludzi (ordinary people); oraz subiektywnym, który musi odpowiedzieć na pytanie, czy oskarżony wie o tym, że zgodnie $\mathrm{z}$ obiektywnym standardem jego zachowanie było nieuczciwe. Z jednej strony zastosowanie testu Ghosh w sprawach kartelowych

98 Por. Sekcja 44ZZRF(1) i 44ZZRG(1) australijskiej Competition and Consumer Act 2010.

99 Por. Sekcja 44ZZRF(2) 44ZZRG(2) australijskiej Competition and Consumer Act 2010.

100 Decyzja Rady Konkurencji (Conseil de la Concurrence) z dnia 11 marca 2004 r., 04-D-07 - podaję za: M. Lévy, N. Tardif, France: Cartels, [w:] The European Antitrust Review 2012, dostępne pod adresem: http://www.globalcompetitionreview.com/reviews/37/sections/132/ chapters/1392/france-cartels/.

$101 R$ v. Ghosh [1982] QB 1053, CA. 
ma licznych przeciwników, którzy twierdzą, że w przypadkach przestępstw kartelowych jest on zbyt łatwy do spełnienia w części obiektywnej, z drugiej podkreśla się, że test ten jest gruntownie osadzony w orzecznictwie w sprawach karnych, w tym w sprawach zmów w celu oszustwa (conspiracy to defraud $)^{102}$. Obaw o zbyt niski standard nie potwierdzają również dotychczasowe brytyjskie doświadczenia - przeciwnie, Izba Lordów w sprawie Norris uznała, że zwykłe ustalanie cen (mere price fixing), rozumiane jako zawieranie i wykonywanie porozumień cenowych bez cech obciążających, nie było przestępstwem kartelowym ${ }^{103}$; takie liberalne stanowisko spotkało się jednak z krytyką doktryny104. Dotąd brakuje zatem w praktyce brytyjskiej powszechnie akceptowanej wykładni pojęcia „nieuczciwości” używanego w definicji przestępstwa kartelowego. We Francji, gdzie również nieuczciwość stanowi jedno ze znamion przestępstwa monopolizacji rynku ${ }^{105}$, sam organ ochrony konkurencji w decyzji wnioskującej do prokuratora o wszczęcie postępowania karnego wskazał, że należy wykazać intencjonalne złamanie określonych reguł konkurencji przez oskarżonego, przy czym owa intencjonalność może wynikać $\mathrm{z}$ innych zachowań przestępczych, takich jak np. korupcja ${ }^{106}$.

Objęcie znamienia nieuczciwości definicją przestępstwa kartelu ma za zadanie „sygnalizowanie, że przestępstwo jest poważne i wymaga zasadniczej kary" oraz wykluczenie (a przynajmniej znaczne utrudnienie) możliwości wykorzystania argumentu obronnego, że zarzucane działanie może przynosić korzyści gospodarcze i korzystać z wyłączenia na podstawie prawa krajowego lub unijnego ${ }^{107}$.

$\mathrm{Na}$ umieszczenie przesłanki nieuczciwości wśród znamion przestępstwa monopolizacji zdecydował się również ustawodawca francuski i rumuński108;

102 M. O'Kane, The Law of Criminal Cartels, Oxford 2009, s. 49.

103 Norris v. Government of the United States [2008] UKHL 16, [2008] 2 WLR 673.

104 Por. m.in. A Stephan, How Dishonesty Killed the Cartel Offence, Criminal Law Review 2011, vol. 6, s. 446-455.

105 Artykuł L420-6 Code de Commerce: "Est puni d'un emprisonnement de quatre ans et d'une amende de 75000 euros le fait, pour toute personne physique de prendre frauduleusement [podkr. - aut.] une part personnelle et déterminante dans la conception, l'organisation ou la mise en oeuvre de pratiques visées aux articles L. 420-1 et L. 420-2".

106 Decyzja Rady Konkurencji (Conseil de la Concurrence) z dnia 11 marca 2004 r., 04-D-07 - podaję za: M. Lévy, N. Tardif, France: Cartels, [w:] The European Antitrust Review 2012, op. cit.

107 A. Hammonnd, R. Penrose, Proposed criminalization of cartels in the UK, Office of Fair Trading, November 2001, pkt 2.5 (dostępne pod adresem: http://www.oft.gov.uk/ shared_oft/reports/comp_policy/oft365.pdf).

108 Por. art. 63 ust. 1 rumuńskiej ustawy o ochronie konkurencji, który posługiwał się sformułowaniem fraudulent intent - artykuł ten został uchylony przez art. 55 Ordonanta de urgentanr $75 \mathrm{z}$ dnia 30 czerwca $2011 \mathrm{r}$. 
propozycja taka, ostatecznie nie przyjęta, pojawiła się również w projektach regulacji kryminalizujących przestępstwa kartelowe w Australii ${ }^{109}$.

\subsubsection{Prawnokarne aspekty administracyjnego trybu egzekwowania prawa ochrony konkurencji}

W tym miejscu podjęta zostanie próba odkodowania elementów prawnokarnych (wpisujących się w nurt tzw. prawa administracyjno-karnego) w systemie procedowania z naruszeniami zakazów praktyk ograniczających konkurencję i systemie ich sankcjonowania (tradycyjnie postrzeganych jako system procedur i sankcji administracyjnych). Charakter penalny może być przypisany zarówno „tradycyjnym” (przynajmniej w europejskim modelu prawnej ochrony konkurencji) sankcjom (karom) pieniężnym nakładanym na przedsiębiorców dopuszczających się naruszenia zakazów praktyk ograniczających konkurencję ${ }^{110}$, jak i sankcjom nakładanym na osoby fizyczne, którym można przypisać odpowiedzialność za takie naruszenia. W efekcie całe postępowanie prowadzące do nałożenia takich sankcji należy traktować jako postępowanie karne, czego konsekwencją jest przede wszystkim obowiązek zapewnienia bardzo wysokiego standardu ochrony praw przedsiębiorców, którym zarzuca się naruszenie prawa.

Tendencja do przypisywania procedurom i sankcjom związanym $\mathrm{z}$ antykonkurencyjnymi praktykami charakteru prawnokarnego jest widoczna, mimo tego że ustawodawcy sytuują prawo ochrony konkurencji jako prawo (gospodarcze) administracyjne (ze wszystkimi tego konsekwencjami w sferze proceduralnej i ustrojowej), a nawet przesądzają o administracyjnoprawnym charakterze sankcji pieniężnych (jak ma to miejsce w prawie unijnym). Co prawda polski Trybunał Konstytucyjny w wyroku z dnia 4 lipca 2002 r., P 12/01111 uznał, że o charakterze środków prawnych decyduje zakładana przez ustawodawcę funkcja wiązana $\mathrm{z}$ określoną kategorią odpowiedzialności prawnej, jednak - jak słusznie zauważa P. Burzyński - jest to tylko kryterium posiłkowe, które nie może być uznane za wiążące, ponieważ „doprowadziłoby do przekreślenia wielu gwarancji konstytucyjnych związanych ze stosowaniem

109 Krytycznie o tej przesłance w prawie australijskim - B. Fisse, The Australian Cartel Criminalisation Proposals: An Overview and Critique, The Competition Law Review 2007, vol. 4(1), s. 52-53; C. Beaton-Wells, F. Haines, Making Cartel Conduct Criminal: A Case-Study of Ambiguity in Controlling Business Behaviour, Australian and New Zealand Journal of Criminology 2009, vol. 42(2), s. 218-243.

110 Por. rozdział VII, pkt 7.2.1.2.

111 OTK-A 2002, z. 4, poz. 50. 
szczególnej reakcji państwa wobec podmiotu pozostającego pod jego imperium - kary" 112 .

Ważny impuls dla powstania i umacniania przekonania o karnoprawnym charakterze prawa ochrony konkurencji wypłynął z orzecznictwa Europejskiego Trybunału Praw Człowieka, który zwykł rozszerzająco interpretować art. 6 EKPC, obejmując pojęciem sprawy karnej także te sprawy (postępowania), które mają status spraw (postępowań) administracyjnych ${ }^{113}$. Przypisanie określonej sprawie charakteru karnego w rozumieniu EKPC wymaga spełnienia warunków sformułowanych w orzecznictwie ETPC, znanych jako „kryteria Engel”114, a obejmujących: formalną klasyfikację sprawy w prawie krajowym, naturę (charakter) sprawy, rodzaj i surowość kary. Kryteria te nie muszą być spełnione kumulatywnie, wystarczające może być nawet spełnienie jednego z nich, zaś dwa ostatnie mogą być postrzegane łącznie, nawet jeśli samoistnie nie są one przesądzające o karnym charakterze sprawy ${ }^{115}$. W pochodzącym z 2011 r. orzeczeniu w sprawie Menarini ${ }^{116}$ ETPC nie pozostawił żadnych wątpliwości co do prawnokarnej natury sankcji pieniężnych przewidzianych we włoskim prawie ochrony konkurencji, zwłaszcza jeśli kary te są dotkliwe.

W Unii Europejskiej pogląd o prawnokarnym charakterze regulacji z zakresu ochrony konkurencji był tym trudniejszy do zaakceptowania, że do wejścia $\mathrm{w}$ życie traktatu $\mathrm{z}$ Lizbony UE nie posiadała kompetencji do tworzenia norm prawa karnego. Stąd w orzecznictwie sądów unijnych można odnotować stanowisko, jeśli nie zupełnie przeciwne, to przynajmniej łagodzące stanowisko ETPC co do karnoprawnych aspektów prawa ochrony konkurencji: Sąd oraz Komisja zwracały uwagę na okoliczność, że sprawy antymonopolowe nie należą do „jądra prawa karnego" (hard core of criminal

112 P. Burzyński, Ustawowe określenie sankcji karnej, Oficyna a Wolters Kluwer business, Warszawa 2008, s. 66.

113 Na temat pojęcia „postępowania w sprawie karnej” por. K. Kowalik-Bańczyk, Prawo do obrony w unijnych postępowaniach antymonopolowych. W kierunku unifikacji standardów proceduralnych $w$ Unii Europejskiej, LEX a Wolter Kluwer business, Warszawa 2012, s. 301-307.

114 Wyrok ETPC z dnia 8 czerwca 1976 r. w sprawie Engel $i$ inni przeciwko Holandii, nr 5100/71. Por. także Wyrok ETPC z 21 lutego 1984 r. w sprawie Öztürk przeciwko Niemcom, nr 8544/79.

115 M. Bernatt, Gwarancje proceduralne w sprawach z zakresu ochrony konkurencji i regulacji, majacych charakter karny w świetle EKPCz - glosa do wyroku SN z 14.04.2010 r., EPS 2011, nr 6. Por. także A. Błachnio-Parzych, The Nature of Resposibility of An Undertaking in Antitrust Proceeding and the Concept of 'Criminal Charge' in the Jurisprudence of the European Court of Human Rights, YARS 2012, vol. 5(6), s. 37-41.

116 Menarini v. Italy (43509/08) Unreported September 27, 2011 ECtHR. 
law), więc gwarancje przewidziane w art. 6 EKPC nie stosują się wobec nich w pełni ${ }^{117}$. Jedynie w nielicznych orzeczeniach można znaleźć (pośrednie) potwierdzenie kryminalnego charakteru kar pieniężnych ${ }^{118}$, generalnie sądy unijne potwierdzają administracyjną naturę kar pieniężnych (określoną wprost w art. 23 ust. 5 rozporządzenia 1/2003), czego powodem jest fakt, że hołdują one wykładni celowościowej ${ }^{119}$.

Skłonność do traktowania postępowań w sprawach ochrony konkurencji i w sprawach regulacyjnych zgodnie ze standardami przewidzianymi dla procedury karnej (standardami ustanowionymi w EKPC) jest natomiast widoczna w ostatnich latach w polskim orzecznictwie. Nawet jeśli Sąd Najwyższy stoi na stanowisku, że kary pieniężne nakładane przez organ administracji (w tym organ ochrony konkurencji czy organ regulacyjny) nie mają charakteru sankcji karnych, to „zasady sądowej weryfikacji prawidłowości orzeczenia organu (...) w tym zakresie, powinny odpowiadać wymogom analogicznym do tych, jakie obowiązują sąd orzekający w sprawie karnej"120.

Do orzecznictwa ETPC nawiązuje również wielu reprezentantów doktryny, przypisując sankcjom prawa antymonopolowego charakter sankcji karnych ${ }^{121}$

117 Por. wyrok Sądu z dnia 13 lipca 2011 r. Schindler v. Komisja, pkt 53. Por. U. Soltesz, Due process and judicial review - mixed signals from Luxembourg in cartel cases, E.C.L.R. 2012, vol. 33(5), s. 243-244.

118 Wyrok Sądu z dnia 15 grudnia 2010 r. w sprawie T-141/08 E.ON v. Komisja (Zb. Orz. 2010, s. 5761), pkt 52; wyrok TS z dnia 8 lipca 1999 r. w sprawie C-199/92 P Hüls $A G$ v. Komisja (Zb. Orz. 1999, s. I-4287), pkt 150. Por. także opinia Rzecznika Generalnego Colomera w sprawie Buzzi Unicem (C-217/00 P), pkt 29: "The procedure for finding infringement of Articles 81 EC and 82 EC is sanctionative by nature." ${ }^{34}$. Por. np. wyrok TS z dnia 28 czerwca 2005 r. w sprawach połączonych C-189/02 P, C-202/02 P, C-205/02 P do C-208/02 P oraz C-213/02 P Dansk Rørindustri A/S v. Komisja (Zb. Orz. 2005, s. I-5425), pkt 68-71. Stanowisko sądów unijnych w tym zakresie analizują szerzej: K. Kowalik-Bańczyk, Problematyka ochrony praw podstawowych $w$ unijnych postępowaniach $w$ sprawach z zakresu ochrony konkurencji, Zeszyty CEN (nr 39), Natolin 2010, s. 34-37; M. KrólBogomilska, Standards of Entrepreneur Rights in Competition Proceedings - a Matter of Administrative or Criminal Law, YARS 2012, vol. 5(6), s. 20-22.

119 Tak W. Moshel, Fines in European competition law, s. 371.

120 Wyrok SN z dnia 14 kwietnia 2010 r., III SK 1/10, Lex 577853. Por. także wyrok SN z dnia 21 września 2010 r., III SK 8/10, Lex 646358, OSN 2012, nr 3-4, poz. 52; wyrok SA w Warszawie z dnia 4 lipca 2012 r., VI ACa 202/12.

$121 \mathrm{~W}$ polskim piśmiennictwie z poglądem tym sympatyzuje wielu autorów, m.in. M. KrólBogomilska, [w:] Kary antymonopolowe..., s. 37 oraz Standards of Entrepreneur Rights..., s. 13; M. Bernatt, Prawo do rzetelnego procesu w sprawach ochrony konkurencji i regulacji rynku (na tle art. 6 EKPC), PiP 2012, nr 1, s. 57; A. Stawicki, [w:] A. Stawicki, E. Stawicki (red.), Ustawa o ochronie konkurencji i konsumentów. Komentarz, LEX a Wolters Kluwer business, Warszawa 2011, s. 1163; w piśmiennictwie obcym - por. m.in. D. Slater, S. Thomas, D. Waelbroeck, Competition law proceedings before the European Commission 
lub co najmniej mieszanych: administracyjno-karnych ${ }^{122}$. Pogląd o karnym charakterze sankcji uznaję również za własny. Należy odnotować i taki pogląd, zgodnie z którym „nie ma bezwzględnej potrzeby definitywnego (ostatecznego) rozstrzygania, czy sankcje pieniężne [...] mają w rzeczywistości charakter czysto administracyjny, mieszany, quasi-karny czy też karny [...]"123.

$\mathrm{Z}$ kolei kary pieniężne nakładane na osoby fizyczne za naruszenia norm materialnych prawa ochrony konkurencji są postrzegane w piśmiennictwie głównie jako część prawa administracyjno-karnego ${ }^{124}$, a tym samym zwykle nie są zaliczane do „właściwych” regulacji karnych prawa ochrony konkurencji i nie mieszczą się w nurcie kryminalizacji. W moim przekonaniu, sankcjom tego rodzaju należy nadać charakter stricte prawnokarny ${ }^{125}$, podobnie zresztą jak sankcji w postaci zakazu zajmowania określonego stanowiska. Jeśli indywidualne sankcje dotykające osoby fizyczne mają spełniać przewidziane dla nich funkcje, tj. z jednej strony funkcję represyjną, z drugiej - prewencyjną, konieczne jest wartościowanie ich jako „stygmatyzujących”, a tę wartość w lepszy sposób zapewnią sankcje prawnokarne. Za przykład może tu posłużyć sprawa menadżerów oskarżonych w związku z kartelem bankowym w Austrii, którego funkcjonowanie zostało potwierdzone decyzją Komisji Europejskiej w 2002 r. ${ }^{126}$. Przeciwko menadżerom, którzy pełnili w tym kartelu kierowniczą rolę w Austrii wszczęto postępowanie karne, ostatecznie jednak nie doszło nawet do formalnego procesu, ponieważ oskarżeni skorzystali z procedury „zastępczej”, która pozwoliła uniknąć stygmatyzującego procesu karnego w zamian za uznanie swojej odpowiedzialności prawnej i zapłacenie „neutralnego” świadczenia pieniężnego ${ }^{127}$.

and the right to a fair trial: no need for reform?, European Competition Journal 2009, vol. 5(1), s. 103-107, 111.

122 Tak m.in. M. Sachajko, Istota i charakterystyka prawna antymonopolowych kar pieniężnych, RPEiS 2002, nr 1, s. 60; R. Molski, [w:] T. Skoczny, A. Jurkowska, D. Miąsik (red.), Ustawa o ochronie konkurencji i konsumentów. Komentarz, C. H. Beck, Warszawa 2009, s. $1650(\mathrm{Nb} \mathrm{5)}$.

123 B. Turno, Leniency - program tagodzenia kar pieniężnych $w$ polskim prawie ochrony konkurencji, LEX a Wolters Kluwer business, Warszawa 2013, s. 192.

124 M. Zuleeg, [w:] C. D. Ehlermann, I. Atanasiu (red.), European Competition Law Annual 2001: Effective Private Enforcement of EC Antitrust Law, Hart Publishing, Oxford-Portland-Oregon 2003, s. 389, 460.

$125 \mathrm{Ku}$ takiemu stanowisku w polskim piśmiennictwie wydaje się również skłaniać Sz. Syp - por. tenże, $O$ odpowiedzialności osób fizycznych w polskim prawie konkurencji - de lege lata $i$ de lege ferenda, iKAR 2012, nr 4 (1), s. 7-19.

126 Decyzja z dnia 11 czerwca 2002 r., COMP/36.571/D-1 (sprawa Lombard).

127 Szerzej na temat tej sprawy i krytycznych komentarzy co do jej ostatecznego rozstrzygnięcia - P. Lewisch, Enforcement of antitrust law: the way from criminal individual punishment to semi-penal sanctions in Austria, [w:] K. J. Cseres, M. P. Schinkel, F. O. W. Vogelaar 
Postrzeganie kar pieniężnych nakładanych na osoby fizyczne za sankcje administracyjne (nawet jeśli administracyjno-karne) może sprzyjać również przyjmowaniu tak ,egzotycznych” rozwiązań, jak np. uzależnienie wysokości kary od sytuacji materialnej osoby karanej, stanowiące indywidualizację kary ${ }^{128}$, której sprzeciwia się doktryna prawa karnego.

Nie tylko - a nawet nie przede wszystkim - kwestie efektywności sankcji powinny jednak zadecydować o prawnokarnym charakterze takich sankcji, kluczowym argumentem wydaje się tutaj konieczność poszanowania standardów ochrony praw jednostek w postępowaniu służącym nałożeniu takich kar odpowiadających standardom procesu karnego -zastosowanie musi znaleźć wobec nich w pełni EKPC. W prawie polskim wątpliwości może budzić również zgodność takiego rozwiązania z art. 42 ust. 2 Konstytucji RP.

W konsekwencji zatem orzekanie o karach tego rodzaju należy oddać kompetencji sądów karnych ${ }^{129}$, a nie organów ochrony konkurencji (zwłaszcza jeśli mają one - jak w Polsce - administracyjny i monokratyczny charakter).

\subsubsection{Stan zaawansowania kryminalizacji prawa ochrony konkurencji}

Kryminalizacja prawa konkurencji jest zjawiskiem - jak pisze W. P. J. Wils - „o wielu twarzach”. W najszerszym ujęciu kryminalizacja polega na wprowadzeniu sankcji penalnych (karnych) za przestępstwa, których istota spro-

(red.), Criminalization of Competition Law Enforcement: Economic And Legal Implications For The EU Member States, Edward Elgar Publishing 2006, s. 298-300.

128 Takie rozwiązanie zaproponował Prezes UOKiK w projekcie (z dnia 15 maja 2012 r.) założeń projektu ustawy o zmianie ustawy o ochronie konkurencji i konsumentów pkt F, s. 22-25 (rzeczony projekt przewidywał karę do 500 tys. EUR za naruszenia obydwu zakazów praktyk ograniczających konkurencję). Rozwiązanie to spotkało się z istotną krytyką - por. m.in A. Piszcz, Kilka uwag do projektu zatożeń ustawy o zmianie ustawy o ochronie konkurencji i konsumentów, iKAR 2012, nr 2, s. 14-15; A. Stawicki, B. Turno, [w:] Proponowane przez UOKiK..., s. 51-54; Sz. Syp, O odpowiedzialności osób fizycznych..., s. 19. W finalnym projekcie nowelizacji ustawy o ochronie konkurencji i konsumentów ograniczono odpowiedzialność osób zarządzających do zakazów z art. 6 uokik i art. 101 TFUE (por. art. 1 pkt 59 projektu nowelizacji uokik z dnia 21 listopada 2012 r.).

129 Tak również M. Król-Bogomilska, Uwagi do projektu zatożeń do projektu ustawy o zm. ustawy o ochronie konkurencji i konsumentów z dnia 15 maja 2012 r. ogtoszonych na stronie Urzędu Ochrony Konkurencji i Konsumentów (w zakresie dotyczacym problematyki kar i polityki łagodzenia kar) (pismo z dnia 5 czerwca 2012 r.), dostępne pod adresem: http://legislacja.rcl.gov.pl/docs//1/43452/43453/43456/dokument40047.pdf?lastUpdateDay $=03.08 .12 \&$ lastUpdateHour $=4 \% 3 \mathrm{~A} 06 \&$ userLogged $=$ false $\&$ date $=$ Sunday $\% 2 \mathrm{C}+5+\mathrm{Au}$ gust+2012 (5.08.2012). 
wadza się do naruszenia zakazów praktyk ograniczających konkurencję, przy czym sankcje te mogą być nakładane (indywidualnie) na jednostki (osoby fizyczne) lub na podmioty zbiorowe (korporacje). W najszerszym ujęciu kryminalizacja może przejawiać się w nakładaniu kar pieniężnych (grzywien) i kary pozbawienia wolności na osoby fizyczne i/lub jednostki organizacyjne (kara pozbawienia wolności wykonywana ewentualnie wobec przedstawiciela jednostki). W najwęższym ujęciu kryminalizacja oznacza możliwość orzekania kary pozbawienia wolności (wobec osób fizycznych) za naruszenie zakazów praktyk ograniczających konkurencję.

Analizując proces kryminalizacji prawa ochrony konkurencji należy mieć na względzie kontrowersje wokół charakteru prawnego niektórych sankcji stosowanych przez organy ochrony konkurencji (np. kary pieniężne nakładane na osoby fizyczne w związku $\mathrm{z}$ naruszeniem reguł materialnoprawnych) ${ }^{130}$. Problem klasyfikacji poszczególnych rodzajów sankcji traci swoją ostrość, jeśli rozważania nad egzekwowaniem zakazów antykonkurencyjnych praktyk przebiegają nie tyle według trybu egzekwowania prawa ochrony konkurencji, ile według dwupodziału sankcji na indywidualne i korporacyjne (zbiorowe) ${ }^{131}$.

W ostatniej dekadzie w rozwoju prawa ochrony konkurencji dość silnie zaznacza się tendencja do kryminalizacji zakazów praktyk ograniczających konkurencję. W pewnym stopniu zjawisko to można traktować jako „powrót do źródeł" - dwa najstarsze systemy ochrony konkurencji (amerykański i kanadyjski) zostały ukształtowane właśnie w modelu prawnokarnym; również w niektórych państwach europejskich w czasach, gdy krajowe prawo ochrony konkurencji nie było inspirowane jeszcze rozwiązaniami unijnymi, istniała kategoria przestępstw kartelowych. Dopiero powstanie unijnego (wcześniej wspólnotowego) modelu ochrony konkurencji, ukształtowanego jako model w dużej mierze administracyjny, skłoniło tak państwa członkowskie, jak i inne, pozostające pod wpływem legislacji unijnej bądź to do takiego przebudowania systemów ochrony konkurencji, które eliminowałoby regulacje karne, bądź do ukształtowania całkowicie nowego systemu, pozbawionego elementów karni- stycznych. W literaturze przedmiotu panuje w zasadzie zgoda co do tego, że przyjęcie administracyjnego modelu ochrony konkurencji i odejście od prawnokarnych „tradycji” było podyktowane głównie tym, że Wspólnota (a później przez długi czas także sama UE) nie posiadała żadnych kompetencji do tworzenia norm prawnokarnych (choć

130 Por. pkt 2.2.4. w niniejszym rozdziale.

131 Przeciwstawienie sankcji indywidualnych i korporacyjnych stanowi główną oś rozważań m.in. w artykule F. Thépot, Leniency and Individual Liability: Openining the Black Box of the Cartel, The Competition Law Review 2011, vol. 7(2), s. 221-240. 
niektórzy autorzy wyrażali pogląd - moim zdaniem całkowicie błędny - iż ustanowienie sankcji karnych w obszarze prawa ochrony konkurencji było możliwe na podstawie dzisiejszego art. 103 TFUE $^{132}$ ). Kompetencje takie zostały przyznane Unii przez traktat z Lizbony - art. 83 ust. 1 TFUE przewiduje, że Parlament Europejski i Rada mogą ustanowić normy harmonizacji minimalnej odnoszące się do określania przestępstw i kar „w dziedzinach szczególnie poważnej przestępczości o wymiarze transgranicznym (...)". W przepisie tym upatruje się możliwości przyjęcia przepisów prawnokarnych w obszarze ochrony konkurencji133 - oczekiwanie to wydaje się uzasadnione o tyle, że polityka konkurencji prowadzona przez Komisję, zwłaszcza w dziedzinie walki $\mathrm{z}$ najpoważniejszymi kartelami, od dawna opiera się na retoryce właściwej raczej dla prawa karnego niż administracyjnego. Co prawda wykaz dziedzin poważnej przestępczości w art. 83 ust. 1 TFUE nie obejmuje ogólnej kategorii przestępstw gospodarczych, w jakiej ewentualnie mogłyby mieścić się przestępstwa związane $\mathrm{z}$ naruszenie zakazów praktyk ograniczających konkurencję, jednak dla Rady zastrzeżone zostało uprawnienie do poszerzenia tej listy o nowe dziedziny przestępczości. Ostatecznie możliwe byłoby zakwalifikowanie karteli do przestępczości zorganizowanej, wymienionej expressis verbis $\mathrm{w}$ art. 83 ust. 1 TFUE ${ }^{134}$.

Niezależnie od działań (lub raczej ich braku) na szczeblu unijnym, niektóre państwa członkowskie samodzielnie zdecydowały się na wprowadzenie do swoich porządków prawnych regulacji ustanawiających zasady odpowiedzialności karnej za naruszenie materialnych reguł konkurencji; wśród tych państw znalazły się przede wszystkim Irlandia (kryminalizacja antykonkurencyjnych praktyk od 1996 r.) i Wielka Brytania (kryminalizacja wprowadzona w 2003 r.), a ponadto: Czechy, Estonia, Grecja, Słowacja. Tendencja do kryminalizacji praktyk antykonkurencyjnych widoczna jest zresztą w całym świecie, a inspiracji tego zjawiska należy doszukiwać się przede wszystkim w doświadczeniach amerykańskich, w mniejszym zakresie - w najnowszym dorobku brytyjskim i irlandzkim. Wśród państw, które w ostatnich latach zdecydowały o wprowadzeniu sankcji karnych za naruszenie prawa ochrony konkurencji, znalazły się m.in.: Australia, Japonia, Izrael, Korea, Meksyk, Brazylia, RPA. Obraz zjawiska wymaga jednak spojrzenia również na trend odwrotny, tj. dekryminalizację prawa ochrony konkurencji. Spektakularnym europejskim przykładem dekryminalizacji pozostaje Austria, gdzie indywi-

132 Por. G. Hakopian, Criminalization of EU Competition Law Enforcement - A Possibility after Lisbon?, The Competition Law Review 2010, vol. 7(1), s. 158-159.

133 Tak M. Zuleeg, [w:] C. D. Ehlermann, I. Atanasiu (red.), European Competition Law Annual 2001..., s. 389.

134 Tak G. Hakopian, Criminalization of EU Competition..., s. 164. 
dualne sankcje karne za przestępstwa kartelowe zniesiono w 2002 r., zastępując je systemem kar stosowanych przez nowoutworzony organ ochrony konkurencji. W piśmiennictwie spotyka się pogląd, że zmiana ta nie była podyktowana żadnymi głębszymi przemyśleniami nad modelem realizacji polityki konkurencji, a stanowiła ona jedynie wynik obietnic wyborczych ${ }^{135}$. Inaczej było w Chile, gdzie powodem uchylenia w 2003 r. przepisów prawnokarnych w zakresie ochrony konkurencji była całkowita „niestosowalność” regulacji (ani jednego przypadku w latach 1973-2003), ostatecznie jednak odpowiedzialność karną za przestępstwa kartelowe przywrócono w 2009 r. ${ }^{136}$.

Podkreślenia wymaga fakt, że samo zjawisko kryminalizacji antykonkurencyjnych praktyk nie jest jednolite: możemy mieć do czynienia z kryminalizacją generalną i fragmentaryczna (punktową). Poprzez kryminalizację generalną rozumiem sytuację, w której ustanawia się nową kategorię przestępstwa polegającego na dopuszczeniu się praktyki (lub dopuszczeniu do praktyki) ograniczającej konkurencję - zakres takiego przestępstwa może być szerszy (wszystkie antykonkurencyjne praktyki, tzn. porozumienia horyzontalne i wertykalne oraz nadużycie pozycji dominującej) lub węższy (z reguły tylko kartele, tj. porozumienia horyzontalne). Jako kryminalizację fragmentaryczną określam natomiast sytuację, w której przestępstwem jest jedynie konkretny typ praktyki danego rodzaju, zazwyczaj jest to porozumienie w postaci zmowy przetargowej (takie regulacje funkcjonują m.in. w Niemczech ${ }^{137}$, Austrii ${ }^{138}$ i na Węgrzech ${ }^{139}$ ). F. Wagner von-Papp wskazuje, że penalizacji tylko karteli przetargowych często w ogóle nie uznaje się w piśmiennictwie za przejaw kryminalizacji antykonkonurencyjnych praktyk $^{140}$. Specyficzne rozwiązanie przewidziane jest w prawie hiszpań-

135 P. Lewisch, Enforcement of antitrust law:..., [w:] K. J. Cseres, M. P. Schinkel, F. O. W. Vogelaar (red.), Criminalization of Competition Law..., s. 295.

136 P. Montt, Cartel Enforcement and Leniency Programmes: The Experience of Chile, wrzesień 2010, dokument dostępny pod adresem: http://www.ucl.ac.uk/laws/conferences/latin-america/montt_ucl_sept2010.pdf.

137 Por. sekcja $29 \overline{8}$ niemieckiego kodeksu karnego.

138 Por. § 168 b austriackiego kodeksu karnego.

139 Por. § 296B węgierskiego kodeksu karnego; P. Mezei, Wanted: Antitrust Criminals. Criminalization of Cartel law with a special view to Hungary, New Journal of European Criminal Law 2011, vol. 2, s. 160, tekst dostępny także pod adresem: http://www.bpugyvedikamara.hu/files/120/120560.pdf. O regulacjach indywidualnej odpowiedzialności osób zarządzających za naruszenie reguł konkurencji w wybranych systemach prawnych piszę również [w:] Odpowiedzialność prawnokarna menadżerów za antykonkurencyjne praktyki przedsiębiorców, [w:] Księga jubileuszowa z okazji 40-lecia Wydziatu Zarządzania UW, Wyd. Naukowe WZ UW, Warszawa 2012, s. 122-133.

140 F. Wagner von-Papp, What If All Bid-Riggers Went To Prison and Nobody Noticed? Criminal antitrust law enforcement in Germany, [w:] C. Beaton-Wells, A. Ezrachi (red.), Crimi- 
skim, gdzie kodeks karny ustanawia karę pozbawienia wolności za: praktyki cenowe zakłócające konkurencję (art. 284), zmowy przetargowe w licytacjach i przetargach publicznych (art. 262) oraz za praktyki kontyngentowe polegające na ograniczeniu dostępu do surowców lub innych niezbędnych towarów w celu limitowania dostaw lub zakłócania cen (art. 281) ${ }^{141}$.

Pewnych trudności może nastręczać polska terminologia służąca charakteryzowaniu przestępstw, zwłaszcza tych stanowiących przedmiot kryminalizacji ogólnej. Nie ma oczywiście żadnych wątpliwości, że przestępstwa polegające na zawieraniu i/lub realizacji horyzontalnych porozumień ograniczających konkurencją będą określane jako przestępstwa kartelowe (cartel offence). Termin ten nie wydaje się jednak właściwy już dla porozumień wertykalnych (które w sensie ekonomicznym nie są kartelami), nie mówiąc o praktykach nadużywania pozycji dominującej. Nie jest właściwe, moim zdaniem, zastosowanie kalki z terminologii angielskiej (antitrust offence ${ }^{142}$ lub antitrust crimes) i określanie przestępstw naruszenia zakazów praktyk ograniczających konkurencję „przestępstwami antymonopolowymi” - określenie to, w moim przekonaniu, sugerowałoby, że przestępne działanie polega właśnie na działaniach antymonopolowych, podczas gdy istotą takich przestępstw jest monopolizacja rynku (czy to indywidualnie przez dominanta, czy zbiorowo poprzez np. uczestników karteli), dlatego też przestępstwa, których istota sprowadza się do naruszenia zakazów praktyk ograniczających konkurencję będę określała jako przestępstwa monopolizacji rynku (lub krócej: przestępstwa monopolizacji).

W państwach, w których mamy do czynienia z kryminalizacją generalną (m.in., Francja, Irlandia, USA), przestępstwa polegające na nadużywaniu pozycji dominującej, choć formalnie mają identyczny status jak przestępstwa kartelowe, to $\mathrm{w}$ praktyce do ich ścigania dochodzi znacznie rzadziej. Znakomitym przykładem pozostają Stany Zjednoczone, gdzie odpowiedzialność karna przewidziana jest co prawda za obie postaci monopolizacji rynku, jednak wytyczne praktyki wskazują na konieczność zainteresowania DOJ przede wszystkim przestępstwami kartelowymi ${ }^{143}$ (co nie oznacza, że w ogóle postę-

nalising Cartels: Critical Studies of International Regulatory Movement, Hart Publishing, Oxford 2010.

141 Por. R. García-Gallardo, Spain: Cartels, [w:] The European Antitrust Review 2012, dostępne pod adresem: http://www.globalcompetitionreview.com/reviews/37/sections/132/chapters/ 1403/spain-cartels/.

142 Por. np. M. S. Gal, Monopoly Pricing as an Antitrust Offense in the U.S. and the EC: Two Systems of Belief About Monopoly?, Antitrust Bulletin 2004, vol. 49, s. 343-384.

143 Por. An Antitrust Primer for Federal Law Enforcement Personnel, Antitrust Division, U.S. Department of Justice, August 2003 (revised April 2005), dostępne pod adresem: http:// www.justice.gov/atr/public/guidelines/209114.htm. 
powania w sprawie monopolizacji rynku wskutek naruszenia sekcji 2 . Sherman Act nie są podejmowane). Z kolei kategoria przestępstw kartelowych obejmuje najpoważniejsze kartele (hardcore cartels): cenowe, kontyngentowe i podziałowe, a w niektórych ustawodawstwach - także zmowy (kartele) przetargowe. Możliwa jest również sytuacja, gdy co prawda odpowiedzialność prawnokarna przewidziana jest za przestępstwa monopolizacji rynku (tj. za wszystkie praktyki ograniczające konkurencję), jednak w przypadku karteli mamy do czynienia z odpowiedzialnością na zaostrzonych zasadach ${ }^{144}$.

\subsubsection{Aktualne możliwości kwestionowania praktyk antykonkurencyjnych w świetle polskiego prawa karnego w Polsce}

\subsubsection{Przestępstwo zmowy przetargowej}

Mimo że w Polsce nie ma regulacji przestępstwa monopolizacji rynku (czy przestępstwa kartelowego), możliwe jest zidentyfikowanie takich przestępstw przeciwko obrotowi gospodarczemu, których znamiona mogą być wypełnione przynajmniej przez niektóre praktyki antykonkurencyjne. Mam tu na myśli art. 305 i art. 296 Kodeksu karnego ${ }^{145}$.

Artykuł 305 kk określa przestępstwo uniemożliwiania lub utrudniania przetargu, ale jednocześnie pozwala na ściganie zmów przetargowych. Ma on co prawda szerszy zakres niż niemiecki czy węgierski przepis odnoszący się stricte do przestępstw kartelowych, niemniej jednak ustanawia odpowiedzialność karną za niektóre działania na szkodę właściciela mienia albo osoby lub instytucji, na rzecz której dokonywany jest publiczny przetarg. Kodeks karny nie chroni przetargu dokonywanego w trybie innym niż publiczny ${ }^{146}$, zakres przedmiotowy art. $305 \mathrm{kk}$ nie pokrywa się zatem z zakresem przedmiotowym zakazu z art. 6 ust. 1 pkt 7 uokik obejmującym wszystkie rodzaje przetargów (także te regulowane przez Kodeks cywilny). W literaturze nie ma zgody co do tego, jakiego rodzaju przetarg ma charakter „publiczny” w rozumieniu art. 305 kk. Wśród kryteriów publicznego charakteru przetargu można wskazać m.in. kierowanie zaproszenia do składania ofert do nieograniczonego kręgu adresatów ${ }^{147}$; kierowanie tego

144 Na przykład w Irlandii odpowiedzialność indywidualna menadżerów jest możliwa tylko w odniesieniu do karteli - por. sekcja 8(6) Competition Act 2002.

145 Ustawa z dnia 6 czerwca 1997 r. - Kodeks karny (Dz. U. 1997 Nr 88, poz. 553 ze zm.).

146 P. Szustakiewicz, Ustawa o zamówieniach publicznych a przestępstwo utrudniania przetargu, Prok. i Pr. 2004, nr 2, s. 87.

147 Por. wyrok SA w Warszawie z dnia 11 marca 1998 r., II Aka 247/97, OSA 1999, nr 3, poz. 25. 
zaproszenia także do ograniczonego kręgu adresatów, o ile wyznaczeni są oni na podstawie kryterium generalnego; organizowanie przetargu przez instytucję publiczną. W najszerszym ujęciu za przetarg publiczny uznaje się taki, który jest organizowany na podstawie przepisów prawa powszechnie obowiązującego, przez podmiot do tego zobowiązany lub uprawniony na podstawie tych przepisów - przede wszystkim chodzi o ustawę o zamówieniach publicznych; A. Twarowski uważa, że art. $305 \mathrm{kk}$ znajdzie zastosowanie także do przetargów publicznych prowadzonych w trybie licytacji w toku postępowania egzekucyjnego lub upadłościowego ${ }^{148}$. Przyjęcie określonej definicji przetargu może również skutkować decyzją, czy wszystkie (ewentualnie: jakie) tryby zamówień publicznych będą mieściły się w tej definicji. Jeśli przyjąć, że kryterium przetargu publicznego jest instytucja organizująca procedurę lub pochodzenie środków przeznaczonych do wydatkowania, to należałoby przyjąć, że wszystkie tryby zamówień regulowane w ustawie o zamówieniach publicznych stanowią przetarg w rozumieniu art. $305 \mathrm{kk}^{149}$. W piśmiennictwie można jednak spotkać pogląd, że art. $305 \mathrm{kk}$ chroni prawidłowość procedur zamówień publicznych, realizowanych jedynie w trybie przetargu, nie odnosi się on natomiast do innych trybów przewidzianych ustawą o zamówieniach publicznych, takich jak np. zapytanie o cenę czy negocjacje z zachowaniem konkurencji 150 .

Penalizowane działanie może polegać na: udaremnieniu lub utrudnieniu przetargu publicznego albo wejściu w porozumienie $\mathrm{z}$ inną osobą, działając na szkodę właściciela mienia albo osoby lub instytucji, na rzecz której przetarg jest dokonywany (art. $305 \S 1 \mathrm{kk}$ ) bądź na rozpowszechnianiu informacji lub przemilczaniu istotnych okoliczności mających znaczenie dla zawarcia umowy będącej przedmiotem przetargu albo wejściu w porozumienie $\mathrm{z}$ inną osobą, działając na szkodę właściciela mienia albo osoby lub instytucji, na rzecz której przetarg jest dokonywany (art. $305 \S 2 \mathrm{kk}$ ). Jak słusznie podkreśla się $\mathrm{w}$ piśmiennictwie zakres zastosowania art. $305 \mathrm{kk}$ jest szerszy niż zakres zastosowania art. 6 ust. 1 pkt 7 uokik - ten ostatni pojęciem „zmowy przetargowej” obejmuje wyłącznie uzgadnianie warunków ofert ${ }^{151}$. W przypadku $\S 1$ celem sprawcy musi być chęć osiagnięcia korzyści majątkowej dla siebie lub innej osoby, dla zastosowania $§ 2$ cel sprawcy nie ma znaczenia.

148 A. Twarowski, Odpowiedzialność za naruszenia zwiazane z udzielaniem zamówień publicznych - zagadnienia ogólne, Prawo Zamówień Publicznych 2006, nr 4, s. 48.

149 Ibidem, s. 50.

150 P. Szustakiewicz, Ustawa o zamówieniach publicznych..., s. 89-90.

151 A. Stawicki, [w:] A. Stawicki, E. Stawicki (red.), Ustawa o ochronie konkurencji..., s. 264. 
W doktrynie rysują się dwa stanowiska co do postrzegania wejścia w porozumienie: jedno z nich wskazuje, że znamię ,wchodzi w porozumienie z inną osobą" należy w przypadku czynu, o którym mowa w art. $305 \S 1$, rozumieć jako wprowadzenie karalności czynności przygotowawczych do udaremniania lub utrudniania przetargu"152; drugie wydaje się sugerować, że wejście $\mathrm{w}$ porozumienie $\mathrm{z}$ inną osobą stanowi czyn odrębny od udaremniania lub utrudniania przetargu bądź rozpowszechniania albo przemilczania informacji. M. Bojarski, przywołując poglądy J. Makarewicza, twierdzi, że „w świetle art. 305 porozumienie to staje się sui generis przestępstwem dokonanym. (...) Jest to zatem zmowa licytantów, której celem jest niedopuszczenie do sprzedaży po cenach odpowiadających wartości. Porozumienie takie może polegać na uzyskaniu przez kupującego biernego zachowania się innych licytantów bądź też na kupnie na wspólny rachunek przedmiotów przetargu. W obu wypadkach cena sprzedaży licytacyjnej będzie niewiele wyższa od minimum, od którego, stosownie do przepisów ustawowych, dany przedmiot może być sprzedany" 153 .

$\mathrm{Z}$ punktu widzenia drugiego ze wskazanych stanowisk istotne znaczenie ma fakt, że ustawodawca nie dookreślił, czego ma dotyczyć penalizowane porozumienie, co w doktrynie prawa karnego słusznie odczytuje się jako sprzeczność z zasadą nullum crimen sine lege certa ${ }^{154}$. Wydaje się, że zmowami przetargowymi zakazanymi przez prawo ochrony konkurencji będą przede wszystkim przestępstwa, o których mowa w art. $305 \S 1 \mathrm{kk}$, rzadziej przestępstwa stypizowane w art. $305 \S 2 \mathrm{kk}$.

Szkoda w przypadku zmowy przetargowej może polegać choćby na wykluczeniu możliwości wyboru przez organizatora przetargu oferty najbardziej konkurencyjnej, musi być to szkoda wyrządzona organizatorowi przetargu lub osobie, na rzecz której przetarg został zorganizowany, a nie wyłącznie oferentom ${ }^{155}$ (w przypadku zmów przetargowych szkoda będzie $\mathrm{z}$ reguły odczuwalna dla obydwu kategorii podmiotów). Przestępstwo zmowy przetargowej zagrożone jest karą pozbawienia wolności do lat 3.

152 Tak A. Michalska-Warias, [w:] M. Szwarczyk, A. Michalska-Warias, J. Piórkowska-Flieger, T. Bojarski (red.), Kodeks karny. Komentarz, LexPolonica Maxima/2011.

153 M. Bojarski, [w:] L. Tyszkiewicz, S. Hoc, A. Wąsek, W. Filipkowski, Z. Siwik, M. Kulik, M. Bojarski, W. Radecki, P. Hofmański, Z. Sienkiewicz, L. Wilk, O. Górniok, M. Filar, M. Kalitowski, L. K. Paprzycki, E. Pływaczewski, R. A. Stefański, Kodeks karny. Komentarz, LexPolonica Maxima 2012.

154 Tak W. Wróbel, [w:] A. Zoll (red.), Kodeks karny. Komentarz, t. III, Kraków 2008, s. 776; D. E. Wojtczak, Zwalczanie zmów przetargowych w Polsce, PiP 2010, nr 7, s. 68-77.

155 Tak m.in. M. Bojarski, [w:] L. Tyszkiewicz i in., Kodeks karny...; W. Jaroch, Przestępstwa w systemie zamówień publicznych, Prok. i Pr. 2004, nr 4. 
Naruszenia art. 305 może się dopuścić każdy podmiot, który jest zdolny do ponoszenia odpowiedzialności karnej, w tym również podmioty zbiorowe na mocy art. 16 ust. 1 pkt 1 lit. a) ustawy o odpowiedzialności podmiotów zbiorowych za czyny zabronione pod groźbą kary. Przestępstwo to jest ścigane na wniosek, chyba że pokrzywdzonym pozostaje Skarb Państwa.

Wskazane powyżej wątpliwości czynią z art. 305 kk stosunkowo wymagającą podstawę dla zastosowania go do przestępstw kartelowych, regulacja ta - ze względu na jej rzadkie używanie w praktyce - określana jest nawet jako „martwa”156. Niemniej jednak w polskiej doktrynie można odnotować pogląd aprobujący stosowanie art. 305 wobec przestępstw kartelowych (zmów kartelowych) ${ }^{157}$. Pośrednio istnienie możliwości stosowania art. 305 kk wobec zmów kartelowych przyznał sam UOKiK: na marginesie należy zaznaczyć, że wśród przedstawionych przez UOKiK w maju 2012 r. propozycji nowelizacji ustawy o ochronie konkurencji i konsumentów znalazł się zapis dotyczący wykluczenia stosowania art. $305 \mathrm{kk}$ wobec tych osób fizycznych, co do których Prezes UOKiK podjął decyzję o darowaniu lub złagodzeniu (w związku z odpowiedzialnością osób fizycznych za dopuszczenie do popełnienia praktyki ograniczającej konkurencję). Rozwiązanie to, zdaniem UOKiK, „ma na celu zwiększenie ochrony osób, które zgłaszają się z wnioskiem leniency dotyczącym zmów przetargowych"158.

\subsubsection{Przestępstwo nadużycia zaufania}

Artykuł 296 kk ustanawia przestępstwo określane z reguły jako „nadużycie zaufania”, ale także jako „karalna niegospodarność” lub „niegospodarność menadżera"159. Wskutek nowelizacji Kodeksu karnego w 2011 r. ${ }^{160}$ do artykułu tego włączono również szczególną postać nadużycia zaufania, jaką stanowi przestępstwo działania na szkodę spółki (nadużycia zaufania spółki161), regulowane uprzednio (tj. przed nowelizacją) w art. $585 \mathrm{ksh}^{162}$

156 D. E. Wojtczak, Zwalczanie zmów..., s. 77.

157 A. Stawicki, [w:] A. Stawicki, E. Stawicki (red.), Ustawa o ochronie konkurencji..., s. 264.

158 Projekt, pkt F, s. 25. Por. także rozdział VII, pkt 7.9.

$159 \mathrm{Na}$ temat określeń stosowanych dla nazwania omawianego przestępstwa por. A. Zientara, Przestępstwo nadużycia..., s. 88-89.

160 Ustawa z dnia 9 czerwca 2011 r. o zmianie ustawy - Kodeks karny oraz niektórych innych ustaw (Dz. U. $2011 \mathrm{Nr}$ 133, poz. 767).

161 Por. J. Giezek, P. Kardas, Konstrukcja dziatania na szkodę spótki handlowej oraz przestępstwa stanowiace jej odpowiednik - projekt nowelizacji, Palestra 2011, nr 1-2, s. 154.

162 Ustawa z dnia 15 września 2000 r. - Kodeks spółek handlowych (Dz. U. 2000 Nr 94, poz. 1037 ze zm.). 
(obecnie uchylonym) ${ }^{163}$. Istota nadużycia zaufania z art. $296 \mathrm{kk}$ sprowadza się do „naruszenia przez sprawcę obowiązku wierności podmiotowi, który powierzył swoje interesy ekonomiczne jemu do prowadzenia wyrządzając tym interesom szkodę"164. Podmiotem tym może być każda prowadząca działalność gospodarczą osoba fizyczna, prawna albo jednostka organizacyjna nie mająca osobowości prawnej. Działanie na szkodę przedsiębiorcy może przybrać zarówno formę aktywną, jak i pasywną - w kontekście praktyk antykonkurencyjnych może być to np. podjęcie decyzji o wejściu w kartel, ale także niesprzeciwianie się antykonkurencyjnym praktykom firmy.

W doktrynie panują rozbieżności co do precyzyjnego określenia dobra chronionego przez art. 296 kk. Sąd Najwyższy uznał, że „indywidualnym (szczególnym) przedmiotem ochrony tego przepisu jest majątek (interesy majątkowe) wymienionych w nim podmiotów gospodarczych i ich prawidłowa działalność na tym polu (gospodarczym). Finalnie przepis art. 296 k.k. ma zapobiec powstaniu szkody majątkowej, w tym uszczerbkowi (stracie, ubytkowi) w majątku podmiotu gospodarczego. Zamach sprawcy jest więc obrócony przeciwko temu majątkowi (...)"165. W piśmiennictwie dobro chronione postrzegane jest niekiedy (według mnie słusznie) znacznie szerzej: A. Zientara uznała, że omawiany przepis „,chroni interesy wszelkich podmiotów, nie tylko prowadzących działalność gospodarczą, a więc przedsiębiorców"166, w związku z czym autorka kwalifikuje jako dobro chronione ,interes majątkowy każdej osoby, nie tylko przedsiębiorcy"167 (w tym również osób fizycznych nie prowadzących działalności gospodarczej). Po nowelizacji art. $296 \mathrm{kk}$ aktualność zachowują, moim zdaniem, poglądy wyrażone w odniesieniu do dawnego art. $585 \mathrm{ksh}$, iż dobrem chronionym w tym przypadku są interesy przedsiębiorstwa (w tym spółki) jako całości, jej wierzycieli i wspólników ${ }^{168}$.

163 Nowelizacja Kodeksu karnego nie polegała jednak na prostym włączeniu treści art. 585 ksh do art. 296 kk, gdyż dotychczasowa treść art. 585 ksh uległa znacznym modyfikacjom: odpowiedzialność karna została powiązana ze znaczną szkodą materialną, odpowiedzialność karna za prowadzenie niebezpieczeństwa wyrządzenia szkody została rozszerzona na wspólników spółek osobowych, wprowadzono wnioskowy tryb ścigania (chyba, że pokrzywdzonym jest Skarb Państwa). Szerzej zmiany te omawia M. Romanowski, Dziatanie na szkodę spótki - uwagi po uchyleniu art. 585 k.s.h., PPH 2012, nr 4, s. 43-51.

164 O. Górniok, Przestępstwa przeciwko obrotowi gospodarczemu, [w:] O. Górniok (red.), Prawo karne gospodarcze, C. H. Beck, Warszawa 2003, s. 75.

165 Wyrok SN - Izba Karna z dnia 26 stycznia 2011 r., II KK 214/2010, OSP 2012, nr 1, poz. 5. 166 A. Zientara, Przestępstwo nadużycia..., s. 90.

167 Ibidem. Tak również O. Górniok, Przestępstwa przeciwko..., [w:] O. Górniok (red.), Prawo karne..., s. 81.

168 O. Górniok, Czyny karalne przewidziane w Kodeksie spótek handlowych (Tytut V), [w:] O. Górniok (red.), Prawo karne..., s. 125. Tak również w odniesieniu do art. 296 § 1a kk - M. Romanowski, Dziatanie na szkodę..., s. 48. 
Zakres podmiotowy tego przestępstwa wyznaczają podstawy prawne i treść kompetencji powierzonych sprawcy przez jakikolwiek podmiot posiadający interesy majątkowe lub prowadzący działalność gospodarczą. Art. $296 \S 1 \mathrm{kk}$ wymienia tu: akt normatywny, decyzję właściwego organu oraz umowę. W kontekście działań antykonkurencyjnych najczęściej będzie wchodzić $\mathrm{w}$ grę ta ostatnia podstawa prawna. W literaturze podkreśla się przy tym, że podmiotem przestępstwa nadużycia zaufania może być tylko osoba zajmująca się sprawami majątkowymi lub działalnością gospodarczą na cudzy rachunek i w cudzym imieniu ${ }^{169}$, z tym, że zajmowanie się sprawami majątkowymi nie może polegać tylko na dbaniu o stan powierzonego mienia, ale także na „przysparzaniu mienia w procesie gospodarowania” ${ }^{170}$.

Jak stwierdził SA w Warszawie ${ }^{171}$, „zajmowanie się sprawami majątkowymi w rozumieniu art. $296 \S 1$ k.k. to m.in.: wykonywanie czynności o kompetencjach władczych, kierowanie sprawami majątkowymi w sposób identyczny lub zbliżony zakresowo do tego, co czynić może sam mocodawca, podejmowanie czynności polegających na zarządzaniu mieniem, decydowanie w zakresie składników majątkowych, zawieranie umów, w wyniku których następuje przeniesienie własności, obciążenie majątku, zniesienie obowiązków lub przyjęcie zobowiązań obciążających majątek, zawieranie ugody sądowej, ochrona interesów mocodawcy". W orzecznictwie uznano, że do kręgu osób, jakie mogą być pociągnięte do odpowiedzialności karnej na podstawie art. $296 \mathrm{kk}$ należą „niewątpliwie dyrektorzy i ich zastępcy poszczególnych, wyodrębnionych zakładów (działów), funkcjonujących w ramach spółki kapitałowej i zatrudnieni w niej w oparciu i umowę o pracę, mimo że nie wchodzą w skład statutowych władz tej spółki”"172.

Naganne działanie sprawcy polega na nadużyciu uprawnień lub niedopełnieniu obowiązków. Pierwsze z wymienionych działań nie jest jednoznaczne z przekroczeniem uprawnień - określone zachowanie może mieścić się $\mathrm{w}$ prawnym zasięgu uprawnień, ale może pozostawać w sprzeczności $\mathrm{z}$ celami, dla których uprawnienia te zostały przekazane. $\mathrm{Z}$ taką sytuacją możemy mieć do czynienia w przypadku działań polegających np. na podjęciu przez menadżera decyzji o przystąpieniu do kartelu: samo podpisywanie umów mieści się bowiem w kompetencjach menadżera, ale już nie

169 A. Zientara, Przestęstwo nadużycia..., s. 116.

170 Por. wyrok SN - Izba Karna z dnia 7 lipca 2009 r., V KK 82/2009, OSNWSK 2009, poz. 1455.

171 Wyrok SA w Warszawie z dnia 28 listopada 2008 r., II AKa 361/08, LexPolonica nr 2061139, Prok. i Pr. - wkł. 2009, nr 10, poz. 35.

172 Wyrok SA w Katowicach z dnia 27 października 2005 r., II AKa 88/05, Prok. i Pr. 2006, nr 7-8, poz. 28. 
podpisywanie umów sprzecznych z prawem. Niedopełnienie obowiązków może z kolei polegać bądź na całkowitej bezczynności, bądź na częściowej realizacji obowiązków lub ich niestarannym wykonywaniu.

Przestępstwo z art. $296 \S 1$ kk jest przestępstwem materialnym ${ }^{173}$, którego skutkiem może być znaczna (§ 1) lub - w typie kwalifikowanym - wielka (§ 3) szkoda majątkowa. Natomiast przestępstwo stypizowane w art. 296 $\S 1$ a kk polega wyłącznie na sprowadzeniu bezpośredniego niebezpieczeństwa wyrządzenia znacznej szkody majątkowej - w doktrynie nie było zgody co do tego, czy przestępstwo stypizowane w art. 585 ksh (którego następcą jest art. 296 § 1a kk) jest przestępstwem materialnym czy formalnym ${ }^{174}$. W treści art. 296 § 1a kk znamię znacznej szkody majątkowej wydaje się przesuwać racje w stronę uznania tego przestępstwa za przestępstwo skutkowe (materialne).

W orzecznictwie i doktrynie nie ma zgody co do zakresu pojęcia szkody w świetle art. 296 kk, należy jednak zgodzić się z poglądami opowiadającymi się za przyjęciem takiego rozumienia szkody, które gwarantuje spójność systemową, tj. uznawania za szkodę na gruncie omawianego przepisu, na wzór rozumienia cywilistycznego, zarówno damnum emergens, jak i lucrum cessans $^{175}$. W polskim piśmiennictwie obecny jest - zasługujący na pełną aprobatę - pogląd, że kara pieniężna nałożona na przedsiębiorcę przez organ ochrony konkurencji za naruszenie przepisów prawa ochrony konkurencji powinna być uznana za szkodę w rozumieniu art. $296 \mathrm{kk}$, ponieważ „konieczność zapłaty kary będzie stanowiła uszczuplenie majątku zarządzanego podmiotu, które - gdyby działanie zarządcy było prawidłowe nie nastąpiłoby" ${ }^{176}$. Słusznie jednak A. Zientara wskazuje na potrzebę zbilansowania strat i korzyści w sytuacji, gdy praktyka antykonkurencyjna co prawda spowodowała konieczność uiszczenia kary pieniężnej, ale jednocześnie przyczyniła się do osiągnięcia korzyści przez przedsiębiorcę ${ }^{177}$. Do tego bilansu, w moim przekonaniu, należałoby włączyć również ewentualne roszczenia cywilnoprawne kierowane przeciwko przedsiębiorcy, który dopuścił się naruszenia. Dokonanie takiego bilansu jest możliwe i konieczne tylko wówczas, jeśli przyjmiemy, że art. 296 kk chroni prawo mandanta do osiągnięcia zysku, nawet jeśli jest on pozyskany metodami nielegal-

173 Wyrok SN z dnia 8 lutego 2000 r., V KKN 557/99, Prok. i Pr. 2000, nr 9, poz. 9 (wkładka).

174 Problematykę tę szeroko zaprezentował P. Kardas, Dziatania na szkodę spótki-konkretne czy abstrakcyjne narażenie na niebezpieczeństwo, PiP 2006, nr 6, s. 58-72.

175 Tak m.in. A. Zientara, Przestępstwo nadużcia..., s. 104. Autorka w swojej pracy wyczerpująco prezentuje przegląd stanowisk doktrynalnych i orzeczniczych odnoszących się do spornej kwestii - por. s. 100-113.

176 Ibidem, s. 111.

177 Ibidem. 
nymi. Należy jednak zaznaczyć, że pogląd o możliwości zaliczenia w poczet szkody kary nałożonej przez organ ochrony konkurencji niekoniecznie jest podzielany w orzecznictwie: SN uznał bowiem, że ,nie do podzielenia jest mniemanie, że (nieuregulowany podatek VAT) czy jakakolwiek należność publiczno-prawna może być dla podmiotu gospodarczego szkodą majątkową o której mowa w art. 296 k.k."178.

Przestępstwo nadużycia zaufania zagrożone jest karą pozbawienia wolności od 3 miesięcy do 5 lat, jeśli jednak wyrządzona została szkoda majątkowa w wielkich rozmiarach, kara pozbawienia wolności może być orzeczona na okres od roku do 10 lat. Jeśli przestępstwo zostało popełnione nieumyślnie lub polega ono wyłącznie na narażeniu na niebezpieczeństwo wyrządzenia znacznej szkody majątkowej, kara pozbawienia wolności wynosi do 3 lat. Natomiast działanie umyślne w celu osiągnięcia korzyści majątkowej podlega karze pozbawienia wolności od 6 miesięcy do 8 lat.

Przestępstwo nadużycia zaufania jest ścigane $\mathrm{z}$ urzędu, wyjątkiem pozostaje bezpośrednie sprowadzenie niebezpieczeństwa szkody z art. 296 $\S 1 \mathrm{a}$ kk, które w tym trybie jest ścigane tylko wówczas, gdy pokrzywdzonym jest Skarb Państwa. Podobnie jak przestępstwo z art. 305 kk, przestępstwo nadużycia zaufania może być popełnione zarówno przez osobę fizyczną, jak i podmioty zbiorowy [na mocy art. 16 ust. 1 pkt 1 lit. a) ustawy o odpowiedzialności podmiotów zbiorowych za czyny zabronione pod groźbą kary].

Art. $296 \S 5$ zawiera klauzulę niepodlegania karze opartą na przesłance czynnego żalu, a stanowiąca , „wraz traktowania pokrzywdzonego jako równoprawnej strony postępowania karnego"179. M. Romanowski uważa, że poprzez obowiązywanie tego przepisu „ustawodawca wysyła wyraźny sygnał, że celem

178 Wyrok SN - Izba Karna z dnia 26 stycznia 2011 r., II KK 214/2010, OSP 2012, nr 1, poz. 5. Na marginesie należy zaznaczyć, że możliwość egzekwowania przez przedsiębiorców od menadżerów kar i innych wydatków poniesionych w związku z prowadzonym postępowaniem antymonopolowym napotkała zdecydowany sprzeciw w brytyjskich sądach, które zastosowały w takim przypadku zasadę ex turpi causa non oritur actio. Por. wyroki w sprawach: Safeway Stores Ltd v Twigger (Leave to Appeal) Unreported April 4, 2011 (SC); Safeway Stores Ltd v Twigger [2010] EWCA Civ 1472; [2011] Bus. L.R. 1629 (CA (Civ Div)) - szerzej na ten temat zob. G. Sproul, UK courts rule out recovery of competition penalties from directors and employees, G.C.L.R. 2011, vol. 4(2), s. 74-78; S. Richards, S. Thevarajaha, Liability of directors under competition law, E.C.L.R. 2012, vol. 33(1), s. 1-4. Inne stanowisko wobec tego problemu zajął sąd holenderski, stwierdzając, że menadżer, którego odpowiedzialność za antykonkurencyjną praktykę została potwierdzona, może być zobowiązany do zwrotu kary zapłaconej w postępowaniu antymonopolowym przez przedsiębiorcę - por. wyrok Den Bosch Court of Appeal, May 18, 2010 LJN: BM5941; szerzej na ten temat zob. Dutch Court of Appeal rules that director may be personally liable for company's competition fine, G.C.L.R. 2010, vol. 3(4), R86.

179 O. Górniok, Przestęstwa przeciwko..., [w:] O. Górniok (red.), Prawo karne..., s. 78. 
art. 296 kk jest przeciwdziałanie wyrządzeniu szkody, a w konsekwencji, iż brak szkody usuwa konieczność (ultima ratio) stosowania tak drastycznego środka represji, jakim jest sankcja karna pozbawienia wolności"180.

Należy zaznaczyć, że żadna ze wskazanych powyżej podstaw prawnych nie jest w stanie skutecznie pełnić podstawy ścigania przestępstw monopolizacji rynku. W przypadku art. $305 \mathrm{kk}$ istotną słabością regulacji jako podstawy zwalczania praktyk antykonkurencyjnych jest wnioskowy charakter ścigania tego przestępstwa, odbierający jej charakter uniwersalnej podstawy prawnokarnej dla walki z kartelami. Artykuł 296 kk co prawda daje możliwość ścigania $\mathrm{z}$ urzędu, jednak wymaga dowiedzenia istnienia (choćby potencjalnie, jak w przypadku art. 296 § 1a kk) szkody - wielkiej lub znacznej, podczas gdy najtwardsze kartele powinny być penalizowane bez względu na skutek. Ponadto zastosowanie art. 296 kk wymaga konkretyzacji szkody w odniesieniu do określonego podmiotu, co wyklucza możliwość ścigania tych karteli, które, nawet jeśli w niewielkim stopniu oddziałują na danego przedsiębiorcę, w znacznym stopniu ograniczają (lub mogą ograniczać) konkurencję. Reasumując, żaden $\mathrm{z}$ istniejących w polskim prawie karnym przepisów nie realizuje - w moim przekonaniu - najważniejszych założeń kryminalizacji prawa ochrony konkurencji.

\subsubsection{Odpowiedzialność karna podmiotów zbiorowych}

W polskim piśmiennictwie wyróżnia się dwa nurty odpowiedzialności podmiotów zbiorowych ${ }^{181}$ : pierwszy z nich stanowi prawo administracyjno-karne, przewidujące odpowiedzialność za tzw. delikty administracyjne, ponoszoną co prawda przed organami administracyjnymi, ale obejmującą dotkliwe sankcje o charakterze majątkowym; należy dodać, że podobny charakter mają również sankcje za delikty administracyjne nakładane na jednostki. Drugim wskazywanym w piśmiennictwie nurtem jest model tzw. odpowiedzialności prejudycjalnej, polegający na tym, że pociągnięcie przedsiębiorcy do odpowiedzialności przez organ administracji uzależnione jest od uprzedniego prawomocnego skazania za określone przestępstwo lub umorzenia postępowania karnego. W tym nurcie mieszczą się - zdaniem niektórych autorów - prawnokarne przepisy ustawy o zwalczaniu nieuczciwej konkurencji oraz ustawa o odpowiedzialności karnej podmiotów zbiorowych. Rozwiązania te mogą być uznane za realizację modelu karnej odpowiedzialności identyfi-

180 M. Romanowski, Działanie na szkodę..., s. 45.

181 S. Waltoś, O odpowiedzialności karnej podmiotów zbiorowych, Edukacja Prawnicza 2003, nr 12. 
kacyjnej podmiotów zbiorowych, w tym odpowiedzialności za naruszenia zakazów praktyk ograniczających konkurencję.

W pierwszej kolejności należy przypomnieć, że odpowiedzialności karnej osób prawnych za naruszenia z zakresu prawa ochrony konkurencji dopatrywano się w Polsce już pod rządami ustawy kartelowej z 1933 r. ${ }^{182}$ (po nowelizacji w 1935 r.) ${ }^{183}$. W regulacji tej przewidywano nałożenie na osobę prawną kary grzywny lub aresztu (na reprezentantów tej osoby) w związku $\mathrm{z}$ wykonywaniem porozumienia kartelowego uznanego za nieważne. Jednoznaczne stanowisko co do istnienia odpowiedzialności karnej osób prawnych zajął Sąd Kartelowy, wskazując, że ,jeżeli chodzi o ustawę o kartelach, to redakcja jej poszczególnych przepisów (np. art. 11), a także różnica w wysokości przewidzianej grzywny pomiędzy przepisami, które niewątpliwie dotyczą osób fizycznych, a temi, które mogą również dotyczyć osób prawnych, zdaje się wskazywać na to, że ustawa ta uznaje odpowiedzialność karną osób prawnych"184. Pogląd o funkcjonowaniu karnej odpowiedzialności zbiorowej w przedwojennej ustawie kartelowej podtrzymują także współcześni autorzy, m.in. S. Waltoś185 (który podkreśla, że istniejące regulacje nie miały żadnego praktycznego znaczenia).

Możliwość wprowadzenia odpowiedzialności karnej podmiotów zbiorowych otworzyła w Polsce na nowo Ustawa z dnia 28 października 2002 r. o odpowiedzialności podmiotów zbiorowych za czyny zabronione pod groźbą kary186. W polskiej doktrynie nie ma jednak nawet zgodności co do tego, czy model odpowiedzialności wprowadzony tą ustawą ma rzeczywiście charakter odpowiedzialności karnej (ustawodawca nie przesądził tego w tytule ustawy). Do zwolenników poglądu, że jest to odpowiedzialność karna podmiotów zbiorowych należy zaliczyć J. Skupińskiego ${ }^{187}$, S. Waltosia ${ }^{188}$,

182 Ustawa z dnia 28 marca 1933 r. o kartelach (Dz. U. 1933 Nr 31, poz. 270).

183 Dekret Prezydenta Rzeczypospolitej z dnia 27 listopada 1935 r. w sprawie zmiany ustawy z dnia 28 marca 1933 r. o kartelach (Dz. U. $1935 \mathrm{Nr}$ 86, poz. 529).

184 Uzasadnienie do orzeczenia Sądu Kartelowego, OPA 1936, nr 1459, s. 345-346 - cytuję za: M. Pniewska, Problematyka charakteru prawnego odpowiedzialności podmiotów zbiorowych za czyny zabronione pod groźba kary w prawie polskim, Studia Iuridica Toruniensia 2006, Tom VI, s. 193. Autorka wskazuje, że istnienie odpowiedzialności karnej osób prawnych w ustawie kartelowej potwierdzali także J. Makarewicz i S. Śliwiński.

185 S. Waltoś, $O$ odpowiedzialności karnej..., op. cit.

186 Test jednolity Dz. U. z 2012 r., poz. 768, 769 i 1193; dalej jako uokpz.

187 J. Skupiński, Odpowiedzialność podmiotów zbiorowych na tle ustawy z dnia 28 października 2002 roku (próba zarysu problematyki), [w:] Aktualne problemy prawa i procesu karnego; księga ofiarowana Profesorowi Janowi Grajewskiemu, Gdańskie Studia Prawnicze, 2003, t. XI, s. 371.

188 S. Waltoś, $O$ odpowiedzialności..., op. cit. 
M. Filara ${ }^{189}$; inny pogląd prezentuje B. Namysłowska-Gabrysiak, która uważa, że polska ustawa odrzuca bezpośrednią odpowiedzialność podmiotów zbiorowych ${ }^{190}$. Również Trybunał Konstytucyjny w wyroku z dnia 3 listopada 2004 r., K 18/03191, uznał, że model odpowiedzialności przyjęty w ustawie „nie ma charakteru odpowiedzialności karnej sensu stricto”.

$\mathrm{Z}$ definicji legalnej podmiotu zbiorowego (art. 2 uokpz) wynika, że za podmiot taki nie będzie uznany przedsiębiorca będący osobą fizyczną (ani spółka cywilna ${ }^{192}$ ), a także Skarb Państwa, jednostki samorządu terytorialnego oraz ich związki; podmiotem zbiorowym będzie natomiast m.in. podmiot $\mathrm{w}$ stanie likwidacji czy zagraniczna jednostka organizacyjna (art. 2 ust. 2 uokpz). Podmiot zbiorowy odpowiada za czyn zabroniony popełniony przez osobę fizyczną, jeśli mógł on przynieść temu podmiotowi korzyść, choćby niemajątkową. Z brzmienia art. 5 uokpz wynika, że podmiot zbiorowy odpowiada na zasadzie winy, przy czym, jak podkreśla się w piśmiennictwie, wina ta ma charakter „nieco cywilistyczny”193, bowiem, jak stwierdził Sąd Najwyższy, przyjmuje postać culpa in eligendo i culpa in custodiendo ${ }^{194}$. Wina polega bowiem co najmniej na braku należytej staranności w wyborze osoby fizycznej lub co najmniej braku należytego nadzoru nad osobą fizyczną dopuszczoną do działania w wyniku przekroczenia uprawnień lub niedopełnienia obowiązków przez osobę działającą w imieniu lub w interesie podmiotu zbiorowego (w ramach swoich uprawnień lub obowiązków) bądź działającą $w$ imieniu lub interesie podmiotu zbiorowego, za zgodą lub wiedzą osoby działającej w imieniu lub w interesie podmiotu zbiorowego (w ramach swoich uprawnień lub obowiązków) (art. 5 ust. 1 uokpz). Popełnienie czynu zabronionego przez osoby, które w strukturze podmiotu zbiorowego działają w jego imieniu lub $w$ interesie i w ramach własnego uprawnienia lub obowiązku (np. członkowie zarządu spółek prawa handlowego), nie stanowi podstawy prawnej do orzeczenia odpowiedzialności podmiotu zbiorowego za czyny zabronione pod groźbą kary195. Wina może polegać również na

189 M. Filar (red.), Z. Kwaśniewski, D. Kala, Komentarz do ustawy o odpowiedzialności podmiotów zbiorowych za czyny zabronione pod groźba kary, wyd. TNOiK Toruń 2003, s. 26.

190 B. Namysłowska-Gabrysiak, Odpowiedzialność karna osób prawnych, C. H. Beck, Warszawa 2003, s. 192.

191 Dz.U. 2004 Nr 243, poz. 2442.

192 Por. uchwała SN - Izba Karna z dnia 26 kwietnia 2007 r., I KZP 7/2007, OSNKW 2007, nr 5, poz. 38.

193 S. Waltoś, $O$ odpowiedzialności..., op. cit.

194 Wyrok SN - Izba Karna z dnia 11 kwietnia 2011 r., V KK 27/2011, OSNKW 2011, nr 9 poz. 77.

195 Wyrok SN - Izba Karna z dnia 6 kwietnia 2011 r., V KK 15/2011, OSNKW 2011, nr 8, poz. 72 . 
takiej organizacji działalności podmiotu zbiorowego, która nie zapewniała uniknięcia popełnienia czynu zabronionego przez daną osobę, podczas gdy mogło je zapewnić zachowanie należytej staranności wymaganej w danych okolicznościach przez organ lub przedstawiciela podmiotu zbiorowego (art. 5 ust. 2 uokpz) ${ }^{196}$. Odpowiedzialność podmiotu zbiorowego jest nierozerwalnie powiązana z odpowiedzialnością karną osoby fizycznej - zgodnie $\mathrm{z}$ art. 4 uokpz podmiot zbiorowy podlega odpowiedzialności tylko wówczas, gdy popełnienie czynu zabronionego zostało potwierdzone prejudycjalnym wyrokiem. Wobec podmiotu zbiorowego możliwe jest orzeczenie kary pieniężnej (art. 7 uokpz) oraz wskazanych w ustawie środków zbliżonych do środków karnych ${ }^{197}$ (art. 8-9 uokpz).

Ustawodawca przyjął, że podmioty zbiorowe ponoszą odpowiedzialność jedynie za przestępstwa enumeratywnie wyliczone w art. 16 uokpz. Wśród czynów tych znajdują się przestępstwa określone w art. 23-24b uznk (art. 16 pkt 10 uokpz), jak również przestępstwa $\mathrm{z}$ obszaru ochrony własności intelektualnej określone w art. 115-1181 ustawy Prawo autorskie (art. 16 pkt 11 uokpz). W obecnym brzmieniu omawiana ustawa nie przewiduje oczywiście odpowiedzialności podmiotów zbiorowych za naruszenia zakazów praktyk ograniczających konkurencję, jednak można wyobrazić sobie, że przestępstwo monopolizacji rynku (przestępstwo kartelowe) mogłoby znaleźć się w wykazie z art. 16 uokpz $^{198}$. Warunkiem sine qua non byłoby oczywiście uprzednie stypizowanie przestępstwa $\mathrm{w}$ ustawie o ochronie konkurencji i konsumentów lub Kodeksie karnym.

\subsubsection{Wspólistnienie prawnokarnego trybu egzekwowania zakazów antykonkurencyjnych praktyk $\mathrm{z}$ innymi trybami}

\subsubsection{Tryb prawnokarny a tryb administracyjnoprawny}

Zasadnicze pytanie, jakie pojawia się w tym kontekście dotyczy racjonalności współistnienia karnego i administracyjnego systemu egzekwowania prawa ochrony konkurencji. Programując zrównoważony model ochrony

196 Por. wyrok SN - Izba Karna z dnia 28 października 2011 r., III KK 266/2011, LexPolonica nr 3047452.

197 Nazwanie środków przewidzianych w art. 8-9 uokpz może budzić sprzeciw - por. J. Giezek, G. Łabuda, System sankcji w ustawie o odpowiedzialności podmiotów zbiorowych za czyny zabronione pod groźba kary Prok. i Pr. 2004, nr 11-12, s. 81.

$198 \mathrm{~W}$ polskim piśmiennictwie zwolenniczką wprowadzenia regulacji odnoszących się do odpowiedzialności karnej podmiotów zbiorowych za czyny antykonkurencyjne jest M. Król-Bogomilska, Kary antymonopolowe..., s. 256-260. 
konkurencji należałoby również rozważyć, czy kryminalizacja prawa ochrony konkurencji nie powinna prowadzić do wykluczenia sankcji administracyjnych (administracyjno-karnych) dla przedsiębiorców. Wydaje się, że pożądanym byłoby, aby odbywa systemy ze sobą współistniały, gdyż sankcje indywidualne (karne) należy postrzegać jako komplementarne wobec sankcji korporacyjnych (administracyjnych). Zagrożenie tymi pierwszymi w żaden sposób nie eliminuje odstraszającego efektu sankcji nakładanych na przedsiębiorców jako jednostki organizacyjne. W braku sankcji dla przedsiębiorców firmy wykazywałyby interes wręcz w zachęcaniu swoich pracowników do podejmowania działań antykonkurencyjnych ${ }^{199}$. Brak sankcji nakładanych na przedsiębiorców oznaczałby również wyeliminowanie programu leniency, uważanego współcześnie za jeden z filarów efektywnej polityki konkurencji. Niewątpliwie najbardziej rewolucyjnym scenariuszem byłaby rezygnacja $z$ administracyjnego trybu egzekwowania zakazów praktyk antykonkurencyjnych i przeniesienie „ścigania” antykonkurencyjnych zachowań przedsiębiorców do trybu karnego. Obserwując tendencje rozwojowe prawa ochrony konkurencji nie można wykluczyć ziszczenia się tego scenariusza, co faktycznie oznaczałoby „amerykanizację” modelu egzekwowania prawa ochrony konkurencji. Istotną przeszkodą może jednak okazać się tu, w moim przekonaniu, zarówno europejska tradycja ochrony antymonopolowej, jak i standardy i zasady kontynentalnego prawa karnego. Podstawowej trudności upatruję w takim określeniu znamion przestępstwa monopolizacji rynku, by możliwe było zastosowanie przepisu przy zachowaniu standardów ochrony praw podstawowych, gwarantowanych tak przez EKPC i unijną Kartę praw podstawowych, jak i konstytucje krajowe. Doświadczenia brytyjskie i irlandzkie wydają się potwierdzać te obawy. Wskazanie znamion przestępstwa wydaje się prostsze w przypadku najtwardszych karteli (niż w przypadku praktyk nadużywania pozycji dominującej), dlatego prawdopodobny wydaje się „,rozszczepiony”, trójdzielny model egzekwowania prawa ochrony konkurencji, w którym kartele będą przestępstwami, zaś porozumienia wertykalne oraz nadużywanie pozycji dominującej - deliktami administracyjnymi. Ponadto ze względu na liczne kontrowersje towarzyszące korporacyjnej odpowiedzialności karnej, należałoby postulować takie ukształtowanie publicznego trybu egzekwowania zakazów antykonkurencyjnych praktyk, w którym odpowiedzialność karna przewidziana będzie dla osób fizycznych, zaś odpowiedzialność administracyjna (aczkolwiek nie wolna od elementów prawnokarnych) - dla przedsiębiorców. Wymaga to oczywiście przyjęcia określonych rozwiązań dotyczących zbiegu sankcji w przypadku, gdy przed-

199 P. Whealan, A Principled Argument..., s. 30. 
siębiorcą poddanym sankcjom administracyjnoprawnym jest osoba fizyczna prowadząca działalność gospodarczą. W takim wypadku należałoby rozważyć rozwiązanie, zgodnie z którym wobec osoby fizycznej prowadzącej działalność gospodarczą stosowana byłaby sankcja surowsza.

Do rozważania pozostaje także to, czy w warunkach kryminalizacji prawa ochrony konkurencji (choćby poprzez karę pozbawienia wolności dla osób fizycznych), sankcjom nakładanym na przedsiębiorców w trybie administracyjnym nie należałoby odebrać charakteru prawnokarnego, przyznając im funkcje sankcji typowo administracyjnych. Rozwiązanie takie, choć poprawne „dogmatycznie”, mogłoby jednak zanadto stępić ostrze polityki konkurencji prowadzonej przez organy ochrony konkurencji, co w dłuższej perspektywie (jak wielokrotnie podkreślam w niniejszej rozprawie) mogłoby prowadzić do osłabienia prywatnego trybu egzekwowania zakazów praktyk ograniczających konkurencję.

Model publicznoprawnego trybu egzekwowania zakazów antykonkurencyjnych praktyk, w którym odpowiedzialność karna przewidziana jest dla osób fizycznych, zaś odpowiedzialność za delikty administracyjne - dla przedsiębiorców (abstrakcyjnych podmiotów prawnych), można określić jako umiarkowany, wypośrodkowany, a jego wprowadzenie nie wymagałoby, w moim przekonaniu, nazbyt rewolucyjnych zmian legislacyjnych, jednocześnie pozwalałoby wyeliminować kontrowersje towarzyszące wprowadzaniu odpowiedzialności administracyjno-karnej osób fizycznych. Gdyby jednak polski ustawodawca zdecydował się na kryminalizację prawa ochrony konkurencji, z dużym prawdopodobieństwem przestępstwa monopolizacji rynku (przestępstwa kartelowe) znalazłyby się wśród przestępstw poddanych odpowiedzialności karnej podmiotów zbiorowych. Oznaczałoby to dopuszczalny - w świetle art. 6 uokpz - zbieg odpowiedzialności karnej i administracyjnej przedsiębiorcy200 na podstawie ustawy o ochronie konkurencji i konsumentów. W sytuacji takiego zbiegu postępowań należałoby przyjąć, że wyrok sądu karnego ma charakter prejudycjalny dla administracyjnego postępowania antymonopolowego ${ }^{201}$ (choć $\mathrm{w}$ praktyce oznaczałoby to niejednokrotnie zawieszenie na dłuższy czas postępowania przed organem ochrony konkurencji).

Kluczowym elementem wspólistnienia karnego i administracyjnego trybu egzekwowania zakazów antykonkurencyjnych praktyk pozostają programy darowania i lagodzenia kar. Zagadnienie to będzie przedmiotem rozważań w rozdziale poświęconym sankcjom ${ }^{202}$, w tym miejscu poprzestanę na

200 Por. wyrok NSA z dnia 18 kwietnia 2008 r., I FSK 526/2007, LexPolonica nr 2492026.

201 Prejudycjalny charakter postępowań karnych przewiduje art. 46 hiszpańskiej ustawy o konkurencji (ustawa nr 15/2007 z dnia 3 lipca 2007 r., BOE nr 159 z dnia 4 lipca 2007 r.).

202 Por. rozdział VII, pkt 7.9. 
stwierdzeniu, znajdującym zresztą potwierdzenie w literaturze ${ }^{203}$, że dla zrównoważonego modelu egzekwowania zakazów praktyk ograniczających konkurencję optymalne wydaje się funkcjonowanie programu leniency zarówno dla przedsiębiorców, jak i dla osób fizycznych.

Antycypując kryminalizację prawa ochrony konkurencji, towarzyszącą rezygnacji z administracyjnego trybu egzekwowania zakazów praktyk ograniczających konkurencję, należy uwzględniać okoliczność, że w okresie przejściowym obydwa publiczne tryby będą współistnieć, co wymaga odpowiedniego ukształtowania strony instytucjonalnej ochrony konkurencji. Po pierwsze należy postulować (co zostało już zaznaczone powyżej) orzekanie o odpowiedzialności karnej, zwłaszcza osób fizycznych, przez sądy karne. Po drugie jeśli ustawodawca decyduje się na utrzymanie sankcji o charakterze administracyjno-karnym bez przyznawania odpowiednich kompetencji sądom karnym, konieczne jest takie ukształtowanie modelu instytucjonalnego, aby organy (jednostki) wykonujące funkcje „prokuratorskie” były całkowicie odrębne od organów (jednostek) wykonujących funkcje orzecznicze 204 . Rozwiązanie takie nie tylko dostarcza skuteczniejszych gwarancji poszanowania praw „oskarżonych”, ale ma również niebagatelne znaczenie w sytuacji, gdy przystąpienie do leniency może skutkować zwolnieniem z odpowiedzialności karnej - rozdzielenie funkcji pozwoli na obiektywną ocenę zasadności zastosowania zwolnienia.

\subsubsection{Tryb prawnokarny a tryb prywatnoprawny}

Przedstawiciele doktryny są zgodni co do tego, że prywatne egzekwowanie prawa ochrony konkurencji nie stanowi alternatywy dla kryminalizacji naruszeń prawa ochrony konkurencji ${ }^{205}$. Zgadzam się ze stanowiskiem, że obydwa tryby należy postrzegać jako komplementarne wobec siebie. W tym kontekście na uwagę zasługują wyniki badań prowadzonych w Stanach Zjednoczonych przez R. H. Lande i J. P. Davisa, a koncentrujących się

203 F. Thépot, Leniency and Individual Liability..., s. 234-239.

204 Takie rozwiązanie przyjęte zostało przez ustawodawcę francuskiego - Rada Konkurencji występuje do prokuratora (procureur de la république) z wnioskiem o wszczęcie postępowania karnego. Sądy pierwszej i odwoławczej instancji, orzekające w sprawie z odwołania od decyzji Rady Konkurencji o wystąpieniu do prokuratora z wnioskiem o wszczęcie postępowania karnego, uznały się za niewłaściwe do oceny takiej decyzji, co w praktyce oznacza, że decyzja o skierowaniu sprawy na ścieżkę prawno karną jest całkowicie dyskrecjonalna (por. wyrok paryskiego sądu apelacyjnego z dnia 22 lutego 2006 r. 1st CH, sect H - podaję za: M. Lévy, N. Tardif, France: Cartels, [w:] The European Antitrust Review 2012, op. cit.).

205 W. P. J. Wils, Is Criminalization..., s. 39; P. Whelan, A Principled Argument..., s. 36-37. 
na porównaniu odstraszającego efektu prywatnego i karnego trybu egzekwowania zakazów antykonkurencyjnych praktyk. Porównaniu podlegała wielkość świadczeń uzyskanych w sprawach cywilnych oraz wielkość sankcji pieniężnych nałożonych w postępowaniu prawnokarnym. Wnioski płynące $\mathrm{z}$ tego porównania doprowadziły autorów do stwierdzenia, że prywatne dochodzenie roszczeń $\mathrm{z}$ tytułu naruszenia zakazów antykonkurencyjnych praktyk może wywierać lepszy skutek odstraszający niż sankcje karne stosowane przez Antitrust Division DOJ (podsumowanie świadczeń uzyskanych w procesach dotyczących tylko trzynastu karteli spośród wszystkich spraw od początku $1990 \mathrm{r}$. wskazało, że ich wysokość - szacunkowo 5,6-7 mld USD - była równa sumie kar nałożonych we wszystkich sprawach karnych) ${ }^{206}$. Odnosząc się do tych wyników G. J. Werden, S. D. Hammond, B. A. Barnett słusznie wskazali, że aktywność organów publicznych (w ramach prawno karnego trybu egzekwowania antykonkurencyjnych praktyk) ma kolosalne znaczenie dla sądowego dochodzenia roszczeñ ${ }^{207}$ (de facto w większości przypadków w ogóle je umożliwia) - nieuwzględnienie tej okoliczności we wnioskowaniu o zakresie efektu odstraszającego, w moim przekonaniu, fałszuje tezę o silniejszym efekcie odstraszającym prywatnego egzekwowania prawa ochrony konkurencji.

\subsection{Uwagi końcowe}

Ostateczny kształt zintegrowanego i zrównoważonego modelu egzekwowania zakazów praktyk ograniczających konkurencję zależy od szczegółowych rozwiązań prawnych przyjętych dla każdego z submodeli. Ukształtowanie kompleksowego modelu pozostaje zatem kwestią specyficzną dla danego (krajowego) porządku prawnego, nawet jeśli możliwe jest odtworzenie pewnego zgeneralizowanego wzorca publicznoprawnego trybu egzekwowania zakazów antykonkurencyjnych praktyk, stosowanego w wielu porządkach prawnych.

Na obecnym etapie rozwoju prawa ochrony konkurencji tak w Polsce, jak i w Unii Europejskiej i jej innych państwach członkowskich, pierwszoplanową rolę odgrywa publicznoprawny tryb egzekwowania prawa ochrony konkurencji, a w jego ramach - tryb administracyjnoprawny. Niemniej jednak coraz silniejszy nurt kryminalizacji prawa ochrony konkurencji, widoczny

206 Szerzej por. R. H. Lande, P. J. Davis, Comparative Deterrence from Private Enforcement and Criminal Enforcement of the U.S. Antitrust Laws, University of San Francisco School of Law Legal Studies Research Paper Series No. 2010-17.

207 G. J. Werden, S. D. Hammond, B. A. Barnett, Deterrence and detection..., s. 230-233. 
także w Polsce (zwłaszcza w propozycjach nowelizacyjnych ustawy o ochronie konkurencji i konsumentów z 2012 r.), pozwala przypuszczać, że sytuacja ta w przyszłości może ulec zmianie. Zmiany tej należy się spodziewać przede wszystkim w prawie krajowym, mniej prawdopodobna wydaje się ona w prawie unijnym (głównie ze względu na nadal ograniczone kompetencje Unii Europejskiej w dziedzinie prawa karnego). Ewolucja publicznoprawnego trybu egzekwowania zakazów praktyk ograniczających konkurencję w stronę wzmocnienia filaru karnoprawnego będzie jednak w istocie dotyczyła karteli, objętych zakazem porozumień ograniczających konkurencję, poza zakresem prawa karnego powinny pozostać porozumienia wertykalne i nadużywanie pozycji dominującej. W praktyce oznacza to, że model współistnienia publicznoprawnego i prywatnoprawnego egzekwowania zakazów praktyk ograniczających konkurencję dla karteli może w przyszłości wyglądać inaczej niż dla porozumień wertykalnych i nadużywania pozycji dominującej. 
Rozdział III

\section{Prywatnoprawny tryb egzekwowania zakazów praktyk ograniczających konkurencję}

\subsection{Uwagi wstępne}

Ze względu na publicznoprawny rodowód przepisów o ochronie konkurencji, w tym przepisów ustanawiających zakazy praktyk ograniczających konkurencję, możliwość prywatnego trybu egzekwowania reguł konkurencji nie jest - w przeciwieństwie do naturalnej ścieżki publicznoprawnej - oczywista. Nie dotyczy to oczywiście sytuacji, w których dla prywatnego egzekwowania reguł konkurencji przewidziana została samodzielna podstawa prawna, ale tego typu rozwiązania należą do rzadkości, znacznie częściej sądowe dochodzenie roszczeń z tytułu naruszenia zakazów antykonkurencyjnych praktyk wynika $\mathrm{z}$ akceptacji takiego rozwiązania w orzecznictwie. Nie oznacza to, że prywatny tryb egzekwowania reguł konkurencji nie jest w żaden sposób „zakotwiczony” w przepisach antymonopolowych - kluczową (i w części europejskich porządków prawnych - jedyną) normą, z jakiej można wywodzić możliwość dochodzenia roszczeń na drodze sądowej, jest norma ustanawiająca sankcję nieważności praktyk ograniczających konkurencję. To właśnie cywilnoprawna (prywatnoprawna) sankcja ustanowiona w regulacjach tradycyjnie kwalifikowanych jako publicznoprawne dała asumpt do rozwoju prywatnego egzekwowania prawa konkurencji, umożliwiając rozwinięcie $\mathrm{w}$ tym kierunku praktyki sądowej.

Regulacje prywatnego egzekwowania reguł konkurencji mogą być w różnoraki sposób wpisane w krajowe porządki prawne.

Po pierwsze regulacje mogą być włączone do podstawowego aktu z zakresu ochrony konkurencji (prawa antymonopolowego), odpowiednika ustawy o ochronie konkurencji i konsumentów w Polsce. Mało prawdopodobne 
wydaje się jednak to, aby akt prawny tego rodzaju zawierał kompleksową regulację sądowego dochodzenia roszczeń z tytułu naruszenia reguł konkurencji, wysoce prawdopodobne są odesłania do aktów regulujących procedurę cywilną (odpowiedników polskiego Kodeksu postępowania cywilnego). Takie rozwiązanie należy oceniać jako „nobilitację” sądowego dochodzenia roszczeń związanych z naruszeniem reguł konkurencji; przyczynia się ono do równoważnego postrzegania obydwu trybów egzekwowania reguł konkurencji.

Po drugie możliwa jest modyfikacja wskazanej powyżej opcji, polegająca na tym, że podstawowy akt prawa antymonopolowego zawiera jedynie punktowe regulacje odnoszące się do prywatnego egzekwowania reguł konkurencji (są to zwykle przepisy odnoszące się do styku publicznego i prywatnego egzekwowania reguł konkurencji, np. dotyczące udostępniania dowodów gromadzonych w postępowaniu publicznym albo występowania organu ochrony konkurencji jako amicus curiae $)^{1}$.

Trzecie rozwiązanie może polegać na przyjęciu całkowicie odrębnej, acz wyczerpującej (z ograniczonymi do minimum odesłaniami do innych aktów zawierających normy proceduralne) regulacji prywatnego egzekwowania prawa ochrony konkurencji; rozwiązanie takie wydaje się jednak mało prawdopodobne, choćby dlatego, że mimo kilku istotnych trudności, postępowanie w sprawie roszczeń z tytułu naruszenia reguł konkurencji, nie różni się zasadniczo od postępowania w sprawach roszczeń wynikających z naruszenia innych norm prawa materialnego (np. w obszarze zwalczania nieuczciwej konkurencji). Według mojej najlepszej wiedzy taki model regulacyjny pozostaje czysto teoretyczny i nie został przyjęty w żadnym ustawodawstwie.

Zbliżone rozwiązanie polega na wyodrębnieniu (jako części składowej, np. działu) regulacji prywatnego egzekwowania reguł konkurencji w akcie prawnym regulującym ogólnie procedurę cywilną (w taki sposób, jak obecnie w polskim kpc regulowane jest postępowanie w sprawach ochrony konkurencji). Z powodów wskazanych powyżej, a odnoszących się do rozwiązania drugiego, wskazana trzecia opcja również wydaje się mało prawdopodobna do zaistnienia w rzeczywistości.

Piąte rozwiązanie można określić jako „opcję zero”, polegającą na tym, że ustawodawca przyjmuje postawę bierną i w ogóle powstrzymuje się od wprowadzenia jakichkolwiek regulacji poświęconych prywatnemu egzekwowaniu reguł konkurencji. W takiej sytuacji, z którą mamy zresztą do czynienia w Polsce, sądowe dochodzenie roszczeń z tytułu naruszenia zakazów antykonkurencyjnych praktyk odbywa się na zasadach ogólnych, ustanowionych w akcie generalnie regulującym procedurę cywilną.

1 Takie rozwiązania przyjęto m.in. w: Finlandii, Irlandii, Niemczech, Szwecji. 
Wybór lokalizacji przepisów poświęconych prywatnemu egzekwowaniu reguł konkurencji jest co prawda decyzją samego ustawodawcy, jednak w przypadku, gdy pojawiłyby się wiążące regulacje prawa UE, decyzja ta w znacznym stopniu determinowana byłaby treścią przepisów unijnych.

Zadanie badawcze polegające na modelowaniu zrównoważonych korelacji między publicznoprawnym i prywatnoprawnym egzekwowaniem reguł konkurencji wymaga choćby syntetycznej prezentacji podstaw prawnych, ram instytucjonalnych i proceduralnych prywatnoprawnego egzekwowania zakazów antykonkurencyjnych praktyk w polskim porządku prawnym. Podkreślenia wymaga przy tym okoliczność, że w polskim piśmiennictwie nie ma zgody co do tego, jakie akty prawne mogą stanowić podstawę prawną dochodzenia roszczeń z tytułu naruszenia zakazów praktyk ograniczających konkurencję.

Specyfika (możliwości) prywatnoprawnego egzekwowania reguł konkurencji w Polsce zostania zaprezentowana na tle dotychczasowego dorobku (legislacyjnego, orzeczniczego) Unii Europejskiej w tym obszarze. To właśnie działania instytucji unijnych (zwłaszcza Trybunału Sprawiedliwości) postrzegam bowiem jako źródło lub przynajmniej jako czynnik motywujący do intensyfikacji omawianego trybu egzekwowania zakazów praktyk ograniczających konkurencję w Polsce.

\subsection{Prywatne egzekwowanie wspólnych reguł konkurencji Unii Europejskiej}

\subsection{1. Źródła uprawnień jednostek do dochodzenia roszczeń z tytułu naruszenia art. 101 i 102 Traktatu o funkcjonowaniu Unii Europejskiej}

Źródeł możliwości prywatnego egzekwowania reguł konkurencji należy poszukiwać zarówno w samym prawie ochrony konkurencji, jak i w szerszym kontekście, który można określić jako ustrojowy czy konstytucyjny (w przypadku prawa unijnego - „konstytucyjnym”), a nawet kulturowoprawny. Podejmując rozważania nad tymi źródłami, należy zauważyć, że dla zdecydowanej większości autorów, a także i dla Trybunału Sprawiedliwości, ,prototypem” odpowiedzialności podmiotów prywatnych (jednostek) za naruszenia prawa unijnego pozostają zasady odpowiedzialności państw członkowskich za naruszenie ponadnarodowego porządku prawnego ${ }^{2}$. Uwa-

2 Por. m.in. M. Szpunar, Odpowiedzialność podmiotu prywatnego z tytułu naruszenia prawa wspólnotowego, Oficyna a Wolters Kluwer business, Warszawa 2008, s. 291-292; M. Adamczak-Retecka, Odpowiedzialność odszkodowawcza jednostek za naruszenie prawa wspólnotowego, IWEP, Warszawa 2010, s. 91 i n. 
żam jednak, że ze względu na specyfikę art. 101 i art. 102 TFUE na tle innych przepisów Traktatu o funkcjonowaniu Unii Europejskiej (przede wszystkim fakt, że przepisy te adresowane są do przedsiębiorstw, a nie państw członkowskich) ${ }^{3}$, teza ta tylko częściowo znajduje zastosowanie wobec odpowiedzialności podmiotów prywatnych za naruszenia unijnych zakazów praktyk ograniczających konkurencję.

W obszarze prawa unijnego możliwości sądowego dochodzenia roszczeń z tytułu naruszenia zakazów antykonkurencyjnych praktyk można wywodzić z następujących, wskazanych poniżej, źródeł.

Po pierwsze za źródło takie może być uznany fakt, że art. 101 i 102 są niemal jedynymi przepisami Traktatu adresowanymi do jednostek (podmiotów prywatnych), a nie państw członkowskich UE.

Po drugie regulacjom traktatowym ustanawiającym zakazy praktyk ograniczających konkurencję przypisywany jest skutek bezpośredni, przejawiający się dostępnością krajowej drogi sądowej dla podmiotów wskazujących na naruszenia art. 101 lub $102 \mathrm{TFUE}^{4}$. Istnieje bogate orzecznictwo Trybunału Sprawiedliwości potwierdzające bezpośrednią skuteczność art. 101 TFUE $^{5}$ i art. 102 TFUE - warto przywołać choćby, szeroko komentowane w literaturze, wyroki w sprawach: BRT v. SABAM ${ }^{6}$, Simmenthal ${ }^{7}$, Factortame ${ }^{8}$, Tetra Pak ${ }^{9}$, Delimitis ${ }^{10}$, Ahmead Saed ${ }^{11}$, czy Ecco

3 Tak również M. Szpunar, Odpowiedzialność podmiotu prywatnego..., s. 332.

4 Celem niniejszych rozważań nie jest definiowanie pojęcia skutku bezpośredniego - w tym zakresie dostępna jest bardzo bogata literatura zarówno zagraniczna, jak i krajowa. W tym ostatnim obszarze na uwagę zasługuje przegląd poglądów doktryny na temat rozumienia bezpośredniego skutku dokonany przez M. Szpunara [w:] Odpowiedzialność podmiotu prywatnego..., s. 40-48.

5 Orzeczenia wydane w stanie prawnym sprzed 1 maja 2004 r. odnoszą się w zasadzie do bezpośredniej skuteczności art. 101 ust. 1 TFUE, dopiero wejście w życie rozporządzenia 1/2003 uczyniło cały art. 101 (łącznie z ust. 3) TFUE bezpośrednio skutecznym.

6 Wyrok Trybunału z dnia 30 czerwca 1974 r. w sprawie 127/73 Belgische Radio en Televisie v SV SABAM and NV Fonior (Zb. Orz. 1974, s. 00051).

7 Wyrok Trybunału z dnia 9 marca 1978 r. w sprawie 106/77 Amministrazione delle Finanze dello Stato $v$ Simmenthal SpA (Zb. Orz. 1978, s. 00629).

8 Wyrok Trybunału z dnia 19 czerwca 1990 r. w sprawie C-213/89 The Queen v Secretary of State for Transport, ex parte: Factortame Ltd i inni (Zb. Orz. 1990, s. I-02433).

9 Wyrok SPI z dnia 14 listopada 1996 r. w sprawie Tetra Pak International SA v. Komisja Wspólnot Europejskich (Zb. Orz. 1996, s. II-05951).

10 Wyrok Trybunału z dnia 28 lutego 1991 r. w sprawie C-234/89 Stergios Delimitis v Henninger Bräu $A G$ (Zb. Orz. 1991, s. I-0935).

11 Wyrok Trybunału z dnia 11 kwietnia 1989 r. w sprawie 66/86 Ahmed Saeed Flugreisen and Silver Line Reisebüro GmbH v Zentrale zur Bekämpfung unlauteren Wettbewerbs e.V. (Zb. Orz. 1989, s. 00803). 
Swiss ${ }^{12}$. Pogląd o bezpośrednim skutku przepisów unijnego prawa ochrony konkurencji jako warunku odpowiedzialności odszkodowawczej jest powszechnie akceptowany w piśmiennictwie ${ }^{13}$. W polskiej doktrynie M. Szpunar uznaje przy tym za bezpośrednio skuteczny przepis, „na podstawie którego - w konkretnym stanie faktycznym - można określić podmiot zobowiązany, podmiot uprawniony oraz treść przysługujących uprawnień"14 - spełnienie tych warunków w przypadku traktatowych reguł konkurencji może być niekiedy dość trudne, choćby w świetle sporów o przyznanie legitymacji czynnej tzw. nabywcom pośrednim ${ }^{15}$. Niemniej jednak autor ten akceptuje odpowiedzialność odszkodowawczą za naruszenie prawa unijnego, w tym reguł konkurencji, słusznie argumentując, że „naturalną konsekwencją bezpośredniego obowiązywania normy wspólnotowej w krajowym porządku prawnym jest to, że jej naruszenie musi być odpowiednio sankcjonowane"16.

Stanowisko zajęte przez TS we wskazanych powyżej wyrokach odnoszących się do bezpośredniej skuteczności zakazów antykonkurencyjnych praktyk i/lub właściwości sądów krajowych co do zastosowania art. 101 i 102 TFUE, znalazło swoje potwierdzenie także w tych orzeczeniach, które już bezpośrednio odnoszą się do różnych aspektów prywatnego egzekwowania unijnych reguł konkurencji. W wyroku w sprawie C-453/99 Courage TS przypomniał, że „traktat stworzył własny porządek prawny, włączony do systemu prawnego państw członkowskich i wiążący dla ich sądów, którego podmiotami są nie tylko państwa członkowskie, ale także pochodzące z nich jednostki, i który nie tylko nakłada na jednostki zobowiązania, lecz może również być źródłem uprawnień stanowiących element statusu prawnego tych jednostek; nie muszą to być uprawnienia nadane wprost w traktacie, lecz powstają one również jako skutek zobowiązań, które nakłada on w sposób ściśle określony zarówno na jednostki, jak i na państwa członkowskie oraz instytucje wspólnotowe (...)"17.

Po trzecie prywatnego egzekwowania unijnych reguł konkurencji wymaga konieczność zapewnienia pełnej skuteczności art. 101 i 102 TFUE (effet utile).

12 Wyrok TS z dnia 1 czerwca 1999 r. w sprawie C-126/97 Eco Swiss China Time Ltd v. Benetton International NV (Zb. Orz. 1999, s. I-I-03055).

13 W polskim piśmiennictwie por. m.in. D. Miąsik, [w:] A. Wróbel, K. Kowalik-Bańczyk, M. Szwarc-Kuczer (red.), Traktat o funkcjonowaniu Unii Europejskiej. Komentarz. Tom II, LEX a Wolters Kluwer business, Warszawa 2012, s. 196-197; M. Szpunar, Odpowiedzialność podmiotu prywatnego..., s. 70, 297; M. Adamczak-Retecka, Odpowiedzialność odszkodowawcza..., s. 170.

14 M. Szpunar, Odpowiedzialność podmiotu prywatnego..., s. 70, 297.

15 Por. rozdział IV, pkt 4.3.2.2.

16 M. Szpunar, Odpowiedzialność podmiotu prywatnego..., s. 297.

17 Pkt 19 wyroku w sprawie Courage. Por. także pkt 23 tego wyroku. 
„Takie uprawnienie umacnia bowiem funkcjonowanie przepisów wspólnotowych dotyczących konkurencji i zniechęca do - często ukrytych - porozumień i praktyk mogących ograniczyć lub zakłócić konkurencję. $Z$ tego punktu widzenia skargi o odszkodowanie przed sądami krajowymi mogą przyczynić się w znaczący sposób do utrzymania skutecznej konkurencji we Wspólnocie"18. Wymóg pełnej skuteczności zakazów praktyk ograniczających konkurencję zdeterminował stanowisko Trybunału co do konieczności przyznania uprawnień do sądowego dochodzenia roszczeń z tytułu naruszenia reguł konkurencji każdej osobie poszkodowanej wskutek antykonkurencyjnych praktyk, choćby była ona stroną nielegalnego porozumienia ${ }^{19}$. To właśnie $\mathrm{z}$ zasady skuteczności w wyroku w sprawie Manfredi ${ }^{20}$ TS wywiódł konieczność włączenia do odszkodowania z tytułu naruszenia reguł konkurencji, obok rzeczywistych szkód (damnum emergens), także utraconych korzyści (lucrum cessans) oraz odsetek. Należy jednak odnotować głosy wskazujące na to, że korzystanie z doktryny effet utile jest na obecnym etapie rozwoju unijnego prawa ochrony konkurencji dalece niewystarczające, nie pozwala bowiem na określenie dokładnego zakresu dostępnych środków ochrony, co w konsekwencji może utrudniać dochodzenie roszczeń przez podmioty prywatne ${ }^{21}$.

Źródeł możliwości sądowego dochodzenia roszczeń z tytułu naruszenia art. 101 i 102 TFUE upatrywać można również w art. 47 Karty praw podstawowych $^{22}$, gwarantującym prawo do skutecznego środka prawnego i dostępu do bezstronnego sądu dla każdego, „kogo prawa i wolności zagwarantowanie przez prawo Unii zostały naruszone"23, a zatem także

18 Pkt 27 wyroku w sprawie Courage; pkt 60, 90-91 wyroku Trybunału z dnia 13 lipca 2006 r. w połączonych sprawach C-295-298/04 V. Manfredi v. Lloyd Adriatico Assicurazioni SpA, Antonio Cannito v. Fondiaria Sai SpA, Nicolò Tricarico, Pasqualina Murgolo v. Assitalia SpA (Zb. Orz. 2006, s. I-06619), dalej jako wyrok w sprawie Manfredi; pkt 29 wyroku Trybunału z dnia 14 czerwca 2011 r. w sprawie C-360/09 Pfleiderer AG v. Bundeskartellamt; dalej jako: wyrok w sprawie Pfleiderer; pkt 42 pkt 41 wyroku Trybunału z dnia 6 listopada 2012 r. w sprawie C-199/11 Europese Gemeenschap v Otis NV i inni (niepubl.), dalej jako: wyrok w sprawie Otis.

19 Pkt 26 wyroku w sprawie Courage; pkt 41 wyroku w sprawie Otis.

20 Pkt 95 wyroku w sprawie Manfredi.

21 T. Eilmansberger, The relationship between rights and remedies in EC law: In search of the missing link, CMLR 2004, vol. 41(5), s. 1233. Por. także M. Adamczak-Retecka, Ubi ius, ibi remedium? czyli: odpowiedzialność jednostki za naruszenia prawa wspólnotowego $w$ świetle orzeczenia Trybunatu Sprawiedliwości w sprawie C-453/99 Courage Ltd., Gdańskie Studia Prawnicze 2005, Tom XIV, s. 603-604.

22 Dz. Urz. UE 2010 C 83.

23 Treść art. 47 KPP określana jest w doktrynie także jako „prawo do sprawiedliwego procesu" - por. M. Bernatt, Sprawiedliwość proceduralna w postępowaniu przed organem ochrony konkurencji, Wyd. Naukowe WZ UW, Warszawa 2011, s. 78. 
dla tych podmiotów, które mogą być potencjalnie poszkodowane wskutek antykonkurencyjnych praktyk. W piśmiennictwie podkreśla się, że prawo gwarantowane w art. 47 KPP nie ma charakteru oryginalnego, ale stanowi zasadę wspólną dla tradycji konstytucyjnych państw członkowskich, wzmocnioną obowiązywaniem art. 6 i art. $13 \mathrm{EKPC}^{24}$. Na kwestię tę zwrócił zresztą uwagę również belgijski sąd (Rechtbank van koophandel te Brussel), kierując do Trybunału Sprawiedliwości pytanie prejudycjalne w sprawie C-199/11 Otis - drugie pytanie prejudycjalne sąd krajowy rozpoczyna od stwierdzenia, że art. $47 \mathrm{KPP}$ i art. 6 EKPC gwarantują prawo do rzetelnego procesu ${ }^{25}$; na analogię $\mathrm{z}$ art. 6 EKPC wskazał także $\mathrm{w}$ opinii $\mathrm{w}$ tej sprawie rzecznik generalny Pedro Cruza Villalón, uznając za uzasadnione odwołania do orzecznictwa ETPC26. Ostatecznie również i Trybunał Sprawiedliwości w wyroku w sprawie Otis potwierdził, że „,art. 47 zapewnia, w prawie Unii, ochronę przyznaną na mocy art. 6 ust. 1 EKPC"27. Istotna rola art. $47 \mathrm{KPP}$ może polegać na tym, że stanowi on dobrą podstawę dla kształtowania przez Trybunał Sprawiedliwości Unii Europejskiej zasad dochodzenia przez podmioty prywatne roszczeń opartych na prawie unijnym ${ }^{28}$ - ta funkcja art. 47 KPP wydaje się szczególnie ważna w braku unormowań proceduralnych $\mathrm{w}$ zakresie prywatnego egzekwowania reguł konkurencji.

Wreszcie, za specyficzne źródło możliwości realizacji interesu jednostki poprzez sądowe dochodzenie roszczeń należy uznać sankcję nieważności ustanowioną w art. 101 ust. 2 TFUE ${ }^{29}$, a w drodze analogii stosowaną także wobec praktyk zakazanych przez art. 102 TFUE $^{30}$. Należy przy tym zastrzec,

24 Ch. Mak, Rights and remedies. Article 47 EUCFR and Effective Judicial Protection in European Private law Matters, Amsterdam Law School Research Paper No. 2012-88, Centre for the Study of European Contract Law Working Paper Series No. 2012-11, s. $4,15$.

25 Pytanie to zostało skierowane do Trybunału Sprawiedliwości w dniu 28 kwietnia $2011 \mathrm{r}$.

26 Opinia rzecznika generalnego Pedra Cruza Villalóna w sprawie C-199/11 została przedstawiona w dniu 26 czerwca 2012 r. (dostępna pod adresem: http://curia.europa.eu/ juris/document $/$ document.jsf?text $=\&$ docid $=124362 \&$ pageIndex $=0 \&$ doclang $=$ PL $\&$ mod $\mathrm{e}=1 \mathrm{st} \& \operatorname{dir}=\&$ occ $=$ first\&part $=1 \& \mathrm{cid}=5762983$ ). Por. pkt 35 oraz pkt. $56-67$ tej opinii. Pogląd o zbieżności treści art. $47 \mathrm{KPP} \mathrm{z}$ art. $6 \mathrm{EKPC}$ w polskim piśmiennictwie wyrażają: M. Bernatt, Sprawiedliwość proceduralna..., s. 79; K. Kowalik-Bańczyk, Problematyka ochrony praw podstawowych $w$ unijnych postępowaniach $w$ sprawach $z$ zakresu ochrony konkurencji, Zeszyty CEN, z. 39, Warszawa 2010, s. 45.

27 Pkt 47 wyroku w sprawie Otis.

28 Ch. Mak, Rights and remedies..., s. 15.

29 Por. pkt 21 wyroku Trybunału z dnia 20 września 2001 r. w sprawie C-453/99 Courage Ltd v. Bernard Crehan and Bernard Crehan v. Courage Ltd and Others (Zb. Orz. 2001, s. I-06297); dalej jako Courage.

$30 \mathrm{Na}$ temat sankcji nieważności - por. rozdział VII, pkt 7.6. 
że nieważność jako źródło dla uprawnień do prywatnego egzekwowania reguł konkurencji - w przeciwieństwie do pozostałych wskazanych wyżej źródeł - nie jest charakterystyczna tylko dla prawa unijnego.

\subsubsection{Ramy proceduralne dla dochodzenia roszczeń wynikających z naruszenia wspólnych reguł konkurencji Unii Europejskiej}

Egzekwowanie prawa unijnego przed sądami krajowymi, odbywające się - w braku odpowiednich uregulowań unijnych - według procedur prawa krajowego, podlega wypracowanym w orzecznictwie zasadom służącym realizacji praw jednostek gwarantowanych przez przepisy Unii Europejskiej. Prawidłowość ta dotyczy również prawa ochrony konkurencji, przynajmniej do czasu przyjęcia przez Unię Europejską regulacji ujednolicających lub co najmniej harmonizujących reguły proceduralne sądowego dochodzenia roszczeń z tytułu naruszenia traktatowych reguł konkurencji (choć w przypadku wydania dyrektywy wskazane poniżej zasady mogą przynajmniej częściowo zachować swoją aktualność - zdarzy się tak w przypadku przyjęcia niekompletnych reguł proceduralnych $\left.{ }^{31}\right)$.

Zasada autonomii (niezależności) proceduralnej państw członkowskich oznacza niezależność państw członkowskich w kształtowaniu przepisów proceduralnych, jak również ustrojowych (ustrój organów ochrony prawnej), rządzących dochodzeniem roszczeń z tytułu naruszenia prawa unijnego przed sądami krajowymi. A. P. Komninos uważa - a pogląd ten wydaje się szczególnie aktualny w kontekście prywatnego egzekwowania reguł konkurencji - że na autonomię proceduralną państw członkowskich, obok norm postępowania cywilnego, administracyjnego czy karnego, składają się również normy materialnoprawne, zwłaszcza dotyczące środków ochrony (remedies) - w konsekwencji właściwym jest posługiwanie się opisowym pojęciem autonomii proceduralnej i autonomii w zakresie środków ochrony (remedial/procedural autonomy) ${ }^{32}$ bądź po prostu - pojęciem autonomii proceduralno-materialnej ${ }^{33}$. Jak podkreśla w polskim piśmiennictwie A. Wróbel, zasada autonomii proceduralnej odnosi się do stanowienia prawa przez

31 K. Kowalik-Bańczyk, Procedural Autonomy of Member States and the EU Rights of Defence in Antitrust Proceedings, YARS 2012, vol. 5(7), s. 219.

32 A. P. Komninos, EC Private Antitrust Enforcement. Decentralised Application of EC Competition Law by National Courts, Hart Publishing, Oxford and Portland, Oregon 2008, s. 147.

33 Podobny pogląd o konieczności stosowania rozszerzonego pojęcia autonomii proceduralnej w polskim piśmiennictwie wyrażają: W. Postulski, Zasada efektywnej ochrony praw wspólnotowych, [w:] A. Wróbel (red.), Stosowanie prawa Unii Europejskiej przez sądy, 
państwa członkowskie, a nie jego stosowania ${ }^{34}$. Państwa członkowskie mogą korzystać z autonomii proceduralnej wyłącznie w sytuacji, gdy - jak obecnie w dziedzinie prywatnego egzekwowania traktatowych reguł konkurencji nie obowiązują unijne uregulowania proceduralne bądź jeśli nie są one kompleksowe (np. prawo unijne ustanawia terminy procesowe, ale nie normuje skutków ich przekroczenia $\left.{ }^{35}\right)$. W kontekście prywatnego egzekwowania reguł konkurencji Trybunał Sprawiedliwości przyznał, że w zakres autonomii proceduralnej państw członkowskich (w braku uregulowań unijnych) wchodzi m.in.: zdefiniowanie zasad dotyczących związku przyczynowego między szkodą a działaniem stanowiącym naruszenie zakazów praktyk ograniczających konkurencję ${ }^{36}$, określenie terminów przedawnienia i zasad ich stosowania ${ }^{37}$, czy dopuszczalność tzw. odszkodowań represyjnych ${ }^{38}$.

Za granicę zasady autonomii proceduralnej należy uznać wynikające z jurysprudencji Trybunału Sprawiedliwości (oryginalnie z wyroku w sprawie Francovich ${ }^{39}$ ): zasadę ekwiwalentności (principle of equivalence) oraz zasadę skuteczności (principle of effectiveness) ${ }^{40}$. Ponadto $\mathrm{w}$ wyroku $\mathrm{w}$ sprawie VEBIC Trybunał uznał, że autonomię proceduralną państw członkowskich limituje również poszanowanie praw podstawowych ${ }^{41}$. Zgodnie z pierwszą ze wskazanych zasad, określaną w polskiej literaturze także jako zasada równo-

Zakamycze, Kraków 2005, s 426; M. K. Kolasiński, Obowiąek wspótpracy gospodarczej w prawie antymonopolowym, TNOiK, Toruń 2009, s. 67.

34 A. Wróbel, Autonomia proceduralna państw cztonkowskich..., s. 39. Z poglądem tym polemizuje K. Kowalik-Bańczyk, która zauważa, że stanowisko to wyklucza możliwość traktowania jako wiążącego dorobku sądów europejskich w zakresie np. standardów postępowania antymonopolowego - Procedural Autonomy..., s. 219.

35 D. Miąsik, Zasada efektywności, [w:] A. Wróbel (red.), Stosowanie prawa Unii Europejskiej przez sady. Tom I, wyd. 2, Lex a Wolters Kluwer business, Warszawa 2010, s. 241. Por. pkt 29 wyroku Trybunału z dnia 20 stycznia 2005 r. w sprawie C-245/03 Merck (Zb. Orz. 2005, s. I-637).

36 Pkt 64 wyroku Trybunału z dnia 13 lipca 2006 r. w połączonych sprawach C-295-298/04 V. Manfredi v Lloyd Adriatico Assicurazioni SpA, Antonio Cannito v Fondiaria Sai SpA, Nicolò Tricarico, Pasqualina Murgolo v Assitalia SpA (Zb. Orz. 2006, s. I-06619), dalej jako: wyrok w sprawie Manfredi.

37 Pkt 73-82 wyroku w sprawie Manfredi.

38 Pkt 83-94 wyroku w sprawie Manfredi.

39 Wyrok Trybunału z dnia 19 listopada 1990 r. w połączonych sprawach C-6/90 i C-9/90 Andrea Francovich i Danila Bonifaci i inni v. Republika Wtoska (Zb. Orz. 1991, s. I-05357).

40 Por. pkt 63 opinii rzecznika generalnego P. Mengozziego, dostarczonej w dniu 25 marca 2010 r., w sprawie C-439/08 VEBIC. Por. także N. Reich, Horizontal liability in EC law: hybridization of remedies for compensation in case of breaches of EC rights, CMLR 2007, vol. 44(3), s. 742.

41 Pkt 63 wyroku Trybunału z dnia 7 grudnia 2010 r. w sprawie C-439/08 VEBIC (Zb. Orz. 2010, s. I-12471); dalej jako: wyrok w sprawie VEBIC. 
ważności, „w braku właściwych uregulowań wspólnotowych do wewnętrznego porządku prawnego każdego państwa członkowskiego należy wyznaczenie właściwych sądów i ustalenie zasad proceduralnych dotyczących środków prawnych, (...) przy czym zasady te nie mogą być mniej korzystne od zasad proceduralnych odnoszących się do odpowiednich środków prawnych dotyczących wyłącznie prawa krajowego" 42 . Zasada ekwiwalentności stanowi „emanację zasady niedyskryminacji” w obszarze krajowych uregulowań proceduralnych ${ }^{43}$. Praktyczne stosowanie zasady ekwiwalentności może jednak w praktyce prowadzić do tego, że w różnych państwach członkowskich poszkodowani wskutek jednej praktyki ograniczającej konkurencję, będą cieszyć się zróżnicowanym poziomem ochrony prawnej44. Różnice te przemawiają oczywiście za przyjęciem unijnego standardu sądowego dochodzenia roszczeń z tytułu naruszenia zakazów praktyk ograniczających konkurencję.

Zasada skuteczności, określana w polskiej literaturze także jako zasada praktycznej wykonalności ${ }^{45}$, sprowadza się natomiast do kierowanego do państw członkowskich zakazu uczynienia wykonywania praw przyznanych przez unijny porządek prawny praktycznie niemożliwym bądź nadmiernie utrudnionym, „a konkretnie, w dziedzinie prawa konkurencji, powinny zapewnić, by stanowione bądź stosowane przez nie reguły nie stały na przeszkodzie skutecznemu stosowaniu art. 101 TFUE i 102 TFUE"46. Zasada skuteczności sprowadza się zatem do „efektywnej ochrony praw podmiotowych wynikających z prawa Unii Europejskiej” 47 . Aby ocenić, czy krajowe regulacje proceduralne czynią niemożliwym lub nadmiernie utrudnionym wykonywanie praw przyznanych przez prawo unijne, TS zaleca uwzględnienie miejsca przepisu w całym postępowaniu, tryb postępowania i jego szczególne cechy przed różnymi sądami krajowymi, a także zasady stanowiące podstawę krajowego systemu sądowniczego, takie jak np.: zasada ochrony prawa do obrony, zasada pewności prawa oraz zasada prawidłowego prze-

42 Pkt 29 wyroku w sprawie C-453/99 Courage; pkt 62 i 71 wyroku w sprawie Manfredi. Por. także wyrok z dnia 10 lipca 1997 r. w sprawie C-261/95 Palmisani (Zb. Orz. 1997, s. I-4025), pkt 27.

43 D. Miąsik, Zasada efektywności, [w:] A. Wróbel (red.), Stosowanie prawa..., s. 242.

44 M. Bernatt, Glosa do wyroku w sprawie Manfredi, [w:] A. Jurkowska-Gomułka (red.), Orzecznictwo sądów wspólnotowych w sprawach konkurencji w latach 2004-2009, Oficyna a Wolters Kluwer business, Warszawa 2010, s. 89.

45 M. Adamczak-Retecka, Odpowiedzialność odszkodowawcza..., s. 212-213.

46 Pkt 24 wyroku w sprawie Pfleiderer; pkt 57 wyroku w sprawie VEBIC.

47 Tak M. Bernatt, Glosa..., [w:] A. Jurkowska-Gomułka (red.), Orzecznictwo sądów wspólnotowych..., s. 89. 
biegu postępowania ${ }^{48}$. Zasada ta nie wymaga natomiast, aby środki proceduralne przewidziane w prawie krajowym dla realizacji roszczeń opartych na prawie unijnym były możliwie najskuteczniejsze dla uprawnionych ${ }^{49}$. Jak słusznie jednak zauważa M. Bernatt, „przyjęcie perspektywy skuteczności prawa Unii Europejskiej nie bierze pod uwagę skuteczności dochodzenia roszczeń opartych na krajowym prawie konkurencji. Skutkować to może wyższym standardem ochrony praw wynikających z prawa Unii Europejskiej, nawet w sytuacji, w której stan faktyczny i wielkość poniesionej szkody jest zbliżona" 50 .

W wyroku w połączonych sprawach C-295-298/04 Manfredi (bezpośrednio związanym z prywatnym egzekwowaniem traktatowych reguł konkurencji) zarzut naruszenia zasady ekwiwalentności i zasady skuteczności powstał m.in. w związku z tym, że prawo krajowe przewidywało rozpatrywanie roszczeń odszkodowawczych z tytułu naruszenia krajowych reguł konkurencji przez sądy jednego typu, podczas gdy - w braku analogicznych szczególnych uregulowań - roszczenia wynikające z naruszenia unijnych reguł konkurencji miałyby być rozpatrywane przez sądy innego typu ${ }^{51}$. Podkreślenia wymaga okoliczność, że zasady: autonomii proceduralnej, równoważności, skuteczności nie wymagają istnienia w poszczególnych państwach członkowskich jednolitego systemu proceduralnego dochodzenia roszczeń z tytułu naruszenia unijnego i krajowego prawa ochrony konkurencji - różnice takie na poziomie proceduralnym mogą występować o tyle, o ile warunki zaspokajania analogicznych roszczeń na podstawie unijnego prawa ochrony konkurencji nie są gorsze niż te stosowane dla roszczeń opartych na krajowym prawie ochrony konkurencji.

Propozycją dla rozstrzygnięcia problemu stosowania odpowiednich reguł proceduralnych (środków ochrony) dla realizacji praw podmiotów prywatnych gwarantowanych przez prawo unijne może być również koncepcja $u b i$ ius ibi remedium, której rzecznik generalny W. van Gerven przyznał status zasady prawa unijnego ${ }^{52}$. Zgodnie z propozycją W. van Gervena jeśli z prawa

48 Pkt 65 opinii rzecznika generalnego P. Mengozziego w sprawie C-439/08 VEBIC. Por. pkt 33 wyroku Trybunału z dnia 7 czerwca 2007 r. w sprawach połączonych od C-222/05 do C-225/05 van der Weerd $i$ in. (Zb. Orz. 2007, s. I-4233).

49 D. Miąsik, Zasada efektywności, [w:] A. Wróbel (red.), Stosowanie prawa..., s. 253.

50 M. Bernatt, Glosa..., [w:] A. Jurkowska-Gomułka (red.), Orzecznictwo sądów wspólnotowych..., s. 89.

51 Pkt 66-72 wyroku w połączonych sprawach C-295-298/04 Manfredi.

52 W. van Gerven, Of Rights, Remedies and Procedures, CMLR 2000, vol. 37(3), s. 501 i n. W polskiej literaturze na temat tej koncepcji por. W. Postulski, Jednolite i efektywne stosowanie prawa wspólnotowego przed sądami państw cztonkowskich, Przegląd Sądowy 2002, nr 6, s. 45 i n.; N. Półtorak, Odpowiedzialność odszkodowawcza państwa ..., s. 97 i n. 
unijnego wynika jakieś uprawnienie, przepisy prawa krajowego powinny zapewnić dla niego odpowiedni środek ochrony. Przedstawiciele doktryny podkreślają jednak, że w rzeczywistości relacja między prawem unijnym (jako źródłem uprawnienia/roszczenia) a prawem krajowym (jako „narzędziem” jego realizacji) może układać się całkowicie odwrotnie (tzn. jako ubi remedium ibi ius). W polskim piśmiennictwie M. Szpunar stoi na stanowisku, że uczynienie zadość zasadzie ubi ius ibi remedium oznacza konieczność określenia w prawie unijnym ,zasadniczych przesłanek uprawnienia, którego realizacja następuje w prawie krajowym (...)"53.

\subsubsection{Prywatne egzekwowanie prawa ochrony konkurencji w unijnych inicjatywach legislacyjnych i orzecznictwie}

\subsubsection{Akty prawne odnoszące się do sądowego dochodzenia roszczeń z tytułu naruszenia art. 101 i 102 TFUE}

Możliwości sądowego dochodzenia roszczeń z tytułu naruszenia art. 101 i 102 TFUE przewidywano już w związku z wydaniem pierwszego rozporządzenia wdrażającego traktatowe zakazy praktyk ograniczających konkurencję, tj. rozporządzenia 17/62, kiedy to dla Parlamentu Europejskiego przygotowany został tzw. raport Deringera, wskazujący na konieczność zapewnienia warunków dla występowania przez podmioty prywatne z roszczeniami związanymi z naruszeniem reguł konkurencji. Raport przewidywał potrzebę przygotowania badań nad przepisami państw członkowskich w celu zidentyfikowania potencjalnych barier dla działań tego rodzaju. Badanie takie zostało przeprowadzone przez Komisję w 1966 r. i doprowadziło do wniosku, że w państwach członkowskich istnieją środki ochrony, które można zastosować w przypadku naruszenia reguł konkurencji ${ }^{54}$. Wniosek ten Komisja prawdopodobnie uznała za satysfakcjonujący na tyle, że przez kolejne dwie dekady nie podjęła praktycznie żadnych działań na rzecz promowania prywatnego egzekwowania reguł konkurencji. Pewne wątki z tego zakresu pojawiły się w wydanym w 1993 r. obwieszczeniu Komisji w sprawie współpracy między Komisją a sądami państw członkowskich przy stosowaniu art. 85 i 86 TEWG $^{55}$. W dokumencie tym Komisja - głównie pod wpły-

53 M. Szpunar, Odpowiedzialność podmiotu prywatnego..., s. 255.

54 Podaję za: A. P. Komninos, EC Private Antitrust Enforcement..., s. 162-163.

55 Dz. Urz. WE 1993 C 39/1. Polskie tłumaczenie tego aktu opublikowane zostało w: Prawo konkurencji Wspólnoty Europejskiej. Źródta. Tom 1. Reguly generalne (wybór i opracowanie T. Skoczny), Wyd. Naukowe WZ UW, Warszawa 2002, s. 513-522. 
wem orzeczeń Trybunału Sprawiedliwości w sprawie C-234/89 Delimitis ${ }^{56}$ i Sądu Pierwszej Instancji w sprawie T-24/90 Automec - podkreśliła, że w przeciwieństwie do niej jako organu powołanego do działania w interesie publicznym „sądy państw członkowskich są powołane do ochrony podmiotowych praw osób prywatnych w ich stosunkach wzajemnych” (pkt 4) i „mogą na wniosek stron lub z urzędu zapewnić przestrzeganie reguł konkurencji w interesie osób prywatnych" (pkt 6). Komisja wprost wskazała również na okoliczność, że „adresaci prawa wspólnotowego mają roszczenie o to, (...) aby przyznawano odszkodowania za szkody powstałe w wyniku tych naruszeń, jeżeli takich samych roszczeń można dochodzić w porównywalnym postępowaniu na postawie prawa krajowego" (pkt 11).

„Nowe otwarcie” aktywności Komisji w obszarze prywatnego egzekwowania reguł konkurencji wiąże się z procesem modernizacji europejskiego prawa ochrony konkurencji, jaki miał miejsce na początku XXI w. ${ }^{57} \mathrm{~W}$ sztandarowym modernizacyjnym akcie prawnym, tj. w rozporządzeniu 1/2003, w motywie 7 preambuły pojawiło się stwierdzenie, że „sądy krajowe mają do odegrania zasadniczą rolę $\mathrm{w}$ dziedzinie stosowania wspólnotowych reguł konkurencji. Kiedy rozstrzygają spór między podmiotami prywatnymi, chronią prawa przedmiotowe na mocy prawa wspólnotowego, na przykład przyznając odszkodowanie poszkodowanym (...)”. Wielu komentatorów upatruje w tym zapisie niemal normatywnego źródła prywatnego egzekwowania zakazów ustanowionych w art. 101 i 102 TFUE $^{58}$, niemniej jednak jest to tylko

56 Wyrok Trybunału z dnia 28 lutego 1991 r. w sprawie C-234/89 Stergios Delimitis v. Henninger Bräu $A G$ (Zb. Orz. 1991, s. I-935), pkt 44; wyrok SPI z dnia 17 września 1992 r. w sprawie T-24/90 Automec v. Komisja (Zb. Orz. 1992, s. II-0223).

57 Jeszcze w latach 90-tych w piśmiennictwie postulowano wprowadzenie do prawa unijnego takich zmian, które umożliwiałyby rozwój prywatnego egzekwowania reguł, postrzeganego jako główny czynnik sukcesu europejskiej polityki konkurencji - por. C. Jones i E. Sharpston, Beyond Delimitis: Pluralism, Illusions, and Narrow Constructionism in Community Antitrust Litigation, Columbia Journal of European Law 1996/97, vol. 3, s. 108. Zmiany legislacyjne w kierunku wzmocnienia prywatnego egzekwowania unijnych reguł konkurencji postulowali także m.in.: B. J. Rodger, A. MacCulloch, Community Competi tion Law Enforcement Deregulation and Re-regulation: The Commision, National Authorities and Private Enforcement, Columbia Journal of European Law 1998, vol. 4, s. 579-610.

58 Pogląd, że rozporządzenie 1/2003 wzmocni prywatne egzekwowanie reguł konkurencji wyraził m.in. D. Woods, Private Enforcement of Antitrust Rules - Modernization of EU Rules and the Road Ahead, Loyola Consumer Law Review 2004, vol. 16(4), s. 461. Krytycznie co do takich możliwości - T. Eilmansberger, Green Paper on Damages Actions for Breach of the EC Antitrust Rules and Beyond: Reflections on the Utility and Feasibility of Stimulating Private Enforcement Through Legislative Actions, CMLR 2007, vol. 44(2), s. 434. 
zapis preambuły, którego znaczenia nie należy przeceniać. Nie ma wątpliwości, że sama Komisja potraktowała zapis motywu 7 preambuły wiążąco i podjęła szereg działań zmierzających do stworzenia otoczenia prawnego dla prywatnego trybu egzekwowania zakazów antykonkurencyjnych praktyk ustanowionych w Traktacie. Jednocześnie należy odnotować, że ustanowienie w art. 1 ust. 1 i 2 rozporządzenia 1/2003 zasady bezpośredniego stosowania całego art. 101 TFUE (łącznie z ust. 3) przez organy krajowe było „koniecznym, choć niewystarczającym narzędziem promowania prywatnego egzekwowania reguł konkurencji" 59 .

Wcześniej, tj. już przed 1 maja 2004 r. - datą wejścia w życie rozporządzenia 1/2003 - pewne wskazówki dla sądów krajowych stosujących unijne reguły konkurencji zawarte były w obwieszczeniu Komisji dotyczącym współpracy z sądami krajowymi w zakresie stosowania traktatowych reguł konkurencji.

$\mathrm{W}$ ramach pakietu modernizacyjnego unijnego prawa konkurencji wydane zostało nowe obwieszczenie w sprawie współpracy Komisji i sądów krajowych państw członkowskich UE w zakresie stosowania art. 81 i 82 TWE (obecnie art. 101 i 102 TFUE) ${ }^{60}$. Obwieszczenie wprost wskazuje możliwość bezpośredniego stosowania art. 101 i 102 TFUE w relacjach między podmiotami prywatnymi, w tym $\mathrm{w}$ powództwach związanych $\mathrm{z}$ umowami lub dochodzeniem roszczeń odszkodowawczych (pkt 2 i 3). Co więcej reguły prawa unijnego, potwierdzone w orzecznictwie Trybunału Sprawiedliwości UE, wymagają, aby w sytuacji, gdy naruszenie art. 101 lub 102 TFUE powoduje szkody jednostkom, podmioty te miały możliwość dochodzenia odszkodowania [pkt 10 lit. b)]. Sądy krajowe nie są przy tym zobowiązane do równoległego stosowania unijnych i krajowych reguł konkurencji (tj. mogą stosować wyłącznie wspólne reguły konkurencji UE), o ile przedmiotem sprawy nie jest praktyka ograniczająca konkurencję wpływająca na handel między państwami członkowskimi UE (pkt 5). Granicą autonomii sądów krajowych w zakresie egzekwowania art. 101 i 102 TFUE, także na gruncie prywatnym, pozostaje zgodność z aktami prawa wtórnego (np. rozporządzeniami wyłączającymi niektóre kategorie porozumień spod zakazu porozumień ograniczających konkurencję), z uprzednimi rozstrzygnięciami

59 A. P. Komninos, EC Private Antitrust Enforcement..., s. 141. T. Eilmansberger uznaje, że zmiana ta jest co najwyżej neutralna z punktu widzenia ułatwiania prywatnego egzekwowania reguł konkurencji - tenże, Green Paper on Damages..., s. 434. W polskim piśmiennictwie por. K. Kowalik-Bańczyk, Sądowe stosowanie unijnego prawa konkurencji, [w:] A. Wróbel (red.), Stosowanie prawa Unii Europejskiej przez sady. Tom 1, Wolters Kluwer, Warszawa 2010, s. 794.

60 Dz. Urz. UE 2004 C 101/4. 
Komisji ${ }^{1}$, a także $\mathrm{z}$ dorobkiem orzeczniczym Trybunału Sprawiedliwości UE oraz z zasadami ogólnymi prawa unijnego (pkt 6-10). Obwieszczenie ustanawia reguły współpracy między sądami a Komisją również w sytuacji, gdy ta ostatnia występuje jako amicus curiae (pkt 17)62.

W grudniu 2005 r. Komisja opublikowała zieloną księgę - Roszczenia o odszkodowanie za stosowanie praktyk ograniczających konkurencję i nadużywanie pozycji dominującej63, której towarzyszył dokument roboczy Komisji zatytułowany „Damages actions for breach of the EC antitrust rules" 64 . Na etapie przygotowawczym do opracowania obydwu dokumentów Komisja zleciła opracowanie prawnoporównawczego raportu na temat warunków dochodzenia roszczeń odszkodowawczych za naruszenie unijnych reguł konkurencji w 25 państwach członkowskich UE65. Wnioski z niego dowiodły, że prywatne egzekwowanie reguł konkurencji przedstawia obraz „kompletnego niedorozwoju” (total underdevelopment) ${ }^{66}$. Swój komentarz do Zielonej księgi przedstawił również w formie rezolucji Parlament Europejski67, wskazując, jakie szczegółowe kwestie wymagają zdaniem eurodeputowanych regulacji przez prawo unijne.

Kolejnym krokiem na drodze budowania regulacji prywatnego egzekwowania art. 101 i 102 TFUE było opublikowanie przez Komisję - w ślad za Zieloną księgą - w kwietniu 2008 r. białej księgi w sprawie roszczeń o naprawienie szkody wynikłej z naruszenia wspólnotowego prawa ochrony konku-

61 Kluczowe znaczenie ma tutaj tzw. reguła Masterfoods, zawarta w art. 16 rozporządzenia 1/2003. Szerzej por. Rozdział VI, pkt 6.3.1.

62 Szerzej por. Rozdział VI, pkt 6.5.

63 Zielona księga - Roszczenia o odszkodowanie za stosowanie praktyk ograniczających konkurencję i nadużywanie pozycji dominującej, KES(2005) 1732; COM/2005/672 wersja ostateczna; dalej jako: Zielona księga. Konsultacje publiczne Zielonej księgi odbyły się w terminie 20 grudnia 2005 r.-21 kwietnia 2006 r.

64 Commission Staff Working Paper. Annex to the Green Paper Damages actions for breach of the EC antitrust rules, COM(2005) 672 final; dalej jako: Green Paper Staff Working Document.

65 D. Waelbroeck, D. Slater, G. Evan-Shoshan, Study on the conditions of claims for damages in case of infringement of EC competition rules. Comparative report, 31 sierpnia 2004; dostępny pod adresem: http://ec.europa.eu/competition/antitrust/actionsdamages/ comparative_report_clean_en.pdf. Ze względu na afiliację autorów raport jest popularnie określany jakko „raport Ashursta” (Ashurt's Report).

66 Pkt 1.2. Zielonej księgi.

67 Rezolucja Parlamentu Europejskiego z dnia 25 kwietnia 2007 r. w sprawie Zielonej księgi dotyczącej roszczeń o odszkodowanie za stosowanie praktyk ograniczających konkurencję i nadużywanie pozycji dominującej (2006/2207 (INI)); dostępna pod adresem: http:// www.europarl.europa.eu/sides/getDoc.do?pubRef=-//EP//TEXT+TA+P6-TA-2007-0152 $+0+\mathrm{DOC}+\mathrm{XML}+\mathrm{V} 0 / / \mathrm{PL}$. 
rencji ${ }^{6}$. Dokument ten można postrzegać jako apogeum działań Komisji na rzecz budowania podstaw prawnych dla prywatnego egzekwowania unijnych reguł konkurencji. Białej księdze towarzyszył ogólny dokument roboczy Komisji69, uszczegóławiający rozwiązania zaproponowane w dokumencie głównym, a także dokument roboczy analizujący oddziaływanie proponowanych regulacji w różnych sferach ${ }^{70}$. Ocena oddziaływania poszczególnych scenariuszy regulacji prywatnego egzekwowania reguł konkurencji została przedstawiona w specjalnym raporcie przygotowanym na zlecenie Komisji ${ }^{71}$, którego opublikowanie poprzedziło wydanie Białej księgi. Podobnie jak miało to miejsce w przypadku Zielonej księgi, także w sprawie Białej księgi Parlament Europejski przyjął w marcu 2006 r. rezolucję ${ }^{72}$. Stanowisko wobec zaproponowanych przez Komisję rozwiązań zajął w tym samym czasie również Europejski Komitet Ekonomiczno-Społeczny ${ }^{73}$.

Zgodnie z założeniem Białej księgi, jej pokłosiem był projekt dyrektywy w sprawie prywatnego stosowania prawa konkurencji ${ }^{74}$, który jednak nigdy

68 \{SEC(2008) 404SEC (2008) 405SEC (2008) 406\}; dalej jako: Biała księga. Konsultacje publiczne Białej księgi odbyły się między 3 kwietnia a 15 lipca 2008 r. Przegląd najbardziej kontrowersyjnych opinii co do poszczególnych rozwiązanych proponowanych przez Komisję znajduje się w: V. Soyez, What the international legal community think about the European Commission's White Paper?, GCLR 2008, vol. 1(3), s. 153-160.

69 Commission staff working paper accompanying the White paper on damages actions for breach of the EC antitrust rules $\{\mathrm{COM}(2008) 165$ final\} \{SEC (2008) 405\} \{SEC (2008) 406\} /* SEC/2008/0404 final */; dalej jako: White Paper Staff Working Document.

70 Commission staff working document accompanying the White paper on damages actions for breach of the EC antitrust rules - Impact assessment $\{\mathrm{COM}(2008) 165$ final $\}$ SEC(2008) 404\} \{SEC(2008) 406\}/* SEC/2008/0405 final */; dalej jako: Impact Assessment.

71 Making antitrust damages actions more effective in the EU: welfare impact and potential scenarios. Final report (A. Renda, J. Peysner, A. J. Riley, B. F. Rodger, R. J. Van Den Bergh, S. Keske, R. Pardolesi, E. L. Camili, P. Caprile), Bruksela-Rzym-Rotterdam, 21 grudnia 2007 r.; dostępny pod adresem: http://ec.europa.eu/competition/antitrust/ actionsdamages/files_white_paper/impact_study.pdf.

72 Rezolucja Parlamentu Europejskiego z dnia 26 marca 2009 r. w sprawie białej księgi w sprawie roszczeń o naprawienie szkody wynikłej z naruszenia wspólnotowego prawa ochrony konkurencji (2008/2154(INI)); dostępny pod adresem: http://www.europarl.europa.eu/sides/ getDoc.do?pubRef=-//EP//TEXT+TA+P6-TA-2009-0187+0+DOC+XML+V0//PL.

73 Opinia Europejskiego Komitetu Ekonomiczno-Społecznego w sprawie Białej Księgi w sprawie roszczeń o naprawienie szkody wynikłej z naruszenia wspólnotowego prawa ochrony konkurencji, COM(2008)165 final (Dz. Urz. UE 2009 C 228/6).

74 Komisja opowiedziała się za harmonizacją poprzez dyrektywę, natomiast już kilka lat wcześniej W. van Gerven wyraził pogląd o potrzebie przyjęcia rozporządzenia dotyczącego prywatnego egzekwowania reguł konkurencji - por. tenże, Substantive Remedies for the Private Enforcement of EC Antitrust Rules Before National Courts, [w:] C.D. Ehlermann, I. Atanasiu (red.), European Competition Law Annual 2001: Effective Private Enforcement of EC Antitrust Rules, Hart Publishing, Oxford, Portland, Oregon 2003, s. 53-82. 
nie stał się oficjalnym projektem poddanym procesowi legislacyjnemu. Nowy projekt dyrektywy został ponownie wpisany do programu legislacyjnego Komisji na 2012 r. i spodziewany był w grudniu 2012 r. ${ }^{75}$; ostatecznie nie został on jednak przedstawiony do końca 2012 r. Atmosfera wokół potencjalnej unijnej regulacji tego obszaru nie jest (i w gruncie rzeczy nie była) specjalnie przychylna - nie do rzadkości należą głosy wskazujące na brak, czy to kompetencji ${ }^{76}$, czy potrzeby regulacji prywatnego egzekwowania reguł konkurencji na poziomie $\mathrm{UE}^{77}$.

Mimo niepowodzeń prac nad regulacją prywatnego egzekwowania reguł konkurencji Komisja prowadziła działania na rzecz wypracowania wytycznych dotyczących metod obliczania szkody w sprawach z zakresu ochrony konkurencji - rzeczywiście jest to jedno z zagadnień wskazywanych jako podstawowa trudność $\mathrm{w}$ dochodzeniu roszczeń $\mathrm{z}$ tytułu naruszenia zakazów praktyk ograniczających konkurencję. Problemy obliczania szkód podnoszony był zarówno w raporcie Ashursta, jak i w raporcie poprzedzającym wydanie Białej księgi, Komisja zdecydowała się jednak na zlecenie opracowania odrębnego raportu poświęconego tylko tej kwestii. Raport „Quantifying Antitrust Damages. Towards non-binding guidance for courts"78 został opublikowany w 2009 r. i stanowił podstawę przyjęcia przez Komisję projektu wytycznych w sprawie ustalania wysokości szkody w dochodzeniu roszczeń odszkodowawczych z tytułu naruszenia art. 101 lub 102 Traktatu79; wytyczne te mają być adresowane przede wszystkim do sądów krajowych, orzekających w sprawach roszczeń odszkodowawczych, ale nie ma wątpliwości co

75 http://ec.europa.eu/atwork/pdf/forward_programming_2012.pdf.

76 Tak np. F. Rizutto, Does the European Community have legal competence to harmonise national procedural rules governing private actions for damages from infringements of European Community antitrust rules?, G.C.L.R. 2009, vol. 2(1), s. 29-48.

77 Argumenty przemawiające za i przeciw harmonizacji przepisów na poziomie Unii Europejskiej prezentuje T. Eilmansberger, Green Paper on Damages..., s. 435-444. Krytycznie o planach regulacji prywatnego egzekwowania unijnych reguł konkurencji jako niepożądanej „harmonizacji tylnymi drzwiami” - m.in. F. Marcos, A. Sánchez Graells, Damages for breach of the EC antitrust rules: harmonising Tort Law through the back door?, Revista Para El Análisis del Derecho 2008, Nr 1, s. 2-21.

78 Quantifying Antitrust Damages. Towards non-binding guidance for courts. Study prepared for the European Commission, December 2009, Publication Office of the European Union, Luxembourg 2010 (raport przygotowany przez Oxera i międzynarodową grupę prawników pod kierownictwem A. Komninosa); dostępny pod adresem: http://ec.europa.eu/competition/antitrust/actionsdamages/quantification_study.pdf; dalej jako: raport Oxera.

79 Dokument, z przeznaczeniem do konsultacji publicznych, opublikowany został w czerwcu 2011 r.; dostępny pod adresem: http://ec.europa.eu/competition/consultations/2011_ actions_damages/draft_guidance_paper_pl.pdf. 
do tego, że dokument ten będzie wykorzystywany również przez inne grupy podmiotów, m.in.: strony postępowań, ich reprezentantów, biegłych.

\subsubsection{Orzecznictwo sądów Unii Europejskiej dotyczące prywatnego egzekwowania art. 101 i 102 TFUE}

Działania Komisji w pewnym stopniu inspirowane były orzecznictwem Trybunału Sprawiedliwości odnoszącym się do prywatnego egzekwowania traktatowych reguł konkurencji. Dorobek orzeczniczy w tym obszarze jest stosunkowo szeroki, jeśli przyjąć, że mieszczą się w nim również wszystkie wyroki Trybunału, które wskazują na możliwość bezpośredniego stosowania art. 101 i 102 TFUE w relacjach między jednostkami w postępowaniach przed sądami krajowymi 80 ; wyroki te określam mianem orzeczeń „pierwszej generacji”"1. Wyrokami „drugiej generacji” są natomiast orzeczenia, w których Trybunał potwierdził możliwość dochodzenia roszczeń z tytułu naruszenia traktatowych reguł konkurencji i ewentualnie orzekł o kwestiach proceduralnych związanych z prywatnym egzekwowaniem tych przepisów.

Do grupy tych ostatnich wyroków zaliczam również orzeczenie w sprawie C-128/92 H. J. Banks \& Company Limited v. British Coal Corporation $^{82}$, wydane co prawda w odniesieniu do zakazów praktyk ograniczających konkurencję ustanowionych w Traktacie o Europejskiej Wspólnocie Węgla i Stali, ale rozstrzygające o statusie prejudycjalnym decyzji Komisji dotyczącej naruszenia tych reguł konkurencji w ewentualnych postępowaniach przed sądami krajowymi. Wyrok w sprawie C-128/92 H.J. Banks \& Company Limited v. British Coal Corporation miał jednak o tyle limitowane znaczenie dla rozwoju prywatnego egzekwowania art. 101 i 102 TFUE, że - jak potwierdził TS w przywołanym orzeczeniu - art. 65 i 66(7) TEWWiS nie mogły być bezpośrednio stosowane w stosunkach między podmiotami prywatnymi w postępowaniach przed sądami krajowymi ${ }^{83}$. W opinii poprzedzającej wydanie tego orzeczenia rzecznik generalny van Gerven stwierdził, że „(...) w rezultacie obowiązku zapewnienia w pełni skutecznego przestrzegania prawa wspólnotowego oraz ochrony praw udzielanych przez nie jednostkom,

80 Por. pkt 3.2.1. w niniejszym rozdziale.

81 Por. A. Jurkowska, Prywatnoprawne wdrażanie wspólnotowego prawa konkurencji, Zeszyty CEN, z. 19, Warszawa 2004, s. 20.

82 Wyrok Trybunału z dnia 13 kwietnia 1994 r. w sprawie C-128/92 H. J. Banks \& Company Limited v. British Coal Corporation (Zb. Orz. 1994, s. I-01209). M. Adamczak-Retecka określa ten wyrok jako „zapowiedź precedensu”, jakim według autorki był wyrok w sprawie C-453/99 Courage - por. Odpowiedzialność odszkodowawcza..., s. 111.

83 Pkt 19 wyroku w sprawie C-128/92 H. J. Banks \& Company Limited v. British Coal Corporation. 
sądy krajowe mają obowiązek przyznawania odszkodowań w związku ze szkodami poniesionymi przez przedsiębiorstwo w wyniku naruszenia przez inne przedsiębiorstwo bezpośrednio skutecznych przepisów wspólnotowego prawa ochrony konkurencji”.

Kamieniem milowym dla popularyzowania prywatnego egzekwowania art. 101 i 102 TFUE okazał się wyrok Trybunału w sprawie C-453/99 Courage v. Crehan. Orzeczenie to postrzegane jest w doktrynie jako pierwszy w historii wyrok, w którym TS przyznał odszkodowanie jednostce z tytułu naruszenia prawa unijnego przez inną jednostkę ${ }^{84}$. W wyroku tym TS musiał zmierzyć się przede wszystkim z problemem wyznaczenia kręgu podmiotów legitymowanych czynnie do ubiegania się o odszkodowanie z tytułu naruszenia traktatowych reguł konkurencji. Pytania prejudycjalne leżące u podstaw tego wyroku zmusiły TS do zajęcia stanowiska co do tak szczegółowej kwestii, jak to, czy strona zakazanego antykonkurencyjnego porozumienia jest uprawniona do uzyskania odszkodowania w związku z naruszeniem art. 101 TFUE. Wyrażony w orzeczeniu w sprawie C-453/99 Courage pogląd Trybunału, że „każdy może powoływać się przed sądem na naruszenie art. 85 ust. 1 Traktatu [obecnie art. 101 ust. 1 TFUE - przyp. aut.], nawet jeśli sam jest stroną umowy mogącej ograniczyć lub zakłócić konkurencję, w rozumieniu tego przepisu" 85 , choć spotkał się również z krytyką, generalnie został zaakceptowany, tak w późniejszych wyrokach Trybunału ${ }^{86}$, jak i dokumentach Komisji, jako fundamentalna zasada prywatnego egzekwowania unijnych reguł konkurencji. Wśród innych kwestii istotnych dla prywatnego egzekwowania reguł konkurencji, podniesionych w wyroku w sprawie C-453/99 Courage, znalazły się również rozważania nad istotą sankcji nieważności z art. 101 ust. 2 TFUE ${ }^{87}$, koniecznością oparcia krajowych procedur sądowych służących egzekwowaniu unijnych zakazów antykonkurencyjnych praktyk na zasadzie słuszności i równoważności ${ }^{88}$, czy potrzebą wykluczenia możliwości bezpodstawnego wzbogacenia się osób realizujących prawa gwarantowane przez unijny porządek prawny ${ }^{89}$. W wyroku w sprawie C-453/99 Courage TS przedstawił spójną koncepcję prywatnego egzekwowania traktatowych reguł konkurencji (A. Komninos dopatruje się w nim wręcz zasad o „charakterze

84 M. Adamczak-Retecka, Odpowiedzialność odszkodowawcza..., s. 113.

85 Pkt 24 wyroku w sprawie C-453/99 Courage.

86 Por. pkt 59 i 61 Manfredi, pkt 28 wyroku w sprawie Pfleiderer.

87 Pkt 21-22 wyroku w sprawie C-453/99 Courage. Na zasadzie analogii rozważania te zachowują aktualność także w odniesieniu do naruszenia zakazu z art. 102 TFUE, mimo że zakaz ten nie jest wprost opatrzony taką sankcją.

88 Pkt 29-31 wyroku w sprawie C-453/99 Courage.

89 Pkt 30 wyroku w sprawie C-453/99 Courage. 
konstytucyjnym"90), choć oczywiście orzeczenie to nie rozwiązało znaczącej liczby nadal problematycznych kwestii związanych z sądowym dochodzeniem roszczeń z tytułu naruszenia zakazów antykonkurencyjnych praktyk ${ }^{91}$. Wyrok w sprawie Courage ma jednak pewien niewykorzystany potencjał - mimo swoich walorów merytorycznych nie spowodował on bynajmniej intensyfikacji prywatnego egzekwowania unijnych reguł konkurencji w państwach członkowskich.

Poglądy Trybunału wyrażone w wyroku w sprawie C-453/99 Courage znalazły swoje potwierdzenie w orzeczeniu w połączonych sprawach C-295298/04 Manfredi ${ }^{92}$. W orzeczeniu tym TS potwierdził wprost legitymację czynną indywidualnych konsumentów do ubiegania się o odszkodowanie z tytułu naruszenia art. 101 lub 102 TFUE, wywodząc ją jednakże z prawa każdej jednostki do realizacji uprawnień gwarantowanych jej przez prawo unijne ${ }^{93}$. Ponadto TS zajął się takimi zagadnieniami, jak: zakres odszkodowań (w tym możliwość zasądzania odszkodowań represyjnych [punitive dama ges ${ }^{94}$ ), właściwość sądów orzekających w sprawach związanych z prywatnym egzekwowaniem reguł konkurencji ${ }^{95}$, terminy przedawnienia. W wyroku w sprawie Manfredi jeszcze silniej niż w orzeczeniu w sprawie Courage TS akcentował konieczność oparcia sądowego dochodzenia roszczeń z tytułu naruszenia unijnych reguł konkurencji na zasadach równoważności i skuteczności, z uwzględnieniem jednak (i w ramach) zasady autonomii proceduralnej.

Kolejnym wyrokiem w obszarze prywatnego egzekwowania unijnych reguł konkurencji jest orzeczenie w sprawie C-360/09 Pfleiderer. Głównym przedmiotem rozstrzygnięcia Trybunału stał się problem dostępu powoda w postępowaniu sądowym zmierzającym do zaspokojenia roszczeń odszkodowawczych z tytułu naruszenia reguł konkurencji do akt zgromadzonych w postępowaniu antymonopolowym, a dotyczących darowania lub złagodzenia (leniency) ${ }^{96}$. Ze wszystkich orzeczeń „drugiej generacji” to właśnie wyrok w sprawie Pfleiderer najlepiej obrazuje „napięcie” między publicznym

90 A. P. Komninos, New Prospects For Private Enforcement of EC Competition Law: Courage v. Crehan and the Community Right To Damages, CMLR 2002, vol. 39, s. 483.

91 Tak R. Whish, Competition Law, 5th ed., LexisNexis Butterworths 2003, s. 300.

92 Wyrok Trybunalu z dnia 13 lipca $2006 \mathrm{r}$. w połączonych sprawach C-295-298/04 V. Manfredi v Lloyd Adriatico Assicurazioni SpA, Antonio Cannito v Fondiaria Sai SpA, Nicolò Tricarico, Pasqualina Murgolo v Assitalia SpA (Zb. Orz. 2006, s. I-06619).

93 Pkt 60-61 wyroku w sprawie Manfredi.

94 Na temat tych odszkodowań por. rozdział VII, pkt 7.7.3.3.6.

95 Pkt 66 wyroku w sprawie Manfredi.

96 Pkt 30-32 wyroku w sprawie C-360/09 Pfleiderer. Zagadnienie to jest przedmiotem rozważań w rozdziale $\mathrm{V}$, pkt 5.3.4.3. 
a prywatnym trybem egzekwowania reguł konkurencji, jednocześnie jest to, w moim przekonaniu, wyrok najmniej satysfakcjonujący w tym sensie, że TS uchylił się w zasadzie od rzeczowego rozwiązania jakże istotnego problemu współfunkcjonowania obydwu trybów stosowania prawa ochrony konkurencji ${ }^{97}$.

Kolejnym wyrokiem zasługującym na wzmiankę, choć dotyczącym prywatnego egzekwowania reguł konkurencji jedynie pośrednio, jest orzeczenie Sądu w sprawie T-437/08 CDC Hydrogene Peroxide ${ }^{98}$, koncentrującej się - podobnie jak wyrok w sprawie Pfleiderer - wokół udostępniania podmiotom zamierzającym wystąpić $\mathrm{z}$ roszczeniami na drogę sądową akt (a w tym przypadku - jedynie ich spisu treści) postępowania antymonopolowego prowadzonego przez Komisję. Dostęp do akt zgromadzonych przez Komisję wnioskowany był - na podstawie rozporządzenia 1049/2001 w sprawie publicznego dostępu do dokumentów ${ }^{99}$ - przez wyspecjalizowaną firmę zajmującą się pomocą prawną w obszarze prywatnego egzekwowania reguł konkurencji. Stwierdzając nieważność decyzji Komisji całkowicie odmawiającej dostępu do spisu treści akt postępowania antymonopolowego, Sąd - odwołując się do stanowiska Trybunału Sprawiedliwości w wyrokach w sprawach Courage i Manfredi - uznał, że „mając na uwadze prawo każdego do ubiegania się o odszkodowanie za szkody spowodowane przez zachowanie mogące powodować ograniczenie lub zakłócenie konkurencji” nie można przyjąć, że uniknięcie powództw przez spółkę uczestniczącą w kartelu stanowi interes handlowy w rozumieniu art. 4 ust. 2 tiret pierwsza rozporządzenia 1049/2001, uzasadniający odmowę dostępu do akt100.

Ostatnim z rozstrzygnięć odnoszących się do prywatnego egzekwowania reguł konkurencji jest wyrok w sprawie Otis - zasadniczym zagadnieniem rozpatrywanym przez Trybunał była dopuszczalność występowania Unii Europejskiej jako powoda dochodzącego roszczeń odszkodowawczych w związku z działalnością kartelu, którego istnienie zostało wykryte przez Komisję i potwierdzone w uprzedniej decyzji Komisji. Nawiązując do

97 Krytyczną ocenę orzeczenia w sprawie C-360/09 Pfleiderer prezentuję w: Między efektywnościq walki z kartelami a efektywnościa dochodzenia roszczeń $z$ tytutu naruszenia art. 101 ust. 1 TFUE - glosa do wyroku TS z 14.06.2011 $\mathrm{r}$. w sprawie C-360/09 Pfleiderer AG v. Bundeskartellamt, EPS 2012, nr 7, s. 39-46.

98 Wyrok Sądu z dnia 15 grudnia 2011 r. w sprawie T-437/08 CDC Hydrogene Peroxide v. Komisja.

99 Rozporządzenie (WE) nr 1049/2001 Parlamentu Europejskiego i Rady z dnia 30 maja 2001 r. w sprawie publicznego dostępu do dokumentów Parlamentu Europejskiego, Rady i Komisji (Dz. Urz. WE 2001 L 145/43).

100 Pkt 49 wyroku w sprawie CDC Hydrogene Peroxide. Zagadnienia te są przedmiotem rozważań w rozdziale $\mathrm{V}$. 
orzeczeń w sprawach Courage i Manfredi, Trybunał raz jeszcze powtórzył w tym wyroku, że każdy ma prawo dochodzenia roszczeń z tytułu naruszenia art. 101 lub 102 TFUE - „prawo to przysługuje zatem również Unii” ${ }^{101}$. Ponadto w wyroku tym Trybunał analizuje zasady, na jakich Komisja Europejska może występować jako powód w cywilnoprawnych postępowaniach z zakresu ochrony konkurencji, jeśli przedmiotem tych postępowań są sprawy odnoszące się do naruszeń reguł konkurencji potwierdzonych w uprzednich decyzjach Komisji działającej jako publiczny organ ochrony konkurencji.

Wartość dorobku orzeczniczego Trybunału Sprawiedliwości w dziedzinie prywatnego egzekwowania reguł konkurencji ma w istocie charakter uniwersalny, wykraczający poza prawo unijne. Wskazówki Trybunału dotyczące choćby okresów przedawnienia czy dostępu do dowodów zgromadzonych $\mathrm{w}$ postępowaniu antymonopolowym mogą być z powodzeniem wykorzystywane na potrzeby krajowych regulacji i praktyki stosowania prawa w związku z sądowym dochodzeniem roszczeń z tytułu naruszenia krajowych reguł konkurencji ${ }^{102}$. Ten pozaunijny wymiar rozstrzygnięć Trybunału zachowuje istotne znaczenie w sytuacji braku rozstrzygnięć unijnych ujednolicających bądź harmonizujących krajowe procedury sądowego dochodzenia roszczeń w sprawach o naruszenie zakazów praktyk ograniczających konkurencję $e^{103}$.

\subsubsection{Podsumowanie}

Rozstrzygnięcia legislacyjne i orzecznicze dotyczące prywatnego egzekwowania art. 101 i 102 TFUE mają istotne znaczenie zarówno dla samego prawa unijnego, jak i dla prawa krajowego. Nie ma wątpliwości co do tego, że porządek prawny Unii Europejskiej stanowi dla systemów prawnych wielu państw członkowskich wzorzec do naśladowania i punkt odniesienia dla rozstrzygnięć krajowych. Potwierdza to także polskie orzecznictwo.

Mimo głosów sprzeciwu wobec unijnych inicjatyw legislacyjnych na rzecz prywatnego egzekwowania reguł konkurencji ${ }^{104}$, tak państwa członkowskie,

101 Pkt 44 wyroku w sprawie Otis.

$102 \mathrm{~W}$ polskiej literaturze pogląd taki wyraził m.in. M. Bernatt, który w glosie do wyroku w sprawie Manfredi stwierdził, że rozwiązania przyjęte w tym orzeczeniu przez Trybunał „stać się mogą (...) inspiracją do dokonania zmian unormowań bądź orzecznictwa na gruncie prawa konkurencji państw członkowskich (prawa krajowego)" - M. Bernatt, Glosa..., [w:] A. Jurkowska-Gomułka (red.), Orzecznictwo sądów wspólnotowych..., s. 87.

103 Tak również F. Rizutto, The private enforcement of European Union competition law: what next?, G.C.L.R. 2010, vol. 3(2), s. 57.

104 Najbardziej znanym antagonistą wzmacniania prywatnego egzekwowania reguł konkurencji jest W. P. J. Wils, Should Private Antitrust Enforcement Be Encouraged in 
jak i - jak się wydaje - podmioty potencjalnie zainteresowane sądowym dochodzeniem roszczeń wydają się nawet oczekiwać od Unii Europejskiej działań na rzecz rozwoju prywatnoprawnego modelu egzekwowania zakazów antykonkurencyjnych praktyk, czy to w formie aktów prawnych (w tym również aktów prawa miękkiego), czy to w formie wskazówek orzeczniczych. $\mathrm{O}$ te ostatnie jest o tyle trudno, że w ich przypadku mamy do czynienia ze sprzężeniem zwrotnym: im intensywniejsze będzie prywatnoprawne egzekwowanie reguł konkurencji w państwach członkowskich, tym możemy spodziewać się większej liczby orzeczeń prejudycjalnych rozstrzygających o różnych aspektach dochodzenia roszczeń z tytułu naruszenia reguł konkurencji. Wydanie unijnej regulacji poświęconej prywatnemu egzekwowaniu prawa ochrony konkurencji z dużym prawdopodobieństwem będzie skutkowało również dla procedury dochodzenia analogicznych roszczeń opartych na prawie krajowym. Co prawda zasada ekwiwalentności wymaga jedynie tego, aby w procedurze krajowej środki związane z dochodzeniem roszczeń opartych na prawie unijnym nie miały charakteru dyskryminującego wobec tych stosowanych dla roszczeń wynikających z prawa krajowego, jednak można spodziewać się, że implementując dyrektywę państwa członkowskie zastosują „zasadę ekwiwalentności a rebours”, zapewniając roszczeniom związanym z krajowymi regułami konkurencji zasady dochodzenia sądowego nie gorsze niż zasady gwarantowane w dyrektywie dla roszczeń „unijnych”. Rozwiązanie takie byłoby racjonalne, biorąc pod uwagę fakt, że w wielu przypadkach dochodzenie roszczeń będzie dotyczyło praktyk ograniczających konkurencję naruszających jednocześnie krajowe i unijne reguły konkurencji. Ponadto rozwiązanie takie byłoby o tyle pożądane, że do pewnego stopnia wyeliminowałoby ono problem forum shopping w obszarze prywatnego egzekwowania reguł konkurencji. Argumenty te można zresztą postrzegać również jako przemawiające na rzecz regulacji prywatnego egzekwowania art. 101 i 102 TFUE poprzez rozporządzenie, a nie dyrektywę.

Europe?, World Competition 2003, vol. 26(3), s. 473-488. Autor sprzeciwia się przede wszystkim realizacji celu odstraszania (prewencji) poprzez prywatne egzekwowanie reguł konkurencji. Krytyczny wobec stanowiska W. P. J. Wilsa jest C. A. Jones, Private Antitrust Enforcement in Europe: A Policy Analysis and Reality Check, World Competition 2004, vol. 27(1), s. 13-24. Autor ten twierdzi nawet, że stanowisko to jest sprzeczne z unijnym porządkiem prawnym (s. 15). 


\subsection{Prywatne egzekwowanie prawa ochrony konkurencji w Polsce}

\subsubsection{Możliwości wykorzystania obowiązujących regulacji jako podstawy roszczeń z tytułu naruszenia art. 6 i 9 uokik}

\subsubsection{Wprowadzenie}

Polska należy do tych państw, które - jeśli chodzi o regulacje prywatnego egzekwowania prawa ochrony konkurencji - opowiedziały się (choć trudno uznać, że była to świadoma decyzja ustawodawcy, raczej wynik jego bierności) za „opcją zero"105. Mimo że orzecznictwo już od wczesnych lat dziewięćdziesiątych wskazuje na możliwość występowania na drogę sądową $\mathrm{z}$ roszczeniami wynikającymi z naruszenia reguł konkurencji, ustawodawca nie zdecydował się na stworzenie otoczenia prawnego wyłącznie na użytek prywatnego egzekwowania reguł konkurencji. Nieprawdziwe byłoby jednak stwierdzenie, że ustawodawca nie rozpoznał potrzeby realizacji prywatnej ścieżki egzekwowania reguł konkurencji - wśród argumentów decydujących o rezygnacji z wnioskowego trybu wszczynania postępowań antymonopolowych w ustawie o ochronie konkurencji i konsumentów z 2007 r. znalazł się wszak argument o tym, że realizacja interesów prywatnych powinna odbywać się na drodze sądowej; wykluczenie wnioskowego inicjowania postępowań z publicznego trybu egzekwowania nie pociągnęło jednak za sobą przyjęcia żadnych pozytywnych rozwiązań legislacyjnych na rzecz prywatnoprawnego egzekwowania reguł konkurencji106.

Obecnie za ugruntowane można uznać orzecznictwo sądowe wskazujące na możliwość prywatnego egzekwowania zakazów antykonkurencyjnych praktyk („dopuszczalne jest stosowanie przez sądy powszechne przepisów uppm, a obecnie uokik"107). Takie deklaracje orzecznicze pojawiały się w Polsce już w początkach lat dziewięćdziesiątych w związku ze stosowaniem ustawy o przeciwdziałaniu praktykom monopolistycznym. W wyroku z dnia 29 grudnia 1993 r., XVII Amr 42/93, SAM zadeklarował, że „brak zagrożenia interesu publiczno-prawnego nie oznacza bynajmniej, aby osoba dotknięta skutkami sprzecznych z prawem działań podmiotu gospodarczego

105 Por. pkt 3.1. w niniejszym rozdziale.

106 W piśmiennictwie można odnaleźć ślady oczekiwania takiej aktywności od ustawodawcy: B. Nowak-Chrząszczyk pisała: „Jest oczywiste, że nowa ustawa zakłada reformę cywilnej drogi ochrony konkurencji” - por. Roszczenie odszkodowawcze w postępowaniu w sprawie o naruszenie wspólnotowego prawa konkurencji, [w:] E. Piontek (red.), Nowe tendencje w prawie konkurencji UE, Oficyna a Wolters Kluwer business, Warszawa 2008, s. 458.

107 Wyrok SN z dnia 5 stycznia 2007 r., III SK 17/2006, LexPolonica nr 2025330. 
była pozbawiona możliwości ochrony swych praw podmiotowych. Nie ma bowiem przeszkód do dochodzenia tych praw przed sądami powszechnymi”"108. Choć wielokrotnie sądy stwierdzały, że celem ustawy o ochronie konkurencji i konsumentów „nie jest ochrona indywidualnego przedsiębiorcy”109 bądź, że ustawa „nie odnosi się do ochrony roszczeń indywidualnych” 110 , to sformułowania te należy odnosić nie tyle do samych materialnoprawnych reguł zawartych w ustawie, ile do trybu ich egzekwowania. Sądy niejednokrotnie podkreślały rozłączność trybów egzekwowania zakazów antykonkurencyjnych praktyk, stwierdzając, że „orzekanie o cywilnoprawnych roszczeniach stanowi kognicję sądu powszechnego, a nie organu administracyjnego" 111 lub że ,indywidualne prawa podmiotowe uczestników obrotu gospodarczego podlegają ochronie w trybie dochodzenia roszczeń przed sądem powszechnym bądź przed sądem administracyjnym"112. W wyroku z dnia 5 stycznia 2007 r., III SK 17/2006, SN wskazał, że „postępowanie wywołane wniesieniem odwołania od decyzji Prezesa UOKiK nie jest bowiem postępowaniem, w którym rozstrzyga się o prawach i obowiązkach stron umowy, a jedynie ocenia się zgodność zachowania przedsiębiorców z przepisami prawa antymonopolowego. Sąd Apelacyjny nie mógł zatem stosować art. $58 \S 1 \mathrm{kc} \mathrm{w}$ zw. $\mathrm{z}$ art. 8 ust. 2 uppm, ponieważ przepisy te stosowane są przez sądy powszechne w postępowaniu cywilnym (zwykłym lub gospodarczym)"113.

Skoro zatem sama możliwość prywatnego egzekwowania reguł konkurencji jest uznawana, tak w orzecznictwie, jak i - pośrednio - przez samego ustawodawcę (dotyczy to przy tym roszczeń opartych na prawie krajowym, źródła możliwości dochodzenia roszczeń wynikających z prawa unijnego omówione zostały powyżej), niezbędna jest identyfikacja podstaw prawnych dla sądowego dochodzenia roszczeń z tytułu naruszenia reguł konkurencji. Należy przy tym podkreślić, że w świetle zasady autonomii proceduralnej państw członkowskich wskazanie przepisów proceduralnych (czy szerzej: przepisów proceduralno-materialnych, w tym tych wskazujących środki

108 Wyrok SAM z dnia 29 grudnia 1993 r., XVII Amr 42/93, Wokanda 1994, nr 5.

109 Por. m.in. wyrok SAM z dnia 21 listopada 2001 r., XVII Ama 2/2001, Dz. Urz. UOKiK 2002 Nr 1, poz. 47; wyrok SN z dnia 29 maja 2001 r., I CKN 1217/98, OSNC 2002, nr 1, poz. 13 .

110 Wyrok SN z dnia 16 października 2008 r., III SK 2/2008, LexPolonica nr 255102.

111 Wyrok SAM z dnia 21 listopada 2001 r., XVII Ama 2/2001, Dz. Urz. UOKiK 2002 $\mathrm{Nr} 1$, poz. 47.

112 Wyrok SN z dnia 29 maja 2001 r., I CKN 1217/98, OSNC 2002, nr 1, poz. 13.

113 Wyrok SN z dnia 5 stycznia 2007 r., III SK 17/2006, LexPolonica nr 2025330. 
ochrony) skutkuje dla prywatnego egzekwowania zarówno art. 6 i 9 uokik, jak i art. 101 i 102 TFUE.

W polskim piśmiennictwie wskazuje się na trzy akty prawne, których przepisy mogą być wykorzystane na potrzeby sądowego dochodzenia roszczeń z tytułu naruszenia zakazów praktyk ograniczających konkurencję (wśród nich nie ma ustawy o ochronie konkurencji i konsumentów). Do aktów tych zaliczane są: Kodeks cywilny, ustawa o zwalczaniu nieuczciwej konkurencji114 oraz ustawa o przeciwdziałaniu nieuczciwym praktykom rynkowym ${ }^{115}$. Trudno jednak mówić o pełnej zgodzie doktryny co do tak zidentyfikowanych podstaw prawnych prywatnego egzekwowania reguł konkurencji: o ile pozycja Kodeksu cywilnego jako regulacji ogólnej, służącej za podstawę dochodzenia wszelkich roszczeń w stosunkach cywilnoprawnych jest niepodważalna, to już relacje między ustawą o ochronie konkurencji i konsumentów (a ściślej art. 6 i 9 uokik) i traktatowymi odpowiednikami krajowych zakazów praktyk ograniczających konkurencję a ustawą o zwalczaniu nieuczciwej konkurencji czy ustawą o przeciwdziałaniu nieuczciwym praktykom rynkowym są już co najmniej dyskusyjne. Za tak ukształtowanymi trzema podstawami prawnymi w doktrynie opowiedzieli się: P. Podrecki116, A. Piszcz ${ }^{117}$, A. Stawicki ${ }^{118}$.

Ustawy o przeciwdziałaniu nieuczciwym praktykom rynkowym nie mogli oczywiście wskazywać autorzy wypowiadający się co do prywatnego egzekwowania reguł konkurencji przed $2007 \mathrm{r}$., tj. zanim ustawa ta została wydana. Można zatem odnotować, że zwolennikami wywodzenia odpowiedzialności cywilnoprawnej za naruszenia reguł konkurencji z Kodeksu cywilnego oraz z ustawy o zwalczaniu nieuczciwej konkurencji byli również R. Janusz, M. Sachajko i T. Skoczny119.

114 Ustawa z dnia 16 kwietnia 1993 r. o zwalczaniu nieuczciwej konkurencji (tekst jednolity: Dz. U. 2003 Nr 153, poz. 1503 ze zm.); dalej jako uznk.

115 Ustawa z dnia 23 sierpnia 2007 r. o przeciwdziałaniu nieuczciwym praktykom rynkowym (Dz. U. $2007 \mathrm{Nr}$ 171, poz. 1206); dalej jako upnpr.

116 P. Podrecki, Civil Law Actions in the Context of Competition Restricting Practices Under Polish Law, YARS 2009, vol. 2(2).

117 Por. A. Piszcz, Wybrane problemy zwiazane ze stosowaniem prawa antymonopolowego Unii Europejskiej przez sady krajowe, [w:] N. Szczęch (red.), Księga Jubileuszowa z okazji 5-lecia Wydziału Prawa Wyższej Szkoty Menedżerskiej w Legnicy „Ius est ars boni et aequi”, Legnica 2010, s. 550-551 oraz pośrednio, A. Piszcz, Still-unpopular Sanctions: Developments in Private Antitrust Enforcement in Poland After the 2008 White Paper, YARS 2012, vol. 5(7), s. 67.

118 A. Stawicki, Poland, [w:] G. Blanke, R. Nazzini (red.), International Competition Litigation: A Multi-jurisdictional Handbook, Kluwer Law International BV 2012, s. 572.

119 R. Janusz, M. Sachajko, T. Skoczny, Nowa ustawa o ochronie konkurencji i konsumentów, KPPubl. 2001, nr 3. 
Osobiście nie postrzegam jednak ustawy o przeciwdziałaniu nieuczciwym praktykom rynkowym jako właściwej podstawy prawnej dla prywatnego egzekwowania reguł konkurencji ${ }^{120}$ (podobnie, aktu tego nie wskazuje D. Hansberry-Bieguńska ${ }^{121}$ ).

\subsubsection{Kodeks cywilny}

Jeśli chodzi o Kodeks cywilny, to przepisami wskazywanymi w piśmiennictwie i orzecznictwie jako podstawa roszczeń z tytułu naruszenia reguł konkurencji są regulacje dotyczące: odpowiedzialności deliktowej (art. $415 \mathrm{kc}$ ), odpowiedzialności kontraktowej (art. $471 \mathrm{kc}$ ), a także bezpodstawnego wzbogacenia (art. $405 \mathrm{kc}$ ). Ponownie należy jednak podkreślić, że w polskim piśmiennictwie nie ma całkowitej zgodności co do takiego właśnie ukształtowania katalogu podstaw prawnych dla roszczeń wynikających z naruszenia art. 6 i 9 uokik lub art. 101 i 102 TFUE. Ta triada podstaw prawnych jest akceptowana w piśmiennictwie przez M. Kozak122 i M. Sieradzką ${ }^{123}$. Niektórzy autorzy (P. Podrecki, A. Stawicki) sceptycznie jednak podchodzą do możliwości wykorzystania art. $471 \mathrm{kc}$ jako podstawy prawnej dla roszczeń z tytułu naruszenia zakazów antykonkurencyjnych praktyk ${ }^{124}$; również M. K. Kolasiński za podstawę prawną roszczeń uznaje tylko art. $415 \mathrm{kc}^{125}$. Z kolei A. Piszcz dopuszcza co prawda możliwość powołania się na art. 18 ust. 1 uznk, przewidujący roszczenie o wydanie bezpodstawnie uzyskanych korzyści, ale już nie upatruje podstaw prawnych dla roszczeń z tytułu naruszenia zakazów antykonkurencyjnych praktyk w art. 405 kc126. Podobnie jako potencjalnej podstawy roszczeń odszkodowawczych art. $405 \mathrm{kc}$ nie wymienia B. Nowak-Chrząszczyk ${ }^{127}$.

120 Por. pkt 3.3.1.4. w niniejszym rozdziale.

121 D. Hansberry-Bieguńska, Poland, [w:] I. K. Gotts (red.), The Private Competition Enforcement Review, 4. ed., Law Business Research, London 2011, s. 257.

122 M. Kozak, Private enforcement of competition rules under Community and Polish law comments after accession, International Business Law Journal 2005, no. 3, s. 382.

123 M. Sieradzka, Pozew grupowy jako instrument prywatnoprawnej ochrony interes konsumentów $z$ tytutu naruszenia regut konkurencji, LEX a Wolters Kluwer business, Warszawa 2012, s. 279.

124 P. Podrecki, Civil Law Actions..., s. 80; A. Stawicki, Poland..., [w:] G. Blanke, R. Nazzini (red.), International Competition Litigation..., s. 586.

125 M. K. Kolasiński, Obowiazek wspótpracy gospodarczej..., s. 68.

126 A. Piszcz, Wybrane problemy..., [w:] N. Szczęch (red.), Księga Jubileuszowa..., s. 551.

127 B. Nowak-Chrząszczyk, Roszczenie odszkodowawcze..., [w:] E. Piontek (red.), Nowe tendencje..., s. 448-449. 


\subsubsection{Ustawa o zwalczaniu nieuczciwej konkurencji}

Ustawa o zwalczaniu nieuczciwej konkurencji może być brana pod uwagę jako podstawa prawna dla roszczeń z tytułu naruszenia reguł konkurencji128 ze względu na klauzulę generalną, jaką posługuje się art. 3 ust. 1 uznk, wprowadzającą bardzo szeroką definicję czynu nieuczciwej konkurencji jako „działania sprzecznego z prawem lub dobrymi obyczajami, jeżeli zagraża lub narusza interes innego przedsiębiorcy lub klienta”. Uważam, że „sprzeczność z prawem" jako element konstytuujący czyn nieuczciwej konkurencji pozwala zakwalifikować jako takie czyny zachowania przedsiębiorców naruszające zakaz z art. 6 lub 9 uokik bądź art. 101 lub 102 TFUE $^{129}$. M. Zdyb wskazuje, że sprzeczne z prawem (w rozumieniu art. 3 ust. 1 uznk) są „czyny zakazane przepisami administracyjnymi lub przepisami publicznego prawa gospodarczego” i „czyny zabronione przepisami o charakterze cywilnym, sprzeczne z nakazami zawartymi w prawie cywilnym lub prawie administracyjnym" ${ }^{130}$. Dla zaistnienia czynu nieuczciwej konkurencji wystarczające jest spełnienie przesłanki bezprawności, „nie jest natomiast konieczne istnienie winy w sensie umyślnego działania czy niedbalstwa"131. Za możliwością kwalifikacji tego samego zachowania jako czynu nieuczciwej konkurencji i praktyki ograniczającej konkurencję wprost opowiadają się w piśmiennictwie T. Skoczny i M. Bernatt ${ }^{132}$ oraz J. Sroczyński i M. Mioduszewski133.

Za prawidłowością kwalifikacji antykonkurencyjnych praktyk (w rozumieniu ustawy o ochronie konkurencji i konsumentów i/lub traktatu) jako czynów nieuczciwej konkurencji przemawia także cel ustawy, sformułowany

128 Na możliwość analogicznego stosowania w ramach prywatnego egzekwowania zakazów antykonkurencyjnych praktyk roszczeń wykorzystywanych w odniesieniu do czynów nieuczciwej konkurencji wskazuje się także w literaturze obcej - por. Outlook: the link between unfair competition law and antitrust law, [w:] T. M. J. Möllers, A. Heinemann (red.), The Enforcement of Competition Law in Europe, Cambridge University Press 2009, s. 659-663.

129 Pogląd taki wyraziłam [w:] A. Jurkowska, Antitrust Private Enforcement - Case of Poland, YARS 2008, vol. 1(1), s. 65.

130 Por. M. Zdyb, [w:] M. Zdyb, M. Sieradzka (red.), Ustawa o zwalczaniu nieuczciwej konkurencji. Komentarz, LEX a Wolters Kluwer business, Warszawa 2011, s. 99.

131 E. Nowińska, M. du Vall, Komentarz do ustawy o zwalczaniu nieuczciwej konkurencji, LexPolonica 2010 (Komentarz do art. 3, teza 2).

132 T. Skoczny, M. Bernatt [w:] J. Szwaja (red.), Ustawa o zwalczaniu nieuczciwej konkurencji. Komentarz, C. H. Beck, Warszawa 2012, s. 566 (Komentarz do art. 15, Nb 4). Por. także A. Jurkowska, W stronę umocnienia prywatnoprawnego wdrażania zakazów praktyk ograniczajacych konkurencję - glosa do uchwaty SN z 23.07.2008 r. (III CZP 52/08), EPS 2010, nr 5, s. 48.

133 J. Sroczyński, M. Mioduszewski, [w:] M. Zdyb, M. Sieradzka (red.), Ustawa.., s. 477. 
przez ustawodawcę w art. 1 jako ,zapobieganie i zwalczanie nieuczciwej konkurencji w działalności gospodarczej (...) - w interesie publicznym, przedsiębiorców oraz klientów”. Omawiana ustawa nie ma zatem charakteru stricte prywatnoprawnego - o ile zadaniem ustawy antymonopolowej jest ochrona konkurencji jako mechanizmu, to zadaniem ustawy o zwalczaniu nieuczciwej konkurencji jest ochrona uczciwości tej konkurencji, podejmowana również $\mathrm{w}$ interesie publicznym, tyle że dla ochrony tego interesu ustawa przewiduje środki ochrony, które mogą być realizowane przez jednostki (przedsiębiorców). Na publicznoprawny wymiar ustawy o zwalczaniu nieuczciwej konkurencji zwracał także uwagę niejednokrotnie Sąd Najwyższy, stwierdzając, że „(...) omawiane przepisy zapewniają także ochronę publicznych interesów”134, a ustawa „służy zapobieganiu i zwalczaniu - w interesie publicznym oraz w interesie uczestników rynku - zjawisk niepożądanych w działalności gospodarczej”135. W tym samym duchu wypowiadają się J. Sroczyński i M. Mioduszewski: „ustawa o zwalczaniu nieuczciwej konkurencji również chroni rynek przed działaniami zaburzającymi warunki wolnego i równego współzawodnictwa (...)”136. Zdaniem tych autorów reżim ustawy o zwalczaniu nieuczciwej konkurencji w pierwszym rzędzie działa w interesie ochrony samych uczestników obrotu, „ale jego skutki systemowe obejmują także interes publiczny oraz przedsiębiorców i klientów w ogólności"137.

Poza klauzulą generalną z art. 3 ust. 1 uznk za podstawę roszczeń mogą służyć także przepisy „typizujące” te czyny nieuczciwej konkurencji, których charakter odpowiada istocie antykonurencyjnych praktyk w świetle zakazów z art. 6 i 9 uokik lub art. 101 i 102 TFUE. Na marginesie należy wskazać na ewolucję stanowiska Sądu Najwyższego w zakresie relacji między art. 3 ust. 1 uznk a przepisami ustanawiającymi poszczególne kategorie czynów nieuczciwej konkurencji (przepisami rozdziału 2 ustawy o zwalczaniu nieuczciwej konkurencji). W wyroku z dnia 2 lutego 2001 r., IV CKN 255/2000, SN wykluczył co prawda możliwość kumulatywnego stosowania art. 3 i przepisów typizujących poszczególne czyny nieuczciwej konkurencji138 (przypisując tym samym art. 3 ust. 1 uznk funkcję uzupełniającą), jednak w późniejszym wyroku z dnia 30 maja 2006 r., I CSK 85/2006139, SN zdecydowanie opowiedział się za uznaniem również funkcji korygującej klauzuli

134 Por. wyrok SN z dnia 5 marca 2002 r., I CZ 4/2002, LexPolonica nr 394322.

135 Wyrok SN z dnia 2 lutego 2001 r., IV CKN 255/2000, OSNC 2001, nr 9, poz. 137.

136 J. Sroczyński, M. Mioduszewski, [w:] M. Zdyb, M. Sieradzka (red.), Ustawa..., s. 476.

137 Ibidem.

138 Wyrok SN z dnia 2 lutego 2001 r., IV CKN 255/2000, OSNC 2001, nr 9, poz. 137.

139 Wyrok SN z dnia 30 maja 2006 r., I CSK 85/2006, OSP 2008, nr 5, poz. 55. 
generalnej z art. 3 ust. 1 uznk, co w praktyce oznacza, że ,jeżeli określony czyn co prawda wypełnia hipotezę normy wynikającej z przepisu rozdziału 2 ustawy, jednakże nie wystąpi zarazem określona w art. 3 ust. 1 uznk przesłanka zagrożenia lub naruszenia interesu innego przedsiębiorcy, to uznać należy, że nie stanowi on czynu nieuczciwej konkurencji. W razie przyjęcia tego założenia zachodzi zatem in concreto nie tylko możliwość, lecz potrzeba jednoczesnej oceny postępowania przedsiębiorcy zarówno z punktu widzenia przepisów rozdziału 2, jak i art. 3 ust. 1 uznk"140. Pogląd o dwojakiej funkcji klauzuli generalnej $\mathrm{z}$ art. 3 ust. 1 uznk podtrzymywany jest również w najnowszym orzecznictwie Sądu Najwyższego ${ }^{141}$; w wyroku z dnia 16 kwietnia 2009 r., I CSK 24/2009 SN stwierdził wprost, że „art. 3 oraz przepisy wymienione $\mathrm{w}$ rozdziale 2 uzupełniają się i mogą być stosowane kumulatywnie"142.

Wobec antykonkurencyjnych praktyk, zakazanych przez art. 6 lub 9 uokik bądź art. 101 lub 102 TFUE, obok klauzuli generalnej z art. 3 ust. 1 uznk, zastosowanie może znaleźć również art. 15 uznk opisujący czyn nieuczciwej konkurencji polegający na utrudnianiu innym przedsiębiorcom dostępu do rynku ${ }^{143}$. W myśl art. 15 uznk czyn nieuczciwej konkurencji polegający na utrudnianiu dostępu do rynku może przybrać różne postacie, jednak $\mathrm{z}$ punktu widzenia praktyk ograniczających konkurencję relewantne są zachowania określone w art. 15 ust. 1 i 2 uznk $^{144}$. Pogląd, że czyn nieuczciwej konkurencji w postaci utrudniania dostępu do rynku może być kwalifikowany zarówno jako praktyka ograniczająca konkurencję (w rozumieniu uokik), jak i czyn nieuczciwej konkurencji (w rozumieniu uznk), co w konsekwencji pozwala sądom cywilnym na orzekanie o roszczeniach z tytułu takiej praktyki (czynu) o „podwójnej kwalifikacji” również w oparciu o ustawę o zwalczaniu nieuczciwej konkurencji, wyrażają w doktrynie T. Skoczny i M. Bernatt ${ }^{145}$, J. Sroczyński i M. Mioduszewski ${ }^{146}$ oraz E. Nowińska i M. du Vall. Ci ostatni autorzy stanęli przy tym na stanowisku, że podstawą prawną powództwa

140 Ibidem.

141 Por. m.in. wyroki Sądu Najwyższego: z dnia 25 maja 2012 r., I CSK 498/2011, LexPolonica nr 3880826; z dnia 4 listopada 2011 r. I CSK 796/2010 LexPolonica nr 3882091.

142 Wyrok Sądu Najwyższego z dnia 16 kwietnia 2009 r. I CSK 24/2009, OSP 2011, nr 1, poz. 12. Por. także wyrok SN z dnia 28 października 2010 r., II CSK 191/2010, OSNC 2011, nr 6, poz. 71.

143 Tak P. Podrecki, Civil Law Actions..., s. 81-82.

144 E. Nowińska i M. du Vall ograniczają to wyliczenie do art. 15 ust. 1 pkt 1-3 - E. Nowińska, M. du Vall, Komentarz do ustawy..., (Komentarz do art. 15, teza 62).

145 T. Skoczny, M. Bernatt, [w:] J. Szwaja (red.), Ustawa..., s. 569-571 (Komentarz do art. 15, $\mathrm{Nb}$ 11-13).

146 J. Sroczyński, M. Mioduszewski, [w:] M. Zdyb, M. Sieradzka (red.), Ustawa..., s. 477-482. 
będzie art. $15 \mathrm{w}$ związku z art. 3 ust. 1 uznk ${ }^{147}$, natomiast J. Sroczyński i M. Mioduszewski nie przewidują możliwości oparcia roszczeń samodzielnie na podstawie art. 6 lub 9 uokik.

W konsekwencji kwalifikowania antykonkurencyjnych praktyk jako czynów nieuczciwej konkurencji w rozumieniu art. 3 ust. 1 uznk poszkodowani mogą skorzystać z roszczeń przewidzianych w art. 18 ust. 1 uznk. W celu realizacji dwóch z sześciu rodzajów roszczeń przewidzianych w tym przepisie (naprawienie wyrządzonej szkody [art. 18 ust. 1 pkt 4] i wydanie bezpodstawnie uzyskanych korzyści [art. 18 ust. 1 pkt 5]) ustawodawca odwołuje się do „zasad ogólnych”, które należy utożsamiać z regulacjami Kodeksu cywilnego - okoliczność ta potwierdza wzmiankowany powyżej uniwersalny charakter Kodeksu cywilnego jako podstawy roszczeń z tytułu naruszenia zakazów antykonkurencyjnych praktyk. Ponadto możliwość wystąpienia $\mathrm{z}$ roszczeniami na podstawie ustawy o zwalczaniu nieuczciwej konkurencji mają wyłącznie przedsiębiorcy, pozbawieni są jej konsumenci ${ }^{148}$, co w znacznym stopniu osłabia efektywność omawianej ustawy jako podstawy roszczeń z tytułu naruszenia zakazów antykonkurencyjnych praktyk ${ }^{149}$. Cztery z sześciu przewidzianych w art. 18 ust. 1 uznk rodzajów roszczeń mogą być dochodzone przez przedsiębiorców indywidualnych, jak i przez organizacje krajowe lub regionalne, których celem statutowym jest „ochrona interesów przedsiębiorców” (art. 19 ust. 1 pkt 2 uznk) - taki przypadek należy również kwalifikować jako prywatne egzekwowanie reguł konkurencji, choć zbiorowa realizacja interesu przez organizację nosi pewne znamiona działania w interesie publicznym; możliwość przewidziana w art. 19 ust. 1 pkt 2 uznk nie jest jednak tożsama $\mathrm{z}$ postępowaniem grupowym.

\subsubsection{Ustawa o przeciwdziałaniu nieuczciwym praktykom rynkowym?}

Jak już wskazano, wielu autorów postrzega ustawę o przeciwdziałaniu nieuczciwym praktykom rynkowym jako samodzielną podstawę prawną dla sądowego dochodzenia roszczeń z tytułu antykonkurencyjnych praktyk. Wynika to prawdopodobnie $\mathrm{z}$ faktu, że regulacja ta przejęła częściowo zadania ustawy o zwalczaniu nieuczciwej konkurencji w zakresie eliminacji nagannych („nieuczciwych”) praktyk rynkowych skierowanych przeciwko konsumentom. Akceptacja dopuszczalności roszczeń z tytułu antykonkurencyjnych praktyk opartych na przepisach ustawy o przeciwdziałaniu nieuczci-

147 E. Nowińska, M. du Vall, Komentarz do ustawy..., (Komentarz do art. 15, teza 61).

148 Por. E. Nowińska, M. du Vall, Komentarz do ustawy..., (Komentarz do art. 3, teza 3).

149 Pogląd taki prezentują również: M. Kozak, Private enforcement..., s. 386; B. Turno, Program tagodzenia kar..., s. 209. 
wym praktykom rynkowym pozwoliłaby skutecznie zapełnić lukę związaną z faktem, że ustawa o zwalczaniu nieuczciwej konkurencji nie znajduje zastosowania wobec roszczeń wnoszonych przez konsumentów. W moim przekonaniu, przepisy ustawy o przeciwdziałaniu nieuczciwym praktykom rynkowym nie dają podstaw dla kwalifikacji działań naruszających art. 6 lub 9 uokik bądź art. 101 lub 102 TFUE jako praktyk, które mogą być sankcjonowane na podstawie omawianej ustawy. Dzieje się tak głównie ze względu na fakt, że choć ustawa nawiązuje w swojej strukturze do ustawy o zwalczaniu nieuczciwej konkurencji, to klauzula generalna - jaką posługuje się art. 4 ust. 1 upnpr - definiująca ,nieuczciwą praktykę rynkową” nie odwołuje się (w przeciwieństwie do art. 3 ust. 1 uznk) do przesłanki niezgodności (sprzeczności) z prawem. W piśmiennictwie wyrażone zostały rozbieżne stanowiska co do tego, czy brak tej przesłanki stanowi zamierzony zabieg ustawodawczy ${ }^{150}$, czy jest to „ewidentne niedopatrzenie" 151 . Za trafne należy uznać stanowisko Sądu Ochrony Konkurencji i Konsumentów wskazujące, że „działanie przedsiębiorcy należy uznać za sprzeczne z dobrymi obyczajami, jeżeli wykracza przeciw uznanym w społeczeństwie zasadom moralnym lub przyjętej w obrocie uczciwości, kiedy przedsiębiorca chroni swe interesy, nie biorąc dostatecznie pod uwagę praw i interesów konsumenta"152.

Wzajemne relacje ustawy o przeciwdziałaniu nieuczciwym praktykom rynkowym i ustawy o ochronie konkurencji i konsumentów kształtują się zgoła inaczej w obszarze praktyk ograniczających konkurencję i praktyk naruszających zbiorowe interesy konsumentów - relacje te w pierwszym przypadku - moim zdaniem - nie występują, natomiast w drugim przypadku są one wyraźnie określone przez ustawodawcę, który poprzez art. 24 ust. 2 pkt 3 uokik wprost stanowi, że nieuczciwe praktyki rynkowe są praktykami naruszającymi zbiorowe interesy konsumentów.

Za wykluczeniem ustawy o przeciwdziałaniu nieuczciwym praktykom rynkowym jako podstawy prywatnego egzekwowania naruszenia reguł konkurencji przemawia także, moim zdaniem, argument natury prawnoporów-

150 Takie stanowisko zajmuje E. Nowińska, Zakaz nieuczciwych praktyk rynkowych (art. 3 u.p.n.p.r.) i klauzula generalna nieuczciwych praktyk rynkowych (art. 4 u.p.n.p.r), [w:] E. Nowińska, D. Kasprzycki (red.), Nieuczciwe praktyki rynkowe. Ocena regulacji, Wyd. Uniwersytetu Jagiellońskiego, Kraków 2012, s. 151. Na brak tego elementu klauzuli generalnej - jako zasadniczą różnicę między brzmieniem art. 4 ust. 1 upnpr a art. 3 ust. 1 uznk - wskazuje R. Stefanicki, Ustawa o przeciwdziałaniu nieuczciwym praktykom rynkowym. Komentarz, LexisNexis, Warszawa 2009 (Komentarz do art. 4, teza 1).

151 Tak A. Michalak, Przeciwdziatanie nieuczciwym praktykom rynkowym. Komentarz, C. H. Beck, Warszawa 2008, s. 71.

152 Wyrok SOKiK z dnia 10 czerwca 2010 r., XVII Ama 124/2009, LexPolonica nr 3072420. 
nawczej - motyw szósty preambuły do dyrektywy 2005/29/WE o nieuczciwych praktykach rynkowych ${ }^{153}$ (której implementację do prawa krajowego stanowi omawiana ustawa) wskazuje, że dyrektywa nie dotyczy nieuczciwych praktyk handlowych szkodzących jedynie interesom gospodarczym konkurentów lub dotyczących transakcji między przedsiębiorcami. Prawodawca unijny - w tym samym szóstym motywie dyrektywy - przyznaje, że nieuczciwe praktyki rynkowe szkodzą pośrednio interesom gospodarczym konkurentów działających zgodnie z prawem, niemniej jednak należy pamiętać o tym, że istotą praktyk antykonkurencyjnych (a w zasadzie zakazu takich praktyk) pozostaje ich wpływ na konkurencję, rozumianą jako zjawisko rynkowe (gospodarcze), a punkt ciężkości zagrożenia (czy też szkody) interesów w prawie ochrony konkurencji kształtuje się zgoła inaczej niż założył to ustawodawca w odniesieniu do regulacji dotyczących nieuczciwych praktyk rynkowych: praktyki antykonkurencyjne dotykają przede wszystkim przedsiębiorców (ujawniają się w relacjach między przedsiębiorcami), a dopiero pośrednio oddziałują na konsumentów. Ratio legis przepisów o przeciwdziałaniu nieuczciwym praktykom rynkowym nie wpisuje się zatem w prywatne egzekwowanie zakazów antykonkurencyjnych praktyk. T. Targosz słusznie wskazuje, że przyjęty przez polskiego ustawodawcę sposób wdrożenia dyrektywy do krajowego porządku prawnego (ustanowienie odrębnego od ustawy o zwalczaniu nieuczciwej konkurencji aktu poświęconego przeciwdziałaniu nieuczciwym praktyko rynkowym) sprawia, iż „z pola zainteresowania usuwane są w istocie procesy konkurencji" 154 .

Reasumując, nie istnieją - w moim przekonaniu - przesłanki pozwalające na kwalifikowanie antykonkurencyjnych praktyk jako nieuczciwych praktyk rynkowych w rozumieniu art. 4 ust. 1 upnpr. W piśmiennictwie można co

153 Dyrektywa 2005/29/WE Parlamentu Europejskiego i Rady z dnia 11 maja 2005 r. dotycząca nieuczciwych praktyk handlowych stosowanych przez przedsiębiorstwa wobec konsumentów na rynku wewnętrznym oraz zmieniająca dyrektywę Rady 84/450/EWG, dyrektywy 97/7/WE, 98/27/WE i 2002/65/WE Parlamentu Europejskiego i Rady oraz rozporządzenie (WE) nr 2006/2004 Parlamentu Europejskiego i Rady (Dz. Urz. UE 2005 L 149/22).

154 Tak T. Targosz, Ustawa o przeciwdziataniu nieuczciwym praktykom rynkowym - model ochrony, zasady, zakres ochrony, implikacje dla systemu prawa konkurencji i konsumentów, [w:] E. Nowińska, D. Kasprzycki (red.), Nieuczciwe praktyki rynkowe..., s. 43. Ten autor zresztą krytycznie wypowiada się co do „chirurgicznego cięcia” polegającego na rozgraniczeniu regulacji, na podstawie której chronione są relacje typu B2B (uznk) oraz regulacji chroniącej wyłącznie relacje typu $\mathrm{B} 2 \mathrm{C}$ - por. tenże, Ustawa o przeciwdziałaniu..., s. 43-46. Podobnie krytyczne stanowisko wobec przyjętego modelu regulacji oraz postulat stworzenia spójnego „prawa uczciwości zachowań rynkowych” wyraża m.in. A. Tischner, Miejsce implementacji dyrektywy 2005/29/WE do prawa polskiego, [w:] E. Nowińska, D. Kasprzycki (red.), Nieuczciwe praktyki rynkowe..., s. 62-63. 
prawda odnaleźć pogląd, zgodnie z którym w omawianej ustawie „nieuczciwość" funkcjonuje jako kryterium bezprawności zachowania (rozumianej jako negatywna ocena przez system prawny) ${ }^{155}$, jednakże okoliczność, że „nieuczciwość” rozumiana (jak w art. 4 ust. 1 upnpr) jako sprzeczność z dobrymi obyczajami może stanowić o bezprawności określonej praktyki z punktu widzenia odpowiedzialności deliktowej w świetle Kodeksu cywilnego, nie uzasadnia, moim zdaniem, wskazywania ustawy o przeciwdziałaniu nieuczciwym praktykom rynkowym jako odrębnej podstawy prawnej dla egzekwowania roszczeń wynikających z antykonkurencyjnych praktyk - de facto bowiem w opisywanym przypadku podstawą odpowiedzialności będą wyłącznie przepisy Kodeksu cywilnego. Zgadzam się z poglądem E. Nowińskiej, zgodnie z którym „kryterium słusznościowe znajdzie zastosowanie wszędzie tam, gdzie dla określonych działań (zaniechań) brak jest ustawowego unormowania lub unormowanie to należy skorygować"156 - w przypadku zakazów praktyk ograniczających konkurencję ustawodawca takie unormowanie zapewnił).

\subsubsection{Uwagi końcowe}

W kontekście prywatnego egzekwowania reguł konkurencji Kodeks cywilny należy postrzegać jako regulację uniwersalną, do której mogą odwołać się poszkodowani należący do wszystkich kategorii poszkodowanych wskutek antykonkurencyjnych praktyk. W przypadku zbiegu przepisów Kodeksu cywilnego oraz innych przepisów stanowiących potencjalnie podstawę prawną dla roszczeń z tytułu deliktów antymonopolowych do poszkodowanych należy wybór tej podstawy prawnej, która zapewni najlepszą ochronę indywidualnych interesów prywatnych ${ }^{157}$ (istotnym czynnikiem może być m.in. termin przedawnienia). $\mathrm{Z}$ tego względu uzasadnione wydają się wątpliwości co do możliwości wykorzystania ustawy o zwalczaniu nieuczciwej konkurencji jako podstawy prawnej dla roszczeń związanych z antykonkurencyjnymi praktykami - potencjalni powodowie, korzystając z takiej podstawy prawnej, muszą (w porównaniu z reżimem Kodeksu cywilnego) udowodnić dodatkową przesłankę (wykazanie, że określone zachowanie pozwanego lub pozwanych wypełnia znamiona czynu nieuczciwej konku-

155 Tak T. Targosz, Ustawa o przeciwdziataniu..., [w:] E. Nowińska, D. Kasprzycki (red.), Nieuczciwe praktyki rynkowe..., s. 39.

156 E. Nowińska, Zakaz nieuczciwych praktyk..., [w:] E. Nowińska, D. Kasprzycki (red.), Nieuczciwe praktyki rynkowe..., s. 155.

157 Tak również P. Podrecki, Civil Law Actions..., s. 81. 
rencji) ${ }^{158}$. Z drugiej jednak strony, jak słusznie podkreślają J. Sroczyński i M. Mioduszewski, dochodzenie roszczeń z tytułu popełnienia czynu nieuczciwej konkurencji w postaci utrudniania dostępu do rynku (art. 15 uznk), które jednocześnie spełnia przesłanki porozumienia ograniczającego konkurencję lub nadużycia pozycji dominującej159, nie wymaga wykazywania istnienia porozumienia ani dominacji rynkowej, co z kolei można postrzegać jako ułatwienie dowodowe ${ }^{160}$. Również P. Podrecki wyrażał pogląd, że „roszczenia oparte na ustawie o zwalczaniu nieuczciwej konkurencji są znacznie lepszym środkiem służącym do ochrony indywidualnych interesów", a „prawo ochrony konkurencji stanowi (...) bardziej elastyczny instrument realizowania roszczeń osób trzecich dotkniętych niedozwolonymi zachowaniami mającymi źródło w naruszeniach prawa konkurencji”'161.

\subsubsection{Proceduralne i instytucjonalne aspekty prywatnego egzekwowania prawa ochrony konkurencji - zarys zagadnienia}

\subsubsection{Postępowanie przed sądem powszechnym (zwykłe postępowanie sądowe)}

Podstawy prawne, jakie kształtują prywatne egzekwowanie reguł konkurencji, determinują ramy proceduralne, w jakich realizowane jest dochodzenie roszczeń z tytułu naruszenia reguł konkurencji. $\mathrm{W}$ istocie w kontekście proceduralnym nie mają znaczenia żadne wskazane powyżej wątpliwości co do wyboru podstaw prawnych dla roszczeń, jako że wszystkie uwzględnione akty prawne, tj. Kodeks cywilny, ustawa o zwalczaniu nieuczciwej konku-

158 Tak w odniesieniu do oparcia roszczeń na ustawie o zwalczaniu nieuczciwej konkurencji - A. Stawicki, Poland, [w:] G. Blanke, R. Nazzini (red.), International Competition Litigation..., s. 579.

159 J. Sroczyński, M. Mioduszewski, [w:] M. Zdyb, M. Sieradzka (red.), Ustawa..., s. 478.

160 Bardziej kontrowersyjna jest kwestia konieczności wyznaczania rynku właściwego - formalnie na gruncie ustawy o zwalczaniu nieuczciwej konkurencji nie ma takiego obowiązku, jednak - jak wskazali E. Nowińska i M. du Vall - „skoro hipotezą art. 15 objęte są w znacznym zakresie takie same sytuacje, jak wchodzące w zakres ustawy o ochronie konkurencji i konsumentów, to pojęcie „rynek” należy rozumieć zgodnie z art. 4 pkt 11 u.o.k.k., tj. w taki sposób, jak to zobowiązany jest uczynić Prezes UOKiK. Umożliwi to w szczególności wyłączenie z zakresu regulacji przypadków zachowań przedsiębiorców, które - chociaż literalnie są objęte hipotezą poszczególnych punktów art. 15 ust. 1 u.z.n.k. - nie wpływają jednak (negatywnie) na możliwości działania przedsiębiorcy nim dotkniętego" (por. E. Nowińska, M. du Vall, Komentarz do ustawy..., (Komentarz do art. 15 , teza 5).

161 P. Podrecki, Porozumienia monopolistyczne i ich cywilnoprawne skutki, Zakamycze, Kraków 2000, s. 218. 
rencji oraz ustawa o przeciwdziałaniu nieuczciwym praktykom rynkowym są praktycznie wdrażane przy wykorzystaniu przepisów Kodeksu postępowania cywilnego jako aktu „normującego postępowanie sądowe w sprawach ze stosunków z zakresu prawa cywilnego (...) oraz w innych sprawach, do których przepisy tego Kodeksu stosuje się z mocy ustaw szczególnych (sprawy cywilne)" (art. $1 \mathrm{kpc}$ ). Nie ma żadnych wątpliwości co do tego, że dochodzenie roszczeń opartych nie tylko na przepisach Kodeksu cywilnego, ale również na ustawie o zwalczaniu nieuczciwej konkurencji oraz na ustawie o przeciwdziałaniu praktykom rynkowym stanowi „sprawę cywilną” w sensie materialnym i odpowiada „regulacyjnej definicji «sprawy cywilnej» jako przedmiotu sądowego postępowania cywilnego, a więc tego, co jest rozpoznawane (załatwiane) przez sąd w postępowaniu cywilnym"162. Zgodnie z koncepcją tzw. roszczenia procesowego o dopuszczalności drogi sądowej „nie decyduje obiektywne istnienie prawa podmiotowego, lecz jedynie twierdzenie strony o jego istnieniu"163.

Wobec spraw, których przedmiot stanowią roszczenia z tytułu naruszenia reguł konkurencji, znajdują zastosowanie przede wszystkim przepisy Kodeksu postępowania cywilnego odnoszące się do postępowania procesowego zwykłego (art. 15-42412 kpc), możliwe jest wykorzystanie również rozpatrywania sporu $\mathrm{w}$ ramach postępowania przed sądem polubownym (arbitrażowym) ${ }^{164}$.

Postępowanie sądowe toczące się w związku z prywatnym egzekwowaniem reguł konkurencji nie jest natomiast postępowaniem w sprawach z zakresu ochrony konkurencji, regulowanym przez art. 47928-47978 kpc, uznawane za jeden $\mathrm{z}$ rodzajów postępowania odrębnego ${ }^{165}$. $\mathrm{Z}$ tego względu nie jest właściwym określanie spraw cywilnych, mieszczących się w obszarze prywatnego egzekwowania reguł konkurencji, „sprawami z zakresu ochrony konkurencji”, ponieważ to określenie - dzięki nomenklaturze Kodeksu postępowania cywilnego - zastrzeżone jest dla spraw rozpatrywanych przez sąd ochrony konkurencji i konsumentów, wymienionych w art. $47928 \S 1$ - są to sprawy cywilne w znaczeniu formalnym ${ }^{166}$ (odwołania od decyzji Prezesa UOKiK,

162 J. Gudowski, [w:] M. Jędrzejewska, P. Grzegorczyk, K. Weitz, T. Ereciński, J. Gudowski, Kodeks postępowania cywilnego. Komentarz, LexisNexis, Warszawa 2012 (Komentarz do art. 1, teza 1).

163 Ibidem. Por. także m.in. uchwała składu 7 sędziów SN z dnia 12 marca 2003 r., III CZP 85/02, LexPolonica nr 360045, OSN 2003, nr 10, poz. 129; wyrok TK z dnia 10 lipca 2000 r., SK 12/99, LexPolonica nr 347787, OTK 2000, nr 5, poz. 143.

164 Por. pkt 3.3.2.2. w niniejszym rozdziale.

165 T. Ereciński, [w:] M. Jędrzejewska, P. Grzegorczyk, K. Weitz, T. Ereciński, J. Gudowski, Kodeks postępowania cywilnego... (Komentarz do art. 47928, teza 1).

166 Ibidem. 
zażalenia na postanowienia Prezesa UOKiK wydane w postępowaniach prowadzonych na podstawie ustawy o ochronie konkurencji i konsumentów lub przepisów odrębnych, zażalenia na postanowienia wydane przez Prezesa UOKiK $w$ postępowaniu zabezpieczającym prowadzonym na podstawie przepisów ustawy, zażalenia na postanowienia wydawane w postępowaniu egzekucyjnym prowadzonym w celu wykonania decyzji lub postanowień Prezesa UOKiK). Stronami postępowania w sprawach z zakresu ochrony konkurencji są: Prezes UOKiK i podmiot będący stroną w postępowaniu przed Prezesem UOKiK lub podmioty wnoszące zażalenie (art. 47929 $\S 1 \mathrm{kpc}$ ). W piśmiennictwie sprawy z zakresu ochrony konkurencji słusznie charakteryzowane są jako „spory przedsiębiorców z organem administracji publicznej o zasadność i legalność wprowadzenia ograniczeń" swobody działalności gospodarczej167.

Wraz ze zniesieniem postępowania odrębnego w sprawach gospodarczych (wskutek nowelizacji Kodeksu postępowania cywilnego na mocy ustawy z dnia 16 września 2011 r. ${ }^{168}$ ) można mówić o ujednoliceniu zasad proceduralnych prywatnego egzekwowania reguł konkurencji dla (cywilnych) spraw gospodarczych (tych, w których obydwie strony mają status przedsiębiorców) i pozostałych spraw (tych, w których jedna ze stron nie jest podmiotem profesjonalnym a jest konsumentem). Zmiana ta jest o tyle istotna, że w dyskusjach nad prywatnym egzekwowaniem reguł konkurencji w Polsce często podnoszono argument, że jedną z zasadniczych barier tego rozwoju stanowią ograniczenia proceduralne charakteryzujące postępowanie w sprawach gospodarczych, a w żaden sposób nie przystające - i nie uzasadnione - do specyfiki spraw z zakresu naruszenia zakazów praktyk ograniczających konkurencję (z krytyką spotykała się przede wszystkim właściwa dla postępowania w sprawach gospodarczych prekluzja dowodowa) ${ }^{169}$.

Ponadto przepisy Kodeksu postępowania cywilnego wyposażają potencjalnych powodów w ramach prywatnego egzekwowania reguł konkurencji w dodatkowy instrument ochrony ich praw, jaki może stanowić roszczenie o ustalenie istnienia lub nieistnienia stosunku prawnego (określane również

167 E. Stefańska, [w:] P. Pruś, E. Stefańska, M. Sieńko, K. Tomaszewski, M. Radwan, M. Manowska, Kodeks postępowania cywilnego. Komentarz, LexisNexis, Warszawa 2011 (Komentarz do art. 47928, teza 2).

168 Ustawa z dnia 16 września 2011 r. o zmianie ustawy Kodeks postępowania cywilnego oraz niektórych innych ustaw (Dz. U. $2011 \mathrm{Nr}$ 233, poz. 1381). Ustawa weszła w życie w dniu 3 maja 2012 r.

169 Sceptycznie co do rzeczywistego pozytywnego wymiaru nowelizacji kpc dla postępowań w zakresie prywatnego egzekwowania reguł konkurencji wypowiada się A. Piszcz, Stillunpopular Sanctions..., s. 72-73. 
jako roszczenie o ustalenie nieważności czynności prawnej), przewidziane w art. $189 \mathrm{kpc}^{170}$.

\subsubsection{Postępowanie przed sądem polubownym (postępowanie arbitrażowe)}

Specyfika postępowania przed sądem polubownym (określanego przez ustawodawcę także jako postępowanie arbitrażowe) polega przede wszystkim na tym, że jest ono mniej sformalizowane (sąd polubowny nie jest związany przepisami Kodeksu postępowania cywilnego), a jednocześnie „pozwala na rozwiązywanie powstających $w$ gospodarce sporów prywatnoprawnych w sposób godzący sprzeczne interesy stron i w konsekwencji umożliwia kontynuowanie łączących je relacji prawnych" 171 . W postępowaniu arbitrażowym strony dysponują „możliwością swobodnego wybrania prawa właściwego dla rozstrzygania sporu” ${ }^{172}$, a ponadto sąd polubowny „może oprzeć orzeczenie także na względach słuszności lub celowości rozstrzygnięcia w konkretnym wypadku"173. Co więcej sądy polubowne mogą korzystać z wyspecjalizowanych arbitrów, znacznie lepiej przygotowanych niż sędziowie do radzenia sobie z problemami np. wyliczania wielkości szkód antymonopolowych ${ }^{174}$. Należy jednak pamiętać o tym, że postępowanie arbitrażowe toczy się zwykle tylko w jednej instancji, a jedynej możliwości rewizji orzeczenia arbitrażowego należy upatrywać w skardze o jego uchylenie - wówczas toczy się wieloinstancyjne, jak w każdej „zwykłej” sprawie cywilnej, postępowanie o uchylenie wyroku sądu polubownego - w literaturze słusznie zwraca się uwagę na fakt, że w takiej sytuacji przez dłuższy czas może istnieć stan niepewności co do obowiązywania wyroku sądu arbitrażowego ${ }^{175}$, co w konsekwencji pozbawia postępowanie przed sądem polubownym niektórych jego zalet. Kwestie te mogą mieć istotne znaczenie dla stron sporów związanych z naruszaniem reguł konkurencji, tym samym można przyjąć, że sądownictwo arbitrażowe stanowi „naturalne” środowisko dla prywatnego egzekwowania

170 Por. rozdział VII, pkt 7.6.4.

171 Tak T. Ereciński, [w:] J. Ciszewski, P. Grzegorczyk, K. Weitz, T. Ereciński, Kodeks postępowania cywilnego. Międzynarodowe postępowanie cywilne. Sąd polubowny (arbitrażowy), LexPolonica 2012 (Komentarz do art. 1154, teza 5).

172 P. Pruś, [w:] P. Pruś, E. Stefańska, M. Sieńko, K. Tomaszewski, M. Radwan, M. Manowska, Kodeks postępowania cywilnego..., (Komentarz do art. 1154, teza 2).

173 T. Ereciński, [w:] J. Ciszewski, P. Grzegorczyk, K. Weitz, T. Ereciński, Kodeks postępowania cywilnego..., (Komentarz do art. 1154, teza 5).

174 G. I. Zekos, Antitrust/Competition Arbitration in EU verus U.S. Law, Journal of International Arbitration 2008, vol. 25(1), s. 27.

175 Tak T. Ereciński, [w:] J. Ciszewski, P. Grzegorczyk, K. Weitz, T. Ereciński, Kodeks postępowania cywilnego..., (Komentarz do art. 1154, teza 5). 
zakazów antykonkurencyjnych praktyk, jak się wydaje - szczególnie w tych państwach, gdzie brakuje rozwiązań prawnych specyficznych wyłącznie dla tego rodzaju sporów, jak również w UE, gdzie z kolei brak europejskich sądów prawa prywatnego ${ }^{176}$. Wykorzystanie sądów polubownych wymaga oczywiście minimum dobrej woli obydwu stron dla rozstrzygnięcia toczącego się konfliktu.

Odwołując się do doświadczeń innych niż polski porządków prawnych, należy stwierdzić, że podstawowy problem związany z poddawaniem sporów związanych $\mathrm{z}$ realizacją roszczeń wynikających $\mathrm{z}$ naruszenia zakazów praktyk ograniczających konkurencję arbitrażowi, podnoszony w piśmiennictwie i rozpoznawany $\mathrm{w}$ orzecznictwie, wiązał się głównie z publicznoprawnym charakterem norm prawa ochrony konkurencji i faktem, że normy te postrzegane były wyłącznie jako część polityki publicznej. Orzecznictwo amerykańskie do lat osiemdziesiątych odrzucało możliwość arbitrażu w sprawach antymonopolowych, podkreślając właśnie ich silny wymiar publicznoprawny177; krytycznie o zdatności arbitrażowej spraw antymonopolowych wypowiadali się również przedstawiciele doktryny178. Przełom nastąpił dopiero w wyroku w sprawie Mitsubishi Motors v. Soler Chrysler Plymouth $^{179}$, gdzie Sąd Najwyższy dopuścił możliwość międzynarodowego arbitrażu w sprawach antytrustowych, a następnie możliwość tę potwierdził w odniesieniu do arbitrażu krajowego w wyroku w sprawie Shearson/American Express v. McMahon ${ }^{180}$. W orzecznictwie unijnym problem stosowania arbitrażu w sprawach dotyczących ochrony konkurencji był przedmiotem wyroku w sprawie C-126/97 Eco Swiss ${ }^{181}$. Wyrok ten nie rozstrzygał co

176 J. Rajski, Rola sqadów arbitrażowych w procesie postępujacej europeizacji prawa kontraktów, e-Przegląd Arbitrażowy 2011, nr 4, s. 39.

177 Por. wyrok w sprawie American Safety Equip. Corp. v. J. P. Maguire \& Co., 391 F. 2d 821 (2d Cir. 1968).

178 Por. m.in. R. Pitofsky, Arbitration and Antitrust Enforcement, The Arbitration Journal 1975, vol. 25(1), s. 40-52.

179473 U.S. 614, 105 S. Ct. 3346 (1985).

180482 U.S. 220 (1987). W późniejszym orzecznictwie por. m.in. Kotam Electronic, Inc. v. JBL Consumer Products Inc. 93 F.3d 724 (11th Cir. 1996); JLM Industries v. Stolt Nielsen SA, 387 F.3d 163 (2nd Cir. 2004).

181 Wyrok TS z dnia 1 czerwca 1999 r. w sprawie C-126/97 Eco Swiss China Time Ltd v. Benetton International $N V$ (Zb. Orz. 1999, s. I-03055). Szerzej na temat stosowania prawa konkurencji Unii Europejskiej przez sądy arbitrażowe w polskim piśmiennictwie - por. J. Kolber, Zasady stosowania prawa konkurencji UE przez sady arbitrażowe, Kwartalnik ADR 2012, nr 3; J. Kociubiński, Arbitraż w europejskim prawie konkurencji - zarys problemu, Kwartalnik ADR 2012, nr 2; M. Szpunar, Stosowanie prawa konkurencji UE przez sądy arbitrażowe, [w:] J. Okólski i inni (red.), Księga pamiątkowa 60-lecia Sadu Arbitrażowego przy Krajowej Izbie Gospodarczej, LexisNexis, Warszawa 2010, s. 613-631. 
prawda bezpośrednio o dopuszczalności stosowania arbitrażu w sporach wynikających z naruszenia reguł konkurencji, jednak można przyjąć, że przynajmniej nie wykluczył możliwości poddawania sporów na tle art. 101 lub 102 TFUE sądownictwu polubownemu, o ile jest to akceptowane w prawie krajowym (przez państwowe sądy krajowe) ${ }^{182}$. Właściwym problemem rozpatrywanym przez Trybunał Sprawiedliwości w wyroku w sprawie C-126/97 Eco Swiss była kwestia unieważnienia wyroku sądu arbitrażowego przez sąd państwowy ze względu na nieuwzględnienie w treści orzeczenia sądu polubownego naruszenia przepisu art. 101 ust. 1 TFUE (wówczas art. 85 TEWG).

Według mojej najlepszej wiedzy żadne orzeczenie polskiego sąd powszechnego nie potwierdziło dotąd wprost możliwości poddania roszczeń wynikających z naruszenia reguł konkurencji arbitrażowi, poglądy aprobujące taką możliwość wyrażane są natomiast w piśmiennictwie (choć dorobek doktrynalny $\mathrm{w}$ tym zakresie jest bardzo skromny) ${ }^{183}$. W związku z tym spory związane z prywatnym egzekwowaniem reguł konkurencji mogą być przedmiotem postępowania przed sądem polubownym zgodnie $\mathrm{z}$ przepisami art. 1154-1217 kpc. Wskazane przepisy kodeksowe odpowiadają współczesnym standardom międzynarodowym w tym względzie, jako że wzorowane są na ustawie modelowej UNCITRAL o międzynarodowym arbitrażu handlowym z 1985 r. ${ }^{184}$

\subsubsection{Sądy zaangażowane w prywatne egzekwowanie prawa ochrony konkurencji}

Dochodzenie roszczeń z tytułu naruszenia zakazów praktyk ograniczających konkurencję zarówno tych zawartych w prawie krajowym, jak i w Traktacie o funkcjonowaniu UE, zgodnie z zasadą domniemania drogi sądowej (art. $2 \S 1 \mathrm{kpc}$ ), może odbywać się w Polsce przed sądami powszechnymi (sądy rejonowe, sądy okręgowe, sądy apelacyjne) ${ }^{185}$ oraz przed Sądem Najwyższym. Sprawy cywilne z obszaru prywatnego egzekwowania reguł konkurencji mogą być sprawami ze stosunków między (wyłącznie) podmiotami profesjonalnymi (między przedsiębiorcami) - i wówczas sprawy takie

182 Tak również G. I. Zekos, Antitrust/Competition Arbitration..., s. 20.

183 Por. S. Syp, P. Nowaczyk, Arbitraż a prawo konkurencji, Gazeta Finansowa z dnia 27 kwietnia 2012 r.; A. Stawicki, Poland, [w:] G. Blanke, R. Nazzini (red.), International Competition Litigation..., s. 609.

184 Tekst przyjęty 21 czerwca 1985 r. przez Komisję Międzynarodowego Prawa Handlowego ONZ, tłum. PPHZ 1992, nr 16.

185 Por. art. 175 ust. 1 Konstytucji RP oraz art. $1 \S 1$ ustawy z dnia 27 lipca 2001 r. Prawo o ustroju sądów powszechnych (Dz. U. 2001 Nr 98, poz. 1070 ze zm.); dalej jako upusp. 
będą kwalifikowane jako sprawy gospodarcze w rozumieniu art. 2 ustawy o rozpoznawaniu przez sądy spraw gospodarczych ${ }^{186}$ definiującego sprawy gospodarcze jako „sprawy ze stosunków cywilnych między przedsiębiorcami w zakresie prowadzonej przez nich działalności gospodarczej”. Dochodzenie roszczeń z tytułu naruszenia zakazów praktyk antykonkurencyjnych może odbywać się również w stosunkach między przedsiębiorcami a podmiotami nieprofesjonalnymi (konsumentami), nie działającymi w ramach prowadzonej działalności gospodarczej - sprawy tego rodzaju nie spełniają oczywiście definicji spraw gospodarczych. Do dnia 3 maja 2012 r. (wejście w życie nowelizacji Kodeksu postępowania cywilnego, znoszącej m.in. postępowanie odrębne w sprawach gospodarczych) sprawy gospodarcze były rozpatrywane przez sądy gospodarcze działające jako odrębne jednostki w sądach rejonowych i okręgowych.

Obecnie wszystkie sprawy z obszaru prywatnego egzekwowania reguł konkurencji, niezależnie od statusu prawnego ich uczestników, rozpatrywane są przez wydziały cywilne i gospodarcze sądów powszechnych oraz przez Izbę Cywilną Sądu Najwyższego. Co do zasady rozpatrywanie wszystkich spraw powierzone jest sądom rejonowym, $\mathrm{z}$ wyjątkiem spraw, dla których zastrzeżona jest właściwość sądów okręgowych (art. $16 \mathrm{kpc}$ ). Jeden z takich wyjątków stanowi uznanie właściwości sądów okręgowych w sprawach o prawa majątkowe, w których wartość przedmiotu sporu przewyższa 75 tys. złotych (art. 17 pkt 4 kpc) ${ }^{187}$.

Likwidacja odrębnego postępowania w sprawach gospodarczych pociągnęła za sobą zmiany w zakresie organizacji sądów (działalności dotychczasowych sadów gospodarczych). Obecnie ustawa Prawo o ustroju sądów powszechnych przewiduje jedynie możliwość (nie obowiązek) utworzenia wydziałów gospodarczych w sądach rejonowych (art. $12 \S 1$ 1a pkt 3 upusp) i okręgowych (art. $16 \S 4$ a pkt 2 upusp). Wydziały takie zajmują się „sprawami gospodarczymi oraz innymi sprawami z zakresu prawa gospodarczego i cywilnego należących do sądu gospodarczego na podstawie odrębnych ustaw". W sądach apelacyjnych sprawami tego rodzaju zajmują się wydziały cywilne (art. $18 \S 1$ pkt 1 upusp).

Postępowania arbitrażowe prowadzone są natomiast przed sądami polubownymi (arbitrażowymi), które nie mają statusu sądów państwowych, a ich działanie co do zasady wyklucza orzecznictwo sądów państwowych. Pod-

186 Ustawa z dnia 24 maja 1989 r. o rozpoznawaniu przez sądy spraw gospodarczych (Dz. U. $1989 \mathrm{Nr} 33$, poz. $125 \mathrm{ze} \mathrm{zm}$.).

187 Przed wejściem w życie nowelizacji Kodeksu postępowania cywilnego właściwość sądów okręgowych w sprawach gospodarczych dotyczyła praw majątkowych o wartości ponad 100 tys. zł. 
stawę funkcjonowania sądów polubownych stanowią, z jednej strony wola stron dokonujących zapisu na sąd polubowny, z drugiej - przepisy Kodeksu postępowania cywilnego „uznające sądownictwo polubowne, zezwalające na poddanie określonych sporów pod rozstrzygnięcie tych sądów i określające warunki, pod którymi orzeczenie wydane przez sąd polubowny będzie zrównane z orzeczeniem sądu państwowego"188. Sądy arbitrażowe mogą mieć charakter stały lub mogą być powoływane ad hoc. Sprawy związane z naruszeniem zakazów antykonkurencyjnych praktyk mogą być rozstrzygane przez obydwie kategorie sądów.

\subsection{Uwagi końcowe}

Prywatnoprawne egzekwowanie zakazów praktyk ograniczających konkurencję w Polsce jest możliwe: mimo braku wyspecjalizowanych przepisów w tym obszarze, możliwe jest wskazanie aktów prawnych, które mogą służyć za podstawę prawną tego trybu dochodzenia roszczeń z tytułu zakazanych antykonkurencyjnych praktyk, kontrowersji nie budzi także aspekt proceduralno-instytucjonalny: prywatnoprawne egzekwowanie zakazów praktyk ograniczających konkurencję może być realizowane poprzez cywilne postępowanie sądowe lub postępowanie arbitrażowe. Przedstawione w niniejszym rozdziale otoczenie prawne prywatnego egzekwowania reguł konkurencji, choć niedoskonałe, nie tworzy moim zdaniem zasadniczych barier dla wzrostu popularności sądowego dochodzenia roszczeń z tytułu naruszenia zakazów antykonkurencyjnych praktyk (choć jednocześnie trudno uznać obecne ramy prawne za motywujące do rozwoju prywatnoprawnego egzekwowania reguł konkurencji). Mimo tego w Polsce, podobnie jak w całym regionie Europy Środkowo-Wschodniej, prywatne egzekwowanie reguł konkurencji jest słabo rozwinięte i nie cieszy się popularnością.

Inaczej bowiem niż w Stanach Zjednoczonych, gdzie sądowe dochodzenie roszczeń z tytułu naruszenia reguł konkurencji zawsze stanowiło immanentną część proceduralnego aspektu modelu ochrony konkurencji ${ }^{189}$, rozwój prywatnego trybu egzekwowania reguł konkurencji w Europie ma

188 T. Ereciński, [w:] J. Ciszewski, P. Grzegorczyk, K. Weitz, T. Ereciński, Kodeks postępowania cywilnego... (Komentarz do art. 1154, teza 1).

189 Orzecznictwo Sądu Najwyższego Stanów Zjednoczonych po 2005 r. wydaje się zmierzać w kierunku podwyższania wymogów dla skutecznego sądowego dochodzenia roszczeń związanych z naruszeniami reguł konkurencji (co przekłada się na zmniejszającą się liczbę pozwów) - tak O. Odudu, Developing private enforcement in the EU: Lessons from the Roberts Court, Antitrust Bulletin 2008, vol. 53(4), s. 873-902. 
krótszą historię ${ }^{190}$. Największy dorobek orzeczniczy w tym zakresie należy przypisać Wielkiej Brytanii, gdzie ze względu na rodzaj systemu prawnego występują najmniejsze bariery w recepcji doświadczeń amerykańskich. Jak dotąd nie znalazły pokrycia w rzeczywistości prognozy co do tego, że to inicjatywy podejmowane na poziomie UE przyczynią się do intensyfikacji prywatnego egzekwowania reguł konkurencji w państwach członkowskich (i innych pozostających pod wpływem regulacji unijnych ze względu np. na status państw stowarzyszonych z UE) ${ }^{191}$.

Dla rozwoju prywatnego egzekwowania reguł konkurencji, tak w Polsce, jak i innych państwach, niewielkie znaczenie wydają się mieć powszechnie uznawane korzyści związane $\mathrm{z}$ tym trybem egzekwowania zakazów antykonkurencyjnych praktyk. $\mathrm{Z}$ perspektywy kształtowania zrównoważonego modelu egzekwowania reguł konkurencji wśród tych korzyści na plan pierwszy wysuwa się okoliczność, że prywatne egzekwowanie prawa ochrony konkurencji eliminuje dyskrecjonalność w publicznym egzekwowaniu zakazów praktyk ograniczających konkurencję, a organy ochrony konkurencji czyni bardzie odpowiedzialnymi za decyzje o niewszczynaniu postępowania antymonopolowego ${ }^{192}$, co jest szczególnie istotne tam, gdzie - jak w Polsce

190 Intensyfikacja działań promujących prywatne egzekwowanie reguł konkurencji w Unii Europejskiej i jej (niektórych) państwach członkowskich skłania do wniosku, że dysproporcje między amerykańskim i europejskim modelem egzekwowania prawa ochrony konkurencji zmieniają się - por. A. E. Foer, E. P. Schultz, Will Two Roads Still Diverge? Private Enforcement of Antitrust Law Is Getting Harder in the United States. But Europe May Be Making It Easier, G.C.L.R. 2011, vol. 4(3), s. 107-112. Nie brakuje także głosów ostrzegających przed przejęciem w Europie takich reguł prywatnego egzekwowania prawa ochrony konkurencji, które pozwalają na nadużywanie drogi sądowej w sprawach antymonopolowych - por. m.in. D. H. Ginsburg, Comparing Antitrust Enforcement in the United States and Europe, Journal of Competition Law and Economics 2005, vol. 1(3), s. 427-439; K.S. Bernard, Private antitrust litigation in the European Union - why does the EC want to embrace what the US FTC is trying to avoid?, G.C.L.R. 2010, vol. 3(2), s. 69-84. Również w polskim piśmiennictwie R. Molski, uznając amerykański model egzekwowania prawa konkurencji za „dość ekscentryczny”, wskazuje, że możliwość wzorowania krajowych systemów ochrony konkurencji na tym modelu, „pozostaje kwestią do dyskusji” - tenże, Prywatnoprawna ochrona konkurencji $w$ amerykańskim prawie antytrustowym, KPP 2005, z. 3, s. 807.

191 Niski poziom rozwoju prywatnego egzekwowania reguł konkurencji odnotowywano także w pozaeuropejskich krajach wysokouprzemysłowionych, takich jak np. Japonia por. Y. Miwa, M. Ramseyer, Toward a Theory of Jurisdictional Competition: the Case of the Japanese FTC, Journal of Competition Law and Economics 2005, vol. 1(2), s. 254; S. Ezaki, T. Motoyoshi, V. Moussis, Recent trends in private antitrust litigation in Japan, G.C.L.R. 2010, vol. 3(1), s. 41-46.

192 K. Roach, M. J. Trebilcock, Private enforcement of competition laws, Osgoode Hall Law Journal 1996, vol. 34(3), s. 482-484. 
- inicjowanie postępowań następuje wyłącznie z urzędu. W badaniach ekonomicznych poświęconych relacjom między publicznym i prywatnym egzekwowaniem reguł konkurencji podkreśla się fakt, że drugi z wymienionych trybów pozwala na wykorzystanie przewagi informacyjnej (co do naruszeń prawa konkurencji), jaką podmioty prywatne posiadają (w przypadku większości naruszeń) nad publicznym organem ochrony konkurencji ${ }^{193}$. Prywatne egzekwowanie reguł konkurencji może wręcz przyczyniać się do zmiany warunków funkcjonowania rynku dzięki poprawie jego efektywności i konkurencyjności 194 . Póki co korzyści te nie zostały docenione ani przez krajowego ustawodawcę (który mógłby opowiedzieć się za nimi poprzez wprowadzenie specjalnych regulacji prawnych poświęconych prywatnemu egzekwowaniu reguł konkurencji), ani przez samych poszkodowanych wskutek naruszenia zakazów praktyk ograniczających konkurencję.

193 Por. R. P. McAfee, H. M. Mialon, S. H. Mialon, Private v. Public Antitrust Enforcement: A Strategic Analysis, Journal of Public Economics 2008, vol. 92(10-11), dostępny także pod adresem: http://papers.ssrn.com/sol3/papers.cfm?abstract_id=775245\#\#, s. 2-3; I. R. Segal, M. Whinston, Public v. Private Enforcement of Antitrust Law: A Survay, Stanford Law and Economics Olin Working Paper No. 335, dostępny pod adresem: http://papers.ssrn.com/sol3/papers.cfm?abstract_id=775245\#\#, s. 4-6.

194 Tak R.H. Lande, J. P. Davis, Benefits from Private Antitrust Enforcement: An Analysis of Forty Cases, University of San Franciso Law Review 2008, vol. 42, s. 905. 


\section{Interes publiczny i prywatny w egzekwowaniu zakazów praktyk ograniczających konkurencję}

\subsection{Uwagi wstępne}

Reguły prawa materialnego ustanawiane są dla realizacji określonego celu, który należy utożsamiać $\mathrm{z}$ interesem bądź to ogólnym (publicznym ${ }^{1}$ ), bądź jednostkowym (prywatnym). Interes leżący u podstaw reguł materialnoprawnych należy definiować, w moim przekonaniu, poprzez zbiór wartości i celów, jakie powinny być uwzględniane (realizowane) w procesie egzekwowania tych regu ${ }^{2}$. Definicja interesu odpowiada zatem przyjętej przez ustawodawcę aksjologii regulacji - Sąd Najwyższy kilkakrotnie stwierdzał, że „pojęcie interesu [publicznego] należy interpretować przez pryzmat aksjologii ustawodawstwa antymonopolowego"3. Dekodowania wartości konstytuujących realizowany przez reguły prawne interes należy dokonywać w toku wykładni celowościowej i systemowej określonych przepisów materialnych.

1 Pojęcie interesu publicznego w przeszłości bywało również utożsamiane z pojęciem interesu społecznego - por. poświęconą problemowi interesu społecznego monografię M. Wyrzykowskiego, Pojęcie interesu społecznego w prawie administracyjnym, Wyd. Uniwersytetu Warszawskiego, Warszawa 1986.

2 W piśmiennictwie pojęcie ,interesu” odnosi się także do procesu dążenia do osiągnięcia korzyści rozumianej jako „partycypacja w dobrach (wartościach) występujących w ograniczonej ilości (...)”, przy czym „korzyść powinna być rozumiana szerzej, tak aby pojęciem tym objąć również te sytuacje, kiedy jej urzeczywistnieniem jest także uniknięcie przez dany podmiot niebezpieczeństwa naruszenia jego «interesu», czyli jego ochrona" - por. A. Wilczyńska, Interes publiczny w prawie stanowionym i orzecznictwie Trybunału Konstytucyjnego, PPH 2009, nr 6 i cyt. tam literatura.

3 Wyrok SN z dnia 27 sierpnia 2003 r., I CKN 527/2001, LexPolonica nr 362998; wyrok SN z dnia 5 czerwca 2008 r., III SK 40/07, OSNP 2009 Nr 19-20, poz. 272; wyrok SN z dnia 19 lutego 2009 r., III SK 31/2008, LexPolonica nr 2302381. 
Do prawa konkurencji w szerokim znaczeniu należą regulacje realizujące interes publiczny i prywatny. Ten pierwszy tradycyjnie utożsamiany jest z tzw. ustawami antymonopolowymi (zwalczającymi antykonkurencyjne praktyki i przeciwdziałającymi antykonkurencyjnym koncentracjom), drugi - z ustawami zwalczającymi nieuczciwą konkurencję. Z kolei prawo konkurencji w wąskim znaczeniu (określane jako prawo ochrony konkurencji) koncentruje się na realizacji interesu publicznego (poprzez wdrażanie ustaw antymonopolowych). Możliwość prywatnego egzekwowania prawa ochrony konkurencji przełamuje wskazane powyżej zwyczajowe przyporządkowanie poszczególnych kategorii interesów (prywatnego i publicznego) do określonych aktów prawnych, pozwalając na wykorzystanie w celu realizacji interesu prywatnego regulacji ustanowionej co do zasady w interesie publicznym.

Poszukiwanie zrównoważonego modelu wspólistnienia dwóch trybów egzekwowania reguł konkurencji wymaga określenia granic wzajemnych wpływów interesu publicznego i interesu prywatnego w ramach każdego z trybów egzekwowania zakazów antykonkurencyjnych praktyk. W tym celu niezbędna jest nie tylko próba uchwycenia złożoności pojęcia interesu publicznego i interesu prywatnego, ale także określenie zakresu ekspansji interesu publicznego w prywatnoprawny tryb egzekwowania reguł konkurencji i - ewentualnie - zakresu realizacji interesu prywatnego w trybie publicznoprawnym.

O ile w przypadku interesu publicznego można mówić o jednostkowym, choć niekoniecznie wewnętrznie spójnym, pojęciu, o tyle w odniesieniu do interesu prywatnego bardziej adekwatne wydaje się posługiwanie się liczbą mnogą dla określenia wartości poszukiwanych przez różne kategorie podmiotów (np. przedsiębiorcy, konsumenci), zainteresowanych dochodzeniem roszczeń z tytułu naruszenia zakazów antykonkurencyjnych praktyk na drodze sądowej. Rozważania nad interesem prywatnym prowadzą do wyznaczenia kręgu (zróżnicowanych) podmiotów legitymowanych czynnie do występowania $\mathrm{z}$ takimi roszczeniami. W Europie, w tym jak się wydaje także w Polsce, znacznie mniej emocji niż w Stanach Zjednoczonych, budzi przynależność do tego kręgu tzw. nabywców pośrednich. W wielu porządkach prawnych istotną rolę w prywatnym egzekwowaniu zakazów praktyk ograniczających konkurencję przypisuje się ochronie uwspólnionych interesów podmiotów dotkniętych antykonkurencyjnymi praktykami, realizowanej za pomocą tzw. pozwów zbiorowych (grupowych) - w Polsce instrument ten pozostaje niewykorzystaną szansą. 


\subsection{Interes publiczny realizowany przez prawo ochrony konkurencji}

Polska ustawa o ochronie konkurencji - podobnie jak stanowiące jej odpowiednik unijne przepisy traktatowe, należące do sfery prawa (gospodarczego) publicznego - mają za zadanie realizować - co oczywiste - interes publiczny. Jak stwierdził SN ,ustawa antymonopolowa ma charakter publicznoprawny, zaatem jej celem jest służenie interesom publicznym"4; Prezesowi UOKiK przypisana została rola rzecznika interesu publicznego, wynikająca zdaniem SAM, z jego zadań w strukturze administracji publicznej ${ }^{5}$.

Prawodawca unijny nie deklaruje co prawda wprost - jak czyni to polski ustawodawca - że interwencja antymonopolowa podejmowana jest w interesie publicznym, jednak cel (interes) publiczny można w przypadku prawa unijnego wywieść z celów samego Traktatu o funkcjonowaniu Unii Europejskiej. Nawet jeśli na mocy traktatu z Lizbony spośród celów gospodarczych UE usunięte zostało zapewnienie funkcjonowania systemu niezakłóconej konkurencji (dawny art. 3 ust. 1 lit. g) TWE), to wspólne reguły konkurencji UE należy postrzegać jako immanentną część składową reguł funkcjonowania rynku wewnętrznego, na co wprost wskazuje art. 3 ust. 1 lit. b) TFUE oraz protokół nr 27 do Traktatu w sprawie rynku wewnętrznego i konkurencji, wskazujący, że rynek wewnętrzny obejmuje system zapewniający niezakłóconą konkurencję. Rolę przesłanki interesu publicznego w art. 101 i 102 TFUE należy, moim zdaniem, przypisać przesłance wpływu na handel między państwami członkowskimi, realizującej założenia właściwego funkcjonowania rynku wewnętrznego. Przepisy traktatowe nie zawierają definicji wpływu na handel wewnątrzunijny, jednak orzecznictwo w tej materii jest niezwykle bogate, a jego podsumowanie stanowią wytyczne Komisji w sprawie pojęcia wpływu na handel zawartego w art. 81 i 82 Traktatu? Inaczej niż ma to miejsce na gruncie polskiej ustawy o ochronie konkurencji i konsumentów (o czym mowa będzie poniżej), regulacje traktatowe nie

4 Wyrok SN z dnia 16 października 2008 r., III SK 2/08.

5 Wyrok SAM z dnia 21 listopada 2001 r., XVII Ama 2/2001, Dz. Urz UOKiK 2002 Nr 1, poz. 47.

6 Szerzej na temat aksjologii unijnych reguł konkurencji i ich miejsca w unijnym systemie prawnym piszemy wraz z T. Skocznym [w:] A. Jurkowska-Gomułka, T. Skoczny, Wspólne reguly konkurencji Unii Europejskiej, Warszawa 2010, s. XXIV-1-XXIV-5. Por. także D. Miąsik, [w:] A. Wróbel, K. Kowalik-Bańczyk, M. Szwarc-Kuczer (red.), Traktat o funkcjonowaniu Unii Europejskiej. Komentarz. Tom II, LEX a Wolters Kluwer business, Warszawa 2012, s. 189-192.

7 Commission Notice - Guidelines on the effect on trade concept contained in Articles 81 and 82 of the Treaty (OJ 2004 C 101/86). Wytyczne nie zostały opublikowane w polskiej wersji językowej w Dz. Urz. UE. 
pozostawiają miejsca na spekulacje co do tego, czy każdy przypadek, kiedy spełnione są przesłanki zakazu antykonkurencyjnych praktyk niesie ze sobą równoczesne naruszenie interesu publicznego - jeśli przyjmujemy, że emanacją tego interesu w aspekcie unijnym jest przesłanka wpływu na handel między państwami członkowskimi, to spełnienie tej przesłanki jest niezbędne dla podjęcia interwencji antymonopolowej w każdym przypadku. Ze względu na to, że przesłanka wpływu na handel jest „wbudowana” bezpośrednio w zakazy z art. 101 i 102 TFUE, również skuteczne prywatne egzekwowanie zakazów praktyk ograniczających konkurencję możliwe jest jedynie wówczas, gdy dowiedzione zostanie spełnienie tego warunku zakazów.

Polski ustawodawca już w art. 1 ust. 1 uokik deklaruje, że ochrona interesów przedsiębiorców i konsumentów, w zakresie regulowanym ustawą, podejmowana jest $\mathrm{w}$ interesie publicznym. Zapis ten został przejęty z ustawy o ochronie konkurencji i konsumentów z 2000 r., gdzie pojawił się po raz pierwszy - ustawa antymonopolowa z $1990 \mathrm{r}$. nie posługiwała się kategorią interesu publicznego, choć nie ma wątpliwości co do tego, że i tamta regulacja ukierunkowana była na realizację interesu publicznego - już w pierwszych wyrokach Sądu Antymonopolowego pojawiały się odniesienia do interesu publicznego jako przesłanki interwencji podejmowanej na podstawie ustawy antymonopolowej. Przykładowo, w wyroku z dnia 24 stycznia 1991 r., Amr 8/90, SAM stwierdzi1, że „nie każde naruszenie prawa w stosunkach cywilnoprawnych kwalifikuje sprawę do postępowania o przeciwdziałaniu praktykom monopolistycznym. Decyduje tu naruszenie przez podmiot gospodarczy, w następstwie stosowania zabronionych praktyk monopolistycznych, interesu publiczno-prawnego w zakresie ochrony rozwoju konkurencji, ochrony podmiotów gospodarczych narażonych na stosowanie praktyk monopolistycznych oraz ochrony interesów konsumentów"8. Niewątpliwie to właśnie orzecznictwo antymonopolowe doprowadziło do uczynienia z interesu publicznego (w uokik z 2000 r. i 2007 r.) samodzielnej przesłanki materialnoprawnej interwencji organu ochrony konkurencji $^{9}$. Niektórzy autorzy twierdzą nawet, że art. 1 ust. 1 uokik jest ,jedynie wyartykułowaniem już istniejącej normy prawnej”10, tj. normy wypracowanej

8 Por. wyrok SAM z dnia 24 stycznia 1991 r., Amr 8/90, Wokanda 1992, nr 2.

9 Za rozumieniem interesu publicznego jako przesłanki zastosowania ustawy opowiadają się m.in.: D. Miąsik, Controlled Chaos with Consumer Welfare as the Winner - a Study of the Goals of Polish Antitrust Law, YARS 2008, vol. 1(1), s. 41; E. Stawicki, [w:] A. Stawicki, E. Stawicki (red.), Ustawa o ochronie konkurencji i konsumentów. Komentarz, LEX a Wolters Kluwer business, Warszawa 2011, s. 32.

10 C. Banasiński, E. Piontek (red.), Ustawa o ochronie konkurencji i konsumentów. Komentarz, Wyd. LexisNexis, Warszawa 2009, s. 17 (Komentarz do art. 1, teza 6). 
w orzecznictwie. Postrzeganie interesu publicznego jako przesłanki stosowania ustawy oznacza, że samo spełnienie przesłanek zakazów praktyk ograniczających konkurencję nie wystarczy do podjęcia interwencji przez organ - „nie każda praktyka ograniczająca konkurencję musi zakończyć się decyzją z art. 9 ustawy właśnie ze względu na interes publicznoprawny"11. Sytuacja, w której określone zachowanie przedsiębiorcy spełnia przesłanki zakazów z art. 6 lub 9 uokik, ale nie realizuje przesłanki interesu publicznego, wskazanej w art. 1 ust. 1 uokik, nie wyklucza możliwości dochodzenia roszczeń na drodze sądowej12. Pogląd taki wyrażony został przez SN, który stwierdzil, że „nie każda praktyka ograniczająca konkurencję musi zakończyć się interwencją Prezesa UOKiK właśnie ze względu na interes publicznoprawny. W konsekwencji sąd powszechny rozpoznający spór między stronami umowy władny jest dokonać samodzielnych ustaleń odnośnie dostosowania praktyk ograniczających konkurencję przy zawieraniu umowy jako przesłanki stwierdzenia jej nieważności" ${ }^{13}$. W piśmiennictwie przesłankę interesu publicznego określa się jako „przesłankę interwencyjną” ${ }^{14}$. Sam ustawodawca, poprzez wskazanie w art. 7 i 8 uokik - kategorii porozumień wyłączonych spod zakazu porozumień ograniczających konkurencję - zadecydował o zakresie spraw, które nie są „ścigane” w interesie publicznym.

Mimo „posadowienia” ustawy o ochronie konkurencji i konsumentów na interesie publicznym, ustawodawca nie zdecydował się na wprowadzenie do ustawy jego definicji - jak określił to $\mathrm{SN}$, interes publiczny w art. 1 ust. 1 został wskazany, ale nie zdefiniowany ${ }^{15}$. Jak dotąd, nie wypracowano spójnej definicji interesu publicznego ani w doktrynie, ani w orzecznictwie, choć można wskazać pewne tendencje co do wykładni tej przesłanki (o czym poniżej). Artykuł 1 ust. 1 uokik postrzegany jest często w piśmiennictwie jako klauzula generalna, co - przynajmniej zdaniem K. Kohutka - pozwala na przypisywanie mu różnorodnych znaczeń i treści16.

11 Wyrok SN z dnia 2 marca 2006 r., I CKS 83/2005, LexPolonica nr 2050337.

12 Pogląd taki w polskim piśmiennictwie wyrazili: K. Kohutek, Naruszenie interesu publicznego a naruszenie konkurencji (na tle praktyk rynkowych dominantów), PiP 2010, nr 7, s. 45; C. Banasiński, E. Piontek (red.), Ustawa..., s. 22 (Komentarz do art. 1, teza 10).

13 Wyrok SN z dnia 5 stycznia 2007 r., III SK 17/2006, LexPolonica nr 2025330.

14 D. Miąsik, T. Skoczny, [w:] T. Skoczny, A. Jurkowska, D. Miąsik (red.), Ustawa o ochronie konkurencji i konsumentów. Komentarz, C. H. Beck, Warszawa 2009, s. 46 (Komentarz do art. $1, \mathrm{Nb} 46)$.

15 Wyrok SN z dnia 7 stycznia 2009 r., III SK 16/2008, OSNP 2010 Nr 13-14, poz. 177.

16 K. Kohutek, Naruszenie interesu publicznego..., s. 45. Por. także piśmiennictwo poświęcone interesowi publicznemu poza prawem ochrony konkurencji: A. Żurawik, Klauzula interesu publicznego w prawie gospodarczym krajowym i unijnym, EPS 2013, nr 1; R. Blicharz, M. Kania, Klauzula interesu publicznego w publicznym prawie gospodarczym, PUG 2010, 
Analiza orzecznictwa prowadzi do identyfikacji dwóch koncepcji interesu publicznego ${ }^{17}$, które można określić jako koncepcję kwantytatywną i koncepcję jakościową. Sposób konkretyzacji interesu publicznego odzwierciedla przy tym do pewnego stopnia rozumienie pojęcia konkurencji ${ }^{18}$.

Koncepcja kwantytatywna interesu publicznego, którą można powiązać ze strukturalnym rozumieniem konkurencji zakłada, że interes publiczny doznaje uszczerbku wówczas, gdy doszło do naruszenia interesów znaczącej grupy podmiotów ${ }^{19}$ („nie wyłącznie interesu prawnego jednostki lub grupy"20). Jak zauważa D. Miąsik, przyjęcie tej koncepcji prowadzi do wniosku, że nie każde naruszenie przepisów ustawy prowadzi do interwencji antymonopolowej - aby Prezes UOKiK wszczął postępowanie w sprawie niezbędne jest, aby określona praktyka wpływała na proces konkurowania ${ }^{21}$. „Zwykłe” naruszenie interesów przedsiębiorców, zazwyczaj konkurentów, nie jest wystarczające dla podjęcia interwencji przez organ ochrony konkurencji, gdyż konkurencja rozumiana jest nie jako „sytuacja pojedynczego przedsiębiorcy, lecz jako zjawisko charakteryzujące funkcjonowanie gospodarki" 22 . W orzecznictwie i doktrynie ${ }^{23}$ można zidentyfikować pogląd, zgodnie z którym z naruszeniem interesu publicznego mamy do czynienia także w sytuacji, gdy praktyka dotyka co prawda pojedynczego podmiotu, ale jest to podmiot zbiorowy, jak np. spółdzielnia ${ }^{24}$ lub gmina ${ }^{25}$. Kwantytatywna koncepcja interesu publicznego jest obecna w orzecznictwie antymonopolowym od wczesnych lat dziewięćdziesiątych. W wyroku z dnia 24 stycznia 1991 r., Amr 8/90, SAM wskazywał, że „,naruszenie interesu publicznoprawnego może przykładowo mieć miejsce, gdy skutkami działań sprzecznych $\mathrm{z}$ ustawą o przeciwdziałaniu praktykom monopolistycznym dotknięty

nr 5, a w starszym piśmiennictwie - M. Wyrzykowski, Pojęcie interesu społecznego..., s. $28,29$.

17 Nie mogę zgodzić się z poglądem, że „W orzecznictwie funkcjonuje definicja interesu publicznego" (autorom zdaje się chodzić o jedną definicję) - tak C. Banasiński, E. Piontek (red.), Ustawa..., s. 17 (Komentarz do art. 1, teza 7).

18 K. Kohutek, Naruszenie interesu publicznego..., s. 46.

19 Por. m.in. wyroki SN: z dnia 29 maja 2001 r., I CKN 1217/98, OSNC 2002 nr 1, poz. 13; z dnia 28 stycznia 2002 r., I CKN 112/99, OSNC 2002 nr 11, poz. 144; z dnia 24 lipca 2003 r., I CKN 496/2001, Dz. Urz. UOKiK 2004 nr 1, poz. 283.

20 Wyrok SAM z dnia 21 listopada 2001 r., XVII Ama 2/2001, Dz. Urz. UOKiK 2002 $\mathrm{Nr}$ 1, poz. 47.

21 D. Miąsik, Controlled Chaos..., s. 42.

22 Wyrok SAM z dnia 21 listopada 2001 r., XVII Ama 2/2001, Dz. Urz. UOKiK 2002 $\mathrm{Nr}$ 1, poz. 47.

23 Tak C. Banasiński, E. Piontek (red.), Ustawa..., s. 19.

24 Wyrok SN z dnia 27 sierpnia 2003 r., I CKN 523/01, LexPolonica nr 362988.

25 Wyrok SOKiK z dnia 4 maja 2006 r., XVII Ama 119/04, LexPolonica nr 1402240. 
jest szerszy krąg uczestników rynku, względnie gdy działania te wywołują w rynku inne niekorzystne zjawiska”.

Zgodnie z koncepcją jakościową, którą z kolei można utożsamiać z funkcjonalnym rozumieniem konkurencji, o naruszeniu interesu publicznego należy mówić wówczas, gdy dana praktyka zagraża konkurencji jako instytucji gospodarki wolnorynkowej. W ujęciu jakościowym interes publiczny polega na zapewnieniu właściwych warunków funkcjonowania rynku ${ }^{26}$, „mechanizmu konkurencji jako optymalnego sposobu podziału dóbr w społecznej gospodarce rynkowej”27, zaś „ochrona konkurencji podejmowana jest w interesie państwa, niezależnie od działań jednostek i niezależnie od ich interesów”28. „Naruszenie interesu publicznoprawnego ma miejsce wówczas, gdy zachowanie przedsiębiorcy będące przedmiotem postępowania antymonopolowego wywołało lub może wywołać na rynku niekorzystne - z punktu widzenia celów ustawodawstwa antymonopolowego - skutki w postaci wpływu na ilość, jakość, cenę towarów lub zakres wyboru dostępny konsumentom lub innym nabywcom, gdyż istnienie interesu publicznoprawnego należy oceniać przez pryzmat szerszego spojrzenia, uwzględniającego całość negatywnych skutków działań monopolisty na określonym rynku"29. Sąd Najwyższy podkreślił, że „wyrazem tej linii orzecznictwa [określonej przeze mnie jako jakościowa koncepcja interesu publicznego - przyp. aut.] jest zastosowanie przepisów do praktyk, których „ofiarami” były pojedyncze podmioty”30, sama zaś „liczba podmiotów dotkniętych skutkami praktyki ograniczającej konkurencję jest nieistotna z punktu widzenia dopuszczalności zastosowania ustawy antymonopolowej" 31 .

W orzecznictwie nie ma także zgodności co do tego, czy kategoria interesu publicznego jest kategorią jednolitą czy złożoną (tj. czy interes publiczny jest de facto wiązką wielu interesów). Na to ostatnie rozwiązanie wskazywałoby posługiwanie się przez SN liczbą mnogą dla określenia celu (celów) ustawy o ochronie konkurencji. Przykładowo, w wyroku z dnia

26 Por. m.in. wyrok SN z dnia 27 sierpnia 2003 r., I CKN 527/10, LEX nr 137525; wyrok SOKiK z dnia 21 marca 2005, XVII Ama 16/2004, Dz. Urz. UOKiK 2005 Nr 2, poz. 27; wyrok Sądu Apelacyjnego w Warszawie z dnia 29 czerwca 2007 r., VI ACa 1222/2006, Dz. Urz. UOKiK 2007 Nr 4, poz. 48.

27 Wyrok SN z dnia 7 stycznia 2009 r., III SK 16/2008, OSNP 2010 Nr 13-14, poz. 177.

28 Wyrok SN z dnia 5 czerwca 2008 r., III SK 40/07, OSNP 2009 Nr 19-20, poz. 272. Por. także wyrok SN z dnia 16 października 2008 r., III SK 2/2008, LexPolonica nr 2551023; wyrok SA z dnia 11 lutego 2011 r., VI ACa 1078/2010, LexPolonica nr 2614075.

29 Wyrok SN z dnia 19 lutego 2009 r., III SK 31/2008, LexPolonica nr 2302381.

30 Wyrok SN z dnia 5 czerwca 2008 r., III SK 40/07, OSNP 2009 Nr 19-20, poz. 272. Por. także wyrok SN z dnia 16 października 2008 r., III SK 2/2008, LexPolonica nr 2551023.

31 Wyrok SN z dnia 16 października 2008 r., III SK 2/2008, LexPolonica nr 2551023. 
16 października 2008 r. (III SK 2/08) SN wskazal, że „ustawa antymonopolowa ma charakter publicznoprawny, zatem jej celem jest służenie interesom publicznym" 32 .

Brak definicji interesu publicznego w art. 1. ust. 1 uokik skutkuje koniecznością każdorazowej identyfikacji tego interesu w aktach stosowania prawa (decyzjach organu antymonopolowego i wyrokach sądów) - „rozważając, czy zachodzą podstawy do wszczęcia postępowania, a następnie - po jego przeprowadzeniu - wydając decyzje, organ antymonopolowy musi wskazać na czym polegał interes publiczny w podjęciu interwencji w odniesieniu do konkretnej praktyki, której postępowanie dotyczyło"33.

\subsection{Interes publiczny a interes prywatny w publicznym trybie egzekwowania zakazów praktyk ograniczających konkurencję}

O ile pojęcie interesu publicznego, przynajmniej w świetle polskiej ustawy o ochronie konkurencji i konsumentów, rodzi pewne trudności interpretacyjne, a „to co jest, a co nie jest w interesie publicznym wynika częściowo z norm prawnych, może być jednak także ustaleniem wykładni orzeczniczej i polityki ochrony konkurencji”"34, o tyle nie ma wątpliwości co do tego, że interes prywatny, jaki może być realizowany w związku z regulacjami antymonopolowymi należy utożsamiać z ochroną indywidualnych praw podmiotowych ${ }^{35}$ (ochroną indywidualnych roszczeńn ${ }^{36}$ ).

Praktyka stosowania ustawy o ochronie konkurencji i konsumentów przynosi jednak liczne problemy w rozgraniczeniu sfery interesu prywatnego i publicznego - wątpliwości te wydają się zresztą narastać w związku z przyjęciem jakościowej koncepcji interesu publicznego, która poza zakresem interpretacji pojęcia interesu publicznego pozostawia kwestię liczebności kręgu podmiotów dotkniętych praktyką. Wątpliwości co do charakteru naruszanego interesu (publiczny czy prywatny), rozstrzygnięte ostatecznie na rzecz interesu prywatnego (jako sprawy dotyczące ochrony interesu indywidualnego), pojawiły się w orzecznictwie np. w związku z umowami

32 Problematykę ,interesu publicznego jako wehikułu określenia podstawowego celu ochrony konkurencji lub celów dodatkowych" analizują D. Miąsik i T. Skoczny, [w:] T. Skoczny, A. Jurkowska, D. Miąsik (red.), Ustawa..., s. 50-55 (Komentarz do art. 1, Nb 61-72. Wyrok SN z dnia 5 czerwca 2008 r., III SK 40/07, OSNP 2009 Nr 19-20, poz. 272.

34 Wyrok SA w Warszawie z dnia 22 września 2010 r., VI ACa 181/2010, LexPolonica nr 2389682.

35 Por. m.in. wyrok SN z dnia 29 maja 2001 r., I CKN 1217/98, OSNC 2002, nr 1, poz. 13.

36 Wyrok SN z dnia 5 czerwca 2008 r., III SK 40/07, OSNP 2009 Nr 19-20, poz. 272. 
najmu, których egzekwowanie miało być stanowić praktykę nadużywania pozycji dominującej37, czy w związku z niewyznaczeniem przez samorząd zawodowy siedziby wykonywania zawodu przez adwokata ${ }^{38}$. Trudności w rozgraniczeniu spraw koncentrujących się wokół interesu prywatnego i tych, których rozwiązanie powinno nastąpić w interesie publicznym nie redukuje możliwe do zaakceptowania uogólnienie, że „przeważająca większość spraw z zakresu wykonania umów (nawet w sytuacji, gdy jedna ze stron dysponuje znacząco wyższą siłą rynkową od siły, jaką ma druga strona), to sprawy cywilne, a organami właściwymi do ich rozstrzygania są sądy powszechne, to już spory na etapie przedumownym, zwłaszcza w sytuacji kwalifikowanej siły rynkowej - pozycji dominującej - jednej ze stron, niekoniecznie mają u podłoża wyłącznie jednostkowe, prywatne interesy" 39 .

Rozgraniczenie interesu prywatnego i publicznego jest niezbędne dla wyznaczenia zakresu stosowania ustawy o ochronie konkurencji i konsumentów. Sąd Najwyższy stwierdził, że „naruszenie interesu publicznego pozwala organowi antymonopolowemu dokonywać swoistej selekcji spraw, w których podejmie interwencję" 40 - przesłanka interesu publicznego wskazana w art. 1 ust. 1 uokik pełni zatem „funkcję selekcyjną"41, tj. ostatecznie przesądza o tym, czy Prezes UOKiK podejmuje interwencję w danej sprawie. W czysto inkwizycyjnym modelu postępowania antymonopolowego (gdy wszczęcie postępowania następuje wyłącznie z urzędu) selekcja taka dokonywana jest na etapie poprzedzającym inicjację postępowania antymonopolowego przez organ, w tym także w toku postępowania wyjaśniającego (w myśl art. 48 ust. 2 pkt 1 uokik celem tego postępowania jest „wstępne ustalenie, czy nastąpiło naruszenie przepisów ustawy uzasadniające wszczęcie postępowania antymonopolowego (...)” - ustalenie to może dotyczyć - w moim przekonaniu - także spełnienia przesłanki interesu publicznego). Inkwizycyjny model postępowania antymonopolowego, choć nie wyklucza całkowicie dylematów związanych $\mathrm{z}$ identyfikacją interesu publicznego przeciwstawionego interesowi prywatnemu, to przynajmniej znacznie ogranicza ich zakres, o czym świadczy marginalna liczba postępowań antymonopolowych w sprawach praktyk ograniczających konkurencję kończących się umorzeniem $\mathrm{z}$ powodu niespełnienia przesłanki interesu publicznego. Zgoła inaczej sytuacja kształtowała się w tym stanie prawnym, który dawał

37 Wyrok SAM z dnia 21 listopada 2001 r., XVII Ama 2/2001, Dz. Urz. UOKiK 2002 $\mathrm{Nr}$ 1, poz. 47.

38 Wyrok SN z dnia 29 maja 2001 r., I CKN 1217/98, OSNC 2002, nr 1, poz. 13.

39 E. Stawicki, [w:] A. Stawicki, E. Stawicki (red.), Ustawa..., s. 36.

40 Wyrok SN z dnia 5 czerwca 2008 r., III SK 40/07, OSNP 2009, nr 19-20, poz. 272.

41 K. Kohutek, Naruszenie interesu publicznego..., s. 51. 
możliwość wszczynania postępowań na wniosek uprawnionych podmiotów, tj. pod rządami ustawy o przeciwdziałaniu praktykom monopolistycznym oraz ustawy o ochronie konkurencji i konsumentów z 2000 r. Ocena wniosków o wszczęcie postępowania antymonopolowego pod kątem zasadności takiego wszczęcia w znacznej mierze stanowiła ocenę tego, czy w określonym przypadku dochodzi do naruszenia interesu publicznego, czy chodzi wyłącznie o naruszenie interesu prywatnego. Podmiotami uprawnionymi do składania wniosków byli: przedsiębiorcy i ich związki (wykazujący interes prawny we wszczęciu postępowania), organ samorządu terytorialnego, organ kontroli państwowej, rzecznik konsumentów i organizacja konsumencka ${ }^{42}$. Uzasadnione wydaje się przyjęcie, że zdecydowana większość wniosków pochodzących od przedsiębiorców i konsumentów składana była w sytuacji, gdy same te podmioty czuły się dotknięte potencjalnymi antykonkurencyjnymi praktykami. Inaczej mogło być natomiast w przypadku wnioskodawców instytucjonalnych, których zadaniem była bardziej kompleksowa ocena wpływu praktyk na konkurencję, choć i tu nie można wykluczyć, że wniosek o wszczęcie postępowania złożony został przez np. rzecznika konsumentów w następstwie indywidualnej skargi jednostki. Możliwość wnioskowego wszczynania postępowań antymonopolowych nie jest co prawda sama w sobie ukierunkowana na realizację interesu prywatnego w trybie publicznego egzekwowania zakazów praktyk ograniczających konkurencję, nie należy jej zatem traktować jako alternatywy dla prywatnego egzekwowania zakazów antykonkurencyjnych praktyk ${ }^{43}$, niemniej jednak interesu publicznego i prywatnego nie można bynajmniej postrzegać jako całkowicie przeciwstawnych ${ }^{44}$. Specyfika prawa ochrony konkurencji powoduje, że interwencja publicznego organu ochrony konkurencji (podejmowana w interesie publicznym) w każdym przypadku będzie korzystnie skutkować dla podmiotów prywatnych dotkniętych antykonkurencyjnymi praktykami - efekt taki osiągnięty będzie poprzez nakaz zaniechania zakazanych praktyk, stanowiący konieczny element decyzji uznającej dane działanie (zachowanie) przedsiębiorców za ograniczające konkurencję ${ }^{45}$. Oddziaływanie prywatnego trybu egzekwowania zakazów praktyk ograniczających konkurencję na interes

42 Por. art. 84 ust. 1 uokik 2000.

43 W. P. J. Wils postrzega jednak możliwość wnioskowego wszczynania postępowań antymonopolowych (przed Komisją) jako argument osłabiający potrzebę prywatnego egzekwowania wspólnych reguł konkurencji Unii Europejskiej - por. W. P. J. Wils, Should Private Antitrust Enforcement Be Encouraged in Europe?, World Competition 2003, vol. 26(3), s. 476.

44 Inaczej: W. P. J. Wils, Should Private Antitrust Enforcement..., s. 482-483, 488.

45 Por. rozdział VII, pkt 7.2.1. 
publiczny nie jest już co prawda tak ewidentne, niemniej jednak podjęcie drogi sądowej przez podmiot prywatny może przyczynić się do realizacji interesu ogólnego - wyroki sądów powszechnych mogą także prowadzić do zaniechania antykonkurencyjnych praktyk, nie tylko w wymiarze indywidualnym. W piśmiennictwie wyraża się - bliski mi pogląd - że „nie da się rozpatrywać interesu publicznego w oderwaniu od interesu indywidualnego"46, przy czym nie każde naruszenie interesu indywidualnego stanowi od razu naruszenie interesu publicznego - ta zależność wydaje się natomiast działać w drugą stronę, tzn. naruszenie interesu publicznego zawsze wiąże się $\mathrm{z}$ naruszeniem interesu jakiegoś konkretnego podmiotu, co otwiera przestrzeń dla prywatnego egzekwowania zakazów praktyk ograniczających konkurencję. Nawet jeśli interes publiczny ujmowany jest z perspektywy jakościowej, to mechanizm konkurencji jako instytucji wolnego rynku nie jest przecież mechanizmem abstrakcyjnym, ale takim, który angażuje podmioty sfery realnej - zagrożenie dla mechanizmu konkurowania stwarza zatem zagrożenie dla konkretnych podmiotów (konkurentów, kontrahentów, konsumentów).

Powyższe rozważania wskazują, że niezasadnym jest utożsamianie publicznego trybu egzekwowania zakazów antykonkurencyjnych wyłącznie z interesem publicznym, a prywatnego trybu egzekwowania prawa konkurencji - wyłącznie z interesem prywatnym. W tym kontekście zasadne wydaje się rozważenie kwestii, czy sprawdził się w praktyce, towarzyszący uchwaleniu ustawy o ochronie konkurencji i konsumentów z 2007 r., zamysł ustawodawcy, że eliminacja wnioskowego trybu wszczynania postępowań przyczyni się do rozwoju dochodzenia roszczeń z tytułu naruszenia reguł konkurencji na drodze prywatnoprawnej. Dorobek orzeczniczy ostatnich lat (od wejścia w życie uokik z 2007 r.) nie potwierdza jednak w zasadzie żadnego zwiększenia zainteresowania prywatnym egzekwowaniem zakazów z art. 6 i 9 uokik. Osobiście należałam do grona zwolenników rezygnacji z wnioskowego wszczynania postępowań antymonopolowych ${ }^{47}$, jednak kilka lat stosowania tego rozwiązania skłania mnie do refleksji, że zmiana modelu wszczynania postępowań antymonopolowych przyczyniła się co najwyżej do wzmocnienia publicznego trybu egzekwowania zakazów z art. 6 i 9 uokik,

46 Tak M. Sieradzka, Pozew grupowy jako instrument prywatnoprawnej ochrony interesów konsumentów z tytułu naruszenia regut konkurencji, LEX a Wolters Kluwer business, Warszawa 2012, s. 79.

47 A. Jurkowska, D. Miąsik, T. Skoczny, M. Szydło, Nowa uokik z 2007 r - kolejny krok w kierunku doskonalenia podstaw publicznoprawnej ochrony konkurencji w Polsce, PUG 2007, nr 4, s. 4-7. 
w żaden sposób nie przyczyniła się do popularyzacji sądowego dochodzenia roszczeń z tytułu naruszenia zakazów antykonkurencyjnych praktyk.

$\mathrm{W}$ uzasadnieniu projektu ustawy jako jeden z zasadniczych powodów zmiany charakteru postępowania z mieszanego (inkwizycyjno-wnioskowego), jaki obowiązywał na gruncie ustawy z 2000 r., na czysto inkwizycyjny wskazano okoliczność, że ochrona interesu prywatnego może i powinna być realizowana $w$ ramach prywatnego trybu egzekwowania zakazów praktyk ograniczających konkurencję. Nie sposób odmówić takiemu rozwiązaniu logiki ${ }^{48}$, zmiana ta spotkała się zresztą z akceptacją przedstawicieli doktryny. Jednak mimo tego, że teza o konieczności podziału ochrony interesu publicznego i prywatnego między odrębne tryby egzekwowania zakazów praktyk ograniczających konkurencję zasługuje na poparcie, to jej praktyczna realizacja wymaga sprawnie działającego i spopularyzowanego systemu dochodzenia roszczeń na drodze sądowej - w innym wypadku przyjęcie inkwizycyjnego trybu wszczynania postępowań w znacznej mierze pozbawi potencjalnych poszkodowanych możliwości ochrony przed antykonkurencyjnymi praktykami, nawet jeśli ustawodawca przewidział możliwość składania organowi ochrony konkurencji niewiążących zawiadomień o podejrzeniu stosowania praktyk ograniczających konkurencję, jak w art. 86 uokik. Decyzja Prezesa UOKiK co do wszczęcia postępowania w oparciu o takie zawiadomienie jest bowiem w pełni dyskrecjonalna i nie podlega weryfikacji w żadnym trybie, co więcej w świetle obecnego brzmienia art. 86 uokik nie jest jasne, jakie obowiązki informacyjne spoczywają na organie w związku $\mathrm{z}$ otrzymanym zawiadomieniem. W świetle dotychczasowego orzecznictwa sądów administracyjnych brak reakcji organu na zawiadomienie, niewszczęcie właściwego postępowania antymonopolowego (po uprzednio przeprowadzonym postępowaniu wyjaśniającym), czy też brak informacji co do postępowania $\mathrm{z}$ zawiadomieniem nie stanowią bezczynności organu w rozumieniu art. 3 $\S 2$ pkt 8 ustawy Prawo o postępowaniu przed sądami administracyjnymi ${ }^{49}$,

48 Trudno wyobrazić sobie wdrożenie w Polsce proponowanego w literaturze rozwiązania przewidującego zobowiązanie podmiotów prywatnych wnioskujących o wszczęcie postępowania antymonopolowego do częściowego pokrywania kosztów postępowania, co miałoby stanowić rekompensatę za wydanie decyzji stwierdzającej naruszenie prawa ochrony konkurencji, a tym samym - ułatwienie dochodzenia roszczeń na drodze sądowej - R. P. McAfee, H. M. Mialon, S. H. Mialon, Private v. Public Antitrust Enforcement: A Strategic Analysis, Journal of Public Economics 2008, vol. 92(10-11), dostępny także pod adresem: http://papers.ssrn.com/sol3/papers.cfm?abstract_id=775245\#\#, s. 3 .

49 Ustawa z dnia 30 sierpnia 2002 r. - Prawo o postępowaniu przed sądami administracyjnymi (Dz. U. Nr 153, poz. 1270 ze zm.). 
na który przysługiwałaby skarga do sądu administracyjnego ${ }^{50}$. Na marginesie należy dodać, że w prawie unijnym wszczynanie postępowań antymonopolowych może nastąpić zarówno w trybie inkwizycyjnym, jak i wnioskowym (art. 7 ust. 2 rozporządzenia 1/2003).

W zrównoważonym modelu wspólistnienia publicznego i prywatnego trybu egzekwowania zakazów praktyk ograniczających konkurencję uzasadnione jest przyjęcie w zakresie trybu publicznego wyłącznie inkwizycyjnego modelu wszczynania postępowań antymonopolowych. W moim przekonaniu, taki krok jest jednak pożądany tylko wówczas, gdy zarówno regulacja, jak i warunki organizacyjne wymiaru sprawiedliwości, zachęcają do składania pozwów w sprawach $\mathrm{z}$ tytułu naruszenia reguł konkurencji w sądach powszechnych. Doświadczenia polskie wydają się świadczyć o tym, że dotąd nie istnieją żadne ramy regulacyjne dla prywatnego egzekwowania prawa ochrony konkurencji, eliminacja wnioskowego modelu inicjowania postępowań antymonopolowych jest nieco przedwczesna i nie odnosi skutku zamierzonego przez ustawodawcę51. W sytuacji, gdy z wnioskowego trybu inicjowania postępowań antymonopolowego polski ustawodawca zrezygnował kilka lat temu, mało prawdopodobny wydaje się powrót do stanu sprzed 1 kwietnia 2007 r. Zamiar ustawodawcy co do rozwoju prywatnego trybu egzekwowania zakazów antykonkurencyjnych praktyk ziściłby się prawdopodobnie w większym stopniu, gdyby wprowadzone zostały przepisy normujące dochodzenie roszczeń przed sądami powszechnymi. W braku takich przepisów, a w efekcie w braku spraw sądowych z zakresu ochrony konkurencji, należy jednak - w moim przekonaniu - nieco wzmocnić obecność „interesu prywatnego" w publicznym trybie egzekwowania zakazów antykonkurencyjnych praktyk ${ }^{52}$.

50 Por. m.in. postanowienie WSA w Warszawie z dnia 9 marca 2011 r., VII SA/Wa 47/11; postanowienie WSA w Warszawie z dnia 3 czerwca 2011 r., VII SA/Wa 9/11. Problematykę kontroli sądowej bezczynności Prezesa UOKiK szerzej analizuje M. Błachucki, Wtaściwość sądów administracyjnych $i$ sq̨dów powszechnych $w$ sprawach antymonopolowych, [w:] M. Błachucki, T. Górzyńska (red.), Aktualne problemy rozgraniczenia wtaściwości sądów administracyjnych i powszechnych, Naczelny Sąd Administracyjny, Warszawa 2011, s. $146-150$.

51 Pogląd ten jest podzielany przez wielu autorów - por. m.in. R. Stankiewicz, O konieczności zwiększenia partycypacji podmiotów trzecich w postępowaniu antymonopolowym, $\mathrm{iKAR}$ 2012, nr 2, s. 50; M. Bernatt, Sprawiedliwość proceduralna w postępowaniu przed organem ochrony konkurencji, Wyd. Naukowe WZ UW, Warszawa 2011, s. 158.

52 Por. rozdział VIII, pkt 8.3. 


\subsection{Interes prywatny w egzekwowaniu zakazów antykonkurencyjnych praktyk}

\subsubsection{Zarzut naruszenia prawa ochrony konkurencji jako "tarcza" i "miecz"}

Jeśli nawet kategoria interesu publicznego w prawie ochrony konkurencji nie jest jednolita i spójna, tym bardziej cech takich nie wykazuje kategoria interesu prywatnego. D. Gerber słusznie podkreśla, że prywatne egzekwowanie reguł konkurencji „zmienia «głos» prawa konkurencji”, pozwalając na to, by „zamiast jednego organu publicznego i ewentualnie jednego lub dwóch sądów wykorzystujących określone koncepcje, formułujących i interpretujących cele i normy, prywatne egzekwowanie oznacza raczej, że wiele głosów będzie wykorzystywać koncepcje i uczestniczyć w procesie definiowania celów systemu"53.

Realizacja interesu prywatnego w ramach sądowego dochodzenia roszczeń z tytułu naruszenia zakazów praktyk ograniczających konkurencję może następować na dwa sposoby, wyróżniane ze względu na cel, w jakim wykorzystywany jest zarzut naruszenia art. 6 lub 9 uokik bądź art. 101 lub 102 TFUE. Pierwszy cel, identyfikowany w literaturze jako korzystanie z zarzutu antykonkurencyjnych praktyk jako „miecza”54, wiąże się z proaktywną postawą podmiotów poszkodowanych, zorientowaną bezpośrednio na realizację sformułowanych przez te podmioty roszczeń. Najbardziej ewidentnym przypadkiem korzystania z zarzutu naruszenia zakazów antykonkurencyjnych praktyk jako „miecza” jest dochodzenie przed sądem powszechnym odszkodowania za szkody poniesione $\mathrm{w}$ związku z praktykami, ale rolę „miecza” mogą mieć również inne roszczenia. Przykładem wykorzystania zarzutu nadużycia pozycji dominującej jako „miecza” w polskim orzecznictwie jest sprawa Toruńskie Przedsiębiorstwo Przemystu Drzewnego (TPPD) p. Skarbowi Państwa - Nadleśnictwo Dobrzejewice, w której TPPD zażądało unieważnienia umowy cesji wierzytelności zawartej z nadleśnictwem, podnosząc, że zawarcie tej umowy, stanowiące warunek sprzedaży drewna przez nadleśnictwo, było przejawem nadużywania przez ten ostatni podmiot pozycji dominującej55.

53 D. Gerber, Private enforcement of competition law: a comparative perspective, [w:] T. M. J. Möllers, A. Heinemann (red.), The Enforcement of Competition Law in Europe, Cambridge University Press 2009, s. 450.

54 Por. m.in. R. Van Den Bergh, S. Keske, Private Enforcement of European Competition Law: Quo Vadis?, European Review of Contract Law 2007, nr 4, s. 468.

55 Por. uchwała SN z dnia 23 lipca 2008 r., III CZP 52/08, OSNC 2009, nr 7-8, poz. 107. 
Realizacja zarzutu naruszenia zakazów praktyk antykonkurencyjnych poprzez taktykę „miecza” stanowi najpełniejszą emanację prywatnego modelu egzekwowania prawa konkurencji. Znaczna liczba spraw sądowych, w których zarzut naruszenia zakazów antykonkurencyjnych praktyk kierowany jest przeciw pozwanemu, może być traktowany jako jeden ze wskaźników dojrzałości modelu prywatnego egzekwowania prawa konkurencji.

Drugi sposób wykorzystywania zarzutów naruszenia prawa konkurencji określany jest jako taktyka „tarczy”. Polega ona na wysuwaniu zarzutu naruszenia zakazów praktyk ograniczających konkurencję, a ściślej zarzut nieważności czynności prawnej ${ }^{56}$ stanowiącej naruszenie art. 6 lub 9 uokik bądź art. 101 lub 102 TFUE, dla obrony przed roszczeniami drugiej strony. Korzystanie przez pozwanego z zarzutu naruszenia prawa konkurencji jako kontrzarzutu stanowi nieco mniej wysublimowaną formę prywatnego egzekwowania zakazów praktyk antykonkurencyjnych - taki praktyczny wymiar zarzutu naruszenia zakazów jest charakterystyczny dla tych porządków prawnych, w których sądowe dochodzenie roszczeń z tytułu naruszenia prawa konkurencji nie jest szczególnie rozwinięte lub wręcz określane jest jako „niedorozwinięte” (underdeveloped). W. P. J. Wils podkreśla, i opinię tę można odnieść również do prawa krajowego, że w gruncie rzeczy sankcja nieważności przewidziana w art. 101 ust. 2 TFUE (analogicznie art. 6 ust. 2 uokik) uprawnia do korzystania $\mathrm{z}$ art. 101 TFUE (analogicznie art. 6 uokik) tylko w formie „tarczy”57.

Przykładem wykorzystania zarzutu naruszenia art. 6 uokik jako „tarczy” w polskim orzecznictwie jest następująca sprawa: dwóch przedsiębiorców, rozwiązując spółkę, zawarło umowę, „w której zastrzeżono, iż powód lub podmiot, na który sceduje on swoje prawa wynikające $\mathrm{z}$ umowy, ma prawo do wyłącznej współpracy i zawierania umów handlowych z wyliczonymi w umowie dwunastoma ocynkowniami ogniowymi. Pozwana spółka zobowiązała się do niedokonywania obrotu $\mathrm{z}$ tymi podmiotami, a $\mathrm{w}$ razie naruszenia tego zakazu zobowiązała się do zapłaty kary umownej w wysokości 100000 euro. (...) Pozwana spółka złamała postanowienia umowy dotyczące zakazu dokonywania obrotu z określonymi ocynkowniami stanowiącymi producen-

56 Por. M. Będkowski-Kozioł, Prywatne wdrażanie prawa antymonopolowego $w$ RFN - uwagi na tle regulacji siódmej noweli kartelowej, PUG 2007, nr 12, s. 10. Autor ten wskazuje na to, że egzekwowanie norm prawa antymonopolowego może odbywać się „w sposób niejako 'pasywny' w odniesieniu np. do skutku nieważności umowy, jak i w sposób 'aktywny' (...)".

57 W. P. J. Wils, Should Private Antitrust Enforcement..., s. 475. 
tów materiałów cynkonośnych" 58 , co zaskutkowało żądaniem zapłaty kary umownej. Okoliczność, że postanowienia umowy o wyłączności dostaw naruszały zakaz porozumień ograniczających konkurencję, stanowiła powód, dla którego przedsiębiorca odmówił zapłaty kary umownej.

\subsubsection{Locus standi w sądowym dochodzeniu roszczeń z tytułu naruszenia zakazów praktyk ograniczających konkurencję}

\subsubsection{Uwagi wstępne}

Problematyka locus standi stanowi pochodną zagadnienia wyznaczania związku przyczynowego między antykonkurencyjnym działaniem a tzw. szkodą antymonopolową ${ }^{59}$, przy czym konieczna jest świadomość, że krąg podmiotów objętych ochroną materialnymi regułami konkurencji nie musi być tożsamy $\mathrm{z}$ grupą podmiotów upoważnionych do występowania z roszczeniami z tytułu naruszenia tych reguł60.

Określenie kręgu podmiotów legitymowanych do występowania z roszczeniami z tytułu naruszenia zakazów antykonkurencyjnych praktyk wymaga w pierwszej kolejności decyzji co do tego, czy legitymowanym może być wyłącznie podmiot poszkodowany bezpośrednio, czy także podmiot poszkodowany pośrednio (istotnych trudności nastręcza zresztą samo zdefiniowanie szkody pośredniej) ${ }^{61}$. Za bezpośrednio poszkodowanych należy uznać konkurentów, kontrahentów i - ewentualnie - konsumentów przedsiębiorcy naruszającego reguły konkurencji (o ile nabywają towary lub usługi bezpo-

58 Wyrok SA w Warszawie z dnia 25 listopada 2009 r., VI Aca 422/09, niepubl. Sąd Apelacyjny uchylił wyrok sądu niższej instancji z tego powodu, że nie uwzględnił on zarzutu bezwzględnej nieważności umowy ustanawiającej wyłączność współpracy (zdaniem powoda umowa ta była porozumieniem podziałowym w rozumieniu art. 5 uokik 2000).

59 Por. rozdział VII, pkt 7.7.3.3.

60 D. Berger, R. Bernstein, An Analytical Framework for Antitrust Standing, Yale Law Review 1977, vol. 86, s. 835-836.

61 W polskim piśmiennictwie kategoryzacji podmiotów posiadających legitymację czynną w ramach prywatnoprawnego stosowania reguł konkurencji dokonała M. Sieradzka, wskazując na dwie główne grupy podmiotów - kontrahentów podmiotu naruszającego reguły konkurencji oraz osoby trzecie (M. Sieradzka, Pozew grupowy..., s. 286). Następnie autorka ta dokonuje dalszej, w moim przekonaniu niezbyt przejrzystej klasyfikacji, pisząc: „uszczegóławiając powyżej wyróżnione dwie kategorie podmiotów poszkodowanych w wyniku stosowanych praktyk ograniczających konkurencję, należy wyróżnić: osoby bezpośrednio związane $\mathrm{z}$ uczestnikami porozumienia ograniczającego konkurencję lub podmiotem, który nadużywa pozycji dominującej na rynku, podmioty bezpośrednio dotknięte skutkami praktyk ograniczających konkurencję oraz osoby trzecie (w tym podmioty bezpośrednio lub pośrednio poszkodowane)" - por. M. Sieradzka, Pozew grupowy..., s. 288. 
średnio od podmiotu naruszającego zakaz antykonkurencyjnych praktyk). Do grupy pośrednio poszkodowanych należą podmioty powiązane gospodarczo z konkurentami i kontrahentami przedsiębiorcy naruszającego zakazy praktyk ograniczających konkurencję - są to zatem: partnerzy gospodarczy (handlowi) kontrahentów naruszyciela, konsumenci (ostateczni użytkownicy) nabywający towary lub usługi od kontrahentów naruszyciela i ich partnerów, a także np. franchisobiorcy, licencjobiorcy, dostawcy przedsiębiorcy będącego bezpośrednio poszkodowanym wskutek praktyk ograniczających konkurencję. Listy tej nie należy traktować jako zamkniętej, w rzeczywistości gospodarczej kreowane są bowiem bardzo skomplikowane relacje interpodmiotowe. Orzecznictwo amerykańskie odnotowało sprawy, w których z roszczeniem wystąpili nawet wynajmujący, których dochody z tytułu najmu obniżyły się ze względu na to, że najemcy zostali dotknięci skutkami praktyk antykonkurencyjnych ${ }^{62}$.

Specyficzną kategorią poszkodowanych wskutek antykonkurencyjnych praktyk są podmioty nie pozostające $\mathrm{w}$ żadnych relacjach $\mathrm{z}$ przedsiębiorcami naruszającymi zakazy antykonkurencyjnych praktyk. Pierwszą kategorię takich podmiotów stanowią nabywcy produktów i usług pochodzących od konkurentów tych przedsiębiorców, którzy zaangażowani są w antykonkurencyjne praktyki (podmioty takie, przede wszystkim konsumenci, określane są jako „ofiary parasolowe” [umbrella victims] ${ }^{63}$. Drugą kategorię podmiotów nie pozostających w żadnych relacjach gospodarczych z naruszycielami reguł konkurencji stanowią ci, którzy odstąpili od zakupu towarów lub usług objętych antykonkurencyjnymi praktykami (np. dlatego że oferowano im zbyt wygórowane ceny zakupu lub niekorzystne inne warunki umowne) bądź uniemożliwiono im zakup takich towarów lub usług (np. wskutek kolektywnych lub jednostronnych praktyk dyskryminacyjnych lub kontyngentowych). Podmioty te, które można określić, podążając za terminologią angielską, „nie-nabywcami” (nonbuyers), ponoszą pewną szkodę z tytułu antykonkurencyjnych praktyk, jednak nawet orzecznictwo amerykańskie nie odnotowało - według mojej najlepszej wiedzy - spraw, w których nie-nabywcy ubiegaliby się o odszkodowania ze względu na naruszenia ${ }^{64}$.

62 Por. m.in. Melrose Realty Co. v. Loew's Inc., 234 F 2d 518 (3d Cir.), 352 US 890 (1956); Harrison v. Paramount Pictures, 115 F Supp. 312 (ED Pa. 1953), 211 F 2d 405 (3d Cir.), 348 US 828 (1954). W każdym z tych przypadków sąd odmówił wynajmującym prawa do wystąpienia z roszczeniami jako pośrednio poszkodowanym.

63 J. M. Lave, Umbrella standing: the tradeoff between plaintiff suit and speculative claims, Antitrust Bulletin 2003, vol. 48(1), s. 223-269.

64 Takie stanowisko zają $\mathrm{W}$. H. Page, Policy choices in defining the measure of antitrust damages, OECD Journal: Competition Law and Policy 2009, vol. 2, s. 51. 
Ustawodawca może sam zdecydować o tym, jakie podmioty mogą występować $\mathrm{z}$ roszczeniami z tytułu naruszenia zakazów antykonkurencyjnych praktyk, jednak w praktyce dzieje się tak niezwykle rzadko, a określenie kręgu uprawnionych podmiotów jest z reguły bardzo ogólnikowe. Znakomitym przykładem takiego generalnego określenia kategorii uprawnionych jest sekcja 4 Clayton Act stanowiąca, że legitymację czynną posiada „każda osoba poszkodowana w zakresie swojej działalności gospodarczej lub własności poprzez jakiekolwiek działania zakazane przez prawo antymonopolowe (...) [any person injured in his business or property by reason of anything forbidden in the antitrust laws (...)]". Wskazanie tego przepisu jest na tyle niejednoznaczne, że w praktyce jego stosowania wypracowano znaczną liczbę doktryn i testów (skrótowo omówionych poniżej), zmierzających do określenia grupy podmiotów uprawnionych do dochodzenia roszczeń z tytułu naruszenia reguł konkurencji.

Prawo unijne nie obejmuje co prawda przepisów określających legitymację czynną w sprawach z zakresu ochrony konkurencji, TrybunałSprawiedliwości wypracował jednak w tym zakresie regułę orzeczniczą, która poniekąd pełni rolę normy prawnej: w wyroku w sprawie Courage Trybunał podkreślał, że „każdy podmiot” (any individual) może dochodzić roszczeń $\mathrm{z}$ tytułu naruszenia art. 101 ust. 1 TFUE ${ }^{65}$. Zdaniem Trybunału ograniczenie możliwości dochodzenia roszczeń przez każdy podmiot, któremu została wyrządzona szkoda przez umowę lub działanie ograniczające lub zniekształcające konkurencję, powodowałoby ryzyko dla pełnej skuteczności art. 101 TFUE, a zwłaszcza dla praktycznego skutku zakazu ustanowionego w art. 101 ust. 1 TFUE ${ }^{66}$. Przytoczone tezy zostały generalnie zaakceptowane również przez doktrynę (choć z tym zastrzeżeniem, że celem Trybunału w wyroku w sprawie Courage nie było wypracowanie jakichkolwiek zasad wpływających na zakres legitymacji czynnej w sprawach ochrony konkurencji w państwach członkowskich, ale utrwalenie ogólnych reguł bezpośredniej skuteczności zakazów z art. 101 i 102 TFUE67; legitymacja czynna została oderwana od celów prawa ochrony konkurencji ${ }^{68}$ ). Głosy krytyczne co do tak

65 Pkt 24 wyroku w sprawie Courage.

66 Pkt 26 wyroku w sprawie Courage. Por. także pkt 25 opinii Rzecznika Generalnego Mischo w sprawie Courage.

67 F. Cengiz, Passing-On Defense and Indirect Purchaser Standing in Actions for Damages against the Violations of Competition Law: What Can EC Learn from US?, ESRC Centre for Competition Policy and School of Law, University of East Anglia, CCP Working Paper 2007, No. 21, s. 29.

68 A. P. Komninos, EC Private Antitrust Enforcement. Decentralised Application of EC Competition Law by National Courts, Hart Publishing, Oxford and Portland, Oregon 2008, s. 193. 
szerokiego ukształtowania zakresu uprawnionych były stosunkowo nieliczne, choć niektórzy autorzy podkreślali konieczność bardziej szczegółowego określenia kręgu uprawnionych ${ }^{69}$. N. Reich wskazał nawet, że - paradoksalnie - taki nieograniczony krąg uprawnionych do dochodzenia roszczeń może działać na niekorzyść potencjalnych powodów ${ }^{70}$. Z kolei A. Komninos w świetle tak szeroko określonego zakresu podmiotów uprawnionych do dochodzenia roszczeń - kwestionuje zasadność wyodrębniania poszczególnych kategorii podmiotów posiadających legitymację czynną w sprawach z zakresu praktyk ograniczających konkurencję (np. nabywcy pośredni, konsumenci, konkurenci) ${ }^{71}$.

Stanowisko wyrażone w wyroku w sprawie Courage zostało powtórzone przez TS zarówno w wyroku w sprawie Manfredi $^{72}$, jak i w wyroku w sprawie Pfleiderer ${ }^{73}$, przy czym w pierwszym $\mathrm{z}$ wymienionych orzeczeń TS podkreślit, że „każda osoba jest uprawniona żądać naprawienia poniesionej szkody, jeśli między tą szkodą a porozumieniem lub praktyką zakazanymi przez art. 81 WE istnieje związek przyczynowy" - deklaracja ta mogłaby być postrzegana jako wykluczenie możliwości ograniczania uprawnień nabywców pośrednich do występowania $\mathrm{z}$ roszczeniami, jednak ostateczna decyzja co do istnienia wystarczającego związku przyczynowego oparta jest na prawie krajowym, więc ocena ta nie może być jednoznaczna ${ }^{74}$.

W polskim piśmiennictwie nie podjęto dotąd rzeczowej dyskusji nad zakresem locus standi $\mathrm{w}$ sprawach $\mathrm{z}$ zakresu ochrony konkurencji, kwestia ta była natomiast podnoszona w piśmiennictwie obcym. Najbogatsze doświadczenia w tym obszarze posiada oczywiście orzecznictwo i doktryna amerykańska - nawet jeśli ich wpływ na praktykę europejską (unijną i krajową) wydaje się być ograniczony, mają one istotną wartość prawnoporównawczą. Jedna z takich koncepcji, określana jako „test obszaru docelowego” (target area test), sformułowana w wyroku w sprawie Conference of Studio Unions v. Loew's, Inc. ${ }^{75}$, zakłada, że legitymację czynną w sprawach z zakresu ochrony konkurencji mają jedynie podmioty funkcjonujące „w sfe-

69 Por. T. Eilmansberger, The relationship between rights and remedies in EC law: In search of the missing link, CMLR 2004, vol. 41(5), s. 1226-1227; N. Reich, The "Courage" Doctrine: Encouraging or Discouraging Antitrsut Injuries?, CMLR 2005, vol. 42(1), s. 49; A. Albors-Llorens, Courage v. Crehan: Judicial Activism or Consistent Approach?, The Cambridge Law Journal 2002, vol. 61(1), s. 38-41.

70 N. Reich, The "Courage" Doctrine..., s. 40.

71 A.P. Komninos, EC Private Antitrust Enforcement..., s. 193.

72 Pkt 59-61 wyroku w sprawie Manfredi.

73 Pkt 28 wyroku w sprawie Pfleiderer.

74 F. Cengiz, Passing-On Defense..., s. 30.

75 Conference of Studio Unions v. Loew's, Inc. 193 F 2d 51, 54 (9 $9^{\text {th }}$ Cir. 1951), 342 US 919 (1952). 
rze zagrożonej zakłóceniem warunków konkurowania w określonej branży (area of the economy endangered by a break down of competitive conditions in a particular industry)". Test ten wyklucza możliwość dochodzenia roszczeń przez podmioty, które tylko incydentalnie (przypadkowo) zostały dotknięte skutkami antykonkurencyjnych praktyk, tj. podmiotów pozostających poza „obszarem docelowym”. Przykładowo, obszar taki zdefiniowany został jako część rynku obejmująca wytwórców i dystrybutorów produktów wykluczonych z rynku przez niedozwolone porozumienie o wyłącznej dystrybucji ${ }^{76}$. W literaturze przedmiotu wskazuje się na niejednolite stosowanie testu obszaru docelowego przejawiające się w tym, że niektóre sądy przyznawały prawo dochodzenia roszczeń tylko tym podmiotom, które intencjonalnie objęte były antykonkurencyjnymi skutkami praktyk, inne zaś prawo to przyznawały także tym podmiotom, co do których przewidywalne było antykonkurencyjne oddziaływanie ${ }^{77}$. Pewne podobieństwo do przedstawionego testu wykazuje stosowana przez sądy niemieckie (do czasu wprowadzenia tzw. siódmej noweli do ustawy o ograniczeniach konkurencji) i austriackie teoria normy ochronnej (Schutznormtheorie) ${ }^{78}$, przewidująca, że status powoda w postępowaniu przysługuje tylko tym podmiotom indywidualnym lub przynależącym do określonej grupy, przeciw którym kierowane było naruszenie (podkreślenia wymaga okoliczność, że zastosowanie tej koncepcji wyklucza w wielu przypadkach możliwość dochodzenia roszczeń przez konsumentów, którzy nie są bezpośrednim „celem” działań antykonkurencyjnych) ${ }^{79}$.

Inna koncepcja zaproponowana w amerykańskim orzecznictwie w latach siedemdziesiątych (wyrok w sprawie Malamud ${ }^{80}$ ), a określana jako „test strefy interesów" (zone of interests test), zakładała, że ochronie podlega ten interes indywidualny, który znajduje się w strefie interesów chronionych przez ustawodawstwo antymonopolowe. Na marginesie zaznaczę, że istota tego testu przypomina - w moim przekonaniu - koncepcję jakościową

76 Karseal v. Richifield Oil Corp. 221 F 2d 358 (9th Cir. 1955).

77 C. A. Jones, Private enforcement of antitrust law in the EU, UK and USA, Oxford 2005, s. 164.

78 Nieco szerzej na temat wykorzystania tej teorii pisze M. Szpunar, Odpowiedzialność podmiotu prywatnego z tytutu naruszenia prawa wspólnotowego, Oficyna a Wolters Kluwer business, Warszawa 2008, s. 268-276; M. Będkowski-Kozioł, Prywatne wdrażanie..., s. 13-14.

79 Popularny jest pogląd o negatywnym (hamującym) wpływie tej teorii na rozwój prywatnego egzekwowania reguł konkurencji w Niemczech - por. m.in. H. L. Buxbaum, German Legal Culture and the Globalization of Competition Law: A Historical Perspective on the Expansion of Private Antitrust Enforcement, Berkeley Journal of International Law 2005, vol. 23(2), s. 484.

80 Malamud v. Sinclair Oil Corp., 521 F 2d 1142 (6 $6^{\text {th }}$ Cir. 1975). 
interesu publicznego w ramach stosowania polskiej ustawy o ochronie konkurencji i konsumentów.

Test strefy interesów stosunkowo szybko został wyparty przez „test kontekstu faktycznego" (factual matrix test) sformułowany w wyroku w sprawie Cromar ${ }^{81}$, gdzie sąd zalecił, aby oceniając potencjalną przynależność do kręgu podmiotów uprawnionych do występowania z roszczeniami z tytułu naruszenia prawa konkurencji, uwzględniać takie czynniki jak m.in. charakter rynku, na którym dochodzi do naruszenia reguł konkurencji, relacje między powodem a domniemanym naruszycielem, potencjalny wpływ naruszenia konkurencji na powoda. Analiza tych czynników, także w kontekście społecznych skutków naruszenia prawa antymonopolowego, ma prowadzić do wniosku, czy powód jest tym podmiotem, którego ochrona stanowi podstawowy cel regulacji antymonopolowych.

Do ostatniego z wymienionych testów nawiązał także Sąd Najwyższy, wypracowując we wczesnych latach osiemdziesiątych, w wyrokach w sprawach $M c C r e a d y 82$ i $A G C^{83}$ koncepcję „testu wieloczynnikowego" (multi-factor test), ocenianego w doktrynie jako najbardziej spójna koncepcja definiująca podmioty uprawnione do dochodzenia roszczeń z tytułu naruszenia reguł konkurencji ${ }^{84}$. Koncepcja ta opiera się na założeniu, że reguły prawa antymonopolowego (we wskazanych sprawach Sekcja 4 Clayton Act) mają realizować w możliwie najszerszym zakresie cele wyrównawcze (naprawienia szkód) i cele prewencyjne - w braku zatem ustaleń faktycznych, które zaprzeczałyby realizacji tych celów, należy uznać szeroki zakres podmiotów uprawnionych do występowania z pozwami z tytułu naruszenia reguł konkurencji. Test wieloczynnikowy ma charakter otwarty, wyklucza on w zasadzie możliwość stworzenia zamkniętej listy podmiotów (definiowanych nawet przez określone cechy) uprawnionych do pozywania jako poszkodowani wskutek antykonkurencyjnych praktyk.

Istotne znaczenie dla określenia kręgu podmiotów legitymowanych czynnie do występowania z roszczeniami ma również amerykańska „doktryna szkody antymonopolowej" (antitrust injury doctrine), której rozwój zapoczątkowało orzeczenie Sądu Najwyższego w sprawie Brunswick ${ }^{85}$. Sąd stwierdził w nim, że status powoda ma każdy, kto udowodni szkodę antymonopolową, czyli taką szkodę, której prawo antymonopolowe ma przeciwdziałać, a która

81 Cromar Co. v. Nuclear Materials \& Equipment Corp., 543 F 2d 501 (3 ${ }^{\text {rd }}$ Cir. 1976).

82 Blue Shield of Virginia v. McCready, 457 US 465 (1982).

83 Associated General Contractor of California v. California State Council of Carpenters, 459 US 519 (1983).

84 C. A. Jones, Private enforcement..., s. 167.

85 Brunswick Corp. v. Pueblo Bowl-O-Mat Inc., 429 US 477 (1977). 
wynika z tego, co czyni zachowanie pozwanego nielegalnym. Zastosowanie tej doktryny nie wymaga przy tym dowiedzenia przez powoda, że doszło do rzeczywistego ograniczenia konkurencji. Inaczej niż miało to miejsce w teście bezpośredniej szkody lub w teście obszaru docelowego doktryna szkody antymonopolowej abstrahuje od ustalania bezpośredniego związku przyczynowego na rzecz analizy rodzaju szkody i jej relacji z domniemanym antykonkurencyjnym zachowaniem ${ }^{86}$. W piśmiennictwie podkreśla się, że literalne odczytanie doktryny szkody antymonopolowej, tak jak została ona sformułowana w orzeczeniu w sprawie Brunswick, wskazuje na jej poprawność i spójnośćc7. Spotyka się jednak również i szersze interpretacje, które wynik zastosowania tej doktryny uzależniają w dużej mierze od osobistych przekonań sędziego co do celów prawa antymonopolowego. Słabości tej doktryny upatruje się w tym, że Sąd w zasadzie nie wskazał źródła wymogu dowiedzenia szkody antymonopolowej jako warunku dopuszczalności dochodzenia roszczeń przez określone grupy podmiotów - czyni to tę doktrynę nadmiernie podatną na zmiany ${ }^{88}$. Istotną wadę omawianej doktryny stanowi również brak pewności co do tego, czy wykazanie szkody antymonopolowej jest warunkiem koniecznym do cywilnoprawnego dochodzenia roszczeń - w piśmiennictwie wyraża się zarówno poglądy traktujące szkodę antymonopolową jako element konstytuujący legitymację czynną w sprawach z zakresu ochrony konkurencji, jak i takie, które postrzegają szkodę antymonopolową jako element sprawy antymonopolowej całkowicie odrębny od zagadnienia uprawnień o występowanie z roszczeniami z tytułu naruszenia reguł konkurencji 89 .

Krąg podmiotów, którym przyznaje się legitymację czynną do występowania $\mathrm{z}$ roszczeniami związanymi z prawem ochrony konkurencji może decydować m.in. o popularności trybu prywatnego egzekwowania zakazów praktyk ograniczających konkurencję Można założyć, że im więcej kategorii podmiotów cieszy się legitymacją czynną, tym większe jest prawdopodobieństwo, że podmioty te będą dochodzić swoich roszczeń - w konsekwencji realne zagrożenie sankcjami cywilnoprawnymi, o które mogą występować różnorodne podmioty, może prowadzić do większego zdyscyplinowania przedsiębiorców co do przestrzegania prawa ochrony konkurencji. Objęcie możliwością występowania z roszczeniami szerokiego kręgu podmiotów może rodzić jednak i takie zagrożenie, że roszczenia, zwłaszcza pieniężne,

86 Chrysler Corp. v. Fedders Corp., 643 F 2d 1229, 1235 (6th Cir. 1979), 454 US 893 (1981).

88 Tak D. J. Polden, Antitrust Standing..., s. 187-188.

89 Tak m.in. C. A. Jones, Private enforcement..., s. 176-177. 
realizowane przez znaczącą liczbę podmiotów, nawet dość luźno powiązanych gospodarczo (rynkowo) z przedsiębiorcami naruszającymi reguły konkurencji, doprowadzą do upadku tych ostatnich ze względu na rozmiar obciążeń finansowych. D. Berger i R. Bernstein podkreślają, że argument o „rujnujących” odszkodowaniach może być wysuwany przeciw uznaniu legitymacji czynnej danego podmiotu (zwłaszcza podmiotu pośrednio poszkodowanego), jedynie wówczas, gdy jej przyznanie określonemu podmiotowi z dużym prawdopodobieństwem powodowałoby długotrwałe szkody dla konkurencji ${ }^{90}$.

Stosunkowo precyzyjne określenie kategorii podmiotów uprawnionych do występowania $\mathrm{z}$ roszczeniami z tytułu naruszenia zakazu antykonkurencyjnych praktyk spowoduje także, jeśli nie identyczne, to przynajmniej zbliżone traktowanie podmiotów znajdujących się w podobnej sytuacji w przypadku naruszenia reguł konkurencji, co z kolei również może przełożyć się na spójność (a z nią także pewność i popularność) prywatnego egzekwowania prawa ochrony konkurencji.

\subsubsection{Kontrahenci (nabywcy i dostawcy)}

Najbardziej predestynowaną grupę potencjalnych powodów w zakresie prywatnego egzekwowania zakazów antykonkurencyjnych praktyk stanowią kontrahenci podmiotów zaangażowanych w antykonkurencyjne praktyki. Pojęcie „kontrahentów” nie ma definicji legalnej ani w polskim, ani unijnym ustawodawstwie, ale należy przyjąć, że obejmuje ono nabywców oraz dostawców towarów i usług objętych antykonkurencyjnymi praktykami.

Nabywcami mogą być zarówno podmioty profesjonalne, jak i konsumenci (definiowani w większości ustawodawstw, także polskim, jako osoby fizyczne) ${ }^{91}$, przy czym nie każdy nabywca jest konsumentem, natomiast każdy konsument jest nabywcą. Ekonomiczna definicja nabywcy, co do zasady szersza niż definicja konsumenta, obejmuje „każdego, kto będąc uczestnikiem rynku, nabywa towar, bez względu na jego status prawny lub cel dokonania transakcji. Nabywcami (użytkownikami) są w szczególności przedsiębiorcy nabywający wszelkiego rodzaju towaru na swój własny użytek związany z prowadzeniem działalności gospodarczej, jak i nabywający towary w celach dalszej odsprzedaży"92. Podobnie jak w przypadku pojęcia „kontrahenta” polska ustawa o ochronie konkurencji i konsumentów ani

90 D. Berger, R. Bernstein, An Analytical Framework..., s. 852.

91 Por. pkt 4.3.2.5. w niniejszym rozdziale.

92 D. Miąsik, [w:] T. Skoczny, A. Jurkowska, D. Miąsik (red.), Ustawa .., s. 270 (Nb 501). 
Traktat o funkcjonowaniu UE nie przewidują definicji legalnej nabywcy, jednak taką definicję można odnaleźć odpowiednio w krajowym i unijnym rozporządzeniu wyłączającym porozumienia wertykalne spod zakazu porozumień ograniczających konkurencję. Definicje te są węższe niż zaproponowane powyżej ekonomiczne rozumienie pojęcia nabywcy, ograniczając je w aspekcie podmiotowym do przedsiębiorców ${ }^{93}$, przy czym prawodawca unijny ogranicza w zasadzie definicję „nabywcy” do nabywcy pośredniego ${ }^{94}$, natomiast prawodawca polski obok definicji „nabywcy” wskazuje na legalne rozumienie pojęcia „dystrybutor"95.

Niekwestionowany status poszkodowanych wskutek antykonkurencyjnych praktyk posiadają nabywcy bezpośredni, możliwość dochodzenia roszczeń przez nabywców pośrednich budzi natomiast wiele kontrowersji wynikających z zagadnienia przerzucania obciążeń (nadwyżek cenowych) związanych z praktykami antykonkurencyjnymi na nabywców na dalszych szczeblach obrotu gospodarczego (problematyka ta będzie przedmiotem rozważań poniżej).

Chociaż najczęściej roszczenia z tytułu naruszenia zakazów antykonkurencyjnych praktyk pochodzą od podmiotów działających na tych poziomach obrotu gospodarczego, które znajdują się poniżej szczebla (szczebli), na którym dopuszczono się antykonkurencyjnej praktyki, to status powodów posiadają również dostawcy (przedsiębiorcy działający na rynku wyższego szczebla niż ten, na którym doszło do naruszenia reguł konkurencji) praktyki antykonkurencyjne po popytowej stronie rynku zdarzają się jednak zdecydowanie rzadziej niż praktyki po stronie podażowej. Jak się wydaje, dostawcy będą poszkodowanymi częściej przez praktyki nadużywania pozycji dominującej niż poprzez porozumienia ograniczające konkurencję. Podobnie jak w przypadku nabywców, pojęcie „dostawcy” definiowane jest w ustawo-

93 Por. $\S 3$ pkt 8 rozporządzenia Rady Ministrów z dnia 30 marca 2011 r. w sprawie wyłączenia niektórych rodzajów porozumień wertykalnych spod zakazu porozumień ograniczających konkurencję (Dz. U. 2011 Nr 81, poz. 441); art. 1 ust. 1 lit. h) rozporządzenia Komisji (UE) nr 330/2010 z dnia 20 kwietnia 2010 r. w sprawie stosowania art. 101 ust. 3 Traktatu o funkcjonowaniu Unii Europejskiej do kategorii porozumień wertykalnych i praktyk uzgodnionych (Dz. Urz. UE 2011 L 102/1).

94 W taki sposób należy, moim zdaniem, rozumieć definicję nabywcy jako „przedsiębiorstwa, które zgodnie z porozumieniem wchodzącym w zakres stosowania art. 101 ust. 1 Traktatu, sprzedaje towary lub usługi w imieniu innego przedsiębiorstwa" - por. art. 1 ust. 1 lit. h) rozporządzenia 330/2010.

95 Por. $§ 3$ pkt 9 rozporządzenia Rady Ministrów z dnia 30 marca 2011 r. w sprawie wyłączenia niektórych rodzajów porozumień wertykalnych spod zakazu porozumień ograniczających konkurencję. 
dawstwie jedynie w regulacji wyłączającej porozumienia wertykalne - inaczej jednak niż w przypadku nabywców, w regulacji wyłącznie krajowej96.

\section{Nabywcy pośredni}

Problem określenia kręgu podmiotów uprawnionych do występowania $\mathrm{z}$ roszczeniami z tytułu naruszenia zakazów antykonkurencyjnych praktyk ujawnia się $\mathrm{z}$ całą mocą $\mathrm{w}$ ramach łańcucha dystrybucji. Jeśli praktyka ograniczająca konkurencję, przede wszystkim zmowa cenowa, miała miejsce na etapie produkcji lub początkowej sprzedaży gotowego produktu, pierwszy podmiot nabywający produkt, którego cena została nielegalnie ustalona, może „przerzucić” nielegalną nadwyżkę ceny na kolejny podmiot w łańcuchu dostaw. Sytuacja taka stwarza potencjalną możliwość dublowania odszkodowań - występowania z roszczeniami przeciw naruszycielowi reguł konkurencji zarówno przez pierwszego (bezpośredniego), jak i drugiego (pośredniego) nabywcę produktu. W przypadku dochodzenia roszczeń przez nabywców pośrednich możemy mieć do czynienia nie tylko z postępowaniem sądowym wielostronnym, ale wręcz - wielopoziomowym, co oczywiście podwyższa ryzyko multiplikowania (dublowania) zasądzanych odszkodowań. Rysuje się tu zatem ostry konflikt między rozwiązaniem zmierzającym do osiągnięcia celu kompensacyjnego i odstraszającego (co miałoby ziścić się poprzez przyznanie uprawnień do dochodzenia roszczeń przez nabywców pośrednich) oraz rozwiązaniem zorientowanym na wykluczenie dublowania odszkodowań (co z kolei oznacza eliminację możliwości występowania z roszczeniami odszkodowawczymi przez nabywców pośrednich) ${ }^{97}$. Odrębnym problemem „transferowania” (przerzucania) nadwyżek cenowych pozostaje również bezpodstawne wzbogacenie, w zależności od okoliczności - nabywcy pośredniego lub podmiotu dopuszczającego się naruszenia reguł konkurencji. W dokumencie roboczym towarzyszącym Białej księdze wyrażona została opinia, że wielokrotna odpowiedzialność jest jednak mniej prawdopodobna niż fakt bezpodstawnego wzbogacenia pozwanego ${ }^{98}$. Dochodzenie roszczeń przez nabywców pośrednich wymaga ponadto szcze-

96 Por. $§ 3$ pkt 7 rozporządzenia Rady Ministrów z dnia 30 marca 2011 r. w sprawie wyłączenia niektórych rodzajów porozumień wertykalnych spod zakazu porozumień ograniczających konkurencję.

97 D. Berger, R. Bernstein, An Analytical Framework..., s. 872. Należy odnotować także pogląd, w myśl którego zagrożenie multiplikowaniem odszkodowań jest problemem teoretycznym, sztucznym i nie znajduje potwierdzenia w praktyce - por. A. I. Gavil, State Indirect Purchaser Actions, Proposal for a Reform, OECD Journal: Competition Law and Policy 2009, vol. 11(2), s. 68.

98 Pkt 218 White Paper Staff Working Paper (Chapter 7B2). 
gólnie trudnego procesu dowodzenia przerzucanych obciążeń - zwłaszcza w przypadku tych nabywców, którzy usytuowani są na końcu (lub niemal na końcu) łańcucha dostaw, w oddaleniu od „źródła” naruszenia zakazów praktyk ograniczających konkurencję ${ }^{99}$. Wskazuje się również, że możliwość wykorzystywania zarzutu przerzucania obciążeń na niższe szczeble obrotu będzie stanowić czynnik zniechęcający bezpośrednich nabywców do występowania $\mathrm{z}$ roszczeniami ${ }^{100}$.

Mimo że dopuszczalność dochodzenia roszczeń przez nabywców pośrednich i dopuszczalność obrony poprzez przerzucanie obciążeń (pass-on) stanowią awers i rewers tego samego zjawiska ekonomicznego, to prawny punkt widzenia (w tym np. wymogi dowodowe) nakazuje odrębne rozpatrywanie tych dwóch aspektów. Podejście takie potwierdza pośrednio stanowisko Komisji Europejskiej przedstawione w Białej księdze. Akcentując, że „Trybunał kładzie nacisk na zasadę wyrównania szkody i jej przesłankę, zgodnie z którą naprawienie szkody przysługuje każdej osobie, która ją poniosła i która może wykazać istnienie wystarczającego związku przyczynowego między szkodą a naruszeniem prawa”, Komisja, po pierwsze skłania się ku dopuszczalności obrony poprzez zarzut przerzucania obciążeń ${ }^{101}$, jednocześnie nie zgadzając się na obniżenie standardów dowodowych (w porównaniu do tych, jakie obowiązują dla wykazania szkody). Na marginesie należy zaznaczyć, że w orzecznictwie unijnym można zidentyfikować rozstrzygnięcia akceptujące przerzucanie obciążeń jako zarzut obronny, choć akurat nie w sprawach z zakresu ochrony konkurencji 102 .

Po drugie Komisja nie tylko opowiedziała się za przyznaniem nabywcom pośrednim prawa dochodzenia roszczeń z tytułu naruszenia zakazów antykonkurencyjnych praktyk, ale zaproponowała również zmniejszenie rygorów dowodowych poprzez ustanowienie na korzyść nabywców pośred-

99 Należy jednak odnotować, że istnieją modele ekonometryczne pozwalające na szacowanie obciążeń - por. T. van Dijk, F. Frank Verboven, Implementing the passing-on defence in cartel damages actions, G.C.L.R. 2010, vol. 3(3), s. 98-105.

100 Por. pkt 204 White Paper Staff Working Paper.

101 Pkt 2.6. Białej księgi. Por. także pkt 208-214 White Paper Staff Working Paper (Chapter 7B1). Inaczej W. van Gerven, Private Enforcement of EC Competition Rules in the ECJ - Courage v. Crehan and the Way Ahead, [w:] J. Basedow (red.), Private Enforcement of EC Competition Law, Kluwer Law International 2007, s. 34.

102 Por. C-68/79 Hans Just I/S v. Danish Ministry for Fiscal Affairs (Zb. Orz. 1980, s. 501); C-199/82 Amministrazione delle Finanze dello Stato v SpA San Giorgio (Zb. Orz. 1983, s. 3595). Problematykę tę szerzej prezentuje S. Parlak, Passing-On Defence and Indirect Purchaser Standing: Should the Passing-On Defence Be Rejected Now the Indirect Purchaser Has Standing After Manfredi and the White Paper of the European Commission?, World Competition 2010, vol. 33(1), s. 44-45. 
nich wzruszalnego domniemania, że obciążenie cenowe zostało na nich w całości przerzucone. Niezależnie od propozycji Białej księgi w literaturze przedmiotu dominuje pogląd, że w kontekście stanowiska Trybunału co do szerokiego zakresu legitymowanych czynnie do dochodzenia roszczeń z tytułu naruszenia zakazów z art. 101 lub 102 TFUE nieuzasadnione byłoby odmawianie uprawnień nabywcom pośrednim 103 .

Problem uprawnień nabywców pośrednich do występowania z roszczeniami jest szczególnie widoczny w amerykańskim orzecznictwie i literaturze przedmiotu. Doktrynę nabywcy pośredniego (indirect purchaser doctrine) ukształtowały dwa rozstrzygnięcia: w sprawie Hanover Shoe ${ }^{104}$ oraz Illinois Brick ${ }^{105}$. W wyroku w sprawie Hanover Shoe Sąd odrzucif argument obronny pozwanego, że nadwyżka ceny została transferowana przez powoda na kolejny szczebel obrotu, w związku z czym nie można uznać go za poszkodowanego (w ten sposób Sąd zakwestionował możliwość obrony poprzez tzw. przerzucanie obciążeń [pass-on defence]). W wyroku w sprawie Illinois Brick Sąd Najwyższy natomiast opowiedział się za tym, by nabywca bezpośredni występował z roszczeniami obejmującymi całą nadwyżkę cenową. Reasumując, Sąd odrzucił możliwość zarówno defensywnego, jak i ofensywnego wykorzystania zarzutu przerzucania obciążeń (nadwyżek). Jednocześnie Sąd ustanowił dwa wyjątki od ogólnego zakazu dochodzenia roszczeń przez nabywców pośrednich: pierwszy z wyjątków dotyczy sytuacji, gdy istniejąca umowa ustalająca wielkość i cenę dostaw pozwala takiemu nabywcy na występowanie z roszczeniami, o ile bezpośredni nabywca nie ma nic wspólnego ze spadkiem sprzedaży, która w innym przypadku mogłaby nastąpić wskutek przeniesienia nadwyżek cenowych, a sam efekt w postaci nadwyżek jest z góry określony i nie ma potrzeby prowadzenia złożonych ustaleń faktycznych. Drugi wyjątek dotyczy sytuacji, gdy bezpośredni nabywca stanowi własność lub jest kontrolowany przez swojego klienta (faktycznie tworzą oni jeden organizm gospodarczy). W wyniku wydanego w $1981 \mathrm{r}$. orzeczenia w sprawie J. Truett Payne Co., Inc. v. Chrysler Motors Corp. ${ }^{106}$ Sąd Najwyższy nieco złagodził doktrynę Illinois Brick, zezwalając na to, by podmioty nie mające żadnych bezpośrednich relacji z członkami kartelu mogły występować $\mathrm{z}$ roszczeniami innymi niż odszkodowawcze w sądach stanowych.

103 Tak m.in. A. P. Komninos, EC Private Antitrust Enforcement..., s. 203.

104 Hanover Shoe, Inc. v. United Shoe Machinery Corp., 392 US 481 (1968).

105 Illinois Brick Co.v. Illinois, 431 US 720 (1977). Doktrynę nabywcy pośredniego określa się często w literaturze jako „doktrynę Illinois Brick”.

106451 US 557 (1981). 
Amerykańska doktryna nabywcy pośredniego spotkała się $\mathrm{z}$ istotną krytyką, także ze strony (również europejskich) ekonomistów ${ }^{107}$. Krytycy podnoszą m.in., że doktryna Illinois Brick z elastycznej i funkcjonalnej reguły zmieniła się w sztywną regułę nieodpowiadającą celom prywatnego egzekwowania zakazów praktyk antykonkurencyjnych ${ }^{108}$. Jeden ze współczesnych poglądów wskazuje, że doktryna ta w rzeczywistości ułatwia zmowy między dostawcami, którzy mogą zapobiegać prywatnemu egzekwowaniu reguł konkurencji tak długo, jak długo bezpośredni odbiorcy na rynku niższego szczebla odnoszą z istnienia kartelu korzyści większe niż odszkodowanie, którego mogliby się domagać ${ }^{109}$. Wśród krytyków przeważa pogląd, że najważniejszym argumentem, który skłonił Sąd Najwyższy do przyjęcia takiego, a nie innego rozstrzygnięcia w sprawie Illinois Brick była dbałość o spójność orzecznictwa (w tym przypadku zgodność z rozstrzygnięciem w sprawie Hanover Shoe). A. I. Gavil uważa za optymalne dopuszczenie możliwości ofensywnego podnoszenia zarzutu przerzucania obciążeń przy jednoczesnym wykluczeniu możliwości stosowania tego zarzutu dla celów obronnych ${ }^{110}$. Dla porządku należy odnotować, że w piśmiennictwie bliższym czasowo wydaniu wyroku w sprawie Illinois Brick podejmowano także obronę tej doktryny111.

W obliczu krytyki doktryny Illinois Brick amerykański Kongres podjął kilkukrotnie starania o przyjęcie aktów prawnych przełamujących wypracowaną przez Sąd Najwyższy zasadę - żadna z podjętych prób nie zakończyła się jednak sukcesem ${ }^{112}$. Odpowiednie regulacje przyjęte zostały natomiast - i są z powodzeniem stosowane - w niektórych stanach ${ }^{113}$ (działo się to

107 Za sztandarowy artykuł krytyczny uznaje się publikację R. G. Harrisa i A. Sullivana, Passing on the Monopoly Overcharge: A Comprehensive Policy Analysis, University of Pennsylvania Law Review 1980, vol. 128, s. 269 I n. Por. także krytyczne stanowisko europejskich ekonomistów: M. P. Schinkel, J. Rüggeberg, Consolidating Antitrust Damages in Europe: A Proposal for Standing in Line with Efficient Private Enforcement, Amsterdam Center for Law and Economics, Working Paper No. 2006-04, s. 5-6.

108 B. D. Richman, Ch. R. Murray, Rebuilding Illinois Brick: A Functionalist Approach to the Indirect Purchaser Rule, Southern California Law Review 2007, vol. 81, s. 89.

109 M. P. Schinkel, J. Tuinstra, J. Rüggeberg, Illinois Walls: how barring indirect purchaser suits facilitates collusion, RAND Journal of Economics 2008, vol. 39(3), s. 683-698.

110 A. I. Gavil, State Indirect Purchaser..., s. 66.

111 W. M. Landes, R. Posner, Should Indirect Purchasers Have Standing to Sue Under the Antitrust Laws? An Economic Analysis of the Rule of Illinois Brick, University of Chicago Law Review 1979, vol. 46, s. 602 i n.

112 Najważniejszą próbę uchylenia doktryny pośredniego nabywcy stanowił raport przygotowany w 2007 r. przez Antitrust Modernization Commission.

113 D. R. Karon, Your Honor, Tear Down that Illinois Brick Wall!: The National Movement Towards Indirect Purchaser Antitrust Standing and Consumer Justice, William Mitchell 
niejako za przyzwoleniem Sądu Najwyższego, który w 1989 r. w orzeczeniu w sprawie California v. ARC America Corp. potwierdził, że przyjęcie odpowiedniego ustawodawstwa dotyczącego uprawnień nabywców pośrednich leży w kompetencjach poszczególnych stanów).

W literaturze wyrażony został pogląd, że rozstrzygnięcia wykluczające możliwość dublowania odszkodowań powinny należeć do sfery ustawodawczej, nie praktycznej114. Należy zgodzić się z C. A. Jonesem, że doktryna nabywcy pośredniego odzwierciedla wybór przez sąd rozwiązania lepiej promującego prywatne egzekwowanie prawa ${ }^{115}$. Wybór ten, zwłaszcza $\mathrm{w}$ systemach prawa kontynentalnego, powinien być dokonany przez samego ustawodawcę - tylko w taki sposób można zagwarantować spójne traktowanie roszczeń, z którymi występują nabywcy pośredni poszkodowani wskutek antykonkurencyjnych praktyk. Nieunikniony formalizm charakteryzujący takie stanowisko legislacyjne jest ceną, jaka musi być zapłacona za tę spójność.

W tym kontekście na uwagę zasługują rozwiązania niemieckie. Jeśli chodzi o orzecznictwo, przyjmuje się, że sądy niemieckie nie wykluczyły wprost możliwości dochodzenia roszczeń przez nabywców pośrednich: w wyroku dotyczącym międzynarodowego kartelu witaminowego Landgericht Mannheim rozstrzygnął, że członkowie kartelu nie ponoszą odpowiedzialności wobec bezpośrednich nabywców, jeśli powód przeniósł obciążenia na odbiorców na niższych szczeblach obrotu ${ }^{116}$, a następnie Oberlandesgericht Karlsruhe ${ }^{117}$ stwierdził, że bezpośredni nabywcy są w stanie regularnie przerzucać obciążenia na niższe szczeble obrotu. Niemniej jednak w ramach tzw. siódmej poprawki do ustawy o ograniczeniach konkurencji wprowadzono przepis $\S 33$ ust. 3 zd. 2 przewidujący, że jeśli towar lub usługa zostały zakupione po zawyżonej cenie, nie wyklucza się istnienia szkody w sytuacji, gdy towar lub usługa zostały odsprzedane. Jeśli chodzi natomiast o możliwość występowania z roszczeniami przez nabywców pośrednich, to w literaturze

Law Review 2004, vol. 30, s. 1351-1402. Przegląd regulacji stanowych umożliwiających występowanie z roszczeniami przez nabywców pośrednich zawarty jest w publikacji: E. J. McCarthy, G. S. Seador, Ch. R. Price (red.), Indirect Puchaser Lawsuites. A Stateby-State Survey, Chicago 2010. W polskim piśmiennictwie zob. R. Molski, Prywatnoprawna ochrona konkurencji w amerykańskim prawie antytrustowym, KPP 2005, z. 3, s. 784-785.

114 Tak D. Berger, R. Bernstein, An Analytical Framework..., s. 878. Za koniecznością wprowadzenia rozwiązań legislacyjnych, m.in. w odniesieniu do sytuacji nabywców pośrednich i możliwości wykorzystania pass-on defence, opowiedział się także W. Van Gerven, Private Enforcement..., s. 30-36.

115 C. A. Jones, Private enforcement..., s. 180.

116 LG Mannheim, 106 GRUR 182 (2004).

117 OLG Karlsruhe, 57 NJW 2243, 2244 (2004). 
przedmiotu wskazuje się na brak rozstrzygającego charakteru przepisu § 33 ust. $1 \mathrm{zd}$. $3^{118}$, choć najbardziej popularny wydaje się pogląd, że przepis zachęca do dochodzenia roszczeń od nabywców pośrednich ${ }^{119}$ - wykładnię taką przyjął także Bundesgerichtshof w wyroku z dnia 28 czerwca 2011 r. ${ }^{120}$ Warto także wskazać - za A. P. Komninosem ${ }^{121}$ - że takie odgórne wybory ustawodawcy, „uprzywilejowujące” odpowiedzialność jednego podmiotu wobec odpowiedzialności innego są znane prawu unijnemu - wyboru takiego europejski ustawodawca dokonał np. w odniesieniu do odpowiedzialności za produkt niebezpieczny ${ }^{122}$, która w pierwszej kolejności przypisana jest producentowi, a nie dostawcy produktu.

W piśmiennictwie amerykańskim zaproponowano np. dopuszczalność roszczeń pochodzących od nabywców pośrednich, ale jedynie w warunkach obligatoryjnej konsolidacji wszystkich roszczeń (zarówno tych od nabywców pośrednich, jak i bezpośrednich). Według autorów tej koncepcji obowiązkowa konsolidacja roszczeń realizowałaby najważniejsze cele prywatnego egzekwowania reguł konkurencji poprzez wzmocnienie efektu odstraszającego i zapewnienie kompensacji wszystkim rzeczywiście poszkodowanym (bez względu na to, czy szkoda ma charakter bezpośredni, czy pośredni) ${ }^{123}$.

Zastosowanie takiego rozwiązania byłoby bardzo trudne w przypadku naruszenia unijnych reguł konkurencji, gdzie pozwy mogą przecież wpłynąć do sądów w różnych państwach członkowskich. Zaleca się w takim przypadku skorzystanie $\mathrm{z}$ procedury przewidzianej $\mathrm{w}$ art. 28 rozporządzenia 41/2001124. Ponadto potencjalna konsolidacja roszczeń (bez względu na to, czy obowiązkowa, czy fakultatywna) jest możliwa tylko w przypadku roszczeń równoległych, przy czym tę równoległość należy tutaj rozumieć jako równoczesność (roszczenia wniesione w określonej jednostce czasu) oraz jako równość pozycji rynkowej (wielu nabywców pośrednich, ale działających na tym samym szczeblu obrotu, pozostających w tej samej sytuacji rynko-

118 F. Cengiz, Passing-On Defense..., s. 33; W. Wurmnest, A New Era for Private Antitrust Litigation in Germany? A Critical Appraisal of the Modernized Law againts Restraints of Competition, German Law Journal 2005, vol. 6(8), s. 1182; N. Reich, Horizontal liability in EC law: hybridization of remedies for compensation in case of breaches of EC rights, CMLR 2007, vol. 44(3), s. 710.

119 M. Będkowski-Kozioł, Prywatne wdrażanie..., s. 15-16.

120 BGH,KZR 75/10 - ORWI.

121 A. P. Komninos, EC Private Antitrust Enforcement..., s. 205.

122 Dyrektywa 85/374/EWG z dnia 25 lipca 1985 r. w sprawie zbliżenia przepisów ustawowych, wykonawczych i administracyjnych Państw Członkowskich dotyczących odpowiedzialności za produkty wadliwe (Dz. Urz. EWG 1985 L 210/29).

123 B. D. Richman, Ch. R. Murray, Rebuilding Illinois Brick..., s. 101-104.

124 Por. pkt 224 White Paper Staff Working Paper (Chapter 7B3). 
wej). Jakakolwiek konsolidacja roszczeń jest natomiast wykluczona wówczas, gdy nabywcy pośredni (nawet $\mathrm{z}$ tego samego szczebla obrotu) występują z roszczeniami w różnym czasie, niektórzy także po tym, jak zapadły już orzeczenia w analogicznych sprawach. Kluczowe pozostaje wówczas określenie roli takich wcześniejszych wyroków w rozstrzyganiu późniejszych spraw (np. przyznanie im statusu rozstrzygających dowodów). Komisja Europejska w Białej księdze proponuje w takim przypadku „wykorzystanie wszelkich środków dostępnych na mocy prawa krajowego, wspólnotowego i międzynarodowego w celu uniknięcia niedostatecznego oraz nadmiernego naprawienia szkody wyrządzonej naruszeniem prawa ochrony konkurencji” 125 .

$\mathrm{Na}$ marginesie należy dodać, że w podobnej jak nabywcy pośredni sytuacji znajdują się tzw. nabywcy parasolowi (nabywcy towarów lub usług od konkurentów przedsiębiorców dopuszczających się antykonkurencyjnych praktyk). Problem dopuszczalności roszczeń pochodzących od takich nabywców pojawił się w orzecznictwie amerykańskim. Nawet jeśli można zidentyfikować orzeczenia potwierdzające możliwość dochodzenia roszczeń przez takich nabywców, to dominującą linią orzeczniczą jest wykluczenie dochodzenia roszczeń przez „ofiary parasolowe” antykonkurencyjnych praktyk. Wśród argumentów przemawiających za brakiem możliwości dochodzenia roszczeń przez poszkodowanych tego rodzaju sądy wskazywały na wyjątkowo spekulacyjny charakter roszczeń takich podmiotów, zwłaszcza, że sądy nie są w stanie ustalić, jaka część podwyżki ceny była działaniem normalnych sił rynkowych, a jaka - wynikiem antykonkurencyjnego zachowania pozwanych ${ }^{126}$. Innym przywoływanym argumentem była sprzeczność odszkodowań dla nabywców parasolowych z celem prawa antymonopolowego, polegającym na utrzymywaniu konkurencyjnej gospodarki ${ }^{127}$. W piśmiennictwie amerykańskim można jednak zidentyfikować pogląd wskazujący, że roszczenia nabywców parasolowych realizują odstraszającą funkcję prywatnego egzekwowania reguł konkurencji, a zatem roszczenia pochodzące od takich podmiotów powinny być dopuszczalne ${ }^{128}$.

125 Pkt 2.6. Białej księgi.

126 Mid-West Paper Product Co. v. Continental Group Inc., 596 F 2d. Por. także In re Coordinated Pretrial Proceedings in Petroleum Products Antitrust Litigation, 691 F 2d.

127 Mid-West Paper Product Co. v. Continental Group Inc., 596 F 2d. Ostatni z przytoczonych argumentów krytycznie oceniony przez J. M. Lave, Umbrella standing..., s. 231.

128 J. M. Lave, Umbrella standing..., s. 257. Za dopuszczalnoscia roszczeń od nabywcow parasolowych opowiadaja sie takze P. E. Areeda, H. Hovenkamp, Antitrust Law: An Analysis of Antitrust Principles and Their Application, Aspen Publishers, Nowy Jork 1992, par. 337.3. 
Na zakończenie rozważań nad sytuacją nabywców pośrednich w ramach prywatnego egzekwowania reguł konkurencji należy odnotować stanowisko polskiego orzecznictwa i doktryny. Za możliwością stosowania obrony poprzez przerzucanie obciążeń oraz za dopuszczalnością dochodzenia roszczeń odszkodowawczych bezpośrednio od przedsiębiorców zaangażowanych w antykonkurencyjną praktykę przez nabywców finalnych (w tym konsumentów) opowiadają się w polskiej literaturze m.in. A. Piszcz ${ }^{129}$, M. K. Kolasiński ${ }^{130}$. Możliwość korzystania $\mathrm{z}$ argumentu obronnego w postaci przerzucania kosztów, mimo braku odpowiednich uregulowań, widzą również praktycy: D. Hansberry-Bieguńska ${ }^{131}$, A. Stawicki ${ }^{132}$.

\subsubsection{Konkurenci}

Prywatnym egzekwowaniem zakazów praktyk ograniczających konkurencję mogą być zainteresowani również konkurenci przedsiębiorców zaangażowanych $\mathrm{w}$ niedozwolone działania: konkurenci uczestników antykonkurencyjnych porozumień oraz konkurenci dominanta nadużywającego swojej pozycji rynkowej.

W polskim prawie ochrony konkurencji konkurent definiowany jest przez art. 4 pkt 11 uokik jako przedsiębiorca (w szerokim rozumieniu nadanym temu pojęciu przez prawo konkurencji ${ }^{133}$ ) - podmiot uczestniczący w wymianie towarowej; konkurenci mogą występować na rynku właściwym zarówno po stronie podaży, jak i po stronie popytu, może ich łączyć stosunek konkurencji potencjalnej lub rzeczywistej. W prawie unijnym analogiczną definicję konkurenta („przedsiębiorstwa konkurującego”) odnajdujemy w rozporzą-

129 A. Piszcz, Wybrane problemy zwiazane ze stosowaniem prawa antymonopolowego Unii Europejskiej przez sądy krajowe, [w:] N. Szczęch (red.), Księga Jubileuszowa z okazji 5-lecia Wydziału Prawa Wyższej Szkoty Menedżerskiej w Legnicy „Ius est ars boni et aequi”, Legnica 2010, s. 555-557.

130 M. K. Kolasiński, Odpowiedzialność cywilna za szkody powstałe w wyniku naruszenia wspólnotowych zakazów praktyk ograniczających konkurencję i nadużywania pozycji dominujacej, PPH 2007, nr 11, s. 17-19.

131 D. Hansberry-Bieguńska, Poland, [w:] I. K. Gotts (red.), The Private Competition Enforcement Review, 4. ed., Law Business Research, London 2011, s. 251, 259.

132 A. Stawicki, Poland, [w:] G. Blanke, R. Nazzini (red.), International Competition Litigation: A Multi-jurisdictional Handbook, Kluwer Law International BV 2012, s. 582.

133 Por. art. 4 pkt 1 uokik. Definicję konkurenta, aczkolwiek skonstruowaną poprzez odesłanie do art. 4 pkt 11 uokik, zawiera $§ 2$ pkt 8 rozporządzenia Rady Ministrów z dnia 30 lipca 2007 r. w sprawie wyłączenia niektórych rodzajów porozumień dotyczących transferu technologii spod zakazu porozumień ograniczających konkurencję (Dz. U. $2007 \mathrm{Nr}$ 137, poz. 963). 
dzeniu wyłączającym porozumienia wertykalne ${ }^{134}$ oraz rozporządzeniach wyłączających porozumienia badawczo-rozwojowe ${ }^{135}$ i specjalizacyjne ${ }^{136}$; ponadto konkurenta legalnie definiuje również rozporządzenie wyłączające porozumienia transferu technologii, przy czym w tym akcie definicja zawężona jest do konkurentów rzeczywistych ${ }^{137}$.

Do antykonkurencyjnych zachowań, które bez większych kontrowersji mogą być kwestionowane przed sądami powszechnymi przez konkurentów, należą przede wszystkim praktyki wykluczające $\mathrm{z}$ rynku, $\mathrm{w}$ tym również bojkoty, a także praktyki dyskryminacyjne. C. A. Jones wymienia także drapieżnictwo cenowe ${ }^{138}$, ale w świetle aktualnych tendencji doktrynalnych i orzeczniczych negatywny wpływ takich praktyk na konkurencję nie jest całkowicie jednoznaczny.

Najpoważniejszym problemem w przypadku konkurentów pozostaje pytanie o to, czy doznana przez nich szkoda, zwłaszcza w postaci utraconych zysków, jest rzeczywiście szkodą antymonopolową uzasadniająca realizację roszczeń, czy tylko efektem wzmożonej walki konkurencyjnej. Dla zilustrowania tego problemu W. H. Page wskazuje przykład horyzontalnych fuzji, które same w sobie w istocie mogą prowadzić rywali rynkowych uczestników fuzji do utraty zysków, ale jednocześnie wymuszają ich większą efektywność139.

Dodatkową motywacją dla konkurentów do występowania z roszczeniami w sprawach praktyk antykonkurencyjnych może być fakt, że posiadają oni istotną wiedzę o funkcjonowaniu rynków, na których dochodzi do niedozwolonych działań i/lub na których odczuwalne są ich antykonkurencyjne skutki. Wiedza ta może przyczynić się do sprawniejszego przebiegu postępowania i jego ostatecznego pozytywnego wyniku.

134 Por. art. 1 ust. 1 lit. c) rozporządzenia 330/2010.

135 Por. art. 1 ust. 1 lit. r) rozporządzenie Komisji (UE) nr 1217/2010 z dnia 14 grudnia 2010 r. w sprawie stosowania art. 101 ust. 3 Traktatu o funkcjonowaniu Unii Europejskiej do niektórych kategorii porozumień badawczo-rozwojowych (Dz. Urz. UE 2010 L 335/36).

136 Por. art. 1 ust. 1 lit. l) rozporządzenie Komisji (UE) nr 1218/2010 z dnia 14 grudnia 2010 r. w sprawie stosowania art. 101 ust. 3 Traktatu o funkcjonowaniu Unii Europejskiej do niektórych kategorii porozumień specjalizacyjnych (Dz. Urz. UE 2010 L 335/43).

137Por. art. 1 ust. 1 lit. j) rozporządzenia Komisji (WE) nr 772/2004 z dnia 7 kwietnia 2004 r. w sprawie stosowania art. 81 ust. 3 Traktatu do kategorii porozumień o transferze technologii (Dz. Urz. UE 2004 L 123/11).

138 C. A. Jones, Private enforcement..., s. 180-181.

139 W. H. Page, Policy choices..., s. 51. 


\subsubsection{Konkurenci i kontrahenci będący stronami zakazanych porozumień ograniczających konkurencję}

Kontrowersyjnym zagadnieniem może być kwestia włączenia w zakres podmiotów posiadających locus standi $\mathrm{w}$ sprawach $\mathrm{z}$ zakresu ochrony konkurencji przedsiębiorców będących stronami zakazanych porozumień ograniczających konkurencję. Źródłem kontrowersji jest przede wszystkim ugruntowana zasada, że nie można czerpać korzyści z naruszania przez siebie prawa. W zakresie prywatnego egzekwowania zakazów praktyk ograniczających konkurencję stosowanie tej zasady może jednak być limitowane (choć nie wykluczone całkowicie), co znalazło swoje potwierdzenie zarówno w orzecznictwie amerykańskim (wyrok w sprawie Perma Life Mufflers Inc. v. International Parts Corp. ${ }^{140}$ ), jak i europejskim (wyrok w sprawie Courage). Wskazane orzeczenie Trybunału Sprawiedliwości niemal w całości koncentruje się na odpowiedzi na pochodzące od angielskiego sądu pytanie prejudycjalne dotyczące tego, czy art. 101 TFUE może być interpretowany w taki sposób, by uznać stronę porozumienia niezgodnego $\mathrm{z}$ tym przepisem za uprawnioną do ubiegania się o odszkodowanie związane $\mathrm{z}$ wykonywaniem tej umowy. Pytanie to postawione zostało w kontekście obowiązującego prawa krajowego, które wykluczało możliwość uzyskania odszkodowania przez uczestnika antykonkurencyjnego porozumienia. Trybunał uznał, że przepisy krajowe tego rodzaju, bezwzględnie eliminujące możliwość ubiegania się o odszkodowanie przez stronę porozumienia, nie mogą być zaakceptowane z punktu widzenia podstawowych zasad unijnego porządku prawnego. Trybunał uzasadniał swoje stanowisko bezwzględnym charakterem nieważności przewidzianej w art. 101 ust. 2 TFUE ${ }^{141}$, skutkiem bezpośrednim, jaki przypisany jest do art. 101 i 102 TFUE $^{142}$, a także zagrożeniem (w przypadku niemożliwości dochodzenia roszczeń przez strony porozumień) dla pełnej skuteczności art. 101 TFUE, a tym samym - dla utrzymania skutecznej konkurencji143 w Unii. Stanowisko Trybunału nie wskazuje jednak, że każdy uczestnik antykonkurencyjnego porozumienia ma możliwość dochodzenia roszczeń z tytułu naruszenia zakazu karteli - przeciwnie, TS stwierdzit, że „prawo wspólnotowe nie stoi na przeszkodzie temu, aby prawo krajowe odmawiało jednej ze stron umowy prawa do domagania się odszkodowania od drugiej strony, jeżeli zostanie stwierdzone, że ponosi

\footnotetext{
140 Perma Life Mufflers Inc. v. International Parts Corp., 392 U.S. 134 (1968).

141 Pkt 21-22 wyroku w sprawie Courage.

142 Pkt 23 wyroku w sprawie Courage.

143 Pkt 26-27 wyroku w sprawie Courage.
} 
ona znaczącą odpowiedzialność za zakłócenia konkurencji”144. Używając terminologii bliższej prawu cywilnemu, można powiedzieć, że ocena zasadności roszczeń strony antykonkurencyjnego porozumienia musi uwzględniać fakt i stopień przyczynienia się poszkodowanego do zaistnienia szkody. Zaproponowany przez TS test dopuszczalności roszczeń uczestnika porozumienia obejmuje badanie „kontekstu gospodarczego i prawnego, w którym strony się znajdują, jak również (...) pozycji negocjacyjnej i zachowania każdej ze stron umowy”145; w szczególności analizie należy poddać to, „czy strona, która utrzymuje, iż poniosła szkodę wskutek zawarcia umowy mogącej ograniczyć lub zakłócić konkurencję, znajdowała się w gorszej sytuacji niż druga strona, do tego stopnia, że jej swoboda negocjowania warunków umowy, jak również zdolność do uniknięcia szkody lub ograniczenia jej rozmiaru, w szczególności przy wykorzystaniu w stosownym czasie wszelkich dostępnych środków prawnych, były poważnie ograniczone lub nawet była ich pozbawiona"146. Zdaniem Trybunału dopuszczalność roszczeń z tytułu naruszenia zakazu antykonkurencyjnych porozumień jest szczególnie prawdopodobna wtedy, gdy chodzi o strony takich porozumień, których antykonkurencyjny skutek ujawnia się dopiero w kontekście funkcjonowania sieci porozumień - wówczas „kontrahent posiadacza sieci może nie ponosić znaczącej odpowiedzialności za naruszenie przepisu art. 85, zwłaszcza jeśli warunki umowy zostały mu w istocie narzucone przez posiadacza sieci" 147 .

Wypracowane przez Trybunał stanowisko znalazło dość powszechną akceptację w doktrynie, także polskiej. M. Szpunar zauważa jednak, że problemu dochodzenia roszczeń przez strony zakazanych porozumień nie należy ograniczać jedynie do odpowiedzialności deliktowej, ale należy co najmniej rozważyć zastosowanie w takich przypadkach także reguł odpowiedzialności kontraktowej ${ }^{148}$. Do rzadkości należą poglądy kwestionujące możliwość dochodzenia roszczeń przez strony porozumień, choć H. Schepel zauważył, że odrzucenie przez TS zasady in pari delicto stanowiło nadmierną ingerencję unijnych interesów publicznoprawnych w relacje prywatnoprawne, natomiast u podstaw stanowiska Trybunału leżała wyłącznie chęć zapewnienia skuteczności traktatowym regułom konkurencji ${ }^{149}$. W polskim piśmiennictwie należy odnotować pogląd P. Podreckiego, wyrażony jednak

144 Pkt 31 wyroku w sprawie Courage.

145 Pkt 32 wyroku w sprawie Courage.

146 Pkt 33 wyroku w sprawie Courage.

147 Pkt 34 wyroku w sprawie Courage.

148 M. Szpunar, Odpowiedzialność podmiotu prywatnego..., s. 325-327.

149 H. Schepel, The Enforcement of EC Law in Contractual Relations: Case Studies in How Not to “Constitutionalize” Private Law, ERPL 2004, vol. 5, s. 668 i 669. 
na długo przed wydaniem przez TS orzeczenia w sprawie Courage - według tego autora „Z uwagi na naruszenie art. 85 TR (obecnie art. 101 TFUE przyp. aut.) pomiędzy uczestnikami porozumienia zasadniczo wyłączone są również roszczenia deliktowe" 150 .

Wpływ doktryny Courage na orzecznictwo jest jednak stosunkowo niewielki151 - przyczyn takiego stanu rzeczy można, moim zdaniem, upatrywać w tym, że strony porozumień rzadko występują z roszczeniami wobec innych uczestników porozumień. Dochodzenie roszczeń przez podmioty uczestniczące w porozumieniu będzie się odbywało przede wszystkim poprzez pozwy następcze (follow-on claims), trudno sobie bowiem wyobrazić, aby poprzez wystąpienie z samoistnym pozwem (stand-alone claims) strony zechciały „narażać się” na interwencję organu ochrony konkurencji (skłonność do występowania z pozwami tego rodzaju wzrasta zapewne $\mathrm{z}$ chwilą upływu terminu przedawnienia ścigania antykonkurencyjnych praktyk, choć ze względu na znaczne trudności w określeniu początku biegu terminu przedawnienia, identyfikacja momentu upływu terminu przedawnienia może nastręczać kłopotów).

Nie bez znaczenia dla stosowania „doktryny Courage” pozostaje fakt, że została ona wypracowana $\mathrm{w}$ toku oceny porozumienia wertykalnego, zawartego między podmiotami działającymi na różnych szczeblach obrotu gospodarczego. W takich porozumieniach bardziej prawdopodobne (niż w porozumieniach horyzontalnych) jest takie ukształtowanie relacji między stronami, że jedna z nich pozostaje w zależności ekonomicznej od drugiej strony (np. producent - dystrybutor). Nawet jeśli nie można wykluczyć, że w porozumieniach horyzontalnych również możemy mieć do czynienia z przymusem uczestnictwa w zmowie (np. nieprzystąpienie do kartelu będzie skutkować eliminacją z rynku), to ze względu na charakter relacji stron (bezpośredni konkurenci) znacznie mniej prawdopodobnym jest, że taki przymus uzasadniałby dopuszczalność roszczeń wobec pozostałych uczestników porozumienia.

Niemniej jednak w odniesieniu do możliwości dochodzenia roszczeń przez samych uczestników porozumień, należałoby rekomendować powstrzymanie się ustawodawcy od wykluczenia możliwości dochodzenia roszczeń przez strony zakazanych porozumień.

150 P. Podrecki, Porozumienia monopolistyczne i ich cywilnoprawne skutki, ZNUJ - PWiOWI, z. 74, Zakamycze, Kraków 2000, s. 213.

151 Piszę o tym nieco szerzej w glosie do orzeczenia w sprawie Courage, opublikowanej [w:] A. Jurkowska, T. Skoczny (red.), Orzecznictwo sqdów wspólnotowych w sprawach konkurencji w latach 1964-2004, Oficyna a Wolters Kluwer business, Warszawa 2007, s. 698-706. 


\subsubsection{Konsumenci}

Obserwacja skutków antykonkurencyjnych praktyk prowadzi do wniosku, że w zdecydowanej większości przypadków, niezależnie od charakteru danej praktyki, jej negatywne skutki odczuwają konsumenci. Kryterium szkody dla konsumentów może być wręcz postrzegane jako wyznacznik istoty ograniczenia konkurencji 152 . W piśmiennictwie podkreśla się, że sytuacje, w których konsumenci są bezpośrednio poszkodowanymi (tj. wchodzą w bezpośrednie relacje z podmiotami naruszającymi zakazy praktyk ograniczających konkurencję) są stosunkowo rzadkie, częściej konsumenci występują w roli nabywców pośrednich. W przeciwieństwie jednak do przedsiębiorców usytuowanych na wyższych szczeblach obrotu gospodarczego konsumenci nie mają już możliwości transferowania (przerzucania) ewentualnych nadwyżek cenowych na inne podmioty, stąd sytuacja konsumentów jedynie częściowo pokrywa się z sytuacją nabywców pośrednich o statusie podmiotów profesjonalnych.

W polskim porządku prawnym definicję konsumenta można odnaleźć w samej ustawie o ochronie konkurencji i konsumentów, i mimo słuszności poglądu, że definicja ta znalazła się w ustawie ze względu na jej zakres przedmiotowy odnoszący się do ochrony konsumentów, to w kontekście prywatnego egzekwowania reguł konkurencji może ona mieć znaczenie również dla ochrony konkurencji. D. Miąsik właściwie zauważa, że „gdyby zakres przedmiotowy ustawy ograniczał się do przeciwdziałania praktykom ograniczającym konkurencję, definiowanie pojęcia konsumenta byłoby zbędne. $\mathrm{Z}$ ekonomicznego punktu widzenia konsumentami, których interesy chronione są na mocy przepisów ustawy, są bowiem wszystkie podmioty, które nabywają towary na rynku, niezależnie od ich przeznaczenia"153. Choć zgadzam się z tym stanowiskiem, to uważam, że konsumenci jako podmioty uprawnione do dochodzenia roszczeń z tytułu naruszenia zakazów antykonkurencyjnych praktyk wymagają rozważań nieco odrębnych od tych, które dotyczą nabywców profesjonalnych, chociażby ze względu na pewną „konsumocentryczność” inicjatyw Komisji Europejskiej - w dokumentach z zakresu polityki konkurencji opracowywanych przez Komisję Europejską zauważalna jest wręcz konsumencka perspektywa dla prywatnego egzekwowania zakazów praktyk ograniczających konkurencję ${ }^{154}$, przejawiająca się choćby w dążeniu do regulacji roszczeń zbiorowych.

152 Tak D. Miąsik, Własność intelektualna a szkoda dla konkurencji w prawie UE, Zeszyty CEN 2012, z. 25, s. 28.

153 D. Miąsik, [w:] T. Skoczny, A. Jurkowska, D. Miąsik (red.), Ustawa..., s. 262 (Nb 472).

154 Por. pkt 2.5. Zielonej księgi; pkt 27-42 White Paper Staff Working Paper. 
W polskim porządku prawnym wraz ze zniesieniem odrębnego postępowania w sprawach gospodarczych utracił natomiast aktualność argument, że sprawy z udziałem nabywców-konsumentów i nabywców na wyższych szczeblach obrotu gospodarczego są rozpatrywane z wykorzystaniem różnych rozwiązań proceduralnych.

Definicja konsumenta zawarta w art. 4 pkt 12 uokik ma charakter jedynie blankietowy - przepis odsyła bowiem do art. $22^{1} \mathrm{kc}$ ustanawiającego definicję uniwersalną zarówno dla prawa prywatnego, jak i publicznego (chyba, że w jakiejś regulacji przyjęta została odmienna definicja ${ }^{155}$ ). Elementami konstrukcyjnymi definicji konsumenta są: osoba fizyczna, czynność prawna, działalność gospodarcza i zawodowa, brak bezpośredniego związku czynności prawnej dokonywanej przez osobę fizyczną z działalnością gospodarczą i zawodową.

Jeśli chodzi o legitymację czynną konsumentów w sprawach z zakresu ochrony konkurencji, to naturalne wydają się wątpliwości co do tego, czy konsumenci są rzeczywiście uprawnieni do dochodzenia roszczeń związanych $\mathrm{z}$ naruszeniem reguł zachowań odnoszących się w istocie do relacji między przedsiębiorcami (podmiotami profesjonalnymi). Wątpliwości te należy jednoznacznie rozwiać, wskazując na źródła takich uprawnień konsumentów. Jednym z tych źródeł pozostaje cel współczesnego prawa ochrony konkurencji, za jaki w doktrynie i orzecznictwie uznaje się często zwiększenie poziomu dobrobytu konsumentów. Zakładając, że każde naruszenie reguł konkurencji co najmniej zagraża stagnacją poziomu dobrobytu konsumentów, jeśli nie prowadzi do jego obniżenia, należy przyjąć, że konsumenci mają prawo egzekwowania odpowiedniego poziomu swojego dobrobytu (czy inaczej: wyrównywania „uszczerbków” tego dobrobytu powodowanych antykonkurencyjnymi praktykami). Niektóre ustawodawstwa ustawiają wręcz w jednym szeregu ochronę konkurencji i ochronę konsumentów, a zagrożenie dla tego pierwszego celu utożsamiają z zagrożeniem dla celu drugiego ${ }^{156}$. Z taką sytuacją mamy do czynienia w Polsce (na co wskazuje

155 Jako przykład takiej odmiennej definicji D. Miąsik wskazał m.in. art. 1 ust. 1 ustawy z dnia 27 lipca 2002 r. o szczególnych warunkach sprzedaży konsumenckiej oraz o zmianie Kodeksu cywilnego (Dz. U. 2002 nr 41, poz. 1176 ze zm.) - por. D. Miąsik, [w:] T. Skoczny, A. Jurkowska, D. Miąsik (red.), Ustawa..., s. 264 (Nb 479).

$156 \mathrm{Na}$ ścisłe powiązania celów ochrony konkurencji i ochrony konsumentów wskazuje m.in. przyjęta z własnej inicjatywy opinia Europejskiego Komitetu Ekonomiczno-Społecznego w sprawie: Regulacja konkurencji a ochrona konsumentów, INT/280 CESE 949/2006 (Dz. Urz. UE 2006 C 309/1). Szerzej na temat konieczności włączenia interesów konsumentów w stosowanie reguł konkurencji pisze M. Ioannidou, Enhancing the Consumer's Role in EU Private competition Law Enforcement: A Normative and Practical Approach, The Competition Law Review 2011, vol. 8(1), s. 65-69. Można jednak odnotować poglądy 
sam tytuł ustawy), choć słusznie zauważa się, że o ile ustawowa regulacja ochrony konkurencji ma charakter kompleksowy, o tyle regulacja ochrony konsumentów - charakter fragmentaryczny ${ }^{157}$.

Za przyznaniem konsumentom legitymacji czynnej w sprawach dotyczących praktyk antykonkurencyjnych przemawiają również względy ochrony konsumentów sensu stricto - prawo dochodzenia odszkodowań może być traktowane jako realizacja praw ekonomicznych konsumentów ${ }^{158}$.

Wykluczenie konsumentów z kręgu uprawnionych do dochodzenia roszczeń z tytułu naruszenia zakazów praktyk ograniczających konkurencję stałoby w sprzeczności z podstawowymi zasadami odpowiedzialności deliktowej przyjętymi w europejskiej kulturze prawnej, głównie z regułą, że podmiot poszkodowany ma prawo żądania naprawienia wyrządzonej mu szkody 159 .

Ponadto $\mathrm{w}$ prawie unijnym legitymację czynną konsumentów w sprawach z zakresu ochrony konkurencji wywodzi się z zasady skuteczności wspólnych reguł konkurencji i z zasady bezpośredniego stosowania art. 101 i 102 TFUE160.

Możliwość dochodzenia roszczeń z tytułu naruszenia reguł konkurencji przez konsumentów może być wprost przewidziana w ustawodawstawie lub może ona wynikać z orzecznictwa. Za przykład może służyć dorobek orzecznictwa amerykańskiego: art. 4 Clayton Act stanowi, że uprawnienie do występowania z pozwami przysługuje podmiotom, które doznały szkody „W zakresie swojej działalności gospodarczej lub własności” (business or property) - Sąd Najwyższy w wyroku w sprawie Reiter v. Sonotone Corp. ${ }^{161}$ odczytał pojęcie „własności” bardzo szeroko, wskazując, że konsument naby-

krytyczne wobec wiązania ochrony konkurencji z ochroną konsumentów - por. m.in. O. Andriychuk, Can We Protect Competition Without Protecting Consumers?, The Competition Law Review 2009, vol. 6(1), s. 77-87.

157 Tak R. Janusz, M. Sachajko, T. Skoczny, Nowa ustawa o ochronie konkurencji i konsumentów, KPPubl. 2001, $\mathrm{nr} 3$.

158 Na ten aspekt włączenia konsumentów w prywatne egzekwowanie prawa ochrony konkurencji wskazał Europejski Komitet Ekonomiczno-Społeczny w pkt. 4.5. opinii w sprawie Zielonej księgi w sprawie roszczeń o odszkodowanie za stosowanie praktyk ograniczających konkurencję i nadużywanie pozycji dominującej, $\operatorname{COM(2005)} 672$ wersja ostateczna (Dz. Urz. UE 2006 C 324/01).

159 Por. U. Boge, K. Ost, Up and running or is it? Private enforcement - the situation in Germany and policy perspectives, E.C.L.R. 2006, vol. 27(4), s. 199-201. W polskiej literaturze tak: M. Bernatt w glosie do wyroku w sprawie Manfredi, [w:] A. Jurkowska-Gomułka (red.), Orzecznictwo sądów wspólnotowych w sprawach konkurencji w latach 2004-2009, Oficyna a Wolters Kluwer business, Warszawa 2010, s. 87; M. Sieradzka, Pozew grupowy..., s. 289-290.

160 Por. rozdział III, pkt 3.2.1.

161 Reiter v. Sonotone Corp., 442 U.S. 330, 343-344 (1979). 
wający towary, dla których ustalano ceny odsprzedaży, doznał szkody w swojej własności, któremu to pojęciu należy nadać szerokie znaczenie (naturally broad and inclusive meaning). W wyroku w sprawie Reiter Sąd wykluczył z pojęcia własności jedynie szkody osobowe doznane przez konsumenta.

W orzecznictwie unijnym możliwość dochodzenia roszczeń przez konsumentów została potwierdzona w wyroku Trybunału Sprawiedliwości w sprawie Manfredi. Nie jest mi natomiast znany żaden przypadek dochodzenia roszczeń przez konsumentów w polskim orzecznictwie w obszarze prywatnego egzekwowania prawa ochrony konkurencji.

Orzecznictwo przyznające konsumentom legitymację czynną w zakresie dochodzenia roszczeń z tytułu naruszenia zakazów antykonkurencyjnych praktyk spotkało się jak dotąd z przychylnym przyjęciem w doktrynie. Prawa konsumentów do dochodzenia roszczeń nie są kwestionowane, mimo ich statusu pośrednich nabywców; często natomiast wskazuje się na wynikające $\mathrm{z}$ tego statusu trudności w korzystaniu ze ścieżki sądowej162. Konsumenci są o tyle specyficzną grupą legitymowaną czynnie do dochodzenia roszczeń z tytułu naruszenia zakazów praktyk ograniczających konkurencję, że jak się wydaje - w sprawach z powództwa konsumentów jak w soczewce będą koncentrować się najistotniejsze problemy prywatnego egzekwowania reguł konkurencji, takie jak: trudności w dowodzeniu naruszeń czy trudności w oszacowaniu szkody. Doświadczenia orzecznicze państw członkowskich UE dowodzą, że konsumenci są aktywni w dochodzeniu roszczeń głównie na podstawie pozwów następczych i to przede wszystkim wówczas, gdy w decyzji organu ochrony konkurencji wskazano szacunkową wartość szkody (tak zdarzyło się w decyzji włoskiego organu ochrony konkurencji, która stała się bazą dla wyroku w sprawie Manfredi - w decyzji stwierdzającej istnienie kartelu ubezpieczeniowego uznano, że średnia nadwyżka cenowa (nadpłata) w związku z funkcjonowaniem kartelu wyniosła ok. 20 EUR).

Koszty dochodzenia roszczeń przez konsumentów w porównaniu do wymiaru szkody są na tyle znaczące, że inicjowanie postępowania sądowego jest w wielu indywidualnych przypadkach po prostu nieopłacalne, ponieważ szkody konsumenckie mają często niską wartość163. Dlatego też

162 Tak w polskim piśmiennictwie m.in. M. Sieradzka, Pozew grupowy..., s. 293.

163 Szkody konsumentów powstałe w wyniku funkcjonowania karteli określa się jako „szkody rozproszone” (scattered damages) lub „szkody masowe” (mass damages) - por. B. Cupa, Scattered Damages: A comparative Law Study About the Enforcement Deficit of Low-Value Damages and the Class Action Approach, ERPL 2012, vol. 2, s. 513-514. Na problem dysproporcji między wielkością szkody a kosztami dochodzenia odszkodowania zwraca uwagę w polskim piśmiennictwie m.in. B. Nowak-Chrząszczyk, Roszczenie odszkodowawcze $w$ postępowaniu $w$ sprawie o naruszenie wspólnotowego prawa konkurencji, [w:] 
jednym z warunków efektywnego korzystania przez konsumentów z legitymacji czynnej w sprawach naruszenia zakazów antykonkurencyjnych praktyk jest funkcjonowanie regulacji ustanawiającej mechanizmy zbiorowego dochodzenia roszczeń (będą one przedmiotem rozważań poniżej).

\subsubsection{Inne podmioty}

\subsection{Udziałowcy (akcjonariusze)}

Wskazując na udziałowców (akcjonariuszy) jako potencjalnych powodów w sprawach z zakresu ochrony konkurencji, należy rozróżnić ich dwie kategorie: pierwszą stanowią udziałowcy przedsiębiorcy, który jest ofiarą praktyk antykonkurencyjnych, drugą - udziałowcy przedsiębiorcy, który sam dopuścił się antykonkurencyjnych praktyk (byłoby to zatem roszczenie skierowane przeciwko „własnej” spółce). W każdym ze wskazanych przypadków udziałowcy mogliby domagać się naprawienia szkody odczuwalnej przez nich w postaci zmniejszenia zysków przedsiębiorcy, a poniesionej wskutek pogorszenia pozycji rynkowej w pierwszym przypadku, i konieczności poniesienia sankcji publicznych i prywatnych, zwłaszcza o charakterze pieniężnym, w drugim przypadku. Szkodą może być również utrata przez spółkę możliwości biznesowych stanowiąca pochodną zaangażowania w praktyki ograniczające konkurencję, zwłaszcza kartele ${ }^{164}$.

W obydwu wskazanych powyżej sytuacjach udziałowcy będą dowodzić, że osoby zarządzające spółką (w rozumieniu funkcjonalnym) nie dopełniły swoich obowiązków nadzorczych i/lub kontrolnych wskutek czego nie zapobiegły naruszeniu reguł konkurencji. Zarzut kierowany wobec decydentów spółki może dotyczyć np. niewdrożenia lub niewłaściwego wdrożenia programu zgodności (compliance programme); z drugiej strony istnienie takiego programu w spółce może być istotnym kontrzarzutem uniemożliwiającym udziałowcom skuteczne dochodzenie roszczeń. Podobnie w przypadku roszczeń kierowanych przeciw własnej spółce, kontrzarzutem może być wykazanie, że domniemaną szkodę przewyższają zyski stanowiące wynik antykonkurencyjnej praktyki.

Jeśli chodzi o udziałowców przedsiębiorców, których funkcjonowanie zostało zakłócone wskutek antykonkurencyjnego zachowania innych podmiotów, to wypracowany w orzecznictwie amerykańskim w początkach XX wieku

E. Piontek (red.), Nowe tendencje w prawie konkurencji UE, Oficyna a Wolters Kluwer business, Warszawa 2008, s. 396.

164 S. Ezaki, K. Uemura, Shareholder actions in antitrust cases in Japan, G.C.L.R. 2008, vol. 1(3), s. 121. 
(1910 r.) tzw. test bezpośredniej szkody (direct injury test) wykluczał możliwość dochodzenia przez nich roszczeń. W sprawie Loeb v. Eastman Kodak Co. ${ }^{165}$ sąd (Third Circuit) odmówił prawa do występowania z roszczeniem $\mathrm{z}$ tytułu naruszenia reguł konkurencji przez udziałowca jednej z korporacji, będącej ofiarą praktyk antykonkurencyjnych, twierdząc, że szkoda, której doznał akcjonariusz miała charakter „pośredni (indirect), odległy (remote) i wynikowy (consequential)", natomiast bezpośrednio poszkodowaną (tj. posiadającą legitymację czynną) była sama korporacja. Sąd uznał, że zgoda na występowanie $\mathrm{z}$ roszczeniami przez wszystkich akcjonariuszy doprowadziłaby do sytuacji, w której znacząca liczba pozwów wykazywałaby niższą efektywność ekonomiczną niż pojedynczy pozew wniesiony przez samą korporację. Podobne rozwiązanie sądy amerykańskie przyjęły także w odniesieniu do wierzycieli korporacji166. Testowi bezpośredniej szkody przyznaje się obecnie znaczenie co najwyżej historyczne ${ }^{167}$, został on bowiem przełamany w wyrokach w sprawach $M c C r e a d y$ i $A G C$ przez tzw. test wieloczynnikowy 168 .

Echa testu bezpośredniej szkody odnaleźć można także w orzecznictwie brytyjskim, które, hołdując zasadzie „szkody odzwierciedlonej” (reflective loss rule) odmawiało udziałowcom legitymacji czynnej w zakresie dochodzenia roszczeń z tytułu szkód poniesionych przez spółkę w wyniku naruszenia prawa (w tym reguł konkurencji). Zgodnie ze stanowiskiem orzeczniczym wyrażonym w wyrokach: Prudential Insurance Co. Ltd. v. Newman Industries Ltd. ${ }^{169}$, Johnson v. Gore Wood \& Co. ${ }^{170}$ i Gardner v. Parker ${ }^{171}$ udziałowiec może żądać naprawienia szkody wówczas, gdy spółka nie posiada legitymacji czynnej do dochodzenia roszczeń bądź wtedy, gdy udziałowcowi przysługuje odrębne (od posiadanego przez spółkę) uprawnienie dochodzenia roszczeń, a szkoda poniesiona przez udziałowca jest szkodą odrębną od tej, której doznała spółka172.

Należy mieć na uwadze, że nawet jeśli prawo wewnętrzne państw członkowskich UE nie przewidywałoby możliwości dochodzenia roszczeń przez udziałowców w przypadku naruszenia krajowych reguł konkurencji, to nie-

165 Loeb v. Eastman Kodak Co. 183 F 704 (3d Cir. 1910).

166 Gerli v. Silk Association of America, 36 F 2d 956 (1929).

167 C. A. Jones, Private enforcement..., s. 160.

168 Por. pkt 4.3.2.1. w niniejszym rozdziale.

169 [1982] 1 Ch 204.

170 [2001] 1 All ER 481.

171 [2002] 2 AC 1.

172 P. Hughes, The Enforcement of Private Actions for Breaches of EC Competition Law The Role of the Shareholder under English Law, The Competition Law Review 2006, vol. 3(1), s. 84-85. 
zbędne jest umożliwienie występowania przez udziałowców z roszczeniami wówczas, gdy naruszenie dotyczyłoby art. 101 lub 102 TFUE. Pośrednio przyznanie udziałowcom prawa dochodzenia roszczeń w związku z naruszeniem interesów spółek, w które udziałowcy są zaangażowani, nastąpiło poprzez wyroki w takich sprawach, jak: Brasserie de Pecheur ${ }^{173}$ oraz C-221/89 Factortame ${ }^{174}$.

W odniesieniu do udziałowców (zwłaszcza akcjonariuszy) aktualność wydaje się zachowywać znaczna część trudności, jakie stoją przed konsumentami zainteresowanymi dochodzeniem roszczeń z tytułu naruszenia reguł konkurencji, w tym m.in. relacja kosztów postępowania do spodziewanych wyników. Z tego względu akcjonariusze mogą być kolejną - po konsumentach - grupą, która szczególnie intensywnie będzie korzystać z instytucji pozwów grupowych ${ }^{175}$.

\subsection{Państwa (rządy)}

Możliwość występowania z roszczeniami (zwłaszcza odszkodowawczymi) przez państwo (instytucje stanowiące jego emanację) należy oceniać w dwóch aspektach. W pierwszym $\mathrm{z}$ nich roszczenia miałyby wiązać się $\mathrm{z}$ naruszeniami prawa ochrony konkurencji dotykającymi ogólny interes gospodarczy państwa - w takich przypadkach należy odmówić państwu legitymacji czynnej do występowania z roszczeniami, nie tylko dlatego że możliwość oszacowania szkody dla ogólnego interesu gospodarczego państwa wydaje się bardzo ograniczona, ale przede wszystkim dlatego że funkcję ochrony tego interesu, który może być utożsamiany z zapewnieniem warunków dla niezakłóconego działania konkurencji, realizuje w zasadzie publiczny tryb egzekwowania reguł konkurencji. Amerykański sąd najwyższy wykluczył możliwość występowania $\mathrm{w}$ takim aspekcie $\mathrm{z}$ roszczeniami odszkodowawczymi przez państwo (stan) ${ }^{176}$, argumentując, że sytuacja taka nie może być kwalifikowana jako szkoda w zakresie działalności gospodarczej lub własności w rozumieniu sekcji 4 Clayton Act. Sąd słusznie argumentował, że przyznanie państwu odszkodowania oznaczałoby duplikowanie roszczeń zrealizowanych wobec jednostek (podmiotów prywatnych) również występujących z roszczeniami wobec naruszyciela. Jednocześnie orzecznictwo przyznało amerykańskim stanom prawo do występowania o zastosowanie

173 C-46/93 i 48/93 Brasserie du Pecheur SA v. Bundesrepublik Deutschland (Zb. Orz. 1996, s. I-1029).

174 C-221/89 Queen v. Secretary of State for Transport, ex parte Factortame Limited (Zb. Orz. 1991, s. I-3095). Por. P. Hughes, The Enforcement of Private Actions..., s. 76-78.

175 Por. pkt 4.3.3. w niniejszym rozdziale.

176 Hawaii v. Standard Oil Co., 405 US 251, 264 (1972). 
środków tymczasowych w sytuacji, gdy naruszenia prawa antymonopolowego zagrażałyby szkodą dla gospodarki stanowej177. Stanowisko takie nie zasługuje jednak na aprobatę $\mathrm{z}$ tych samych przyczyn, dla których należy odrzucić możliwość dochodzenia roszczeń przez państwa - ochrona ogólnego interesu gospodarczego państwa powinna odbywać się w trybie publicznego egzekwowania reguł konkurencji.

Drugi aspekt, w jakim państwo może dochodzić roszczeń z tytułu naruszenia reguł konkurencji, związany jest $\mathrm{z}$ występowaniem instytucji państwowych w roli nabywców towarów i usług. W takiej sytuacji państwu należy przypisać status podmiotu legitymowanego czynnie w sprawach z zakresu antykonkurencyjnych praktyk. Znakomity przykład w tym zakresie dała sama Unia Europejska, pozywając producentów wind, które administracja unijna zakupiła do remontowanej siedziby Komisji - producenci uczestniczyli w kartelu, wykrytym przez Dyrekcję Generalną ds. Konkurencji. Pozwani podnosili co prawda przed sądem, że dwoistość funkcji realizowanych przez Komisję (która reprezentowała Unię przed sądem krajowym), polegająca $\mathrm{z}$ jednej strony na wydaniu decyzji kartelowej wiążącej sąd, a z drugiej - na dochodzeniu roszczeń związanych ze stwierdzonym naruszeniem, narusza art. $47 \mathrm{KPP}$ i art. 6 EKPC, jednak TS w swoim wyroku nie dał wiary tym argumentom ${ }^{178}$. Trybunał uznał, że system sądowej kontroli decyzji w sprawach praktyk ograniczających konkurencję gwarantuje prawidłowość rozstrzygnięć wydawanych przez Komisję (także z punktu widzenia bezstronności) ${ }^{179}$. Ponadto Trybunał podkreślił, że w przedmiotowej sprawie nie doszło do naruszenia równości broni, ponieważ przygotowując pozew Komisja korzystała $\mathrm{z}$ informacji ujawnionych w publicznie dostępnej wersji decyzji w sprawie kartelu windowego, zaś sam pozew został przygotowany przez te służby Komisji, które nie mają dostępu do akt gromadzonych przez Dyrekcję Generalną ds. Konkurencji180. Podzielam stanowisko rzecznika generalnego Pedra Cruza Villalóna, zgodnie z którym „prawo dostępu do sądownictwa powszechnego organów administracji publicznej stanowi istotny postęp w umacnianiu państwa prawa, w ramach którego organy publiczne stopniowo tracą uprawnienia do zapewnienia sobie własnej ochrony i przekazują obronę swych praw sądom"181.

177 Por. m.in. Georgia v. Pennsylvania R. Co., 324 US 439 (1945); Burch v. Goodyear Tire \& Rubber Co., $554 \mathrm{~F} 2 \mathrm{~d} 633$ (4th Cir. 1977).

178 Wyrok Trybunału z dnia 6 listopada 2012 r. w sprawie C-199/11 Europese Gemeenschap v Otis NV i inni (niepubl.); dalej jako wyrok w sprawie Otis.

179 Pkt 53-64 wyroku w sprawie Otis.

180 Pkt 70 wyroku w sprawie Otis.

181 Pkt 41 opinii w sprawie C-199/11 Otis, przedstawionej w dniu 26 czerwca 2012 r. 


\subsubsection{Pozwy zbiorowe jako szczególna forma realizacji interesu prywatnego}

\subsubsection{Istota pozwów zbiorowych w kontekście prywatnego egzekwowania prawa konkurencji}

Interes prywatny podmiotów poszkodowanych wskutek praktyk ograniczających konkurencję może być realizowany zarówno indywidualnie, jak i zbiorowo (wspólnie, grupowo). Działania wspólne mogą przyjąć postać powództw reprezentacyjnych lub powództw zbiorowych. Powództwa reprezentacyjne (powództwo reprezentacji wspólnych interesów; collective lub representative actions) wytaczane są przez uprawnione podmioty, takie jak stowarzyszenia konsumentów, organy państwowe lub zrzeszenia branżowe, na rzecz grupy określonych lub możliwych do ustalenia osób ${ }^{182}$. Powództwa zbiorowe (class actions), określane także jako powództwa grupowe, pozwalają łączyć w ramach jednego postępowania sądowego rozpatrywanie takich samych lub co najmniej bardzo zbliżonych roszczeń, opartych na tych samych podstawach (wspólnych przesłankach). O ile powództwa (pozwy) zbiorowe realizują - w moim przekonaniu - interes stricte prywatny, o tyle powództwa reprezentacyjne stanowią w swej istocie realizację interesu publicznego i z tego powodu jedynie pośrednio przyczyniają się do prywatnego egzekwowania reguł konkurencji (jeśli założyć, że tryb ten ma na celu realizację prywatnych interesów); podobnie zresztą należałoby oceniać rozwiązania prawne przewidujące obligatoryjne przystępowanie do grupy wszystkich podmiotów poszkodowanych (a zamierzających występować z roszczeniami) z tytułu konkretnej praktyki ograniczającej konkurencję ${ }^{183}$.

Instytucja powództw zbiorowych kształtowana jest w różny sposób - jej praktyczne wykorzystanie może doznawać ograniczeń podmiotowych lub przedmiotowych. Co do pierwszych ograniczeń - niektóre ustawodawstwa przewidują prawo występowania z pozwami zbiorowymi tylko dla określonych instytucji (np. rzecznik konsumentów) lub określonych grup podmiotów (np. konsumenci). Jeśli chodzi o sposób formowania grupy, powództwa zbiorowe mogą być ukształtowane w modelu opt-in lub opt-out. Pierwszy

182 Pkt 5.3. Opinii Europejskiego Komitetu Ekonomiczno-Społecznego w sprawie definicji roli i systemu powództw zbiorowych w dziedzinie wspólnotowego prawa konsumenckiego (Dz. Urz. UE 2008 C 162/1).

183 Za takim rozwiązaniem jako środkiem wzmacniającym zarówno funkcje kompensacyjne, jak i odstraszające prywatnego egzekwowania reguł konkurencji - a dzięki temu koordynującym publiczne i prywatne egzekwowanie reguł konkurencji - opowiedzieli się D. Rosenberg, J. P. Sullivan, Coordinating Private Class Action and Public Agency Enforcement of Antitrust Law, The Harvard John M. Olin Discussion Paper Series (No. 523), 08/2005, s. 19-28. 
z modeli zakłada, że uczestnictwo w postępowaniu grupowym odbywa się na podstawie wyraźnego oświadczenia o wejściu do grupy, drugi model przewiduje natomiast, że skutki orzeczenia sądowego obejmują wszystkie abstrakcyjnie określone podmioty, które nie złożą wyraźnej deklaracji o wystąpieniu z grupy ${ }^{184}$. Ograniczenia przedmiotowe polegają natomiast na tym, że pozwy zbiorowe mogą być wnoszone tylko w określonych sprawach (np. z zakresu ochrony środowiska, ochrony inwestorów itp.).

Powództwa zbiorowe stanowią element racjonalizacji ekonomii wymiaru sprawiedliwości, w tym kontekście są one postrzegane często jako ułatwienie prywatnego egzekwowania prawa ochrony konkurencji, między innymi z tego względu rozwijają się w ostatnich latach dość dynamicznie w Europie ${ }^{185}$. Rozwój mechanizmów powództw zbiorowych nie jest jednak pozbawiony trudności związanych głównie $\mathrm{z}$ adaptacją filozofii powództw zbiorowych, wywodzących się z kultury prawnej systemu common law, w systemach prawnych Europy kontynentalnej.

Europejska praktyka stosowania pozwów zbiorowych potwierdza, że są one wykorzystywane bardzo często w sprawach, gdzie wartość szkody jest na tyle niska, że indywidualnemu poszkodowanemu nie opłacałoby się wstępować na drogę sądową 186 .

Rozważając problematykę wykorzystania pozwów zbiorowych jako instrumentu egzekwowania zakazów antykonkurencyjnych praktyk, należy odnotować istnienie trzech stanowisk odnoszących się do zasadności korzystania z pozwów zbiorowych w sprawach z zakresu ochrony konkurencji. Stanowisko pierwsze, zdecydowanie dominujące $w$ doktrynie, zachęca do korzystania $z$ tego instrumentu ${ }^{187}$. Stanowisko drugie uznaje pozwy grupowe za przydatne instrumenty prywatnego egzekwowania reguł konkurencji, ale jednocześnie wskazuje na konieczność przyjęcia odrębnych regulacji tego instrumentu, właściwych tylko dla roszczeń wynikających z prawa ochrony

184 Przegląd wad i zalet systemu opt-in oraz opt-out przedstawiony jest wyczerpująco w pkt. 7.1 opinii EKES.

185 Odpowiednie regulacje przyjęte zostały w ostatnich latach m.in. w: Niemczech, Szwecji, Włoszech, Holandii.

186 Por. C. J. Cook, Private Enforcement of EU Competition Law in Member State Courts: Experience to Date and the Path Ahead, Competition Policy International 2008, vol. 4(2), s. 12-15 i opisywane tam przykłady dochodzenia roszczeń grupowych w krajach członkowskich UE.

$187 \mathrm{~W}$ polskim piśmiennictwie zwolenniczką wykorzystywania pozwów zbiorowych w sprawach z obszaru ochrony konkurencji wydaje się być M. Sieradzka, Pozew grupowy..., op. cit. Por. także C. Banasiński, E. Piontek (red.), Ustawa..., s. 22 (Komentarz do art. 1, teza 10). W piśmiennictwie obcym por. m.in.: R. Nazzini, A. Nikpay, Private Actions in EC Competition Law, Competition Policy International 2008, vol. 4(2), s. 120-124. 
konkurencji ${ }^{188}$. Wreszcie, można zidentyfikować i głosy negujące konieczność wprowadzania pozwów zbiorowych w celu zintensyfikowania prywatnego trybu egzekwowania reguł konkurencji ${ }^{189}$.

\subsubsection{Pozwy zbiorowe w inicjatywach legislacyjnych Unii Europejskiej}

Wsparcie dla instytucji pozwów zbiorowych pochodzi także od instytucji Unii Europejskiej, czego dowodzi m.in. wydana w 2008 r. przez Komisję Europejską zielona księga w sprawie dochodzenia zbiorowych roszczeń konsumentów 190 (przy czym KE zastrzegła, że ze względu na odrębność prawa ochrony konkurencji oraz szerokie grono poszkodowanych wskutek naruszenia zakazu praktyk ograniczających konkurencję, Zielona księga nie obejmowała kwestii odszkodowań zbiorowych dla osób poszkodowanych w wyniku naruszenia prawa ochrony konkurencji UE ${ }^{191}$ ). Problem grupowego dochodzenia roszczeń w kontekście reguł konkurencji podniesiony został także w białej księdze w sprawie roszczeń o naprawienie szkody wynikłej z naruszenia wspólnotowego prawa ochrony konkurencji192, gdzie Komisja wyraźnie wskazała na konieczność stworzenia systemów dochodzenia roszczeń zbiorowych, proponując jednocześnie dwa modele ${ }^{193}$ : powództw reprezentacyjnych i powództw zbiorowych. Komisja uznała przy tym, że „oba rodzaje powództw muszą się wzajemnie uzupełniać, tak aby zapewnić skuteczność zbiorowych roszczeń osób poszkodowanych wskutek naruszenia prawa ochrony konkurencji”. Za koniecznością regulacji powództw zbiorowych na poziomie UE opowiedział się także Europejski Komitet Ekonomiczno-Społeczny ${ }^{194}$, wskazując, że nie powinny to być powództwa typu class action, gdyż ich stosowanie w państwach członkowskich UE prowadziłoby do nadużyć. Początkowo zatem, jak się wydaje, Komisja dążyła do realizacji koncepcji wypracowania odrębnych systemów grupowego dochodzenia

188 M. Ioannidou, Enhancing the Consumer's Role..., s. 84.

189 Por. stanowisko Polskiej Konfederacji Pracodawców Prywatnych „Lewiatan” wyrażone w toku konsultacji dokumentu „W kierunku spójnego europejskiego podejścia do roszczeń zbiorowych" (dokument dostępny pod adresem: http://ec.europa.eu/competition/consultations/2011_collective_redress/lewiatan_en.pdf). W stanowisku tym czytamy, że: „prywatne egzekwowanie (reguł konkurencji - przyp. aut.) nie potrzebuje środków w postaci pozwów zbiorowych, aby zagwarantować prawa podstawowe obywateli europejskich" (s. 4).

$190 \operatorname{KOM(2008)} 794$ wersja ostateczna, Bruksela, dnia 27.11.2008 r.

191 Zob. pkt 5 zielonej księgi w sprawie dochodzenia zbiorowych roszczeń konsumentów.

$192 \mathrm{KOM}(2008) 165$ wersja ostateczna, Bruksela, dnia 2.4.2008 r.

193 Zob. pkt 2.1. Białej księgi.

194 Pkt 7.1.2.1. opinii EKES. 
roszczeń dla roszczeń związanych z naruszeniem reguł konkurencji i innych. Przeznaczony do konsultacji społecznych dokument „W kierunku spójnego europejskiego podejścia do roszczeń zbiorowych”, upubliczniony w dniu 4 lutego 2011 r. ${ }^{195}$, wskazuje jednak na wątpliwości Komisji co do wdrażania koncepcji dwutorowych rozwiązań w zakresie roszczeń zbiorowych.

W kontekście rozważań nad modelem wspólistnienia prywatnego i publicznego modelu egzekwowania reguł konkurencji na uwagę zasługują wyniki konsultacji społecznych w zakresie odpowiedzi na pytanie 2 i 3 wskazanego powyżej dokumentu Komisji - obydwa te pytania dotyczyły różnych aspektów wzajemnych zależności między prywatnym dochodzeniem roszczeń odszkodowawczych i działaniem organów publicznych ${ }^{196}$. Większość uczestników konsultacji (zarówno uczestnicy o statusie organów publicznych, jak i przedstawiciele biznesu oraz organizacje konsumenckie ${ }^{197}$ ) wskazała, że prywatny i publiczny tryb egzekwowania przepisów prawnych powinien być od siebie niezależny, jednocześnie zaś istnieje potrzeba koordynacji grupowego dochodzenia roszczeń oraz publicznego egzekwowania prawa ${ }^{198}$. Ci sami uczestnicy zwykle wskazywali na potrzebę zapewnienia komplementarności obydwu trybów i synergii między nimi. Tylko jedna instytucja publiczna wskazała na priorytetowy charakter publicznego trybu egzekwowania prawa w stosunku do prywatnego dochodzenia roszczeń. Uczestnicy konsultacji ze sfer biznesowych podkreślali natomiast, że grupowe dochodzenie roszczeń

195 SEC(2011) 173 wersja ostateczna. Konsultacje w sprawie roszczeń zbiorowych zakończyły się w dniu 30 kwietnia 2011 r. Zestawienie i opracowanie opinii zebranych w procesie konsultacji zawarte jest $\mathrm{w}$ dokumencie przygotowanym przez zespół pracowników z Uniwersytetu w Heidelbergu: B. Hess, T. Pfeiffer, M. Mertens, L. Sabanogullari, Evaluation of contributions to the public consultation and hearing: „Towards a Coherent European Approach to Collective Redress”, Study JUST/2010/JCIV/CT/0027/A4, 2011 (dokument dostępny pod adresem: http://ec.europa.eu/competition/consultations/2011_collective_ redress/study_heidelberg_overview_en.pdf).

196 Pytanie 2 brzmiało: „Czy dochodzenie prywatnych roszczeń odszkodowawczych powinno mieć charakter niezależny, uzupełniający lub subsydiarny w stosunku do egzekucji przez organy publiczne? Czy zachodzi potrzeba koordynacji między prywatnym dochodzeniem roszczeń odszkodowawczych i publiczną egzekucją? Jeśli tak, to w jaki sposób zapewnić taką koordynację?(...)".

Pytanie 3 brzmiało: „Czy UE powinna wzmocnić rolę krajowych organów publicznych lub prywatnych organizacji przedstawicielskich w egzekwowaniu prawa UE? Jeśli tak, w jaki sposób i w jakich dziedzinach należy tego dokonać?".

197 B. Hess, T. Pfeiffer, M. Mertens, L. Sabanogullari, Evaluation of contributions..., s. 5-6 (organy publiczne), s. 18-19 (biznes), s. 29-30 (organizacje konsumenckie).

198 Takie stanowisko zajęło w swojej opinii również polskie Ministerstwo Sprawiedliwości (dokument dostępny pod adresem: http://ec.europa.eu/competition/consultations/2011_ collective_redress/ministry_of_justice_poland_pl.pdf, s. 2). 
powinno mieć charakter subsydiarny wobec interwencji publicznej ${ }^{199}$; z kolei kilka organizacji konsumenckich opowiedziało się przeciwko charakterowi subsydiarnemu grupowego dochodzenia roszczeń, o ile należy je rozumieć jako ograniczenie możliwości prywatnego egzekwowania prawa do roszczeń następczych ${ }^{200}$. Jednocześnie instytucje publiczne wskazywały z reguły na konieczność wzmocnienia roli publicznych i prywatnych organizacji przedstawicielskich, zwłaszcza w dziedzinie prawa konkurencji i prawa konsumenckiego, podczas gdy uczestnicy konsultacji reprezentujący biznes nie widzą potrzeby wzmacniania organizacji ani jednego, ani drugiego typu.

\subsubsection{Możliwość zbiorowego dochodzenia roszczeń z tytułu naruszenia zakazów antykonkurencyjnych praktyk w Polsce}

Mimo braku unijnych rozwiązań w zakresie zbiorowego dochodzenia roszczeń, polski ustawodawca zdecydował o wprowadzeniu takiego rozwiązania, stąd niezbędne jest zwrócenie uwagi na rolę, jaką regulacja ta może odgrywać w realizacji interesów prywatnych w sytuacji naruszenia zakazów antykonkurencyjnych praktyk.

Polska ustawa o dochodzeniu roszczeń w postępowaniu grupowym ${ }^{201}$ została przyjęta - po dość burzliwej debacie - w dniu 17 grudnia 2009 r., weszła w życie w dniu 19 lipca 2010 r. Polski ustawodawca zdecydował się na przyjęcie stosunkowo pojemnego modelu powództw zbiorowych, opartego na zasadzie opt-in: zakres podmiotowy grup nie został w żaden sposób ograniczony, zakres przedmiotowy zaś - choć formalnie limitowany - w praktyce pozostaje jednak bardzo szeroki, co zresztą stanowi przedmiot krytyki ${ }^{202}$.

Ustawa daje możliwość dochodzenia w postępowaniu zbiorowym roszczeń o ochronę konsumentów, roszczeń z tytułu odpowiedzialności za szkodę wyrządzoną przez produkt niebezpieczny oraz $\mathrm{z}$ tytułu czynów niedozwolonych, z wyjątkiem roszczeń o ochronę dóbr osobistych (art. 1 ust. 2). $\mathrm{Z}$ perspektywy dochodzenia roszczeń $\mathrm{w}$ związku $\mathrm{z}$ naruszeniem zakazów antykonkurencyjnych praktyk istotne znaczenie ma wskazanie przez ustawodawcę - jako potencjalnego przedmiotu roszczeń - roszczeń o ochronę

199 Należy odnotować, że Związek Banków Polskich opowiedział się w swoim stanowisku za „równoważnością” publicznego i prywatnego dochodzenia roszczeń zbiorowych (dokument dostępny pod adresem: http://ec.europa.eu/competition/consultations/2011_collective_redress/polish_bank_association_en.pdf).

200 B. Hess, T. Pfeiffer, M. Mertens, L. Sabanogullari, Evaluation of contributions..., s. 29.

201 Ustawa z dnia 17 grudnia 2009 r. o dochodzeniu roszczeń w postępowaniu grupowym (Dz. U. $2010 \mathrm{Nr}$ 7, poz. 44), dalej: ustawa o pozwach zbiorowych.

202 Opinia Polskiej Konfederacji Pracodawców Prywatnych „Lewiatan” w sprawie rządowego projektu ustawy o dochodzeniu roszczeń w postępowaniu grupowym (druk 1829), s. 1. 
konsumentów oraz roszczeń z tytułu czynów niedozwolonych. Jeśli chodzi o te ostatnie, to naruszenie zakazu praktyk ograniczających konkurencję może stanowić czyn niedozwolony w rozumieniu art. 415 Kodeksu cywilnego ${ }^{203}$, co automatycznie daje poszkodowanym wskutek takich praktyk możliwości występowania o zaspokojenie roszczeń w ramach postępowania grupowego, przy czym poszkodowanymi w tym wypadku niekoniecznie muszą być konsumenci (mogą to być inne podmioty, zgodnie ze wskazaniami poczynionymi w rozważaniach prowadzonych w niniejszym rozdziale). Dla zdefiniowania roszczeń o ochronę konsumentów niezbędne jest (mimo że nie robi tego sam ustawodawca) odwołanie się do art. $61 \S 1 \mathrm{kpc}$ (sprawy o ochronę konsumentów), art. $63^{3}$ kpc (spraw o ochronę interesów konsumentów) oraz art. $87 \S 5 \mathrm{kpc}$ (sprawy związane z ochroną praw konsumentów) ${ }^{204}$. Sprawami o ochronę konsumentów są wszystkie sprawy dotyczące roszczeń konsumentów przeciwko przedsiębiorcom, wynikające z różnych podstaw, a zatem również z naruszenia art. 6 lub 9 uokik bądź art. 101 lub 102 TFUE. Dla rozumienia pojęcia konsumenta na gruncie art. 1 ust. 2 ustawy o pozwach zbiorowych kluczowe znaczenie ma definicja konsumenta $\mathrm{z}$ art. $22^{1} \mathrm{kc}$, przypisująca status konsumenta wyłącznie osobom fizycznym. Jednocześnie należy odnotować pogląd, że w sprawach o ochronę konsumentów w postępowaniu grupowym po stronie powodowej niekoniecznie muszą występować konsumenci - w postępowaniu może występować rzecznik konsumentów jako reprezentant grupy ${ }^{205}$. Mimo że rzecznik konsumentów jest organem publicznym, to jego uczestnictwa w postępowaniu grupowym nie należy, w moim przekonaniu, postrzegać jako przejawu publicznego trybu egzekwowania reguł konkurencji.

Konsekwencją takiego ukształtowania zakresu roszczeń przeznaczonych do dochodzenia w postępowaniu grupowym (przy zastrzeżeniu, że w świetle art. 1 ust. 1 ustawa dopuszcza uczestnictwo w postępowaniu grupowym dla osób, których roszczenia są ,jednego rodzaju” i oparte na „tej samej lub

203 Por. rozdział VII, pkt 7.7.3. Za możliwością dochodzenia roszczeń z tytułu naruszenia zakazów antykonkurencyjnych praktyk jako roszczeń z tytułu czynów niedozwolonych w ramach postępowań grupowych opowiadają się komentatorzy ustawy o pozwach zbiorowych - por. T. Jaworski, P. Radzimierski, Ustawa o dochodzeniu roszczeń w postępowaniu grupowym. Komentarz, C. H. Beck, Warszawa 2010, s. 90-91 (Nb 191); M. Sieradzka, Ustawa o dochodzeniu roszczeń w postępowaniu grupowym. Komentarz, Oficyna a Wolters Kluwer business, Warszawa 2010, s. 90-13; M. Rejdak, P. Pietkiewicz, Ustawa o dochodzeniu roszczeń $w$ postępowaniu grupowym. Komentarz, LexPolonica 2011 (Komentarz do art. 1, Nb 46-48). Aprobujące stanowisko w tej kwestii wyraziła również A. Piszcz, Wybrane problemy..., s. 558-559.

204 Tak T. Jaworski, P. Radzimierski, Ustawa..., s. 73 (Nb 150).

205 T. Jaworski, P. Radzimierski, Ustawa..., s. 75 (Nb 159). 
takiej samej podstawie faktycznej”) jest to, że uczestnikiem postępowania zbiorowego mogą być osoby fizyczne, osoby prawne, a także jednostki nie posiadające osobowości prawnej (ułomne osoby prawne). Tak szeroki zakres podmiotowy spotkał się z uzasadnioną krytyką ze strony niektórych prawników opiniujących ustawę oraz podmiotów uczestniczących w konsultacjach społecznych $w$ ramach procesu ustawowego. Z punktu widzenia prywatnego egzekwowania prawa ochrony konkurencji nieograniczony zakres podmiotowy postępowań grupowych należy jednak oceniać pozytywnie potencjalnie zwiększa on bowiem skuteczność tego trybu egzekwowania reguł konkurencji. Nadal jednak, jak się wydaje, najbardziej naturalnymi beneficjentami instytucji pozwów zbiorowych wydają się być konsumenci - to właśnie dla nich „łączenie” roszczeń w ramach jednego postępowania daje szansę na ich skuteczne dochodzenie. Pogląd ten znajduje także potwierdzenie w rządowym uzasadnieniu do ustawy ${ }^{206}$, które egzemplifikując roszczenia możliwe do grupowego dochodzenia, wymienia prawie wyłącznie roszczenia kierowane przez osoby fizyczne, w tym głównie konsumentów. Należy zastrzec, że okoliczność uczestnictwa w grupie dochodzącej zbiorowo roszczeń jedynie konsumentów nie oznacza, że sprawa rozpatrywana w postępowaniu zbiorowym zyskuje status „sprawy o ochronę konsumenta”.

Możliwość grupowego dochodzenia roszczeń może mieć także niebagatelne znaczenie dla innej kategorii osób fizycznych - przedsiębiorców prowadzących jednoosobową działalność gospodarcząa207. Ich potencjalna pozycja procesowa jest bowiem często zbliżona w gruncie rzeczy do pozycji konsumentów, szczególnie wówczas, gdy dochodzone roszczenia stanowią następstwo praktyki nadużycia pozycji dominującej, a zatem przeciwnikiem procesowym pozostaje duży przedsiębiorca, dysponujący z reguły znacznie lepszym dostępem do prawnej pomocy procesowej, także ze względu na swoje zasoby. Podobnie mikroprzedsiębiorcy i mali przedsiębiorcy ${ }^{208}$ mogą doświadczać trudności w skutecznym dochodzeniu roszczeń od dużych, często wręcz globalnych przedsiębiorców zaangażowanych w porozumienia ograniczające konkurencję. Ustawa o pozwach zbiorowych w pewnym zakresie te trudności w zakresie prywatnego egzekwowania prawa ochrony konkurencji eliminuje. Co więcej, w przypadku konsumentów oraz mikroi małych przedsiębiorców możliwość uczestnictwa w postępowaniu grupowym może być argumentem determinującym decyzję o samym fakcie

206 Uzasadnienie do projektu ustawy o dochodzeniu roszczeń w postępowaniu grupowym - druk sejmowy nr 1829 z dnia 25 marca 2009 r., dalej: Uzasadnienie.

207 Por. art. 4 ust. 1 ustawy z dnia 2 lipca 2004 r. o swobodzie działalności gospodarczej (test jedn. Dz. U. z 2010 r., Nr 220, poz. 1447 ze zm.).

208 Por. art. 104 i 105 ustawy o swobodzie działalności gospodarczej. 
wystąpienia z roszczeniami z tytułu szkody poniesionej wskutek praktyki ograniczającej konkurencję. Grupowe dochodzenie roszczeń jest otwarte również dla przedsiębiorców (także dużych), posiadających status osób prawnych. Reprezentantem grupy skupiającej przedsiębiorców nie może być powiatowy (miejski) rzecznik konsumentów, jako że sprawy przedsiębiorców leżą poza jego kompetencją.

Bez względu na formę prawną prowadzenia działalności gospodarczej, możliwość dochodzenia roszczeń zbiorowych przez przedsiębiorców rodzi pytanie o ewentualne uczestnictwo w grupie tych przedsiębiorców, którzy - choć poszkodowani - byli sami zaangażowani w nielegalną praktykę, z której wywodzone są roszczenia. Należy przyjąć, że skoro zgodnie z doktryną Courage przedsiębiorcy będący stronami zakazanych porozumień ograniczających konkurencję mogą występować - pod pewnymi warunkami - z roszczeniami wobec innych „sprawców” takiej praktyki²09, są oni również legitymowani do uczestnictwa w postępowaniu grupowym.

Inną kwestią problemową pozostaje pytanie o to, czy konsumenci i przedsiębiorcy (kontrahenci, konkurenci), aczkolwiek nie uczestniczący w porozumieniu, mogą być członkami tej samej grupy występującej w postępowaniu grupowym. Przesłanką uczestnictwa w jednej grupie jest tożsamość faktów rodzących odpowiedzialność przedsiębiorcy. Zarówno w przypadku konsumentów, jak i innych „poszkodowanych” (przedsiębiorców - konkurentów, kontrahentów) podstawą dochodzenia roszczenia pozostaje ten sam i taki sam fakt, jakim jest naruszenie zakazu praktyk ograniczających konkurencję, co wskazywałoby na formalną możliwość łączenia w jedną grupy różnych kategorii „poszkodowanych” wskutek praktyki antykonkurencyjnej. Należy jednak zwrócić uwagę na okoliczność, że relacje naruszyciela i kontrahenta/ konkurenta oraz relacje naruszyciela i konsumentów mają zupełnie różny charakter gospodarczy, który - w moim przekonaniu - powinien wykluczać możliwość łączenia tych podmiotów w jednej grupie na potrzeby postępowania grupowego. Zróżnicowanie relacji gospodarczych między podmiotami wpływa bowiem nie tylko na zakres roszczeń (w tym ich wysokość), ale także na dobór dowodów i sposób prowadzenia postępowania dowodowego. O ile zróżnicowanie roszczeń może być dokonane w ramach podgrupy, o tyle konieczność analizy różnych dowodów doprowadzi do faktycznego „rozwarstwienia” danego postępowania grupowego na część „konsumencką” oraz część „gospodarczą” („biznesową”). Taki rezultat uważam za sprzeczny $\mathrm{z}$ ratio legis ustawy o pozwach grupowych. Innym pytaniem rodzącym się na tle takiej „mieszanej” grupy stanowiłaby kwestia wyboru reprezentanta

209 Por. pkt 4.3.2.4. w niniejszym rozdziale. 
grupy - jak się wydaje, niemożliwym byłoby reprezentowanie takiej grupy przez powiatowego (miejskiego) rzecznika konsumentów, którego funkcja nie obejmuje interesów przedsiębiorców, z drugiej strony nie wydaje się właściwym pozbawianie konsumentów możliwości bycia reprezentowanym przez rzecznika konsumentów, który ma szansę występować w postępowaniu jako podmiot o szerszej wiedzy profesjonalnej niż konsument-uczestnik grupy.

Nie ma natomiast, moim zdaniem, możliwości łączenia w tej samej grupie przedsiębiorców będących stronami zakazanych porozumień oraz innych podmiotów (przedsiębiorców czy konsumentów) - w takim przypadku nie zachodzi, moim zdaniem, tożsamość faktów stanowiących podstawę roszczeń. W świetle ustawy o ochronie konkurencji i konsumentów zastosowanie zakazu praktyk ograniczających konkurencję jest niezależne od winy (jej istnienia lub jej stopnia) uczestników porozumienia, przedsiębiorcauczestnik antykonkurenyjnego porozumienia pozostaje zawsze „współnaruszycielem", co naturalnie wpływa na możliwość dochodzenia roszczeń przez takich przedsiębiorców. Bezpośrednie przyczynienie się do naruszenia zakazu porozumień ograniczających konkurencję modyfikuje podstawę faktyczną dochodzenia roszczeń na tyle, że staje się ona zupełnie inna niż podstawa faktyczna, z której wywodzone są roszczenia konsumentów lub przedsiębiorców nie uczestniczących w porozumieniu.

Członkostwo w grupie wymaga złożenia oświadczenia o przystąpieniu do grupy, w którym „uprawniony powinien określić swe żądania oraz wskazać okoliczności uzasadniające żądanie, a także przynależność do grupy oraz przedstawić dowody” (art. 12). Należy przyjąć, że powinność „przedstawienia dowodów" dotyczy - na etapie konstytuowania się grupy - jedynie przynależności do grupy. Ustawodawca nie jest tu jednak precyzyjny, skoro w innym miejscu ustawy dla spraw o roszczenia niepieniężne wymaga tylko uprawdopodobnienia uczestnictwa w grupie (art. 16 ust. 1). Wykaz osób, które przystąpiły do grupy sporządza powód (reprezentant grupy) i przedstawia sądowi wraz z oświadczeniami o przystąpieniu do grupy (art. 12 zd. 2), następnie sąd doręcza ten wykaz pozwanemu (art. 12 zd. 3). Z chwilą przedstawienia sądowi oświadczenia o przystąpieniu do grupy między członkiem grupy a pozwanym powstaje „skutek sprawy w toku, co do roszczenia objętego postępowaniem grupowym” (art. 13 ust. 1).

Wejście członków do grupy odbywa się w dwóch etapach: 1) w momencie składania pozwu, do którego należy dołączyć oświadczenia członków grupy o przystąpieniu do grupy (art. 6 ust. 2) oraz 2) gdy po uprawomocnieniu się postanowienia o rozpoznaniu sprawy w postępowaniu grupowym sąd zarządzi ogłoszenie o wszczęciu takiego postępowania, w którym to ogłoszeniu należy umieścić informacje o możliwości przystąpienia do grupy wraz 
z oznaczeniem terminu na dokonanie tej czynności (art. 11 ust. 2 pkt 3). Ogłoszenia takie publikowane są „w poczytnej prasie o zasięgu ogólnokrajowym”, a w szczególnych wypadkach - „w prasie o zasięgu lokalnym” (art. 11 ust. 3). W sprawach $\mathrm{z}$ zakresu prywatnego egzekwowania prawa konkurencji ogłoszenia $\mathrm{w}$ prasie o zasięgu lokalnym stosowane powinny być wówczas, gdy potencjalna praktyka ograniczająca konkurencję ma lub miała miejsce na rynku właściwym o zasięgu lokalnym lub regionalnym (np. nadużywanie pozycji dominującej bądź porozumienie ograniczające konkurencję na lokalnym rynku usług transportu publicznego). Od zarządzenia ogłoszenia o wszczęciu postępowania można odstąpić wówczas, gdy okoliczności sprawy wskazują na to, że wszyscy członkowie grupy złożyli oświadczenia o przystąpieniu do grupy (art. 11 ust. 4) - np. gdy do grupy przystąpili wszyscy klienci ubezpieczyli pozostających w zmowie kartelowej, w wyniku której nastąpiło pobranie zawyżonych opłat za polisy ubezpieczeniowe. W sprawach dotyczących naruszenia zakazu praktyk ograniczających konkurencję stwierdzenie takiej „kompletności” grupy na potrzeby postępowania grupowego będzie w wielu przypadkach trudne ze względu na fakt, że poszkodowanymi mogą być podmioty z różnych szczebli obrotu gospodarczego - o ile stosunkowo łatwe będzie ustalenie, czy do grupy dołączyli np. wszyscy dystrybutorzy hurtowi przedsiębiorców zaangażowanych w praktykę ograniczającą konkurencję, o tyle trudniej ustalić, czy grupa objęła wszystkich poszkodowanych na niższych szczeblach obrotu gospodarczego. Pewne wątpliwości może budzić brak w ustawie regulacji co do tego, kto - reprezentant grupy czy sąd - decyduje o przyjęciu zgłoszenia, a w konsekwencji - członkostwa w grupie. T. Jaworski i P. Radzimierski słusznie twierdzą, że uprawnienie to powinno przysługiwać reprezentantowi grupy ${ }^{210}$, M. Sieradzka wydaje się być bardziej skłonna do przypisania tego uprawnienia sądowi 211 .

Jeśli określony podmiot przed dniem wszczęcia postępowania grupowego wytoczył powództwo przeciwko pozwanemu uczestniczącemu w postępowaniu grupowym o roszczenie, które może być objęte tym postępowaniem grupowym, podmiot ten - do dnia zakończenia postępowania w pierwszej instancji - jest uprawniony do złożenia oświadczenia o przystąpieniu

210 T. Jaworski, P. Radzimierski, Ustawa..., s. 291-297 (Nb 7-16). Autorzy ci wskazują na „napięcie pomiędzy rolą reprezentanta interesu prywatnego (własnego i grupy inicjatywnej) a interesu publicznego - wszystkich osób, które przystąpiły do grupy” (s. 292, $\mathrm{Nb} 7$ ). Użytego w tym kontekście pojęcia interesu publicznego nie należy utożsamiać $\mathrm{z}$ interesem publicznym realizowanym $\mathrm{w}$ postępowaniu antymonopolowym (tj. interesu publicznego, o którym mowa w pkt 4.1. niniejszego rozdziału).

211 M. Sieradzka, Ustawa..., s. 192-193. 
do grupy; pierwotne postępowanie w sprawie tego roszczenia umarza się w takiej sytuacji (art. 13 ust. 2), przy czym nie ma obowiązku uzyskiwania zgody pozwanego na zakończenie pierwotnego procesu indywidualnego.

Należy podkreślić, że uczestnictwo w grupie nie jest obowiązkowe ustawodawca nie zamyka możliwości dochodzenia roszczeń z tytułu tego samego naruszenia zakazu praktyk ograniczających konkurencję dla osób, które w ogóle nie przystąpiły do grupy lub z niej wystąpiły (art. 1 ust. 3).

Ostateczny skład grupy zatwierdzany jest postanowieniem sądu, na które przysługuje zażalenie (art. 17 ust. 1). Ze względu na przyjętą w ustawie o pozwach zbiorowych koncepcję opt-in po przyjęciu postanowienia przez sąd skład grupy nie może ulec zmianie (art. 17 ust. 3), co oznacza, że $\mathrm{z}$ grupy nie można wystąpić212. W opiniach do projektu ustawy podnoszono, że zasada ta stoi w sprzeczności z art. 6 EKPC oraz ze standardami konstytucyjnymi „w szczególności, z uwagi na fakt, że taki „przymusowy” członek grupy będzie objęty powagą rzeczy osądzonej orzeczenia, jakie zapadnie w dalszym postępowaniu, a może mieć uzasadnione podstawy (jak choćby nienależyte prowadzenie postępowania przez powoda), aby zrezygnować z udziału w postępowaniu grupowym"213. Osobiście podzielam jednak stanowisko projektodawcy, który słusznie stwierdził, że „zakaz wystąpienia członka z grupy po uprawomocnieniu się postanowienia co do składu grupy wynika z konieczności zapewnienia sprawności postępowania sądowego. Możliwość dowolnego wystąpienia $\mathrm{z}$ grupy powodowałaby dezorganizację przebiegu postępowania wskutek wystąpienia $\mathrm{z}$ grupy poszczególnych jej członków. Należy wskazać, że jeżeli ktoś zdecyduje się na przystąpienie do grupy, to musi być świadomy wynikających z tego konsekwencji prawnych"214.

Słabością polskiej ustawy pozostaje jednak brak regulacji dotyczący sytuacji, w której już po wszczęciu postępowania w sposób naturalny (wskutek śmierci osoby fizycznej czy ustania osoby prawnej) zmalałaby liczebność grupy poniżej ustawowego „quorum” 10 osób. Ustawodawca nie zdecydował, czy należy wówczas umorzyć postępowanie, czy też należy je kontynuować, ponieważ przesłanka liczebności grupy musi być spełniona jedynie $\mathrm{w}$ momencie składania pozwu. $\mathrm{W}$ moim przekonaniu postępowanie takie powinno być jednak kontynuowane.

Jeśli osoba przystąpiła do grupy, ale nie została objęta postanowieniem sądu co do składu grupy, w ciągu 6 miesięcy od dnia uprawomocnienia się

212 Stanowisko takie wyrażone zostało przez Związek Banków Polskich w opinii do projektu ustawy o pozwach zbiorowych.

213 Zob. A. Kubas, R. Kos, Opinia w sprawie projektu ustawy o dochodzeniu roszczeń w postępowaniu grupowym (druk sejmowy 1829), 20.10.2009 r., s. 10.

214 Uzasadnienie, s. 14. Pogląd ten podziela również M. Sieradzka, Ustawa..., s. 222. 
postanowienia sądu, osoba taka nie może skutecznie wytoczyć powództwa o roszczenie objęte postępowaniem grupowym, gdyż w odniesieniu do tego roszczenia „zostają zachowane skutki wytoczenia powództwa w postępowaniu grupowym" (art. 17 ust. $4 \mathrm{w}$ zw. z art. 10 ust. 3).

\section{Zakres i rodzaje roszczeń}

Ustawa o pozwach zbiorowych nie ogranicza w zasadzie kategorii roszczeń, jakie mogą być dochodzone w trybie postępowań grupowych. $A$ contrario $\mathrm{z}$ art. 2 ust. 1 ustawy o pozwach zbiorowych możemy wywodzić, że dopuszczalne są roszczenia niepieniężne ${ }^{215}$.

W literaturze przedmiotu wskazuje się, że w postępowaniu grupowym można dochodzić również roszczeń o charakterze prewencyjnym, tj. roszczeń o zaniechanie naruszania reguł konkurencji, na podstawie art. $439 \mathrm{kpc}^{216}$.

W sprawach o roszczenia niepieniężne członek grupy może jedynie uprawdopodobnić swoją przynależność do niej, podczas gdy w sprawach o roszczenia pieniężne członek grupy jest zobowiązany udowodnić przynależność do grupy (art. 16 ust. 1), wyjątkiem pozostaje tylko sytuacja, gdy w sprawach o roszczenia pieniężne powództwo ogranicza się do ustalenia odpowiedzialności pozwanego. W odniesieniu do roszczeń pieniężnych ustawodawca opiera koncepcję pozwów zbiorowych na zasadzie ujednolicania wysokości roszczeń każdego członka grupy „przy uwzględnieniu wspólnych okoliczności sprawy” (art. 2 ust. 1). W orzecznictwie uznano, że „ujednolicenie dotyczy nie tylko wysokości świadczeń pieniężnych ale i rodzaju uszczerbku majątkowego (damnum emergens $i$ lucrum cessans), a także podobieństwa przedmiotowego strat, przy jednoczesnym zachowaniu wspólnej płaszczyzny sprawy dla wszystkich członków podgrup w ramach grupy"217.

Ujednolicenie (ryczałtowanie, standaryzacja) wysokości roszczeń przełamuje w pewnym stopniu zasadę pełnego odszkodowania, co jest możliwe ze względu na status ustawy o pozwach zbiorowych jako 218 lex specialis wobec podstawowych regulacji cywilnoprawnych. Ujednolicenie wysoko-

$215 \mathrm{O}$ roszczeniach dopuszczalnych w sprawach związanych z naruszeniem zakazu praktyk ograniczających konkurencję - por. rozdział VII, pkt. 7.7. i 7.8.

216 M. Rejdak, P. Pietkiewicz, Ustawa..., (Komentarz do art. 1, Nb 48).

217 Postanowienie SA w Krakowie z dnia 7 grudnia 2011 r., I ACz 1235/2011, LexPolonica nr 3034141.

218 Zryczałtowane odszkodowania znane są chociażby z regulacji dotyczących ochrony praw pasażerów w transporcie lotniczym - por. art. 7 rozporządzenia (WE) nr 261/2004 Parlamentu Europejskiego i Rady z dnia 11 lutego 2004 r. ustanawiające wspólne zasady odszkodowania dla pasażerów w przypadku odmowy przyjęcia na pokład albo odwołania lub dużego opóźnienia lotów, uchylające rozporządzenie (EWG) nr 295/91 (Dz. Urz. UE 2004 L 46/1). 
ści roszczeń może nastąpić także w podgrupach, liczących co najmniej 2 osoby (art. 2 ust. 2). Możliwość tworzenia podgrup składających się z tak małej liczby członków de facto przełamuje zasadę ujednolicania wysokości roszczeń. Tworzenie wielu podgrup $\mathrm{w}$ ramach jednego postępowania może prowadzić do „rozsadzenia” postępowania grupowego poprzez nadmierne zróżnicowanie roszczeń, szczególnie gdyby przyjąć, że sąd jest uprawniony (zobowiązany?) do weryfikacji wysokości roszczeń (ustawa jednak nie przesądza tego, choć wydaje się to racjonalne). Z punktu widzenia prywatnego egzekwowania prawa ochrony konkurencji możliwość tworzenia podgrup służących ujednolicaniu roszczeń powinna być jednak oceniana pozytywnie, gdyż w postępowaniach tego rodzaju roszczenia nawet jednej kategorii podmiotów (np. kontrahentów) mogą być znacznie zróżnicowane (np. ze względu na czas trwania relacji handlowych czy wielkość kontrahentów przekładającą się na wielkość dostaw). Zasady ujednolicenia wysokości roszczeń pieniężnych członków grupy lub podgrup oraz wysokość roszczenia każdego z członków grupy lub podgrupy należy przedstawić już w pozwie (art. 6 ust. 1 pkt 2 i pkt 3). Na mocy art. 15 ustawy pozwany może pośrednio podważyć ujednolicenie roszczeń $w$ ramach grupy lub podgrup poprzez podniesienie zarzutów co do członkostwa w nich poszczególnych osób.

W wyroku zasądzającym świadczenia pieniężne sąd ma obowiązek ustalić, jaka kwota przypada każdemu członkowi grupy lub podgrupy (art. 21 ust. 1).

Dodatkowo ustawodawca postanowił, że w sprawach o roszczenia pieniężne powództwo może ograniczać się do żądania ustalenia odpowiedzialności pozwanego (art. 2 ust. 3). $\mathrm{Z}$ taką sytuacją będziemy mieć do czynienia szczególnie wówczas, gdy nie jest możliwym ujednolicenie roszczeń - w postępowaniach w sprawach naruszenia reguł konkurencji może być to przypadek, gdy szkodę antymonopolową poniosą podmioty pełniące różne role rynkowe (konsumenci, konkurenci, kontrahenci pozwanego). Ustawodawca nie przesądza co prawda wprost, czy w takiej sytuacji członek grupy może dochodzić roszczeń pieniężnych w innym postępowaniu, jednak racjonalnym wydaje się zaakceptowanie tej możliwości (takie stanowisko wyrażone jest zresztą w uzasadnieniu ustawy ${ }^{219}$ ). Wyrok ustalający odpowiedzialność pozwanego co do zasady, wydany w postępowaniu grupowym, będzie stanowił zatem - zgodnie $\mathrm{z}$ art. $365 \mathrm{kpc}$ - prejudykat $\mathrm{w}$ innym postępowaniu (indywidualnym) ${ }^{220}$. Rozwiązanie to odpowiada wytycznej Komisji Europejskiej, zgodnie z którą „poszkodowani nie mogą być pozbawieni prawa do

219 Uzasadnienie, s. 4.

220 Inaczej J. Lipski, Opinia prawna w sprawie projektu ustawy o dochodzeniu roszczeń w postępowaniu grupowym [druk sejmowy nr 1829], 21 maja 2009 r., s. 4. 
wniesienia indywidualnego powództwa o naprawienie szkody, jeżeli podjęliby taką decyzję"221. Nie ma zresztą przeszkód, aby postępowanie, w którym nastąpi zasądzenie odszkodowań, było również postępowaniem grupowym. Artykuł 2 ust. 3 ustawy o pozwach zbiorowych przewiduje ponadto takie ułatwienie, że w przypadku, gdy powództwo ogranicza się do żądania ustalenia odpowiedzialności, powód nie jest obowiązany wykazywać interesu prawnego w ustaleniu. To udogodnienie procesowe może sprzyjać wykorzystywaniu tego rodzaju powództw w postępowaniach w sprawach naruszenia zakazu praktyk ograniczających konkurencję - podmioty mogą być zainteresowane taką „etapową" realizacją roszczeń ze względu na trudności w ustalaniu wielkości szkody antymonopolowej222.

\section{Status członka grupy w postępowaniu grupowym}

Polski ustawodawca ukształtował postępowanie w taki sposób, że status powoda przysługuje reprezentantowi grupy (art. 4 ust. 1), który prowadzi postępowanie w imieniu własnym, na rzecz wszystkich członków grupy (art. 4 ust. 2). Członkowie grupy lub podgrup mogą być przesłuchiwani w charakterze strony (art. 20), a nie świadka; są oni stroną w znaczeniu materialnym. Niedopuszczalna jest interwencja uboczna członka grupy po stronie powoda (art. 14).

Członkowie grupy (więcej niż połowa) mogą wystąpić z wnioskiem o zmianę reprezentanta grupy, co może nastąpić także po wydaniu wyroku (art. 18 ust. 1 i 3). O zmianie reprezentanta decyduje sąd poprzez postanowienie wydane na posiedzeniu niejawnym. W przypadku zmiany konieczne jest zachowanie reguły, zgodnie z którą reprezentantem może być wyłącznie członek grupy lub powiatowy (miejski) rzecznik konsumentów.

Członkowie grupy są uprawnieni również do wyrażenia zgody na „gospodarowanie" procesem, tj. cofnięcie pozwu, zrzeczenie się lub ograniczenie roszczeń, zawarcie ugody (art. 19 ust. 1). Mimo zgody członków grupy sąd może uznać dokonanie tych czynności za niedopuszczalne, jeśli okoliczności sprawy wskazują, że czynności te są sprzeczne z prawem lub dobrymi obyczajami bądź gdy zmierzają do obejścia prawa albo rażąco naruszają interes członków grupy (art. 19 ust. 2). Uprawnienie sądu do odmowy zmian co do pozwu i roszczeń należy postrzegać jako instrument uniemożliwiający „manipulowanie” pozwami zbiorowymi.

Każdy z członków grupy może wystąpić z wnioskiem o nadanie klauzuli wykonalności wyroku zasądzającego świadczenie niepieniężne, o ile nie

221 Pkt 2.1. Białej księgi.

$222 \mathrm{Na}$ temat szkody antymonopolowej - por. rozdział VII, pkt 7.7.3.3. 
zostanie ono spełnione w ciągu 6 miesięcy od uprawomocnienia się wyroku, a w tym czasie reprezentant grupy nie wystąpi $\mathrm{z}$ wnioskiem o wszczęcie egzekucji (art. 23 ust. 2).

\section{Pozycja pozwanego w postępowaniu grupowym}

Pozwanym w postępowaniu grupowym prowadzonym w ramach prywatnego egzekwowania prawa ochrony konkurencji może być każdy podmiot, który potencjalnie dopuścił się naruszenia zakazu praktyk ograniczających konkurencję. Pozwanym musi być zatem przedsiębiorcą w rozumieniu art. 4 pkt 1 uokik; w przypadku naruszenia art.101 i 102 TFUE pozwany musi odpowiadać szerokiej definicji przedsiębiorstwa (undertaking) wypracowanej w orzecznictwie TS223.

Pozwanemu przysługuje prawo do podniesienia zarzutów co do członkostwa określonych osób w grupie lub w podgrupach (art. 15). Zarzut taki może być oparty na przekonaniu, że dana osoba nie należy do grona poszkodowanych ze względu na brak relacji faktycznych lub prawnych z pozwanym (nie ma nawet statusu nabywcy pośredniego). Możliwe byłoby również wykorzystanie jako uzasadnienia zarzutu braku przynależności do grupy zarzutu pass-on defence.

Pozwany - najpóźniej przy pierwszej czynności procesowej - może domagać się złożenia kaucji na zabezpieczenie kosztów procesu (art. 8 ust. 1), o ile uznana przez niego część roszczenia nie wystarcza na zabezpieczenie kosztów procesu (art. 8 ust. 2). O wysokości kaucji decyduje sąd, „mając na względzie prawdopodobną sumę kosztów" (art. 8 ust. 3 zd. 1). Wysokość kaucji nie może przekroczyć $20 \%$ wartości przedmiotu sporu (art. 8 ust. 3 zd. 2). Pozwany może $\mathrm{w}$ toku postępowania żądać dodatkowego zabezpieczenia, jeśli okaże się, że kaucja nie wystarczy na zabezpieczenie kosztów procesu (art. 8 ust. 4). Kaucję składa powód (reprezentant grupy); ustawodawca nie reguluje jednak zasad obciążania kaucją członków grupy, pozostawiając tę kwestię do wewnętrznego rozstrzygnięcia w ramach grupy. W praktyce obowiązek kaucyjny może zniechęcać do występowania z powództwami zbiorowymi. Problem kaucji będzie szczególnie trudny do rozwiązania w tych sprawach, w których reprezentantem grupy (powodem) miałby być powiatowy (miejski) rzecznik konsumentów 224 .

223 Problematykę tę wyczerpująco omawia: G. Materna, Pojęcie przedsiębiorcy w polskim i europejskim prawie ochrony konkurencji, Oficyna a Wolters Kluwer business, Warszawa 2009.

224 W opinii do projektu ustawy na tę okoliczność zwróciło uwagę Stowarzyszenie Konsumentów Polskich. 
Skutki wyroku wydanego w postępowaniu grupowym

Prawomocny wyrok kończący postępowanie grupowe ma skutek wobec wszystkich członków grupy (art. 21 ust. 3). Sentencja wyroku ma wskazywać wszystkich członków grupy lub podgrupy (art. 21 ust. 1), w wyroku zasądzającym świadczenie pieniężne należy wskazać, ,jaka kwota przypada każdemu członkowi grupy lub podgrupy" (art. 21 ust. 2).

Pojawia się tu jednak pytanie o to, czy osoba, która uzyskała zaspokojenie roszczenia pieniężnego w postępowaniu grupowym, może wystąpić z kolejnym powództwem w celu zaspokojenia pozostałej części roszczeń (tych, które wykraczają poza zryczałtowaną - w ramach ujednolicenia wysokość roszczeń)? Uzasadnienie projektu ustawy sugeruje dopuszczalność takiej możliwości poprzez wskazanie, że „wysokość roszczeń zostaje ujednolicona wyłącznie na potrzeby postępowania grupowego. Nie wyklucza to dochodzenia innych roszczeń w odrębnym procesie"225. Również w doktrynie nie ma zgodności co do dopuszczalności dochodzenia w drodze indywidualnego procesu roszczeń „uzupełniających” (co do wysokości) roszczenia zaspokojone w postępowaniu grupowym ${ }^{226}$. Stanowisko dopuszczające takie indywidualne dochodzenie roszczeń pozostaje - w moim przekonaniu w sprzeczności nie tylko z zasadą powagi rzeczy osądzonej227, ale także z samą istotą postępowania grupowego. Osoba występująca w grupie ma możliwość wyboru między zbiorowym dochodzeniem roszczeń, zakładającym standaryzację wysokości odszkodowania, co w praktyce może oznaczać niepełne pokrycie szkody w zamian za ułatwienia w przebiegu postępowania, a indywidualnym dochodzeniem roszczeń, umożliwiającym uzyskanie pełnego odszkodowania. Za wykluczeniem możliwości dochodzenia pozostałej części roszczeń w postępowaniu indywidualnym przemawia także konieczność zapewnienia minimalnej pewności prawnej dla pozwanych. Umożliwienie dochodzenia roszczeń pieniężnych w dwóch etapach: w postępowaniu grupowym, a następnie w postępowaniu indywidualnym, nosiłoby znamiona nadużywania powództw zbiorowych - eliminuje ono bowiem częściowo efekt postępowań grupowych, jakim ma być racjonalizacja działania wymiaru sprawiedliwości i zmniejszenie liczby jednostkowych spraw. Należy podkreślić, że

225 Uzasadnienie, s. 15.

226 Za niedopuszczalnością indywidualnego „uzupełniającego” dochodzenia roszczeń opowiada się M. Sieradzka, przeciwko - R. Waszkiewicz, Postępowanie grupowe (class action) $w$ systemie polskiego postępowania cywilnego - aspekty praktyczne (niepublikowane materiały z konferencji „Pozwy grupowe - kolejny krok w kierunku wzmocnienia ochrony konsumentów", Warszawa, 22 kwietnia 2010 r.).

227 Tak również J. Lipski, Opinia prawna $w$ sprawie projektu ustawy o dochodzeniu roszczeń w postępowaniu grupowym [druk nr 1829], 21 maja 2009 r., s. 4. 
również KE zastrzegła w Białej księdze konieczność wprowadzenia zabezpieczeń uniemożliwienia naprawienia określonej szkody więcej niż $\mathrm{raz}^{228}$.

Wyrokowi wydanemu w postępowaniu grupowym, zgodnie z literalną wykładnią art. $366 \mathrm{kpc}$, nie przysługuje jednak status powagi rzeczy osądzonej (res iudicata), skoro członkowie grupy nie są stronami postępowania $\mathrm{w}$ sensie formalnym ${ }^{229}$. Taka wykładnia prowadzi jednak do wniosku, że wyrok wydany w postępowaniu grupowym ma powagę rzeczy osądzonej wyłącznie w odniesieniu do reprezentanta grupy (powoda będącego stroną postępowania). Takie zróżnicowanie skutków wyroku kończącego postępowanie grupowe nie wydaje się jednak w żaden sposób uzasadnione w kontekście idei postępowania grupowego. Członkowie grupy pozostają przecież stronami postępowania w sensie materialnym, więc art. $366 \mathrm{kpc}$ powinien znajdować zastosowanie w stosunku do nich. Taka wykładnia art. $366 \mathrm{kpc}$ nie wydaje się możliwa, konieczne byłoby zatem przeformułowanie koncepcji pozwów zbiorowych w taki sposób, aby wyrok miał powagę rzeczy osądzonej nie tylko dla reprezentanta grupy, ale także dla jej członków.

Rokowanie co do stosowania ustawy o pozwach zbiorowych w ramach prywatnego egzekwowania prawa ochrony konkurencji

Postępowanie grupowe powszechnie postrzegane jest jako instrument ułatwiający prywatne egzekwowanie prawa ochrony konkurencji, jednak trudno wyrokować, czy - uwzględniając treść regulacji ustawowej - postępowania te odegrają taką rolę w Polsce ${ }^{230}$. Rozwojowi prywatnego egzekwowania prawa konkurencji sprzyjają takie rozwiązania ustawowe, jak: dopuszczalność uczestnictwa w grupie podmiotów o różnym statusie prawnym (osoby fizyczne, osoby prawne) czy wymóg stosunkowo niskiej liczebności grupy (10 osób ${ }^{231}$. Jednak również na gruncie postępowań grupowych zachowują aktualność wszelkie problemy procesowe, jakie wiążą się z dowodzeniem

228 Pkt 2.1. Białej księgi.

229 Inaczej: A. Kubas, R. Kos, Opinia..., s. 12.

230 Istotnego znaczenia postępowań grupowych dla prywatnego egzekwowania reguł konkurencji upatruje m.in. D. Hansberry-Bieguńska, Poland, [w:] I.K. Gotts (red.), The Private Competition Enforcement Review, 4. ed., Law Business Research, London 2011, s. 251, 259.

231 W kontekście prywatnego wdrażania prawa konkurencji nie zgadzam się z opinią PKPP, że próg liczebności grupy jest zbyt niski i powinien wynosić co najmniej 30 osób „tak aby instytucja pozwów zbiorowych nie stała się instrumentem nacisków na przedsiębiorców, a w szczególności instrumentem szantażu pracodawców” - zob. Opinia Polskiej Konfederacji Pracodawców Prywatnych „Lewiatan” w sprawie rządowego projektu ustawy o dochodzeniu roszczeń w postępowaniu grupowym (druk 1829), s. 4. 
naruszenia zakazu praktyk ograniczających konkurencję, a które są omawiane w innych częściach niniejszej książki.

Wśród szczegółowych rozwiązań przewidzianych w ustawie o dochodzeniu roszczeń w postępowaniu grupowym, które mogą stać na przeszkodzie skutecznemu dochodzeniu roszczeń w tym trybie, można wskazać choćby te dotyczące kaucji czy wynagrodzenia prawników. Wiele wątpliwości praktycznych może budzić proces ujednolicania roszczeń w ramach grupy lub podgrup. Trudności nastręczać będzie również zapewne brak regulacji ustawowych dotyczących relacji reprezentanta grupy i jej członków (np. brak możliwości pobierania wynagrodzenia w zamian za prowadzenie skomplikowanego w swej istocie postępowania). Barierą ekonomiczną w dochodzeniu roszczeń w trybie postępowania grupowego może okazać się również obowiązek złożenia przez powoda kaucji. Wydaje się, że wskazane przeszkody będą łatwiejsze do przezwyciężenia dla przedsiębiorców niż konsumentów.

W kontekście praktyki prowadzenia postępowań grupowych nie należy również lekceważyć argumentu o charakterze politycznym, że postępowania grupowe mogą stać się bronią zwalczającą nie tyle same naruszenia zakazu praktyk ograniczających konkurencję, ile przedsiębiorców jako takich. Jest to scenariusz o tyle możliwy, że koncepcja postępowania grupowego według polskiej ustawy przerzuca na pozwanego wiele ryzyk powiązanych z pozwami zbiorowymi (w tym brak wyrażonego wprost ograniczenia możliwości postępowań indywidualnych „uzupełniających” postępowania zbiorowe). W kontekście takich zagrożeń należy pozytywnie ocenić oparcie polskiego modelu pozwów zbiorowych na koncepcji opt-in.

Zakładam, że wykorzystanie w Polsce pozwów zbiorowych w obszarze prywatnego egzekwowania prawa ochrony konkurencji nastąpi przede wszystkim w przypadkach, w których naruszenie zakazu praktyk ograniczających konkurencję zostanie potwierdzone w decyzji organu ochrony konkurencji (Prezesa UOKiK lub Komisji) - decyzja taka traktowana jest jako prejudykat w postępowaniu sądowym ${ }^{232}$, co ułatwia - przynajmniej częściowo dowodowy aspekt postępowania grupowego. Nie można wykluczyć również tego, że w sytuacjach braku ostatecznej decyzji organu antymonopolowego stwierdzającej antykonkurencyjną praktykę 233 (np. ze względu na przedawnienie antymonopolowe) pozwy zbiorowe będą wykorzystywane jedynie dla ustalenia odpowiedzialności przedsiębiorców z tytułu naruszenia art. 6 lub 9 uokik bądź art. 101 lub 102 TFUE - możliwość tę otwiera art. 2 ust. 3 ustawy o pozwach zbiorowych (możliwość ograniczenia powództwa do żąda-

232 Por. rozdział VI, pkt 6.3 .

233 Decyzją taką nie jest decyzja zobowiązująca. 
nia ustalenia odpowiedzialności pozwanego), wspiera ją także art. 1 ust. 3 tej ustawy (możliwość dochodzenia roszczeń przez osoby spoza grupy lub osoby, które opuściły grupę).

\subsection{Uwagi końcowe}

Zrównoważony model funkcjonowania prywatnego i publicznego trybu egzekwowania reguł konkurencji zakłada, że każdemu ze wskazanych trybów egzekwowania zakazów antykonkurencyjnych praktyk przypisana jest realizacja odpowiednio - prywatnego (indywidualnego) i publicznego (utożsamianego ze zbiorowym) interesu. W rzeczywistości dychotomia interesów odzwierciedlona $\mathrm{w}$ dwupodziale trybów egzekwowania nie jest tak oczywista ${ }^{234}$, choćby ze względu na to, że, słusznie zresztą, odchodzi się od ilościowego rozumienia interesu publicznego, natomiast postępowania w ramach każdego z trybów egzekwowania reguł konkurencji mają szansę oddziaływać na obydwie kategorie interesów, co stanowi silny argument na rzecz zrównoważonego współistnienia i współoddziaływania obydwu trybów. Rozpatrując indywidualne roszczenia, sądy cywilne - orzekając w sprawach ograniczania konkurencji - pośrednio realizują interes publiczny.

Wszystkie kategorie podmiotów wskazanych jako potencjalnie legitymowane czynnie do dochodzenia roszczeń z tytułu naruszenia zakazów antykonkurencyjnych praktyk mogłyby być zainteresowane wszczęciem postępowania antymonopolowego przed organem ochrony konkurencji; inną kwestią pozostaje to, czy ustawodawca zdecydował o tym, że mogą $\mathrm{z}$ tego uprawnienia korzystać. Zdecydowane przypisanie realizacji interesu publicznego postępowaniu antymonopolowemu, zaś realizacji interesu prywatnego - postępowaniu sądowemu (cywilnemu) jest uzasadnione wówczas, gdy to ostatnie jest dla zainteresowanych podmiotów prywatnych łatwo dostępne. Jeśli znaczna jest liczba barier prawnych lub faktycznych w dostępie do skutecznego (tj. umożliwiającego rzeczywiste dochodzenie roszczeń) egzekwowania reguł konkurencji, istnieje ryzyko, że interes prywatny nie będzie zaspokojony, pozbawiając tym samym model egzekwowania prawa konkurencji charakteru „zrównoważonego”. W takiej sytuacji należałoby

234 Tak również m.in. A. P. Komninos, Relationship between Public and Private Enforcement: quod Dei Deo, quod Caesaris Caesari (referat wygłoszony na konferencji Integrating public and private enforcement of competition law: Implications for courts and agencies, Florencja, 17-18 czerwca 2011 r.), dostępny pod adresem: http://papers.ssrn.com/sol3/papers. cfm?abstract_id=1870723, s. 4-5; D. Wilsher, Reconciling the public and private dimensions of competition litigation in the European Union, G.C.L.R. 2011, vol. 4(2), s. 89-91. 
zapewnić mechanizmy gwarantujące realizację - choćby pośrednio - interesu prywatnego $\mathrm{w}$ ramach postępowania antymonopolowego - należy jednak zastrzec, że chodzi o realizację takiego interesu prywatnego, który jednocześnie realizuje interes publiczny; w żadnym wypadku nie jest moim celem postulowanie obowiązku uwzględniania „czystych” interesów prywatnych w postępowaniu przed organem ochrony konkurencji.

Polskie doświadczenia związane $\mathrm{z}$ realizacją interesu konsumentów w ramach prywatnego egzekwowania reguł konkurencji są nader ubogie. Orzecznictwo dostarczyło jak dotąd tylko takich przykładów, w których legitymacja czynna w zakresie dochodzenia roszczeń w sprawach antykonkurencyjnych realizowana była przez przedsiębiorców. Nawet o ustawie o dochodzeniu roszczeń w postępowaniu grupowym - inaczej niż w UE rzadko dyskutowano w kontekście prywatnego egzekwowania reguł konkurencji ${ }^{235}$. Bez względu na ewentualne rozstrzygnięcia legislacyjne dotyczące legitymacji czynnej w zakresie dochodzenia roszczeń z tytułu naruszenia zakazów antykonkurencyjnych praktyk ostateczna dostępność tych roszczeń i tak będzie determinowana przez wykazanie związku przyczynowo-skutkowego między naruszeniem a istotą dochodzonego roszczenia (np. szkodą).

235 Uwaga ta dotyczy okresu przed uchwaleniem ustawy. W późniejszym czasie pojawiła się poświęcona tej tematyce monografia autorstwa M. Sieradzkiej (Pozew grupowy jako instrument prywatnoprawnej ochrony interesów konsumentów z tytulu naruszenia regut konkurencji, LEX a Wolters Kluwer business, Warszawa 2012). 


\section{Rozdział V}

\section{Dostępność dowodów dla celów prywatnego egzekwowania zakazów praktyk ograniczających konkurencję}

\subsection{Uwagi wstępne}

W systemie publicznego prawa ochrony konkurencji standard dowodzenia w sprawach praktyk ograniczających konkurencję wydaje się utrwalony: organy ochrony konkurencji dokonują swobodnej oceny dowodów, a jedyne ograniczenie stanowi okoliczność, że w poczet dowodów mogą być zaliczone jedynie te, z którymi mogły zapoznać się strony postępowania antymonopolowego ${ }^{1}$.

Dostępność dowodów służących identyfikacji naruszeń zakazów praktyk ograniczających konkurencję i wynikających z niego szkód jest jednym z najbardziej kontrowersyjnych problemów prywatnego egzekwowania prawa konkurencji. Głównym powodem kontrowersji (i obaw) ${ }^{2}$ są idee przeszczepienia na grunt europejski amerykańskich rozwiązań dotyczących mechanizmu ujawniania dowodów między stronami (disclosure, discovery), stanowiący jeden $z$ najbardziej charakterystycznych elementów tamtejszego modelu prywatnego egzekwowania prawa konkurencji. Według R. Stürnera różnice między kontynentalnym systemem prawnym a common law nie przejawiają się tylko w odmienności reguł proceduralnych, ale odzwierciedlają one bardziej fundamentalną różnicę $\mathrm{w}$ koncepcji funkcjonowania społeczeństwa:

1 Por. K. Lenaerts, Some Thoughts on Evidence and Procedure in European Community Competition Law, Fordham International Law Journal 2007, vol. 30(5), s. 1463-1495.

2 Tak R. Stürner, Duties of Disclosure and Burden of Proof in the Private Enforcement of European Competition Law, [w:] J. Basedow (red.), Private Enforcement of Competition Law, Kluwer Law International 2007, s. 166. 
społeczeństwo amerykańskie określane jest jako konkurencyjne (competitive society), a solidarność społeczna pojmowana jest głównie jako prywatna działalność pro bono, podczas gdy w modelu kontynentalnym solidarność społeczna stanowi kwestię polityki publicznej, a instrumenty administracyjne są jednym $\mathrm{z}$ instrumentów służących równoważeniu interesów indywidualnych ${ }^{3}$. W tych warunkach proste przeniesienie rozwiązań amerykańskich na grunt europejski może napotykać na istotne bariery.

Mechanizm ujawniania dowodów może przyjąć postać obowiązku udostępniania dowodów nie tylko przez strony, ale także przez osoby trzecie, w tym organy ochrony konkurencji. W tym ostatnim przypadku nieco bardziej adekwatne wydaje się używanie pojęcia „mechanizm udostępniania” niż „mechanizm ujawniania” dowodów, niemniej jednak na potrzeby niniejszego rozdziału termin „ujawnianie” będzie wielokrotnie stosowany bez względu na status podmiotu zobowiązanego do wydania dowodów, poza tymi fragmentami, gdy analizowane będą zagadnienia związane wyłącznie z działalnością organu antymonopolowego.

Zwolennicy wprowadzenia mechanizmu ujawniania dowodów do prywatnego egzekwowania prawa konkurencji dowodzą, że potrzeba taka wynika ze szczególnego charakteru spraw z zakresu naruszenia zakazów praktyk ograniczających konkurencję. O trudnościach w pozyskiwaniu dowodów, zwłaszcza związanych z funkcjonowaniem zmów kartelowych, świadczą choćby szerokie uprawnienia w dziedzinie kontroli przedsiębiorców przyznawane przez ustawodawców organom ochrony konkurencji, a obejmujące w niektórych systemach prawnych nawet kontrowersyjne prawo do przeszukania pomieszczeń prywatnych. Sprawy związane z naruszeniem zakazów praktyk ograniczających konkurencję określane są jako „obfitujące w fakty” (fact-intensive), charakteryzują się one również istotną asymetrią informacji między stronami. Jeśli w danej sprawie toczy się (lub toczyło) postępowanie antymonopolowe (roszczenia następcze), asymetria ta może być wyeliminowana poprzez dostęp do dowodów zgromadzonych przez organ ochrony konkurencji. Jeżeli natomiast mamy do czynienia z roszczeniami samodzielnymi (w sprawach, w których nie toczyło i nie toczy się postępowanie), asymetrii informacji można uniknąć poprzez przyjęcie mechanizmu ujawniania (disclosure) między stronami.

Specyfika spraw antymonopolowych może także skłaniać do obniżenia standardu dowodowego lub odwrócenia ciężaru dowodu w ramach pry-

3 R. Stürner, Duties of Disclosure..., s. 166-168. 
watnego egzekwowania zakazów praktyk ograniczających konkurencję4. W postępowaniu przed organem ochrony konkurencji to na nim ciąży ciężar dowodu naruszenia zakazu praktyk ograniczających konkurencję; na przedsiębiorcach, przeciw którym postępowanie jest prowadzone, spoczywa natomiast ciężar dowiedzenia, że potencjalnie antykonkurencyjne porozumienie może korzystać z wyłączenia spod zakazu porozumień ograniczających konkurencję jako porozumienie de minimis (art. 7 uokik) lub ze względu na spełnienie przesłanek wskazanych $\mathrm{w}$ art. 8 ust. 1 uokik (odpowiednio art. 101 ust. 3 TFUE). W postępowaniu sądowym ciężar dowodu spoczywa $\mathrm{z}$ reguły (w Polsce - na podstawie art. $6 \mathrm{kc}$ ) na powodach występujących $\mathrm{z}$ roszczeniami w związku z naruszeniem zakazów praktyk ograniczających konkurencję. Odwrócenie ciężaru dowodu czy obniżenie standardu dowodowego wydają się jednak rozwiązaniami zbyt daleko idącymi i mimo wszystko nie uzasadnionymi nadzwyczajnym charakterem spraw antymonopolowych. W chórze głosów wskazujących na szczególne trudności dowodowe roszczeń z tytułu naruszenia zakazów praktyk ograniczających konkurencję można wyodrębnić i takie opinie, zgodnie z którymi roszczenia te nie są bardziej wymagające dowodowo niż wiele innych spraw cywilnych - argument ten brzmi szczególnie racjonalnie, jeśli weźmiemy pod uwagę choćby sprawy z zakresu zwalczania nieuczciwej konkurencji. Nie można zgodzić się na obniżenie standardu dowodowego do poziomu uprawdopodobnionego podejrzenia (plausible suspicion), że szkoda spowodowana została naruszeniem zakazu antykonkurencyjnych praktyk. Z kolei odwrócenie ciężaru dowodu nie jest koniecznym do zastosowania środkiem w sytuacji, gdy decyzje organu ochrony konkurencji traktowane będą w postępowaniach sądowych jako prejudykaty.

Ujawnianie dowodów (zwłaszcza między stronami) może być gwarantowane przepisami prawa przed procesem sądowym (pre-trial discovery) bądź na podstawie zarządzenia sądu (court-ordered discovery).

Dla stworzenia zrównoważonego modelu współzależności między publicznym i prywatnym egzekwowaniem prawa konkurencji, do rozważenia pozostaje przyjęcie regulacji poświęconej kwestiom dostępności dowodów $\mathrm{z}$ postępowania antymonopolowego $\mathrm{w}$ cywilnym postępowaniu sądowym. Rozwiązanie takie będzie sprzyjać rozwojowi prywatnego egzekwowania prawa konkurencji, jednak żadna regulacja nie pozwoli uniknąć problemów

4 Rozwiązanie takie zaproponowała Komisja w Zielonej księdze (opcja 9), jednak w Białej księdze już się z nich wycofała. Por. pkt 91-92 Commission staff working paper accompanying the White paper on damages actions for breach of the EC antitrust rules $\{\mathrm{COM}(2008)$ 165 final\} \{SEC (2008) 405\} \{SEC (2008) 406\}/* SEC/2008/0404 final *; dalej jako White Paper Staff Working Document. 
praktycznych związanych z zakresem dostępności dowodów zgromadzonych $\mathrm{w}$ postępowaniu antymonopolowym (o czym dobitnie świadczy orzecznictwo unijne, przede wszystkim wyrok Trybunału Sprawiedliwości w sprawie C-360/09 Pfleiderer ${ }^{5}$ oraz wyrok Sądu w sprawie T-437/08 CDC Hydrogene Peroxide ${ }^{6}$.

W sytuacji braku specjalistycznej regulacji umożliwiającej dostęp do dowodów zgromadzonych w postępowaniu antymonopolowym równowaga między publicznym i prywatnym egzekwowania zakazów antykonkurencyjnych praktyk może być zapewniana w ramach przepisów o dostępie do informacji publicznej.

\subsection{Ważenie interesów: „za” i „przeciw” udostępnianiu dowodów pozyskanych w innym trybie egzekwowania zakazów praktyk ograniczających konkurencję}

Decyzja co do przyjęcia określonego modelu rozwiązań prawnych odnoszących się do problemu obligatoryjnego ujawniania dowodów przez strony lub osoby trzecie wymaga identyfikacji i oceny interesów przemawiających za ochroną bądź ujawnianiem dowodów, w tym także tych zgromadzonych w postępowaniu antymonopolowym. Mechanizm ujawniania dowodów z całą pewności czyni prywatne egzekwowanie prawa konkurencji bardziej efektywnym i racjonalnym - likwiduje (a przynajmniej zmniejsza) asymetrię informacji, zaś w przypadku, gdy zezwala na wykorzystanie materiałów zgromadzonych w postępowaniu antymonopolowym - eliminuje konieczność dublowania czynności dowodowych (działań na rzecz pozyskania dowodów). Jednocześnie należy zauważyć, że dowody pozyskane od organu ochrony konkurencji niekoniecznie będą wystarczające dla potrzeb postępowania sądowego - ich rola wyczerpuje się przy dowodzeniu faktu naruszenia, w przypadku roszczeń odszkodowawczych konieczne jest ponadto dowiedzenie zakresu szkody i związku przyczynowo-skutkowego między naruszeniem a szkodą. Dowody zebrane przez organ ochrony konkurencji mają jednak tę niekwestionowaną wartość, że są one weryfikowane przez wyspecjalizowany organ.

Możliwość ujawniania dowodów, zwłaszcza dowodów zebranych w postępowaniu antymonopolowym, stanowi oczywistą korzyść dla strony powodo-

5 Wyrok TS z dnia 14 czerwca 2011 r. w sprawie C-360/09 Pfleiderer v. Bundeskartellamt (dotychczas niepubl.).

6 Wyrok Sądu z dnia 11 grudnia 2011 r. w sprawie T-437/08 CDC Hydrogene Peroxide v. Komisja (dotychczas niepubl.). 
wej, co rodzi nierówność procesową. Uzasadnienia takiej uprzywilejowanej pozycji dowodowej można jednak upatrywać w sygnalizowanych już powyżej trudnościach dowodzenia naruszeń zakazów praktyk ograniczających konkurencję. Brak dostępu do dowodów zgromadzonych w postępowaniu antymonopolowym nie tylko zresztą utrudnia dowiedzenie naruszenia, ale nawet może je uniemożliwić (a tym samym zablokować egzekwowanie zakazów antykonkurencyjnych praktyk na drodze prywatnoprawnej). Zagwarantowanie dostępu do dowodów, szczególnie zaś akt postępowania antymonopolowego, jest szczególnie pożądane w sytuacji, gdy jako powodowie występują konsumenci, a nie profesjonalni uczestnicy obrotu.

Obok interesu podmiotów poszkodowanych wskutek praktyk ograniczających konkurencję, należy jednak uwzględnić również interesy uczestników postępowania antymonopolowego. Sam fakt naruszenia zakazów praktyk ograniczających nie może być poczytywany jako wystarczający powód dla pozbawienia prawa do ochrony tajemnicy przedsiębiorcy - prawo takie nadal przysługuje zresztą tym przedsiębiorcom, przeciw którym organ ochrony konkurencji kieruje zarzuty, jak i innym przedsiębiorcom, których tajemnice zostały ujawnione (lub istniało ryzyko ich ujawnienia) w postępowaniu antymonopolowym.

Wreszcie, wskutek ujawnienia akt postępowania antymonopolowego ucierpieć może również interes publiczny - dochodzi do tego wówczas, gdy częścią ujawnianych akt są informacje i oświadczenia uzyskane w ramach programu darowania i łagodzenia kar (leniency). Powszechnie uznaje się, że regulacje prawne umożliwiające dostęp do materiałów leniency mogą stanowić istotny czynnik zniechęcający uczestników karteli do samooskarżania ${ }^{7}$, eliminując tym samym jedno ze skutecznych narzędzi realizacji polityki konkurencji.

Ponadto należy rozważyć, czy spójność systemu prawa nie wymaga, aby standardy ochrony praw przedsiębiorców gwarantowane w postępowaniu antymonopolowym były realizowane również $\mathrm{w}$ postępowaniu sądowym w zakresie prywatnego egzekwowania prawa ochrony konkurencji. Interesy pozwanych w postępowaniu sądowym nie mogą być chronione gorzej niż jest to gwarantowane w postępowaniu antymonopolowym - jeśli ustawy antymonopolowe gwarantują np. ochronę tajemnic przedsiębiorcy, to takie gwarancje powinny obowiązywać również w postępowaniu sądowym, w innym przypadku cel takich regulacji uległby degradacji.

7 Por. m.in. stanowisko Komisji przytoczone w pkt. 81 wyroku SPI z dnia 13 kwietnia 2005 r. w sprawie T-2/03 Verein für Konsumenteninformation v. Komisja (Zb. Orz. 2005, s. II-1121); dalej jako wyrok w sprawie VKI. 
Przyjęcie określonych rozwiązań dotyczących dostępu do materiałów dowodowych w ramach modelu współistnienia publicznego i prywatnego egzekwowania prawa konkurencji wymaga założenia konieczności zbilansowania różnych interesów, a także założenia, zgodnie z którym standard ochrony interesów przedsiębiorców w postępowaniu sądowym nie będzie niższy niż w postępowaniu antymonopolowym. Jednocześnie należy przeciwdziałać wszystkim negatywnym zjawiskom, jakie - co wynika z praktyki amerykańskiej - wiążą się z ujawnianiem dowodów, zwłaszcza ujawnianiem między stronami. Do najczęstszych nadużyć mechanizmu ujawniania należą m.in. „ekspedycje połowowe” (fishing expedition), czyli strategia polegająca na bardzo szerokim żądaniu niesprecyzowanych dowodów w oczekiwaniu, że pozwany ujawni dowód pozwalający na korzystne rozstrzygnięcie sprawy, czy „szantaż ujawniania” (discovery blackmail), polegający na stosowaniu strategii żądania takich dowodów i w takim zakresie, aby znacząco obciążyć pozwanego kosztami ujawniania, a tym samym skłonić go do ugody ${ }^{8}$.

\subsection{Wzajemne wykorzystanie dowodów zgromadzonych w postępowaniu przed organem ochrony konkurencji oraz w postępowaniu sądowym}

\subsubsection{Udostępnianie dowodów zgromadzonych w postępowaniu antymonopolowym}

Związanie sądu decyzją administracyjną rozstrzyga co najwyżej fakt naruszenia zakazu praktyk ograniczających konkurencję, co nie jest oczywiście wystarczające dla określenia zakresu odpowiedzialności odszkodowawczej za naruszenie zakazów takich praktyk, stąd właśnie w przypadku roszczeń odszkodowawczych kwestia dostępu do dowodów zgromadzonych w postępowaniu antymonopolowym ma kluczowe znaczenie.

R. Stürner zidentyfikował trzy rodzaje procedur umożliwiających dostęp do akt zgromadzonych w postępowaniu antymonopolowym w celu wykorzystania ich w procesie cywilnym ${ }^{9}$. Po pierwsze mogą one zostać udostępnione na podstawie zarządzenia sądu wydanego na wniosek strony.

Po drugie dowody zebrane przez organ ochrony konkurencji (jako organ administracji) mogą być udostępnione na wniosek sądu. Jeśli wnioski (żądania) sądu są kierowane do krajowych organów ochrony konkurencji, ich podstawę stanowią zazwyczaj ogólne przepisy procedury cywilnej

\footnotetext{
Por. pkt 70 White Paper Staff Working Document.

9 R. Stürner, Duties of Disclosure..., s. 178-179.
} 
(jak np. w Austrii, Niemczech, Francji, Włoszech ${ }^{10}$ ); możliwość wystąpienia $\mathrm{z}$ analogicznym żądaniem do organów $\mathrm{w}$ innych państwach wymaga natomiast $\mathrm{z}$ reguły przepisów szczególnych, zawartych $\mathrm{w}$ regulacjach antymonopolowych ${ }^{11}$. W odniesieniu do postępowań sądowych dotyczących stosowania art. 101 lub 102 TFUE art. 15 ust. 1 rozporządzenia 1/2003 sądy państw członkowskich mogą prosić Komisję „o przekazanie informacji pozostających w jej posiadaniu (...) odnośnie do kwestii dotyczących stosowania wspólnotowego [obecnie unijnego - przyp. aut.] prawa konkurencji”. Przepis ten nie zawiera jednak unormowań proceduralnych co do występowania do Komisji - przyjmuje się, że kwestie te należą do krajowego prawa procesowego (wskazuje na to nie tylko doktryna ${ }^{12}$, ale także motyw 21 preambuły do rozporządzenia 1/2003). Przepisy krajowe w tym zakresie powinny umożliwiać sądom „nieograniczane i efektywne korzystanie z uprawnień” gwarantowanych przez art. 15 (por. pkt 17 obwieszczenia). Mimo że rozporządzenie 1/2003 nie nakłada na Komisję obowiązku realizacji prośby sądu krajowego, to obowiązek taki należy wywodzić z zasad ogólnych prawa unijnego, w tym przede wszystkim zasady lojalnej współpracy; zdaniem K. Kohutka odmowa przekazania informacji może nastąpić tylko wyjątkowo ${ }^{13}$. Komisja zresztą sama postrzega swoją współpracę z sądami krajowymi jako obowiązek, o czym świadczy okoliczność, że w pkt 22 i 29 obwieszczenia o współpracy z sądami krajowymi ustanowiła ona terminy, w jakich zobowiązuje się przekazywać sądom wnioskowane informacje lub opinie (jeden miesiąc od daty otrzymania prośby lub od dnia, kiedy Komisja znalazła się w posiadaniu informacji, w sytuacji, gdy Komisja wystąpiła do sądu krajowego o wyjaśnienia co do wnioskowanych informacji, bądź gdy Komisja musiała skontaktować się z osobą, której dotyczą informacje).

Po trzecie podstawę dostępu do akt mogą stanowić przepisy ogólne o dostępie do informacji publicznej, przy czym w niektórych ustawodawstwach spotyka się ograniczenie polegające na tym, że wstępnym warunkiem dostępu jest uczestnictwo w roli strony w postępowaniu administracyjnym. $\mathrm{Z}$ tego powodu ten sposób dostępu do akt nie może być realizowany w tych systemach ochrony konkurencji, gdzie postępowanie antymonopolowe wsz-

$10 \S 273(2)$ niemieckiego kodeksu postępowania cywilnego; art. 213 włoskiego kodeksu postępowania cywilnego; § 183(1) zd. 3 austriackiego kodeksu postępowania cywilnego; art. 10(1) francuskiego kodeksu cywilnego.

11 Por. np. § 90a (3) niemieckiej ustawy kartelowej.

12 Tak K. Kohutek, Komentarz do art. 15. Teza 2, [w:] Komentarz do rozporzadzenia Rady (WE) $n r$ 1/2003 z dnia 16 grudnia 2002 r. $w$ sprawie wprowadzenia $w$ życie regut konkurencji ustanowionych $w$ art. 81 i 82 Traktatu (Dz.U.UE.L.03.1.1), LEX/el 2006.

13 Ibidem. 
czynane jest wyłącznie z urzędu, a status strony mają jedynie przedsiębiorcy, przeciw którym postępowanie jest prowadzone. Na poziomie stosowania prawa unijnego dostęp do dowodów (na potrzeby postępowania sądowego) zebranych przez Komisję w prowadzonym przez nią postępowaniu antymonopolowym jest możliwy na podstawie rozporządzenia o przejrzystości (rozporządzenie 1049/200114). Jeśli chodzi o obwieszczenie Komisji dotyczące zasad dostępu do akt Komisji w sprawach na mocy art. 81 i 82 Traktatu WE, art. 53, 54 i 57 Porozumienia EOG oraz rozporządzenia Rady (WE) nr 139/200415, to Komisja wyraźnie zastrzega, że ustanowione w tym dokumencie zasady odnoszą się do postępowań prowadzonych przez nią na podstawie rozporządzenia 1/2003 oraz 139/2004, obwieszczenie „nie obejmuje jednak możliwości udostępnienia dokumentów w kontekście innych procedur" (pkt I.1. obwieszczenia), zaś opisane w obwieszczeniu prawo dostępu do dokumentów „różni się od określonego w rozporządzeniu nr 1049/2001 ogólnego prawa dostępu do dokumentów, którego dotyczą inne kryteria i wyjątki oraz które służy innemu celowi” (pkt I.2.). Kierowany do organu ochrony konkurencji wniosek sądu o przekazanie dowodów lub informacji może dotyczyć tylko materiałów będących już w posiadaniu organu. W żadnym wypadku wniosek taki nie może być traktowany jako zobowiązanie lub wniosek do wszczęcia postępowania ${ }^{16}$, czy choćby przeprowadzenia kontroli/przeszukań w toku postępowania antymonopolowego. Polski odpowiednik rozporządzenia o przejrzystości stanowi ustawa o dostępie do informacji publicznej, która również stwarza pewne możliwości dostępu do informacji zgromadzonych przez krajowy organ ochrony konkurencji.

Klasyfikacja R. Stürnera powinna być - w moim przekonaniu - uzupełniona o czwartą kategorię procedur dostępu do akt, tj. procedury gwarantowane przez regulacje wdrażające zakazy antykonkurencyjnych praktyk. W prawie unijnym ograniczone możliwości dostępu do informacji, jakie mogą być wykorzystane w ramach prywatnego egzekwowania prawa konkurencji stwarzają przepisy rozporządzenia 773/2004. Podmiot wnioskujący do Komisji o wszczęcie postępowania antymonopolowego otrzymuje od niej jawną wersję pisma o przedstawieniu zarzutów (art. 6 ust. 1 rozp. 773/2004). W orzecznictwie unijnym odnotowano już przypadek, gdy Sąd (wówczas Sąd Pierwszej Instancji) sprzeciwił się zastosowaniu środka tymczasowego polegającego na zablokowaniu możliwości korzystania z informacji zawartych w jawnej wersji

14 Rozporządzenie (WE) nr 1049/2001 Parlamentu Europejskiego i Rady z dnia 30 maja 2001 r. w sprawie publicznego dostępu do dokumentów Parlamentu Europejskiego, Rady i Komisji (Dz. Urz. WE 2001 L 45/43).

15 Dz. Urz. UE 2005 C 325/07.

16 Por. K. Kohutek, Komentarz do art. 15. Teza 2. 
pisma o przedstawieniu zarzutów (T-12/07 R Polimeri ${ }^{17}$ ). Również w sytuacji, gdy wniosek o wszczęcie postępowania nie został przez Komisję uwzględniony, wnioskodawca może żądać dostępu do dokumentów, na podstawie których Komisja opiera swoją tymczasową ocenę sprawy, przy czym z prawa wglądu wyłączone są tajemnice handlowe oraz „inne poufne informacje należące do innych stron uczestniczących w postępowaniu" (art. 8 ust. 1 zd. 2 rozp. 773/2004); uzyskane w ten sposób informacje mogą być wykorzystane „wyłącznie do celów postępowań sądowych lub administracyjnych” (art. 8 ust. 2 rozp. 773/2004), w których zastosowanie znajdują art. 101 i 102 TFUE - mogą zatem służyć dla dowiedzenia naruszeń unijnych zakazów praktyk ograniczających konkurencję także przed sądami cywilnymi.

W polskim porządku prawnym zawiadamiający o podejrzeniu stosowania praktyk ograniczających konkurencję (por. art. 86 uokik) nie otrzymuje od Prezesa UOKiK postanowienia o wszczęciu postępowania antymonopolowego w jakiejkolwiek postaci.

Barierą dla udostępniania informacji zgromadzonych w postępowaniu antymonopolowym toczącym się przed Prezesem UOKiK może być treść art. 73 ust. 1 uokik, wskazująca, że informacji uzyskanych w toku postępowania nie można wykorzystać $\mathrm{w}$ innych postępowaniach prowadzonych na podstawie odrębnych przepisów. Kolejne przepisy tego artykułu (art. 73 ust. 2-4) przewidują co prawda wyłączenia spod tej zasady, jednak żaden $\mathrm{z}$ nich nie odnosi się expressis verbis do postępowań przed sądami cywilnymi. Zastosowania nie znajdzie nawet art. 73 ust. 2 pkt 5 przewidujący, że zasada nieudostępniania dokumentów nie dotyczy „przekazywania właściwym organom informacji, które mogą wskazywać na naruszenie odrębnych przepisów". W doktrynie obecna jest interpretacja wskazująca, że pod pojęciem „właściwe organy” należy rozumieć organy wszczynające postępowania ex officio, a do takich z całą pewnością nie zaliczają się sądy cywilne. Niektórzy komentatorzy uznają, że ustawodawca „prawdopodobnie” miał na myśli organy władne do wszczynania postępowań z urzędu, a dodatkowym argumentem przeciwko udostępnianiu informacji sądom cywilnym miałoby być to, że pod rządami uokik z 2000 r. Prezes UOKiK „odmawiał sądom cywilnym przekazania informacji zgromadzonych $\mathrm{w}$ toku prowadzonych przez niego postępowań, wskazując, że art. 65 uokik nie przewiduje takiej możliwości"18. Argumentacja odwołująca się do art. 65 uokik z 2000 r. jest jednak o tyle nieadekwatna, że przepis ów nie zawierał odpowiednika

17 Postanowienie Prezesa SPI z dnia 3 maja 2007 r. w sprawie T-12/07 R Polimeri Europa v. Komisja.

18 C. Banasiński, E. Piontek (red.), Ustawa..., s. 689. 
wyłączenia przewidzianego w art. 73 ust. 2 pkt 5 uokik z 2007 r. M. Bernatt wskazuje z kolei, że wyjątek z art. 73 ust. 2 pkt 5 uokik dotyczy tylko takich sytuacji, w których w zakresie przekazywania informacji inicjatywę ma, co do zasady, Prezes UOKiK, a nie organ, który następnie dane informacje będzie mógł wykorzystać 19 - inaczej byłoby jednak w sytuacji, gdyby sąd powszechny wydał zarządzenie zobowiązujące Prezesa do wydania określonych dowodów (informacji). W moim przekonaniu, należałoby jednak przyjąć taki kierunek interpretacji art. 73 ust. 2 pkt 5, który pozwalałby pojęciem „właściwych organów" objąć również sądy ${ }^{20}$. Przemawiałby za tym zamysł ustawodawcy, leżący u podstaw wprowadzenia wyłącznie inkwizycyjnego trybu wszczynania postępowań, co do ułatwiania prywatnego egzekwowania prawa konkurencji i przyjęcie w związku z tym „koncepcji systemu dwubiegunowego”, w której dwa tryby „powinny pełnić wobec siebie rolę komplementarną"21. Wykładnia art. 73 ust. 2 pkt 5 obejmująca pojęciem właściwych organów także sądy cywilne jest pożądana tym bardziej, że w polskim porządku prawnym nie istnieje żaden przepis - wzorowany na art. 15 ust. 1 rozp. 1/2003, który przewidywałby współpracę Prezesa UOKiK z sądami cywilnymi ${ }^{22}$. K. Kohutek uważa ponadto, że naruszenie „odrębnych przepisów”, o jakich mowa w art. 73 ust. 2 pkt 5 może dotyczyć także m.in. przepisów cywilnych ${ }^{23}$.

Jeśli jednak odrzucić proponowaną powyżej interpretację, nie sposób nie podzielać dominującego w polskiej literaturze poglądu, że art. 73 uokik skutecznie blokuje możliwość korzystania z informacji zgromadzonych w postępowaniu przed Prezesem UOKiK w postępowaniu przed sądami cywilnymi24.

Zagadnienie wykorzystania dowodów zgromadzonych w sprawie dotyczy przede wszystkim sytuacji składania pozwów następczych (follow-on claims), tj. wówczas, gdy decyzja o wystąpieniu z roszczeniem podjęta została $\mathrm{w}$ następstwie zamknięcia postępowania przed organem ochrony konkurencji. Potencjalnie problem ten może również - choć zapewne zdecydo-

19 M. Bernatt, [w:] T. Skoczny, A. Jurkowska, D. Miąsik (red.), Ustawa..., s. 1303, Nb 16.

20 Inaczej B. Turno, Leniency - program tagodzenia kar pieniężnych w polskim prawie ochrony konkurencji, LEX a Wolters Kluwer business, Warszawa 2013, s. 551.

21 Uzasadnienie ustawy o ochronie konkurencji i konsumentów, s. 17.

22 Por. M. Bernatt, [w:] T. Skoczny, A. Jurkowska, D. Miąsik (red.), Ustawa..., s. 1298-1299.

23 K. Kohutek, [w:] K. Kohutek, M. Sieradzka, Ustawa o ochronie konkurencji i konsumentów. Komentarz, LEX a Wolters Kluwer business, Warszawa 2008, s. 852.

24 Pogląd taki wyrażają: E. Rumak, P. Sitarek, Polish Leniency Programme and its Intersection with Private Enforcement of Competition Law, YARS 2009, vol. 2(2), s. 112; M. Bernatt, [w:] T. Skoczny, A. Jurkowska, D. Miąsik, Ustawa..., s. 1298, Nb 5; K. Róziewicz-Ładoń, Postępowanie przed Prezesem Urzędu Ochrony Konkurencji i Konsumentów w zakresie przeciwdziatania praktykom ograniczajacym konkurencję, LEX a Wolters Kluwer business, Warszawa 2011, s. 180-181; B. Turno, Leniency - program tagodzenia kar..., s. 551. 
wanie rzadziej - pojawić w sytuacji, gdy pozew składany jest w trakcie trwania postępowania przed organem ochrony konkurencji. W przypadku ujawniania dowodów zgromadzonych w postępowaniu antymonopolowym istotne znaczenie ma decyzja o momencie, w którym ma dojść do tego ujawnienia. Odkrycie dowodów w trakcie postępowania może prowadzić do zmniejszenia efektywności prowadzonego postępowania, łatwo może bowiem wówczas dojść do „przecieków”25. Problematyczne może okazać się ustalenie „bezpiecznego” momentu dla ujawnienia dowodów - przyjęcie rozwiązania, zgodnie z którym dostęp jest możliwy dopiero po zakończeniu postępowania ( $\mathrm{tj}$. po wydaniu decyzji przez organ) wydaje się nadmiernie ostrożnościowe. Możliwe wydaje się tu przyjęcie reguły analogicznej do tej, która w prawie unijnym wyznacza moment dostępu do akt w toku postępowania antymonopolowego - jest nim moment otrzymania przez stronę, przeciw której prowadzi się postępowanie pisma o przedstawieniu zarzutów (art. 15 rozporządzenia 773/2004). W polskiej uokik moment ten nie został precyzyjnie określony, niemniej jednak należy przyjąć, że mógłby to być moment otrzymania przez stronę (lub strony) postanowienia o wszczęciu postępowania antymonopolowego. Przyjęcie takiego rozwiązania jest jednak o tyle problematyczne, że żadne inne podmioty, poza stronami, nie mają możliwości dowiedzenia się o otrzymaniu takiego postanowienia przez strony; Prezes UOKiK nie ma obowiązku informowania opinii publicznej o wszczęciu postępowania antymonopolowego np. poprzez stosowne ogłoszenie w wydawanym przez siebie Dzienniku Urzędowym UOKiK. Również zawiadamiający - podmiot potencjalnie zainteresowany dochodzeniem roszczeń na drodze prywatnoprawnej - niekoniecznie musi uzyskać informację o wszczęciu postępowania antymonopolowego (art. 86 ust. 4 uokik nie precyzuje bowiem obowiązku Prezesa UOKiK w ten sposób, poprzestając na ogólnikowym stwierdzeniu o „przekazaniu informacji na piśmie o sposobie rozpatrzenia zawiadomienia wraz z uzasadnieniem" - informacja o tym, że Prezes UOKiK zamierza wszcząć postępowanie antymonopolowe będzie czyniła zadość dyspozycji przywołanego przypisu, choć nie będzie informacją wskazującą na moment wszczęcia postępowania, a tym samym - moment umożliwienia dostępu do akt postępowania). W tej sytuacji podmioty zainteresowane (na potrzeby prywatnego egzekwowania prawa konkurencji) dostępem do informacji gromadzonych w toku postępowania antymonopolowego mogą podjąć działania dwuetapowe: po pierwsze mogą wystąpić do

25 Tak W. P. J. Wils, The Relationship Between Public Antitrust Enforcement and Private Actions for Damages, World Competition 2009, vol. 32(1); dostępny także pod adresem: http://papers.ssrn.com/sol3/papers.cfm?abstract_id=1296458, s. 23. 
Prezesa UOKiK w trybie przewidzianym ustawą o dostępie do informacji publicznej o informację, czy toczy się postępowanie w określonej sprawie (ewentualnie: na jakim jest ono etapie); po drugie po uzyskaniu tej informacji mogą wystąpić - także na podstawie ustawy o dostępie do informacji publicznej - z wnioskiem o właściwe (pożądane) informacje.

W doktrynie słusznie podnosi się, że brak możliwości udostępniania dowodów lub informacji zgromadzonych przez organ antymonopolowy oznacza marnowanie potencjału publicznych organów administracji powołanych przecież do ochrony konkurencji ${ }^{26}$. Obawy co do tego, że organy ochrony konkurencji zostaną zalane wnioskami o udostępnienie dowodów, są do pewnego stopnia uzasadnione, jednak do czasu, gdy prywatne egzekwowanie prawa konkurencji nie stanie się masowe, nie znajdą one potwierdzenia w rzeczywistości. Wielość poszkodowanych praktykami ograniczającymi konkurencję nie przekłada się bowiem na liczbę wniosków o ujawnienie dowodów, jako że jedna praktyka może być źródłem dużej liczby postępowań sądowych, w których ujawniany będzie identyczny materiał dowodowy.

\subsubsection{Potencjalny status dowodów zgromadzonych w postępowaniu antymonopolowym w postępowaniu przed sądem powszechnym}

Dyskusyjne wydaje się to, czy można przyjąć, że dowody zebrane w toku postępowania antymonopolowego stanowią dokumenty urzędowe w rozumieniu art. $244 \S 1 \mathrm{kpc}$. Dokumenty te nie zostały bowiem w istocie sporządzone przez organ władzy publicznej, a tylko przez ten organ zgromadzone i uporządkowane. Status dokumentu w rozumieniu art. $244 \S 1 \mathrm{kpc}$ może mieć natomiast decyzja organu ochrony konkurencji (Prezesa UOKiK lub Komisji) - na zasadzie analogii do stanowiska judykatury uznającego za dokumenty urzędowe wyroki sądowe ${ }^{27}$, także uniewinniające ${ }^{28}$. Sąd Najwyższy stwierdził, że wyrok uniewinniający wydany w postępowaniu karnym jest dokumentem urzędowym i wiąże się $\mathrm{z}$ nim domniemanie zgodności z prawdą ${ }^{29}$. Również ,postanowienie o umorzeniu śledztwa wprawdzie nie

26 Tak R. Stürner, Duties of Disclosure..., s. 179.

27 Por. m.in. orzeczenie SN z dnia 27 marca 1962 r., IV CR 672/61, SOP 1965 z. 1, poz. 3; orzeczenie SN z dnia 19 lipca 1962 r., II PR 203/62, OSNC 1963 nr 7-8, poz. 165. W doktrynie pogląd taki wyrażają m.in. K. Knoppek, [w:] H. Dolecki, T. Wiśniewski (red.), Kodeks postępowania cywilnego. Komentarz. Tom 1, LEX a Wolters Kluwer business, Warszawa 2011, s. 873.

28 Por. m.in. orzeczenie SN z dnia 17 kwietnia 1962, 4 CR 796/61, RPEiS 1963, nr 2, s. 356; wyrok SN z dnia 18 września 1969 r., II CR 308/69, OSNC 1970, nr 7-8, poz. 130.

29 Wyrok SN z dnia 18 listopada 1970 r., I PR 385/69, Lex nr 6822. 
wiąże sądu cywilnego, lecz jest ono dokumentem publicznym i dlatego łącznie $\mathrm{z}$ materiałem dowodowym zebranym w sprawie karnej powinno być uwzględnione przy ocenie obrony pozwanego"30.

Dokumenty urzędowe korzystają $\mathrm{z}$ dwóch domniemań prawnych: $\mathrm{z}$ domniemania autentyczności oraz $\mathrm{z}$ domniemania zgodności $\mathrm{z}$ prawdą (tj. że zaświadczają prawdziwy stan rzeczy), przy czym $\mathrm{z}$ tego ostatniego korzystają tylko dokumenty narratywne (sprawozdawcze, zawierające oświadczenia wiedzy) - za takie można uznać decyzje Prezesa UOKiK. Obydwa

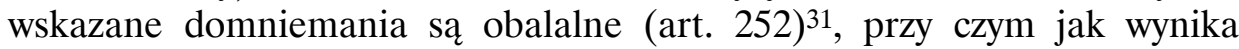
$\mathrm{z}$ orzecznictwa SN niemożliwe jest obalenie domniemania prawdziwości wyroku sądowego ${ }^{32}$ (jak się wydaje, nie można tutaj zastosować analogii i stwierdzić, że brak możliwości obalenia decyzji Prezesa UOKiK, ale jeśli decyzja została utrzymana w mocy wyrokiem sądowym, to również i w tym przypadku należałoby przyjąć, że nie ma możliwości obalenia domniemania jej zgodności z prawdą).

Znaczenie dowodowe mogą mieć tylko niektóre decyzje organów ochrony konkurencji, tj. decyzja uznająca praktykę za ograniczającą konkurencję i decyzja umarzająca postępowanie ze względu na niespełnienie przesłanek zakazu praktyk ograniczających konkurencję. Status decyzji Prezesa UOKiK jest taki sam jak decyzji wydanych przez Komisję lub organy ochrony konkurencji innych państw (nie tylko państw członkowskich UE), ponieważ „Kodeks postępowania cywilnego zasadniczo zrównuje moc dowodową zagranicznych dokumentów urzędowych z polskimi, bez wprowadzania klauzuli wzajemności"33.

Trzeba natomiast zaznaczyć, że przepisy przewidujące możliwość bezpośredniego wykorzystania w postępowaniu sądowym dowodów zgromadzonych $\mathrm{w}$ postępowaniu antymonopolowym przełamywałyby $\mathrm{w}$ istocie regułę wyrażoną w art. $235 \S 1 \mathrm{kpc}$, zgodnie z którą „postępowanie dowodowe odbywa się przed sądem orzekającym”. Należy zastanowić się nad tym, czy dowody zgromadzone w postępowaniu antymonopolowym mogłyby zostać uznane w postępowaniu sądowym za źródła domniemań faktycznych (art. $231 \mathrm{kpc}$ ). W doktrynie podnosi się, że podstawą domniemania

30 Orzeczenie SN z dnia 17 kwietnia 1962 r., IV CR 796/61, RPEiS 1963, nr 2.

31 K. Knoppek, [w:] H. Dolecki, T. Wiśniewski (red.), Kodeks postępowania cywilnego..., s. 874.

32 Wyrok SN z dnia 15 września 1999 r., III CKN 606/99. Pogląd ten oceniany jako trafny przez K. Knoppka, [w:] H. Dolecki, T. Wiśniewski (red.), Kodeks postępowania cywilnego..., s. 893.

33 T. Demendecki, [w:] A. Jakubecki (red.). Kodeks Postępowania Cywilnego. Komentarz, Oficyna a Wolters Kluwer business, Warszawa 2008, s. 364. 
mogą być m.in. fakty powszechnie znane, fakty znane sądowi urzędowo, fakty bezsporne (przyznane i niezaprzeczone), a nawet wniosek innego domniemania faktycznego. Zastosowanie domniemania faktycznego stanowi dyskrecjonalną czynność podejmowaną przez sąd z urzędu ${ }^{34}$.

Można również przyjąć, że fakty dowiedzione poprzez materiał dowodowy zgromadzony w postępowaniu antymonopolowym (a udostępniony dla potrzeb postępowania sądowego), są „faktami znanymi sądowi urzędowo” (art. 228 $\S 2$ ), a więc nie wymagającymi już dowodu (art. $228 \S 2 \mathrm{w}$ zw. z art. 228 $\S 1 \mathrm{kpc}$ ), choć strony muszą się co do nich wypowiedzieć. W doktrynie podnosi się, że za fakty znane sądowi urzędowo uznaje się te, o których sąd dowiedział się przy wykonywaniu czynności urzędowych, w tym przy rozpoznawaniu innej sprawy 35 (w tym innego roszczenia cywilnoprawnego związanego z tym samym naruszeniem zakazu antykonkurencyjnych praktyk), nie ma natomiast znaczenia prywatna wiedza poszczególnych członków składu sędziowskiego, istotna jest za to wiedza nabyta $\mathrm{w}$ ramach wykonywania obowiązków urzędowych, np. w rozmowach $\mathrm{z}$ innymi sędziami ${ }^{36}$. W orzecznictwie można przy tym zidentyfikować pogląd, zgodnie z którym „do skutecznego zastosowania art. $228 \S 2 \mathrm{kpc}$ nie wystarczy ogólnikowe powołanie się na fakty znane sądowi urzędowo $\mathrm{z}$ innych rozpatrywanych spraw; sąd powinien przytoczyć konkretny fakt, wskazać sprawę, w której został on stwierdzony i zwrócić na rozprawie uwagę stron, że zamierza go wykorzystać jako fakt znany sądowi urzędowo" (II CSK 166/0937).

Za fakty znane sądowi urzędowo można byłoby zatem uznać fakty będące przedmiotem rozpoznania Sądu Ochrony Konkurencji i Konsumentów w sprawach z odwołania od decyzji Prezesa UOKiK, sądu apelacyjnego w Warszawie w sprawach z odwołania od wyroku SOKiK czy Sądu Najwyższego w sprawach kasacyjnych. Zakres oddziaływania takich faktów byłby jednak stosunkowo niewielki i sprowadzałby się jedynie do spraw rozpatrywanych we wskazanych sądach.

Faktem znanym sądowi urzędowo w przytoczonym powyżej znaczeniu nie będą natomiast decyzje Prezesa UOKiK. Niemniej jednak zgodnie ze stanowiskiem SN fakty znane sądowi urzędowo są szczególnym rodzajem „faktów

34 Tak P. Rylski, Dziatanie sq̨du z urzędu a faktyczna podstawa wyroku cywilnego, Oficyna a Wolters Kluwer business, Warszawa 2009, s. 279.

35 Tak m.in. K. Flaga-Gieruszyńska, [w:] A. Zieliński (red.), Kodeks Postępowania Cywilnego. Komentarz, C. H. Beck, Warszawa 2011, s. 410.

36 Tak M. Sieńko, [w:] M. Manowska (red.), Kodeks postępowania cywilnego. Komentarz. Tom 1, LexisNexis, Warszawa 2011, s. 493. Por. także wyrok SN z dnia 27 listopada 1978 r., III CRN 238/78, LexPolonica nr 321537.

37 Wyrok SN z dnia 20 sierpnia 2009 r., II CSK 166/09, Rejent 2010, nr 7-8, poz. 178. 
powszechnie znanych"38 (notoryjnych), te ostatnie są uwzględniane przez sąd $z$ urzędu bez powoływania się na nie przez strony (art. $213 \S 1 \mathrm{kpc}$ ). Pozwalałoby to ewentualnie przyjąć, że faktami znanymi sądowi urzędowo będą fakty dotyczące naruszenia zakazu karteli czy zakazu nadużywania pozycji dominującej, jeśli były one przedmiotem głośnych relacji medialnych. W doktrynie podnosi się jednak, że „nie można utożsamiać faktów medialnych będących przedmiotem wypowiedzi i zainteresowania mediów z faktami powszechnie znanymi" 39 , również SN wyraził pogląd, zgodnie z którymi zamieszczenie informacji o fakcie w Internecie nie oznacza, że jest to fakt powszechnie znany ${ }^{40}$. Można zatem przyjąć, że doniesienia medialne o głośnych postępowaniach antymonopolowych, choć mają szansę dać sędziemu pewien zasób wiedzy o sprawie (w tym wiedzę o wydaniu decyzji przez organ ochrony konkurencji), to wiedza ta nie może być uznana za fakt znany sądowi urzędowo w rozumieniu art. $228 \S 2 \mathrm{kpc}$, jako że jest to wiedza prywatna. W tej sytuacji należałoby oczekiwać, że sąd wystąpi do organu ochrony konkurencji o przedstawienie dowodów na podstawie $248 \S 1 \mathrm{kpc}$.

W doktrynie podkreśla się również, że fakty znane sądowi urzędowo można wykorzystać tylko pomocniczo (np. do zawieszenia postępowania), nie stanowią one jednak podstawy do rozstrzygnięcia sprawy merytorycznie ${ }^{41}$.

\subsubsection{Udostępnianie dowodów zgromadzonych w postępowaniu sądowym na rzecz postępowania antymonopolowego}

Mechanizm ujawniania dowód nie dotyczy natomiast możliwości wykorzystania w postępowaniu przed organem ochrony konkurencji dowodów zgromadzonych $\mathrm{w}$ postępowaniu sądowym. Sądów nie należy postrzegać jako organów na tyle wyspecjalizowanych, aby ich ocena dowodów mogła zostać przyjęta jako własna przez organy antymonopolowe. Występowanie do sądów o „przekazanie lub zapewnienie przekazania wszelkich dokumentów koniecznych dla rozstrzygnięcia sprawy" przez organy ochrony konkurencji może być uzasadnione co najwyżej koniecznością przygotowania

38 Por. wyrok SN z dnia 8 marca 1974 r., II CR 1/74.

39 M. Sieńko, [w:] M. Manowska (red.), Kodeks postępowania cywilnego..., s. 492.

40 Por. wyrok SN z dnia 10 lutego 2010 r., V CSK 269/09, OSNC 2010, nr 9, poz. 127.

41 K. Piasecki, Postępowanie sporne rozpoznawcze w sprawach cywilnych, C. H. Beck, Warszawa 2010, s. 256. Tak również H. Dolecki, [w:] H. Dolecki, T. Wiśniewski (red.), Kodeks postępowania cywilnego..., s. 818. 
przez organy ochrony konkurencji stanowiska jako amicus curiae (tak jak przewiduje to art. 15 ust. 3 akapit drugi rozp. 1/2003).

\subsubsection{Zakres przedmiotowy zastosowania mechanizmu ujawniania dowodów}

\subsubsection{Uwagi wstępne}

Dostęp do dowodów (akt) zgromadzonych w postępowaniu antymonopolowym, czy też zakres tego dostępu, może być determinowany charakterem poszczególnych dowodów, które można skategoryzować następująco: 1) dowody zwykłe (nie należące do żadnej z innych kategorii), 2) dowody stanowiące tajemnicę przedsiębiorcy, 3) dowody zebrane $\mathrm{w}$ ramach programu darowania i łagodzenia kar, 4) dowody zgromadzone w postępowaniu zakończonym ugodą.

W przypadku, gdy ujawnieniu miałyby podlegać dowody zgromadzone w postępowaniu antymonopolowym, ujawnieniu powinny podlegać zarówno dowody prowadzące do stwierdzenia naruszenia, jak i te, które doprowadziły do umorzenia postępowania ze względu na niespełnienie przesłanek zastosowania ustawy w ogóle i poszczególnych zakazów praktyk ograniczających konkurencję. W przypadku ujawniania dowodów między stronami nie obowiązuje zasada wolności od samooskarżenia (nemo tenetur edere contra se) - obowiązek ujawnienia musi dotyczyć także środków obciążających pozwanego ${ }^{42}$.

Informacje stanowiące dowody w sprawie mogą dotyczyć faktów, ale mogą mieć również charakter ekonomiczny (np. oszacowanie szkody).

Szczegółowa regulacja dotycząca ujawniania dowodów powinna przewidywać możliwość wykorzystania dowodów zgromadzonych w postępowaniu antymonopolowym na potrzeby procesu cywilnego, przy czym dostępność tych materiałów musi - w moim przekonaniu - doznawać pewnych ograniczeń. W tym wypadku zasadą pozostaje zaspokojenie interesu prywatnego poszkodowanych, wyjątkiem zaś - przyznanie priorytetu interesowi publicznemu i/lub interesowi prywatnemu uczestników postępowania antymonopolowego. O ile w przypadku zastosowania wyłącznie prawa krajowego interes publiczny powinien być analizowany jako przesłanka interwencji antymonopolowej, o tyle w sytuacji, gdy stosowane są również przepisy TFUE, analiza interesu publicznego powinna odbywać się na dwóch płaszczyznach: interwencji antymonopolowej jako takiej oraz interesu Unii Europejskiej43.

42 Por. pkt 120 White Paper Staff Working Document.

43 Por. wyrok w sprawie Pfleiderer, pkt 32. 
Potencjalne wyjątki od zasady ujawniania dowodów miałyby dotyczyć wyłącznie sytuacji, w których udostępnienie dowodów byłoby obligatoryjne (w ramach mechanizmu discovery lub wskutek zarządzenia sądu). Nie uznaję natomiast za słuszne zakazywania przedsiębiorcom dobrowolnego ujawniania dowodów, które w innych okolicznościach objęte byłyby wyłączeniem spod zasady dostępności (tak chce Komisja w odniesieniu do dowodów pozyskanych w ramach programu leniency ${ }^{44}$ ).

Należy zastrzec, że treść art. 73 ust. 1 uokik czyni rozważania nad wyłączeniem ujawniania dowodów w odniesieniu do polskiej praktyki prywatnego egzekwowania zakazów praktyk ograniczających konkurencję bezprzedmiotowymi; prowadzone w dalszej części rozważania mają w odniesieniu do prawa polskiego co najwyżej charakter postulatów de lege ferenda.

\subsubsection{Wyłączenie ujawniania dla dowodów stanowiących tajemnicę przedsiębiorstwa}

Tajemnica przedsiębiorstwa podlega ochronie zarówno w krajowym, jak i unijnym postępowaniu antymonopolowym (jak słusznie stwierdził SOKiK, „postępowanie antymonopolowe nie może stać się bowiem forum dla ujawnienia tajemnic przedsiębiorstwa" ${ }^{45}$ ). Art. 69 ust. 1 uokik przewiduje możliwość ograniczenia przez Prezesa UOKiK, z urzędu lub na wniosek, prawa wglądu do materiału dowodowego załączonego do akt sprawy (w tym materiałów uzyskanych od organów ochrony konkurencji innych państw członkowskich UE na podstawie art. 73 ust. 5, włączonych do postępowania) ze względu na zagrożenie ujawnieniem tajemnicy przedsiębiorstwa (jak również innych tajemnic chronionych na podstawie odrębnych przepisów). Tajemnica przedsiębiorstwa na gruncie ustawy o ochronie konkurencji i konsumentów definiowana jest poprzez odesłanie za pomocą art. 4 pkt 17 uokik do art. 11 ust. 4 uznk. Tajemnicę przedsiębiorstwa stanowią informacje techniczne, technologiczne, organizacyjne przedsiębiorstwa, posiadające wartość gospodarczą, nieujawnione do wiadomości publicznej, co do których przedsiębiorca podjął niezbędne działania w celu zachowania ich poufności ${ }^{46}$. W doktrynie ${ }^{47}$ i orzecznictwie ${ }^{48}$ przeważa szeroka interpretacja tej definicji.

44 Por. pkt 2.9. Białej księgi.

45 Postanowienie SAM z dnia 15 maja 1996 r., XVII Amz 1/96, Wokanda 1997, nr 10, s. 55.

46 Na temat definicji tajemnicy przedsiębiorstwa w kontekście uznk - por. m. in. A. Michalak, [w:] M. Zdyb, M. Sieradzka (red.), Ustawa o zwalczaniu nieuczciwej konkurencji. Komentarz, LEX a Wolters Kluwer business, Warszawa 2011, s. 308-320.

47 Por. m.in. M. Będkowski-Kozioł, [w:] T. Skoczny, A. Jurkowska, D. Miąsik (red.), Ustawa..., s. 289 ( $\mathrm{Nb} 563)$.

48 Por. postanowienie SAM z dnia 28 listopada 2001 r., XVII Amz 14/01, niepubl. 
Unijne rozporządzenie 1/2003 nie posługuje się natomiast pojęciem tajemnicy przedsiębiorstwa, używając w zamian pojęcia tajemnicy handlowej (business secrets). Rozporządzenie nie zawiera jednak definicji legalnej tajemnicy handlowej, w doktrynie podkreśla się, że Komisja w praktyce stosuje szeroką jego interpretację $e^{49}$. W orzecznictwie unijnym tajemnicę handlową określa się jako taką informację o działalności przedsiębiorstwa, której ujawnienie mogłoby spowodować dla tego przedsiębiorstwa szkodę ${ }^{50}$. Obwieszczenie Komisji o dostępie do akt wskazuje przykładowe informacje, które mogą być zakwalifikowane jako tajemnice handlowe, należą do nich m.in.: informacje związane z know-how przedsiębiorstwa, metody wyliczania kosztów, informacje dotyczące produkcji i procesów, źródła dostaw, wyprodukowana i sprzedana ilość towaru, a także udział w rynku' ${ }^{51}$.

Art. 27 ust. 2 rozp. 1/2003 ustanawia prawo wglądu do akt Komisji jako część składową prawa do obrony dla stron, przy czym prawo to ma być realizowane „przy zachowaniu uzasadnionego interesu przedsiębiorstw w zakresie ochrony tajemnicy handlowej”. Komisja nie zgłasza ani nie udostępnia informacji „w takim zakresie, w jakim zawierają tajemnice handlowe lub inne poufne informacje dowolnej osoby" (art. 16. ust. 1 rozp. 773/2004). Art. 8 ust. 1 zd. 2 rozp. 773/2004 zastrzega, że wnioskodawca (o wszczęcie postępowania przez Komisję) może nie uzyskać dostępu do tajemnic handlowych i innych poufnych informacji ${ }^{52}$.

Z kolei art. 4 ust. 2 rozporządzenia o przejrzystości (1049/2001) przewiduje, że instytucje unijne (w tym Komisja) mogą odmówić dostępu do dokumentu, jeśli ujawnienie go naruszyłoby ochronę ,interesów handlowych osoby fizycznej lub prawnej”, w tym praw własności intelektualnej; pojęcie interesów handlowych jest znacznie szersze od pojęcia tajemnicy handlowej, ale niewątpliwie konsumuje ono to ostatnie.

49 T. K. Giannakopoulos, Safeguarding Companies' Rights in Competition and Anti-Dumping/ Anti-Subsidies Proceedings, Kluwer Law International 2011, s. 198.

50 Wyrok SPI z dnia 18 września 1996 r. T-353/94 Postbank v. Komisja (Zb. Orz. 1996, s. II-921), pkt 87.

51 Pkt 18 obwieszczenia Komisji dotyczącego zasad dostępu do akt Komisji.

52 Por. także pkt 8 preambuły do rozporządzenia 773/2004. Również w zawiadomieniu Komisji w sprawie najlepszych praktyk w zakresie prowadzenia postępowań w związku z art. 101 i 102 TFUE (Dz. Urz. UE 2011 C 308/6) Komisja wskazuje, że już na wstępnym etapie postępowania, gdy stronom przedstawiane są „najważniejsze uwagi” zgłoszone Komisji, ta „będzie honorować uzasadnione wnioski złożone przez skarżącego lub zainteresowane osoby trzecie o nieujawnianie przedstawionych przez nie uwag przed wystosowaniem pisemnego zgłoszenia zastrzeżeń, jeśli istnieją rzeczywiste obawy dotyczące poufności, w tym obawy dotyczące działań odwetowych lub związane z ochroną tajemnic handlowych" (pkt 73). 
Ujawnianie dowodów na potrzeby postępowania cywilnego nie powinno co do zasady - obejmować materiałów dowodowych stanowiących tajemnicę przedsiębiorstw. Zasada ta dotyczy zarówno informacji poufnych zgromadzonych w postępowaniu przed krajowym organem ochrony konkurencji, jak i w postępowaniu przed Komisją. Niemniej jednak ochrona tajemnic przedsiębiorstwa nie może być absolutna - jej granicą pozostaje możliwość ubiegania się o zaspokojenie roszczeń: jeśli bez ujawnienia informacji poufnych zaspokojenie roszczenia nie jest możliwe, wówczas należy porzucić ochronę tajemnicy przedsiębiorca. W tym kontekście pomocna powinna być wytyczna Komisji zawarta w pkt. 14 preambuły rozp. 773/2004: „w przypadku, gdy tajemnice handlowe lub inne informacje poufne są konieczne dla udowodnienia naruszenia, Komisja powinna ocenić każdy pojedynczy dokument pod tym kątem, czy potrzeba jego ujawnienia jest większa niż szkoda, jaka mogłaby wyniknąć z ujawnienia”. Sam poufny charakter informacji zależy od subiektywnego odczucia przedsiębiorców, które jednak - na potrzeby ujawniania dowodów - musi być obiektywnie weryfikowane przez organ ochrony konkurencji ${ }^{53}$ lub sąd.

Nawet jeśli w postępowaniu antymonopolowym interes w postaci ochrony tajemnicy przedsiębiorstwa ma pierwszeństwo przed realizacją zasady czynnego udziału stron $w$ postępowaniu ${ }^{54}$ oraz zasady jawności postępowania, to $\mathrm{w}$ ramach prywatnego egzekwowania reguł konkurencji przedsiębiorca, którego prawa są chronione na podstawie przepisów antymonopolowych, może tę ochronę utracić (wskutek ujawnienia akt na potrzeby procesu cywilnego), jeśli dostęp do określonych informacji stanowi warunek niezbędny do skutecznego wniesienia roszczeń. Standard ochrony antymonopolowej nie może być utrzymany, ponieważ w istocie mamy do czynienia $\mathrm{z}$ zupełnie różnymi sytuacjami. W postępowaniu antymonopolowym informacje poufne są znane organowi ochrony konkurencji, więc poufność nie stoi na przeszkodzie skutecznemu wdrożeniu zakazów praktyk ograniczających konkurencję, zaś ochrona tajemnicy przedsiębiorcy jest de facto ochroną przed ich dostępnością dla pozostałych stron i ewentualnie osób trzecich (wnioskodawców, jeśli postępowanie antymonopolowe wszczynane jest również na wniosek). W postępowaniu cywilnym potencjalna ochrona infor-

53 W przypadku organu ochrony konkurencji ocena, czy w toku postępowania może dojść do naruszenia tajemnicy przedsiębiorstwa jest podyktowana realizacją zasady ogólnej czuwania nad interesem strony w postępowaniu (art. 9 in fine KPA) - tak R. Stankiewicz, M. Pawełczyk, Ochrona tajemnicy przedsiębiorstwa $w$ postępowaniu antymonopolowym, Radca Prawny 2005, nr 5.

54 Por. C. Banasiński, E. Piontek (red.), Ustawa..., s. 668. 
macji poufnych oznaczałaby całkowity brak dostępu do tych informacji dla powoda, co w ogóle mogłoby wykluczyć możliwość dochodzenia roszczeń.

W przypadku ochrony tajemnicy przedsiębiorstwa mamy do czynienia ze szczególnie delikatnym ważeniem interesów, ponieważ na obydwu szalach znajduje się interes prywatny (co znacząco odróżnia tę sytuację od ważenia interesów w ramach ujawniania informacji z leniency, gdzie obok interesów prywatnych przedsiębiorców zaangażowany jest również interes publiczny ${ }^{55}$ ). Na problem tego rodzaju zwrócił uwagę Trybunał Sprawiedliwości w orzeczeniu w sprawie C-275/06 Promusicae ${ }^{56}$, którego istotą był konflikt między prawami podstawowymi: prawem do poszanowania życia prywatnego $\mathrm{z}$ jednej strony i prawem do skutecznego środka prawnego (oraz prawem do ochrony własności) z drugiej.

$\mathrm{Na}$ sądach spoczywa zatem trudne zadanie zastosowania testu proporcjonalności w celu rozstrzygnięcia, któremu z interesów przyznać pierwszeństwo ${ }^{57}$. Kluczowym elementem tego testu powinno być zbadanie, czy ujawnienie poufnych informacji jest niezbędne do zaspokojenia roszczeń (to znaczy, czy bez tych informacji powód nie może wystąpić z pozwem). Waga materiału dowodowego, tak jak w postępowaniu antymonopolowym stanowi przesłankę ograniczenia prawa wglądu ${ }^{58}$, tak i w postępowaniu sądowym powinna odgrywać główną rolę dla celu ujawniania dowodów. Niezbędnymi będą przede wszystkim takie informacje, które stanowią o istocie antykonkurencyjnej praktyki oraz takie, które mogą bezpośrednio potwierdzać jej istnienie. Słusznie podkreśla się przy tym w doktrynie, że za tajemnicę przedsiębiorstwa nie można w zasadzie uznać informacji stanowiącej istotę praktyki ograniczającej konkurencję (choć nie można również bezwzględnie tego wykluczyć) ${ }^{59}$. Naruszenia tajemnicy handlowej nie uzasadnia natomiast - w moim przekonaniu - fakt, że ujawniana informacja miałaby być kluczowa dla ustalenia wielkości/zakresu szkody. Ujawnieniu nie powinny

55 Por. pkt 2.4.3. poniżej.

56 Wyrok TS z dnia 29 stycznia 2008 r. w sprawie C-275/06 Productores de Música de España (Promusicae) v. Telefónica de España SAU (Zb. Orz. 2008, I-00271). Por. E. Prejs, Udostępnianie danych osobowych internatów dla celów postępowania cywilnego - glosa do wyroku ETS z 29.01.2008 r. w sprawie C-275/06 Productores de Música de España (Promusicae) v. Telefónica de España SAU, EPS 2009, nr 4, s. 49-55.

57 Zasadę proporcjonalności nakazał również uwzględnić Trybunał Sprawiedliwości w rozstrzygnięciu konfliktu praw podstawowych we wzmiankowanym powyżej orzeczeniu w sprawie C-275/06 Promusicae (por. pkt 70 wyroku).

58 Por. M. Bernatt, [w:] T. Skoczny, A. Jurkowska, D. Miąsik (red.), Ustawa..,, s. 1275 $(\mathrm{Nb} 26)$.

59 Tak C. Banasiński, E. Piontek (red.), Ustawa..., s. 669. 
natomiast podlegać informacje irrelewantne dowodowo dla sprawy, które jednocześnie spełniają przesłankę tajemnicy przedsiębiorstwa ${ }^{60}$.

Istotna wydaje się również ocena stopnia prawdopodobieństwa naruszenia zakazu porozumień ograniczających konkurencję przez przedsiębiorcę, którego tajemnice podlegają ochronie ${ }^{61}$. Jednym $\mathrm{z}$ możliwych rozwiązań jest również przyjęcie zasady, że bezpośredni dostęp do dowodów przysługuje tylko prawnikom stron lub innym profesjonalistom (np. biegłym rewidentom), którzy byliby w stanie przygotować streszczenie informacji lub przygotować zestawienie zagregowanych danych, pozbawione już przymiotu poufności62.

Nie bez znaczenia dla zastosowania testu proporcjonalności pozostaje również okoliczność, czyja tajemnica miałaby zostać ujawniona na potrzeby procesu cywilnego - jeśli będzie to tajemnica sprawcy naruszenia, obawy co do ujawnienia tajemnicy powinny być mniejsze niż w przypadku, gdy chodzi o ujawnienie tajemnicy osoby trzeciej (np. przedsiębiorcy, który nie dopuścił się naruszenia, ale dostarczył dowodu na jego istnienie; lub świadka) ${ }^{63}$.

W kontekście „przepływu” informacji między organem ochrony konkurencji a sądem uzasadnione byłoby przyjęcie zasady, że jeśli w postępowaniu antymonopolowym określone informacje były jawne (tj. żaden podmiot nie wnioskował o ograniczenie prawa wglądu do nich), to muszą one pozostać jawne również w postępowaniu sądowym. Reguła ta sprawdza się jednak wyłącznie wówczas, gdyby o ograniczenie jawności materiałów w postępo-

60 Tak C. Banasiński, E. Piontek (red.), Ustawa..., s. 670. Por. postanowienie z dnia 15 maja 1996 r., XVII Amz 1/96, Wokanda 1997, nr 10, s. 55; postanowienie SOKiK z dnia 30 maja 2006 r., XVII Amz 21/06, niepubl. Niemniej jednak w polskiej doktrynie wyrażane jest również stanowisko, że art. 69 uokik nie pozwala na tworzenie dodatkowej przesłanki uzasadniającej ograniczenie prawa wglądu do materiału dowodowego, jaką jest brak istotnego dla postępowania charakteru informacji - tak M. Bernatt, [w:] T. Skoczny, A. Jurkowska, D. Miąsik (red.), Ustawa..., s. 1275-1276 (Nb 26) oraz G. Materna, Ograniczenie prawa wgladu do materiału dowodowego $w$ postepowaniach przed Prezesem UOKiK, PPH 2008, nr 4, s. 33. Zdaniem pierwszego z wymienionych autorów wskazują na to również niektóre postanowienia SOKiK: z dnia 19 kwietnia 2004 r., XVII Amz 4/04, niepubl. i z dnia 22 czerwca 2006 r., XVII Amz 67/05, niepubl. Spór ten nie wydaje się mieć znaczenia dla prywatnego egzekwowania prawa konkurencji, w zakresie którego wartość dowodowa poszczególnych materiałów może być odmienna od tej, jaką reprezentują one dla postępowania antymonopolowego.

61 Por. pkt 116 White Paper Staff Working Document.

62 Por. pkt 116 White Paper Staff Working Document.

63 W polskiej doktrynie panuje zgoda co do tego, że podmiotem wnioskującym do Prezesa UOKiK o ograniczenie prawa wglądu do informacji stanowiących tajemnicę przedsiębiorstwa mogą wnioskować nie tylko strony, ale każdy pomiot, który ma w tym interes prawny - tak G. Materna, Ograniczenie prawa wgladu..., s. 28-29. 
waniu sądowym miałaby wystąpić strona postępowania antymonopolowego bądź inny podmiot, który wiedział o toczącym się postępowaniu i mógł wystąpić o ograniczenie prawa wglądu do akt w trybie art. 69 uokik. Ze względu bowiem na czysto inkwizycyjny charakter postępowania antymonopolowego, możliwa jest sytuacja, kiedy podmiot, który na etapie postępowania wyjaśniającego udostępnił określone informacje i potencjalnie był zainteresowany ochroną ich poufności, nie wystąpił z wnioskiem o ograniczenie prawa wglądu do materiałów, jako że nie wiedział o toczącym się „właściwym” postępowaniu antymonopolowym. Należy jednak zastrzec, że w świetle uchwały SN, III SZP 1/1064, możliwość wnioskowania o ograniczenie prawa wglądu do akt istnieje już na etapie postępowania wyjaśniającego, więc podmiot, który udzielił Prezesowi UOKiK informacji w trybie art. 50 uokik i jest zainteresowany ochroną ich poufności, musi zadbać o to już na etapie postępowania wyjaśniającego. Brak wniosku o ograniczenie dostępu do akt w momencie udzielania informacji Prezesowi UOKiK należy odczytywać jako brak zainteresowania ochroną ich poufności. Ponadto zasada braku ochrony w postępowaniu sądowym informacji niechronionych w postępowaniu antymonopolowym może doznać wyjątku, gdyby nadzwyczajna zmiana okoliczności faktycznych spowodowała, że określona informacja zyskała status poufnej.

Zasada ochrony poufności informacji nie działa jednak w odwrotną stronę - tzn. jeśli informacje zostały utajnione w postępowaniu antymonopolowym, to niekoniecznie muszą one pozostać poufne w postępowaniu sądowym, choć w wielu wypadkach tak zapewne mogłoby się zdarzyć.

Jeśli do przekazania informacji poufnych miałoby dojść w ramach współpracy między sądami a organami ochrony konkurencji, dodatkowym warunkiem korzystania $\mathrm{z}$ takich informacji powinna być gwarancja ochrony poufności przez sąd. Gwarancje poufności należy przy tym rozumieć tak, że informacje te nie powinny być ujawniane w zakresie szerszym niż jest to niezbędne dla rozstrzygnięcia sprawy. Poufność powinna być zachowana wobec wszystkich osób poza tą, która dostarczyła informacje ${ }^{65}$. W prawie unijnym wymóg gwarancji poufności dla przekazywania informacji przez Komisję sądom krajowym ustanowiony został w pkt. 25 obwieszczenia Komisji o współpracy z sądami krajowymi. Nie mogę przy tym zgodzić się z poglądem K. Kohutka, który uważa, że za udostępnianiem sądom krajowym informacji poufnych będących w posiadaniu Komisji przemawia zasada

64 Uchwała SN z dnia 8 kwietnia 2010 r., III SZP 1/10. Por. glosa aprobująca M. Sieradzkiej, PUG 2011, nr 5, s. 28-32.

65 Por. pkt 23 obwieszczenia Komisji o współpracy z sądami państw członkowskich. 
lojalności66, źródło poufności informacji stanowią wszak z reguły prawa jednostki (podmiotu prywatnego), chronione także przez prawo unijne, a nie interes państwa członkowskiego.

Te same zasady powinny stosować się również do innych niż tajemnice handlowe informacji poufnych. Ustawa o ochronie konkurencji i konsumentów nie definiuje co prawda tego pojęcia, w doktrynie wskazuje się, że informacjami tymi są przede wszystkim: tajemnica państwowa i służbowa ${ }^{67}$ w rozumieniu ustawy o ochronie informacji niejawnych ${ }^{68}$ oraz informacje chronione na podstawie przepisów ustawy Prawo bankowe ${ }^{69}$, ustawy o działalności ubezpieczeniowej ${ }^{70}$, ustawy o funduszach inwestycyjnych ${ }^{71}$, a ponadto ${ }^{72}$ - ustawy o statystyce publicznej ${ }^{73}$, ustawy o obrocie instrumentami finansowymi ${ }^{74}$. W prawie unijnym natomiast za informacje poufne uznaje się informacje inne niż tajemnice handlowe, których ujawnienie mogłoby narazić osobę lub przedsiębiorstwo na szkodę. Obwieszczenie o dostępie do akt wymienia przykładowo listy od klientów przedsiębiorstw, których ujawnienie mogłoby spowodować działania odwetowe ${ }^{75}$. M. Bernatt wskazuje, że zakres ,innych poufnych informacji” w prawie unijnym jest znacznie szerszy niż w prawie krajowym ${ }^{76}$.

66 K. Kohutek, Komentarz do art. 15. Teza 3.

67 Tak M. Bernatt, [w:] T. Skoczny, A. Jurkowska, D. Miąsik (red.), Ustawa ..., s. 1270, Nb 8.

68 Ustawa z dnia 22 stycznia 1991 r. o ochronie informacji niejawnych (tekst jedn. Dz. U. z 2005 r., Nr 196, poz. 1631 ze zm.).

69 Ustawa z dnia 29 sierpnia 1997 r. - Prawo bankowe (tekst jedn. Dz. U. 2002 $\mathrm{Nr} 72$, poz. 665 ze zm.).

70 Ustawa z dnia 22 maja 2003 r. o działalności ubezpieczeniowej (Dz. U. Nr 124, poz. 1151 ze zm.).

71 Ustawa z dnia 27 maja 2004 r. o funduszach inwestycyjnych (Dz. U. Nr 146, poz. 1546). Tak K. Kohutek, [w:] K. Kohutek, M. Sieradzka, Ustawa ..., s. 839; M. Bernatt, [w:] T. Skoczny, A. Jurkowska, D. Miąsik (red.), Ustawa..., s. 1270, Nb 9; G. Materna, Ograniczenie prawa wgladu..., s. 32.

72 Tak C. Banasiński, E. Piontek (red.), Ustawa..., s. 668.

73 Ustawa z dnia 19 czerwca 1995 r. o statystyce publicznej (Dz. U. Nr 88, poz. 439 ze zm.).

74 Ustawa z dnia 29 lipca 2005 r. o obrocie instrumentami finansowymi (Dz. U. Nr 183, poz. $1538 \mathrm{ze} \mathrm{zm}$.).

75 Pkt 19 obwieszczenia Komisji o dostępie do akt. Por. także powołane tam orzecznictwo unijne z zakresu praktyk ograniczających konkurencję: wyrok SPI z dnia 1 kwietnia 1993 r. w sprawie T-65/89 BPB Industries and British Gyspsum v. Komisja (Zb. Orz. 1993, II-389) i wyrok TS z dnia 6 kwietnia 1995 r. w sprawie C-310/93P BPB Industries and British Gypsum (Zb. Orz 1995, I-865).

76 M. Bernatt, Can the Right To Be Heard Be Respected without Access to Information about the Proceedings? Deficiencies of National Competition Procedure, YARS 2012, vol. 5(6), s. 66 . 


\subsubsection{Wyłączenie ujawniania dla dowodów związanych z programem darowania i łagodzenia kar (leniency)}

Chociaż darowanie lub złagodzenie kary pieniężnej w publicznym trybie egzekwowania zakazu porozumień ograniczających konkurencję nie chroni przedsiębiorców od cywilnoprawnych konsekwencji naruszenia tego zakazu ${ }^{77}$ (i nie powinno tego robić 78 ), to jednak należy rozważyć wyłączenie spod obowiązku ujawniania informacji wykorzystanych $\mathrm{w}$ związku $\mathrm{z}$ zastosowaniem programu darowania i łagodzenia kar. Również w postępowaniu antymonopolowym informacje pozyskane $w$ ramach leniency korzystają ze szczególnej ochrony ich poufności - zgodnie z art. 70 ust. 1 uokik informacje te nie mogą być co do zasady udostępniane w ramach prawa wglądu do akt postępowania, chyba że przedsiębiorca występujący o darowanie lub złagodzenie kary wyrazi na to pisemną zgodę (art. 70 ust. 3). Przepis ten ma wzmacniać ochronę wnioskodawcy leniency, przede wszystkim przed pozostałymi uczestnikami porozumienia, doktryna jest zgodna co do tego, że należy go traktować jako dodatkową zachętę do przystępowania do programu przez przedsiębiorców ${ }^{79}$. W taki sam sposób należałoby traktować przepis wyłączający możliwość dostępu do informacji zgromadzonych $\mathrm{w}$ toku procedury leniency $\mathrm{w}$ oparciu o ustawę o dostępie do informacji publicznej (przepis taki został zaproponowany w ramach nowelizacji ustawy o ochronie konkurencji i konsumentów, której projekt został przedstawiony w listopadzie 2012 r. $)^{80}$.

Informacje i dowody leniency są udostępniane stronom przed wydaniem decyzji (art. 70 ust. 2). Warto odnotować, że w prawie unijnym nie ma analogicznej regulacji.

77 Por. pkt 39 obwieszczenia Komisji w sprawie zwalniania z grzywien i zmniejszania grzywien w sprawach kartelowych (Dz. Urz. UE 2006 C 298/17).

78 Jak słusznie wskazuje W. P. J. Wils zwolnienie z odpowiedzialności cywilnej nie powinno być postrzegane jako element zwiększenia atrakcyjności programów leniency, gdyż cel ten może być realizowany innymi środkami, np. poprzez zwiększenie kar stanowiących punkt odniesienia dla darowania lub złagodzenia kar w przypadku indywidualnych przedsiębiorców - por. W. P. J. Wils, The Relationship..., s. 31. Por. także rezolucję przyjętą na spotkaniu szefów organów ochrony konkurencji w ramach European Competition Network (Resolution of the Meeting of Heads of the European Competition Authorities of 23 May 2012 - Protection of leniency material in the context of civil damages actions); tekst rezolucji dostępny pod adresem: http://ec.europa.eu/competition/ecn/leniency_material_protection_en.pdf.

79 Tak M. Bernatt, [w:] T. Skoczny, A. Jurkowska, D. Miąsik (red.), Ustawa..., s. 1278, Nb. 2; K. Kohutek, [w:] K. Kohutek, M. Sieradzka, Ustawa..., s. 843-844.

80 Por. art. 1 pkt 30 projektu ustawy o zmianie ustawy o ochronie konkurencji i konsumentów (nowy art. 70a). 
Bez wyłączenia spod obowiązku ujawniana informacji i dowodów cel wdrażania leniency, jakim jest zwiększenie poziomu wykrywalności porozumień ograniczających konkurencję, może być poważnie zagrożony81. $\mathrm{Z}$ punktu widzenia efektywności programu darowania i łagodzenia kar niepożądana jest sytuacja, w której przedsiębiorcy przystępujący do leniency (a więc ułatwiający organowi ochrony konkurencji realizację zadań z zakresu polityki publicznej) pozostają w mniej korzystnym położeniu niż pozostali uczestnicy kartelu ${ }^{82}$ (dowody naruszenia w ich przypadku będą bowiem pełniejsze, ponieważ będą obejmować także przyznanie się do naruszenia). Podmioty występujące $\mathrm{z}$ wnioskami o darowanie lub złagodzenie kary i tak muszą liczyć się - jako konsekwencją swojego zachowania - z możliwością licznych pozwów następczych; nałożenie na te podmioty kolejnego „zagrożenia”, jak można postrzegać ujawnianie informacji, mogłoby stać się istotnym przyczynkiem do decyzji odrzucającej możliwość przystąpienia do leniency. W literaturze podnosi się, że regulacje ograniczające dostęp do informacji i dowodów zgromadzonych w leniency w samym postępowaniu antymonopolowym stanowią środek ochrony prawa do obrony przedsiębiorcy występującego o odstąpienie od wymierzenia lub złagodzenie kary (M. Bernatt pisze, że „konieczność ochrony informacji i dowodów uzyskanych w trybie leniency wiązać należy również z koniecznością zachowania gwarancji prawa do obrony w postępowaniu cywilnoprawnym, w którym pozwanym będzie przedsiębiorca, wobec którego w ramach postępowania publicznoprawnego zastosowano tryb darowania lub obniżenia kary"83).

Nieskorzystanie z programu leniency w wielu sytuacjach może spowodować szkodę dla realizacji celów publicznej ochrony konkurencji, podnosząc prawdopodobieństwo niewykrycia kartelu ${ }^{84}$. Realne wystąpienie takiej szkody dla interesu publicznego bezpośrednio rzutowałoby również na sferę interesów prywatnych podmiotów poszkodowanych wskutek funkcjonowania kartelu - niewykrycie kartelu oznaczałoby w niektórych sytuacjach nawet nieświadomość istnienia szkody, brak decyzji stwierdzającej

81 Na efektywność programu leniency jako potencjalną przesłankę decyzji sądu cywilnego o zarządzeniu ujawnienia dowodu w postaci oświadczenia o leniency uwagę zwracają w polskiej literaturze przedmiotu E. Rumak i P. Sitarek - Polish leniency programme..., s. 114.

82 Pkt 287 White Paper Staff Working Document. Za wykluczeniem ujawniania informacji nabytych w ramach leniency opowiada się również brytyjski OFT - por. Private action in competition law: effective redress for consumer and business, Discussion paper, OFT, April 2007, pkt 3.7 oraz Private action in competition law: effective redress for consumer and business. Recommendations from the OFT, November 2007, pkt 9.5.

83 M. Bernatt, [w:] T. Skoczny, A. Jurkowska, D. Miąsik (red.), Ustawa..., s. 1279 (Nb. 3).

84 W. P. J. Wils, The Relationship..., s. 24. 
naruszenie wymagałby przeprowadzenia pełnego dowodu wszystkich przesłanek odpowiedzialności odszkodowawczej. Za wykluczeniem ujawniania dokumentów leniency, zwłaszcza w przypadku przedsiębiorców ubiegających się o darowanie kary, przemawiają także argumenty ekonomiki programów darowania kar ${ }^{85}$.

Wykluczenie ujawniania informacji pozyskanych w ramach leniency ma jednak również swoich przeciwników. R. Stürner uważa, że pełna ochrona uczestników leniency może często prowadzić do całkowitego wykluczenia możliwości występowania z roszczeniami, co - zdaniem tego autora - stanowi konsekwencję „nieuczciwą, nie bardzo racjonalną, a może nawet niekonstytucyjną" 86.

Dla rozważań nad możliwością ujawnienia wniosków leniency pewne znaczenia może mieć forma, w jakiej przedsiębiorca ubiega się o darowanie lub obniżenie kary - jeśli wniosek został złożony ustnie do protokołu ${ }^{87}$, kwestią sporną pozostaje ewentualny dostęp do takiego dokumentu sporządzonego przez organ ochrony konkurencji - według C. Cauffman ustne złożenie oświadczenia o samooskarżeniu (corporate statement) wyklucza możliwość zarządzenia przez sąd udostępnienia takiego dowodu ${ }^{88}$, w polskiej literaturze podobne stanowisko prezentują E. Rumak i P. Sitarek ${ }^{89}$; są jednak autorzy,

85 Por. J. Green, I. McCall, Leniency and civil claims. Should leniency programmes extend to private actions?, Competition Law Insights, 28 July 2009, s. 3-5. Por. także F. Jenny, Deterrence and Compliance. The Organisational Dimension of Implementing Competition Law (wystąpienie na 14th Annual Irish European Law Forum, Dublin 23 marca 2012 r.); dostępne pod adresem: http://www.tca.ie/images/uploaded/documents/2012-03-23\%20 Jenny $\% 20-\% 20$ Deterrence $\% 20$ and $\% 20$ compliance- $\% 20$ The $\% 20$ organisational $\% 20$ dimension $\% 20$ of $\% 20$ implementing $\% 20$ competition $\% 201$ aw $\% 20-\% 20$ slides.pdf. R. Stürner, Duties of Disclosure..., s. 183.

87 Możliwość złożenia wniosku leniency ustnie do protokołu przewiduje $\S 2$ ust. 3 rozporządzenia RM z dnia 26 stycznia 2009 r. w sprawie trybu postępowania w przypadku wystąpienia przedsiębiorców do Prezesa UOKiK o odstąpienie od wymierzenia kary pieniężnej lub jej obniżenie (Dz. U. Nr 20, poz. 109) oraz pkt 32 obwieszczenia Komisji w sprawie zwalniania z grzywien i zmniejszania grzywien w sprawach kartelowych (Dz. Urz. UE 2006 C 298/17).

88 C. Cauffman, The Interaction of Leniency Programmes and Actions for Damages, The Competition Law Review 2011, vol. 7(2), s. 198. M. K. Kolasiński twierdzi, że w kontekście prywatnego egzekwowania reguł konkurencji postanowienia obwieszczenia w sprawie leniency są wręcz sprzeczne z aksjologią rozporządzenia 1/2003, zwłaszcza zawarta w art. 16 regułą Masterfoods; autor ten krytycznie odnosi się do pozbawienia stron i sądu w procesie cywilnym prawa do zapoznania się z dokumentami zgromadzonymi w ramach leniency, uznając to za „niezrozumiałe” - M. K. Kolasiński, Wspólnotowa polityka zwalniania $z$ grzywien $i$ zmniejszania ich wysokości $w$ sprawach kartelowych po reformie $z 2006$ r., EPS 2008, nr 6, s. 28.

89 Por. E. Rumak, P. Sitarek, Polish Leniency Programme..., s. 114. 
którzy uważają, że nie ma całkowitej pewności ani absolutnych gwarancji co do tego, że dokument taki nie będzie ujawniony ${ }^{90}$.

Wyłączenie z obowiązku ujawnienia dowodów powinno - w moim przekonaniu - dotyczyć zarówno oświadczenia przedsiębiorcy o samooskarżeniu, jak i innych towarzyszących mu informacji. Stanowisko takie zajęła także Komisja w Białej księdze, opowiadając się za ochroną wszystkich oświadczeń składanych przez przedsiębiorców lub w ich imieniu w procedurze leniency ${ }^{91}$. Również Trybunał Sprawiedliwości pośrednio podzielił ten pogląd w wyroku w sprawie Pfleiderer, jako że nie odniósł się do stanowiska rzecznika generalnego Mazáka, który w opinii w sprawie Pfleiderer sugerował zróżnicowane traktowanie samooskarżających oświadczeń przedsiębiorców $\mathrm{i}$ innych informacji otrzymanych $\mathrm{w}$ ramach leniency ${ }^{92}$. Ochrona przed ujawnieniem dokumentów zgromadzonych w ramach leniency powinna dotyczyć zarówno okresu przed, jak i po wydaniu decyzji ${ }^{3}$. Realizacja celu programu darowania i łagodzenia kar wymaga również tego, aby wyłączenie spod obowiązku ujawniania dotyczyło wszystkich informacji uzyskanych w ramach leniency, niezależnie od tego, czy wniosek o przystąpienie do programu został zaakceptowany, czy nie ${ }^{94}$. Odpowiedź przedsiębiorstwa wnioskującego o darowanie lub złagodzenie kary na pismo o przedstawieniu zarzutów (statement of objections) może być udostępniona, o ile nie zawiera informacji zaczerpniętych z innych dokumentów związanych z leniency ${ }^{95}$.

90 Tak A. Petrasincu, Discovery revisited - the impact of the US discovery rules on the European Commission's leniency programme, E.C.L.R. 2011, vol. 32(7), s. 366.

91 Pkt 2.9. Białej księgi. Dodatkową opcją proponowaną przez Komisję (w celu zwiększenia atrakcyjności programu leniency) jest możliwość ograniczenia odpowiedzialności cywilnej podmiotów, które przystąpiły do leniency. W Zielonej księdze Komisja zaproponowała ponadto również wyłączenie wspólnej odpowiedzialności dla przedsiębiorcy, którego wniosek o darowanie lub złagodzenie kary został uwzględniony. Por. także pkt 295 White Paper Staff Working Document.

92 Por. pkt. 44-47 opinii rzecznika generalnego Mazáka w sprawie Pfleiderer, przedstawionej w dniu 16 grudnia $2010 \mathrm{r}$.

93 Pkt. 2.9. Białej księgi. Por. także pkt 299 White Paper Staff Working Document. Takie stanowisko zajmuje także Komisja w pkt. 40 obiweszczenia leniency; analogiczne wytyczne wydane przez Prezesa UOKiK w ogóle nie dotykają tego problemu.

94 Por. pkt 297 White Paper Staff Working Document.

95 Taki pogląd Komisja wyraziła w opinii przedstawionej przez nią (jako amicus curiae) w postępowaniu przed English High Court, rozpatrującym roszczenie National Grid wobec uczestników kartelu rozdzielnic z izolacją gazową - por. E. Coulson, We will not have to wait long to see what a national court - in this case, the English High Court - makes of the Pfleiderer decisions, Competition Law Insight, 20 września 2011, s. 7 (dostępne pod adresem: http:// www.blplaw.com/media/pdfs/News\%20and\%20Views/Leniency_and_disclosure.pdf.). 
Ograniczenia w ujawnianiu dowodów związanych z leniency nie powinny jednak dotyczyć dobrowolnego działania przedsiębiorców - nie podzielam stanowiska Komisji, która twierdzi, że możliwość ujawniania dowodów przez samych przedsiębiorców powinna być zablokowana przynajmniej do momentu wydania pisma o przedstawieniu zarzutów (statement of objections $)^{96}$.

Dowody bezpośrednio związane z leniency powinny być objęte znanym prawu amerykańskiemu „przywilejem dochodzeniowym wdrażania prawa” (law enforcement investigatory privilege), zakazującym ujawniania materiałów uzyskanych przez organy administracji państwowej w toku prowadzonych przez nie „dochodzeń” (investigations). Zakaz ujawniania materiałów nie ma jednak charakteru bezwzględnego - możliwe jest przełamanie go pod warunkiem zaistnienia „przemożnej potrzeby” (compelling need), której interes publiczny musi ustąpić pierwszeństwa ${ }^{97}$. Zgodnie $\mathrm{z}$ amerykańskim orzecznictwem przywilej ten może dotyczyć tylko tych materiałów, które pozostają w wyłącznym posiadaniu określonego organu ${ }^{98}$ (np. protokół z ustnego złożenia wniosku leniency) ${ }^{99}$. Doktryna przywileju dochodzeniowego, choć dość powszechnie akceptowana w orzecznictwie amerykańskim, nie została jednak recypowana w orzecznictwie europejskim, natomiast - jak się wydaje - jej rzeczniczką pozostaje Komisja ${ }^{100}$, czego potwierdzeniem jest choćby stanowisko Komisji wobec żądania amerykańskiego sądu co

96 Pkt 2.9. Białej księgi. Por. także pkt 302 White Paper Staff Working Document.

97 In re City of New York, 607 F.3d. 923, 945 (2d. Cir. 2010). Por. I. Vandenborre, The confidentiality of EU Commission cartel records in civil litigation: the ball is in the EU court, E.C.L.R. 2011, vol. 32(3), s. 120.

98 In re Vitamin Cartel Litigation, Misc. No. 99-197 (THF) \& MDL. No. 1285, 2002 U.S. Dist.

99 Por. A. M. Wiseman, Protection of Confidentiality: a U. S. Perspective, s. 5 (materia1 przedstawiony na Global Competition Review Competition Litigation Conference, 4 października 2011 r.).

100 Por. stanowisko Komisji w przywołanej powyżej sprawie kartelu witaminowego (In re Vitamin Cartel Litigation). Należy jednak zastrzec, że w innych sprawach Komisja uzasadniała odmowę ujawnienia materiałów leniency doktryną international comity - por. R. Grasso, The E.U. Leniency Program and U.S. Civil Discovery Rules: A Fraternal Fight?, Michigan Journal of International Law 2008, vol. 29(1), s. 590-604; I. Vandenborre, The confidentiality of EU Commission cartel records..., s. 118-119.

Zwolennikiem law enforcement investigatory privilege jest również amerykański Departament Sprawiedliwości, który w sprawie Flat Glass ostrzegał, że „szkoda poniesiona przez program leniency Unii Europejskiej mogłaby skutkować szkodą dla amerykańskiego programu leniency i towarzyszącą jej szkodą dla zdolności Stanów Zjednoczonych w zakresie wykrywania i oskarżania międzynarodowych karteli” - cytuję za: S. M. Miller, K. Nordlander, J. C. Owens, U.S. Discovery of European Union and U.S. Leniency Applications and Other Confidential Investigatory Materials, CPI Antitrust Journal, marzec 2010(1), s. 13. 
do ujawnienia dowodów pozyskanych w postępowaniu antymonopolowym prowadzonym przez Komisję w sprawie globalnego kartelu witaminowego; możliwość skorzystania z przywileju dochodzeniowego wskazana jest również w dokumencie roboczym Komisji towarzyszącym Białej księdze ${ }^{101}$.

Te same przesłanki, jakie leżą u podstaw amerykańskiego przywileju dochodzeniowego, stanowią również źródło tych przepisów w prawie unijnym i krajowym, na mocy których określone zachowania są zabronione z tego względu, że zakłócają lub wykluczają osiągnięcie celu dochodzenia (postępowania). W prawie unijnym przepisem takim jest art. 4 ust. 2 tiret trzecie rozporządzenia 1049/2001, przewidujący możliwość odmowy dostępu do akt postępowania ze względu na ochronę celu kontroli, dochodzenia czy audytu (chyba że za ujawnieniem dokumentu przemawia interes publiczny); na przepis ten powołuje się zresztą sama Komisja w pkt. 40. wytycznych leniency. W świetle rozporządzenia o przejrzystości cel dochodzenia nie może być jednak pojmowany abstrakcyjnie jako zapewnienie efektywności polityce konkurencji, np. poprzez program leniency, ale musi być analizowany w kontekście konkretnego postępowania ${ }^{102}$. Inną perspektywę daje natomiast przepis sekcji 406e niemieckiego kodeksu postępowania karnego, który prawo dostępu do akt wyłącza w sytuacji, gdy ujawnienie akt zagrażałoby danemu dochodzeniu (postępowaniu) lub jakiemukolwiek innemu postępowaniu. W przeciwieństwie do art. 4 ust. 2 tiret trzecie rozporządzenia 1049/2001 niemiecki przepis pozwala na pewną generalizację wyłączenia, czego zresztą dokonał Amtsgericht w Bonn w wyroku wydanym w sprawie Pfleiderer - powołując się na przywołany przepis, sąd wykluczył dostęp osób trzecich do dokumentów zgromadzonych w ramach procedury leniency, gdyż uznał, że wszystkie postępowania prowadzone przez niemiecki organ antymonopolowy są innymi postępowaniami w rozumieniu sekcji 406e kodeksu postępowania karnego 103 .

Orzecznictwo sądów unijnych wydaje się być raczej niechętne generalnemu wyłączeniu informacji związanych z leniency spod obowiązku ujawniania ${ }^{104}$. Sądy, choć nie wykluczają ochrony informacji pozyskanych w ramach

101 Por. pkt 119 White Paper Staff Working Document.

102 Por. pkt 69 wyroku w sprawie T-437/08 CDC Hydrogene Peroxide.

103 Wyrok Amtsgericht Bonn z dnia 18 stycznia 2012 r. (wyrok ostateczny) - podaję za: http://f.datasrvr.com/fr1/712/78475/German_Court_Excludes_Third_Party_Access.pdf. Por. Ch. Steinle, J. Hattass, The tide has turned: private enforcement of competition law in Germany, G.C.L.R. 2008, vol. 1(1), s. 63.

104 Por. także F. Rizutto, The procedural implication of Pfleiderer for the private enforcement of European Union competition law in follow-up actions for damages, G.C.L.R. 2011, vol. 4(3), s. 121. 
programu darowania i łagodzenia kar, stoją na stanowisku, że przypadki odmowy dostępu do materiałów zgromadzonych w ramach programu darowania i łagodzenia kar powinny być absolutnie marginalne. W sztandarowym (jak dotychczas) wyroku w tym zakresie (wyrok w sprawie Pfleiderer) Trybunał Sprawiedliwości stwierdził, że prawo Unii nie stoi na przeszkodzie ujawnieniu poszkodowanym informacji o sprawcy naruszenia (uczestniku kartelu), który przystąpił do programu leniency; przyjęcie odmiennego rozwiązania naruszałoby, zdaniem Trybunału, potwierdzone w orzecznictwie prawo każdej osoby do naprawienia szkody wyrządzonej jej wskutek naruszenia zakazu porozumień ograniczających konkurencję ${ }^{105}$ - argumentacja ta z powodzeniem daje się wykorzystać również w sprawach, gdzie zastosowanie znajduje prawo krajowe. Praktycy odczytali to stanowisko Trybunału także jako sygnał dla sądów amerykańskich, że mogą one być znacznie bardziej śmiałe $\mathrm{w}$ żądaniu ujawniania dowodów z leniency będących $\mathrm{w}$ posiadaniu Komisji ${ }^{106}$.

Zdaniem Trybunału dostęp do dowodów pozyskanych w ramach leniency powinien być udzielany (lub nie) każdorazowo „po rozważeniu interesów chronionych przez prawo Unii”; ocena interesów ma być dokonana przez sądy państw członkowskich. Trybunał nakazuje sądom „wyważyć interesy przemawiające za ujawnieniem informacji oraz za ochroną informacji przekazanych dobrowolnie przez osobę wnioskującą o zniesienie lub złagodzenie sankcji” (pkt 30 wyroku w sprawie Pfleiderer), jednak nie udziela żadnych bardziej szczegółowych wskazówek co do istoty tych interesów - stanowisko TS skłania niektórych przedstawicieli doktryny do refleksji, że jest to asumpt do rozwoju forum shopping zorientowanego na znalezienie tego porządku prawnego, w którym sądy są najbardziej liberalne, jeśli chodzi o udostępnianie dokumentów z postępowań antymonopolowych ${ }^{107}$. Niemniej jednak w wyroku w sprawie T-437/08 CDC Hydrogene Peroxide Sąd uznał, że odmowa dostępu do dowodów nie może być podyktowana interesem przedsiębiorcy-uczestnika kartelu, polegającym na uniknięciu powództw cywilnoprawnych - nie jest to ,interes godny ochrony, mając na uwadze prawo każdego do ubiegania się o odszkodowanie za szkody spowodowane przez

105 Por. pkt 28 i 29 wyroku w sprawie Pfleiderer. Tak również w publikacji wydanej dwa lata przed wyrokiem w sprawie Pfleiderer - W. P. J. Wils, The Relationship..., s. 31.

106 H. M. Silton, C. S. Davis, D. Levisohn, Pfleiderer AG v. Bundeskartellamt: A Step Forward in Efforts to Obtain Discovery from European Commission Antitrust Proceedings, Westlaw Journal Antitrust, 2011, vol. 19(6), s. 3, 6.

107 Stanowisko takie wyraziły m.in. I. Vandenborre, S. B. Thomas, European Court of Justice provides limited guidance on the disclosure of leniency documents, E.C.L.R. 2011, vol. 32(10), s. 489. 
zachowanie mogące powodować ograniczenie lub zakłócenie konkurencji” (pkt 49 wyroku w sprawie CDC Hydrogene Peroxide). W kontekście stosowania traktatowych zakazów praktyk ograniczających konkurencję należy podkreślić również, że zaakceptowanie wyłączenia ujawniania dowodów uzyskanych w związku z leniency na poziomie prawa unijnego oznacza, że w odniesieniu do przedmiotowych materiałów Komisja nie będzie realizować obowiązków współpracy z sądami krajowymi ${ }^{108}$. Ponadto ujawnianie informacji pozyskanych $\mathrm{w}$ toku procedury leniency $\mathrm{w}$ wyniku współpracy organów w ramach Europejskiej Sieci Konkurencji może zagrażać efektywności tej kooperacji. W świetle wyroku w sprawie Pfleiderer skuteczność współpracy organów ochrony konkurencji nie może być postrzegana jako przesłanka ochrony poufności informacji związanych z wnioskiem leniency 109 .

Koronnym argumentem przesądzającym o pierwszeństwie (co do omawianej kwestii) publicznego egzekwowania prawa konkurencji przed prywatnoprawną metodą egzekwowania zakazów praktyk ograniczających konkurencję wydaje się obniżenie atrakcyjności programu leniency, choć zdaniem W. P. J. Wilsa nie ma co do tego pełnej zgody ani w doktrynie ani w orzecznictwie ${ }^{110}$. Nie jest to również okoliczność (przesłanka), którą Komisji łatwo byłoby udowodnić111.

Proponowane, także przez Komisję ${ }^{112}$, rozwiązanie polegające na tym, że jeśli wnioskodawca o leniency udostępnia składane przez siebie dowody powodom w postępowaniu sądowym, może on liczyć na „rabaty” przy określaniu wysokości odszkodowań wymaganych od uczestników programu leniency, mogłoby - w warunkach dostępności dowodów - stanowić wystarczającą zachętę dla składania wniosków leniency ${ }^{113}$, jest ono jednak obciążone istotnymi wadami, które zostaną omówione w rozdziale poświęconym sankcjom, w podrozdziale dotyczącym wzajemnego oddziaływania sankcji

108 Por. pkt 299 White Paper Staff Working Document.

109 Szerzej na ten temat: A. Jurkowska-Gomułka, Między efektywnościq walki z kartelami a efektywnościa dochodzenia roszczeń z tytułu naruszenia art. 101 ust. 1 Traktatu o funkcjonowaniu Unii Europejskiej (glosa do wyroku Trybunatu Sprawiedliwości z dnia 14 czerwca 2011 r. $w$ sprawie C-360/09 Pfleiderer przeciwko Bundeskartellamt), EPS 2012, nr 7.

110 Tak W. P. J. Wils, The Relationship..., s. 24 (przypis 95). Taki pogląd wyraża także $\mathrm{J}$. Suderow, Access to evidence in European Commission proceedings and the limits established by its leniency programmes, [w:] L. A. Velasco i inni (red.), Private enforcement of competition law, Valladolid 2011, s. 534.

111 Por. R. Hempel, Access to DG Competition's files: an analysis of recent EU court case law, E.C.L.R. 2012, vol. 33(4), s. 201.

112 Commission Staff working paper accompanying Green Paper, pkt 235.

113 Tak R. Stürner, Duties of Disclosure..., s. 183. 
publicznego i prywatnego trybu egzekwowania zakazów praktyk ograniczających konkurencję ${ }^{114}$.

\subsubsection{Problem ochrony poufności informacji zgromadzonych w postępowaniu ugodowym}

Należy rozważyć, czy podobnie jak w przypadku programu leniency argumenty za wyłączeniem jawności informacji mogłyby uzasadniać wyłączenie jawności informacji i dokumentów zgromadzonych w postępowaniu antymonopolowym, które zakończyło się ugodą. W prawie unijnym możliwość takiego zakończenia postępowania, jedynie w odniesieniu do porozumień ograniczających konkurencję, przewiduje art. 10a rozp. 773/2004115. Postępowanie ugodowe nie wyklucza nałożenia na uczestników kartelu kar pieniężnych. Różnicą w stosunku do „standardowego” postępowania antymonopolowego jest między innymi to, że w postępowaniu ugodowym Komisja nie ma obowiązku przekazania wnioskodawcy (o wszczęcie postępowania antymonopolowego) niejawnej wersji pisma o przedstawieniu zarzutów, uwzględniającej propozycje ugodowe. O ile jednak procedura leniency służy samemu aktowi wykrywania karteli, o tyle postępowanie ugodowe ma zapewnić organowi ochrony konkurencji „szybsze i skuteczniejsze rozstrzyganie spraw kartelowych"116. Cele obydwu procedur nie są zatem w pełni zbieżne ${ }^{117}$, co uzasadnia zróżnicowane traktowanie problemu poufności informacji i dowodów pozyskanych w związku z procedurą leniency oraz informacji i dowodów zgromadzonych w postępowaniu ugodowym. Jeśli ujawnienie $\mathrm{w}$ postępowaniu cywilnym dowodów zebranych $\mathrm{w}$ ramach leniency, mogłoby zniechęcić przedsiębiorstwa do samooskarżenia, to ujawnienie informacji i dowodów pozyskanych w postępowaniu ugodowym nie

114 Por. rozdział VII, pkt 7.9.

115 Artykuł ten został wprowadzony do rozp. 773/2004 na mocy art. 1 pkt 4 rozporządzenia Komisji (WE) nr 622/2008 z dnia 30 czerwca 2008 r. zmieniającego rozporządzenie (WE) nr 773/2008 w odniesieniu do prowadzenia postępowań ugodowych w sprawach kartelowych (Dz. Urz. UE 2008 L 171/3).

116 Pkt 4 preambuły rozp. 622/2008. Na podstawowe różnice między procedurą leniency a postępowaniem ugodowym wskazują K. Mehta, M.L.T. Centella, Settlement procedure in EU cartel cases, Competition Law International, June 2008, s. 11-12.

117 Tak U. Soltesz, Ch. Von Kockritz, EU cartel settlements in practice - the future of EU cartel law enforcement?, E.C.L.R. 2011, vol. 32(5), s. 258. Autorzy ci wprost stwierdzają, że program ugody i program leniency mają różne cele (different objectives). Inaczej twierdzi R. Gamble, który program leniency oraz postępowanie ugodowe postrzega jako części składowe programu darowania kar (immunity programme) - R. Gamble, „Speaking (formally) with the enemy” - cartel settlements evolve, E.C.L.R. 2011, vol. 32(9), s. 449-456. 
powinno wywołać efektu braku zainteresowania przedsiębiorstw ugodą w braku procedury ugodowej przeprowadzone zostałoby pełne postępowanie antymonopolowego, z którego dowody nie byłyby objęte ochroną poufności (chyba, że chodziłoby o tajemnice przedsiębiorstwa lub inne chronione tajemnice). W piśmiennictwie zwraca się uwagę na fakt, że w postępowaniu ugodowym przedsiębiorcy „negocjują” $\mathrm{z}$ organem ochrony konkurencji, a w konsekwencji - mają wpływ na treść ostatecznej decyzji: sytuacja taka może powodować osłabienie pozycji procesowej potencjalnych powodów, zwłaszcza wówczas, gdy decyzje organów ochrony konkurencji są wiążące dla sądów118. W literaturze wskazuje się ponadto, że ugody ułatwiają wnoszenie pozwów przeciw zaangażowanym przedsiębiorstwom i umożliwiają uczynienie tego szybciej niż w przypadku standardowego postępowania antymonopolowego; wzrost prawdopodobieństwa skarg prywatnych może zniechęcać przedsiębiorstwa do ugod ${ }^{119}$. Nawet jeżeli taki efekt zaistniałby w rzeczywistości, to nie uzasadnia on - w moim przekonaniu - ochrony poufności dowodów i informacji zebranych w postępowaniu ugodowym, szczególnie wówczas, gdyby ujawnienie dowodów i informacji miało nastąpić po zakończeniu postępowania ugodowego. Komplementarność publicznego i prywatnego egzekwowania prawa konkurencji wymaga, aby tym razem interes publiczny w postaci sprawniejszego i szybszego postępowania antymonopolowego ustąpił miejsca interesowi prywatnemu, również w postaci bardziej efektywnej i szybszej realizacji roszczeń. Inne stanowisko prezentuje Komisja, która twierdzi, że „publiczne ujawnienie dokumentów oraz pisemnych lub utrwalonych $\mathrm{w}$ innej formie oświadczeń (w tym propozycji ugodowych) złożonych w kontekście niniejszego obwieszczenia [o ugodzie w sprawach kartelowych - przyp. aut.] prowadziłoby zasadniczo do podważenia ochrony określonych publicznych lub prywatnych interesów, przykładowo utrudniałoby realizację celu kontroli i dochodzeń (...), nawet jeśli miałoby to miejsce już po wydaniu decyzji w danej sprawie"120.

118 Tak Ch. Cook, M. Piergiovanni, Implications of settling an EU cartel investigation for a prospective civil damages defendant: bad or good?, G.C.L.R. 2011, vol. 4(2), s. 57-66.

119 A. Ascione, M. Motta, Settlements in cartel cases, EUI Robert Schuman Centre for Advanced Studies, 2008 EU Competition Law Workshop/Proceedings, Florence 2008, s. 9 (dostępne pod adresem: http://www.eui.eu/Documents/RSCAS/Research/Competition/ Motta-Ascione-2008.pdf); referat opublikowany również [w:] C. D. Ehlerman, M. Marquis (red.), European Competition Law Annual 2008: Antitrust Settlements under EC Competition Law, Hart Publishing, Oxford and Portland 2009.

${ }^{120}$ Pkt 40 obwieszczenia Komisji w sprawie prowadzenia postępowań ugodowych w związku z przyjęciem decyzji na mocy art. 7 i 23 rozporządzenia Rady (WE) nr 1/2003 w sprawach kartelowych (Dz. Urz. UE 2008 C 167/1). 
Efektywność postępowania ugodowego wymaga natomiast tego, aby w sytuacji, gdy postępowanie przed organem ochrony konkurencji i postępowanie sądowe toczą się jednocześnie, sądy powstrzymywały się od zarządzania ujawniania dowodów wykorzystywanych w postępowaniu ugodowym ${ }^{121}$ (a w przypadku, gdyby przedstawienie takich dowodów zostało zarządzone, aby organy ochrony konkurencji mogły skutecznie takiego przedstawienia odmówić). W obwieszczeniu w sprawie postępowań ugodowych Komisja zastrzegła, że „nie przekazuje propozycji ugodowych sądom krajowym bez zgody stosownych wnioskodawców"122.

W polskiej praktyce opisywany problem nie istnieje, ponieważ obecnie obowiązująca ustawa o ochronie konkurencji i konsumentów (z 2007 r.) nie przewiduje instytucji ugody w odniesieniu do postępowań antymonopolowych w sprawach praktyk ograniczających konkurencję; możliwość zawarcia ugody ustawodawca wprowadził w art. 102 uokik wyłącznie w odniesieniu do postępowań w sprawach praktyk naruszających zbiorowe interesy konsumentów, przy czym powszechny jest pogląd wykluczający możliwość urzeczywistnienia takiej ugody ze względu na fakt, że również postępowania w sprawie naruszenia zbiorowych interesów konsumentów są wszczynane wyłącznie z urzędu, stąd nie występują tu strony o spornych interesach ${ }^{123}$.

Niemniej jednak w świetle założeń planowanej nowelizacji ustawy również w polskim systemie ochrony konkurencji ma szanse pojawić się - w sprawach kartelowych - ugoda, określana jako „dobrowolne poddanie się karze” (proponowana terminologia może dziwić o tyle, że ugoda była już w przeszłości instytucją polskiego prawa antymonopolowego ${ }^{124}$ ). Zakłada ona przyznanie się przedsiębiorców do zarzutów w zamian za obniżenie kary pieniężnej o 10\%; aby zachować redukcję kary, przedsiębiorcy nie mogliby wnosić odwołań do sądu ${ }^{125}$. Przewidziane rozwiązanie realizowałoby postulaty pol-

121 Pkt 119 White Paper Staff Working Document.

122 Pkt 39 obwieszczenia Komisji w sprawie prowadzenia postępowań ugodowych w sprawach kartelowych.

123 Por. m.in. M. Rypina, M. Wierzbowski, Umowa z organem w postępowaniu administracyjnym, PiP 2010, nr 4, s. 17.

$124 \mathrm{~W}$ polskim piśmiennictwie $\mathrm{z}$ zakresu prawa administracyjnego pojęcie ugody oznacza układ między stronami postępowania administracyjnego, zawierany przed organem prowadzącym postępowanie i zatwierdzany przez organ, zastępujący decyzję administracyjną - tak J. Zimmermann, Prawo administracyjne, Oficyna a Wolters Kluwer, Warszawa 2010, s. 350. W przypadku postępowania antymonopolowego nie ma stron, więc należy mówić raczej o umowie administracyjnej.

125 Por. art. 1 pkt 37 projektu nowelizacji ustawy o ochronie konkurencji i konsumentów z dnia 21 listopada 2012 r. (propozycja nowego art. 88a). Por. także afirmatywnie o kształcie nowej instytucji: M. Krasnodębska-Tomkiel, Czas na zmiany w prawie antymo- 
skiej doktryny co do wprowadzenia do prawa administracyjnego (w ogóle, ale i w poszczególnych jego dziedzinach) konsensualnych form działalności administracji ${ }^{126}$. Polski ustawodawca zdecydował się jednak potraktować informacje uzyskiwane $\mathrm{w}$ procedurze dobrowolnego poddawania się karze (ugodowej) w taki sam sposób jak informacje pozyskane w ramach procedury leniency - projekt nowelizacji ustawy o ochronie konkurencji przewiduje wyłączenie dostępu do tych informacji na podstawie ustawy o dostępie do informacji publicznej127.

\subsection{Możliwość dostępu do informacji i dowodów gromadzonych przez organy ochrony konkurencji na podstawie regulacji o dostępie do informacji publicznej}

\subsubsection{Stosowanie unijnego rozporządzenia o przejrzystości w celu uzyskania dostępu do dokumentów zgromadzonych w postępowaniu antymonopolowym}

\subsubsection{Zasady realizacji prawa dostępu do dokumentów Komisji w świetle orzecznictwa}

Dostęp do akt postępowania antymonopolowego prowadzonego przez Komisję jest możliwy - na podstawie rozporządzenia 1/2003 oraz rozporządzenia 773/2004 - jedynie dla przedsiębiorstw, przeciwko którym prowadzone jest postępowanie oraz - w nieco bardziej ograniczonym zakresie - dla wnioskodawców wszczęcia takiego postępowania. Osoby trzecie, niezwiązane bezpośrednio z prowadzonym postępowaniem, mogą ubiegać się o dostęp do dokumentów Komisji (w tym tych zgromadzonych w postępowaniach antymonopolowych $)^{128}$ na podstawie rozporządzenia nr 1049/2001 w sprawie publicznego dostępu do dokumentów Parlamentu Europejskiego,

nopolowym, iKAR 2012, nr 1(1), s. 8-9; krytycznie - E. Krajewska, Settlement $w$ świetle doświadczeń europejskich $-w$ poszukiwaniu najlepszych rozwiazań, iKAR 2012, nr 4(1), s. $73-75$.

126 Por. m.in. M. Rypina, M. Wierzbowski, Umowa z organem..., s. 15-27; A. Kubiak, Koncepcja umowy administracyjnej (na tle projektu Przepisów ogólnych prawa administracyjnego), PiP 2009, nr 4.

127 Por. art. 1 pkt 30 projektu ustawy o zmianie ustawy o ochronie konkurencji i konsumentów z dnia 21 listopada 2012 r. (nowy art. 70a).

128 W literaturze wskazuje się na wyraźne rozróżnienie dostępu do akt (prawo przysługujące stronom) oraz dostępu do dokumentów (prawo przysługujące osobom trzecim) - por. S. White, Rights of defence in administrative investigations: access to the file in EC investigations, Review of European Administrative Law 2009, vol. 2(1), s. 64. 
Rady i Komisji (zwanego rozporządzeniem o przejrzystości). Prawo dostępu do dokumentów, stanowiące emanację zasady przejrzystości ${ }^{129}$, gwarantowane jest w UE już na poziomie prawa pierwotnego poprzez art. 15 ust. 3 TFUE 130 .

Mimo wielu kontrowersji związanych z pytaniem, czy rozporządzenie o przejrzystości może obowiązywać w odniesieniu do dokumentów zgromadzonych $\mathrm{w}$ postępowaniach antymonopolowych, jeśli istnieją specjalne regulacje dostępu do tych dokumentów, obecnie nie ma wątpliwości co do tego, że regulacja ta może stanowić podstawę udostępnienia akt postępowań Komisji w sprawach konkurencji także podmiotom bezpośrednio w nie niezaangażowanym (możliwość ta jest ograniczona w przypadku postępowań z zakresu pomocy publicznej, gdzie TS przyjął domniemanie ogólne, zgodnie z którym ujawnienie dokumentów zgromadzonych w aktach postępowań administracyjnych Komisji dotyczących postępowań kontrolnych w sprawie pomocy państwa narusza ochronę celów dochodzenia $\left.{ }^{131}\right)$. Możliwość ta została potwierdzona przez kilka orzeczeń sądów unijnych (choć nie wszystkie z nich dotyczyły postępowań antymonopolowych ${ }^{132}$ ), ma ona również swoich zwolenników w doktrynie ${ }^{133}$.

Cel rozporządzenia 1049/2001 definiowany jest w jego art. 1 jako zapewnienie możliwie najszerszego prawa do publicznego dostępu do dokumen-

129 Na temat dyskusji o zasadzie przejrzystości jako zasadzie ogólnej prawa unijnego - por. m.in. S. Prechal, M. E. de Leeuw, Transparency: A General Principle of EU Law?, [w:] U. Bernitz, J. Nergelius, C. Cardner (red.), General Principles of EU Law in a Process of Development, Kluwer Law International 2008, s. 201-242.

130 Zdaniem K. Kowalik-Bańczyk przepis art. 15 ust. 3 TFUE nie jest jednak bezpośrednio skuteczny ze względu na to, że nie jest on dostatecznie jasno zdefiniowany i wymaga dodatkowych działań prawodawczych - K. Kowalik-Bańczyk, [w:] A. Wróbel, K. KowalikBańczyk, M. Szwarc-Kuczer (red.), Traktat o funkcjonowaniu Unii Europejskiej. Komentarz. Tom II, LEX a Wolters Kluwer business, Warszawa 2012, s. 288.

131 Por. pkt 87 wyroku TS z dnia 10 grudnia 2010 r. w połączonych sprawach T-494/08 do T-500/08 i T-509/08 Ryanair v. Komisja (Zb. Orz. 2010, s. II-5723). Por. także wyrok TS z dnia 29 czerwca 2010 r. w sprawie C-139/07 Komisja v. Technische Glaswerke Ilmenau (Zb. Orz. 2010, s. I-05885).

132 Wyroki dotyczące dostępu do dokumentów z postępowań antymonopolowych: wyrok Sądu z dnia 15 grudnia 2011 r. w sprawie T-437/08 CDC Hydrogene Peroxide v. Komisja (dotąd niepubl.); wyrok SPI z dnia 13 kwietnia T-2/03 Verein für Konsumenteninformation v. Komisja (Zb. Orz. 2005, s. II-1121); dalej jako wyrok w sprawie VKI. Na temat stosowania rozporządzenia 1049/2001 w sprawach z zakresu ochrony konkurencji zob. G. Goddin, Recent Judgments Regarding Transparency and Access to Documents in the Field of Competition Law: Where Does the Court of Justice of the EU Strike the Balance?, Journal of European Competition Law \& Practice 2011, vol. 2(1), s. 10-23.

133 J. Suderow, Access to evidence..., [w:] L. A. Velasco i inni (red.), Private enforcement..., s. 531. 
tów będących w posiadaniu instytucji unijnych ${ }^{134}$. Takie sformułowanie celu pozwala przyjąć, że dostęp do dokumentów powinien być zasadą, zaś odmowa dostępu - jedynie wyjątkiem od reguły.

Obowiązki w zakresie dostępu do dokumentów określone zostały w rozporządzeniu 1049/2001 w aspekcie podmiotowym - regulację stosuje się do dokumentów zebranych przez Komisję, Radę i Parlament Europejski, przesłanką nie jest natomiast to, czy dokumenty zostały pozyskane w związku ze stosowaniem prawa unijnego. W konsekwencji przepisy rozporządzenia 1049/2001 nie znajdą zastosowania wobec krajowych organów ochrony konkurencji prowadzących postępowanie w związku z naruszeniem art. 101 lub 102 TFUE, w takim przypadku zastosowanie znajdą analogiczne regulacje krajowe.

Dotychczasowe orzecznictwo pozwala na sformułowanie wytycznych dla Komisji co do jej postępowania z wnioskami o udzielenie dostępu do dokumentów. Od organu ochrony konkurencji co do zasady wymaga się, aby analiza w zakresie możliwości udostępnienia dokumentu dotyczyła konkretnego dokumentu, a nie np. całej kategorii dokumentów, na które Komisja podzieliła posiadane przez siebie akta ${ }^{135}$, analiza Komisji musi mieć charakter indywidualny i konkretny ${ }^{136}$. Niemniej jednak Sąd dopuścił możliwość odstąpienia od takiej analizy, „gdy ze względu na szczególne okoliczności danej sprawy jest oczywiste, że należy udzielić dostępu bądź go odmówić. $\mathrm{Z}$ taką sytuacją możemy mieć do czynienia w szczególności, gdy pewne dokumenty są albo ewidentnie objęte w całości wyjątkiem od prawa dostępu albo, przeciwnie, ewidentnie dostępne w całości, bądź też były już uprzednio przedmiotem konkretnej i indywidualnej oceny Komisji dokonanej w podobnych okolicznościach"137. Wyjątek od obowiązku instytucji w zakresie indywidualnej i konkretnej analizy może być podyktowany tym, że „nakład pracy administracyjnej spowodowany konkretną i indywidualną analizą dokumentów okazuje się szczególnie znaczny, przekraczając w ten sposób granice tego, czego można rozsądnie oczekiwać, dopuszcza się wyjątek od rzeczonego obowiązku przeprowadzenia analizy"138. Sama

134 Por. motyw 4 preambuły rozp. 1049/2001 oraz pkt 32 wyroku w sprawie T-437/08 CDC Hydrogene Peroxide.

135 Pkt 69 wyroku w sprawie T-2/03 VKI.

136 Pkt 74 wyroku w sprawie T-2/03 VKI. Por. także pkt 77 wyroku SPI z dnia 14 grudnia 2006 r. w sprawie T-237/02 Technische Glaswerke Ilmenau (Zb. Orz. 2006, s. II-05131).

137 Pkt 75 wyroku w sprawie T-2/03 VKI. Por. także pkt 86 i 89 wyroku w sprawie T-237/02 Technische Glaswerke Ilmenau.

138 Pkt 112 wyroku w sprawie T-2/03 VKI. 
znaczna liczba stron w postępowaniu nie jest wystarczającym uzasadnieniem znacznego nakładu pracy ${ }^{139}$.

\subsubsection{Przesłanki odmowy dostępu do dokumentów Komisji w świetle orzecznictwa}

Odmowa dostępu do dokumentów instytucji UE może być uzasadniona możliwością naruszenia interesu prywatnego lub publicznego. W odniesieniu do tego pierwszego uzasadnieniem odmowy dostępu do dokumentów może być m.in. ochrona interesów handlowych osoby fizycznej lub prawnej (art. 4 ust. 2 tiret pierwsza rozp. 1049/2001) oraz ochrona prywatności i integralności osoby fizycznej (art. 4 ust. 1 lit. b), w odniesieniu do drugiego - polityka ekonomiczna Unii lub państwa członkowskiego (art. 4 ust. 1 lit. a tiret czwarte), ochrona postępowania sądowego i porady prawnej (art. 4 ust. 2 tiret drugie) oraz ochrona celu kontroli, dochodzenia czy audytu (art. 4 ust. 2 tiret trzecie). Oprócz wymienionych art. 4 rozp. 1049/2001 obejmuje również inne przesłanki, które jednak nie będą miały pierwszorzędnego znaczenia dla dostępu do dokumentów związanych z postępowaniami w sprawach z zakresu ochrony konkurencji. Art. 4 ust. 2 zastrzega przy tym, że przesłanka ochrony interesów handlowych osoby fizycznej i prawnej, ochrona postępowania sądowego i porady prawnej, czy wreszcie - ochrona celu postępowania nie znajdzie zastosowania wówczas, gdy za ujawnieniem dokumentu przemawia interes publiczny. Przy tym sam fakt, że dokumenty, do których dostępu żądają określone podmioty, dotyczą chronionego interesu, nie może sam w sobie uzasadniać stosowania wyjątku ${ }^{140}$. Analiza orzeczeń dotyczących stosowania rozporządzenia o przejrzystości wobec dokumentów zgromadzonych w postępowaniu antymonopolowym wskazuje, że Sąd nie pozwala Komisji na zbyt szerokie stosowanie wymienionych powyżej wyjątków, przeciwnie - muszą one być przedmiotem ścisłej wykładni ${ }^{141}$, a naruszenie chronionego interesu, uzasadniające zastosowanie wyjątków dla odmowy dostępu do dokumentów musi być faktyczne i konkretne ${ }^{142}$. Ochrona wnioskodawców leniency nie może na przykład korzystać z wyjątku ochrony celu dochodzenia, ponieważ - jak stwierdził Sąd - „rozporządzenie nr 1049/2001 w żaden sposób nie pozwala zakładać, iż polityka konkurencji Unii powinna (...) korzystać z traktowania odmiennego niż pozostałe dzie-

139 Por. pkt 117 wyroku w sprawie T-2/03 VKI.

140 Por. pkt 63 wyroku w sprawie T-437/08 CDC Hydrogene Peroxide; pkt 77 wyroku w sprawie T-237/02 Technische Glaswerke Ilmenau.

141 Por. pkt 75 wyroku TS z dnia 21 lipca 2011 r. w sprawie C-506/08 P Królestwo Szwecji v. MyTravel i Komisja (niepubl.).

142 Por. pkt 53 wyroku w sprawie C-139/07 Technische Glaswerke Ilmenau. 
dziny polityki Unii. Nie ma zatem żadnego powodu, by wykładni pojęcia celów dochodzenia na gruncie polityki konkurencji dokonywać w inny sposób niż na gruncie innych dziedzin polityki Unii”"143. Ochrona wnioskodawców leniency może natomiast mieć miejsce $\mathrm{w}$ oparciu o przesłankę ochrony interesów handlowych ${ }^{144}$. Nie bez znaczenia dla dostępności dokumentów na potrzeby prywatnego egzekwowania prawa konkurencji będzie zapewnie opinia Europejskiego Rzecznika Praw Obywatelskich, który wskazał na trzy kategorie dokumentów, jakie mogą być udostępniane przez Komisję, i co do których w różny sposób należy stosować rozporządzenie o przejrzystość. Jeśli chodzi o dokumenty dobrowolnie przekazane przez wnioskodawców leniency oraz dokumenty uzyskane przez Komisję w odpowiedzi na żądanie informacji, udostępnienie może upośledzać kompetencję organu do gromadzenia faktów, takiego niebezpieczeństwa nie ma, zdaniem Rzecznika w odniesieniu do dokumentów pozyskanych w toku kontroli. Rzecznik przyznał, że wzmacnianie prywatnego egzekwowania prawa konkurencji leży $\mathrm{w}$ interesie publicznym, jednak sam ten fakt nie oznacza jeszcze wymogu ujawniania dokumentów 145 .

W wyroku w sprawie T-237/02 Technische Glaswerke Ilmenau Sąd stwierdzil, że wyjątek w postaci ochrony celu dochodzenia nie może być również uzasadniony ogólnym wymogiem lojalnej współpracy i wzajemnym zaufaniem między Komisją, państwami członkowskimi i zainteresowanymi przedsiębiorstwami, które to zasady mają według Komisji umożliwiać różnym stronom swobodną wypowiedź w toku postępowania. Sąd uznał ten argument za „paradoksalny”, a ocena ta pojawiła się w sprawie dotyczącej dostępu do dokumentów z postępowania z zakresu pomocy publicznej146, jednak może ona z powodzeniem znaleźć zastosowanie również w odniesieniu do postępowań antymonopolowych. Niemniej jednak TS w odwołaniu od powyższego wyroku uznał, że ocena Sądu nie uwzględniła faktu, że zgodnie z przepisami rozporządzenia 659/1999 dostępu do dokumentów w postępowaniu z zakresu pomocy publicznej nie mają żadne inne podmioty za wyjątkiem Komisji i państw członkowskich; okoliczność ta, zdaniem TS,

143 Pkt 72 wyroku w sprawie T-437/08 CDC Hydrogene Peroxide.

144 Por. pkt 73-74 wyroku w sprawie T-437/08 CDC Hydrogene Peroxide.

145 Por. pkt 102-103 decyzji Europejskiego Rzecznika Praw Obywatelskich z dnia 6 kwietnia 2010 r. zamykającej postępowanie w sprawie skargi 3699/2006/ELB przeciwko Komisji (dokument dostępny pod adresem: http://www.ombudsman.europa.eu/cases/decision. faces/en/4752/html.bookmark).

146 Por. pkt 88 i 92 wyroku w sprawie T-237/02 Technische Glaswerke Ilmenau. 
powinna mieć wpływ na wykładnię art. 4 ust. 2 tiret trzecie rozporządzenia 1049/2001147.

Rozporządzenie 1049/2001 przewiduje, że w odniesieniu do dokumentów stron trzecich instytucja mająca udzielić dostępu do dokumentów skonsultuje ze stroną, czy można zastosować wyjątki wskazane w art. 3 ust. 1 i 2 , „chyba że jest jednoznaczne, że dokumenty zostanie ujawniony lub nie" (art. 4 ust. 4).

Dodatkowo art. 4 ust. 3 akapit pierwszy rozp. 1049/2001 przewiduje możliwość odmowy dostępu do dokumentu wewnętrznego instytucji lub dokumentu otrzymanego przez instytucję, jeśli dokumenty te odnoszą się do spraw, w których nie została wydana decyzja, a dostęp do takich dokumentów „poważnie naruszyłby proces podejmowania decyzji przez tę instytucję”, wyjątkiem jest jednak również sytuacja, że za ujawnieniem dokumentu przemawia interes publiczny. Słusznie podkreśla się, że przepis ten oferuje wyższy poziom ochrony prawa dostępu do dokumentów niż pozostałe regulacje rozp. 1049/2001148. W wyroku w sprawie C-506/08 P Królestwo Szwecji przeciwko Komisji TS potwierdził stanowisko Sądu, zgodnie z którym za dokumenty zawierające opinie na użytek wewnętrzny Komisji mogą być uznane sprawozdania urzędnika ds. wysłuchań, uwagi DG ds. konkurencji skierowane do komitetu konsultacyjnego i uwagi do akt dotyczące kontroli w siedzibie przedsiębiorstwa ${ }^{149}$. Trybunał uznał również, że odmowa dostępu do dokumentów nie może być podyktowana obawą, że „ujawnienie opinii służby prawnej Komisji dotyczącej projektu decyzji może wzbudzić wątpliwości co do zgodności z prawem ostatecznej wersji tej decyzji; należy stwierdzić, że to właśnie przejrzystość w tym względzie, pozwalająca na to, by rozbieżności między szeregiem punktów widzenia były poddane otwartej debacie, przyczynia się do większej legitymizacji instytucji w oczach obywateli Unii i do zwiększenia ich zaufania" 150 .

W wyroku w sprawie T-437/08 CDC Hydrogene Peroxide Sąd stwierdził, że „czynności dochodzeniowe w konkretnej sprawie należy uznać za zakończone z chwilą wydania ostatecznej decyzji, bez względu na ewentualne późniejsze stwierdzenie nieważności tej decyzji przez sądy, skoro to w tym momencie sama instytucja prowadząca postępowanie uznaje postępowanie za zamknięte"151. Sąd uznał również, że realizacja prawa dostępu do

147 Por. pkt 56 wyroku w sprawie C-139/07 Technische Glaswerke Ilmenau.

148 Tak D. Adamski, How wide is "the widest possibile"? Judicial interpretation of the exceptions o the right of access to official documents revisted, CMLR 2009, vol. 46(2), s. 542.

149 Pkt 95 wyroku w sprawie C-506/08 P Królestwo Szwecji v. Komisja.

150 Pkt 113 wyroku w sprawie C-506/08 P Królestwo Szwecji v. Komisja.

151 Pkt 62 wyroku w sprawie T-437/08 CDC Hydrogene Peroxide. 
dokumentów nie może być uzależniona od zdarzeń losowych, tj. skutków skargi, a także od wydarzeń przyszłych i niepewnych, zależnych od decyzji przedsiębiorstw będących adresatami decyzji oraz od decyzji organów ochrony konkurencji152. Odnosząc się do celu dochodzenia jako przesłanki uzasadniającej odmowę dostępu do dokumentów w orzeczeniu w sprawie T-437/08 CDC Hydrogene Peroxide Sąd podkreślił, że celem tego wyjątku „nie jest ochrona czynności dochodzeniowych jako takich, ale ochrona celu dochodzenia, który polega - w przypadku postępowania w dziedzinie konkurencji - na zbadaniu, czy naruszenie art. $81 \mathrm{WE}$ lub art. $82 \mathrm{WE}$ miało miejsce, i ewentualnie na ukaraniu odpowiedzialnych przedsiębiorstw. To właśnie dlatego poszczególne dokumenty zgromadzone w aktach sprawy, których dotyczą różne czynności dochodzeniowe, mogą być objęte rozpatrywanym wyjątkiem do czasu osiągnięcia tego celu, nawet jeśli konkretne dochodzenie lub kontrola, w wyniku których sporządzono wnioskowany dokument, zostały zakończone"153.

$\mathrm{Z}$ obowiązku udostępniania - bez względu na etap postępowania (przed czy po wydaniu decyzji) - wyłączone są natomiast „dokumenty zawierające opinie do wykorzystania wewnętrznego jako część rozważań i konsultacji wstępnych w obrębie rzeczonej instytucji”, jeśli ujawnienie dokumentu poważnie naruszałoby proces wydania decyzji, chyba że za ujawnieniem przemawia interes publiczny (art. 4 ust. 3 akapit drugi). Wyjątki mogą dotyczyć jedynie części dokumentów, co zobowiązuje instytucję do ujawnienia pozostałej części dokumentu (art. 4 ust. 6).

Stosowanie wyjątków jest ograniczone czasowo do okresu, „przez który ochrona ta jest uzasadniona w oparciu o treść dokumentu", ale nie dłuższy niż 30 lat - przedawnienie okresu ochrony nie dotyczy dokumentów objętych wyjątkiem z powodu ochrony prywatności oraz interesów handlowych oraz dokumentów sensytywnych (art. 4 ust. 7). Przepis ten nie wydaje się mieć znaczenia w kontekście wykorzystywania rozporządzenia o przejrzystości jako podstawy prawnej dla dostępu do dokumentów w celach prywatnego egzekwowania prawa ochrony konkurencji, a to ze względu na okresy przedawnienia roszczeń wynikających $\mathrm{z}$ naruszenia przepisów o ochronie konkurencji, które z reguły wynoszą znacznie mniej niż 30 lat.

Jeśli dokumenty zgromadzone w postępowaniu antymonopolowym przez Komisję obejmują także dokumenty pochodzące od państw członkowskich, te mogą zażądać od Komisji nieujawniania dokumentu bez ich uprzedniej zgody (art. 4 ust. 5).

152 Por. pkt 64 wyroku w sprawie T-437/08 CDC Hydrogene Peroxide.

153 Pkt 59 wyroku w sprawie 437/08 CDC Hydrogene Peroxide. 


\subsubsection{Uwagi końcowe}

Orzeczenia wydane w związku ze stosowaniem rozporządzenia 1049/2001 w sprawach z zakresu ochrony konkurencji wskazują, że z regulacji tej często korzystają bądź to podmioty zainteresowane zbiorowym dochodzeniem roszczeń (jak w orzeczeniu w sprawie T-2/03 VKI, gdzie o dostęp do dokumentów zebranych w postępowaniu w sprawie kartelu bankowego „klub Lombard” 154 wystąpiło austriackie stowarzyszenie konsumentów, dysponujące uprawnieniami do wnoszenia do austriackich sądów cywilnych spraw w celu dochodzenia niektórych praw konsumentów o charakterze materialnym, które to prawa owi konsumenci uprzednio scedowali na stowarzyszenie), bądź podmioty profesjonalnie zajmujące się dochodzeniem roszczeń $\mathrm{w}$ ramach prywatnego egzekwowania prawa konkurencji (jak w orzeczeniu w sprawie T-437/08 CDC Hydrogene Peroxide, gdzie skarżącym była spółka akcyjna, której przedmiotem działalności była obrona interesów i odzyskiwanie na drodze sądowej i pozasądowej wierzytelności przedsiębiorstw poszkodowanych w wyniku kartelu nadtlenku wodoru i nadboranu sodu ${ }^{155}$ ).

Dotychczasowe orzecznictwo Sądu otwiera możliwość korzystania z rozporządzenia o przejrzystości na potrzeby prywatnego egzekwowania prawa konkurencji, co najdobitniej potwierdza orzeczenie w sprawie T-437/08 CDC Hydrogene Peroxide ${ }^{156}$, jednak - jak podkreśla się w literaturze - nie jest to idealny środek pozyskiwania dowodów ${ }^{157}$, głównie ze względu na niedookreślony zakres stosowania wyjątków określonych w art. 4 rozp. 1049/2001158.

154 Por. decyzja Komisji 2004/138/WE z dnia 11 czerwca 2002 r. w sprawie postępowania na podstawie art. 81 WE (Banki austriackie - „klub Lombard”) (Dz. Urz. UE 2004 L 56/1).

155 Decyzja Komisji C (2006) 1766 wersja ostateczna z dnia 3 maja 2006 r. dotyczącą postępowania na mocy art. 81 [WE] i art. 53 porozumienia o EOG (sprawa COMP/F/38.620 - Nadtlenek wodoru i nadboran sodu).

$156 \mathrm{~W}$ tym kontekście można również odnotować pogląd, że prywatne egzekwowanie prawa konkurencji wiele waży dla rozporządzenia 1049/2001 - tak R. Hempel, Access to DG Competition's files: an analysis of recent EU court case law, E.C.L.R. 2012, vol. 33(4), s. $195-202$.

157 Tak J. Suderow, Access to evidence..., [w:] L. A. Velasco i inni (red.), Private enforcement..., s. 532.

158 Dla usunięcia tych obszarów niepewności w literaturze proponuje się nawet wydanie przez Komisję odpowiedniego obwieszczenia dotyczącego stosowania rozporządzenia 1049/2001 w sprawach z zakresu ochrony konkurencji - E. F. Pérez Carillo, Access to documents and transparency: elements to facilitate damages actions arising from competition law infringements in the European Union, [w:] L. A. Velasco i inni (red.), Private enforcement..., s. 439. 
Jak podkreślił unijny Ombudsman, realną alternatywą dla udostępniania dokumentów na podstawie rozporządzenia o przejrzystości pozostaje współpraca Komisji z sądami krajowymi oparta o art. 15 rozp. 1/2003159. Stanowisko to nie tylko zasługuje na pełną aprobatę, ale równocześnie wskazuje jak istotne jest zapewnienie odpowiednich krajowych procedur kooperacji sądów i organów ochrony konkurencji. Kwestie, które mogą zostać rozstrzygnięte wewnątrz systemu ochrony konkurencji, powinny znajdować takie właśnie rozwiązania, odwołania do przepisów o bardziej generalnym charakterze zawsze będą bowiem obarczone pewnym poziomem niepewności co do skuteczności podejmowanych kroków.

\subsubsection{Stosowanie ustawy o dostępie do informacji publicznej w celu uzyskania dostępu do informacji zgromadzonych w postępowaniu przed Prezesem UOKiK}

\subsubsection{Uwagi wstępne}

Podobnie jak ma to miejsce w UE w odniesieniu do rozporządzenia o przejrzystości, również na gruncie polskiego porządku prawnego można rozważyć możliwość dostępu do akt postępowania prowadzonego przez Prezesa UOKiK na podstawie ustawy o dostępie do informacji publicznej160. Korzystanie z tej podstawy w celu uzyskania dostępu do informacji, które miałyby być wykorzystane w postępowaniu cywilnoprawnym (a zatem: prywatnym), nie jest bynajmniej powszechnie akceptowane. Bliski jest mi pogląd M. Bernaczyka i M. Jabłońskiego, że „z pewnością mamy solidne podstawy prawne, aby w ramach szeroko pojmowanej wolności gospodarczej korzystać z uzyskanej informacji publicznej”161, jednak wielu autorów nie podzielało tego poglądu. Przeciwko możliwości wykorzystywania udip jako podstawy do żądania ujawnienia akt postępowania antymonopolowego zdawała się przemawiać wykładnia celowościowa aktu, którego celem powinno być „,informowanie obywateli o sposobie i zasadach funkcjonowania podmiotów lub osób realizujących zadania publiczne, lub gospodarujących mieniem publicznym w celu poprawy tego funkcjonowania, a tym samym

159 Por. pkt 114 decyzji Europejskiego Rzecznika Praw Obywatelskich z dnia 6 kwietnia 2010 r. zamykającej postępowanie w sprawie skargi 3699/2006/ELB przeciwko Komisji.

160 Ustawa z dnia 6 września 2001 r. o dostępie do informacji publicznej (Dz. U. 2001 $\mathrm{Nr}$ 112, poz. 1198 ze zm.); dalej jako udip.

161 M. Bernaczyk, M. Jabłoński, Praktyczne problemy wdrażania ustawy o dostępie do informacji publicznej. Komercjalizacja informacji publicznej, elektroniczna Administracja 2007, nr 1 , s. 8 . 
poprawy funkcjonowania państwa"162. Część doktryny podkreśla, że prawo do informacji gwarantowane przez omawianą ustawę jest nadużywane, „a składane wnioski służą uzyskaniu informacji, które mają zostać wykorzystane do celów komercyjnych (jak w przypadku wniosków kancelarii prawniczych) lub też realizacji osobistych subiektywnych celów wnioskodawcy"163. Argument ten ma jednak zdecydowanie słabszy wydźwięk w świetle nowelizacji ustawy z 2011 r., mocą której prawo do informacji publicznej zostało uzupełnione prawem do ponownego wykorzystania informacji publicznej (art. 2a ust. 1) ${ }^{164}$. Pozyskanie informacji publicznych dla celów prowadzonego postępowania sądowego może stanowić realizację prawa do ponownego wykorzystania informacji publicznej - ustawodawca nie dostarczył co prawda definicji ponownego wykorzystania informacji publicznej, jednak biorąc pod uwagę fakt, że ustawa ma implementować dyrektywę 2003/98/WE w sprawie ponownego wykorzystania informacji sektora publicznego ${ }^{165}$ usprawiedliwione wydaje się odwołanie do definicji legalnej ponownego wykorzystania informacji publicznej zawartej w tym akcie prawnym. Artykuł 2 pkt 4 dyrektywy stanowi, że „ponowne wykorzystywanie oznacza wykorzystywanie przez osoby fizyczne lub prawne dokumentów będących w posiadaniu organów sektora publicznego, do celów komercyjnych lub niekomercyjnych, innych niż ich pierwotne przeznaczenie w ramach zadań publicznych, dla których te dokumenty zostały wyprodukowane (...)".

\subsubsection{Zakres przedmiotowy ustawy o dostępie do informacji publicznej a akta postępowania antymonopolowego}

Dostęp do informacji regulowany jest już na poziomie Konstytucji RP (art. 54, 61 oraz 73 ust. 3 Konstytucji, przy czym każdy z tych przepisów reguluje inny aspekt dostępu do informacji). Kluczowe znaczenie dla ustawy o dostępie do informacji publicznej ma art. 61 ustanawiający powszechne prawo obywatelskie do informacji o działalności organów władzy publicznej oraz osób pełniących funkcje publiczne; sama ustawa, określając tryb

162 I. Kamińska, M. Rozbicka-Ostrowska, Ustawa o dostępie do informacji publicznej. Komentarz praktyczny, LexisNexis, Warszawa 2008, s. 16.

163 I. Kamińska, M. Rozbicka-Ostrowska, Ustawa o dostępie..., s. 16.

164 Por. art. 1 pkt 3 ustawy z dnia 16 września 2011 r. o zmianie ustawy o dostępie do informacji publicznej oraz niektórych innych ustaw (Dz. U. $2011 \mathrm{Nr}$ 204, poz. 1195).

165 Dyrektywa 2003/98/WE Parlamentu Europejskiego i Rady z dnia 17 listopada 2003 r. w sprawie ponownego wykorzystywania informacji sektora publicznego (Dz. Urz. UE 2003 L 345/90). 
udzielania informacji publicznej, wypełnia postanowienie art. 61 ust. 4166 . Ustawa nie definiuje pojęcia informacji publicznej, stanowiąc $w$ art. 1 ust. 1, że „każda informacja o sprawach publicznych stanowi informację publiczną w rozumieniu ustawy”. W literaturze można spotkać pogląd, że „informację stanowi każdy opis rzeczywistości - niezależnie od tego, czy jest zgodny z prawdą, czy też nie”167, zaś „szeroki zakres definicji zawartej w art. 1 ust. 1 ustawy sprawia, że wszystko, co ma jakiekolwiek konotacje ze sferą publiczną może zostać uznane za informację publiczną"168. Naczelny Sąd Administracyjny w uzasadnieniu wyroku z dnia 16 kwietnia 2010 r., I OSK 1715/09, wskazał natomiast, że art. 1 ust. 1 udip „należy potraktować jak powtórzenie generalnej zasady demokratycznego państwa prawa - zasady jawności działania władz i wydatkowania funduszy publicznych (art. 61 Konstytucji RP) - poprzez pokreślenie, że każda informacja o sprawach publicznych stanowi informację publiczną"169. Naczelny Sąd Administracyjny wielokrotnie wskazywał na zasadę powszechnego dostępu do wiedzy o sprawach publicznych jako wytyczną co do tego, czy żądana informacja mieści się w przedmiocie uregulowanym udip. Przyjęcie takiej wytycznej oznacza, że organ interpretując zapisy ustawowe, powinien zawsze dążyć do tego, aby informacja została ujawniona; interpretacja przepisów powinna następować na korzyść wykonującego prawo do informacji ${ }^{170}$.

Artykuł 6 udip zawiera katalog typów (kategorii) informacji publicznej, niektórzy autorzy podkreślają, że nie może on jednak stanowić „pomocniczego kryterium dla definiowania pojęcia informacji publicznej" ${ }^{171}$, ponieważ rolą tego przepisu pozostaje wskazanie, jakie typy informacji podlegają zamieszczeniu w Biuletynie Informacji Publicznej. Niemniej jednak NSA zajął stanowisko, zgodnie z którym ,przy odkodowywaniu pojęcia «informacja publiczna» należy mieć na uwadze także treść art. 6 ustawy, w którym określono przedmiotowo, jakie informacje podlegają udostępnieniu w omawianym trybie"172. Jedna z podstawowych wątpliwości, jakie powstały

166 Tak J. Jendrośka, M. Stoczkiewicz, Ustawa o dostępie do informacji publicznej a regulacje szczegótowe, PiP 2003, z. 6, s. 92.

167 T. R. Aleksandrowicz, Komentarz do ustawy o dostępie do informacji publicznej, LexisNexis, Warszawa 2002, s. 71. Szerzej na temat zakresu pojęcia „informacja publiczna” - por. M. Ulasiewicz, Pojęcie i rodzaj informacji publicznej, PPP 2009, nr 11.

168 P. Sitniewski, Ustawa o dostępie do informacji publicznej. Komentarz, Presscom, Wrocław 2011, s. 15.

169 Wyrok NSA z dnia 16 marca 2010 r., I OSK 1715/09.

170 Por. m.in. wyrok NSA, II S.A. 837/03 Monitor Prawniczy nr 17/2003, s. 770; wyrok NSA z dnia 17 czerwca 2011 r., I OSK 490/11.

171 Tak P. Sitniewski, Ustawa o dostepie..., s. 117.

172 Wyrok NSA z dnia 17 czerwca 2011 r., I OSK 490/11. 
w związku z treścią art. 6 udip, dotyczyła tego, czy pojęcie informacji publicznej może być zawężane do dokumentów urzędowych, zdefiniowanych w art. 6 ust. 2 udip jako „treść oświadczenia woli lub wiedzy, utrwalona i podpisana $\mathrm{w}$ dowolnej formie przez funkcjonariusza publicznego w rozumieniu Kodeksu karnego, w ramach jego kompetencji, skierowana do innego podmiotu lub złożona do akt sprawy”. Jak podkreślił NSA w przywołanym powyżej wyroku w sprawie I OSK 490/11 „pojęcie dokumentu urzędowego różni się od dokumentu zawierającego informację publiczną. To ostatnie pojęcie jest znacznie szersze. Znaczenie ma zatem nie to czy dokument został sporządzony przez funkcjonariusza publicznego w znaczeniu przepisów kodeksu karnego, lecz przede wszystkim to czy zawiera on informację publiczną".

Nawet jeśli ustawa nie definiuje pojęcia informacji publicznej, to określa ona zakres przedmiotowy „prawa do informacji publicznej” (art. 2), przyznając również „prawo do ponownego wykorzystania informacji publicznej” (art. 2a ust. 1). Prawo do informacji publicznej obejmuje prawo uzyskania informacji publicznej (art. 3 ust. 1 pkt 1) oraz prawo wglądu do dokumentów urzędowych (art. 3 ust. 1 pkt 2). Prawo wglądu do dokumentów urzędowych, stanowiące część składową prawa do informacji, obejmuje m.in. prawo wglądu do dokumentów urzędowych, które w doktrynie rozumiane jest zarówno jako możliwość zapoznania się z treścią dokumentu i sporządzenia z niego notatek, jak i możliwość sporządzenia fotokopii 173 . W literaturze podkreśla się, że prawo wglądu do dokumentów nie może być utożsamiane $\mathrm{z}$ prawem wglądu $\mathrm{w}$ akta jakiejś sprawy ${ }^{174}$. W orzecznictwie (głównie wojewódzkich sądów administracyjnych) pojawił się pogląd, zgodnie z którym art. 3 ust. 2 udip należy interpretować rozszerzająco i prawem wglądu objąć nie tylko dokumenty urzędowe ${ }^{175}$ - wszystkie dokumenty; źródeł tego poglądu należy upatrywać w art. 61 ust. 2 Konstytucji, który prawa dostępu do informacji nie ogranicza bynajmniej do dokumentów urzędowych. Stanowisko to w literaturze poparł P. Sitniewski ${ }^{176}$. Akceptacja tego poglądu pozwala przyjąć, że informacje zgromadzone w postępowaniu antymonopolowym, nawet jeśli nie są dokumentami urzędowymi w rozumieniu art. 6 ust. 2 udip, podlegają prawu do informacji publicznej gwarantowanemu w omawianej ustawie.

Artykuł 5 ust. 3 ustawy gwarantuje „dostęp do informacji o sprawach rozstrzyganych $\mathrm{w}$ postępowaniu przed organami państwa, w szczególności

\footnotetext{
173 Tak słusznie I. Kamińska, M. Rozbicka-Ostrowska, Ustawa o dostępie..., s. 29.

174 P. Sitniewski, Ustawa o dostęie..., s. 69.

175 Por. wyrok WSA we Wrocławiu z dnia 22 listopada 2006 r., IV SA/Wr 712/06.

176 P. Sitniewski, Ustawa o dostepie..., s. 71.
} 
w postępowaniu administracyjnym, karnym lub cywilnym” - nie istnieją przesłanki, dla których spod prawa do informacji publicznej należałoby wyłączać informacje dotyczące spraw rozstrzyganych w postępowaniu antymonopolowym (nawet jeśli nie ma ono czysto administracyjnego charakteru).

Nie ma wątpliwości co do tego, że informację publiczną stanowią decyzje Prezesa UOKiK - spełniają one bowiem definicję legalną dokumentu urzędowego z art. 6 ust. 2 udip; zgodnie zaś ze stanowiskiem NSA „decyzja administracyjna wydana $\mathrm{w}$ indywidualnej sprawie jest informacją publiczna w rozumieniu art. 1 ust. 1 ww. ustawy"177. Co do wydawanych przez siebie decyzji Prezes UOKiK realizuje prawo dostępu do informacji poprzez publikację (wybranych) decyzji w Dzienniku Urzędowym UOKiK oraz w pełnym zakresie - poprzez zamieszczanie pełnych tekstów decyzji (przynajmniej w odniesieniu do praktyk ograniczających konkurencję) w bazie orzecznictwa Prezesa UOKiK na stronie internetowej Urzędu.

Informacją publiczną będą wszystkie te dokumenty i informacje zgromadzone $\mathrm{w}$ postępowaniu antymonopolowym (lub nawet w postępowaniu wyjaśniającym), które mogą zostać uznane za dokument urzędowy (ich udostępnienie będzie możliwe o tyle, ile nie zachodzą przesłanki do ograniczenia prawa do informacji określone w art. 5 udip). Akta administracyjne same w sobie nie stanowią dokumentu urzędowego ${ }^{178}$, zaś sam fakt nadania określonej formy zbiorowi informacji nie powinien być postrzegany jako wytworzenie informacji przez organ administracji 179 . W świetle definicji legalnej dokumentu urzędowego (art. 6 ust. 2) - w moim przekonaniu - za dokument urzędowy może być uznany protokół z przesłuchania świadków sporządzony $\mathrm{w}$ toku postępowania antymonopolowego, ale statusu dokumentu urzędowego nie będą miały dokumenty prywatne ${ }^{180}$ pozyskane przez Prezesa UOKiK np. w wyniku przeprowadzonego przeszukania. Jednakże sam fakt, że informacja została wytworzona przez przedsiębiorcę (a nie przez organ) nie dyskwalifikuje jej jako informacji publicznej181. W wyroku z dnia 17 czerwca 2011 r., I OSK 490/11 (jednym z nielicznych, które dotyczyły wniosku o udostępnienie informa-

177 Wyrok NSA z dnia 16 kwietnia 2010 r., I OSK 83/10. Por. także postanowienie NSA z dnia 23 września 2009 r., I OSK 1165/09.

178 Pogląd ten jest zgodnie podzielany w doktrynie - por. I. Kamińska, M. Rozbicka-Ostrowska, Ustawa o dostępie..., s. 65; P. Sitniewski, Ustawa o dostępie..., s. 21; H. KnysiakMolczyk, Prawo do informacji w postęowaniu administracyjnym, sadowo-administracyjnym oraz w ustawie o dostępie do informacji publicznej, PPP 2010, nr 3, s. 75.

179 Tak I. Kamińska, M. Rozbicka-Ostrowska, Ustawa o dostępie..., s. 21.

180 Por. wyroki NSA: z dnia 19 sierpnia 2009 r., I OSK 683/09; z dnia 20 marca 2008 r., II GSK 459/07.

181 Por. wyrok NSA z dnia 17 czerwca 2011 r., I OSK 490/01. 
cji publicznej kierowanego do Prezesa $\mathrm{UOKiK}^{182}$ ), NSA podkreślit, że „organ może być zobowiązany nie tylko do poinformowania o swojej działalności, lecz także do udostępnienia źródeł tej informacji. Zatem informacją może być również udostępnienie dokumentu, akt i materiałów, które świadczą lub mogą świadczyć o działalności organu władzy publicznej i innych podmiotów zobowiązanych na gruncie omawianej ustawy do udostępniania informacji publicznej. Tym samym przedmiotowy walor mają dokumenty, akta i inne materiały wytworzone przez wskazane organy i podmioty, jak też inne dokumenty, akta i materiały, które wprawdzie nie zostały przez nie wytworzone, ale są w ich posiadaniu, gdyż związane są z realizacją przez nie prawem przewidzianych zadań publicznych". Wielu informacjom zgromadzonym w postępowaniu dowodowym w ramach postępowania antymonopolowego w rzeczywistości można przypisać rolę źródeł, o jakich mowa w przytoczonym fragmencie stanowiska NSA. W tym samym wyroku NSA stwierdzit, że dokumenty, które zostały dostarczone organowi w toku prowadzonego przez niego postępowania oraz związane są z wykonywaniem wydanej przez niego decyzji, „stanowią część akt sprawy administracyjnej i tym samym - jako odnoszące się do działalności podmiotu publicznego, a mianowicie organu administracji publicznej - stanowią informację publiczną w rozumieniu art. 1 ust. 1 udip". W konsekwencji NSA przyjąt, że informacją publiczną mogą być dokumenty wytworzone przez przedsiębiorcę w toku wykonywania przez niego decyzji Prezesa UOKiK (chodziło o kopie projektów umów przedwstępnych i ostatecznych określających zasady przejmowania przez przedsiębiorcę od inwestorów zewnętrznych urządzeń wodociągowych i/lub kanalizacyjnych; przedsiębiorca był zobowiązany do przekazania tych projektów Prezesowi UOKiK w terminie określonym w skierowanej do niego decyzji). Odrębnym problemem pozostaje natomiast to, czy informacja taka może zostać udostępniona, biorąc pod uwagę względy ochrony tajemnicy przedsiębiorcy (art. 5 ust. 2 udip) ${ }^{183}$.

G. Sibiga uważa, że za informację publiczną nie mogą być uznane te dokumenty z akt administracyjnych, które odnoszą się do kwestii prywatnych, osobistych czy intymnych ${ }^{184}$. Nie można wykluczyć, że również

182 Por. także wyrok WSA w Warszawie z dnia 16 listopada 2009 r., II SA/Wa 1197/09 (wniosek dotyczył udostępnienia przez Prezesa UOKiK wyroków sądowych podnoszących problem zatrzymania $\mathrm{w}$ toku przeszukania dokumentów chronionych tajemnicą zawodową).

183 Naczelny Sąd Administracyjny po rozpoznaniu skargi kasacyjnej uchylił wyrok WSA w Warszawie z dnia 26 listopada 2010 r., II SAB/Wa 275/10 i przekazał sprawę do ponownego rozpoznania.

184 G. Sibiga, Dostęp do informacji publicznej a prawa do prywatności jednostki i ochrony jej danych osobowych, Sam. Teryt. 2003, nr 11, s. 5-6. 
w aktach postępowania antymonopolowego znajdą się informacje tego rodzaju, choć będą one należały do rzadkości. Opinie biegłych, które mogą być przedstawiane w postępowaniu antymonopolowym, nie są dokumentem urzędowym, ale mogą mieć status informacji publicznej, jeśli zawierają informację publiczną i nie zachodzą co do nich wyłączenia spod prawa do informacji ${ }^{185}$.

Informację publiczną stanowią również wyroki sądowe. W postępowaniach cywilnych w zakresie prywatnego egzekwowania prawa konkurencji istotne znaczenie może mieć dostęp do wyroków SOKiK, SA czy SN weryfikujących decyzje Prezesa UOKiK. Pewną rolę może odgrywać również dostęp do wyroków innych sądów cywilnych z zakresu prywatnego trybu egzekwowania zakazów praktyk ograniczających konkurencję.

W kontekście rozważań nad możliwością wykorzystania udip jako podstawy prawnej dla udostępnienia informacji zebranych $\mathrm{w}$ postępowaniu antymonopolowym kluczowe znaczenie ma rozstrzygnięcie, czy akta postępowania stanowią informację publiczną w rozumieniu art. 1 ust. 1 udip. W dorobku sądów administracyjnych widoczna była liberalna linia orzecznicza, zgodnie z którą akta sprawy administracyjnej jako odnoszące się do działania organów administracji publicznej stanowią informację publiczną, są one wytworzone przez władze publiczne i nie ma znaczenia, czy są to informacje $w$ formie dokumentów urzędowych czy nie ${ }^{186}$. Nie jest to jednak stanowisko w pełni akceptowane w literaturze, I. Kamińska i M. RozbickaOstrowska uznają je za „zbyt daleko idące”187. Również nowsze orzecznictwo wydaje się odchodzić od tego poglądu - w uzasadnieniu wyroku z dnia 28 października 2008 r., I OSK 714/09, NSA stwierdzit, że „,akta sprawy nie są w całości informacją publiczną, są bowiem zbiorem informacji takich, które są informacją publiczną i takich, które jej nie stanowią", podtrzymując to stanowisko w wyroku z dnia 16 kwietnia 2010 r., I OSK 83/10 NSA uznał, że wydaje się ono uzasadnione przez art. 3 ust. 1 pkt 2 udip, który jedno $\mathrm{z}$ uprawnień $\mathrm{w}$ ramach prawa do informacji publicznej formułuje jako uprawnienie do wglądu do dokumentów, nie zaś jako umożliwienie przeglądania akt sprawy (jak w art. $73 \S 1$ k.p.a.).

185 Tak NSA w wyroku z dnia 17 czerwca 2011 r., I OSK 490/11.

186 Por. m.in. wyrok NSA z dnia 11 maja 2006 r., II OSK 812/05, Lex nr 236465; wyrok WSA w Krakowie z dnia 8 lutego 2008 r., II SA/Kr 942/07; wyrok WSA w Lublinie z dnia 16 grudnia 2005 r., II SAB/Lu 74/05; wyrok WSA w Poznaniu z dnia 5 kwietnia 2005 r., IV SA/Po 1541/04, niepubl.; wyrok WSA w Rzeszowie z dnia 4 sierpnia 2004 r., II SAB/Rz 26/04, niepubl.

187 I. Kamińska, M. Rozbicka-Ostrowska, Ustawa o dostępie..., s. 20. 


\subsubsection{Zakres podmiotowy ustawy o dostępie do informacji publicznej a podmioty legitymowane do wystąpienia z roszczeniami z tytułu naruszenia zakazów praktyk ograniczających konkurencję}

Prawo do informacji przysługuje każdemu (art. 2 ust. 1), niezależnie od wykazywanego interesu prawnego lub faktycznego (art. 2 ust. 2)188, tym bardziej zatem może ono przysługiwać podmiotom, które ze względu na planowane lub toczące się postępowanie przed sądem cywilnym, byłyby zainteresowane dostępem do informacji wytwarzanych przez Prezesa UOKiK. Regulacja dostępu stron do informacji w postępowaniu antymonopolowym stanowi jednak lex specialis wobec udip, stąd „każdym” w rozumieniu art. 2 nie będzie strona postępowania przed Prezesem UOKiK, przynajmniej w toku postępowania ${ }^{189}$. Nie można jednak wykluczyć, że strona może żądać dostępu do akt sprawy już po jej zakończeniu (gdyż wówczas pojawi się potrzeba zasięgnięcia określonych informacji, np. dotyczących działań innych uczestników kartelu lub kontrahentów, na potrzeby obrony w postępowaniu cywilnym) - w takim przypadku stronom zakończonego postępowania antymonopolowego przysługuje prawo do informacji publicznej na podstawie udip ${ }^{190}$. Ustawa o ochronie konkurencji i konsumentów nie daje w chwili obecnej możliwości dostępu do informacji zgromadzonych w postępowaniu antymonopolowym osobom trzecim (innym niż strony), np. wnioskodawcy o wszczęcie postępowania. To przede wszystkim dla tych podmiotów udip może mieć istotne znaczenie dla skutecznego prywatnego egzekwowania prawa konkurencji, choć trzeba mieć na uwadze, że zakres dostępu do informacji dla osób trzecich w trybie udip będzie się różnił od tego, jaki realizują strony na podstawie uokik (osoby trzecie mogą uzyskać dostęp do tych informacji, które mieszczą się w zakresie art. 1 ust. 1 udip). Również w orzecznictwie utrwalił się pogląd, że dostęp do akt postępowania administracyjnego na podstawie przepisów udip ograniczony jest jednak

188 Wyjątek stanowi sytuacja, gdy żądanie dotyczy informacji przetworzonej - por. art. 3 ust. 1 pkt 1 udip.

189 Analogicznie w innych postępowaniach administracyjnych podstawą prawną dostępu do akt postępowania dla stron będzie art. 73 i 74 k.p.a., a nie uodip - tak słusznie I. Kamińska, M. Rozbicka-Ostrowska, Ustawa o dostępie..., s. 40-41; P. Sitniewski, Ustawa o dostępie..., s. 20.

190 H. Knysiak-Molczyk w odniesieniu do wskazanej powyżej sytuacji (dostępu do akt na podstawie k.p.a.) wskazuje jednak, że „Nie jest jasne, czy po zakończeniu postępowania strony mogą nadal realizować uprawnienia procesowe w zakresie dostępu do akt sprawy, czy też ich prawa ograniczają się do możliwości przewidzianych w ustawie o dostępie do informacji publicznej” - por. H. Knysiak-Molczyk, Prawo do informacji..., s. 78-79. 
do podmiotów niebędących stronami postępowania administracyjnego ${ }^{191}$ (o dostęp do informacji na podstawie udip mogą występować natomiast inni uczestnicy postępowania, np. świadkowie ${ }^{192}$ ). Niektórzy autorzy podtrzymują pogląd wyrażony $\mathrm{w}$ jednym $\mathrm{z}$ wyroków NSA ${ }^{193}$, że korzystanie z prawa do informacji publicznej uzależnione jest od wykazania obiektywnego, a nie subiektywnego, interesu w jej uzyskaniu ${ }^{194}$. Choć poglądowi temu nie można odmówić poprawności w kontekście celu ustawy, to jednak egzekwowanie konieczności wykazania interesu obiektywnego w uzyskaniu dostępu do informacji wydaje się niemożliwe ze względu na brak bezpośredniej podstawy prawnej. Każdym w rozumieniu art. 2 udip jest zarówno osoba fizyczna, jak i prawna, bez względu na obywatelstwo/ miejsce siedziby podmiotu 195 .

Zobowiązanymi do udostępniania informacji publicznej są m.in. „organy władzy publicznej” (art. 4 ust. 1 pkt 1), do których z pewnością zaliczyć można Prezesa UOKiK, ale także - w świetle przywołanego przepisu - m.in. Prezesa sądu196. Realizacja obowiązku udostępniania informacji publicznej spoczywa na tych organach, które są w posiadaniu żądanych informacji.

191 Por. wyroki NSA: z dnia 28 października 2009 r., I OSK 485/09; z dnia 16 listopada 2007 r., II OSK 1523/06; z dnia 11 maja 2006 r., II OSK 812/05. Inaczej H. KnysiakMolczyk, która twierdzi, że skoro zgodnie z art. 1 ust. 2 udip przepisy tej ustawy nie naruszają przepisów innych ustaw określających odmienne zasady i tryb dostępu do informacji będących informacjami publicznymi, to „strony postępowań mogą skorzystać z przysługujących im uprawnień proceduralnych umożliwiających szeroki dostęp do akt sprawy lub z węższych uprawnień wynikających z ustawy o dostępie do informacji publicznej" - por. H. Knysiak-Molczyk, Prawo do informacji..., s. 78.

192 Por. wyrok WSA w Krakowie z dnia 8 lutego 2008 r., II SA/Kr 942/07.

193 Wyrok NSA z dnia 19 września 2007 r., I OSK 1992/06.

194 Tak I. Kamińska, M. Rozbicka-Ostrowska, Ustawa o dostępie..., s. 23; P. Sitniewski, Ustawa o dostępie..., s. 54-55.

195 Tak P. Sitniewski, Ustawa o dostępie..., s. 48. Jednakże w myśl art. 61 Konstytucji RP prawo dostępu do informacji przysługuje obywatelowi; rozbieżność co do zakresu podmiotowego prawa dostępu do informacji między Konstytucją a udip rodziła nawet wątpliwości co do konstytucyjności tej ostatniej - stanowiska doktryny w tej kwestii prezentuje szerzej A. Błaszyńska, Zakres podmiotowy prawa do informacji publicznej, PPP 2010, nr 6, s. 50-54; autorka opowiada się przy tym „,za objęciem prawem do informacji publicznej podmiotów, które co prawda nie są obywatelami polskimi, ale pozostają pod jurysdykcją państwa polskiego" - s. 55.

196 Wyrok WSA w Warszawie z dnia 25 maja 2004 r., II SAB/Wa 58/04. 


\subsubsection{Ustawowe przesłanki ograniczenia dostępu do informacji publicznej a ograniczenia dostępu do informacji zgromadzonych w postępowaniu antymonopolowym}

Ustawa o ochronie informacji niejawnych określa całkowicie autonomicznie sposób dostępu do informacji przez siebie chronionych. Warto zauważyć, że ustawa o dostępie do informacji publicznej „przewiduje konstrukcję bezwzględnych przesłanek ograniczenia dostępności informacji w tym znaczeniu, że zaistnienie chociaż jednej z nich skutkuje automatyczną odmową udostępnienia"197. Spośród przesłanek dopuszczalnego ograniczenia dostępu do informacji wymienionych w art. 5 ustawy w kontekście spraw antymonopolowych znaczenie może mieć przede wszystkim przesłanka tajemnicy przedsiębiorcy (art. 5 ust. 2), w mniejszym zakresie - także ograniczenia przewidziane $\mathrm{w}$ przepisach o ochronie informacji niejawnych oraz o ochronie innych tajemnic ustawowo chronionych (art. 5 ust. 1). Ustawa o dostępie do informacji publicznej wskazuje na podmiotową stronę tajemnicy przedsiębiorcy 198 , nie zaś - jak uznk czy uokik - na stronę przedmiotową lub funkcjonalną (tajemnica przedsiębiorstwa). Zasadne jest zatem pytanie o to, czy pojęcie tajemnicy przedsiębiorcy w rozumieniu art. 5 ust. 2 udip jest tożsame $\mathrm{z}$ pojęciem tajemnicy przedsiębiorstwa $\mathrm{z}$ art. 11 ust. 4 uznk. G. Sibiga wskazuje na dwa odmienne stanowiska doktryny w tej kwestii: potwierdzające tę tożsamośćc ${ }^{199}$ oraz uznające, że udip stworzyła „nowy rodzaj tajemnicy, której zakres jest różny (szerszy) od tajemnicy przedsiębiorstwa" (na taką rozbieżność pojęć wskazuje A. Piskorz-Ryń200). Ten sam autor określając swoje stanowisko jako pośrednie - uznaje, że ochrona tajemnicy przedsiębiorcy (w rozumieniu udip) opiera się na ochronie tajemnicy przedsiębiorstwa, ,ale $\mathrm{z}$ uwzględnieniem odmienności wynikających z art. 5 ust. 2 udip"201. Odmienność ta polega na tym, że ograniczenia nie stosuje się w sytuacji, gdy przedsiębiorca zrezygnował z ochrony tajemnicy oraz jeśli

197 G. Sibiga, Wtaściwość sąów administracyjnych i powszechnych $w$ sprawach $z$ zakresu dostępu do informacji publicznej, [w:] M. Błachucki, T. Górzyńska (red.), Aktualne problemy rozgraniczenia właściwości sądów administracyjnych i powszechnych, Naczelny Sąd Administracyjny, Warszawa 2011, s. 229.

198 M. Ulasiewicz twierdzi, że ustawodawca traktuje „tajemnicę przedsiębiorcy” jako „surogat prawa do prywatności jednostki” - por. tenże, Ograniczenia dostępu do informacji publicznej - zagadnienia wybrane, PPP 2010, nr 9, s. 14.

199 Stanowisko takie prezentują w doktrynie m.in.: M. Jaśkowska, Dostęp do informacji publicznej w świetle orzecznictwa Naczelnego Sąu Administracyjnego, Toruń 2002, s. 78; P. Szustakiewicz, Zasady ustawy o dostepie do informacji publicznej, Jurysta 2002, nr 1, s. 8.

200 Por. A. Piskorz-Ryń, Dostęp do informacji publicznej - zasady konstrukcyjne ustawy, KPPubl. 2002, nr 4, s. 214.

201 G. Sibiga, Właściwość sądów administracyjnych..., s. 223. 
chodzi o informacje dotyczące osób pełniących funkcje publiczne, mających związek z pełnieniem tych funkcji. W moim przekonaniu, przynajmniej w przypadku, gdy organem udostępniającym informacje miałby być Prezes UOKiK, uzasadnione jest postulowanie, aby pojęcie tajemnicy przedsiębiorcy $\mathrm{z}$ art. 5 ust. 2 udip interpretowane było spójnie z pojęciem tajemnicy przedsiębiorstwa z uokik (a w zasadzie z uznk). Nieadekwatne wydaje mi się szczególnie odsyłanie $\mathrm{w}$ toku interpretacji tego pojęcia do definicji przedsiębiorcy z ustawy o swobodzie działalności gospodarczej202 - przyjęcie tak wąskiego stanowiska oznaczałoby, że z ochrony tajemnicy nie mogłyby korzystać podmioty, które posiadają status przedsiębiorcy w rozumieniu uokik, natomiast nie posiadają go w rozumieniu ustawy o swobodzie działalności gospodarczej. Nie mogę również - w kontekście udostępniania informacji dotyczących postępowania antymonopolowego - zgodzić się z poglądem, że „niezależnie od (...) wątpliwości trzeba przyznać, że o uznaniu konkretnej informacji za tajemnicę decyduje zawsze sam przedsiębiorca"203. W przypadku postępowań antymonopolowych to w istocie przedsiębiorca decyduje o tym, co stanowi tajemnicę (przedsiębiorstwa), jednak ostateczna decyzja co do jej ochrony należy do Prezesa UOKiK. Jeśli zatem chodzi o informację publiczną, do której dostarczenia zobligowany jest Prezes UOKiK, spod obowiązku udostępniania na podstawie art. 5 ust. 2 udip wyłączona jest ta informacja, o której ochronę wnioskował przedsiębiorca w postępowaniu antymonopolowym (jako ochronę tajemnicy przedsiębiorstwa na podstawie art. 69 ust. 1), a Prezes UOKiK do tego wniosku się przychylił, bądź informacje chronione jako tajemnica przedsiębiorstwa $\mathrm{z}$ urzędu przez organ antymonopolowy.

\subsubsection{Tryb udostępniania informacji publicznej przez Prezesa UOKiK}

Przyjmując, że przynajmniej niektóre $\mathrm{z}$ dowodów wykorzystanych w postępowaniu antymonopolowym mają status dokumentów urzędowych, które w świetle ustawy mogą podlegać udostępnieniu, bądź też podzielając stanowisko, że nie tylko dokumenty urzędowe stanowią informację publiczną, należy przyjąć, że informacje stanowiące informację publiczną zgromadzone w postępowaniu antymonopolowym mogą być udostępniane na wniosek, tj. w trybie art. 10 ustawy 204 . Procedura występowania o dostęp do informacji publicznej jest w znacznym stopniu odformalizowana, stąd

202 Tak M. Ulasiewicz, Ograniczenia dostępu..., s. 14.

203 Tak M. Ulasiewicz, Ograniczenie dostępu..., s. 15.

204 Tryb ten przewidziany jest dla informacji, które nie zostały zamieszczone w Biuletynie Informacji Publicznej - por. art. 7 ust. 1 pkt 1 udip. 
wniosek musi zawierać jedynie podstawową identyfikację żądającego informacji (np. poprzez adres, także poczty elektronicznej), zakres żądanych informacji, a także miejsce i sposób dostarczenia.

Odmowa udzielenia informacji następuje w drodze decyzji, od której co do zasady przysługuje odwołanie (art. 16 ust. 2), w przypadku Prezesa UOKiK, który jest centralnym organem administracji możliwość ta nie może być jednak zrealizowana; istnieje jednak możliwość wniesienia skargi do sądu administracyjnego w trybie przewidzianym w ustawie Prawo o postępowaniu przed sądami administracyjnymi (art. 21) ${ }^{205}$. Sama odpowiedź organu co do tego, że żądana informacjia nie stanowi informacji publicznej jest postrzegana w orzecznictwie jako czynność materialno-techniczna ${ }^{206}$, nie wydaje się decyzji administracyjnej w tej sprawie, a trybem, w jakim można zweryfikować stanowisko podmiotu, do którego wnioskowano o dostęp do informacji, jest skarga na bezczynność kierowana do sądu administracyjnego ${ }^{207}$. W orzecznictwie ugruntował się pogląd co do tego, że także udostępnienie informacji publicznej stanowi czynność materialno-techniczną ${ }^{208}$, w doktrynie odmienny pogląd formułował T. R. Aleksandrowicz ${ }^{209}$.

W 2011 r. uchylony został przepis art. 22 udip ${ }^{210}$ przewidujący, że jeśli przyczyną odmowy udostępnienia informacji jest wyłączenie jej jawności ze względu na ochronę danych osobowych, prawo do prywatności oraz tajemnicę inną niż państwowa, służbowa, skarbowa lub statystyczna, to stronom przysługuje prawo wniesienia powództwa do sądu powszechnego o udostępnienie tej informacji (art. 22); powództwo to wnoszone było do sądu rejonowego właściwego ze względu na miejsce siedziby organu, który odmówił dostępu do informacji. Sądy administracyjne orzekały w sprawach odmowy podyktowanej względami ochrony informacji niejawnych oraz

205 Ustawa z dnia 30 sierpnia 2002 r. Prawo o postępowaniu przed sądami administracyjnymi (tekst jedn. Dz. U. 2012 Nr 153, poz. 1270).

206 Por. wyrok NSA z dnia 11 grudnia 2002 r., II SA 2867/02, Wokanda 2003, nr 6, s. 33.

207 Por. wyrok NSA z dnia 16 kwietnia 2010 r., I OSK 83/10. Szerzej na ten temat: P. Szustakiewicz, Postępowanie w spawie bezczynności w zakresie udzielania informacji publicznej w orzecznictwie sądów administracyjnych, PPP 2012, nr 6, s. 74-83.

208 Por. wyroki NSA: z dnia 20 czerwca 2002 r., II SA/Lu 507/02, niepubl.; z dnia10 stycznia 2007 r., I OSK 50/06, niepubl.; z dnia13 marca 2007 r., I OSK 243/07, niepubl. Por. także wyrok WSA w Warszawie z dnia 14 lutego 2008 r., II SA/Wa 1927/07.

209 T. R. Aleksandrowicz, Komentarz..., s. 160-161.

210 Przepis ten został uchylony przez art. 1 pkt 9 ustawy z dnia 16 września 2011 r. o zmianie ustawy o dostępie do informacji publicznej oraz niektórych innych ustaw (Dz. U. 2011 Nr 204, poz. 1195). 
ochrony tajemnicy skarbowej i statystycznej211. Obecnie wszystkie skargi na odmowę udostępnienia informacji rozpatrywane są przez sądy administracyjne (art. 21).

Udostępnienie informacji może nastąpić także bez pisemnego wniosku, jeśli informacja może być „udzielona niezwłocznie” (art. 10 ust. 2). Ten przyspieszony tryb jedynie w rzadkich przypadkach znajdzie zastosowanie w odniesieniu do informacji uzyskanych w postępowaniu antymonopolowym, zwłaszcza jeśli żądanie dotyczy informacji z akt postępowania już zakończonego. Niezwłocznie udzielone mogą być natomiast informacje dotyczące przebiegu postępowania (np. informacja, czy w następstwie postępowania wyjaśniającego zostało wszczęte postępowanie antymonopolowe). Udostępnienie informacji przez organ ma nastąpić bez zbędnej zwłoki, w terminie nie dłuższym niż 14 dni od dnia złożenia wniosku (art. 13 ust. 1); w przypadku, gdy organ opóźnia udzielenie informacji, musi poinformować występującego z wnioskiem o przyczynach opóźnienia oraz o nowym terminie udzielenia informacji, który nie może być dłuższy niż 2 miesiące (art. 13 ust. 2). Taki wydłużony termin oczekiwania na informacje stanowi przesłankę wnioskowania przez powoda żądającego informacji od Prezesa UOKiK o zawieszenie postępowania przez sąd.

Udostępniona informacja może być kopiowana, wydrukowana, przesłana lub przeniesiona na nośnik informacji (art. 12 ust. 2).

\subsubsection{Uwagi końcowe}

Powyższe rozważania prowadzą do wniosku, że ustawa o dostępie do informacji publicznej stwarza możliwości dostępu do informacji będących w posiadaniu Prezesa UOKiK, a przydatnych dla podmiotów zaangażowanych w spory przed sądami cywilnymi w związku z naruszeniem zakazów praktyk ograniczających konkurencję. Regulacji tej nie można jednak postrzegać jako instrumentu doskonałego i w pełni skutecznego, przeciwnie - skorzystanie z przepisów udip wydaje się ryzykowne, a rezultat złożenia wniosku o udostępnienie informacji publicznej - niepewny. Źródłem tej niepewności jest przede wszystkim fakt, że wdrażanie udip w dużej mierze kształtuje orzecznictwo, które w wielu kwestiach, takich jak choćby status akt postępowania administracyjnego w świetle udip, nie jest jednolite. Sukcesu w dziedzinie udostępnienia informacji upatrywać należy w tej linii orzeczniczej sądów administracyjnych, która nakazuje postrzeganie aktów

211 Krytycznie o dualizmie kompetencyjnym sądów co do odwołań od decyzji o odmowie udzielenia informacji - G. Sibiga, Wtaściwość sądów administracyjnych..., s. 215-236. 
postępowania administracyjnego jako informacji publicznej, bez względu na to, czy tworzące je dokumenty mają formę dokumentów urzędowych, czy też nie. Szczególne precedensowe znaczenie może mieć wyrok NSA z dnia 17 czerwca 2011 r., I OSK 490/10, w którym pośrednio potwierdzona została możliwość uznania za informację publiczną projektów umów przeznaczonych do stosowania przez przedsiębiorcę, jeśli powstały one w wykonaniu decyzji Prezesa UOKiK. Orzeczenie to pozwala na wniosek, że NSA jest orędownikiem możliwie najszerszego zakresu dostępu do informacji, tj. dostępu do wszystkich informacji zgromadzonych w związku z postępowaniem antymonopolowym, o ile nie istnieją przesłanki dla ograniczenia dostępu do określonych informacji. Trzeba jednak mieć na uwadze okoliczność, że zarówno Prezes UOKiK, jak i WSA w Warszawie miały inne zdanie w tej kwestii, a upływ czasu (w oczekiwaniu na rozstrzygnięcie NSA) może mieć kapitalne znaczenie dla rozpoczęcia i przebiegu postępowania przed sądem cywilnym.

Wnioskowanie o dostęp do informacji zgromadzonych w postępowaniu antymonopolowym może następować przed wniesieniem powództwa do sądu cywilnego, w celu oceny, czy powództwo takie jest uzasadnione i czy ma szansę realizacji (może to dotyczyć zarówno powództw samoistnych, jak i następczych). W przypadku zamiaru wniesienia powództwa samoistnego droga ta może być wykorzystana dla zasięgnięcia informacji co do tego, czy przed Prezesem UOKiK toczy się postępowanie w sprawie konkretnej praktyki, do której miałoby odnosić się powództwo (i ewentualnie na jakim jest ono etapie); użyteczna dla potencjalnego powoda może być również informacja o tym, czy toczyło się (lub toczy) postępowanie wyjaśniające dotyczące praktyk na rynku/rynkach właściwych, z którymi powiązane byłoby ewentualne powództwo oraz ewentualnie, jaki był wynik takiego postępowania. W przypadku zamiaru wniesienia powództwa następczego celem odwołania się do udip będzie przede wszystkim pozyskanie informacji, które mogą być wykorzystane jako dowody w postępowaniu przed sądem powszechnym.

Należy pamiętać o tym, że dostęp do informacji publicznej na podstawie udip (jeśli za taką uznać informacje zgromadzone w aktach postępowania antymonopolowego lub wyjaśniającego) jest możliwy tylko dla osób trzecich, nie zaś dla samych stron postępowania. Może zatem zdarzyć się tak, że przedsiębiorca, przeciw któremu toczyło się postępowanie antymonopolowe, a następnie wobec którego postępowanie takie zostało umorzone (ze względu na niespełnienie przesłanek praktyki), nie uzyska dostępu do informacji zgromadzonych w postępowaniu antymonopolowym w stosunku do innych przedsiębiorców, wskutek czego - jeśli zostanie wniesione prze- 
ciw niemu powództwo z tytułu naruszenia zakazu praktyk ograniczających konkurencję - możliwość jego obrony w postępowaniu cywilnym będzie nieco osłabiona.

Dobrym prognostykiem co do możliwości wykorzystania udip jako podstawy dostępu do informacji wzmacniających powództwo cywilne wydaje się również orzecznictwo unijne odnoszące się do stosowania rozporządzenia o przejrzystości w sprawach konkurencji. W dotychczasowych orzeczeniach Sąd definiował prawo dostępu do dokumentów szeroko, nie pozwalając Komisji na swobodne stosowanie wyjątków określonych w art. 4, zwłaszcza wyjątku w postaci ochrony celu dochodzenia. Należy jednak zauważyć, że unijna regulacja o przejrzystości ma węższy zakres przedmiotowy niż polska ustawa o dostępie do informacji publicznej, jako że dotyczy dostępu do dokumentów, podczas gdy przepisy krajowe odnoszą się do dostępu do informacji (tj. kategorii obszerniejszej niż dokumenty).

\subsection{Ujawnianie dowodów między stronami}

Instytucja ujawniania dowodów - w Stanach Zjednoczonych przewidziana Federalnymi Regułami Postępowania Cywilnego (U.S. Federal Rules of Civil Procedure, reguły 26-37), w Wielkiej Brytanii Cywilnymi Regułami Proceduralnymi (Civil Procedure Rules 31.6) - daje możliwość nałożenia na strony obowiązku przedstawienia wszystkich dowodów przydatnych dla sprawy, w tym także dowodów samooskarżających, ułatwiając tym samym powodowi dowiedzenie naruszenia. Ujawnianie dowodów ma służyć właściwemu przygotowaniu się stron do procesu, przy czym w amerykańskim systemie wymiaru sprawiedliwości na etapie przedsądowym nie ma potrzeby wyszczególniania faktów i potwierdzających ich środków dowodowych, a strony mogą rozpocząć właściwy proces jedynie na podstawie ogólnego podejrzenia naruszenia $^{212}$. U podstaw instytucji ujawniania dowodów leży przekonanie, że kwestia zbierania dowodów jest kwestią odrębną od problemu ich dopuszczalności. Mechanizm ujawniania dowodów stanowi ważną zachętę, z jednej strony do występowania z pozwami, z drugiej - do zawierania ugody na etapie przedsądowym ${ }^{213}$. Teoretycznie zastosowanie mechanizmu ujawniania ma również sprzyjać obniżaniu kosztów oraz czasochłonności procesu, w praktyce procedurę disclosure ocenia się jako wysoce kosztowną214 i przy-

212 Por. D. Woods, Private Enforcement of Anitrust Rules - Modernization of EU Rules and the Road Ahead, Loyola Consumer Law Review 2004, vol. 16(4), s. 442.

213 Por. R. Grasso, The E.U. Leniency Program and U.S. Civil Discovery Rules..., s. 587.

214 Tak m.in. D. Woods, Private Enforcement..., s. 444. 
czyniającą się do długotrwałości procesów związanych z naruszeniem reguł antymonopolowych ${ }^{215}$. Procedura ujawniania dowodów na etapie przedsądowym (pretrial discovery) w sprawach antytrustowych postrzegana jest jako szczególnie ważna ze względu na fakt, że z reguły kluczowe dowody naruszenia leżą w rękach samych pozwanych ${ }^{216}$. Stanowisko to znajduje potwierdzenie również w orzecznictwie, tak amerykańskim ${ }^{217}$, jak i brytyjskim (High Court of Justice, Chancery Division, stwierdził, że „w braku satysfakcjonującej procedury ujawniania dowodów dochodzenie odszkodowań przez tych, którzy ucierpieli wskutek kartelu, staje się trudne i jednostronne [one-sided]"218).

Amerykański system discovery przewiduje cztery sposoby ujawniania dokumentów: 1) wnioski o wydanie dokumentów (document requests), 2) zapytania (interrogatories), 3) zeznania (oświadczenia) indywidualne (individual deposits) oraz 4) zeznania (oświadczenia) korporacyjne (corporate deposits). Strony same określają zakres czasowy i terytorialny wymaganych dowodów, sąd rozwiązuje dopiero ewentualne spory wynikające na tym tle, przy czym interwencje sądowe $\mathrm{w}$ zakresie mechanizmu discovery mają miejsce stosunkowo rzadko.

Wielu przedstawicieli europejskiej doktryny wyklucza możliwość wprowadzenia automatycznego i bezpośredniego ujawniania dowodów między stronami i rekomenduje, by ujawnianie odbywało się na wniosek stron lub na podstawie zarządzenia sądu ${ }^{219}$. Najprostszym i - jak się wydaje najbardziej akceptowalnym, przynajmniej w polskim porządku prawnym (ale i w innych kontynentalnych systemach prawnych) jest zatem przyjęcie rozwiązania, zgodnie z którym sąd może nakazać stronom ujawnienie nawzajem dowodów, a jednocześnie sąd posiada realną kontrolę nad procesem ujawniania dowodów. Proponowany mechanizm ujawniania dowodów powinien być - w większym stopniu niż w Stanach Zjednoczonych - „sądocentryczny”. Rozwiązanie to wydaje się lepiej odpowiadać istocie tradycyjnego procesu kontynentalnego, którym jest przedstawianie faktów (fact pleading). Takie stanowisko zajęła także Komisja, która w Białej księdze optuje za rozwiązaniem opartym na: 1) przedstawieniu faktów, 2) ścisłej kontroli sądowej zasadności roszczenia, 3) proporcjonalności wniosku

215 D. Woods, Private Enforcement..., s. 444 i cytowana tam opinia angielskiego sędziego Laddie przedstawiona w wyroku w sprawie Iberian UK Ltd. v. BPB Indus. PLC et al. [1996] C.M.L.R. 601.

216 Tak H. M. Silton, C. S. Davis, D. Levisohn, Pfleiderer AG v. Bundeskartellamt..., s. 3.

217 In re Uranium Antitrust Litig., 480 F. Supp. 1138, 1155 (N.D. III.1979).

218 National Grid Electr. Transimission Plc. v. ABB Ltd. \& Ors, [2011] EWHC (ch) 1717, [9].

219 Tak R. Stürner, Duties of Disclosure..., s. 175. 
o ujawnienie 220 . Mechanizm ujawniania dowodów zaproponowany przez Komisję został słusznie zaprojektowany jako nadzwyczajna procedura gromadzenia dowodów, stosowana w sytuacji, gdy powód przekona sąd, że nie był w stanie, przy dochowaniu należytej staranności, zdobyć niezbędnych dowodów w inny sposób (pierwszy warunek ujawnienia dowodów). Powodowie powinni przedstawić na tym etapie ogólne fakty uzasadniające roszczenia; sądy powinny zaś blokować rażąco nieuzasadnione roszczenia ${ }^{221}$. Drugim warunkiem zastosowania mechanizmu ujawniania jest przedstawienie „wszystkich faktów i środków dowodowych, do których powód przy dołożeniu należytej staranności mógł mieć dostęp, o ile uprawdopodobniają one podejrzenie, że powód poniósł szkodę wskutek naruszenia prawa ochrony konkurencji przez pozwanego"222. Komisja słusznie postuluje, że warunek ten jest spełniony wówczas, gdy wykazane zostanie, iż bez dostępu do wnioskowanych dowodów roszczenia nie będą miały szansy na zaspokojenie ${ }^{223}$. Kolejnym warunkiem efektywności mechanizmu ujawniania jest dokładne określenie kategorii dowodów, do których wymaga się dostępu (należy je określić możliwie wąsko i możliwie szczegółowo) ${ }^{224}$. Ostatnim wskazanym przez Komisję warunkiem zastosowania mechanizmu ujawnienia dowodów jest przekonanie sądu, że udostępnienie proponowanych dowodów jest odpowiednie, niezbędne i proporcjonalne, tzn. wnioskowane dowody są rzeczywiście przydatne dla realizacji roszczeń, nie jest możliwe zastosowanie innych, równie odpowiednich lub mniej obciążających środków225. Zaproponowany przez Komisję standard jest przez nią traktowany jako minimalny, niemniej jednak wydaje się on być wystarczającym.

Warto podkreślić, że w ocenie Komisji mechanizm ujawniania dowodów przewiduje dyrektywa 2004/48/WE Parlamentu Europejskiego i Rady z dnia 29 kwietnia 2004 r. w sprawie egzekwowania praw własności intelektualnej (tzw. dyrektywa enforcement) ${ }^{226}$. Artykuł 6 ust. 1 dyrektywy stanowi, że strona, która przedstawiła „należyte dowody wystarczające do poparcia jej roszczeń oraz, potwierdzające te roszczenia, wyszczególnione dowody znajdujące się pod kontrolą strony przeciwnej” może wnioskować do sądu

220 Pkt 2.2. Białej księgi.

221 Por. pkt 100-102 White Paper Staff Working Document.

222 W Zielonej księdze Komisja proponowała trzy zakresy ujawniania dokumentów: 1) ujawnienie indywidualnego dokumentu, 2) ujawnienie określonych kategorii dokumentów, 3) ujawnienie wszystkich dokumentów określonych jako właściwe dla sprawy, a zgromadzonych przez powoda na określonej liście.

223 Por. pkt 103-104 White Paper Staff Working Document.

224 Por. pkt 105-106 White Paper Staff Working Document.

225 Por. pkt 107-109 White Paper Staff Working Document.

226 Dz. Urz. UE 2004 L 157/45. 
o nakazanie przedstawienia takich dowodów stronie przeciwnej. Przedstawienie dowodów musi uwzględniać ochronę informacji poufnych. Przywołany przepis nie wymaga jednak od państw członkowskich, aby możliwość ujawniania dowodów $\mathrm{w}$ przewidzianej w nim procedurze następowała na etapie przedprocesowym. Polskie Ministerstwo Kultury i Dziedzictwa Narodowego w raporcie poświęconym wdrażaniu dyrektywy enforcement słusznie wskazuje, że art. 6 należy uznać za implementowany, ponieważ Kodeks postępowania cywilnego przewiduje możliwość zgłaszania przez strony wniosków dowodowych obejmujących dowód z dokumentu lub przedmiotów znajdujących się w posiadaniu strony przeciwnej (art. 248, 249, 293 i $308 \mathrm{kpc})^{227}$. $\mathrm{Z}$ punktu widzenia podniesienia skuteczności powoda $\mathrm{z}$ punktu widzenia postępowania dowodowego zbliżoną do ujawniania dowodów funkcję można przypisać prawu do informacji regulowanemu w art. 8 dyrektywy. Przepis przewiduje możliwość nakazania przez sąd (,w odpowiedzi na uzasadnione i proporcjonalne żądanie powoda") przedstawienia informacji dotyczących pochodzenia i dystrybucji towarów naruszających prawo własności intelektualnej. Do przedstawienia takich informacji może być zobowiązany zarówno naruszający, jak i jakakolwiek inna osoba powiązana (w sposób wskazany $\mathrm{w}$ przypisie) z przedmiotami naruszenia. Wskazane rozwiązania zostały recypowane także do prawa polskiego 228 .

Instrumentem wspomagającym mechanizm disclosure miałyby być sankcje za niszczenie dowodów lub odmowę ich ujawnienia. Sankcje mogą mieć charakter typowo procesowy i przyjąć postać oddalenia zarzutów, czy uznania twierdzeń strony przeciwnej za udowodnione; mogą one również mieć charakter prawnokarny i przyjąć postać kary pieniężnej lub pozbawienia wolności. Proponowaną przez Komisję sankcją miałoby być przyjęcie za udowodnione twierdzeń strony przeciwnej (powoda) ${ }^{229}$ - w przypadku, gdy adresatem zarządzenia o ujawnieniu dowodów jest strona). Rozwiązanie takie wydaje się wystarczające, w doktrynie postuluje się wprowadzenie (lub w niektórych porządkach prawnych - wzmocnienie) skutecznych sankcji wobec osób trzecich, na które nałożono obowiązek ujawnienia dowodów 230 .

227 Sprawozdanie z wdrożenia w Polsce dyrektywy 2004/48/WE Parlamentu Europejskiego i Rady z dnia 29 kwietnia 2004 r. w sprawie egzekwowania praw własności intelektualnej, Ministerstwo Kultury i Dziedzictwa Narodowego, Warszawa, kwiecień 2009, s. 4-5 (dostępne pod adresem: http://www.mkidn.gov.pl/media/docs/enforcement_sprawozdanie_przyjete_przez_KERM.pdf).

228 Por. pkt 6.7. niniejszego rozdziału.

229 Por. pkt 130 White Paper Staff Working Document.

230 Tak R. Stürner, Duties of Disclosure..., s. 175. 
Jeśli przyjąć, że mechanizm ujawniania byłby stosowany, to ujawnieniu powinny podlegać wszystkie rodzaje dowodów dopuszczone przez prawo. Zarządzenie o ujawnieniu sądy mogłyby kierować zarówno do stron, jak i osób trzecich (w tym organów ochrony konkurencji). Należy rozstrzygnąć, czy środki dowodowe mogą być czynnościami jedynie między stronami, czy też zawsze muszą być realizowane z udziałem sądu (np. czy przesłuchanie świadków jest możliwe również poza sądem) ${ }^{231}$ - przy założeniu sądocentrycznego mechanizmu ujawniania dowodów racjonalne wydaje się przyznanie kluczowej roli sądowi.

Co do zakresu podmiotowego zarządzenia o ujawnianiu dowodów, to w pierwszej kolejności powinno być ono kierowane do stron; nakładanie obowiązku ujawnienia dowodów na osoby trzecie powinno stanowić wyjątek i odnosić się tylko do sytuacji, gdy określony dowód nie jest w posiadaniu stron $^{232}$. Słusznie podkreśla się, że adresatom zarządzenia o ujawnieniu dokumentów musi przysługiwać prawo do wysłuchania ${ }^{233}$.

Uzasadnione - zwłaszcza w świetle twierdzeń o znaczących trudnościach dowodowych spraw antymonopolowych - wydaje się pytanie o to, czy w ramach mechanizmu ujawniania dowodów dopuszczalne jest przeszukanie (na podstawie zarządzenia sądu) pomieszczeń należących do pozwanego (instrument tego rodzaju funkcjonuje w prawie brytyjskim i znany jest jako Anton Piller order ${ }^{234}$ ). Przeciwnicy tego rozwiązania słusznie podnoszą jednak, że na instrument tego rodzaju nie ma miejsca w procesie cywilnym, którego celem - w przeciwieństwie do postępowania administracyjnego czy procesu karnego - nie jest ustalanie prawdy materialnej 235 .

\subsection{Możliwość ujawniania dowodów w polskim postępowaniu cywilnym}

\subsubsection{Zarządzanie ujawnienia dowodu przez sąd}

Na przebieg i zakres postępowania dowodowego mogą oddziaływać już czynności z zakresu przygotowania rozprawy. Artykuł 207 § 1 KPC umożliwia pozwanemu wniesienie odpowiedzi na pozew, jest to jednak uprawnienie fakultatywne, o ile wniesienie odpowiedzi (w wyznaczonym terminie) nie zostanie zarządzone przez sąd (art. $207 \S 2 \mathrm{kpc}$ ). Przed pierwszym

\footnotetext{
231 Por. pkt 111 White Paper Staff Working Document.

232 Por. pkt 124 White Paper Staff Working Document.

233 Por. pkt 127 White Paper Staff Working Document.

234 Anton Piller v. Manufctoring Processes [1979] Ch 55 (CA).

235 Tak R. Stürner, Duties of Disclosure..., s. 177.
} 
posiedzeniem przewodniczący może zobowiązać strony do wymiany pism przygotowawczych, wskazując termin i porządek składania pism, a także okoliczności podlegające wyjaśnieniu (art. 207 § 3 zd. pierwsze kpc). W toku sprawy złożenie pism przez strony jest możliwe tylko wówczas, gdy obejmuje wniosek o przeprowadzenie dowodu (art. $207 \S 3$ zd. drugie kpc). Ponadto przewodniczący przed rozprawą może, $w$ ramach zarządzenia mającego na celu przygotowanie rozprawy, zażądać na rozprawę od państwowej jednostki organizacyjnej (...) znajdujących się u niej dowodów, jeśli strona sama nie może otrzymać tych dowodów (art. $208 \S 1$ pkt 2), jak i zarządzić przedstawienie dokumentów (art. $208 \S 1$ pkt 5) ${ }^{236}$. W ten sposób sąd realizuje zasadę koncentracji materiału procesowego 237 .

Artykuł 232 zd. pierwsze kpc zobowiązuje strony do wskazania dowodów dla stwierdzenia faktów, z których wywodzone są skutki prawne. Jeśli strona wskazuje środek dowodowy, ale nim nie dysponuje, sąd może wydać postanowienie o przeprowadzeniu dowodu i zażądać przedstawienia go przez tego, kto nim dysponuje. Zarządzenie ujawnienia dowodu przez sąd może odbyć się z urzędu lub na wniosek strony (np. zawarty w pozwie - por. art. $187 \S 2$ pkt 3). Zarządzenie sądu może być wydane także wówczas, gdy strona powołuje się w pozwie na dowód z dokumentu (art. 129 KPC zobowiązuje ją do złożenia oryginału dokumentu), a dokumentu tego nie składa ${ }^{238}$.

Artykuł $248 \S 1 \mathrm{kpc}$ nakłada na „każdego” obowiązek przedstawienia „na zarządzenie sądu w oznaczonym terminie i miejscu dokumentu znajdującego się w jego posiadaniu i stanowiącego dowód faktu istotnego dla rozstrzygnięcie sprawy, chyba że dokument ten zawiera informacje niejawne" (za informacje niejawne należy uznać informacje w rozumieniu ustawy z dnia 5 sierpnia 2010 r. o ochronie informacji niejawnych ${ }^{239}$ ). Należy przyjąć, że przepis ten dotyczy dokumentów „wszelkiego rodzaju" 240 , przede wszystkim oryginałów, a w przypadku ich zaginięcia lub zniszczenia - także ich odpisów241. Przedstawienie dokumentu nie może ograniczać się jedynie do przedstawienia dokumentu sądowi do wglądu ${ }^{242}$;

236 T. Ereciński, J. Gudowski, M. Jędrzejewska, [w:] T. Ereciński (red.), Kodeks postępowania cywilnego. Komentarz. Tom 1, LexisNexis, Warszawa 2007, s. 585.

237 P. Telenga, [w:] A. Jakubecki (red.). Kodeks Postępowania Cywilnego..., s. 319.

238 Por. wyrok SN z dnia 3 października 2008 r., I CSK 62/08, LEX nr 470020.

239 Dz. U. Nr 182, poz. 1228.

240 T. Ereciński, J. Gudowski, M. Jędrzejewska, [w:] T. Ereciński (red.), Kodeks postępowania cywilnego..., s. 585.

241 T. Demendecki, [w:] A. Jakubecki (red.). Kodeks Postępowania Cywilnego..., s. 373.

242 Orzeczenie SN z dnia 26 czerwca 1963 r., II PR 282/62, RPEiS 1964, nr 3. 
nie zapewnia to bowiem „warunków należytego zapoznania się z dokumentami przez sąd" 243 .

Jak podkreśla się w literaturze, „przepis ten [art. $248 \S 1$ - przyp. aut.] nie może stanowić podstawy do zobowiązania na wniosek strony jej przeciwnika czy innego podmiotu do wytworzenia dokumentu, zrobienia zestawienia pewnych informacji bądź też do poszukiwania bliżej niesprecyzowanych dokumentów, które mogłyby ewentualnie zostać wykorzystane w procesie"244. Można natomiast na tej podstawie żądać wydania dokumentu, o którego istnieniu wiadomo np. $\mathrm{z}$ uprzedniej decyzji organu ochrony konkurencji. Uprawnienia powoda i pozwanego są w tym zakresie symetryczne, co stanowi konsekwencję zasady równości stron ${ }^{245}$.

W doktrynie podkreśla się, że obowiązek przedstawienia dokumentu ciąży na różnorodnych podmiotach, w tym stronach postępowania, świadkach, interwenientach, innych podmiotach niezwiązanych z procesem, w tym państwowych i samorządowych jednostkach organizacyjnych ${ }^{246}$. Wskazany w przepisie szeroki (w zasadzie nieograniczony) zakres podmiotowy tego obowiązku uprawnia do stwierdzenia, że obowiązek ten może być nałożony także na organy administracji publicznej247, w tym Prezesa UOKiK oraz na organy międzynarodowe (Komisja Europejska). Obowiązek przedstawienia dowodu nałożony na organ administracji ma charakter bezwarunkowy w tym sensie, że trudno wyobrazić sobie, aby znalazł zastosowanie art. 248 $\S 2$ kpc przewidujący wyłączenia od tego obowiązku. Od przedstawienia dowodu może uchylić się osoba, która występując w roli świadka byłaby uprawniona do odmowy zeznań na okoliczność objętą treścią dokumentu albo osoba, która posiada dokument $\mathrm{w}$ imieniu osoby trzej, która $\mathrm{z}$ tych samych powodów mogłaby przeciwstawić się przedstawieniu dokumentu. Prawo uchylenia się od przedstawienia dokumentu nie istnieje jednak wtedy, gdy dokument wystawiony jest $w$ interesie strony żądającej przeprowadzenia dowodu 248 lub gdy posiadacz dokumentu bądź osoba trzecia zobowiązani są do tego przedstawienia względem co najmniej jednej ze stron (art. 248 $\S 2$ zd. drugie kpc). Odmowa przedstawienia dokumentu nie może być

243 T. Ereciński, J. Gudowski, M. Jędrzejewska, [w:] T. Ereciński (red.), Kodeks postępowania cywilnego..., s. 586.

244 M. Sieńko, [w:] M. Manowska (red.), Kodeks postępowania cywilnego..., s. 526.

245 K. Knoppek, [w:] H. Dolecki, T. Wiśniewski (red.), Kodeks postępowania cywilnego..., s. 886.

246 Tak M. Sieńko, [w:] M. Manowska (red.), Kodeks postępowania cywilnego..., s. 501.

247 Tak T. Ereciński, J. Gudowski, M. Jędrzejewska, [w:] T. Ereciński (red.), Kodeks postępowania cywilnego..., s. 585.

248 Ibidem, s. 586. 
jednak uzasadniona ryzykiem przegrania jakiegokolwiek ${ }^{249}$ (niekoniecznie tego, który akurat się toczy ${ }^{250}$ ) procesu ${ }^{251}$; jest to zatem odstępstwo od zasady, że nikt nie jest obowiązany przedstawiać dowodów samooskarżających (nemo contra se edere tenetur) ${ }^{252}$.

Skutkiem nieuzasadnionej odmowy przedstawienia dokumentu przez osobę trzecią będzie skazanie takiej osoby na grzywnę (art. $251 \mathrm{kpc}$ ), natomiast skutki odmowy przedstawienia dowodu przez stronę będą dopiero podlegać ocenie sądu (art. $233 \S 2 \mathrm{kpc}$ ). Ocena ta powinna być dokonana według tych samych zasad, które wyznaczają granice swobodnej oceny dowodów, tj. wymogi prawa procesowego, doświadczenie życiowe, reguły logicznego myślenia oraz pewien poziom świadomości prawnej, która pozwala sądowi na rozważenie materiału dowodowego w sposób bezstronny, racjonalny i wszechstronny ${ }^{253}$. W literaturze wskazuje się, że „strona, której przeciwnik odmówi przedstawienia dowodu lub uniemożliwi jego przeprowadzenie, nie jest bezsilna, ponieważ może wykorzystać inne środki będące w jej dyspozycji, np. art. $231 \mathrm{kpc} " 254$. Wzmiankowany przepis odnosi się do domniemań faktycznych i stanowi, że sąd może uznać za ustalone fakty mające istotne znaczenie dla rozstrzygnięcia sprawy, jeśli wniosek taki można wyprowadzić $\mathrm{z}$ innych ustalonych faktów. Za fakty istotne dla rozstrzygnięcia sprawy uznaje się przede wszystkim fakty opisane w hipotezach norm prawa materialnego 255 .

Ujawnienie dowodu na podstawie zarządzenia sądu może w wielu wypadkach istotnie przyczynić się do dowiedzenia naruszenia zakazów praktyk ograniczających konkurencję, jak również ewentualnej szkody wynikłej z naruszenia. Również Trybunał Sprawiedliwości zaakcentował konieczność zastosowania przez sąd krajowy „wszelkich środków proceduralnych przysługujących mu zgodnie z prawem krajowym, wśród których figuruje zarządzenie koniecznych środków dowodowych, w tym przedłożenie okre-

249 T. Demendecki, [w:] A. Jakubecki (red.). Kodeks Postępowania Cywilnego..., s. 374.

250 Tak K. Flaga-Gieruszyńska, [w:] A. Zieliński (red.), Kodeks Postępowania Cywilnego..., s. 440.

251 M. Sieńko, [w:] M. Manowska (red.), Kodeks postępowania cywilnego..., s. 526.

252 Tak T. Ereciński, J. Gudowski, M. Jędrzejewska, [w:] T. Ereciński (red.), Kodeks postępowania cywilnego..., s. 586; K. Knoppek, [w:] H. Dolecki, T. Wiśniewski (red.), Kodeks postępowania cywilnego..., s. 887.

253 Por. T. Demendecki, [w:] A. Jakubecki (red.). Kodeks Postępowania Cywilnego..., s. 350 oraz przywołane przez tego autora bogate orzecznictwo.

254 H. Dolecki, Postępowanie cywilne. Zarys wyktadu, wyd. 3, LexisNexis, Warszawa 2007, s. $184-185$.

255 Tak m.in. H. Dolecki, [w:] H. Dolecki, T. Wiśniewski (red.), Kodeks postępowania cywilnego..., s. 814 . 
ślonych dokumentów przez jedną ze stron lub osobę trzecią”, jeśli miałoby to zapewnić skuteczność prawa unijnego ${ }^{256}$.

W polskiej doktrynie wyrażony został pogląd, że - ze względu na art. 73 ust. 1 uokik - polski sąd nie może nakazać Prezesowi UOKiK udostępnienia dokumentów zebranych w postępowaniu antymonopolowym, a gdyby strona wnioskowała o odpowiednie zarządzenie sądu, wniosek taki powinien zostać oddalony ${ }^{257}$. Ci sami autorzy, którzy wyrazili przytoczony pogląd, rozważają jednocześnie możliwość wnioskowania (na podstawie art. 187 § 2 pt $3 \mathrm{kpc}$ ) przez powoda o przedstawienie przez pozwanego jego oświadczenia leniency, słusznie wskazując przy tym, że sąd nie jest związany wnioskami tego rodzaju i do jego uznania pozostaje decyzja co do obowiązku ujawnienia takiego dowodu 258 . Oświadczenie leniency stanowi co prawda informację zebraną w toku postępowania (o której mowa w at. 73 ust. 1 uokik), jednak jako informacja dobrowolnie dostarczana przez przedsiębiorcę pozostaje ona również w dyspozycji samego podmiotu prywatnego.

\subsubsection{Dopuszczanie dowodów z urzędu}

Polskie postępowanie cywilne nie zna procedury discovery w jej amerykańskim wydaniu. Realizacja prywatnego egzekwowania prawa konkurencji wymaga rozważań nad tym, w jaki sposób strony - przede wszystkim powód - mogą uzyskać dostęp do dowodów gwarantujących im powodzenie $\mathrm{w}$ procesie. Jednym z rozwiązań może być prawo przeprowadzania przez sąd dowodów nie wskazanych przez stronę, stanowiące uzupełnienie zasady kontradyktoryjności ${ }^{259}$. Kodeks postępowania cywilnego daje jednak sądowi możliwość dopuszczenia dowodów nie wskazanych przez stronę (art. 232 zd. drugie), uprawnienie to dotyczy wszystkich środków dowodowych ${ }^{260}$ - dowodami takimi (o statusie dowodów z dokumentu) mogłyby być przynajmniej hipotetycznie 261 - akta postępowania przed organem ochrony

256 Wyrok TS z dnia 7 września 2006 r., C-526/04 Laboratoires Boiron SA przeciwko Urssaf (Zb. Orz. 2006, s. I-07529), pkt 55.

257 Tak E. Rumak, P. Sitarek, Polish Leniency Programme..., s. 112.

258 Ibidem, s. 114.

259 Por. H. Dolecki, Postępowanie cywilne..., s. 55-56.

260 T. Ereciński, J. Gudowski, M. Jędrzejewska, [w:] T. Ereciński (red.), Kodeks postępowania cywilnego..., s. 551; T. Demendecki, [w:] A. Jakubecki (red.). Kodeks Postepowania Cywilnego..., s. 349; M. Sieńko, [w:] M. Manowska (red.), Kodeks postępowania cywilnego..., s. 500. Por. wyroki SN: z dnia 7 października 1998 r., II UKN 246/98, OSNAPiUS 1999 nr 20, poz. 660; z dnia 24 listopada 1999 r., I CKN 223/98, Wokanda 2000, nr 3, s. 7.

261 Hipotetyczność ta podyktowana jest treścią art. 73 ust. 1 uokik. 
konkurencji (Prezes UOKiK lub Komisja). Według niektórych autorów ratio legis tego przepisu pozostaje dążenie przez sądy do wykrycia przez nie prawdy obiektywnej262, choć w doktrynie wyrażony został również pogląd, że obecnie (po zmianach kpc ustawą z dnia 2 lipca 2004 r.) „trudno uzasadniać działanie sądu z urzędu ustawowym obowiązkiem wykrycia prawdy w procesie"263.

Analogiczne regulacje umożliwiające sądom nakazanie udostępnienia dowodów funkcjonują w wielu porządkach prawnych, np. we Francji (art. 10, 11, 138-142 i 145 Kodeksu postępowania cywilnego) i we Włoszech (art. 115 i 20 Kodeksu postępowania cywilnego).

Dopuszczenie dowodów z urzędu jest co do zasady „wspierającym uprawnieniem sądu"264, a nie jego obowiązkiem ${ }^{265}$. Orzecznictwo stoi przy tym na stanowisku, że dopuszczenie dowodu niewskazanego przez stronę może być incydentalnie traktowane jako obowiązek, aczkolwiek „tylko w wyjątkowych wypadkach, mogących być przyczyną nieprawidłowego rozstrzygnięcia sprawy, podważającego funkcję procesu" (III CSK 30/11266).

Dopuszczenie $\mathrm{z}$ urzędu dowodów, które umożliwiłyby sprawdzenie prawdziwości faktów przedstawionych przez wnioskodawcę, może być uzasadnione powzięciem przez sąd wątpliwości co do wiarygodności przedstawionych przez stronę dowodów ${ }^{267}$. Dopuszczenie dowodów z urzędu nie może mieć na celu zapewnienia równości stron postępowania ${ }^{268}$.

W polskiej doktrynie dominuje pogląd o nadzwyczajnym charakterze tego przepisu, co oznacza, że art. 232 zd. drugie kpc powinien być stosowany

262 Tak T. Demendecki, [w:] A. Jakubecki (red.). Kodeks Postępowania Cywilnego..., s. 348.

263 T. Ereciński, J. Gudowski, M. Jędrzejewska, [w:] T. Ereciński, Kodeks postępowania cywilnego..., s. 548.

264 K. Flaga-Gieruszyńska, [w:] A. Zieliński (red.), Kodeks Postępowania Cywilnego..., s. 415. Por. także T. Ereciński, J. Gudowski, M. Jędrzejewska, [w:] T. Ereciński (red.), Kodeks postępowania cywilnego..., s. 548. Według P. Rylskiego o dyskrecjonalności dopuszczania dowodów z urzędu świadczy okoliczność, że art. 232 zd. 2 nie wskazuje żadnych przesłanek do skorzystania przez sąd z tego uprawnienia - P. Rylski, Działanie sadu..., s. 348.

265 Por. uchwała SN z dnia 19 maja 2000 r., III CZP 4/00, OSNC 2000, nr 11, poz. 195; wyrok SN z dnia 11 lipca 2001 r., V CKN 406/00, Prok. i Pr. Nr 4/2002. Por. także wyrok SN z dnia 17 kwietnia 2008 r., I CSK 79/08.

266 Wyrok SN z dnia 17 listopada 2011 r., III CSK 30/11. Por. także uchwała SN (7) z 19 maja 2000 r., III CZP 4/00, OSNC Nr 11/2000, poz. 195; wyroki Sądu Najwyższego z dnia 15 stycznia 2010 r., I CSK 199/09, niepubl.; z dnia 11 stycznia 2011 r., I PK 152/10, niepubl.; z dnia 15 czerwca 2011 r., V CSK 382/10, niepubl. i postanowienie z dnia 12 maja 2011 r., III CSK 238/10, niepubl.

267 Por. wyrok SN z 6.12.2000 r., II UKN 118/00, OSNP Nr 15/2002, poz. 363.

268 Por. wyrok SN z dnia 15 grudnia 2005 r., V CK 400/05, OSP 2006, nr 11, poz. 127, z glosą P. Rylskiego; wyrok SN z dnia 19 kwietnia 2007 r., I CSK 27/07, Biuletyn SN 2007, nr 11. 
tylko wówczas, ,jeśli przemawiają za tym szczególne względy”269, „w minimalnym zakresie”, a „sąd w zasadzie nie powinien dopuszczać dowodów z urzędu" 270; z drugiej strony jest to czynność sądu postrzegana jako „uzupełniająca w stosunku do aktywności stron”271. „Sąd powinien traktować zawsze dopuszczenie dowodu z urzędu jako środek ostateczny, jeśli nie może w inny sposób przeciwstawić się niebezpieczeństwu nieprawidłowego rozstrzygnięcia sprawy"272. Aktywność sądu przewidziana w art. 232 kpc może być bowiem postrzegana jako „przekreślenie zasady kontradyktoryjności procesu cywilnego" 273 . Co do takiego stanowiska nie ma jednak zgody nawet w samym orzecznictwie, gdzie z jednej strony formułowany jest pogląd, że stosowanie art. $232 \mathrm{zd} .2 \mathrm{kpc}$ może stanowić „naruszenie prawa do bezstronnego sądu i odpowiadającemu mu obowiązku przestrzegania zasady równego traktowania stron” 274 , z drugiej zaś - SN wyraził m.in. pogląd, że „dopuszczenie dowodu z urzędu nie może być uznane za działanie naruszające zasady bezstronności i równości stron” (IV CK 24/03275); podobne stanowisko SN zajął w wyroku I CK 81/02276, wydanym w związku z ustawą o przeciwdziałaniu praktykom monopolistycznym z 1990 r., gdzie Sąd stwierdził: „oczywiście zachowanie zasady kontradyktoryjności ma charakter wiodący, wszakże możliwość dopuszczenia przez sąd dowodów nie wskazanych przez strony winna być szerzej ujmowana zwłaszcza w sytuacji, gdy brak jest ustaleń w przedmiocie przesłanki, której istnienie warunkuje

269 Tak M. Sieńko, [w:] M. Manowska (red.), Kodeks postępowania cywilnego..., s. 498.

270 Tak K. Flaga-Gieruszyńska, [w:] A. Zieliński (red.), Kodeks Postępowania Cywilnego..., s. 415. Por. także T. Demendecki, [w:] A. Jakubecki (red.). Kodeks Postępowania Cywilnego..., s. 348.

271 Tak H. Dolecki, [w:] H. Dolecki, T. Wiśniewski (red.), Kodeks postępowania cywilnego..., s. 831.

272 T. Ereciński, J. Gudowski, M. Jędrzejewska, [w:] T. Ereciński, Kodeks postępowania cywilnego..., s. 548.

273 K. Piasecki, [w:] K. Piasecki (red.), Kodeks Postępowania Cywilnego. Komentarz do art. 1-366. Tom 1, wyd. 5, C. H. Beck, Warszawa 2010, s. 1300. Por. także K. Flaga-Gieruszyńska, [w:] A. Zieliński (red.), Kodeks Postępowania Cywilnego..., s. 415.

274 Wyrok SN z dnia 12 grudnia 2000 r., V CKN 175/00, OSP 2001 Nr 7-8, poz. 116 z aprobującą glosą W. Broniewicza oraz z częściowo krytyczną glosą C. Gromadzkiego, Przegląd Sądowy 2003, nr 3, s. 141. Por. także wyrok SN z dnia 3 kwietnia 2003 r., II PK 223/02, Lex nr 190750.

275 Wyrok SN z dnia 13 lutego 2004 r., IV CK 24/03, OSNC 2004, nr 3, poz. 45 z glosami: B. Wojciechowskiego i Palestra 2005, nr 3-4, s. 280 i P. Rylskiego, Przegląd Sądowy 2005 nr 10, s. 135. Krytycznie o tym stanowisku SN m.in. T. Ereciński, J. Gudowski, M. Jędrzejewska, [w:] T. Ereciński (red.), Kodeks postępowania cywilnego..., s. 547-548. Zwolennikiem tego stanowiska jest natomiast H. Dolecki, [w:] H. Dolecki, T. Wiśniewski (red.), Kodeks postępowania cywilnego..., s. 831.

276 Wyrok SN z dnia 18 września 2003 r., I CK 81/02. 
dokonanie oceny, czy zastosowanie danej normy prawa materialnego było w okolicznościach faktycznych sprawy uzasadnione, czy też normę tę zastosowano niewłaściwie. W przeciwnym razie dokonanie tej oceny nie jest możliwe". W doktrynie wyraża się jednak również pogląd, że obok zasady kontradyktoryjności konieczne jest uwzględnianie także zasady materialnego kierownictwa sądu, a „uprawnienie do wykorzystywania inicjatywy dowodowej przysługującej sądowi, może być wykorzystywane również wtedy, gdy ma na celu wywiązanie się z obowiązku (ciążącego wszak nadal na sądzie) wszechstronnego rozważenia materiału procesowego (art. $233 \S 1$ )"277.

Czynności sądu, jakie mogą być podjęte na podstawie art. $232 \mathrm{zd} .2$, określa się również jako subsydiarne - mogą one być podjęte, „gdy inne działania zmierzające do pobudzenia aktywności stron przez właściwe pouczenia (art. 5, art. 212) czy zobowiązania (art. 207) nie przyniosą właściwego rezultatu"278.

Niemniej jednak w orzecznictwie można także zidentyfikować stanowisko, w myśl którego ustanowione w art. 232 zd. 2 kpc dyskrecjonalne co do zasady uprawnienie sądu może być realizowane $\mathrm{z}$ inspiracji stron i podlegać ich pewnemu wpływowi - SN stwierdził mianowicie, że strona może powołać się na to, ,że zaistniały w sprawie podstawy do podjęcia takiego działania, z tej racji, że sama została pozbawiona takiej możliwości, a ponadto przemawiał za nim charakter sprawy obejmujący również element interesu publicznego oraz dotyczący problemu szerszego grona osób i trudności w określeniu wysokości szkody" (II CSK 602/09279). Również w literaturze można odnaleźć poglądy przemawiające za obowiązkiem działania sądu $\mathrm{z}$ urzędu w sytuacjach, gdy chodzi o interes publiczny ${ }^{280}$.

Wiele spraw, w których rozpatrywane byłyby roszczenia $\mathrm{z}$ tytułu naruszenia zakazów praktyk ograniczających konkurencję, miałoby szansę spełnić wymienione w wyżej przytoczonym wyroku przesłanki, łącznie z przesłanką „interesu publicznego", która w tym wypadku powinna być rozumiana w ten sposób, że roszczenie oparte jest jednak na naruszeniu przepisu ustawy wchodzącej w zakres prawa gospodarczego publicznego.

277 Tak C. Gromadzki, Glosa do wyroku z dnia 12 grudnia 2000 r. (V CKN 175/00), PS 2003, nr 3, s. 154.

278 Tak M. Sieńko, [w:] M. Manowska (red.), Kodeks postępowania cywilnego..., s. 498. Tak również: T. Ereciński, J. Gudowski, M. Jędrzejewska, [w:] T. Ereciński (red.), Kodeks postępowania cywilnego..., s. 548.

279 Wyrok SN z dnia 6 maja 2010 r., II CSK 602/09, LEX nr 585768.

280 Tak A. Jakubecki, Kontradyktoryjność a poznanie prawdy w procesie cywilnym $w$ świetle zmian Kodeksu postępowania cywilnego, PS 1998, nr 10, s. 68. 
Jednak „wyręczanie” przez sąd strony, która mimo istniejących możliwości nie zawnioskowała o określony dowód, może być postrzegane jako uchybienie procesowe ${ }^{281}$. Oczywiście, jeśli strona wnioskowała o dopuszczenie jakiegoś dowodu, wyklucza to inicjatywę sądu co do tego samego dowodu 282 .

Słusznym jest stanowisko nakazujące uwzględnianie przy dopuszczaniu z urzędu zasady ne eat iudex ultra petita partium (art. $321 \S 1 \mathrm{kpc}$ ) i zakazujące jednocześnie wychodzenia poza granice żądania stron, a także wychodzenia „poza krąg okoliczności faktycznych uzasadniających żądanie wysunięte przez stronę" 283 . H. Dolecki podkreśla, że w związku z tym, że $\mathrm{w}$ dowodzeniu faktów, działanie sądu $\mathrm{z}$ urzędu jest istotnie ograniczone, strony powinny, także w sprawach $\mathrm{z}$ art. $322 \mathrm{kpc}$, przedstawiać dowody wykazujące wysokość szkody oraz informować sąd o trudnościach lub braku możliwości wskazania odpowiedniego środka dowodowego. Wcześniejsze orzekanie przez sąd o wysokości szkody na podstawie własnej oceny naruszałoby zasadę równości stron ${ }^{284 "}$.

Do niedawna dodatkowym praktycznym problemem ewentualnego wykorzystania art. 232 zd. $2 \mathrm{kpc}$ w sprawach z zakresu naruszenia zakazów praktyk ograniczających konkurencję mogło być to, czy dopuszczenie dowodu ex officio może mieć miejsce w sprawach gospodarczych, gdzie obowiązywał system prekluzji dowodowej. Stanowisko doktryny w kwestii dopuszczalności dowodów z urzędu w postępowaniach z prekluzyjnym systemem dowodów było niejednolite, choć jak się wydaje przeważająca część doktryny opowiadała się za możliwością inicjatywy dowodowej z urzędu także w takich postępowaniach ${ }^{285}$, taki pogląd wyraził również Sąd Najwyższy 286 . Niemniej

281 Tak m.in. P. Rylski, Działanie sądu..., s. 349, M. Sieńko, [w:] M. Manowska (red.), Kodeks postęowania cywilnego..., s. 499; autorzy ci zastrzegają jednak, że sytuacje takie są wyjątkowe. Por. także H. Dolecki, [w:] H. Dolecki, T. Wiśniewski (red.), Kodeks postępowania cywilnego..., s. 834. Por. także wyroki SN: z dnia 25 marca 1998 r., II CKN 656/97, OSNC 1998, nr 12, poz. 208; z dnia 22 lutego 2006 r., III CK 341/05, Lex nr 182886; z dnia 20 grudnia 2005 r., III CK 121/05, niepubl.

282 Por. wyrok SN z dnia 17 listopada 2011 r., III CSK 30/11.

283 T. Ereciński, J. Gudowski, M. Jędrzejewska, [w:] T. Ereciński (red.), Kodeks postępowania cywilnego..., s. 548.

284 Tak H. Dolecki, [w:] H. Dolecki, T. Wiśniewski (red.), Kodeks postępowania cywilnego..., s. 833. Por. wyrok SN z dnia 4 października 2007 r., V CSK 188/07, Lex nr 485901.

285 Por. P. Rylski, Działanie sądu..., s. 352; J. Akińcza, Dopuszczalność dowodzenia z urzędu w zwiazku z wystapieniem prekluzji dowodowej, Glosa 2007, nr 4, s. 3; M. A. Quoos, Ograniczenia dotyczace powolywania twierdzeń, zarzutów i dowodów na gruncie systemu prekluzji w procesie cywilnym (cz. 2), Palestra 2007, nr 1-2, s. 50; H. Dolecki, [w:] H. Dolecki, T. Wiśniewski (red.), Kodeks postępowania cywilnego..., s. 837.

286 Por. wyrok SN z dnia 22 lutego 2006 r., III CK 341/05, OSNC 2006, Nr 10, poz. 174; wyrok SN z dnia 23 października 2007 r., IIII CSK 107/08, niepubl. 
jednak w postępowaniu odrębnym w sprawach gospodarczych jako postępowaniu, w ramach którego potencjalne może następować dochodzenie roszczeń z tytułu naruszenia zakazów praktyk ograniczających konkurencję, art. $47914 \mathrm{~b}$ wprost wyłączał dopuszczenie $\mathrm{z}$ urzędu dowodu z przesłuchania stron, co należy odczytywać jako możliwość dopuszczenia ex officio innych dowodów 287.

Osobiście postrzegam omawiany przepis (art. 232 zd. 2) jako wystarczające $-\mathrm{z}$ formalnego punktu widzenia - narzędzie do ujawniania dowodów, jednak możliwość korzystania $\mathrm{z}$ niego wymagałaby rewolucyjnej zmiany mentalnościowej w postrzeganiu tego przepisu i uczynienia zeń narzędzia standardowego zamiast nadzwyczajnego. Rewolucję tego rodzaju oceniam jako mało prawdopodobną, konieczna wydaje się jednak inspiracja ustawodawcy. Pewną słabością mogłoby również być to, że licząc na inicjatywy sądu z urzędu, strony mogą popadać w swoisty „oportunizm dowodowy”, w doktrynie dominuje jednak stanowisko, że „brak dbałości o własne sprawy i świadome niewykonywanie obowiązków procesowych" 288 wykluczają działanie sądu z urzędu; sąd nie jest zobowiązany do zastąpienia własnym działaniem bezczynności strony 289 . W literaturze można jednak spotkać pogląd, że „rozważenie potrzeby dopuszczenia z urzędu środków dowodowych może być wskazane w sprawach, w których przedmiotem jest (...) naprawienie szkody wyrządzonej czynem niedozwolonym" 290 .

\subsection{Prawo do informacji w polskim prawie własności przemysłowej i prawie autorskim - wzorzec dla prywatnego egzekwowania zakazów praktyk ograniczających konkurencję?}

Podobnie jak ma to miejsce w sprawach z zakresu ochrony praw własności intelektualnej, tak i w sprawach z zakresu ochrony konkurencji poszkodowany często nie dysponuje pełną wiedzą o rzeczywistych rozmiarach i skutkach naruszenia. Przydatne, a nawet konieczne, jest więc wyposaże-

287 Tak: P. Rylski, Działanie sądu..., s. 323. Za dopuszczalnością z urzędu dowodu, który uległ sprekludowaniu opowiada się również m.in. M. Sieńko, [w:] M. Manowska (red.), Kodeks postępowania cywilnego..., s. 501.

288 M. Sieńko, [w:] M. Manowska (red.), Kodeks postępowania cywilnego..., s. 499.

289 T. Ereciński, J. Gudowski, M. Jędrzejewska, [w:] T. Ereciński (red.), Kodeks postępowania cywilnego..., s. 549. Por. także wyrok SN z dnia 7 listopada 1997 r., III CKN 244/07, OSNC 1998, nr 3, poz. 52.

290 T. Ereciński, J. Gudowski, M. Jędrzejewska, [w:] T. Ereciński (red.), Kodeks postępowania cywilnego..., s. 548. 
nie poszkodowanych w możliwość pozyskania pewnego zasobu informacji pozwalających na określenie skali naruszenia, w konsekwencji „oznaczenie wartości przedmiotu sporu, które stanowi wstępny warunek formalny złożenia pozwu"291. W piśmiennictwie podkreśla się, że niewystarczające są w tym względzie przepisy art. $189 \mathrm{kpc}$ czy art. $460 \mathrm{kc}^{292}$.

Obowiązek implementacji do prawa krajowego dyrektywy 2004/48/WE dotyczącej wdrażania praw własności intelektualnej spowodował konieczność wprowadzenia - w przypadku ustawy Prawo własności przemysłowej293 (dalej upwp) - oraz modyfikacji - w przypadku ustawy Prawo autorskie 294 (dalej upa) - środka prawnego w postaci wniosku o udzielenie informacji $\mathrm{i} /$ lub udostępnienie dokumentacji (wniosek taki określany jest w literaturze także jako „roszczenie informacyjne”, czy bardziej ogólnie - „prawo do informacji”). Wnioski te mogą być wnoszone do sądów przed wytoczeniem powództwa, a ich celem jest stworzenie warunków do przygotowania przyszłego procesu ${ }^{295}$, nie zaś zgromadzenie dowodów ${ }^{296}$. W doktrynie podkreśla się unikatowy charakter tego środka prawnego, związany z tym, że roszczenie informacyjne stanowi „poważny wyłom w zasadzie obciążającej stronę powodową ciężarem dowodu”; dodatkowo realizacja tego roszczenia „przełamuje procesową zasadę, że strona postępowania nie jest obowiązana dostarczać dowodów przeciwko sobie"297.

Roszczenie o udzielenie informacji przewidziane w art. $286^{1}$ upwp ma stanowić „środek pomocny w ustalaniu faktów dotyczących odpowiedzialności cywilnoprawnej za naruszenie praw własności przemysłowej”298. Na podstawie art. $286^{1}$ ust. 1 pkt 2 i pkt 3 upwp osoby uprawnione z patentu,

291 A. Kołodziej, Roszczenie informacyjne w prawie wtasności intelektualnej, [w:] E. Nowińska, M. du Vall (red.), Ksiega pamiatkowa ku czci Profesora Janusza Szwaji, ZNUJ-PIPWI UJ 2004, z. 88, s. 146.

292 Jednocześnie nie brakuje krytycznych ocen tego roszczenia - por. m.in. R. Skubisz, Roszczenie o udzielenie informacji w prawie wtasności przemystowej ( $w$ świetle dyrektywy nr 2004/48 i prawa polskiego), [w:] J. Gudowski, K. Weitz (red.), „Aurea praxis, aurea theoria”. Księga pamiątkowa ku czci Profesora Tadeusza Erecińskiego. Tom 2, LexisNexis, Warszawa 2011, s. 2535 i n.

293 Ustawa z dnia 30 czerwca 2000 r. Prawo własności przemysłowej (tekst jedn. Dz. U. z 2003 r. Nr 119, poz. 1117 ze zm.).

294 Ustawa z dnia 4 lutego 1994 r. Prawo autorskie (tekst jedn. Dz. U. z 2006 r. Nr 90, poz. 631 ze zm.).

295 P. Podrecki, Środki ochrony praw wtasności intelektualnej, LexisNexis, Warszawa 2010, s. 538.

296 Ibidem, s. 539.

297 A. Nowak-Gruca, Roszczenie informacyjne w ustawie - Prawo wtasności przemystowej $w$ świetle ekonomicznej analizy prawa, MoP 2008, nr 15.

298 P. Podrecki, Środki ochrony..., s. 506. 
dodatkowego prawa ochronnego, prawa ochronnego lub prawa $\mathrm{z}$ rejestracji, a także osoby, którym „ustawa na to zezwala”, mogą wnioskować do sądu o zobowiązanie naruszającego, a także osoby innej niż naruszający, do udzielenia informacji, które są niezbędne do dochodzenia roszczeń przewidzianych w art. 297 ust. 1 i 296 ust. 1 upwp. Osobą zobowiązaną do udzielenia informacji (inną niż naruszający) może być osoba posiadająca towary naruszające prawo własności przemysłowej, osoba świadcząca usługi wykorzystywane w działaniach naruszających lub korzystająca z usług naruszających prawo, a także osoba wskazana przez osoby wyżej wymienione jako osoba uczestnicząca w produkcji, wytwarzaniu, dystrybucji towarów lub świadczeniu usług naruszających prawa własności intelektualnej (art. $286^{1}$ ust. 1 pkt 3 lit. a-d upwp), jeśli działania te mają na celu uzyskanie bezpośrednio lub pośrednio zysku lub innej korzyści ekonomicznej (przy czym osobami tymi nie są konsumenci działający w dobrej wierze).

Informacje mają dotyczyć pochodzenia oraz sieci dystrybucji towarów lub usług naruszających określone prawa własności przemysłowej, a ich przedmiotem mogą być nazwy firm i adresy podmiotów mających styczność $\mathrm{z}$ towarami lub usługami stanowiącymi przedmiot naruszenia oraz ilość wyprodukowanych, wytworzonych, zbytych, otrzymanych lub zamówionych towarów naruszających prawo własności przemysłowej (art. $286^{1}$ ust. 1 pkt 2 i 3 oraz art. $286^{1}$ ust. 2). Dodatkową przesłanką korzystania z prawa do informacji (bez względu na osobę zobowiązaną do udzielenia informacji) jest wysokie prawdopodobieństwo naruszenia praw własności intelektualnej.

Ustawodawca zdecydowat, że prawo do informacji przewidziane w art. $286^{1}$ upwp stanowi formę zabezpieczenia roszczeń, o czym świadczy samo sformułowanie ustawy (zabezpieczenie roszczeń przez zobowiązanie do udzielenia informacji). P. Podrecki uważa, że rozwiązanie to powoduje istotne trudności interpretacyjne przede wszystkim w odniesieniu do relacji omawianego przepisu do ogólnej regulacji zabezpieczenia roszczeń w Kodeksie postępowania administracyjnego ${ }^{299}$. Autor ten proponuje, aby roszczenie informacyjne traktować jako zabezpieczenie roszczeń jedynie formalne, uznając, że w rzeczywistości nie pełni ono takich funkcji300, co w konsekwencji prowadzi do wniosku, że środek prawny w postaci prawa do żądania informacji jest niezależny od zabezpieczenia roszczeń ${ }^{301}$.

Wniosek o udzielenie informacji przewidziany jest również w art. 80 ustawy Prawo autorskie (upa). Konstrukcja tego wniosku w prawie autor-

\footnotetext{
299 Ibidem, s. 506.

300 Ibidem, s. 508.

301 Ibidem, s. 511.
} 
skim pozbawiona jest jednak wady, jaką dotknięta jest analogiczna regulacja w prawie własności przemysłowej - w art. 80 upa ustawodawca nie kwalifikuje wniosku o udzielenie informacji jako zabezpieczenia roszczenia. Wniosek może dotyczyć udzielenia informacji lub udostępnienia określonej przez sąd dokumentacji, mającej znaczenie dla roszczeń, o których mowa w ustawie. Udzielenia informacji lub udostępnienia dokumentacji może żądać każdy, kto ma w tym interes prawny, a sam wniosek może być rozpatrzony przed wytoczeniem powództwa (art. 80 ust. 1 upa). Naruszający majątkowe prawa autorskie może być zobowiązany do udzielenia informacji lub udostępnienia dokumentów (art. 80 ust. 1 pkt 2 upa), tylko do udzielenia informacji można zaś zobowiązać inne osoby, jeśli posiadają one towary lub świadczą usługi bądź korzystają z usług naruszających prawa autorskie, a także osoby wskazane przez osoby wymienione jako uczestniczące w produkcji, wytwarzaniu lub dystrybucji towarów bądź świadczeniu usług naruszających prawa autorskie, jeśli te działania mają na celu uzyskanie zysku lub korzyści ekonomicznej i nie są podejmowane przez konsumentów działających w dobrej wierze. Informacje pozyskiwane od takich osób mogą dotyczyć pochodzenia, sieci, dystrybucji, ilości i ceny towarów naruszających majątkowe prawa autorskie.

Zarówno w ustawie Prawo autorskie (art. 80 ust. 2 upa), jak i w ustawie Prawo własności przemysłowej (art. $286^{1}$ ust. 3 upwp) przewidziano, że w stosowaniu omawianego środka prawnego sądy mają zapewniać ochronę tajemnicy przedsiębiorcy i innych tajemnic ustawowo chronionych.

Roszczenia informacyjne stwarzają pewne pole do nadużyć - ze względu na ich przedprocesowy charakter możliwa jest sytuacja, kiedy domniemany naruszający będzie zobowiązany do udostępnienia określonych informacji lub dokumentów, a powód ostatecznie nie wniesie pozwu. Konieczna jest zatem regulacja ustanawiająca w takiej sytuacji obowiązek odszkodowawczy wobec zobowiązanego do udzielenia informacji, choć wyznaczenie rozmiaru takiej szkody może okazać się bardzo trudne 302 .

Przyjęte w obszarze prawa własności przemysłowej rozwiązania dotyczące roszczeń informacyjnych w prawie własności intelektualnej mogą być pomocne w projektowaniu regulacji wspomagających prywatne egzekwowanie prawa konkurencji, choć w literaturze przedmiotu mają one zarówno

302 Na problem ten zwracają uwagę A. Tischner, T. Targosz, Dostosowanie polskiego prawa wtasności intelektualnej do wymogów prawa wspólnotowego. Uwagi na tle projektu $z$ dnia 24 maja 2006 r. ustawy o zmianie ustawy o prawie autorskim i prawach pokrewnych oraz o zmianie innych ustaw, [w:] A. Matlak (red.), Zagadnienia prawa autorskiego, PIPWI UJ, Oficyna a Wolters Kluwer business, Kraków 2007, z. 97, s. 120. 
swoich zwolenników ${ }^{303}$, jak i przeciwników ${ }^{304}$. Nawet jeśli zgodzić się z poglądem, że wniosek o udzielenie informacji nie służy do gromadzenia dowodów (jest to co najwyżej ,instrument pokrewny gromadzeniu dowodów w sprawie" 305 ), to informacje uzyskane w ramach realizacji wniosku w wielu przypadkach pozwolą na ocenę potencjalnej skuteczności przyszłego roszczenia głównego - to wydaje się szczególnie istotne dla roszczeń samoistnych w prywatnym egzekwowaniu prawa konkurencji. $\mathrm{Z}$ całą pewnością złożenie takiego wniosku i uzyskanie stosownego postanowienia sądu zobowiązującego do udzielenia informacji nie może warunkować wniesienia roszczenia właściwego ani też nie może zobowiązywać do wniesienia takiego roszczenia. Do składania wniosków o udzielenie informacji i udostępnienie dokumentów na potrzeby roszczeń związanych $\mathrm{z}$ naruszeniem uokik uprawnione byłyby osoby posiadające interes prawny, zaś zobowiązanymi do udzielania informacji osoby (potencjalnie) naruszające zakaz praktyk ograniczających konkurencję, a także osoby będące stronami relacji gospodarczych z naruszającym na określonym rynku właściwym (np. dystrybutorzy, dostawcy). Słusznie podnosi się, że w przypadku roszczeń informacyjnych „niezbędne są również zabezpieczenia prawne przed nadużywaniem prawa do informacji w celu bezprawnej eksploracji danych dotyczących konkurenta rynkowego, które mogą być cenne w gospodarczej rywalizacji”"306.

\subsection{Uwagi końcowe}

W obszarze dostępności dowodów na potrzeby postępowania cywilnego w sprawach związanych ze stosowaniem zakazów praktyk ograniczających konkurencję trudno mówić o komplementarnych, czy choćby subsydiarnych relacjach między publicznym a prywatnym trybem egzekwowania prawa konkurencji. W polskim porządku prawnym nie istnieją żadne przepisy bezpośrednio nakazujące organowi ochrony konkurencji udostępnienie dowodów zgromadzonych w postępowaniu antymonopolowym (lub ewentualnie w postępowaniu wyjaśniającym) stronom postępowania cywilnego czy samym

303 Por. m.in. A. Tischner, Harmonizacja prawa polskiego $z$ wymogami dyrektywy $w$ sprawie egzekwowania praw własności intelektualnej - cz. I, MoP 2005, nr 13.

304 Por. m.in. A. Nowak-Gruca, Roszczenie informacyjne w ustawie... - autorka krytykuje to rozwiązanie z punktu widzenia efektywności ekonomicznej.

305 A. Kołodziej, Roszczenie informacyjne..., [w:] E. Nowińska, M. du Vall, Księga pamiatkowa..., s. 155.

306 Tak A. Tischner, Harmonizacja prawa polskiego.... 
sądom. Nie istnieją również regulacje przewidujące możliwość ujawniania dowodów między stronami, na wzór rozwiązań w systemie common law.

Brak bezpośrednich przepisów odnoszących się do spraw antymonopolowych, a pozwalających na dostęp do dowodów (ujawnianych bądź to przez organ, bądź przez strony) nie oznacza jednak całkowitego wykluczenia możliwości pozyskania informacji zgromadzonych przez organy ochrony konkurencji - szansę na to stwarzają regulacje dotyczące dostępu do informacji publicznej, czyli - odpowiednio dla stosowania unijnych i polskich zakazów praktyk ograniczających konkurencję - rozporządzenie o przejrzystości (rozp. 1049/2001) oraz ustawa o dostępie do informacji publicznej. Możliwość zastosowania tych regulacji (zwłaszcza polskiej ustawy o dostępie do informacji publicznej) dla pozyskania informacji zgromadzonych w postępowaniach antymonopolowych nie jest jednak oczywista i w dużej mierze uzależniona od postawy sądów. Dotychczasowe orzecznictwo, tak polskie (choć dość ubogie), jak i unijne, pozwala wnioskować, że w praktyce istnieje możliwość wnioskowania do organów ochrony konkurencji (Komisji i Prezesa UOKiK) o dostęp do posiadanych przez nie dokumentów/informacji $\mathrm{w}$ celu wykorzystania ich $\mathrm{w}$ postępowaniu przed sądami cywilnymi. Taki kierunek wykładni regulacji o dostępie do informacji publicznej (dokumentów publicznych) jest właściwy z punktu widzenia proponowanego zrównoważonego modelu współistnienia publicznego i prywatnego egzekwowania prawa konkurencji. $\mathrm{Z}$ tych samych przyczyn udostępnianie informacji/dokumentów przez organy ochrony konkurencji powinno odbywać się z poszanowaniem poufności informacji stanowiących tajemnicę przedsiębiorstwa (to ze względu na potrzebę zapewnienia minimalnego poziomu ochrony praw przedsiębiorców) oraz informacji ściśle związanych z realizacją programów leniency (to ze względu na konieczność zapewnienia efektywności polityki antykartelowej); potrzeba ochrony poufności informacji/dokumentów nie istnieje natomiast - moim zdaniem - w odniesieniu do informacji pozyskanych w postępowaniach kończących się ugodą.

W kodeksie postępowania cywilnego, nawet jeśli nie zawiera on przepisów dotyczących ujawniania dowodów między stronami, również można zidentyfikować regulacje, które mogą wspierać skuteczne przeprowadzenie postępowania w sprawie roszczeń z tytułu naruszenia zakazów praktyk ograniczających konkurencję. Należą do nich: dopuszczenie dowodu z urzędu, czy zarządzenie ujawnienia dowodu przez sąd. Środki te mają jednak charakter szczególny w tym sensie, że czynią z sądu gospodarza sporu, nakazują mu wykraczać poza podstawową funkcję arbitra, a zatem co do istoty stoją w sprzeczności z zasadą kontradyktoryjności, szczególnie w świetle aktualnego brzmienia art. $3 \mathrm{kpc}$. 
Realizacja tych kompetencji przez sąd nie jest możliwa w każdym prowadzonym sporze, ale jedynie wówczas, gdy zaistnieją odpowiednie po temu przesłanki. Standardem postępowania jest bowiem to, że sąd powinien $\mathrm{w}$ pierwszej kolejności pobudzić strony w kierunku przedstawienia koniecznych dowodów, czemu służy zobowiązanie do złożenia dalszych pism przygotowawczych (art. $207 \S 3 \mathrm{kpc}$ ), a w trakcie rozprawy - zadawanie pytań (art. $212 \S 1 \mathrm{kpc})^{307}$. Dopuszczenie dowodu przez sąd z urzędu, jak również zarządzenie ujawnienia dowodu przez sąd nie powinny dotyczyć jednak dowodów związanych z procedurą leniency.

Jeśli zatem chodzi o problematykę dostępności dowodów, to należy uznać, że polskie prawo procesowe nie stwarza ułatwień dla prywatnego egzekwowania prawa konkurencji. Niemniej jednak w kontekście efektywności prywatnego egzekwowania prawa ochrony konkurencji pozytywnie należy oceniać nowelizację Kodeksu postępowania cywilnego, na mocy której od dnia 3 maja 2012 r. zniesione zostało postępowanie odrębne w sprawach gospodarczych oparte na zasadzie prekluzji dowodowej. Zasada koncentracji materiału dowodowego, choć w założeniach słuszna, postrzegana była jako istotna bariera w postępowaniach w sprawach gospodarczych (co mogło dotyczyć również spraw związanych z naruszeniem uokik), zwłaszcza w sytuacji, gdy sądy jedynie wyjątkowo zgadzały się na przedstawianie nowych dowodów w toku trwającego postępowania.

Jak wykazano, precedensowe rozwiązania wprowadzone w sferze prawa własności intelektualnej wskutek implementacji dyrektywy 2004/48/WE, a dotyczące wniosków o udzielenie informacji, mogłyby stanowić punkt odniesienia dla podobnych regulacji wzmacniających prywatne egzekwowanie prawa konkurencji. Nawet jeśli wnioski takie nie prowadzą wprost do ujawnienia dowodów, to mogą one stanowić - w sposób nieznany ogólnym przepisom procedury cywilnej - o poprawie (przyszłej) pozycji procesowej powoda.

307 Por. A. Jakubecki, Kontradyktoryjność a poznanie prawdy..., s. 81. 


\section{Wzajemne oddziaływanie rozstrzygnięć publicznego i prywatnego trybu egzekwowania zakazów praktyk ograniczających konkurencję}

\subsection{Uwagi wstępne}

Status rozstrzygnięć organów ochrony konkurencji w postępowaniu przed sądami cywilnymi (i odwrotnie) jest zdecydowanie jednym z kluczowych zagadnień korelacji publicznego i prywatnego trybu egzekwowania prawa konkurencji. Jak słusznie ujął to SN: „nie może natomiast budzić wątpliwości, że niepożądanym zjawiskiem byłaby sprzeczność w ocenach tych samych praktyk dokonanych przez sąd cywilny i przez organ ochrony konkurencji i konsumentów"1.

Wzajemne oddziaływanie rozstrzygnięć należy rozważać w kategoriach prejudycjalności (prae-iudicium). Pojęcie to w sensie językowym oznacza „orzeczenie, rozstrzygnięcie, które nastąpiło przed innym, danym rozstrzygnięciem”, w sensie techniczno-prawnym zaś - „konieczność rozstrzygnięcia jednej sprawy lub jednego zagadnienia, aby następnie można było rozstrzygnąć inną sprawę (zagadnienie)”, przy czym „obie te sprawy lub zagadnienia pod względem związku prawnego między nimi zachodzącego na podstawie konkretnej normy prawnej pozostają w stosunku okoliczności warunkującej i okoliczności warunkowanej"2. Charakter relacji między zagadnieniem prejudycjalnym oraz przedmiotem postępowania cywilnego określany jest w doktrynie również jako „taki, że bez uprzedniego rozstrzygnięcia kwe-

Uchwała SN z dnia 23 lipca 2008 r., III CZP 52/08.

2 K. Piasecki, Postępowanie sporne rozpoznawcze $w$ sprawach cywilnych, C. H. Beck, Warszawa 2010, s. 23. 
stii prejudycjalnej niemożliwe jest rozstrzygnięcie spraw w toczącym się postępowaniu"3.

W piśmiennictwie wskazuje się na dwie techniki rozstrzygania zagadnień prejudycjalnych: pierwsza opiera się na zasadzie, zgodnie z którą „sąd w każdym przypadku jest uprawniony do autonomicznego (samodzielnego) incydentalnego rozstrzygania zagadnień prejudycjalnych z innej dziedziny niż prawo mające zastosowanie do spornego stosunku prawnego"; druga technika opiera się natomiast na założeniu, że „za formę rozstrzygnięcia zagadnień prejudycjalnych uważa się formę ich rozstrzygania nie w sporze, w którym to zagadnienie wymaga rozwiązania, ale $\mathrm{w}$ innym sporze, w którym rozstrzygnięcie tej kwestii nastąpi principaliter jako głównego przedmiotu sporu (sprawy)" 4 . Tę charakterystykę techniki rozstrzygania zagadnień prejudycjalnych należy uzupełnić o stwierdzenie, że znaczenie kwestii prejudycjalnej (wstępnej) może przejawiać się w szerszym zakresie w obligatoryjnym (bezwzględnym) uzależnieniu podjęcia sprawy przez jeden organ od istnienia uprzedniego rozstrzygnięcia innego organu ${ }^{5}$ lub w węższym zakresie - w obligatoryjnym uwzględnianiu uprzedniego rozstrzygnięcia innego organu, aczkolwiek bez uzależnienia samego aktu podjęcia sprawy od wcześniejszego rozstrzygnięcia.

Postępowanie przed sądem powszechnym dotyczące roszczeń wynikających z naruszenia zakazu praktyk ograniczających konkurencję jest przy tym w zasadzie wolne od wątpliwości, jaka decyzja administracyjna stanowi kwestię wstępną (prejudycjalną) w postępowaniu sądowym - jest nią bowiem zawsze decyzja odnosząca się do istnienia (lub nie) naruszenia zakazów praktyk ograniczających konkurencję.

O statusie rozstrzygnięć organów konkurencji i sądów w postępowaniu cywilnym decydują albo bezpośrednio przepisy prawa, albo zasady ogólne prawa (czy szerzej: zasady kultury prawnej), albo orzecznictwo, przy czym mogą być to regulacje, zasady lub orzeczenia ogólne (dla całego systemu prawnego) bądź też ustanowione lub wypracowane wyłącznie w celu egzekwowania prawa konkurencji. Regulacje prawne poświęcone temu zagadnieniu mogą jednoznacznie przesądzać o statusie rozstrzygnięć (np. stanowiąc, że sąd nie może wydać orzeczenia sprzecznego z decyzją organu

3 Tak A. Jakubecki, [w:] H. Dolecki, T. Wiśniewski (red.), Kodeks postępowania cywilnego. Komentarz, Tom I, LEX a Wolters Kluwer business, Warszawa 2011, s. 613 (Nb 4); J. Rodziewicz, Prejudycjalność w postępowaniu cywilnym, Arche, Gdańsk 2000, s. 8.

$4 \quad$ K. Piasecki, Postepowanie sporne..., s. 24.

5 Tak np. kwestię prejudycjalną w postępowaniu administracyjnym definiuje G. Łaszczyca, Pojęcie zagadnienia wstępnego $w$ kodeksie postępowania administracyjnego, $\mathrm{PiP} 2002, \mathrm{nr} 7$, s. 64. 
administracyjnego) bądź mogą jedynie sugerować określone rozwiązania (np. stanowiąc, że sąd powinien zawiesić postępowanie, jeśli jednocześnie toczy się postępowanie antymonopolowe, aż do czasu zakończenia tego ostatniego). Przepisy stanowiące o wzajemnym oddziaływaniu rozstrzygnięć w sprawach ochrony konkurencji dotyczą statusu decyzji administracyjnych przed sądami, nie odwrotnie 6 . Regulacje takie obowiązują w UE, nie ma ich natomiast w Polsce.

Rozważania nad relacjami decyzji organów ochrony konkurencji i orzeczeń sądów powszechnych opierają się na założeniu, że decyzje w sprawach praktyk ograniczających konkurencję są traktowane jak decyzje administracyjne, mimo że postępowanie antymonopolowe, zwłaszcza w kształcie nadanym przez uokik, nie jest „czystym” postępowaniem administracyjnym, ale postępowaniem hybrydowym.

\subsection{Dostępność drogi sądowej a rozstrzygnięcia w trybie publicznym}

Pytanie o możliwości wystąpienia na drogę sądową $\mathrm{z}$ roszczeniami związanymi z naruszeniem zakazów praktyk ograniczających konkurencję stanowi w istocie pytanie o to, czy dopuszczalne jest wnoszenie pozwów samoistnych (stand-alone actions), czy też wyłącznie pozwów następczych (follow-on actions).

W odniesieniu do problemu prejudycjalności rozumianej jako uzależnienie dostępności drogi sądowej od istnienia uprzedniego rozstrzygnięcia organu administracyjnego, nie istnieją żadne unijne regulacje, nie ma również takich regulacji w polskim prawie, natomiast polskie orzecznictwo w tej kwestii podlegało zasadniczym przeobrażeniom.

W pierwszej połowie lat dziewięćdziesiątych - jeszcze na gruncie ustawy antymonopolowej z 1990 r. ${ }^{7}$ - SN wydawał się opowiadać za całkowita autonomią postępowania sądowego i administracyjnego w sprawach praktyk monopolistycznych; w wyroku z dnia 22 lutego 1994 r., I CRN 238/938, Sąd stwierdził, że „niezależnie od trybu stwierdzania i orzekania o konsekwencjach praktyk monopolistycznych, stwierdzenie, że umowa jest wyrazem takiej praktyki, a w konsekwencji, że jest nieważna, może również nastąpić w sprawie między stronami tej umowy, jako przesłanka rozstrzygnięcia

\footnotetext{
J. Jodłowski, Z. Resich, Postępowanie cywilne, Warszawa 1979, s. 104.

7 Ustawa z dnia 24 lutego 1990 r. o przeciwdziałaniu praktykom monopolistycznym i ochronie konsumentów (tekst jedn. Dz. U. z 1999 r. Nr 52, poz. 547 ze zm.), pierwotnie: ustawa o przeciwdziałaniu praktykom monopolistycznym; dalej jako uppm.

8 Wyrok SN z dnia 22 lutego 1994 r., I CRN 238/93, OSNCP 1994 r., nr 10, poz. 198.
} 
o wynikającym z niej roszczeniu”. Krytycznie ocenił ten wyrok zarówno przedstawiciel doktryny T. Ławicki ${ }^{9}$, jak i rok później - sam Sąd Najwyższy, orzekając w innym składzie. W postanowieniu z dnia 27 października 1995 r., III CZP 135/9510, SN stwierdził, że występowanie z roszczeniem z tytułu naruszenia zakazu karteli możliwe było wyłącznie w sytuacji istnienia uprzednio wydanej decyzji Prezesa UOKiK, stwierdzającej istnienie praktyki ograniczającej konkurencję. Rozstrzygnięcie to spotkało się ze słuszną krytyką S. Gronowskiego ${ }^{11}$, przede wszystkim z tego powodu, że hamowało ono de facto możliwość prywatnego egzekwowania prawa konkurencji. Stanowisko, zgodnie z którym „wyłącznie kompetentne do orzekania w przedmiocie praktyk monopolistycznych są organy antymonopolowe" uznał za nietrafne także P. Podrecki12. Autor ten uważał, że art. 19 uppm nie dawał podstaw do zajęcia takiego stanowiska, z kolei art. 8 ust. 2 uppm oddziaływał bezpośrednio w obszarze prawa cywilnego, co skutkuje kompetencją sądu do orzekania w przedmiocie nieważności, przy czym orzekanie to wymaga „kontroli, czy istnieją wystarczające podstawy nieważności. To zaś jest możliwe jedynie poprzez zbadanie, czy w danym przypadku istnieje praktyka monopolistyczna”13. Również M. Bernatt stwierdził, że „za niewłaściwą należy uznać sytuację, w której decyzje krajowego organu ochrony konkurencji mają charakter prejudycjalny w stosunku do orzeczeń sądów w zakresie konieczności każdorazowego stwierdzenia przez organ ochrony konkurencji faktu naruszenia prawa konkurencji"14. M. Lewandowski uznał za „absurdalne” i „irracjonalne” skutki przyznania decyzjom organów antymonopolowych (w zakresie uznania danego zachowania za czyn sprzeczny z zakazami antymonopolowymi) waloru rozstrzygnięć prejudycjalnych ${ }^{15}$.

Niemniej jednak stanowisko orzecznicze uzależniające możliwość sądowego dochodzenia roszczeń z tytułu naruszenia prawa konkurencji od wcze-

9 T. Lawicki, Glosa do wyroku SN z 22 lutego 1994 r., I CRN 238/93, PiP 1995, nr 7.

10 Postanowienie SN z dnia 27 października 1995 r., III CZP 135/95, OSP 1996 r., nr 6, poz. 112.

11 S. Gronowski, Glosa do postanowienia SN z dnia 27 października 1995 r., III CZP 135/95, OSP 1996, nr 6, poz. 112.

12 P. Podrecki, Porozumienia monopolistyczne i ich cywilnoprawne skutki, ZNUJ - PWiOWI, z. 74, Zakamycze, Kraków 2000, s. 200.

13 Ibidem.

14 M. Bernatt, Prywatny model ochrony konkurencji oraz jego realizacja $w$ postępowaniu przed sadem krajowym, [w:] E. Piontek (red.), Nowe tendencje w prawie konkurencji UE, Oficyna a Wolters Kluwer business, Warszawa 2008, s. 312.

15 M. Lewandowski, Sankcja nieważności w ustawie antymonopolowej - problematyka kompetencji organów $w$ przedmiocie ustalania naruszenia zakazów antymonopolowych, PPH 2012, nr 2, s. 34-35. 
śniejszej decyzji organu ochrony konkurencji (antymonopolowego) było „obowiązującym” przez ponad dekadę. Jeszcze w wyroku z dnia 28 kwietnia 2004 r., III CK 521/02, SN wskazał, że „stwierdzenie nieważności umowy będące konsekwencją naruszenia zakazu wynikającego $\mathrm{z}$ art. 8 ust. 1 i 2 ustawy z 2000 r. o ochronie konkurencji i konsumentów może nastąpić jako przesłanka rozstrzygnięcia w sprawie, wymaga uprzedniego formalnego stwierdzenia przez organy wymienione w ustawie, że doszło do niedozwolonej praktyki”.

Dopiero w wyroku z dnia 2 marca 2006 r., I CSK 83/0516, SN wskazał, że „gdy postępowanie przed Prezesem UOKiK nie zostało wszczęte lub postępowanie wszczęte nie zakończyło się wydaniem decyzji, o których stanowią art. 9 i 10 ustawy o ochronie konkurencji i konsumentów z 2000 r. sąd władny jest dokonać samodzielnych ustaleń odnośnie stosowania praktyk ograniczających konkurencję przy zawieraniu umowy jako przesłanki stwierdzenia jej nieważności”.

Ta linia orzecznicza zdaje się być kontynuowana w nowszym orzecznictwie Sądu Najwyższego. W wyroku z dnia 5 stycznia 2007 r., III SK 17/2006, SN wskazał, że „dopuszczalne jest stosowanie przez sądy powszechne przepisów uppm, a obecnie uokik, niezależnie od tego, czy Prezes UOKiK prowadzi postępowanie w sprawie uznania za praktykę ograniczającą konkurencję zachowania będącego przedmiotem oceny w postępowaniu zawisłym przed sądem cywilnym lub gospodarczym"17. Pogląd o braku zależności postępowania przed sądem powszechnym od uprzedniej publicznej interwencji antymonopolowej został wyrażony przez SN także w uchwale z dnia 23 lipca 2008 r., III CZP 52/08, stwierdzającej, że „odmienność celów realizowanych $\mathrm{w}$ ramach postępowania przed sądem oraz przed organami ochrony konkurencji i konsumentów skłania do wniosku, że postępowania te powinny być od siebie niezależne, przynajmniej co do zasady".

W omawianym zakresie - w braku odpowiednich przepisów - orzecznictwo doprowadziło do konwergencji unijnych i krajowych zasad współistnienia prywatnego i publicznego trybu egzekwowania prawa konkurencji: istniejąca decyzja (pod pewnymi warunkami) organu ochrony konkurencji wiąże sąd powszechny, natomiast $w$ braku rozstrzygnięcia administracyjnego sądy zachowują całkowitą swobodę w orzekaniu w sprawach związanych z naruszeniami zakazów praktyk ograniczających konkurencję. Niezależność rozstrzygnięć prywatnego i publicznego trybu egzekwowania przestrzegania zakazów praktyk ograniczających konkurencję uzasadniają trzy argumenty,

16 Wyrok SN z dnia 2 marca 2006 r., I CSK 83/05, LEX nr 369165.

17 Wyrok SN z dnia 5 stycznia 2007 r., III SK 17/2006, LexPolonica nr 2025330. 
trafnie wskazane przez SN w wyroku z dnia 5 stycznia 2007 r., III SK $17 / 2006^{18}$. Po pierwsze za niezależnością przemawia sam model ochrony przed praktykami ograniczającymi konkurencję oparty na zasadzie ustawowego zakazu, oznaczający, że praktyki te są niedozwolone bez względu na to, czy jakiś organ stwierdzi ich istnienie. Po drugie decyzje Prezesa UOKiK, ze względu na swój deklaratoryjny charakter, nie tworzą same w sobie nowego stanu prawnego. Po trzecie przedmiot ochrony w postępowaniu przed sądem cywilnym, tj. prawa podmiotowe, jest inny niż w postępowaniu przed Prezesem UOKiK, gdzie ochrona dotyczy interesu publicznego ${ }^{19}$.

\subsection{Istniejące decyzje organów ochrony konkurencji a rozstrzygnięcia sądowe}

\subsubsection{Reguła Masterfoods w prawie Unii Europejskiej}

Prawo UE wypracowało przepisy regulujące zasady oddziaływania wydanych już przez Komisję decyzji w sprawach praktyk ograniczających konkurencję na rozstrzygnięcia sądowe. Artykuł 16 ust. 1 zd. pierwsze rozp. 1/2003 stanowi, że sądy krajowe nie mogą wydawać orzeczenia sprzecznego $\mathrm{z}$ uprzednio wydaną decyzją Komisji. Ponadto jeśli postępowanie sądowe toczy się równolegle do postępowania przed Komisją, sądy „muszą unikać wydawania decyzji pozostających w sprzeczności z decyzją rozważaną przez Komisję" (art. 16 ust. 1 zd. drugie), co może oznaczać dla sądów konieczność zawieszenia postępowania (art. 16 ust. 1 zd. trzecie).

Źródłem przyjętego rozwiązania jest stanowisko ETS wyrażone w orzeczeniu prejudycjalnym w sprawie C-344/98 Masterfoods v. HB Ice Cream $L t d^{20}$, gdzie Trybunał stwierdził, że ,jeśli sąd krajowy orzeka w sprawie porozumienia lub praktyki, których zgodność z art. 85 ust. 1 i 86 TEWG jest już przedmiotem decyzji Komisji, nie może on wydać orzeczenia sprzecznego z rozstrzygnięciem Komisji, nawet jeśli rozstrzygnięcie to pozostaje w sprzeczności z orzeczeniem sądu krajowego pierwszej instancji”. Stanowisko Trybunału zostało niemal wprost przeniesione do art. 16 ust. $1 \mathrm{zd} .1$ rozp. 1/2003. W szerszym kontekście źródeł zasady związania sądów decyzjami Komisji można upatrywać w zasadzie lojalności wyrażonej w art. 4 ust.

18 Ibidem.

19 Por. rozdział IV, pkt 4.1.

20 Wyrok Trybunału z dnia 14 grudnia 2000 r. w sprawie C-344/98 Masterfoods v. HB Ice Cream Ltd oraz HB Ice Cream Ltd v. Masterfoods (Mars Ireland) (Zb. Orz. 2000, s. I-11369). 
3 TUE (ex art. 10 TWE) ${ }^{21}$, czy też w ogólnej zasadzie pewności prawa ${ }^{22}$. $\mathrm{W}$ istocie art. 16 nie stanowi wprost, że zasada związania dotyczy także sądów cywilnych - wykładnię taką przedstawił natomiast Trybunał Sprawiedliwości w orzeczeniu w sprawie Otis, stwierdzając, że reguła Masterfoods, skodyfikowana w art. 16 rozporządzenia 1/2003 „obowiązuje również, jeżeli do sądów krajowych wniesione zostaje powództwo o naprawienie szkody poniesionej wskutek porozumienia lub praktyki, których niezgodność z art. 101 TFUE została stwierdzona decyzją tej instytucji”23. Jeszcze zanim wyrok w sprawie Otis został wydany, w doktrynie panowała zgoda co do tego, że postanowienie to nie odnosi się wyłącznie do publicznego trybu egzekwowania zakazów z art. 101 i 102 TFUE. W polskiej literaturze pogląd taki wyraził m.in. M. K. Kolasiński24. Wśród argumentów przemawiających za stosowaniem art. 16 na gruncie prywatnego egzekwowania prawa konkurencji dominują odesłania do motywu 7 preambuły do rozporządzenia 1/2003, a także przekonanie, że art. 6 rozp. 1/2003 odnosi się do wszystkich sądów krajowych (cywilnych, administracyjnych, a nawet karnych) ${ }^{25}$.

$\mathrm{Z}$ art. 16 ust. 1 rozporządzenia 1/2003 nie wynika, aby związanie sądów krajowych decyzjami Komisji dotyczyło wyłącznie tych decyzji Komisji, w których stwierdza ona naruszenie art. 101 lub 102 TFUE; przepis ten należy stosować zatem również do decyzji wydawanych na podstawie art. 10 (decyzja stwierdzająca niestosowanie art. 101 lub 102 TFUE) ${ }^{26}$ oraz na podstawie art. 29 ust. 1 rozporządzenia 1/2003 (decyzja o wycofaniu przywileju wyłączenia grupowego). Warto odnotować pogląd A. Komninosa, zgodnie

21 Por. pkt 52 wyroku Trybunału z dnia 6 listopada 2012 r. w sprawie C-199/11 Europese Gemeenschap v. Otis NV i inni (niepubl.), dalej jako: wyrok w sprawie Otis.

22 Szerzej na temat uzasadnienia reguły Masterfoods w prawie unijnym - A. Komninos, Effect of Commission decisions on private antitrust litigation: setting the story straight, CMLR 2007, vol. 44(10), s. 1389-1392.

23 Pkt 51 wyroku w sprawie Otis.

24 M. K. Kolasiński, Odpowiedzialność cywilna za szkody powstałe w wyniku naruszenia wspólnotowych zakazów stosowania praktyk ograniczajacych konkurencję i nadużwania pozycji dominujacej, PPH 2007, nr 11, s. 20.

25 Tak M. Bernatt, Prywatny model ochrony..., [w:] E. Piontek (red.), Nowe tendencje..., s. 308.

26 Tak również A. P. Komninos, Effect of Commission decisions..., s. 1406. W polskiej literaturze pogląd taki podziela (pośrednio) M. Sieradzka. Według tej autorki zakaz wydawania przez sądy krajowe orzeczeń sprzecznych z decyzją Komisji oznacza m.in., że „sąd krajowy nie może uznać, że przepisy o zakazach konkurencji znajdują zastosowanie, gdy Komisja wyłączyła stosowanie art. 81 lub 82 TWE (obecnie art. 101 lub 102 TFUE) do danego porozumienia" - por. M. Sieradzka, Dochodzenie roszczeń za naruszenie unijnych $i$ krajowych reguła konkurencji a kwestie prejudycjalności rozstrzygnięć organów ochrony konkurencji, PPH 2010, nr 12, s. 49. 
z którym art. 16 ust. 1 rozp. 1/2003 ustanawia pozytywny obowiązek związania sądów decyzją Komisji (positive binding effect) jedynie w odniesieniu do tych decyzji, co do których wydania Komisja posiada wyłączną kompetencję, tj. decyzje o wycofaniu przywileju wyłączenia grupowego. Związanie decyzjami o naruszeniu art. 101 lub 102 TFUE ma charakter negatywnego obowiązku powstrzymania się od rozstrzygnięć sprzecznych z decyzją Komisji (negative duty of abstention) ${ }^{27}$.

Jeśli przesłanką niestosowania art. 101 lub 102 TFUE (inapplicability decision) jest brak wpływu praktyki na handel między państwami członkowskimi UE, podczas gdy spełnione są pozostałe przesłanki zakazu praktyki ograniczającej konkurencję, to sąd krajowy zachowuje możliwość własnej oceny stanu faktycznego naruszenia w oparciu o prawo krajowe.

Wiążące dla sądów krajowych nie są natomiast decyzje zobowiązujące wydawane na podstawie art. 9 rozp. 1/200328: choć nie wynika to wprost z przepisów, to w motywie 13 preambuły Rada wskazała, że „decyzje w sprawie zobowiązań pozostają bez uszczerbku dla uprawnień organów ochrony konkurencji i sądów państw członkowskich w zakresie stwierdzania naruszenia i rozstrzygania w sprawie”, zaś w motywie 22 - że „wydane przez Komisję decyzje w sprawie zobowiązań nie wpływają na uprawnienia sądów i organów ochrony konkurencji państw członkowskich do stosowania art. 81 i 82 Traktatu”. Nie można także uznać za wiążące dla sądów decyzji oddalających skargi (wnioski) na naruszenie art. 101 lub 102 TFUE - decyzja oddalająca oznacza bowiem, że w rzeczywistości Komisja w ogóle nie zajęła się sprawą 29 .

Reguła Masterfoods dotyczy co prawda tylko decyzji Komisji, ale zakładając, że u podstaw tego rozwiązania leży jednolite stosowanie unijnego prawa konkurencji w państwach członkowskich należałoby postulować per analogiam związanie krajowych sądów (cywilnych) także bazującymi na art. 101 i/lub 102 TFUE decyzjami wydanymi przez krajowe organy ochrony konkurencji ${ }^{30}$. Sama Komisja w Białej księdze stwierdziła wręcz, że „nie

27 Por. A. P. Komninos, Effect of Commission decisions..., s. 1392-1395.

28 Tak również K. Kohutek: Komentarz do art. 16, teza 4, [w:] Komentarz do rozporzadzenia 1/2003, LEX/El 2006, choć w innym miejscu autor ten wskazuje, że reguła nadrzędności rozstrzygnięć Komisji dotyczy wszystkich decyzji materialno-prawnych wydanych na podstawie przepisów rozdziału III (art. 7-10) oraz decyzji wydanej na podstawie art. 29 - por. K. Kohutek, Komentarz do art. 16, teza 2.1., [w:] Komentarz do rozporzadzenia $1 / 2003$.

29 Taki pogląd reprezentuje także K. Kohutek, Komentarz do art. 16, teza 2, [w:] Komentarz do rozporzadzenia $1 / 2003$.

30 Szerzej: A. P. Komninos, Effect of Commission decisions..., s. 1396-1397. Za analogicznym stosowaniem reguły Masterfoods wobec decyzji organów krajowych wydanych na 
widzi powodu, dla którego w każdym państwie członkowskim nie należałoby traktować prawomocnej decyzji dotyczącej naruszenia art. 81 lub 82 wydanej przez NCA działający w ramach Europejskiej Sieci Konkurencji oraz ostatecznego orzeczenia wydanego przez sąd sprawujący kontrolę nad tymi organami, utrzymującego w mocy decyzję NCA bądź stwierdzającego istnienie naruszenia jako niepodlegającego obaleniu dowodu naruszenia w późniejszym cywilnym postępowaniu o naprawienie szkody wynikłej z naruszenia" 31 . W tym przypadku Komisja jednoznacznie opowiada się za związaniem wyłącznie decyzjami stwierdzającymi naruszenie ${ }^{32}$. Komisja jest zatem zwolenniczką rozwiązania, zgodnie z którym decyzja organu ochrony konkurencji w jednym z państw członkowskich, stosująca art. 101 lub art. 102 TFUE, była wiążącą „uniwersalnie”, tj. w sądach cywilnych wszystkich państw członkowskich. Rozwiązanie to może być krytykowane jako ograniczające autonomię sądów i autonomię proceduralną państw członkowskich, jednak siła tej krytyki słabnie w obliczu faktu, że zaakceptował ją prawodawca niemiecki, wprowadzając do ustawy kartelowej w par. 33(4) zapis, że sądy krajowe są związane nie tylko decyzją Bundeskartellamt, ale także decyzjami organów z innych państw członkowskich UE. Sama Komisja przyznaje, że nie wyklucza możliwości zastrzeżenia przez państwa członkowskie wyjątku, pozwalającego na odmówienie (nieuwzględnienie) mocy wiążącej decyzji organu ochrony konkurencji w innym państwie członkowskim ze względu na sprzeczność z porządkiem publicznym państwa członkowskiego, w którym ma nastąpić „uznanie” takiej decyzji. Sprzeczność z porządkiem publicznym mogłaby wynikać m.in. z braku gwarancji sprawiedliwego postępowania w państwie, w którym decyzja została wydana ${ }^{33}$. Regulacją, na której może być wzorowane takie rozwiązanie, jest art. 34 pkt 1 rozporządzenia Rady (WE) nr 44/2001 z dnia 22 grudnia 2000 r. w sprawie jurysdykcji i uznawania orzeczeń sądowych oraz ich wykonywania w sprawach cywilnych i handlowych ${ }^{34}$.

Zgodnie $\mathrm{z}$ art. 16 ust. 1 zd. czwarte rozp. 1/2003 zasada nadrzędności decyzji Komisji traci znaczenie w sytuacji, gdy sąd krajowy zwrócił się z pytaniem prejudycjalnym do Trybunału Sprawiedliwości i uzyskał odpowiedź.

podstawie prawa unijnego opowiedział się również Rzecznik Generalny J. Mazák w opinii z dnia 16 grudnia 2010 r. do wyroku w sprawie C-360/09 Pfleiderer - por. pkt 41 opinii („decyzje takie winny być traktowane przez sądy krajowe co najmniej jako dowody potwierdzające").

31 Pkt 2.3. Białej księgi. Por. pkt 145 White Paper Staff Working Document.

32 Por. pkt 152 White Paper Staff Working Document.

33 Por. pkt 162 White Paper Staff Working Document.

34 Dz. Urz. WE 2001 L 12/1. 
Wówczas sąd zobowiązany jest zachować się zgodnie z wytycznymi Trybunału, nawet gdyby miały one być sprzeczne $\mathrm{z}$ rozstrzygnięciem przyjętym przez Komisję. Słusznie podkreśla się $\mathrm{w}$ doktrynie, że wynika to z prymatu prawa pierwotnego (art. 267 TFUE) nad prawem wtórnym (art. 16 rozp. 1/2003) ${ }^{35}$. Wystąpienie z pytaniem prawnym do Trybunału jest niezbędne wówczas, gdyby sąd krajowy miał zamiar wydać rozstrzygnięcie sprzeczne z decyzją Komisji36.

Związanie sądu decyzją Komisji dotyczy wyłącznie faktu naruszenia art. 101 lub 102 TFUE, jeśli chodzi natomiast o rodzaj i zakres szkody oraz związek przyczynowy między stwierdzoną przez organ ochrony konkurencji zakazaną praktyką a szkodą, kwestie te pozostają do rozstrzygnięcia przez sąd cywilny: „,nawet jeśli Komisja była zobowiązana do ustalenia dokładnych skutków naruszenia w swojej decyzji, do sądu krajowego nadal należy określenie w sposób indywidualny szkody spowodowanej w stosunku do każdej z osób, które wniosły powództwo o jej naprawienie. Taka ocena nie jest niezgodna $\mathrm{z}$ art. 16 rozporządzenia $\mathrm{nr} 1 / 2003$ " 37 .

\subsubsection{Związanie decyzją administracyjną w postępowaniu sądowym w Polsce}

\subsubsection{Uwagi wstępne}

W polskim prawie zasada związania sądów decyzjami administracji nie jest zasadą pisaną, jednak jest ona powszechnie respektowana (i utrwalona) w orzecznictwie. W piśmiennictwie podkreśla się, że decyzje administracyjne „korzystają z pewnych określonych przywilejów”38, przy czym nie wszyscy autorzy są zgodni co do trafności używania pojęcia „Związanie” w odniesieniu do relacji między decyzjami administracyjnymi a postępowaniami sądowymi i zapadającymi w ich wyniku wyrokami ${ }^{39}$.

Źródeł związania sądów decyzjami organów administracji upatruje się w konstytucyjnej zasadzie trójpodziału władz (tak SN m.in. w uchwale III

35 Por. K. Kohutek, Komentarz do art. 16, teza 2.3, [w:] Komentarz do rozporzadzenia 1/2003.

36 Pkt 13 obwieszenia Komisji o współpracy KE z sądami krajowymi (Commission Notice on the co-operation between the Commission and the courts of the EU Member States in the application of Articles 81 and 82 EC) (Dz. Urz. UE 2004 C 101/54). Por. także pkt 150 White Paper Staff Working Document.

37 Pkt 66 wyroku w sprawie Otis. Por. także pkt 65 tego wyroku.

38 K. Piasecki, Postępowanie sporne..., s. 33.

39 Por. m.in. S. Hanausek, „Zwiazanie” sqdu cywilnego decyzja administracyjna, SC 1974, t. XXIII, s. 20 i n. 
CZP 46/0740 i w wyroku V CK 251/0441) oraz w rozgraniczeniu drogi sądowej i administracyjnej, odzwierciedlonym w art. $2 \S 3$ i art. $177 \S 1$ pkt $3 \mathrm{kpc}$ oraz art. 16 i art. $97 \S 1$ pkt 4 k.p.a. (tak SN m.in. w wyroku IV CSK 302/08). Według J. Jendrośki związanie sądów cywilnych decyzjami administracyjnymi wynika z równorzędności kompetencji organów administracyjnych i sądowych oraz związanej z nią zasady wzajemnego respektowania objawów woli tych organów, wyrażonych w przewidzianych prawem formach ${ }^{42}$. Moc wiążącą decyzji administracyjnych w cywilnym postępowaniu sądowym wiąże się $\mathrm{w}$ doktrynie również $\mathrm{z}$ problemem prawomocności, powagi rzeczy osądzonej, ze stanem prawnym stworzonym decyzją administracyjną, z autorytatywną konkretyzacją stosunków administracyjnych, ze skutkiem materialnoprawnym ${ }^{43}$.

Związanie sądu decyzją administracyjną ma na celu m.in. ochronę pewności obrotu prawnego i ochronę zaufania obywatela do państwa.

Związanie sądu decyzją oznacza „obowiązek uwzględnienia przez sąd stanu prawnego wynikającego z decyzji administracyjnej i odnoszącego się do sfery stosunków, które zostały poddane uregulowaniu na drodze postępowania administracyjnego" (III CZP 46/07). Sąd ,jest obowiązany uwzględnić stan prawny wynikający z osnowy decyzji” (IV CSK 302/0844). Zarówno w orzecznictwie, jak i w piśmiennictwie rozróżnia się zakres związania ze względu na deklaratywny lub konstytutywny charakter decyzji administracyjnej. Co do tych ostatnich, uznaje się, że generują one obowiązek zawieszenia postępowania przez sąd ${ }^{45}$, tj. sąd jest nimi obligatoryjnie związany ${ }^{46}$. Jeśli chodzi o decyzje deklaratoryjne, a więc również te wydawane przez organy ochrony konkurencji ${ }^{47}$, to konieczność zawieszenia postępowania może wystąpić tylko wówczas, gdy sprawa nie ma w ogóle natury cywilno-

40 Uchwała składu siedmiu sędziów SN z dnia 7 października 2007 r., OSN Izba Cywilna 2008, nr 3, poz. 30.

41 Wyrok SN z dnia 19 listopada 2004 r., V CK 251/04, Lex nr 172465.

42 J. Jendrośka, Pojęcie decyzji administracyjnej i jej trwatość, [w:] Problemy praworzadności $w$ dziataniu administracji państwowej, Wrocław 1980, s. 84 i n.

43 K. Piasecki, Postępowanie sporne..., s. 34.

44 Wyrok SN z dnia 11 grudnia 2008 r., IV CSK 302/08.

45 Wyrok N z dnia 30 września 2010 r., I CSK 680/09, Lex nr 622200.

46 Tak A. Jakubecki, [w:] H. Dolecki, T. Wiśniewski (red.), Kodeks postępowania cywilnego..., s. 617 ( $\mathrm{Nb} 14)$.

47 Deklaratoryjny charakter decyzji Prezesa UOKiK potwierdził m.in. wyrok SN z dnia 5 stycznia 2007 r., III SK 17/2006, LexPolonica nr 2025330. W piśmiennictwie taki charakter decyzji organów ochrony konkurencji (zarówno Prezesa UOKiK, jak i Komisji Europejskiej) aprobuje K. Kowalik-Bańczyk, Sadowe stosowanie unijnego prawa konkurencji, [w:] A. Wróbel (red.), Stosowanie prawa Unii Europejskiej przez sądy. Tom I, LEX a Wolters Kluwer business, Warszawa 2010, s. 779. 


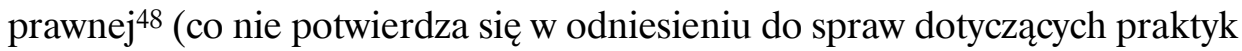
ograniczających konkurencję, które wykazują „podwójną” naturę $\left.{ }^{49}\right)$. Należy odnotować jednakże także poglądy tych przedstawicieli doktryny, którzy opowiadają się za związaniem sądu również deklaratoryjnymi decyzjami administracyjnymi (J. Rodziewicz ${ }^{50}$, A. Jakubecki ${ }^{51}$ ).

Sąd Najwyższy dopuszcza możliwość powoływania się w postępowaniu przed sądem powszechnym na nieważność decyzji administracyjnej, zgodnie $\mathrm{z}$ wypracowaną $\mathrm{w}$ orzecznictwie koncepcją bezwzględnej nieważności (nieistnienia) decyzji administracyjnej. Powołanie się na nieważność rozstrzygnięcia administracyjnego przed sądem może nastąpić tylko wyjątkowo, gdy decyzja jest dotknięta poważną wadą, kwalifikującą ją do kategorii decyzji bezwzględnie nieważnych, określanych też mianem nieistniejących. Ściśle, chodzi o decyzje wydane przez organ oczywiście niewłaściwy lub $\mathrm{z}$ pominięciem wszelkiej procedury52. Możność kwestionowania decyzji administracyjnej $\mathrm{w}$ tak ograniczonym zakresie stanowi przy tym jedynie odstępstwo od zasady związania sądu cywilnego decyzją administracyjną (IV CSK 302/08) ${ }^{53}$. Sąd w postępowaniu cywilnym „nie jest uprawniony do kwestionowania decyzji, w szczególności pod względem jej merytorycznej zasadności, i jest nią związany także wówczas, gdy w ocenie sądu jest wadliwa" (III CZP 46/07) ${ }^{54}$. W postępowaniu sądowym kontroli nie mogą podlegać wady inne niż te, z których według SN wynika nieistnienie decyzji, ponieważ „ocena dokonywana przez sąd cywilny nie może utożsamiać

48 Ibidem. Por. także J. Iwulski, Zwiazanie sądu powszechnego decyzja administracyjna na przyktadzie decyzji dotyczacej stwierdzenia choroby zawodowej, MP 1995, nr 3, s. 72.

49 Inaczej o decyzjach w sprawie istnienia lub nieistnienia praktyki monopolistycznej wypowiada się A. Jakubecki, [w:] H. Dolecki, T. Wiśniewski (red.), Kodeks postępowania cywilnego..., s. 618 ( $\mathrm{Nb} 14)$.

50 J. Rodziewicz, Prejudycjalność..., s. 122 i 126.

51 A. Jakubecki, Prejudycjalność w postępowaniu cywilnym, NP 1982, nr 7-8, s. 97.

52 Por. uchwała SN z dnia 7 lipca 2005 r., IV CK 12/05, niepubl.

53 Por. także wyrok SN z dnia 10 czerwca 2008 r., I UK 376/07, OSNP 2009, nr 21-22, poz. 295. Por. także E. Ochendowski, Moc wiążaca aktu administracyjnego, RPEiS 1968, z. 1, s. 29.

54 Teza ta jest utrwalona w bogatym orzecznictwie Sądu Najwyższego. Por. m.in. orzeczenia Sądu Najwyższego: z dnia 2 stycznia 1962 r., 4 CR 445/61, OSNCP 1963, nr 4, poz. 82; z dnia 12 maja 1964 r., II CR 185/64, OSNCP 1965, nr 3, poz. 41; z dnia 3 lutego 1976 r., II CR 732/75, OSNCP 1976, nr 12, poz. 263; z dnia 18 listopada 1982 r., III CZP 26/82, OSNCP 1983, nr 5-6, poz. 64; z dnia 27 września 1991 r., III CZP 90/91, OSNCP 1992, nr 5, poz. 72; z dnia 9 listopada 1994 r., III CRN 36/94, OSNC 1995, nr 3, poz. 54; z dnia 30 czerwca 2000 r., III CKN 268/00, OSNC 2001, nr 1, poz. 10; z dnia 16 maja 2002 r., IV CKN 1071/00, OSNC 2003, nr 9, poz. 120; z dnia 28 lipca 2004 r., III CK 29 6/03, Biuletyn SN 2005, nr 1, s. 11. 
się z czynnością instancji odwoławczej" (III CZP 46/07). W wyroku z dnia 16 grudnia 2009 r. (I CSK 175/09) SN stwierdził wręcz, że w postępowaniu cywilnym niedopuszczalna jest kontrola prawidłowości zastosowania prawa materialnego stanowiącego podstawę wydania decyzji administracyjnej.

Jednocześnie z orzecznictwa SN wynika, że zasada związania sądu w postępowaniu cywilnym decyzją administracyjną nie wyklucza możliwości dokonywania przez sąd samodzielnej, odmiennej od organu administracyjnego, oceny stanu faktycznego przyjętego za podstawę decyzji (uprawnienie to wynika zresztą z art. $233 \mathrm{kpc}$ ) ani wnioskowania o skutkach prawnych innych niż te, dla osiągnięcia których przewidziane zostało orzekanie na drodze administracyjnej55. Potencjalnie zatem sąd powszechny może dokonać własnych ustaleń faktycznych innych niż okoliczności, które legły u podstaw decyzji organu ochrony konkurencji. Jak bowiem stwierdził SN w wyroku z dnia 25 maja 2007 r. (I CSK 24/07), „decyzja administracyjna ma w sprawie cywilnej znaczenie prejudycjalne, jeśli sąd z uwagi na niedopuszczalność drogi sądowej nie może samodzielnie w sposób wiążący rozstrzygnąć kwestii należących do drogi administracyjnej (...)"56. Niedopuszczalność drogi sądowej występuje przy tym wówczas, „gdy prawo materialne wskazuje jakiś fakt dotyczący przesłanki materialnej postępowania cywilnego, a prawo formalne poddaje ustalenia tego faktu wyłącznej kompetencji organu pozasądowego" 57 . Warto odnotować w tym miejscu stanowisko A. Jakubeckiego, który uważa, że „poglądy przyznające sądowi nieograniczoną kompetencję do rozstrzygania na potrzeby zagadnień prejudycjalnych, dla których przewidziana jest kompetencja organów administracyjnych (...), idą jednak zbyt daleko"58.

Całkowite wykluczenie możliwości dokonywania ustaleń własnych przez sąd byłoby możliwe tylko na mocy uregulowania ustawowego (na wzór art. $11 \mathrm{kpc}$ przewidującego związanie sądu skazującym wyrokiem karnym), stąd uzasadniony wydaje się postulat wprowadzenia odpowiednich zapisów ustawowych ${ }^{59}$. Sąd oczywiście orzeka o skutkach prawnych innych niż organ administracji. Do spraw związanych z naruszeniem zakazów praktyk

55 Por. wyrok SN z dnia 14 kwietnia 1965 r., I PR 88/65, OSNCP 1966, nr 2, poz. 23; uchwała SN z dnia 23 marca 1993 r., II PZP 1/93, OSNCP 1993, nr 12, poz. 211; uchwała składu 7 sędziów SN z dnia 16 czerwca 1994 r., II PZP 4/94, MP 1995, nr 3, s. 73; postanowienie SN z dnia 21 maja 1999 r., III CKN 244/98, OSP 1999, nr 12, poz. 222.

56 Wyrok niepubl., cytuję za: S. Dmowski, K. Kołakowski, [w:] K. Piasecki (red.), Kodeks postępowania cywilnego..., s. 898 (Nb 14).

57 A. Jakubecki, [w:] H. Dolecki, T. Wiśniewski (red.), Kodeks postępowania cywilnego. Komentarz, Tom I, LEX a Wolters Kluwer business, Warszawa 2011, s. 616 (Nb 12).

58 A. Jakubecki, [w:] H. Dolecki, T. Wiśniewski (red.), Kodeks postępowania cywilnego..., s. $617(\mathrm{Nb} \mathrm{13)}$ i s. $619(\mathrm{Nb} 15)$.

59 Por. rozdział VIII, pkt 8.3. 
ograniczających konkurencję z powodzeniem można odnieść refleksję Sądu Najwyższego co do tego, że ocena stanu faktycznego przez sąd „ma swoją specyfikę, niemożliwą do uchwycenia w ramach postępowania administracyjnego. Sąd będzie ukierunkowany na poszukiwanie innych okoliczności i ocenę ich przez pryzmat innych celów niż organ administracji publicznej. To uwrażliwia sąd na badanie odmiennych zagadnień niż te oceniane w ramach postępowania administracyjnego. Można zatem wyciągnąć wniosek, że motywy rozstrzygnięcia i ocena prawna zagadnień cząstkowych, przedstawione $\mathrm{w}$ rozstrzygnięciu organu administracji publicznej i sądu administracyjnego nie wiążą sądu cywilnego" (uchwała III CZP 30/0860).

Przypisanie decyzji administracyjnej charakteru prejudycjalnego oznacza w praktyce konieczność (lub możliwość) zawieszenia postępowania cywilnego do czasu zakończenia postępowania administracyjnego. W doktrynie formułowany jest pogląd, zgodnie z którym jeśli decyzja ma charakter konstytutywny, zawieszenie postępowania ma charakter obligatoryjny, jeśli natomiast ma charakter deklaratoryjny - fakultatywny ${ }^{61}$.

Zarówno orzecznictwo, jak i piśmiennictwo w wymiarze materialnoprawnym przyznają decyzji administracyjnej rolę elementu stanu faktycznego sprawy cywilnej rozpoznawanej przez sąd ${ }^{62}$ bądź rolę zdarzenia prawnego (cywilnoprawnego) ${ }^{63}$ współtworzącego stan faktyczny, bądź niebędące zdarzeniem prawnym źródło określonego stosunku prawnego mieszczącego się w tym stanie faktycznym ${ }^{64}$; decyzja taka jest dokumentem urzędowym i stanowi dowód tego, co zostało w niej stwierdzone (art. $244 \S 1 \mathrm{kpc})^{65}$. Decyzja administracyjna może być również traktowana jako dokument urzędowy podlegający sędziowskiej swobodnej ocenie dowodów ${ }^{66}$. Nawet jeśli sądy nie są formalnie związane decyzją organu ochrony konkurencji, to w praktyce podważenie faktu naruszenia przepisów ustawy o ochronie konkurencji i konsumentów, potwierdzone taką decyzją, będzie mało prawdopodobne.

60 Uchwała SN z dnia 23 kwietnia 2008 r., III CZP 30/08.

61 Tak J. Bodio, [w:] A. Jakubecki (red.), Kodeks postępowania cywilnego. Komentarz, Wolters Kluwer, Warszawa 2008, s. 255.

62 S. Hanausek, „Zwiqzanie” sqdu cywilnego..., s. 31.

63 Ponieważ jednak decyzja administracyjna może stanowić źródło stosunku cywilnoprawnego i z tego względu jako zdarzenie cywilnoprawne, gdy idzie o ocenę ze stanowiska prawa cywilnego, podlega kognicji sądu orzekającego (zob. postanowienie SN z dnia 12 stycznia 2006 r., II CK 335/05, MP 2006, nr 3, poz. 115).

64 S. Grzybowski (red.), System prawa cywilnego. T. I. Część ogólna, Wyd. PAN, Ossolineum 1985, s. 194 i n.

65 Ibidem, s. 604.

66 Tak E. Rumak, P. Sitarek, Polish Leniency Programme and its Intersection with Private Enforcement of Competition Law, YARS 2009, vol. 2(2), s. 117. 


\subsubsection{Związanie sądu cywilnego decyzją Prezesa UOKiK}

Zgodnie $\mathrm{z}$ utrwalonym orzecznictwem (w zakresie procedury cywilnej) w toku postępowania sądowego sąd powszechny musi dokonać ustalenia, czy ma do czynienia $z$ decyzją istniejącą oraz czy decyzja ta jest ostateczna, musi również ustalić, czy zachodzi tożsamość spraw będących przedmiotem postępowania administracyjnego i sądowego.

\section{Decyzja istniejąca}

Decyzją istniejącą w przypadku naruszenia zakazów praktyk ograniczających konkurencję jest decyzja wydana przez Prezesa UOKiK. Bezwzględna nieważność (w rozumieniu wypracowanym przez SN w odniesieniu do decyzji administracyjnych) będzie natomiast dotykać decyzji uznających określone działanie przedsiębiorców za ograniczające konkurencję, a wydanych przez organy regulacyjne, takie jak: Prezes UKE czy Prezes URE, jako że nie są to organy właściwe do stosowania uokik. Decyzją istniejącą będzie decyzja wydana po przeprowadzeniu postępowania antymonopolowego zgodnie z przepisami proceduralnymi przewidzianymi w uokik. Wiele uchybień proceduralnych, w myśl stanowiska SOKiK i sądów kolejnych instancji, nie pozbawia decyzji Prezesa UOKiK (wyjątkiem pozostaje wydanie decyzji bez podstawy prawnej, z rażącym naruszeniem prawa materialnego, adresowanie decyzji do podmiotu niebędącego stroną w sprawie i rozstrzygnięcie sprawy uprzednio rozstrzygniętej inną decyzją ostateczną) ${ }^{67}$, tym bardziej wady proceduralne nie będą miały znaczenia dla statusu decyzji w postępowaniu przed sądem powszechnym.

\section{Decyzja ostateczna}

$\mathrm{Na}$ potrzeby rozważań nad relacjami między prywatnym i publicznym egzekwowaniem reguł konkurencji ostateczność decyzji jako przesłanka związania sądu decyzją może być rozumiana w dwóch aspektach: możliwości zakwestionowania decyzji w trybie odwoławczym (aspekt odwoławczy) oraz merytorycznego rozstrzygnięcia (aspekt merytoryczny). W pierwszym

67 W wyroku z dnia 19 sierpnia 2009 r., III SK 5/09, OSNP 2011, nr 9-10, poz. 144, SN zajął następujące stanowisko: ,jednakże uchybienia proceduralne w zakresie chociażby kwestii dowodowej nie mogą przesądzać o uchyleniu zaskarżonej decyzji, o ile jej postanowienia odpowiadają przepisom prawa materialnego. Uchylenie decyzji w całości powinno nastąpić wówczas, gdy wydanie jej nastąpiło bez podstawy prawnej lub z rażącym naruszeniem prawa materialnego, jak i również wtedy, gdy została ona skierowana do podmiotu niebędącego stroną w sprawie, a także gdy dotyczy sprawy już poprzednio rozstrzygniętej inną decyzją ostateczną. Podstawą do uchylenia decyzji Prezesa Urzędu jest także potrzeba dokonania w całości niezbędnych dla rozstrzygnięcia sprawy ustaleń”. 
ze wskazanych aspektów ostateczność decyzji należy utożsamiać z jej prawomocnością.

O decyzji ostatecznej w aspekcie odwoławczym (prawomocnej) należy mówić wówczas, gdy od decyzji nie zostało wniesione odwołanie, a termin przewidziany na wniesienie odwołania minął lub gdy wskutek wniesienia odwołania decyzja została w całości utrzymana w mocy. W polskim systemie ochrony konkurencji, gdzie rozpatrywanie odwołań od decyzji Prezesa UOKiK następuje w postępowaniu sądowym postrzeganym jako pierwszoinstancyjne, może pojawić się jednak uzasadniona wątpliwość co do tego, czy wniesienie odwołania rzeczywiście przekreśla „ostateczność” decyzji, skoro SOKiK rozpoznaje sprawę od początku. Akceptacja stanowiska, zgodnie z którym każda decyzja Prezesa UOKiK, bez względu na odwołanie złożone wobec niej do SOKiK, jest traktowana jako ostateczna, byłaby rozwiązaniem wygodnym dla uczestników postępowania przed sądem powszechnym, ponieważ oczekiwanie na ostateczne rozstrzygnięcie sprawy we wszystkich instancjach może znacząco wydłużyć okres oczekiwania na uzyskanie wyroku dotyczącego roszczeń cywilnych związanych z naruszeniem uokik, co nie jest korzystne ani dla stron dochodzących roszczeń, ani dla pozwanych (zwłaszcza, gdy są zobowiązani do zapłaty odsetek). Jednocześnie przyjęcie za ostateczną decyzji Prezesa UOKiK bez uwzględniania wyników procedury odwoławczej, niesie ze sobą ryzyko powstania rozbieżności między rozstrzygnięciem w publicznym trybie zastosowania ustawy o ochronie konkurencji i konsumentów, i w trybie prywatnym (zdarzy się tak, gdy decyzja Prezesa UOKiK zostanie zakwestionowana w trybie odwoławczym), co nie jest pożądane z perspektywy zapewnienia spójności egzekwowania zakazów porozumień ograniczających konkurencję. Również Komisja w Białej księdze postuluje, aby za decyzję ostateczną (prawomocną) uznawać taką, co do której pozwany wyczerpał wszystkie środki zaskarżenia ${ }^{68}$.

$\mathrm{Z}$ punktu widzenia merytorycznego za decyzje ostateczne należy uznać decyzje jednoznacznie i pewnie (w sposób udowodniony) rozstrzygające sprawę co do istoty (tj. dopuszczenia się lub nie przez jednego lub więcej przedsiębiorców praktyki ograniczającej konkurencję). Nie ma wątpliwości co do tego, że ostateczną jest decyzja Prezesa UOKiK uznająca praktykę za ograniczającą konkurencję, bez względu na to, czy jej podstawę stanowi art. 10 (decyzja o uznaniu praktyki za ograniczającą konkurencję i nakazująca jej zaniechanie), czy art. 11 uokik (decyzja o uznaniu praktyki za ograniczającą konkurencję i stwierdzająca jej zaniechanie). Prejudycjalny charakter decyzji uznającej praktykę za ograniczającą konkurencję znalazł

68 Pkt 2.3. Białej księgi. Por. także pkt 155 White Paper Staff Working Document. 
również swoje potwierdzenie $\mathrm{w}$ orzecznictwie (por. uchwała $\mathrm{SN}$ z dnia 23 lipca 2008 r., III CZP 52/08).

Łatwo można odnaleźć analogię między decyzją o uznaniu praktyki za ograniczającą konkurencję a wyrokami skazującymi sądów karnych, dla których status prejudykatów wprost przewiduje art. $11 \mathrm{kpc}$. Nieco trudniejsza, także z powodu braku analogii do statusu wyroków sądów karnych, może okazać się akceptacja poglądu, zgodnie z którym za decyzję ostateczną należy uznać również - przynajmniej niektóre - decyzje o umorzeniu postępowania antymonopolowego przez Prezesa UOKiK (rozstrzygnięcia „uniewinniające” przedsiębiorców) ${ }^{69}$. Istotne są tu jednak - w moim przekonaniu - motywy umorzenia postępowania antymonopolowego. Umorzenie postępowania antymonopolowego może nastąpić w oparciu o dwie podstawy prawne: art. $105 \S 1$ k.p.a. w związku z art. 83 uokik (umorzenie $\mathrm{z}$ powodu bezprzedmiotowości postępowania) oraz art. 75 uokik (umorzenie w okolicznościach przewidzianych w ustawie). W tym ostatnim przypadku przyczyną umorzenia będzie obligatoryjnie - przejęcie sprawy przez Komisję Europejską na podstawie przepisów prawa UE (art. 75 ust. 1 pkt 3); zaś fakultatywnie - rozstrzygnięcie sprawy przez właściwy organ ochrony konkurencji państwa członkowskiego UE (art. 75 ust. 2). Postanowienie o umorzeniu postępowania antymonopolowego wydane na podstawie art. 75 nie może być źródłem związania sądu jako „decyzja ostateczna” i to nie ze względów formalnych (postanowienie), ale z powodu braku merytorycznego rozstrzygnięcia sprawy.

Prezes UOKiK umarza postępowanie jako bezprzedmiotowe w sytuacjach, które mogą być klasyfikowane jako: 1) niespełnienie przesłanek generalnych stosowania uokik (brak interesu publicznego uzasadniającego interwencję; brak statusu przedsiębiorcy u podmiotu, któremu zarzucane jest naruszenie ustawy); 2) niespełnienie szczegółowych przesłanek zakazów praktyk ograniczających konkurencję (np. brak porozumienia; brak antykonkurencyjnego celu i/lub skutku porozumienia; brak pozycji dominującej) ${ }^{70}$; 3) przeszkody proceduralne (np. ustanie bytu prawnego podmiotu, któremu

69 Np. w Niemczech decyzje organu ochrony konkurencji są wiążące dla sądów tylko wówczas, gdy stwierdzają one praktykę ograniczającą konkurencję - por. par. 33(4) niemieckiej ustawy kartelowej; szerzej: Ch. Steinle, J. Hattass, The tide has turned: private enforcement of competition law in Germany, G.C.L.R. 2008, vol. 1(1), s. 63, Ch. Rother, E. Staebe, Private antitrust damage claims in Germany - legal foundation and recent trends, G.C.L.R. 2012, vol. 5(1), s. 17.

70 O wątpliwościach związanych z wykorzystaniem w takich sytuacjach jako podstawy prawnej art. $105 \S 1$ k.p.a. piszę szerzej w komentarzu do art. 75 uokik [w:] T. Skoczny, A. Jurkowska, D. Miąsik (red.), Ustawa ... (Nb 8-11), s. 1315-1317. 
zarzucana jest praktyka, ale także tzw. przedawnienie antymonopolowe, o jakim mowa w art. 93 uokik). Leżące u podstaw decyzji umarzającej przesłanki o charakterze proceduralnym również nie mogą powodować, że decyzja Prezesa UOKiK będzie traktowana w postępowaniu sądowym jako ostateczna. W odniesieniu do przedawnienia antymonopolowego bezpośrednio potwierdził to SN w uchwale z dnia 23 lipca 2008 r., III CZP 52/08, stanowiąc, że „ograniczenie terminem możliwości wszczęcia postępowania w sprawie stosowania praktyk monopolistycznych (art. 93 ustawy) nie powinno godzić w interes indywidualny i wyłączać dopuszczalność skorzystania $\mathrm{z}$ drogi procesu cywilnego, w ramach którego zostanie ustalone stosowanie praktyki monopolistycznej jako przesłanka rozstrzygnięcia o żądaniu powoda".

W moim przekonaniu, za ostateczną należałoby uznać decyzję Prezesa UOKiK o umorzeniu postępowania antymonopolowego, której motywem jest niespełnienie szczegółowych przesłanek zakazów praktyk ograniczających konkurencję lub brak - w rozumieniu art. 4 pkt 1 uokik - statusu przedsiębiorcy u podmiotów będących stroną postępowania, decyzja taka nie ma bowiem charakteru ostatecznego w sensie merytorycznym. Za argument sprzeciwiający się przyjęciu takiego rozwiązania można uznać jednak okoliczność, że decyzje tego rodzaju faktycznie nie podlegają w zasadzie rewizji sądowej - dzieje się tak za sprawą ukształtowanego przez uokik modelu kontroli sądowej decyzji Prezesa UOKiK, w którym uprawnienie do wniesienia odwołania posiada wyłącznie strona postępowania (strona postępowania zakończonego decyzją umarzającą nie będzie zainteresowana odwoływaniem się). Ostateczność takiej decyzji w sensie merytorycznym można uznać za niższą niż w przypadku decyzji uznającej praktykę za ograniczającą konkurencję, co do której istnieje większe prawdopodobieństwo i realna szansa, że zostanie zrewidowana przez sąd. Argument ten traci znaczenie w sytuacji, gdy przyjmiemy, że decyzją ostateczną w aspekcie temporalnym jest decyzja wydana przez organ ochrony konkurencji, niezależnie od korzystania z dalszej ścieżki sądowej. Wątpliwość podobnej natury może być podniesiona w odniesieniu do decyzji wydanych w procedurze dobrowolnego poddania się karze (ugody), których podważenie przed sądem jest mało prawdopodobne w sytuacji, gdy będzie to skutkować utratą obniżki kary pieniężnej71.

71 Por. treść art. 88a proponowana przez art. 1 pkt 37 projektu (z dnia 21 listopada 2012 r.) ustawy o zmianie ustawy o ochronie konkurencji i konsumentów oraz o zmianie niektórych innych ustaw. Por. także projekt założeń projektu ustawy o zmianie ustawy o ochronie konkurencji i konsumentów (projekt z dnia 15 maja 2012 r.), pkt D. Dobrowolne poddanie się karze, s. 15-18. 
Nie będzie decyzją ostateczną decyzja Prezesa UOKiK umarzająca postępowanie ze względu na niespełnienie przesłanki interesu publicznego, co jest konsekwencją rozdzielności drogi sądowej (prywatnoprawnej) i administracyjnej (publicznoprawnej). Okoliczność, że w określonym stanie faktycznym Prezes UOKiK nie dopatrzył się zagrożenia dla interesu publicznego, uzasadniającego interwencję organu, nie wyklucza możliwości dochodzenia indywidualnych roszczeń z tytułu naruszenia zakazów praktyk ograniczających konkurencję. Taki pogląd w polskiej doktrynie podziela również K. Kohutek ${ }^{72}$.

Przymiotu ostateczności nie posiada tzw. decyzja zobowiązująca, której podstawę prawną stanowi art. 12 uokik. Stanowisko takie zają $\mathrm{SN}$ w uchwale z dnia 23 lipca 2008 r., III CZP 52/08. Pogląd o nieostatecznym charakterze decyzji zobowiązującej podzielają również niektórzy przedstawiciele doktryny ${ }^{73}$. Decyzja zobowiązująca wydawana jest w sytuacji jedynie uprawdopodobnienia (a nie dowiedzenia) praktyki ograniczającej konkurencję i w istocie nie potwierdza ona, że działanie przedsiębiorcy lub przedsiębiorców narusza ustawowe zakazy. Decyzje zobowiązujące stanowią szczególny instrument interwencji Prezesa UOKiK ukierunkowany na szybkie i skuteczne przywrócenie stanu niezakłóconej (zdrowej) konkurencji. Opowiadając się za rozdzielnością prywatnego i publicznego trybu egzekwowania prawa konkurencji, Sąd Najwyższy słusznie podkreślił w przywołanej uchwale, że: „w szczególności fakt, że z punktu widzenia interesu publicznego korzystniejsze może być wydanie decyzji z art. 11a ustawy [obecnie art. 12 - przyp. aut.] niż ostateczne rozstrzygnięcie kwestii wystąpienia praktyk ograniczających konkurencję, nie powinien wyłączać możliwości ochrony interesu indywidualnego w postępowaniu przed sądem cywilnym".

Decyzja w tej samej sprawie (tożsamość spraw w postępowaniu administracyjnym i sądowym)

Związanie sądu decyzją administracyjną odnosi się tylko do rozstrzygnięć wydanych w tej samej sprawie. Tożsamość sprawy należy rozumieć jako tożsamość podstaw prawnych, tożsamość istoty naruszenia (to samo działanie uznawane jest za potencjalną praktykę ograniczającą konkurencję),

72 K. Kohutek, Naruszenie interesu publicznego a naruszenie konkurencji, PiP 2010, nr 7, s. 45.

73 Por. D. Miąsik, [w:] T. Skoczny, A. Jurkowska, D. Miąsik (red.), Ustawa o ochronie konkurencji i konsumentów. Komentarz, C. H. Beck, Warszawa 2009, s. 752; K Kohutek, [w:] K. Kohutek, M. Sieradzka, Ustawa o ochronie konkurencji i konsumentów. Komentarz, LEX a Wolters Kluwer business, Warszawa 2008, s. 440; C. Banasiński, E. Piontek (red.), Ustawa o ochronie konkurencji i konsumentów. Komentarz, LexisNexis, Warszawa 2009, s. 314. 
tożsamość rynku właściwego (geograficznego i produktowego), tożsamość podmiotów zaangażowanych $\mathrm{w}$ praktykę, taki sam czas trwania naruszenia $^{74}$. W porządkach prawnych, gdzie postępowanie antymonopolowe może być wszczynane na wniosek, powstaje pytanie, czy dla tożsamości sprawy konieczne jest, aby uczestnikiem postępowania sądowego był wnioskodawca ${ }^{75}$. Komisja wydaje się prezentować - jak określa to A. P. Komninos podejście minimalistyczne ${ }^{76}$, wymagając jednak pełnej tożsamości elementów sprawy ${ }^{77}$. Kwestia ta nie ma jednak znaczenia na gruncie polskiego prawa konkurencji przewidującego wyłącznie urzędowe wszczynanie postępowań.

Zakres związania sądu decyzją organu ochrony konkurencji

Przyjęcie (jako reguły legislacyjnej lub orzeczniczej), że decyzja organu ochrony konkurencji wiąże sądy cywilne, wymaga określenia zakresu tego związania. Sekcja 58 brytyjskiego Competition Act 1998 przewiduje, że jeśli sąd inaczej nie postanowi, to ustalenia Office of Fair Trading właściwe dla kwestii podniesionych $\mathrm{w}$ postępowaniu są wiążące dla wszystkich stron. W wyroku w sprawie Enron ${ }^{78}$ CAT potwierdził co prawda, że sądy rozpatrujące pozwy w ramach prywatnego egzekwowania prawa konkurencji są związane ustaleniami faktów zawartymi w decyzji stwierdzającej naruszenie, ale jednocześnie Trybunał uznał, że nie każde twierdzenie w decyzji organu kwalifikuje się jako stwierdzenie faktu. Podtrzymując w mocy wyrok CAT oddalający powództwo obejmujące roszczenia z tytułu naruszenia prawa konkurencji ${ }^{79}$, Court of Appeal uznał, że powodowi nie udało się udowodnić, że naruszenie spowodowało szkodę (stratę) - nie wystarczy bowiem w tym zakresie polegać na decyzji organu ochrony konkurencji jako na jedynym dowodzie, że powód poniósł stratę jako rezultat naruszenia. Stanowisko to,

74 Tak: W. P. J. Wils, The Relationship between Public Antitrust Enforcement and Private Actions for Damages, World Competition 2009, vol. 32(1), dostępny także pod adresem: http://papers.ssrn.com/sol3/papers.cfm?abstract_id=1296458, s. 20 (tekst z SSRN).

75 Sąd belgijski uznał za prejudykat decyzję Komisji w sprawie praktyki izby architektów, mimo że powodowie w sprawie nie byli skarżącymi (claimants) w postępowaniu przed Komisją (wyrok Sądu Apelacyjnego w Brukseli z dnia 28 września 2004 r. w sprawie Eddy Lodiso v. La SPRLU M.o.n.d.e. Podaję za: A. P. Komninos, Effect of Commission decisions..., s. 1398.

76 Por. A. P. Komninos, Effect of Commission decisions..., s. 1397-1401.

77 Pkt 8 obwieszczenia o wspólpracy Komisji z sądami krajowymi.

78 Enron Coal Services Ltd (In Liquidation) v English Welsh \& Scottish Railway Ltd [2009] CAT 36.

79 English Welsh \& Scottish Railway v Enron Coal Services Limited (ECSL) [2011] EWCA Civ 2. 
chociaż krytykowane w doktrynie ${ }^{80}$, należy postrzegać jako właściwe - sądy słusznie uznały, że nie mogą być związane tymi ustaleniami organu ochrony konkurencji, które mają charakter „peryferyjny”, jeśli chodzi o ustalenie faktu naruszenia. Autonomia postępowania sądowego, jeśli nawet ograniczona poprzez wiążący charakter decyzji organu ochrony konkurencji, nie powinna być poddana dalszemu limitowaniu poprzez m.in. pozbawienie sądu możliwości orzekania o wielkości i zakresie szkody w indywidualnych przypadkach. Jeśli zatem organ ochrony konkurencji np. oszacował wysokość szkody poniesionej przez konsumentów wskutek funkcjonowania kartelu cenowego, rozstrzygnięcie takie nie może być wiążące dla sądu, choć niewątpliwie w praktyce stanie się dla niego istotną wskazówką.

Dotychczasowe polskie orzecznictwo pozwala na sformułowanie następującego wniosku: decyzja Prezesa UOKiK może być wiążąca dla sądu powszechnego orzekającego w sprawie roszczeń wynikających $\mathrm{z}$ naruszenia uokik co do stanu prawnego wynikającego $\mathrm{z}$ tej decyzji (stwierdzenie naruszenia lub niestwierdzenie spełnienia przesłanek zakazów praktyk ograniczających konkurencję), sąd może natomiast dokonywać samodzielnych ustaleń dotyczących zagadnień cząstkowych. Związanie sądu ogranicza się do stwierdzenia (niestwierdzenia) faktu naruszenia, natomiast nie dotyczy innych elementów odpowiedzialności cywilnoprawnej, takich jak związek przyczynowy między szkodą i naruszeniem, czy też sama szkoda. Ustalenia te są konieczne ze względu na potrzebę ,indywidualizacji” naruszenia w postępowaniu sądowym (np. w sytuacji, gdy z roszczeniem występuje podmiot będący stroną porozumienia uznanego przez Prezesa UOKiK za ograniczające konkurencję - sąd prawdopodobnie będzie musiał wniknąć w relacje między uczestnikami porozumienia głębiej niż organ ochrony konkurencji).

Pogląd aprobujący związanie sądu cywilnego decyzją organu antymonopolowego należy uznać za powszechny w polskim piśmiennictwie - stanowisko takie wyrazili m.in.: P. Podrecki ${ }^{81}$, M. Sieradzka ${ }^{82}$. Pogląd pośredni wyraził natomiast R. Poździk ${ }^{83}$ - autor ten uważa, że „rozstrzygnięcie

80 Por. T. Woodgate, I. Filippi, The decision that binds: follow on actions for competition damages after Enron, E.C.L.R. 2012, vol. 33(4), s. 175-178.

81 P. Podrecki, Porozumienia monopolistyczne..., s. 200.

82 M. Sieradzka, Dochodzenie roszczeń odszkodowawczych z tytutu naruszenia unijnego i krajowego prawa konkurencji (część I), PUG 2012, nr 1, s. 23; M. Sieradzka, Pozew grupowy jako instrument prywatnoprawnej ochrony interesów konsumentów z tytułu naruszenia regut konkurencji, LEX a Wolters Kluwer business, Warszawa 2012, s. 375.

83 R. Poździk, Glosa do uchwaty SN z 23 lipca 2008 r., sygn. III CZP 52/08, OSP 2009, nr 7-8, s. 604 . 
sądu powszechnego nie powinno podważać ostatecznej decyzji administracyjnej Prezesa UOKiK, a więc stwierdzającej stosowanie przez stronę praktyki ograniczającej konkurencje”, ale jednocześnie twierdzi, że „nie oznacza to związania sądów powszechnych decyzjami administracyjnymi Prezesa UOKiK”.

\subsection{Brak decyzji administracyjnej w sprawie praktyki ograniczającej konkurencję a przebieg postępowania sądowego}

Zgodnie $\mathrm{z}$ zaprezentowanym $\mathrm{w}$ poprzednim podrozdziale stanowiskiem w braku ostatecznej decyzji administracyjnej, tj. w sytuacji złożenia pozwu samoistnego, sąd zachowuje pełną swobodę w rozstrzygnięciu sprawy.

Z brakiem decyzji mamy do czynienia w sytuacjach, gdy: (1) postępowanie antymonopolowe w ogóle nie zostało wszczęte, (2) postępowanie antymonopolowe zostało zakończone wydaniem decyzji o charakterze nieostatecznym z punktu widzenia postępowania sądowego, (3) decyzja organu ochrony konkurencji została uchylona przez organ odwoławczy, (4) postępowanie antymonopolowe jest $\mathrm{w}$ toku.

W ostatnim przypadku sąd może zawiesić postępowanie w oczekiwaniu na rozstrzygnięcie sprawy przez organ ochrony konkurencji. $\mathrm{W}$ prawie unijnym rekomendacja ta zawarta jest $\mathrm{w}$ art. 16 ust. $1 \mathrm{zd} .3$ rozporządzenia 1/2003, który stanowi, że „sąd krajowy może rozważyć, czy konieczne jest zawieszanie toczącego się postępowania”. Należy podkreślić, że przytoczona rekomendacja ma charakter dość stanowczy w kontekście zdania drugiego art. 16 ust. 1, stanowiącego, że „sądy muszą również unikać wydawania decyzji pozostających w sprzeczności z decyzją rozważaną przez Komisję". W obwieszczeniu o współpracy z sądami krajowymi Komisja deklaruje zaufanie do sądów krajowych wskazując, że jeśli sąd krajowy nie ma uzasadnionych wątpliwości co do spodziewanej decyzji Komisji lub jeśli Komisja podejmowała w przeszłości decyzje w podobnej sprawie, sąd może orzekać w zawisłej przed nim sprawie, bez konieczności oczekiwania na decyzję Komisji, czy nawet występowania do unijnego organu o informacje (pkt 12).

Polskie prawo nie zawiera odpowiednika przytoczonego przepisu (w odniesieniu do spraw z zakresu ochrony konkurencji), zawieszenie postępowania może nastąpić na zasadach ogólnych przewidzianych w kpc. Artykuł $177 \S 1$ pkt 3 kpc zezwala sądowi na zawieszenie postępowania, ,jeśli rozstrzygnięcie sprawy zależy od uprzedniej decyzji organu administracyjnego". W doktrynie taką sytuację określa się jako zawieszenie „z przyczyn preju- 
dycjalnych”84 lub „ze względów celowości”85. Postanowienie o zawieszeniu postępowania sąd wydaje fakultatywnie, co jednak nie oznacza dowolności w działaniu sądu - konieczna jest ocena celowości zawieszenia ${ }^{86}$. Jak stwierdził SN w wyroku z dnia 25 maja 2007 r. (I CSK 24/07), „Zawieszenie postępowania na podstawie art. $177 \S 1$ pkt $3 \mathrm{kpc}$ jest celowe wtedy, gdy przedmiot prejudycjalnego postępowania stanowi element podstawy faktycznej rozstrzygnięcia sprawy w postępowaniu cywilnym"87. W tym samym wyroku SN wskazal, że zawieszenie postępowania cywilnego może nastąpić wtedy, gdy określona kwestia nie może być rozstrzygnięta na drodze sądowej. Pogląd ten znajduje potwierdzenie także w piśmiennictwie ${ }^{88}$.

Postępowanie sądowe może być zawieszone zarówno wówczas, gdy postępowanie przed organem ochrony konkurencji się toczy, jak i wówczas, gdy postępowanie antymonopolowe nie zostało (jeszcze) wszczęte ${ }^{89}$.

W sytuacji, gdy postępowanie antymonopolowe już się toczy, postępowanie sądowe powinno być zawieszone jedynie w przypadku, gdy przed Prezesem UOKiK toczy się postępowanie antymonopolowe w sprawie praktyki ograniczającej konkurencję, nigdy zaś wówczas, gdy Prezes UOKiK prowadzi jedynie postępowanie wyjaśniające, które z natury nie kończy się ostatecznym rozstrzygnięciem.

W sytuacji, gdy zawieszenie nastąpiło $\mathrm{z}$ tego powodu, że rozstrzygnięcie sprawy zależy od wyniku innego postępowania (w tym postępowania administracyjnego), sąd podejmuje postępowanie $\mathrm{z}$ urzędu ,z chwilą uprawomocnienia się orzeczenia kończącego to postępowanie" (art. $180 \S 1$ pkt $4 \mathrm{kpc}$ ). Sąd może jednak podjąć dalsze postępowanie także przed tym momentem, „stosownie do okoliczności”.

Możliwość zawieszenia postępowania sądowego powinna być rozważona również w sytuacji, gdy decyzja organu ochrony konkurencji została podważona $\mathrm{w}$ toku procedury odwoławczej. W przypadku podważenia decyzji Komisji sąd może, po pierwsze zawiesić postępowanie, po drugie wystąpić

84 H. Dolecki, Postępowanie cywilne. Zarys wyktadu, LexisNexis, Warszawa 2007, s. 173. Por. także J. Bodio, [w:] A. Jakubecki (red.), Kodeks..., s. 254.

85 W. Broniewicz, Postępowanie cywilne $w$ zarysie, LexisNexis, Warszawa 1996, s. 279.

86 Tak H. Dolecki, Postępowanie cywilne..., s. 174; J. Bodio, [w:] A. Jakubecki (red.), Komentarz..., s. 254.

87 Wyrok niepubl., cytuję za: S. Dmowski, K. Kołakowski, [w:] K. Piasecki (red.), Kodeks postępowania cywilnego..., s. 898 (Nb 14).

88 Tak A. Jakubecki, [w:] H. Dolecki, T. Wiśniewski (red.), Kodeks postęowania cywilnego. Komentarz, Tom I, LEX a Wolters Kluwer business, Warszawa 2011, s. 616 (Nb 12).

89 Tak S. Dmowski, K. Kołakowski, [w:] K. Piasecki (red.), Kodeks postępowania cywilnego..., s. $896(\mathrm{Nb} 9)$. 
do Trybunału Sprawiedliwości z wnioskiem o wydanie orzeczenia prejudycjalnego, jeśli sąd powziął uzasadnione wątpliwości co do ważności decyzji Komisji (sądy krajowe nie mają kompetencji do orzekania o nieważności aktów prawa unijnego ${ }^{90}$. Wytyczną Komisji co do tego, że na czas zawieszenia postępowania sąd krajowy powinien rozważyć zastosowanie środków tymczasowych ${ }^{91}$, należy zastosować także do postępowań czysto krajowych.

Od Prezesa UOKiK można żądać informacji co do tego, czy toczy się postępowanie w określonej sprawie na podstawie art. 5 ust. 4 ustawy o dostępie do informacji publicznej (przepis ten stanowi, że dopuszczalne w świetle tej ustawy ograniczenia dostępu do informacji nie naruszają prawa do informacji o organizacji i pracy organów prowadzących postępowania, w szczególności o czasie, trybie i miejscu oraz kolejności rozpatrywania spraw).

Rozwiązanie polegające na zawieszeniu postępowania należy rekomendować ze względu na zachowanie spójności horyzontalnej rozstrzygnięć w trybie publicznym i prywatnym, a także ze względu na pewność prawa ${ }^{92}$, choć niewątpliwie ogranicza ona niezależność prywatnego trybu egzekwowania reguł konkurencji ${ }^{93}$. Jeśli przyjąć, że o rozstrzyganiu naruszenia zakazów praktyk ograniczających konkurencję sądy mogą decydować autonomicznie, nie jest do tego niezbędna droga administracyjna, to w świetle przywołanych powyżej poglądów Sądu Najwyższego oraz doktryny, zawieszenie postępowania sądowego na podstawie art. $177 \S 1$ pkt $3 \mathrm{kpc}$ może okazać się niemożliwe.

Nieco bardziej sceptyczne podejście do zawieszenia postępowania jako sposobu rozstrzygnięcia potencjalnych rozbieżności między rozstrzygnięciami publicznego i prywatnego trybu egzekwowania zakazów praktyk ograniczających konkurencję zajął w polskiej literaturze P. Podrecki, który stwierdził, że ,jest to co prawda praktyczny sposób uniknięcia sprzeczności (...), ale znajdzie on zastosowanie wyłącznie do ograniczonej grupy przypadków"94.

Zawieszenie postępowania nie jest jednak rozwiązaniem pozbawionym istotnej wady, jaką stanowi wydłużenie postępowania sądowego. Argument

90 Por. pkt 13 obwieszczenia Komisji w sprawie wspólpracy z sądami krajowymi państw członkowskich w zakresie wdrażania art. 81 i 82 TWE (Dz. Urz. UE 2004 C 101, s. 3); dalej jako obwieszczenie w sprawie współpracy z sądami krajowymi.

91 Por. pkt 14 obwieszczenia w sprawie współpracy z sądami krajowymi.

92 Tak również K. Kohutek, Komentarz do art. 16, teza 2.2, [w:] Komentarz do rozporzadzenia $1 / 2003$.

93 Tak A. Jurkowska, Perspektywy prywatnego wdrażania prawa ochrony konkurencji w Polsce na tle doświadczeń Wspólnoty Europejskiej, PUG 2008, nr 1, s. 27.

94 P. Podrecki, Porozumienia monopolistyczne..., s. 206. 
ten ma zasadnicze znaczenie przede wszystkim w przypadku, gdy zawieszenie postępowania następuje w oczekiwaniu na decyzję Komisji, przed którą postępowania antymonopolowe są często długotrwałe. Niemniej jednak w obwieszczeniu o współpracy z sądami Komisja zadeklarowała, że będzie dawała priorytet sprawom, które są przedmiotem zawieszonych postępowań przed sądami krajowymi, zwłaszcza, jeśli wynik postępowania cywilnego zależy od decyzji Komisji (pkt 12). Zagrożenie nadmiernym wydłużeniem postępowania sądowego jest nieco mniejsze w przypadku postępowań antymonopolowych przed Prezesem UOKiK, które zgodnie z art. 92 uokik powinny trwać nie dłużej niż 5 miesięcy; termin ten jednak ma charakter instrukcyjny, a w rzeczywistości postępowania mogą trwać znacznie dłużej95. Argument czasowy zyskuje natomiast znowu na znaczeniu w sytuacjach zawieszenia postępowania w oczekiwaniu na rozstrzygnięcie odwołania od decyzji organu ochrony konkurencji, zarówno jeśli chodzi o oczekiwanie na wydanie wyroku przez sąd unijny, jak i sądy krajowe.

\subsection{Inne możliwości oddziaływania organów ochrony konkurencji na rozstrzygnięcia sądowe}

Bez względu na - formalnie (legislacyjnie) lub orzeczniczo - potwierdzony status decyzji organów ochrony konkurencji w postępowaniu sądowym, organy te mogą wspierać sądy w orzekaniu w sprawach związanych z naruszeniem zakazów praktyk ograniczających konkurencję w roli „przyjaciela sądu" (amicus curiae).

Przyjęcie tezy o konieczności współistnienia publicznego i prywatnego egzekwowania prawa konkurencji oznacza między innymi akceptację możliwości (a nawet - konieczności) wspierania sądów cywilnych przez organy ochrony konkurencji poprzez realizację przez te ostatnie roli „przyjaciela sądu" (amicus curiae). Ta instytucja procesowa wywodzi się z systemu common law ${ }^{96}$.

W prawie unijnym taką rolę dla organów ochrony konkurencji w obszarze stosowania art. 101 i 102 TFUE przewiduje art. 15 rozp. 1/2003. Przepis ten różnicuje formy możliwej współpracy z sądami dla Komisji oraz dla

95 Np. postępowanie w sprawie kartelu cementowego zostało wszczęte w dniu 23 kwietnia 2006 r., a zakończone wydaniem decyzji dopiero w dniu 8 grudnia 2009 r. (decyzja Prezesa UOKiK, DOK-7/09).

96 O źródłach instytucji amicus curiae i jej pozycji w systemie prawa amerykańskiego szerzej piszą: M. Swora, A. Trela, Amicus curiae w postępowaniu antymonopolowym?, Administracja. Teoria-Dydaktyka-Praktyka 2006, nr 1(2), s. 79-100. 
krajowych organów ochrony konkurencji. W przypadku Komisji sądy państw członkowskich mogą same wystąpić do niej z prośbą o przekazanie informacji i opinii o stosowaniu prawa unijnego (art. 15 ust. 1) ${ }^{97}$, a ponadto Komisja może przedstawić sądowi krajowemu z urzędu uwagi pisemne, zaś za zgodą sądu - uwagi ustne dotyczące prawa unijnego, przy czym tego rodzaju aktywność może być podejmowana przez Komisję tylko wówczas, gdy wymaga tego spójne stosowanie art. 101 i 102 TFUE (art. 15 ust. 3 akapit pierwszy zd. trzecie). Warunek ten - zgodnie ze stanowiskiem Trybunału Sprawiedliwości zaprezentowanym w wyroku w sprawie C-429/07 Inspecteur van de Belastingdienst $v$. $X B V$ - może być spełniony także „w wypadku, gdy dane postępowanie nie toczy się w sprawach dotyczących stosowania art. 81 lub 82 traktatu" 98 , z przypadkiem takim mamy do czynienia - jak w powyższym wyroku - w postępowaniu dotyczącym możliwości odliczenia od zysku podlegającego opodatkowaniu kwoty grzywny nałożonej przez Komisję za naruszenie art. 101 lub 102 TFUE albo części tej kwoty99. Choć przepis art. 15 ust. 1 nie przewiduje wprost obowiązku Komisji w zakresie odpowiedzi na prośbę sądu krajowego, jednak w literaturze słusznie podkreśla się, że obowiązek taki ciąży na Komisji na mocy zasad ogólnych, w tym przede wszystkim zasady lojalności (art. 4 ust. 3 TUE) ${ }^{100}$. Przypisanie Komisji roli amicus curiae w postępowaniach przed sądami krajowymi spotkało się również z krytyką koncentrującą się wokół argumentu, że interwencja Komisji przed sądami krajowymi powinna być „zbliżona do zera”, zaś koncepcja amicus curiae jest $\mathrm{z}$ całą pewnością instrumentem o zbyt szerokim zakresie do podejmowania takiej interwencji101.

Organy krajowe mogą z urzędu przedstawiać własnym sądom uwagi pisemne, zaś za zgodą sądu - uwagi ustne dotyczące rozstrzyganej przez

97 Wybrane sprawy, w których sądy krajowe wystąpiły do Komisji o opinię prezentuje K. Wright, European Commission opinions to national courts in antitrust cases: consistent application and the judicial-administrative relationship, ESRC Centre for Competition Policy Working Paper Series 2008/24. Wybrane opinie Komisji występującej jako amicus curiae oraz wyroki sądów krajowych w sprawach, do których odnosiły się te opinie są dostępne na stronie internetowej Komisji pod adresem: http://ec.europa.eu/competition/ court/antitrust_requests.html.

98 Pkt 30 wyroku TS z dnia 11 czerwca 2009 r. w sprawie C-429/07 Inspecteur van de Belastingdienst v. X BV (Zb. Orz. 2009, s. I-04833). Por. F. Rizutto, The private enforcement of European Union competition law: what next?, GCLR 2010, vol. 3(2), s. 61-66.

99 Pkt 40 wyroku w sprawie C-429/07 Inspecteur van de Belastingdienst.

100 Tak K. Kohutek, Komentarz do art. 15. Teza 2, [w:] Komentarz do rozporzadzenia 1/2003.

101 Tak J. Cook, [w:] C. D. Ehlermann, I. Atanasiu (red.), European Competition Law Annual 2000: The Modernisation of EC Antitrust Policy, Hart Publishing, Oxford and Portland, Oregon 2001, s. 482. 
sąd sprawy, aktywność organów krajowych nie jest przy tym uzależniona od spełnienia żadnych dodatkowych przesłanek (art. 15 ust. 3 akapit pierwszy zd. drugie). Trybunał Sprawiedliwości potwierdził przy tym, że „art. 15 ust. 3 akapit pierwszy rozporządzenia (...) nie dotyczy uczestniczenia przez taki organ jako strona pozwana w krajowych postępowaniach sądowych" 102 .

Zarówno Komisja, jak i krajowe organy ochrony konkurencji mogą wnioskować do sądów o przekazanie lub zapewnienie przekazania wszelkich dokumentów koniecznych dla rozstrzygnięcia sprawy (art. 15 ust. 3 akapit drugi). Regulacje krajowe mogą przewidywać szerszy zakres uprawnień co do wnoszenia uwag przed sądy krajowe przez organy ochrony konkurencji (art. 15 ust. 4).

Wykonywanie wskazanych uprawnień czy to przez Komisję, czy to przez organy krajowe musi uwzględniać autonomię sądów, stąd informacje i opinie przekazywane przez organy antymonopolowe nie są dla sądów wiążące ${ }^{103}$. Jak słusznie podkreśla się w obwieszczeniu o współpracy z sądami, Komisja (ale wymóg ten należy odnosić również do organów krajowych) występuje do sądów w obronie interesu publicznego, nie może natomiast wspierać interesu podmiotów prywatnych ${ }^{104}$ (organy pełnią rolę przyjaciela sądu, a nie przyjaciela strony). Przygotowywanie opinii do sądu nie może wiązać się również z przesłuchaniem na tę okoliczność stron ${ }^{105}$.

W polskiej literaturze pojawił się pogląd, że instytucja amicus curiae przewidziana $\mathrm{w}$ art. 15 rozporządzenia $1 / 2003$ może być postrzegana jako instytucja konkurencyjna wobec instytucji pytań prejudycjalnych $\mathrm{z}$ art. 267 TFUE 106 . Pogląd ten nie zasługuje w moim przekonaniu na aprobatę ze względu na różną rolę i kontekst, w jakich obie te instytucje mogą być stosowane. Pytania prejudycjalne zamykają się w obrębie systemu sądowniczego, podczas gdy istotą instytucji procesowej przyjaciela sądu jest włączenie się do postępowania podmiotu zewnętrznego, wyspecjalizowanego. Organy ochrony konkurencji są uprawnione do przedstawiania sądom „,informacji i opinii” (Komisja w świetle art. 15 ust. 1) oraz „uwag” (Komisja i organy krajowe w świetle art. 15 ust. 3), pytania prejudycjalne są natomiast ukierunkowane na wykładnię traktatów oraz ważność i wykładnię aktów przyjętych przez instytucje, organy lub jednostki organizacyjne Unii.

102 Pkt 55 wyroku TS z dnia 7 grudnia 2010 r. w sprawie C-439/08 VEBIC (Zb. Orz. 2010, s. I-12471). Por. pkt 56-59 opinii rzecznika generalnego P. Mengozziego w tej sprawie przedstawiona w dniu 5 marca $2010 \mathrm{r}$.

103 Por. pkt 19 i 29 obwieszczenia w sprawie wspólpracy z sądami krajowymi.

104 Ibidem.

105 Por. pkt 30 obwieszczenia w sprawie współpracy z sądami krajowymi.

106 M. Swora, A. Trela, Amicus curiae..., s. 79 i d. 
Informacje, opinie i uwagi, o których mowa w art. 15 rozp. 1/2003 mogą, moim zdaniem, wychodzić poza kwestie stricte prawne, choć zawsze będą one $\mathrm{z}$ prawem powiązane. Pytania prejudycjalne, poza przypadkami, gdy ich zadanie jest obowiązkowe, zależą od woli i aktywności sądów krajowych, podczas gdy Komisja i krajowe organy ochrony konkurencji moga przedstawiać swoje uwagi z urzędu. Fundamentalna różnica leży również w sposobie oddziaływania „opinii” dostarczanych przez Trybunał i organy ochrony konkurencji: opinie w postaci wyroków Trybunału Sprawiedliwości mają charakter wiążący dla sądów, podczas gdy uwagi przedstawiane przez organy ochrony konkurencji pozostają dla sądów niewiążące. W literaturze spotyka się również pogląd, że opinie przewidziane w art. 15 stanowią uzupełnienie pytań prejudycjalnych ${ }^{107}$. K. Kohutek słusznie wskazuje, że „praktyczną zaletą korzystania przez sąd krajowy z prośby o opinię Komisji (w trybie art. 15 ust. 1) jest brak konieczności zaistnienia jakichkolwiek przesłanek prawnych w możliwości złożenia takiej prośby”, przesłanki takie są natomiast konieczne do złożenia pytania prawnego w trybie art. 267 TFUE. Nie bez znaczenia zdaniem tego autora jest również szybkość uzyskania odpowiedzi od Komisji (czas postępowania przed Trybunałem jest stosunkowo długi) ${ }^{108}$.

Rozporządzenie 1/2003 w żaden sposób nie reguluje proceduralnych aspektów współpracy organów ochrony konkurencji z sądami, pozostawiając tę kwestię prawu krajowemu. Motyw 21 preambuły do rozp. 1/2003 przewiduje, że uwagi organów ochrony konkurencji powinny być składane „zgodnie z krajowymi przepisami procesowymi i ustaloną praktyką”. W obwieszczeniu o współpracy z sądami Komisja stwierdziła, że państwa członkowskie muszą wprowadzić takie rozwiązania proceduralne, które pozwolą Komisji i organom krajowym w pełni skorzystać z przyznanych im uprawnieńn ${ }^{109}$; regulacje krajowe muszą przy tym uwzględniać zasady ogólne prawa unijnego, w tym zasadę proporcjonalności, efektywności i równoważności ${ }^{110}$.

W polskiej ustawie o ochronie konkurencji i konsumentów nie istnieje analogiczny do art. 15 rozp. 1/2003 przepis, który przewidywałby kompetencje Prezesa UOKiK do występowania do sądów cywilnych w sprawach związanych ze stosowaniem uokik. Obowiązku współpracy z sądami nie znajdziemy również w katalogu zadań organu zawartym w art. 31 uokik. Instytucja przyjaciela sądu (opinii przyjaciela sądu) jest co prawda znana

107 K. Wright, European Commission opinions to national courts..., s. 14.

108 Tak K. Kohutek, Komentarz do art. 15. Teza 5, [w:] tenże, Komentarz do rozporzadzenia $1 / 2003 \ldots$

109 Pkt 17 obwieszczenie w sprawie współpracy z sądami krajowymi.

110 Por. pkt 9-10 oraz pkt 35 obwieszczenia w sprawie współpracy z sądami krajowymi. 
polskiemu Kodeksowi postępowania cywilnego ${ }^{111}$, jednak istniejące przepisy nie realizują instrukcji Komisji co do zapewnienia możliwości przedstawiania uwag przez samą Komisję oraz Prezesa UOKiK w postępowaniach przed sądami cywilnymi. Opinia taka może być bowiem złożona jedynie przez organizacje pozarządowe, którym art. $63 \mathrm{kpc}$ przyznaje uprawnienie do przedstawiania sądowi ,istotnego dla sprawy poglądu wyrażonego w uchwale lub w oświadczeniu ich należycie umocowanych organów". Organy administracji publicznej nie mają oczywiście statusu organizacji pozarządowych, stąd nie mogą skorzystać z tej możliwości.

Brak przepisów proceduralnych umożliwiających występowanie Prezesa UOKiK do sądu cywilnego w sprawach z zakresu stosowania uokik należy oceniać negatywnie (w sprawach dotyczących stosowania przepisów prawa unijnego art. 15 rozp. 1/2003 ma bezpośrednie zastosowanie). W ten sposób krajowa praktyka egzekwowania zakazów praktyk ograniczających konkurencje pozbawiona jest ważnego instrumentu zapewniania harmonijnej koegzystencji publicznego i prywatnego egzekwowania prawa konkurencji. Instrument ten wydaje się szczególnie przydatny na etapie rozwoju prywatnego trybu egzekwowania zakazów antykonkurencyjnych praktyk, kiedy to sądy mogą potrzebować realnego wsparcia ze strony wyspecjalizowanego organu ochrony konkurencji, jeśli chodzi o rozstrzyganie sporów. Brak możliwości korzystania z opinii przyjaciela sądu oznacza również pozbawienie interesu publicznego rzecznika, który mógłby ten interes reprezentować przed sądami. Dodatkowym argumentem za wprowadzeniem przepisów proceduralnych dotyczących występowania organu ochrony konkurencji jako przyjaciela sądu jest konieczność zapewnienia efektywnego stosowania prawa unijnego (rozporządzenia 1/2003).

\subsection{Związanie organów ochrony konkurencji wyrokiem sądu cywilnego}

Jak dowiedziono powyżej związanie sądów decyzjami organów administracji jest akceptowalne i możliwe w rzeczywistości, mechanizm związania nie działa jednak w odwrotnym kierunku, tzn. organy administracji nie są związane orzeczeniami sądów cywilnych w sprawach antymonopolowych. Stanowisko takie wydaje się słuszne, ponieważ decyzja administracyjna podejmowana jest przez organ wyspecjalizowany i nie można jej odmówić

111 Problematykę opinii przyjaciela sądu w Polsce szerzej prezentuje m.in. M. Bernatt, Opinia przyjaciela sqadu jako pomocnicza instytucja prawna w orzecznictwie sq̨ów polskich, [w:] Ł. Bojarski (red.), Sprawny sąd. Zbiór dobrych praktyk. Część druga, Warszawa 2008, s. $184-190$. 
wartości dowodowej, podczas gdy sądy cywilne wyspecjalizowane nie są. Istotą rozstrzygnięcia administracyjnego jest stwierdzenie naruszenia (lub jego braku), natomiast w orzeczeniu sądowym istotą jest określenie odpowiedzialności odszkodowawczej, stwierdzenie naruszenia jest tylko jednym $\mathrm{z}$ jej elementów.

Nie ma żadnych podstaw prawnych dla związania organu administracji wyrokiem sądowym w sprawie naruszenia - ani na poziomie krajowym, ani unijnym. Jeśli sąd wydał wyrok w sprawie naruszenia, organ ochrony konkurencji zachowuje swoją kompetencję do działania niezależnego od orzeczenia sądowego. W przypadku Komisji źródłem uprawnienia do „ignorowania" rozstrzygnięcia sądu krajowego jest niezależność kompetencyjna gwarantowana jej przez Traktat ${ }^{112}$, w prawie krajowym - zasada trójpodziału władz.

W sytuacji, gdy uprzednio istniejący wyrok sądu okazałby się sprzeczny z decyzją organu ochrony konkurencji, należy przyjąć, że mimo wszystko ma on status res iudicata między stronami sporu sądowego, nie stoi na przeszkodzie wszczęciu postępowania antymonopolowego ani nie wpływa w żaden sposób na rozstrzygnięcie podejmowane przez organ administracji. Możliwa, choć niepożądana, jest sytuacja, gdy sąd krajowy uzna za nielegalne np. porozumienie wertykalne między producentem a dystrybutorem $\mathrm{X}$, natomiast wskutek przeprowadzonego postępowania organ ochrony konkurencji uzna to samo porozumienie za legalne. Możliwa jest również sytuacja odwrotna, kiedy to sąd nie dopatrzy się naruszenia zakazu praktyki ograniczającej konkurencję, a organ ochrony konkurencji uzna określoną praktykę za antykonkurencyjną ${ }^{113}$. W obydwu sytuacjach nie można wykluczyć wznowienia postępowania sądowego (z tzw. właściwych przyczyn restytucyjnych ${ }^{114}$ ), które mogłoby nastąpić z przyczyn przewidzianych w art. 402 $\S 2 \mathrm{kpc}, \mathrm{tj}$. „wykrycia takich okoliczności faktycznych lub środków dowodowych, które mogłyby mieć wpływ na wynik sprawy, a z których strona nie mogła skorzystać w poprzednim postępowaniu”.

Podobnie jak ma to miejsce w odniesieniu do prejudycjalnego statusu decyzji organu ochrony konkurencji, również w tym wypadku istotne zna-

112 Por. A. P. Komninos, Effect of Commission decisions..., s. 1409.

113 P. Podrecki określił takie sytuacje jako sprzeczność rzeczywistą (gdy organ i sąd dokonały oceny praktyki w świetle uokik), w odróżnieniu od sprzeczności pozornej, która polega na tym, że organ ochrony konkurencji ocenia daną umowę na gruncie uokik i stwierdza jej legalność, a sąd ocenia tę samą umowę na gruncie prawa cywilnego i stwierdza jej nieważność np. ze względu na niedochowanie przepisanej formy prawnej umowy - por. P. Podrecki, Porozumienia monopolistyczne..., s. 202-203.

114 W. Broniewicz, Postępowanie cywilne..., s. 257; H. Dolecki, Postępowanie cywilne..., s. 353. 
czenie będą miały przesłanki rozstrzygnięcia Prezesa UOKiK. I tak, jeśli umorzenie postępowania nastąpiło ze względu na niespełnienie przesłanki interesu publicznego lub ze względu na przedawnienie antymonopolowe, nie będzie to podstawą wznowienia postępowania sądowego, inaczej gdy umorzenie nastąpiło ze względu na niespełnienie merytorycznych przesłanek zakazów praktyk ograniczających konkurencję.

Na wznowienie postępowania jako sposób usuwania sprzeczności między rozstrzygnięciami sądów cywilnych i organów ochrony konkurencji wskazuje także P. Podrecki, choć zastrzega on, że do tej koncepcji „należy podchodzić z dużą ostrożnością"115. Autor ten słusznie także wskazuje, że sprzeczność między rozstrzygnięciami może być wyeliminowana także w toku sądowej kontroli instancyjnej116 - jeśli w jej ramach czasowych wydana zostanie decyzja organu ochrony konkurencji uznająca praktykę za ograniczającą konkurencję, zarzut nieważności czynności prawnej stanowiącej tę praktykę powinien zostać uwzględniony przez sąd $\mathrm{z}$ urzędu.

\subsection{Uwagi końcowe}

Przyjęcie prejudycjalnego charakteru decyzji organów ochrony konkurencji należy postrzegać jako czynnik intensyfikujący prywatne egzekwowanie prawa konkurencji, pozwala bowiem na uruchomienie roszczeń następczych (follow-on actions) niejako „gwarantowanych” stwierdzeniem naruszenia przez organ antymonopolowy ${ }^{117}$. Z drugiej strony może on być jednak postrzegany jako nieuzasadniona supremacja publicznego trybu egzekwowania prawa konkurencji nad trybem prywatnym ${ }^{118}$. Alternatywnym roz-

115 P. Podrecki, Porozumienia monopolistyczne..., s. 205. Taki pogląd prezentuje też M. Lewandowski, Sankcja nieważności..., s. 38.

116 P. Podrecki, Porozumienia monopolistyczne..., s. 206.

117 Argument ten jest akceptowalny nawet dla tych autorów, którzy co do zasady sceptycznie odnoszą się do przyznania statusu prejudycjalnego decyzjom organów antymonopolowych w postępowaniach przed sądami powszechnymi - por. A. P. Komninos, Relationship between Public and Private Enforcement: quod Dei Deo, quod Caesaris Caesari (referat wygłoszony na konferencji Integrating public and private enforcement of competition law: Implications for courts and agencies, Florencja, 17-18 czerwca 2011 r.), dostępny pod adresem: http://papers.ssrn.com/sol3/papers.cfm?abstract_id=1870723, s. 11-12. Autor ten ostatecznie rekomenduje uznawanie rozstrzygnięć organu antymonopolowego za obalalne domniemanie - ibidem, s. 13.

118 D. Wilsher określa sytuację związania sądów decyzjami organów ochrony konkurencji jako „kulturę zależności” (dependency culture) - Reconciling the public and private dimensions of competition litigation in the European Union, G.C.L.R. 2011, vol. 4(2), s. 94. 
wiązaniem dla związania sądów decyzjami administracyjnymi mogłoby być przyjęcie zasady odwrócenia ciężaru dowodu w sprawach tych naruszeń zakazów praktyk ograniczających konkurencję, w których organ ochrony konkurencji wydał już decyzję (pozwany miałby udowodnić, że nie doszło do naruszenia) ${ }^{119}$ - rozwiązanie takie obarczone jest jednak tą wadą, że wymaga ponownego rozstrzygania o samej istocie naruszenia, a więc dochodzi do utraty zasadniczej korzyści z akceptacji prejudycjalności (racjonalizacja procesu stosowania prawa) ${ }^{120}$.

$\mathrm{Za}$ prejudycjalnością rozstrzygnięć organów ochrony konkurencji w postępowaniach sądowych może przemawiać okoliczność, że zasadniczo standard dowodzenia w postępowaniu antymonopolowym nie jest niższy niż w procesie cywilnym ${ }^{121}$ - teza ta będzie prawdziwa zwłaszcza w tych systemach prawnych, gdzie postępowanie dowodowe przed organem ochrony konkurencji wzorowane jest na postępowaniu dowodowym w procesie cywilnym, a przedsiębiorcom, którym zarzucana jest antykonkurencyjna praktyka, gwarantowany jest wysoki poziom prawa do obrony (np. poprzez prawo do wysłuchania, możliwość zapoznania się z materiałem dowodowym itp.).

Niemniej jednak zrównoważone podejście do problemu współistnienia publicznego i prywatnego trybu egzekwowania prawa konkurencji wymaga odrzucenia skrajnych rozwiązań co do wpływu rozstrzygnięć administracyjnych na postępowanie sądowe. Uzależnienie dostępności drogi sądowej od uprzedniego rozstrzygnięcia administracyjnego nadmiernie ogranicza możliwość sądowego dochodzenia roszczeń z tytułu naruszenia zakazów praktyk ograniczających konkurencję, zwłaszcza w przyjętym w Polsce modelu wyłącznie inkwizycyjnego wszczynania postępowań antymonopolowych. Z kolei całkowita niezależność rozstrzygnięć sądowych od istniejących decyzji administracyjnych odnoszących się do naruszenia przepisów uokik osłabiałaby, w moim przekonaniu, spójność stosowania zakazów praktyk, znacznie zwiększając ryzyko rozbieżności rozstrzygnięć w obydwu trybach.

Ze wszech miar akceptowalnym wydaje się aktualne polskie stanowisko orzecznicze, zgodnie z którym istniejące decyzje Prezesa UOKiK są wiążące dla sądów powszechnych, o ile są one ostateczne. Opowiadam się jednocześnie za tym, aby porzucić analogię $\mathrm{z}$ art. $11 \mathrm{kpc}$ i jako ostateczne traktować nie tylko decyzje Prezesa UOKiK uznające praktykę za ograniczającą konkurencję (tj. decyzje wydane na podstawie art. 10 lub 11 uokik),

119 Rozwiązanie takie zaproponowane zostało przez Komisję w Zielonej księdze.

120 Por. pkt 147 White Paper Staff Working Document.

121 Por. pkt 149 White Paper Staff Working Document. 
$\mathrm{w}$ tym ewentualne decyzje wydane $\mathrm{w}$ procedurze dobrowolnego poddania się karze (ugody), ale także decyzje umarzające postępowanie ze względu na niespełnienie przesłanek zakazów. Związanie sądu powinno dotyczyć decyzji prawomocnych, tzn. takich, od których nie wniesiono odwołania do SOKiK bądź takich, które zostały potwierdzone w toku kontroli sądowej122. W sytuacji zbiegu postępowań przed sądem cywilnym i przed organem ochrony konkurencji należy rekomendować zawieszenie postępowania przez sąd na podstawie art. $177 \S 1$ pkt $3 \mathrm{kpc}$.

122 Tak również w polskiej literaturze M. Sieradzka, Dochodzenie roszczeń..., s. 52. 



\section{Rozdział VII}

\section{Sankcje i środki ochrony prawnej w postępowaniu przed organami ochrony konkurencji i przed sądami cywilnymi}

\subsection{Sankcje w publicznoprawnym trybie egzekwowania zakazów praktyk ograniczających konkurencję - uwagi wstępne}

Problematyka sankcji stanowi jedną z zasadniczych różnic między prywatnym i publicznym egzekwowaniem prawa konkurencji. W najszerszym ujęciu sankcja identyfikowana jest jako całokształt gwarancji prawnych zabezpieczających realizację prawa ${ }^{1}$. Sankcja jest pojęciem odnoszącym się do wszelkich negatywnych (ujemnych) skutków, ,zła”2, jakie adresat normy prawnej powinien odczuwać $\mathrm{w}$ związku $\mathrm{z}$ niezastosowaniem się do zakazu i nakazu ustanowionego $\mathrm{w}$ tej normie ${ }^{3}$, $\mathrm{z}$ pojęcia sankcji należy wyłączyć natomiast konsekwencje nieskorzystania przez określony podmiot z przypisanych mu uprawnień ${ }^{4}$. K. Opałka wskazywał przy tym, że sankcja nie jest jednoznaczna z ujemnymi skutkami grożącymi za naruszenie określonej normy, ale stanowi jedynie zapowiedź zastosowania tych skutków w przypadku urzeczywistnienia się tego naruszenia ${ }^{5}$.

Znaczenie pojęcia sankcji rysuje się różnie w poszczególnych gałęziach prawa - w doktrynie prawa karnego przeważa powinnościowe ujęcie sankcji,

1 Tak J. Filipek, Sankcja prawna w prawie administracyjnym, PiP 1963, z. 12, s. 878.

2 A. Redelbach, S. Wronkowska, Z. Ziembiński, Zarys teorii państwa i prawa, Wydawnictwo Naukowe PWN, Warszawa 1992, s. 91.

3 Por. m.in. G. L. Seidler, H. Groszyk, J. Malarczyk, A. Pieniążek, Wstęp do nauki o państwie i prawie, Morpol, Lublin 2000, s. 115.

4 Por. M. Lewicki, Pojęcie sankcji prawnej w prawie administracyjnym, PiP 2002, nr 8, s. 69.

5 K. Opałka, [w:] S. Ehrlich (red.), Teoria państwa i prawa, Warszawa 1957, s. 116-119. Tak również Z. Kmieciak, Skuteczność regulacji administracyjnoprawnej, Łódź 1994, s. 87. 
natomiast w doktrynie prawa cywilnego - sankcja traktowana jest jako realne zagrożenie dla adresata (sankcja egzekucyjna) ${ }^{6}$. Należy jednak zastrzec, że w teorii prawa klasyfikacja sankcji nie jest oparta na podziale na gałęzie prawa - doktrynalnie wyróżnia się z reguły sankcję karną (represyjną, penalną), egzekucyjną oraz sankcję nieważności

W piśmiennictwie podkreśla się, że funkcje sankcji „można wnioskować z samego faktu ustanowienia aktów prawnych zawierających sankcje, a także z płaszczyzny utrwalonej praktyki stosowania tych sankcji wobec podmiotów popełniających delikty zagrożone sankcją"8. Funkcją stosowania sankcji jest zaś cel, jaki prawodawca chce osiągnąć poprzez ustanowienie określonych sankcji w przepisach prawa ${ }^{9}$. Dla określenia funkcji sankcji w modelu kompleksowego egzekwowania prawa ochrony konkurencji właściwe jest przyjęcie dychotomicznego podziału, zaproponowanego przez K. Włodarską-Dziurzyńską dla sankcji w prawie konsumenckim ${ }^{10}$, na funkcje wymuszające zachowania zgodne z prawem (tj. przestrzeganie zakazów praktyk ograniczających konkurencję) oraz funkcje rekompensujące poszkodowanym (innym przedsiębiorcom, konsumentom) szkody wynikające z zaistniałych naruszeń. Te dwie kategorie funkcji sankcji nie wydają się jednak wystarczające w obszarze prawa ochrony konkurencji, należy dodać do nich jeszcze funkcję odstraszającą (K. Włodarska-Dziurzyńska postrzega tę funkcję jako składową funkcji wymuszającej11, jednak ze względu na quasi-karny charakter „tradycyjnych” sankcji prawa antymonopolowego, takich jak: kary pieniężne oraz obserwowany rozwój sankcji typowo karnych w tym obszarze prawa, za właściwe uważam wyodrębnienie jako samoistnej funkcji odstraszającej sankcji w pawie ochrony konkurencji).

Sankcje w każdym z trybów egzekwowania prawa konkurencji co do zasady pełnią role właściwie dla - odpowiednio - prawa publicznego i prawa

6 A. Gryniuk, Przymus prawny. Studium socjologiczno-prawne, Wyd. UMK, Toruń 1994, s. 41.

7 Tak m.in.: A. Gryniuk, Przymus prawny..., s. 43; G. L. Seidler, H. Groszyk, J. Malarczyk, A. Pieniążek, Wstęp do nauki..., s. 116; T. Stawecki, P. Winczorek, Wstęp do prawoznawstwa, C. H. Beck, Warszawa 1996, s. 53; S. Kaźmierczyk, [w:] A. Bator, W. Gromski, A. Kozak, S. Kaźmierczyk, Z. Pulka, Wprowadzenie do nauk prawnych. Leksykon tematyczny, LexisNexis, Warszawa 2006, s. 132.

8 M. Wincenciak, Funkcje sankcji we wspólnotowym prawie ochrony konkurencji, s. 6 (tekst dostępny pod adresem: http://www.law.muni.cz/sborniky/Days-of-public-law-doplnek/files/ pdf/Wincenciak.pdf).

9 Ibidem.

10 K. Włodarska-Dziurzyńska, Sankcje w prawie konsumenckim na przykładzie wybranych umów, LexisNexis, Warszawa 2008, s. 36-37.

11 Ibidem, s. 37. 
prywatnego, jednak budowa zrównoważonego modelu współistnienia dwóch sposobów egzekwowania zakazów praktyk ograniczających konkurencję generuje pytanie o ewentualne nakładanie się tych funkcji i związany z tym problem oddziaływania (,zaliczalności”) sankcji trybu publicznego i prywatnego. Niniejszy rozdział poświęcony jest zatem nie tylko prezentacji poszczególnych rodzajów sankcji w ramach każdego z trybów egzekwowania prawa ochrony konkurencji, ale także wzajemnym wpływom sankcjonowania naruszenia zakazów praktyk ograniczających konkurencję w obydwu trybach.

Sankcje publicznego trybu egzekwowania zakazów praktyk ograniczających konkurencję obejmują przede wszystkim sankcje administracyjne (co wynika z klasyfikowania prawa ochrony konkurencji jako publicznego prawa gospodarczego, określanego również jako administracyjne prawo gospodarcze $)^{12}$, a w wielu krajach także sankcje karne ${ }^{13}$. Należy zastrzec, że taki podział sankcji stosowanych w trybie publicznym stanowi pewne uproszczenie, ponieważ sankcjom w postaci kar pieniężnych, przewidzianym w prawie administracyjnym, często przypisuje się charakter prawnokarny ${ }^{14}$.

Istotne dla dalszych rozważań nad sankcjami właściwymi dla publicznego trybu egzekwowania zakazów praktyk ograniczających konkurencję jest zastrzeżenie, że pojęcie sankcji administracyjnej jest w zasadzie obce samemu ustawodawcy, a i w piśmiennictwie występuje ono stosunkowo rzadko ${ }^{15}$ (znacznie częściej doktryna operuje bardziej opisowym pojęciem „sankcji [prawnej] w prawie administracyjnym”). Pojęciem sankcji administracyjnych niektórzy przedstawiciele doktryny obejmują, tak dolegliwości za naruszenie przepisów prawa, jak i proces ich wymierzania ${ }^{16}$. J. Filipek sprzeciwiał się

12 Odpowiedzialność przedsiębiorców związana z przestrzeganiem przepisów ustawy o ochronie konkurencji i konsumentów określana jest jednoznacznie jako odpowiedzialność o charakterze administracyjnym przez: M. Błachucki, S Jóźwiak, Sankcje strukturalne w prawie antymonopolowym jako sankcje administracyjne, [w:] M. Stahl, R. Lewicka, M. Lewicki (red.), Sankcje administracyjne, LEX a Wolters Kluwer business, Warszawa 2011, s. 450.

13 W piśmiennictwie wskazuje się dodatkowo na „sankcje osobiste” w formie „dyskwalifikacji zawodowej”, polegające na zakazie obejmowania funkcji kierowniczych przez osoby kierujące przedsiębiorstwem, które naruszyło zakaz praktyk ograniczających konkurencję - tak B. Turno, Leniency - program tagodzenia kar pieniężnych $w$ polskim prawie ochrony konkurencji, LEX a Wolters Kluwer business, Warszawa 2013, s. 205-208.

14 Por. rozdział II, pkt 2.2.4. oraz pkt 7.3.2.1. w niniejszym rozdziale.

15 Pojęcie sankcji administracyjnej pojawi się jednak, aczkolwiek ujęte w cudzysłów, m.in. u J. Zimmermanna, Prawo administracyjne, Oficyna a Wolters Kluwer, Warszawa 2010, s. 39. Do upowszechnienia pojęcia sankcji administracyjnej zapewne przyczyni się praca zbiorowa: M. Stahl, R. Lewicka, M. Lewicki (red.), Sankcje administracyjne, LEX a Wolters Kluwer business, Warszawa 2011.

16 Tak M. Wincenciak, Sankcje $w$ prawie administracyjnym i procedura ich wymierzania, Oficyna a Wolters Kluwer business, Warszawa 2008, s. 13. Przeglądu definicji pojęcia 
zwłaszcza ograniczeniu pojęcia sankcji do sumy niekorzystnych skutków za naruszenie prawa, słusznie wskazując, że „liczne są przypadki, w których niepodobna uznać skutków określonych działań w jakimkolwiek znaczeniu za niekorzystne. Sytuacja taka będzie miała miejsce zwłaszcza wtedy, gdy zasadniczym skutkiem określonych działań jest uznanie ich za działania bezprawne, bez przywiązywania do tej ich cechy jakichkolwiek bezpośrednich następstw natury faktycznej lub prawnej"17. Znakomitym przykładem takiej sytuacji w prawie ochrony konkurencji jest sytuacja, w której do naruszenia zakazu praktyk ograniczających konkurencję co prawda doszło, ale naruszenie to zostało zaniechane - wówczas organ ochrony konkurencji wydaje decyzję stwierdzającą naruszenie, ale jednocześnie stwierdzającą zaniechanie nagannego zachowania, może również wówczas odstąpić od nałożenia kary pieniężnej. Z. Kmieciak w odniesieniu do decyzji Prezesa UOKiK zawierających zakazy i nakazy nie posługuje się wprost pojęciem sankcji, ale pojęciem „rozstrzygnięć sankcjonujących”, które odnosi również do kar pieniężnych ${ }^{18}$.

Sankcje $\mathrm{w}$ prawie administracyjnym wiążą się $\mathrm{z}$ reguły $\mathrm{z}$ obowiązkiem świadczenia i w istocie są one środkami przymusu administracyjnego (tj. typowymi sankcjami egzekucyjnymi), których celem jest doprowadzenie do realnego wykonania świadczeń (tj. cel czysto kompensacyjny) ${ }^{19}$. Przyjmując taką definicję sankcji w prawie administracyjnym należy stwierdzić, że prawo ochrony konkurencji dysponuje tylko dwiema sankcjami tego rodzaju - stanowią je: nakaz zaniechania praktyki ograniczającej konkurencję oraz tzw. środki zaradcze.

Sankcjom w prawie administracyjnym przypisuje się również funkcję represji za naruszenie prawa. J. Zimmermann wymienia sankcje karne i egzekucyjne jako „oczywiście” występujące w prawie administracyjnym, a dodatkowo wskazuje na występującą w tej dziedzinie prawa sankcję nieważności, różniącą się jednak tym od cywilnoprawnej sankcji nieważności znanej z prawa ochrony konkurencji, że jest ona skierowana do organów administracyjnych, które wydały akt obarczony kwalifikowaną wadą ${ }^{20} \mathrm{Na}$ gruncie prawa ochrony konkurencji sankcją pierwszego rodzaju będzie kara

sankcji administracyjnej dokonuje M. Stahl, Sankcje administracyjne - problemy wętowe, [w:] M. Stahl, R. Lewicka, M. Lewicki (red.), Sankcje administracyjne, s. 17-30.

17 J. Filipek, Sankcja prawna..., s. 877.

18 Z. Kmieciak, Postępowanie w sprawach ochrony konkurencji a koncepcja procedury hybrydowej, PiP 2002, nr 4, s. 41.

19 A. Gryniuk, Przymus prawny..., s. 42. Należy jednak odnotować wyrażony w polskiej doktrynie pogląd M. Lewickiego, że sankcje egzekucyjne w ogóle nie mieszczą się w pojęciu sankcji, ponieważ nie kształtują one sytuacji prawnej (a jedynie sytuację faktyczną) podmiotu, wobec którego są stosowane - M. Lewicki, Sankcja prawna..., s. 73.

20 J. Zimmermann, Prawo administracyjne, s. 40. 
pieniężna przewidziana w art. 106 ust. 1 pkt 1) uokik, zaś sankcją drugiego rodzaju kara pieniężna za niewykonanie decyzji Prezesa UOKiK, ustanowiona w art. 108 ust. 1 pkt 1) uokik.

Charakterystyczna dla sankcji administracyjnych pozostaje również okoliczność, że sankcje nakładane są zarówno w konsekwencji naruszenia zakazów i nakazów wynikających z przepisów prawnych, jak i aktów administracyjnych ${ }^{21}$.

W piśmiennictwie w obszarze prawa ochrony konkurencji podkreśla się, że w sytuacji, gdy ustawodawca decyduje się na przyjęcie publicznoprawnych środków sankcjonowania naruszeń zakazów praktyk ograniczających konkurencję w postaci środków administracyjno-prawnych antykonkurencyjne zachowania przedsiębiorców uznawane są za „delikty typu administracyjnego” (,delikty antymonopolowe"22), eliminowane za pomocą odpowiednich administracyjnych środków władczych ${ }^{23}$. Przyjmując, że antykonkurencyjne zachowanie w istocie stanowi ,delikt” wobec sankcji stosowanych w prawie ochrony konkurencji zastosowanie znajduje jedna z cech sankcji w prawie administracyjnym, zidentyfikowanych przez J. Filipka, a polegających na zbiegu nieautorytatywnej (tj. wynikającej np. z umowy, deliktu lub innego zdarzenia) i autorytatywnej (decyzja organu administracji) konkretyzacji prawa ${ }^{24}$.

\subsection{Sankcje administracyjne}

\subsubsection{Nakaz zaniechania praktyki ograniczającej konkurencję. Środki zaradcze}

Za podstawowy administracyjno-prawny środek sankcjonowania naruszeń zakazu praktyk ograniczających konkurencję uznawany jest nakaz zaniechania antykonkurencyjnych praktyk ${ }^{25}$. W odróżnieniu od kar pieniężnych

21 M. Lewicki, Sankcja prawna..., s. 69.

22 Por. S. Sołtysiński, Sankcje w ustawie o przeciwdziałaniu praktykom monopolistycznym w gospodarce narodowej, RPEiS 1987, z. 4. Pojęcia „deliktu antymonopolowego” używają w polskim piśmiennictwie również m.in.: K. Kohutek, [w:] K. Kohutek, M. Sieradzka, Ustawa..., s. 1019; M. Błachucki, S Jóźwiak, Sankcje strukturalne..., [w:] M. Stahl, R. Lewicka, M. Lewicki (red.), Sankcje administracyjne, s. 451, 464.

23 M. Sachajko, Administracyjna kara pieniężna jako element systemu sankcjonowania naruszeń wspólnotowych oraz polskich zakazów praktyk ograniczajacych konkurencję, [w:] C. Banasiński, M. Kępiński, B. Popowska, T. Rabska (red.), Aktualne problemy polskiego i europejskiego prawa ochrony konkurencji, UOKiK, Warszawa 2006, s. 190.

24 J. Filipek, Sankcja prawna..., s. 879.

25 Tak. M Sachajko, Administracyjna kara pieniężna..., [w:] C. Banasiński, M. Kępiński, B. Popowska, T. Rabska (red.), Aktualne problemy..., s. 190. 
sankcja ta określona została przez M. Bogomilską-Król jako „typowo administracyjna" ${ }^{26}$. Jest ona stosowana w odniesieniu do obydwu typów praktyk, tj. zarówno antykonkurencyjnych porozumień, jak i nadużywania pozycji dominującej. Sankcji tej należy przypisać głównie egzekucyjny charakter.

Sankcję nakazu zaniechania antykonkurencyjnej praktyki przewiduje zarówno art. 10 uokik, jak i art. 7 ust. 1 rozporządzenia 1/2003. Nakaz zaniechania praktyki ograniczającej konkurencję może być nałożony także przez krajowy organ ochrony konkurencji w ramach przewidzianej w art. 5 tiret pierwsza rozporządzenia 1/2003 decyzji „domagającej się zaprzestania naruszenia".

Sankcja nakazu zaniechania praktyk określona jest w przepisach krajowych i unijnych w sposób pośredni poprzez wskazanie i charakterystykę typów decyzji, jakie organ ochrony konkurencji może wydać po przeprowadzeniu postępowania antymonopolowego.

Nakaz zaniechania antykonkurencyjnych praktyk jest jedyną sankcją publicznoprawną prawa ochrony konkurencji, której nałożenie jest obligatoryjne w przypadku stwierdzenia praktyki ograniczającej konkurencję (nie jest możliwe wydanie decyzji uznającej dane zachowanie za antykonkurencyjną praktykę, a jednocześnie nie nakazujące zaniechania tego działania). Decyzji organu ochrony konkurencji w części, w jakiej nakazuje ona zaniechanie praktyki, niektórzy autorzy przypisują charakter konstytutywny ${ }^{27}$, aczkolwiek nie jest to pogląd dominujący. Za deklaratoryjnym charakterem całej decyzji stwierdzającej praktykę i nakazującą jej zaniechanie przemawia okoliczność, że zakwestionowane przez organ praktyki są niezgodne z prawem od początku ich funkcjonowania ${ }^{28}$.

Mimo podobieństwa sankcji nakazu zaniechania antykonkurencyjnej praktyki, między ukształtowaniem tej sankcji w polskim i unijnym prawie ochrony konkurencji zachodzi zasadnicza różnica. Dotyczy ona możliwego zakresu jej treści - polski ustawodawca sankcję tę ogranicza do nałożenia na przedsiębiorców naruszających zakazy praktyk ograniczających konkurencję ogólnego obowiązku zaniechania praktyki, podczas gdy prawodawca unijny wyposażył Komisję także w kompetencje do zastosowania tzw. środków zaradczych (remedies), tj. wskazania, jakiego rodzaju zachowanie przedsiębiorstw ma służyć nie tylko zaprzestaniu naruszenia, ale także przywróceniu

26 M. Król-Bogomilska, Zmiany $w$ systemie orzekania kar pieniężnych $w$ polskim prawie antymonopolowym po przystapieniu Polski do Unii Europejskiej, Studia Iuridica 2006, z. XLVI, s. 158.

27 Por. K. Kohutek, [w:] K. Kohutek, M. Sieradzka, Ustawa..., s. 421-422; A. Stawicki, [w:] A. Stawicki, E. Stawicki (red.), Ustawa..., s. 388.

28 Tak słusznie C. Banasiński, E. Piontek (red.), Ustawa..., s. 302 (Nb 13). 
skutecznej konkurencji na rynku (ze względu na ingerencję w strukturę konkurencji na rynku sankcje te określa się jako sankcje strukturalne). Korzystanie $\mathrm{z}$ tych kompetencji przez Komisję nie jest przy tym obligatoryjne.

W piśmiennictwie środki zaradcze uznaje się za rodzaj sankcji, podkreślając przy tym ich głównie restytucyjny charakter (co zresztą stanowi podstawę do kwestionowania używania w języku polskim pojęcia „środki zaradcze” jako uwypuklającego domniemaną funkcję prewencyjną tej sankcji ${ }^{29}$. Środki zaradcze należy odróżniać od zobowiązań nakładanych na przedsiębiorców w ramach tzw. decyzji zobowiązujących (art. 12 uokik), których nie należy uznawać za sankcje ${ }^{30}$, ale - jak określił to sam Prezes UOKiK - traktować je jako sposób „polubownego zakończenia postępowań administracyjnych prowadzonych na podstawie ustawy o ochronie konkurencji konsumentów"31.

Polski ustawodawca docenił jednak przydatność sankcji w postaci środków zaradczych i zaproponował jej wprowadzenie w projekcie nowelizacji ustawy z listopada 2012 r. ${ }^{32}$

W aktualnym stanie prawnym Prezes UOKiK, nakazując zaniechanie praktyki, nie może wskazać żadnych warunków zaniechania: ani tego, na czym owo zaniechanie ma polegać (pośrednio wynika to jedynie z uzasadnienia decyzji), ani terminu ${ }^{33}, \mathrm{w}$ jakim przedsiębiorcy mają wywiązać się z nałożonego obowiązku. Co do terminu realizacji nałożonej sankcji, to $\mathrm{w}$ piśmiennictwie wyrażane jest stanowisko, że nakaz zaniechania staje się skuteczny z chwilą uprawomocnienia się decyzji ${ }^{34}$, chyba że został jej

29 A. Piszcz, Kilka uwag do projektu założeń ustawy o zmianie ustawy o ochronie konkurencji i konsumentów, iKAR 2012, nr 2(1), s. 11-12.

30 Pogląd ten podzielają M. Błachucki i S. Jóźwiak, którzy twierdzą, że instrumentów stosowanych w decyzji zobowiązującej „nie można jednak zaliczyć do sankcji administracyjnych sensu stricto, ze względu na cechujący je brak przedmiotowej definitywności rozstrzygnięcia, co do wystąpienia naruszenia” - M. Błachucki, S Jóźwiak, Sankcje strukturalne..., [w:] M. Stahl, R. Lewicka, M. Lewicki (red.), Sankcje administracyjne, s. 457.

31 Pkt I. Wyjaśnień w sprawie wydawania decyzji zobowiązującej w sprawach praktyk ograniczających konkurencję oraz praktyk naruszających zbiorowe interesy konsumentów (Dz. Urz. UOKiK 2012 Nr 1, poz. 2). Krytycznie co do używania sformułowania „polubowny" dla określenia istoty decyzji zobowiązujących - A. Piszcz, Uwagi do Wyjaśnień $w$ sprawie wydawania decyzji zobowiazujacej $w$ sprawach praktyk ograniczajacych konkurencję oraz praktyk naruszających zbiorowe interesy konsumentów, iKAR 2012, nr 4(1), s. 21.

32 Por. art. 1 pkt 6 projektu ustawy o zmianie ustawy o ochronie konkurencji i konsumentów z dnia 21 listopada 2012 r. (nowy art. 10 ust. 4-8 uokik).

33 Por. wyrok SAM z dnia 21 października 1998 r., XVII Ama 50/98, LEX nr 56137.

34 Tak E. Modzelewska-Wąchal, Ustawa o ochronie konkurencji i konsumentów. Komentarz, Twigger, Warszawa 2002, s. 126; K. Kohutek, [w:] K. Kohutek, M. Sieradzka, Ustawa..., 
nadany rygor natychmiastowej wykonalności. Choć poglądowi temu nie można odmówić pewnej słuszności, szczególnie w sytuacji, gdy w związku $\mathrm{z}$ pozostawaniem $\mathrm{w}$ zwłoce $\mathrm{w}$ wykonaniu decyzji na przedsiębiorców może zostać nałożona kara pieniężna, to akceptacja wskazanego stanowiska oznacza de facto sanowanie przez organ ochrony konkurencji antykonkurencyjnej praktyki do czasu uprawomocnienia się decyzji.

Nakaz zaniechania praktyki nie jest jednoznaczny z nakazem usunięcia skutków naruszenia. W literaturze przedmiotu podkreśla się, że faktyczne efekty zastosowania się przedsiębiorców do omawianej sankcji mogą w istocie polegać na zniesieniu (jeśli nie w całości, to przynajmniej częściowo) negatywnych skutków praktyki, np. jeśli praktyka polegała na stosowaniu umów z antykonkurencyjnymi klauzulami zaniechaniem praktyki będzie nie tylko zaprzestanie zawierania kwestionowanych umów, ale również wycofanie takich istniejących (obowiązujących) umów z obrotu ${ }^{35}$. Ze stanowiskiem takim w polskim piśmiennictwie nie zgadza się A. Stawickie, słusznie twierdząc, że skoro umowy takie (w całości lub części) są dotknięte nieważnością, to przedsiębiorca i tak jest zmotywowany do ich zmiany ${ }^{36}$.

Omawiana sankcja nie obejmuje również nakazu zapobiegania antykonkurencyjnym skutkom, które miałyby powstać w przyszłości, choć faktycznie sankcja spełnia taką funkcję, jako że określona praktyka nie będzie kontynuowana.

Prezes UOKiK nie ma zatem żadnych możliwości szczegółowego kształtowania zachowań przedsiębiorców, potencjalne sugestie organu na czym miałoby polegać zaniechanie praktyki są o tyle nieskuteczne, że - jak uznał SAM - „niezastosowanie się do tych sugestii nie może być utożsamiane z niewykonaniem decyzji" 37 .

Inaczej niż polski organ ochrony konkurencji, w zakresie precyzowania wymaganych zachowań przedsiębiorstw, Komisja ma do wyboru środki behawioralne lub strukturalne, wszystkie te środki mają jednak służyć wyeliminowaniu lub neutralizowaniu istniejących skutków naruszeń ${ }^{38}$. Rozporządzenie 1/2003 nie zawiera definicji legalnej tych kategorii środków, definicji tej nie zna także rozporządzenie 139/2004, mimo że w dziedzinie kontroli koncen-

s. 422; A. Stawicki, [w:] A. Stawicki, E. Stawicki (red.), Ustawa..., s. 388; C. Banasiński, E. Piontek (red.), Ustawa..., s. 298 (Nb 6).

35 Por. C. Banasiński, E. Piontek (red.), Ustawa..., s. 298 (Nb 6).

36 A. Stawicki, [w:] A. Stawicki, E. Stawicki (red.), Ustawa..., s. 387.

37 Wyrok SAM z dnia 8 października 2001 r., XVII Ama 113/00, niepubl.

38 K. Kohutek, Komentarz do art. 7. Teza 7.4, [w:] K. Kohutek, Komentarz do rozporzadzenia 1/2003, el/LEX 2006. 
tracji środki tego rodzaju mogą być również stosowane przez Komisję ${ }^{39}$. Pewnych wskazówek co do istoty środków zaradczych dostarcza co najwyżej zawiadomienie Komisji w sprawie środków zaradczych dopuszczalnych na mocy rozporządzenia Rady (WE) nr 139/2004 i rozporządzenia Komisji (WE) nr 802/200440. Trzeba jednak podkreślić, że z dużą ostrożnością należy podchodzić do analogii między środkami zaradczymi w odniesieniu do koncentracji i praktyk ograniczających konkurencję, choćby z tego względu, że w przypadku tych pierwszych Komisja preferuje środki strukturalne przed behawioralnymi ${ }^{41}$, podczas gdy brzmienie art. 7 ust. 1 zd. trzecie rozporządzenia 1/2003 wskazuje na pierwszeństwo środków behawioralnych przed strukturalnymi (zasada względnego pierwszeństwa ${ }^{42}$ ) - te ostatnie mogą być stosowane wówczas, gdy nie istnieją równie skuteczne środki behawioralne lub gdy równie skuteczne środki behawioralne byłyby bardziej uciążliwe dla zainteresowanych przedsiębiorstw niż środki strukturalne ${ }^{43}$. W doktrynie prawa ochrony konkurencji środki behawioralne definiuje się jako takie, które obligują naruszyciela do określonego zachowania ${ }^{44}$. Do środków behawioralnych stosowanych w przypadku praktyk ograniczających konkurencję zalicza się zobowiązania do m.in. udzielenia dostępu do tzw. urządzenia kluczowego, zmiany lub niestosowania określonych warunków umownych, zmiany wysokości cen, wznowienia dostaw, udzielenie licencji praw wyłącznych, świadczenie określonych usług na niedyskryminacyjnych warunkach. Warto podkreślić, że w przeszłości za środki o zbliżonym do środków zaradczych charakterze mogła być uznana - przewidziana w art. 8 ust. 3 uppm - możliwość obniżenia ceny podwyższonej wskutek stosowania praktyki monopolistycznej lub możliwość określenia kwoty nienależnej, uzyskanej przez przedsiębiorcę $\mathrm{w}$ okresie stosowania zawyżonej ceny ${ }^{45}$, przy czym kompetencja organu antymonopolowego ograniczała się do sformułowania samego obowiązku rozliczenia określonej kwoty, bez możliwości doko-

39 Por. art. 8 ust. 4 rozporządzenia 139/2004.

40 Dz. Urz. UE 2008 C 267, s. 1; dalej jako zawiadomienie o środkach zaradczych.

41 Pkt 15 zawiadomienia o środkach zaradczych.

42 Tak M. K. Kolasińki, A. Kustra, Konstytucyjne standardy ochrony przedsiębiorcy a środki zaradcze we wspólnotowym prawie konkurencji, EPS 2008, Nr 5, s. 18.

43 Por. motyw 12 preambuły do rozporządzenia 1/2003.

44 Tak m.in. K. Kohutek, Komentarz do art. 7. Teza 4, [w:] K. Kohutek, Komentarz do rozporzadzenia $1 / 2003 \ldots$.

45 W czasie, gdy polski organ ochrony konkurencji mógł korzystać z tego typu środków zaradczych, nie mogła tego robić Komisja, ponieważ rozporządzenie 17/62 nie przewidywało stosownych kompetencji. 
nywania szczegółowego rozliczenia ${ }^{46}$, a w orzecznictwie przyjęto również wówczas, że „nakaz obniżenia ceny może dotyczyć okresu do daty wydania decyzji, a nie okresu przyszłego" 47 (de facto zatem art. 8 ust. 3 uppm raczej pozwalał na precyzowanie warunków naruszenia niż stosowanie środków zaradczych w ich obecnym rozumieniu).

Za środki strukturalne uznaje się z kolei te, które ingerują w strukturę (kapitałową, organizacyjną, personalną) ${ }^{48}$ przedsiębiorstwa. W motywie 12 preambuły rozporządzenia 1/2003 Rada uściśliła, że zmiany dotyczące struktury przedsiębiorstwa, która istniała przed naruszeniem są możliwe tylko wówczas, „gdy występuje znaczne ryzyko trwania lub powtórzenia naruszenia spowodowanego samą strukturą przedsiębiorstwa"; dodatkowym warunkiem stosowania środków strukturalnych jest również - wzmiankowana już powyżej - nadmierna uciążliwość lub niemożliwość zastosowania środków behawioralnych. Środkiem strukturalnym może być np. nakaz powierzenia wykonywania określonego rodzaju działalności przez daną jednostkę w ramach grupy kapitałowej.

Zarówno środki behawioralne, jak i strukturalne mogą być stosowane przez Komisję tylko wówczas, gdy są proporcjonalne oraz konieczne do zakończenia naruszenia, słusznie podnosi się przy tym w doktrynie, że wymóg proporcjonalności wynika już z unijnego prawa pierwotnego ${ }^{49}$.

Chociaż już sam nakaz zaniechania praktyk ograniczających konkurencję pozwala wpływać w pewnym stopniu na sytuację na rynku, wpływ ten jest znacząco większy w przypadku zastosowania środków behawioralnych, największy zaś - w przypadku środków strukturalnych.

Uzasadnione jest postrzeganie środków zaradczych jako formy ograniczenia wolności gospodarczej i ingerencję w prawo własności, w związku z czym zasadne jest pytanie o ich konstytucyjność (w świetle art. 22 Konstytucji RP przewidującego możliwość ograniczenia wolności gospodarczej tylko w drodze ustawy i ze względu na ważny interes publiczny oraz - w odniesieniu do środków strukturalnych - w świetle art. 21 ust. 2 Konstytucji RP stanowiącego o możliwości wywłaszczenia tylko na cele publiczne za słusznym odszkodowaniem). W polskim piśmiennictwie wyrażony został jednak

46 Por. wyrok SAM z dnia 5 września 2001 r., XVII Ama 103/00, Dz. Urz. UOKiK 2001 $\mathrm{Nr} 3$, poz. 125.

47 Wyrok SN z dnia 29 maja 1991 r., III CRN 120/91, OSNCP 1992, z. 5, poz. 87.

48 Tak m.in. K. Kohutek, Komentarz do art. 7. Teza 4, [w:] K. Kohutek, Komentarz do rozporzadzenia 1/2003...; M. K. Kolasiński, A. Kustra, Konstytucyjne standardy ochrony..., s. 18.

49 Tak K. Kohutek, Komentarz do art. 7. Teza 4.1, [w:] K. Kohutek, Komentarz do rozporzadzenia $1 / 2003 .$. 
pogląd o zgodności środków zaradczych stosowanych w prawie unijnym ze standardami konstytucyjnymi ${ }^{50}$, choć SA w Warszawie odnosząc się do samej możliwości precyzowania przez Prezesa UOKiK obowiązku zaniechania praktyk ograniczających konkurencję uznał, że „naruszałoby to zasadę samodzielności przedsiębiorcy będącą jedną z podstawowych zasad organizujących działalność gospodarczą w warunkach gospodarki rynkowej"51.

Uwypuklenia wymaga również fakt, że decyzje organu ochrony konkurencji nakładające na przedsiębiorców przynajmniej niektóre ze środków zaradczych, takie jak np. obowiązek zawarcia umowy, wywołują nie tylko skutki administracyjne, ale również cywilnoprawne, co stanowi dodatkowy obszar styku publicznego i prywatnego trybu egzekwowania prawa ochrony konkurencji. W sytuacji, gdy środkiem zaradczym był np. obowiązek zawarcia umowy, a środek ten nie został wykonany przez zobowiązanego w decyzji przedsiębiorcę, organy ochrony konkurencji mogą egzekwować ten obowiązek za pomocą dodatkowych kar pieniężnych za niewykonanie decyzji; nie ma jednak przeszkód, aby tego rodzaju skutek cywilnoprawny aktu administracyjnego mógł być egzekwowany również przez podmiot prywatny (podmiot, z którym miała być zawarta umowa) na drodze sądowej52. W przypadku wystąpienia na drogę sądową sąd powszechny nie będzie miał kompetencji do badania samej decyzji administracyjnej, ale będzie niejako wspomagał organ ochrony konkurencji w wykonaniu tej decyzjis3.

Środki zaradcze postrzegane są jako na tyle skuteczne instrumenty egzekwowania polityki konkurencji, że również w Polsce rozważane jest ich wprowadzenie. W projekcie założeń projektu ustawy o zmianie ustawy o ochronie konkurencji i konsumentów UOKiK przyznał, że przedstawione propozycje są wzorowane na rozwiązaniach unijnych ${ }^{54}$. Projekt - podobnie jak unijny pierwowzór - przewiduje dwustopniowy charakter środków zaradczych, przejawiający się $\mathrm{w}$ tym, że pierwszeństwo stosowania miałyby mieć środki behawioralne, środki strukturalne stosowane byłyby tylko w wyjątkowych okolicznościach. Inaczej niż w rozporządzeniu 1/2003 uokik miałaby zawierać otwarty katalog środków behawioralnych. Prezes UOKiK miałby określać termin wykonania określonych obowiązków nie wcześniejszy niż termin przypadający po uprawomocnieniu się decyzji.

50 Tak M. K. Kolasiński, A. Kustra, Konstytucyjne standardy ochrony..., s. 17-21.

51 Wyrok SA w Warszawie z dnia 22 czerwca 2007 r., VI ACa 8/07, niepubl.

52 Por. T. Smyczyński, Skutki cywilnoprawne aktu administracyjnego, Nowe Prawo 1971, nr 1, s. 40, 42-44.

53 Ibidem, s. 45.

54 Por. Projekt założeń projektu ustawy o zmianie ustawy o ochronie konkurencji i konsumentów (projekt z dnia 15 maja 2012 r.), s. 13-15. 
Sankcja w postaci nakazu zaniechania zakazanej praktyki (i ewentualne towarzyszące jej środki zaradcze) może być nakładana na przedsiębiorcę tylko w sytuacji, gdy nie doszło do zaprzestania praktyki w chwili orzekania ${ }^{55}$. Jeśli w toku prowadzonego postępowania antymonopolowego praktyka ustała, a więc nakaz zaniechania praktyki ograniczającej konkurencję stał się bezprzedmiotowy, Prezes UOKiK orzekając o naruszeniu art. 6 lub 9 uokik wydaje na podstawie art. 11 ust. 2 uokik decyzję uznającą praktykę za ograniczającą konkurencję i jednocześnie stwierdzającą zaniechanie jej stosowania, natomiast orzekając o naruszeniu art. 101 lub 102 TFUE może jedynie wydać decyzję stwierdzającą, że „nie ma podstaw do działania” z jego strony (tj. wydać decyzję umarzająca postępowanie na podstawie art. 105 $\S 1$ k.p.a. $)^{56}$. Ewentualny ciężar dowodu, że praktyka została zachowana spoczywa na przedsiębiorcy; słusznie wskazuje się w piśmiennictwie, że jeśli nawet przedsiębiorca zaniechał praktyki, ale nie poinformował o tym organu i nie udowodnił tego, właściwe jest nakazanie adresatowi decyzji zaniechania praktyki ${ }^{57}$.

Za odpowiednik sankcji nakazu zaniechania praktyk w obszarze prywatnego egzekwowania prawa konkurencji można uznać roszczenie o zaniechanie naruszenia ${ }^{58}$, natomiast środki zaradcze mogą przypominać roszczenie o przywrócenie stanu poprzedniego lub roszczenie o usunięcie skutków naruszenia ${ }^{59}$. Zbieżność istoty tych sankcji w publicznym i prywatnym trybie egzekwowania prawa ochrony konkurencji powoduje, że uprzednie zastosowanie tych sankcji w trybie publicznym sprawia, że bezprzedmiotowe staje się wniesienie - jako roszczeń następczych - wskazanych powyżej roszczeń o zaniechanie naruszenia - a w zależności od zastosowanych środków zaradczych - także roszczeń o przywrócenie stanu poprzedniego lub roszczeń o usunięcie skutków naruszenia.

55 Por. art. 11 ust. 1 uokik. Tak również A. Stawicki, [w:] A. Stawicki, E. Stawicki (red.), Ustawa..., s. 386.

56 Por. wyrok TS z dnia 3 maja 2011 r. w sprawie C-375/09 Prezes UOKiK v. Tele2 (dotąd niepubl.), w którym TS stwierdził, że sprzeczne z art. 5 rozporządzenia 1/2003 jest wydanie przez organ krajowy „decyzji stwierdzającej brak naruszenia art. 102 TFUE w sytuacji, gdy w celu zastosowania tego postanowienia organ ten bada, czy spełnione zostały przesłanki tego zastosowania, a następnie uznaje, iż nie doszło do nadużycia pozycji dominującej”.

57 C. Banasiński, E. Piontek (red.), Ustawa..., s. 297 (Nb 4).

58 Por. pkt 7.8.2. w niniejszym rozdziale.

59 Por. pkt 7.8.3. w niniejszym rozdziale. 


\subsubsection{Kary pieniężne}

W większości systemów prawnej ochrony konkurencji naruszenie zakazów praktyk ograniczających konkurencję jest poddane sankcjonowaniu w postaci kar pieniężnych.

Zasadniczą funkcją tych sankcji pozostaje represja (negatywne skutki dla sfery majątkowej podmiotu ukaranego) oraz powiązana z nią prewencja (zapobieganie podobnym naruszeniom prawa w przyszłości); słusznie wskazuje się przy tym, że ograniczanie funkcji kar w prawie antymonopolowym do funkcji retrybutywnej jest zbyt wąskie ${ }^{60}$. Niekiedy jako funkcję odrębną od prewencji wskazuje się również funkcję wychowawczą ${ }^{61}$, choć - w moim przekonaniu - funkcja wychowawcza realizowana jest przez funkcję prewencyjną, w zakresie prewencji ogólnej. Jedynie pośrednio sankcje tego rodzaju mogą służyć zabezpieczeniu wykonania obowiązków wyznaczonych przez normę prawną ${ }^{62}$ Na represyjny i prewencyjny charakter kar pieniężnych $\mathrm{w}$ prawie antymonopolowym wskazuje się tak w piśmiennictwie ${ }^{63}$, jak i w orzecznictwie krajowym ${ }^{64}$ i unijnym. Represyjność kar pieniężnych odzwierciedlona jest $\mathrm{w}$ - ustanowionym przez prawodawcę unijnego (art. 23 ust. 3 rozp. 1/2003) i krajowego (art. 111 uokik) - wymogu uwzględniania przy nakładaniu kary stopnia (ciężaru) naruszenia oraz czasu jego trwania ${ }^{65}$, a także - tylko w przypadku prawa krajowego - okoliczności naruszenia przepisów i uprzedniego naruszenia przepisów ustawy.

Ze względu na administracyjny rodowód prawa ochrony konkurencji kary te są określane jako administracyjne kary pieniężne ${ }^{66}$, niemniej jednak

60 Por. M. Król-Bogomilska, Kary pieniężne naktadane na przedsiębiorców w świetle polskiego i wspólnotowego prawa konkurencji, SE 1998, nr 3, s. 137-138.

61 A. Stawicki, [w:] A. Stawicki, E. Stawicki (red.), Ustawa..., s. 1165.

62 M. Sachajko, Istota i charakterystyka prawna antymonopolowych kar pieniężnych, RPEiS 2002, nr 1, s. 60.

63 Por. w polskiej literaturze m.in. M. Król-Bogomilska, [w:] T. Skoczny, A. Jurkowska, D. Miąsik (red.), Ustawa..., s. 3 (Nb 3); C. Banasiński, E. Piontek (red.), Ustawa..., s. 949 (Nb 7); K. Kohutek, [w:] K. Kohutek, M. Sieradzka, Ustawa ..., s. 1015 (Nb 1).

64 Por. wyroki SN: z dnia 27 sierpnia 2003 r., I CKN 185/03, Dz. Urz. UOKiK 2004 Nr 1; z dnia 24 kwietnia 1996 r., I CRN 49/96, OSNCP 1996, nr 9, poz. 124 (SN wskazał tu na funkcję represyjno-wychowawczą).

65 Tak również W. Moshel, Fines in European competition law, E.C.L.R. 2011, vol. 32(7), s. 370.

66 Administracyjnego charakteru kar pieniężnych przewidzianych w ustawie o ochronie konkurencji i konsumentów nie kwestionował M. Stefaniuk - por. tenże, Zasady wymierzania kar pieniężnych $w$ polskim prawie antymonopolowym, [w:] M. Stahl, R. Lewicka, M. Lewicki (red.), Sankcje administracyjne..., s. 327-338. R. Stankiewicz, uznając co do zasady administracyjny charakter tych kar, przyznaje, że ,jako instrument prawa admi- 
funkcja, jaką kary te odgrywają, skłania do klasyfikowania ich jako sankcji karnych. Kontrowersje wokół określenia charakteru tych kar zasygnalizowane zostały już w rozdziale $\mathrm{II}^{67}$.

W prawie unijnym art. 23 ust. 5 rozporządzenia $1 / 2003^{68}$ przesądza co prawda o tym, że kary nakładane przez Komisję nie mają charakteru sankcji karnych, jednak zastrzeżenie to jest dość powszechnie kwestionowane w doktrynie. Wśród najważniejszych argumentów przemawiających za prawnokarną naturą kar pieniężnych w prawie unijnym wymienia się okoliczność, że podnoszenie poziomu kar za naruszenia zakończone w przeszłości stanowi pogwałcenie zasady nieretroaktywnego działania prawa, a połączenie przepisu art. 23 ust. 5 rozporządzenia 1/2003 z programem leniency narusza domniemanie niewinności oraz zasadę wolności od samooskarżenia ${ }^{69}$. Wreszcie, wskazuje się, że rozporządzenie 1/2003 należy do kategorii prawa wtórnego, które musi pozostawać w zgodzie z prawem pierwotnym, w tym z Kartą praw podstawowych, oraz z EKPC ${ }^{70}$.

Kategoria kar pieniężnych przewidzianych w prawie ochrony konkurencji nie jest jednolita. Prawodawstwo z zakresu ochrony konkurencji przewiduje dwa rodzaje kar pieniężnych: kary pieniężne za naruszenie przepisów materialnoprawnych oraz kary za naruszenia proceduralne. W polskiej ustawie o ochronie konkurencji i konsumentów pierwszy ze wskazanych rodzajów kar przewidziany jest $\mathrm{w}$ art. 106 ust. 1, drugi - w art. 106 ust. 2, art. 107 i art. $108^{71}$. Niektórzy autorzy dokonują innej klasyfikacji kar pieniężnych - M. Sachajko dzieli je na administracyjne kary pieniężne (za naruszenia materialne), kary pieniężne w celu przymuszenia (ich celem jest przymuszenie adresata do wykonania decyzji administracyjnej) oraz środki przymusu proceduralnego (których celem jest zapewnienie prawidłowości przebiegu

nistracyjnego, posiadają (...) wiele elementów karnoprawnych, szczególnie związanych z ustalaniem" - por. tenże, Kilka uwag o istocie administracyjnej kary pieniężnej z tytutu zwtoki $w$ wykonaniu orzeczenia Prezesa UOKiK (art. 107 ustawy antymonopolowej), [w:] M. Stahl, R. Lewicka, M. Lewicki (red.), Sankcje administracyjne..., s. 373.

67 Por. rozdział II, pkt 2.2.4.

68 Przepis ten powtarza treść art. 15 rozporządzenia 17/62.

69 Tak W. Moshel, Fines in European competition law, s. 369.

70 D. Slater, S. Thomas, D. Waelbroeck, Competition law proceedings before the European Commission and the right to a fair trial: no need for reform?, European Competition Journal 2009, vol. 5(1), s. 97-142.

71 Artykuł 108 uokik przewiduje możliwość nakładania kar na osoby fizyczne pełniące funkcję kierowniczą lub wchodzące w skład organu zarządzającego przedsiębiorcy (art. 108 ust. 1) bądź na osobę upoważnioną przez kontrolowanego przedsiębiorcę lub na świadków (art. 108 ust. 2). Przepis ten nie ma swojego odpowiednika w rozporządzeniu 1/2003. 
postępowania antymonopolowego) ${ }^{72}$. Przedmiotem niniejszych rozważań są wyłącznie kary za naruszenia materialnoprawnych zakazów praktyk ograniczających konkurencję ${ }^{73}$.

Sankcje w postaci kar pieniężnych mogą mieć charakter samoistny (jeśli karę nakłada się w sytuacji stwierdzenia, że przedsiębiorca zaniechał praktyki ograniczającej konkurencję) lub komplementarny (jeśli towarzyszy nakazowi zaniechania antykonkurencyjnej praktyki) ${ }^{74}$. Polska ustawa o ochronie konkurencji i konsumentów nie zawiera w pełni autonomicznej regulacji procesowej dotyczącej nakładania $\operatorname{kar}^{75}$ - na mocy odesłania z art. 85 uokik stosuje się przepisy ogólne o postępowaniu przed Prezesem UOKiK.

Inaczej niż ma to miejsce w przypadku nakazu zaniechania antykonkurencyjnych praktyk, nałożenie kary pieniężnej na przedsiębiorcę ma charakter fakultatywny, co czyni tę sankcję ważnym instrumentem kształtowania polityki antymonopolowej, a jednocześnie wyznacza jej rolę komplementarną wobec nakazu zaniechania antykonkurencyjnych praktyk ${ }^{76}$. Organy moga nie nałożyć kary pieniężnej w sytuacji, gdy kwestionowana praktyka, choć o potwierdzonym antykonkurencyjnym skutku, ma jednak charakter precedensowy i nie podlega prostym klasyfikacjom w ramach otwartych katalogów praktyk ograniczających konkurencję77 bądź gdy w toku postępowania antymonopolowego organ stwierdził zaniechanie praktyki.

Fakultatywność w zakresie kar pieniężnych przejawia się nie tylko w swobodzie decyzji co do faktu nałożenia kary, ale także w tym, że tak prawodawca unijny, jak i polski jedynie szczątkowo regulują zasady obciążania karą i kryteria jej wysokości, poprzestając na wskazaniu maksymalnego pułapu kary. Swobodne uznanie organów ochrony konkurencji w zakresie nakładania kar pieniężnych ${ }^{78}$ nie oznacza dowolności stosowania tej sankcji,

72 Por. M. Sachajko, Istota i charakterystyka..., s. 57-78.

73 Na temat kar w celu przymuszenia por. m.in. M. Sachajko, Istota i charakterystyka..., s. $64-71$.

74 C. Banasiński, E. Piontek (red.), Ustawa..., s. 945 (Nb 2).

75 Z. Kmieciak, Postępowanie w sprawach ochrony konkurencji..., s. 41.

76 M. Król-Bogomilska, [w:] T. Skoczny, A. Jurkowska, D. Miąsik (red.), Ustawa .., s. 1608 (Nb 18); C. Banasiński, E. Piontek (red.), Ustawa..., s. 947 (Nb 3), s. 950 (Nb 8).

77 Por. wyrok SOKiK z dnia 29 maja 2006 r., XVII Ama 9/05, Dz. Urz. UOKiK 2006 Nr 4, poz. 58; decyzja Komisji 2001/892/WE z dnia 25 lipca 2001 r. Deutsche Post/British Post Office. Stanowisko takie w polskim piśmiennictwie podzielają: M. Król-Bogomilska, [w:] T. Skoczny, A. Jurkowska, D. Miąsik (red.), Ustawa..., s. 1606-1608 (Nb 17) oraz A. Stawicki, [w:] A. Stawicki, E. Stawicki (red.), Ustawa..., s. 1164-1165.

78 W doktrynie panuje zgoda co do tego, że decyzja Prezesa UOKiK wydana na podstawie art. 106 uokik podejmowana jest w ramach uznania administracyjnego - por. M. Wincenciak, Sankcje w prawie..., s. 121 i n.; M. Król-Bogomilska, [w:] T. Skoczny, A. Jurkowska, D. Miąsik (red.), Ustawa..., s. 1602 (Nb 7). 
w doktrynie sformułowano wiele wytycznych odnoszących się do polityki karania realizowanej przez organy ochrony konkurencji. Wskazuje się, że organ powinien kierować się ogólnymi zasadami m.in. zasadą równości (zasadą jednakowego traktowania przedsiębiorców ${ }^{79}$ ), czy zasadą proporcjonalności ${ }^{80}$. Szczegółowe zasady polityki karania zostały określone przez organy ochrony konkurencji w aktach prawa miękkiego: wytycznych Komisji oraz wyjaśnieniach Prezesa UOKiK. Dokumenty te, choć status takich aktów jest przedmiotem licznych kontrowersji, stanowią istotną gwarancję stałości praktyki organów (pośrednio - pewności prawa) w zakresie karania.

Nawet w przypadku praktyk kolektywnych kary pieniężne nakładane są indywidualnie na każdego uczestnika porozumienia lub każdego przedsiębiorcę nadużywającego pozycji dominującej wespół (kolektywnie) z innymi, jednak subiektywne podstawy nakładania kar pieniężnych budzą w piśmiennictwie nadal sporo kontrowersji. Artykuł 106 ust. 1 i ust. 2 uokik jako przesłankę nałożenia kary wskazuje, że naruszenie (odpowiednio materialne lub proceduralne) musi nastąpić „choćby nieumyślnie”, natomiast art. 23 ust. 1 i 2 rozp. 1/2003 mówią o naruszeniu „umyślnie lub w wyniku zaniedbania”. W piśmiennictwie zwraca się uwagę na fakt, że w prawie unijnym nie ma możliwości nałożenia kary, jeśli naruszenie nastąpiło wskutek lekkomyślności ${ }^{81}$.

W odniesieniu do prawa krajowego winę jako konieczną przesłankę nałożenia kary administracyjnej wskazał również Trybunał Konstytucyjny w wyroku z dnia 1 marca 1994 r., U 7/9382.

M. Król-Bogomilska słusznie zwraca uwagę na fakt ${ }^{83}$, że mimo posłużenia się przez ustawodawcę kategorią „umyślności”/„nieumyślności”, w polskim piśmiennictwie i orzecznictwie dominujące pozostaje pojęcie „winy” lub „zawinienia”. Bez względu jednak na używaną terminologię, kategorie te nie są jednolicie definiowane w literaturze. „Zawinienie” rozumiane jest jako rozeznanie lub świadomość bezprawności postępowania ${ }^{84}$. „Umyślność” jako - pierwotnie - przesłanka nałożenia kary i - wtórnie - jako przesłanka

79 Por. M. Król-Bogomilska, [w:] T. Skoczny, A. Jurkowska, D. Miąsik (red.), Ustawa..., s. $1601(\mathrm{Nb} \mathrm{6)}$.

80 C. Banasiński, E. Piontek (red.), Ustawa..., s. 954 (Nb 17).

81 T. Skoczny, Konsekwencje przyszłego systemu stosowania art. 81 i 82 TWE dla prawa i orzecznictwa $w$ zakresie ochrony konkurencji $w$ Polsce (cz. II), PUE 2001, nr 5, s. 6.

82 OTK 1994, nr 1, poz. 5.

83 Por. M. Król-Bogomilska, [w:] T. Skoczny, A. Jurkowska, D. Miąsik (red.), Ustawa..., s. $1629(\mathrm{Nb} 66)$.

84 S. Gronowski, Polskie prawo antymonopolowe. Zarys wyktadu, Wyd. Zrzeszenia Prawników Polskich, Warszawa 1998, s. 250; K. Kohutek, [w:] K. Kohutek, M. Sieradzka, Ustawa..., s. 1027. 
wysokości kary, koreluje z fakultatywnością nakładania sankcji tego typu - odpowiedzialność za naruszenie zakazów antykonkurencyjnych praktyk jest obiektywna, niezależna od świadomości bezprawności, natomiast nałożenie kary pieniężnej warunkowane jest choćby najmniejszym poziomem zawinienia ${ }^{85}$.

Rozumienie pojęcia winy wypracowane w orzecznictwie i piśmiennictwie antymonopolowym może posłużyć za cenną wskazówkę dla oceny przesłanki winy w ramach roszczeń odszkodowawczych i innych, dla których realizacji niezbędne jest wykazanie przesłanki winy (np. roszczenie o zasądzenie odpowiedniej kwoty na cel społeczny związany ze wspieraniem kultury polskiej lub ochroną dziedzictwa narodowego na podstawie art. 18 ust. 1 pkt 6 uznk) w prywatnym modelu egzekwowania zakazów antykonkurencyjnych praktyk ${ }^{86}$.

Obraz kar pieniężnych jako sankcji administracyjnych kształtowany jest współcześnie także przez zastosowanie programu darowania i łagodzenia kar (leniency), pozwalającego na modyfikację wysokości kary, a nawet „amnestię" po spełnieniu przez przedsiębiorcę naruszającego zakaz porozumień ograniczających konkurencję warunków określonych w art. 109 uokik lub w obwieszczeniu leniency Komisji. Programy darowania i łagodzenia kar postrzegane są jako sztandarowy niemal instrument wzmocnienia efektywności publicznego egzekwowania zakazu antykonkurencyjnych porozumień ${ }^{87}$, przy czym w prawie unijnym instrument ten wymierzony jest wyłącznie w kartele, natomiast w Polsce - we wszystkie, także wertykalne antykonkurencyjne porozumienia. Egzekwowanie zakazu antykonkurencyjnych porozumień na drodze prywatnoprawnej wobec przedsiębiorców objętych leniency stanowi jedno z najpoważniejszych wyzwań dla ukształtowania zrównoważonego modelu egzekwowania prawa ochrony konkurencji. $Z$ jednej strony publiczne organy ochrony konkurencji chcą utrzymać leniency jako narzędzie skuteczności polityki konkurencji poprzez zapewnienie przedsiębiorcom przystępującym do programu maksymalnej liczby zachęt oraz znacznego zakresu „bezkarności” (czy raczej „bezsankcyjności”), z drugiej strony stwarzanie po stronie prywatnego egzekwowania prawa ochrony konkurencji preferencyjnych warunków dla uczestników leniency godzi w wielu aspektach

85 Należy zaznaczyć, że pogląd uznający winę za przesłankę nałożenia kary nie jest powszechny - por. K. Kohutek, [w:] K. Kohutek, M. Sieradzka, Ustawa..., s. 1027.

86 Por. pkt 7.8.6. w niniejszym rozdziale.

87 O efektywności programów leniency świadczą wyniki analiz ekonomicznych - N. H. Miller szacuje, że leniency zmniejsza liczbę powstających karteli o $42 \%$ i zwiększa ich wykrywalność o $62 \%$ (dane dotyczą USA) - por. N. H. Miller, Strategic Leniency and Cartel Enforcement, American Economic Review 2009, vol. 99, s. 750. 
w podstawowe założenia odpowiedzialności cywilnoprawnej. Zagadnienia te są szerzej omawiane w innych częściach niniejszej rozprawy 88 .

Jak już sygnalizowałam w rozdziale II $^{89}$, w moim przekonaniu, kary pieniężne nakładane na osoby fizyczne za naruszenie materialnych reguł konkurencji powinny mieć charakter sankcji prawnokarnych. Obecnie sankcje polegające na nałożeniu kary pieniężnej (grzywny) na osobę fizyczną, przy wskazaniu, że są to sankcje administracyjne (za delikty administracyjne) przewidziane są m.in. w Niemczech ${ }^{90}$, Holandii i Portugalii ${ }^{91}$. Rozwiązanie holenderskie jest o tyle specyficzne, że sankcje dla osób fizycznych w ustawie o ochronie konkurencji ustanowione są poprzez odwołanie do kodeksu karnego i ustawy Prawo administracyjne ${ }^{92}$. Planowana nowelizacja ustawy o ochronie konkurencji nie nadaje jednak karom nakładanym na osoby fizyczne charakteru karnoprawnego, ale pozostawia je w sferze sankcji administracyjnoprawnych ${ }^{93}$.

\subsection{Antymonopolowe sankcje karne}

\subsubsection{Uwagi wstępne}

Wśród podstawowych kryteriów identyfikacyjnych sankcji karnej w piśmiennictwie wskazuje się: dolegliwość, powszechny charakter, a także funkcję retrybutywną oraz cel w postaci prewencji ogólnej94. Sankcjom kar-

88 Por. pkt 7.9. w niniejszym rozdziale oraz rozdział V, pkt 5.3.4.3.

89 Rozdział II, pkt 2.2.

90 Kara pieniężna nakładana na osoby fizyczne może wynosić do 1 mln EUR (w przypadku naruszenia umyślnego) lub do 500 tys. EUR (w przypadku naruszenia nieumyślnego). Sankcje mogą być nałożone na dyrektorów oraz niektórych wyższych rangą menadżerów, nie mogą być ukarani pracownicy niższego szczebla - w przypadku naruszenia przez nich reguł konkurencji na personel wyższego szczebla może zostać nałożona kara za niewłaściwe wykonywanie obowiązku nadzoru - M. Dietrich, P. von Hülsen, Germany: Cartels, [w:] The European Antitrust Review 2012, dostępne pod adresem: http://www. globalcompetitionreview.com/reviews/37/sections/132/chapters/1394/germany-cartels/.

91 Kara pieniężna nakładana na osobę fizyczną może wynosić maksymalnie do $10 \%$ rocznego dochodu, obliczonego dla ostatniego roku, w którym praktyka była realizowana - por. art. 69 ust. 4 ustawy nr 19/2012 z dnia 8 maja 2012 r.

92 Por. art. 57 ustawy o ochronie konkurencji w związku z art. 51 ust. 2 pkt 2 niderlandzkiego kodeksu karnego i art. 5:1 ust. 3 ustawy Prawo administracyjne.

93 Por. art. 1 pkt 59 projektu ustawy o zmianie ustawy o ochronie konkurencji i konsumentów (nowy art. 106a).

94 P. Burzyński, Ustawowe określenie sankcji karnej, Oficyna a Wolters Kluwer business, Warszawa 2008, s. 83-84. 
nym w prawie antymonopolowym przypisuje się tradycyjne funkcje odpowiedzialności prawnokarnej, takie jak zaspokojenie społecznego poczucia sprawiedliwości, oddziaływanie ogólnoprewencyjne czy szczególnoprewencyjne. Kary za przestępstwa mają „głęboki sens publicznoprawny”, oznaczają „zadośćuczynienie społecznemu poczuciu sprawiedliwości”, mają „odpowiednie znaczenie w zakresie tzw. prewencji ogólnej. Wymierzanie kar za przestępstwa (skazywanie ich sprawców) to realizacja ważnej (z wielu względów) funkcji państwa w zakresie wymiaru sprawiedliwości”95. Sankcje ukierunkowane na represję czy prewencję wobec osób fizycznych mają pełnić funkcję uzupełniające wobec sankcji (głównie administracyjnych) nakładanych na przedsiębiorców (głównie jako podmioty zbiorowe). Zagrożenie sankcjami karnymi może skłaniać jednostki do oporu wobec powstających w korporacjach planów angażowania się w zakazane antykonkurencyjne praktyki, jak również skłaniać je do ujawniania informacji o takich zakazanych działaniach ${ }^{96}$. Dodatkowo sankcje te pełnią również „wręcz symboliczną rolę informacyjno-oskarżycielską (...) jako środek wyrazu dezaprobaty społecznej wobec szczególnie nagannych (karygodnych) zachowań (...)"97. Współczesne prawo karne przypisuje karze także cel w postaci naprawienia szkody i zadośćuczynienia pokrzywdzonemu przestępstwem, „prawo karne zmierza do tego, aby już w postępowaniu karnym doszło do likwidacji konfliktu społecznego wywołanego popełnieniem przestępstwa"98. Problem ten oczywiście wpisuje się w próby ukształtowania modelu współistnienia publicznego i prywatnego egzekwowania prawa ochrony konkurencji.

Tradycyjnie odpowiedzialność prawnokarną ponoszą jednostki (osoby fizyczne), jednak w obszarze prawa gospodarczego, w tym prawa ochrony konkurencji, coraz częściej przewiduje się również korporacyjną odpowiedzialność karną. Sankcje karne za naruszenie prawa mogą mieć zatem postać sankcji indywidualnych i zbiorowych ${ }^{99}$. Te ostatnie mogą przyjąć postać wyłącznie grzywien.

95 T. Bojarski, Polskie prawo karne. Zarys części ogólnej, LexisNexis, Warszawa 2008, s. 238. 2007, vol. 9(3), s. 18, 21.

97 R. Molski, Sankcje penalne w prawie kartelowym, [w:] Z. Ofiarski (red.), Ksiega jubileuszowa z okazji 15-lecia Wydziatu Prawa i Administracji Uniwersytetu Szczecińskiego, Wyd. Naukowe USz, Szczecin 2004, s. 514.

98 W. Wróbel, A. Zoll, Polskie prawo karne. Część ogólna, Znak, Kraków 2010, s. 417.

99 Por. rozdział II, pkt 2.2.2. 


\subsubsection{Rodzaje antymonopolowych sankcji karnych}

\subsubsection{Kary właściwe dla przestępstw antymonopolowych}

Antymonopolowe sankcje karne mogą przyjąć - posługując się terminologią właściwą dla polskiego prawa karnego - postać zarówno kar, jak i środków karnych (w przeszłości określanych jako kary „zasadnicze” i kary „dodatkowe”), przy czym te ostatnie mogą być orzekane samodzielnie, niezależnie od orzekania o karze „zasadniczej”. Czyniąc punktem odniesienia polski Kodeks karny, należy wskazać, że wśród kar wymienionych w art. 32 kk jako kary za przestępstwa antymonopolowe można byłoby orzekać: grzywnę, ograniczenie wolności, pozbawienie wolności (kary dwudziestu pięciu lat pozbawienia wolności, a tym bardziej dożywotniego pozbawienia wolności w przypadku przestępstw antymonopolowych wydają się rażąco surowe).

W literaturze podkreśla się, że „przy ustaleniu ustawowego zagrożenia decydującą rolę odgrywa wartość dobra chronionego normą sankcjonowaną i naruszanego przez sprawcę przestępstwa"100. Nie bez wpływu na wprowadzanie sankcji karnych w obszar prawa ochrony konkurencji powinny pozostawać ustalenia ekonomicznej analizy prawa, które w przypadku prawa karnego koncentrują się głównie na rozważaniu ekonomicznych aspektów ustalania, nakładania i wykonywania sankcji. Proponowane modele optymalnych sankcji karnych z reguły przewidują, że stosowanie sankcji niepieniężnych jest racjonalne ekonomicznie tylko wówczas, gdy zastosowanie kar pieniężnych nie jest $\mathrm{w}$ stanie odpowiednio zapobiec popełnianiu czynów zabronionych ${ }^{101}$. Odrębnym problemem pozostaje decyzja co do tego, czy w przypadku przestępstw antymonopolowych kara pozbawienia wolności całkowicie zastępuje grzywnę, czy wymierzana jest obok grzywny (i ewentualnie innych rodzajów kar). Pierwsze ze wskazanych stanowisk zajął rząd brytyjski w białej księdze poświęconej nowemu brytyjskiemu reżimowi ochrony konkurencji102; z kolei autorzy raportu OFT uznali za „niezwykłe” rozwiązanie, w którym przestępstwo zagrożone byłoby wyłącznie karą pozbawienia wolności i sugerowali możliwość nakładania przez sąd grzywien w nieograniczonej wysokości ${ }^{103}$. W polskim prawie karnym grzywna samoistna orzekana jest

100 W. Wróbel, A. Zoll, Polskie prawo karne..., s. 415.

101 K. Pawłusiewicz, B. Brożek, Prawo karne w świetle ekonomicznej teorii prawa (Uwagi krytyczne), PiP 2002, nr 10, s. 49.

102 White Paper: A World Class Comeptition Regime, Department of Trade and Industry (Cm5233), 2001; tekst dostępny pod adresem: http://www.iiiglobal.org/component/jdown loads/finish/389/1401.html.

103 A. Hammonnd, R. Penrose, Proposed criminalization of cartels in the UK, Office of Fair Trading, November 2001, pkt 7.4.-7.5. 
„za przestępstwa o mniejszym ciężarze gatunkowym, jest karą łagodniejszą od kary pozbawienia wolności i kary ograniczenia wolności"104 - dyrektywa ta wydaje się być spełniona w przypadku przestępstw antymonopolowych.

Dyrektyw co do wymiaru antymonopolowych sankcji karnych należy poszukiwać w krajowych przepisach prawa karnego, jak choćby art. $53 \S 1$ Kodeksu karnego wykonawczego, który wskazuje na: stopień winy, stopień społecznej szkodliwości czynu, cele zapobiegawcze i wychowawcze w stosunku do skazanego, potrzeby w zakresie kształtowania świadomości prawnej społeczeństwa. Ponadto w odniesieniu do kar za przestępstwa antymonopolowe, $\mathrm{w}$ tych systemach ochrony konkurencji, gdzie przywiązuje się wagę do funkcjonowania programów zgodności (compliance programmes) na wysokość kary może wpływać zgodność (lub jej brak) zachowania oskarżonego z wytycznymi tego programu. Do innych okoliczności łagodzących wymiar kary można zaliczyć m.in. poziom współpracy oskarżonego w toku postępowania, czy fakt, że do naruszenia doszło po raz pierwszy 105 .

W poszukiwaniu optymalnej długości kary pozbawienia wolności wskazuje się, że kara krótsza jest co prawda bardziej efektywna kosztowo, jednak może nie spełniać dostatecznie dobrze funkcji odstraszającej. Z kolei w przypadku dłuższej kary pozbawienia wolności społeczne koszty realizacji tej kary mogą znacznie przewyższać społeczną korzyść wynikającą z niej106. W Kanadzie przestępstwa kartelowe zagrożone są karą do 14 lat pozbawienia wolności, w Stanach Zjednoczonych, Australii oraz Irlandii ${ }^{107}$ kara pozbawienia wolności za przestępstwa monopolizacji rynku może być orzeczona na maksymalnie 10 lat, w Rosji - na 7 lat, w Izraelu i Wielkiej Brytanii - na 5 lat (w toku debaty nad kryminalizacją praktyk antykonkurencyjnych w Wielkiej Brytanii zaproponowano maksymalny wymiar kary co najmniej na 5 lat, ponieważ przyjęcie takiego wymiaru umożliwiało zaliczenie przestępstw kartelowych do takich, w których można zastosować areszt, autorzy raportu OFT dotyczącego propozycji rozwiązań legislacyjnych w tym obszarze opowiadali się nawet za przyjęciem granicy 7 lat ${ }^{108}$ ). Cztery lata pozbawienia wolności przewiduje się we Francji, 3 lata - w Estonii, Korei i Japonii.

104 T. Bojarski, Polskie prawo karne..., s. 257.

105 A. Hammonnd, R. Penrose, Proposed criminalization of cartels..., pkt 7.2.

106 Cartels: Sanction against Individuals, OECD Journal of Competition Law and Policy 2007, vol. 9(3), s. 23.

107 W Irlandii kara 10 lat pozbawienia wolności może być orzeczona tylko w „pełnym” postępowaniu (conviction on indictment), natomiast w tzw. postępowaniu przyspieszonym (summary conviction) kara może wynosić do 6 miesięcy. Podwyższenie maksymalnego wymiaru kary pozbawienia wolności (z 5 do 10 lat) nastąpiło wskutek nowelizacji ustawy o konkurencji w 2012 r. (Competition Amendment Act 2012).

108 A. Hammonnd, R. Penrose, Proposed criminalization of cartels..., pkt 7.2. 
W Polsce ewentualna kara pozbawienia wolności za przestępstwa antymonopolowe musiałaby oczywiście mieścić się w wyznaczonej w art. 37 kk granicy od miesiąca do 15 lat, przy czym za nieco bardziej szczegółową wytyczną może służyć wymiar kary za przestępstwo nadużycia zaufania z art. 296 kk lub za przestępstwo zmowy przetargowej z art. 305 kk.

Stosunkowo niewielka liczba faktycznie orzeczonych kar pozbawienia wolności w państwach członkowskich UE nie pozwala na jednoznaczne i autorytatywne określenie tendencji dla wyznaczania długości kary pozbawienia wolności. Jeśli jednak najbardziej znane przypadki orzekania o karach potraktować jako miarodajne, to trzeba powiedzieć, że wydane wyroki były raczej łagodne i dalekie od przewidzianych maksymalnych pułapów. W Wielkiej Brytanii w sprawie Marine Hose w sądzie pierwszej instancji zapadły dwa wyroki 3-letniego i jeden wyrok 30-miesięcznego pozbawienia wolności, które następnie wskutek apelacji zostały zamienione na odpowiednio 30-miesięczną, 24-miesięczną i 20-miesięczną karę pozbawienia wolności. W Irlandii do połowy 2012 r. wydane zostały 2 wyroki skazujące w sprawach przestępstw monopolizacji rynku (na 7 spraw w sumie). Pierwszym z nich była sprawa Connaught Oil, rozstrzygnięta w 2006 r. - akty oskarżenia skierowano przeciwko 15 osobom, tylko $1 \mathrm{z}$ nich została skazana ostatecznie na 6 miesięcy pozbawienia wolności $\mathrm{w}$ zawieszeniu na 12 miesięcy oraz 15 tys. EUR grzywny. Drugi wyrok, wydany w sprawie DPP v. Manning w 2007 r. ${ }^{109}$, przyniósł karę pozbawienia wolności o wymiarze 12 miesięcy w zawieszeniu na 2 lata oraz 30 tys. EUR grzywny ${ }^{110}$. Dla porównania w Stanach Zjednoczonych średnia długość kary pozbawienia wolności w latach 2010-2011 wyniosła 24 miesiące, w latach 2000-2009 - 19 miesięcy, a w latach 1990-1999 - 8 miesięcy; wyraźna jest zatem tendencja do zaostrzania odpowiedzialności karnej za przestępstwa kartelowe ${ }^{111}$.

Skorzystanie z katalogu kar wymienionych w art. 32 kk pozwalałoby zastosować wobec jednostek odpowiedzialnych za przestępstwa antymonopolowe również karę ograniczenia wolności (art. $34 \mathrm{kk}$ ). Jej czas trwania wynosi od 1 do 12 miesięcy (w przypadku nadzwyczajnego obostrzenia kary i orzekania kary łącznej - do 2 lat), a wśród obowiązków nałożonych na skazanego, obok braku możliwości zmiany miejsca stałego pobytu bez zgody

109 Szerzej na temat tej sprawy: M. E. Curtis, J. McNally, The Classic Cartel - Hatchback Sentence, The Competition Law Review 2007, vol. 4(1), s. 41-50.

$110 \mathrm{~W}$ czasie, gdy wydane zostały obydwa wyroki maksymalny wymiar kary pozbawienia wolności w Irlandii wynosił 5 lat.

111 Criminal Enforcement. Fines and Jail Charts 2000-2011, US Department of Justice Antitrust Division, dostępne pod adresem: http://www.justice.gov/atr/public/criminal/264101. html. 
sądu i obowiązku udzielania wyjaśnień dotyczących przebiegu odbywania kary, znajduje się także obowiązek wykonywania nieodpłatnej, kontrolowanej pracy na cele społeczne w odpowiednim zakładzie w wymiarze od 12 do 40 godzin miesięcznie (art. $35 \S 1 \mathrm{kk}$ ). Obowiązek wykonywania pracy może być przy tym zamieniony na potrącenie od 10 do 25 procent wynagrodzenia za pracę na rzecz Skarbu Państwa albo na określony cel społeczny. Ponadto sąd może zobowiązać skazanego do naprawienia w całości albo w części szkody wyrządzonej przestępstwem. Do stosowania tej ostatniej sankcji w przypadku przestępstw monopolizacji należy jednak podchodzić z pewną ostrożnością.

O ile kara pozbawienia wolności ma charakter uniwersalny, o tyle kara grzywny wydaje się bardziej związana z uwarunkowaniami lokalnymi (chociażby sytuacją ekonomiczną danego państwa), stąd znaczące różnice w wyznaczaniu pułapu maksymalnych grzywien pomiędzy poszczególnymi porządkami prawnymi. Wysokość grzywny może być wyznaczana w różny sposób: kwotowo (także w stawkach dziennych) lub w relacji do określonej wartości (np. obrotu, przychodu, korzyści uzyskanych z przestępstwa) bądź też alternatywnie (kwotowo lub w odniesieniu do danej wartości). Ten ostatni sposób przyjęto m.in. w Stanach Zjednoczonych ${ }^{112}$, Irlandii ${ }^{113}$ i Australiii14. Grzywna może być również nielimitowana, zależna od uznania sądu (takie rozwiązanie przyjęto w Wielkiej Brytanii i - częściowo - w Kanadzie ${ }^{115}$ ).

Nakładane na jednostki grzywny w przypadku przestępstw monopolizacji mogą być dotknięte takimi słabościami jak to, że grzywna zbyt niska nie będzie pełnić roli odstraszającej, zaś grzywna zbyt wysoka nie będzie moż-

112 W USA od czerwca 2004 r. grzywna nakładana na korporację może wynieść do $100 \mathrm{mln}$ dolarów, zaś grzywna nakładana na jednostkę - do 1 mln dolarów. Alternatywnie możliwe jest nałożenie grzywny do wysokości dwukrotności (brutto) poniesionej szkody finansowej lub zysku wynikającego z naruszenia.

$113 \mathrm{~W}$ Irlandii grzywna w postępowaniu przyśpieszonym może wynosić do 5 tys. EUR, a w postępowaniu pełnym - do wysokości 5 mln EUR lub $10 \%$ obrotu, w zależności od tego, która z wartości jest wyższa.

114 W Australii maksymalna grzywna nie może przekroczyć 10 mln dolarów australijskich; jeśli sąd jest w stanie ustalić wartość korzyści odniesionych przez więcej niż jedną osobę i możliwych do przypisania $\mathrm{w}$ związku z popełnieniem przestępstwa, grzywna nie może przekroczyć trzykrotności tej wartości. Jeśli natomiast sąd nie jest w stanie określić całkowitej wartości tych korzyści, wówczas grzywna nie może przekroczyć $10 \%$ rocznego obrotu przedsiębiorstw w ciągu 12 miesięcy upływających z końcem miesiąca, w którym przedsiębiorca popełnił lub zaczął popełniać przestępstwo - por. sekcja 44ZZRF(3) i 44ZZRG(3) Competition and Consumer Act 2010.

115 Nielimitowana wysokość grzywny dotyczy tylko przestępstw zmów przetargowych, w przypadku pozostałych przestępstw kartelowych (porozumień cenowych, podziałowych i kontyngentowych) grzywna może wynosić 25 mln dolarów kanadyjskich. 
liwa do uniesienia przez osobę fizyczną; ponadto przedsiębiorstwa mogą przyjmować rozmaite rozwiązania z zakresu „kreatywnej księgowości” w celu zrekompensowania ukaranym pracownikom poniesionego uszczerbku majątkowego ${ }^{116}$.

\subsubsection{2. Środki karne właściwe dla przestępstw antymonopolowych}

\subsubsection{1. „Dyskwalifikacja zawodowa”}

Jak już zaznaczono, odpowiedzialność karna z tytułu przestępstw antymonopolowych może być realizowana również za pomocą środków określanych przez polskiego ustawodawcę jako środki karne. Taki charakter ma chociażby znana niektórym ustawodawstwom „dyskwalifikacja zawodowa”, pod którym to pojęciem należy rozumieć utratę możliwości zajmowania stanowiska na szczeblu zarządczym (directors disqualification). Sankcję tego rodzaju przewiduje m.in. prawodawstwo brytyjskie ${ }^{117}$, przy czym w wielu państwach sankcji tego rodzaju przypisuje się charakter administracyjny. Zbliżony rodzaj sankcji znany jest również prawu polskiemu - art. 41 $\S 1 \mathrm{kk}$ ustanawia środek karny w postaci zakazu zajmowania określonego stanowiska albo wykonywania określonego zawodu w sytuacji, gdy „sprawca nadużył przy popełnieniu przestępstwa stanowiska albo okazał, że dalsze zajmowanie stanowiska lub wykonywanie zawodu zagraża istotnym dobrom chronionym prawem”.

Celem środka tego rodzaju jest wyeliminowanie przyszłej działalności skazanego, która mogłaby być szkodliwa dla ogółu ${ }^{118}$ (interesu publicznego), sankcji tej przypisuje się głównie funkcję prewencyjną ${ }^{119}$, choć zakaz wykonywania określonej działalności zawodowej niesie ze sobą również istotny element represji. Pewnych trudności może dostarczać określenie podmiotów, które mogą być dotknięte zakazem zajmowania stanowisk kierowniczych (menadżerskich). Należy przyjąć, że mogą być to osoby bezpośrednio zaangażowane w zarządzanie (bez względu na nazwę swoich funkcji i stanowisk),

116 Cartels: Sanctions against Inidviduals, s. 19-20; P. Whelan, A Principled Argument for Personal Criminal Sanctions As Punishment under EC Cartel Law, The Competition Law Review 2007, vol. 4(1), s. 32.

117 Por. Company Directors Disqualifiaction Act 1986 (w wersji zmienione przez sekcję 204 Enterprise Act 2002); dalej jako CDDA.

118 Por. T. Bojarski, Polskie prawo karne..., s. 269.

119 Z. Sienkiewicz, [w:] L. Tyszkiewicz, S. Hoc, A. Wąsek, W. Filipkowski, Z. Siwik, M. Kulik, M. Bojarski, W. Radecki, P. Hofmański, Z. Sienkiewicz, L. Wilk, O. Górniok, M. Filar, M. Kalitowski, L. K. Paprzycki, E. Pływaczewski, R. A. Stefański, Kodeks karny. Komentarz, LexisNexis, Warszawa 2010 (LexPolonica/2012). 
jak również wszelki „szare eminencje” (shadow directors), tj. osoby, których wytyczne i wskazówki są uwzględniane przez menadżerów firmy ${ }^{120}$. W polskim piśmiennictwie pojęciem stanowiska obejmuje się „pozycję zawodową zajmowaną przez obywatela w systemie i hierarchii instytucji państwowych i społecznych”, a „pełnienie tych funkcji nie musi być związane z dającym się dokładnie sprecyzować zakresem umiejętności o charakterze zawodowym"121. Omawiany środek karny nie mógłby znaleźć zastosowania wobec przestępstw antymonopolowych, jeśli pojęcie „stanowiska” wiązać wyłącznie z organami samorządowymi, rządowymi, instytucjami państwowymi i społecznymi oraz korporacjami zawodowymi ${ }^{122}$, nie zaś z sektorem prywatnym, na który przypada największa liczba naruszeń prawa ochrony konkurencji. Zakaz zajmowania stanowisk kierowniczych może obejmować nie tylko zakaz zarządzania firmą sensu stricto (poprzez bycie członkiem zarządu), ale także pośredni udział $\mathrm{w}$ tworzeniu lub zarządzaniu firmą, czy pełnienie funkcji syndyka upadłościowego. Również wobec przestępstw antymonopolowych aktualna pozostaje dyrektywa Sądu Najwyższego, zgodnie z którą „,zakaz $\mathrm{z}$ art. $41 \S 1 \mathrm{kk}$ powinien zostać sformułowany przez sąd w taki sposób, by wskazywał konkretne stanowisko, oznaczone przez wskazanie pełnionej funkcji bądź zajmowanej pozycji w ściśle określonej dziedzinie życia państwowego, społecznego, a także prywatnego, w związku z którą doszło do popełnienia przestępstwa. Podobnie zakaz wykonywania zawodu musi być tak określony $\mathrm{w}$ treści orzeczenia, by rodzaj wymierzonej w ten sposób dolegliwości był wskazany w sposób precyzyjny"123. Zakaz zajmowania stanowisk kierowniczych może być orzeczony wyłącznie przez sądy po wykazaniu winy ${ }^{124}$, przy czym orzeczenie tego środka karnego może nastąpić zarówno w przypadku przestępstwa umyślnego, jak i nieumyślnego ${ }^{125}$. Należy odnotować, że zakaz zajmowania stanowisk lub wykonywania określonego zawodu może być orzeczony m.in. w przypadku stwierdzenia popełnienia przestępstwa nadużycia zaufania $\mathrm{z}$ art. 296 kk $^{126}$. Przepisy prawa muszą wskazywać

120 Tak M. O'Kane, The Law of Criminal Cartels. Practice and Procedure, Oxford 2009, s. 233.

121 M. Szewczyk, [w:] A. Zoll (red.), Kodeks karny..., s. 573 (Nb 4).

122 Por. A. Marek, Kodeks karny. Komentarz, Wyd. 5., Lex a Wolters Kluwer business, Warszawa 2010, s. 134 (Nb 2).

123 Wyrok SN z dnia 14 stycznia 2009 r., V KK 245/2008, OSNK 2009, poz. 164. Por. także wyrok SN z dnia 14 listopada 2008 r., V KK 256/2008, OSNK 2008, poz. 2298.

124 Por. Sekcja 9A(5) i (6) CDAA.

125 M. Szewczyk, [w:] A. Zoll (red.), Kodeks karny..., s. 573-574 (Nb 6 i 7).

126 Tak A. Zientara, Przestępstwo nadużycia zaufania $z$ art. 296 kodeksu karnego, Oficyna a Wolters Kluwer business, Warszawa 2010, s. 129. Por. rozdział II, pkt 2.2.6.2. 
maksymalny wymiar „dyskwalifikacji zawodowej” lub zakaz wykonywania działalności gospodarczej (w Wielkiej Brytanii wynosi on 15 lat).

Odrębnie art. $41 \S 2 \mathrm{kk}$ przewiduje środek karny polegający na zakazie prowadzenia określonej działalności gospodarczej „w razie skazania za przestępstwo popełnione w związku z prowadzeniem takiej działalności, jeżeli dalsze jej prowadzenie zagraża istotnym dobrom chronionym prawem". Zakaz prowadzenia określonej działalności może wynikać ze stwierdzonego braku kompetencji sprawcy, czy złej organizacji prowadzonego przez niego przedsiębiorstwa. Niedopuszczalne jest orzeczenie zakazu wykonywania wszelkiej działalności gospodarczej ${ }^{127}$. Orzeczenie zakazu wykonywania działalności gospodarczej w przypadku przestępstw antymonopolowych jest o tyle mało prawdopodobne, że specyfika praktyk antykonkurencyjnych wiąże się zazwyczaj z godzeniem w ogólne (powszechne) mechanizmy rynkowe, a nie w konkretne dobra (np. środowisko naturalne); praktyki antykonkurencyjne $\mathrm{w}$ takiej samej postaci mogą być stosowane niejako niezależnie od sektorów, ich specyfika rzadko wiąże się z cechami charakterystycznymi działalności gospodarczej danego rodzaju. Orzeczenie zakazu wykonywania działalności np. w przemyśle odzieżowym w związku z popełnionym przestępstwem antymonopolowym będzie bezzasadne, jeśli skazany może nadal wykonywać działalność gospodarczą w innym sektorze i tam z powodzeniem stosować sprawdzone przez siebie praktyki antykonkurencyjne.

\subsection{Obowiązek naprawienia szkody przez sprawcę}

Wśród innych środków karnych znanych polskiemu prawu karnemu, a mogących być potencjalnie sankcjami za przestępstwa antymonopolowe, należy wymienić obowiązek naprawienia szkody przewidziany w art. $46 \mathrm{kk}$. Koncepcja obowiązku naprawienia szkody jako obowiązku prawnokarnego budziła co prawda w doktrynie wiele wątpliwości ${ }^{128}$, jednak ostatecznie zdecydowano o wprowadzeniu tego środka do Kodeksu karnego. Obowiązek całkowitego lub częściowego naprawienia szkody może zostać orzeczony w razie skazania za każde przestępstwo, popełnione umyślnie lub nieumyślnie (jeśli taki typ przestępstwa przewidziany jest przez ustawę) $)^{129}$. Warunkiem orzeczenia środka przewidzianego $\mathrm{w}$ art. $46 \mathrm{kk}$ jest stwierdzenie winy sprawcy

127 W. Wróbel, A. Zoll, Polskie prawo karne..., s. 447.

128 Por. A. Marek, Naprawienie szkody wyrzadzonej przestępstwem. Refleksje na tle projektu kodyfikacji karnej, [w:] S. Waltoś (red.), Problemy kodyfikacji prawa karnego. Ksiega ku czci Prof. M. Cieślaka, Kraków 1993, s. 212 i n.

129 Tak A. Marek, Kodeks karny. Komentarz, s. 163 (Nb 6); T. Bojarski, Polskie prawo karne..., s. 274; M. Szewczyk, [w:] A. Zoll (red.), Kodeks karny. Część ogólna. Komentarz, LEX a Wolters Kluwer business, Warszawa 2007, s. 639 (Nb 9). 
i zaistnienie szkody wyrządzonej konkretnemu pokrzywdzonemu ${ }^{130}$. Obowiązek naprawienia szkody może być nałożony na wniosek pokrzywdzonego lub innej osoby uprawnionej (wówczas orzeczenie tego środka karnego jest obligatoryjne) ${ }^{131}$, a także z urzędu (orzeczenie jest wtedy fakultatywne). Jeśli sąd karny ma wątpliwości co do rozmiaru szkody, nie może odsyłać sprawy do odrębnego procesu cywilnego ${ }^{132}$, sąd karny ma natomiast możliwość nałożenia obowiązku naprawienia szkody tylko w zakresie bezspornym (w części) bądź też zastąpić środek karny w postaci naprawienia szkody innym środkiem, tj. nawiązką ${ }^{133}$. W piśmiennictwie podkreśla się również, że istocie prawnego środka karnego - jako sprzeczne z zasadą indywidualizacji odpowiedzialności karnej i stosowania kar i środków karnych - nie odpowiada solidarne zobowiązanie do naprawienia szkody ${ }^{134}$, niemniej jednak SN w uchwale z dnia 13 grudnia 2000 r., I KZP 40/2000 ${ }^{135}$, wyraził pogląd, że „orzeczenie środka karnego, przewidzianego w art. $46 \S 1 \mathrm{kk}$, dopuszczalne jest również w postaci solidarnego zobowiązania współsprawców przestępstwa do naprawienia wyrządzonej szkody w całości albo w części”. W związku z omówionym środkiem karnym w sposób oczywisty nasuwa się pytanie o wzajemną zależność zastosowania tego środka oraz sankcji w prywatnym trybie egzekwowania prawa ochrony konkurencji: problem ten sprowadza się do rozwiązania kwestii możliwości występowania z powództwem do sądu cywilnego w sytuacji, gdy sąd karny orzekł o obowiązku naprawienia szkody. Problem ten nie znalazł dotąd jednoznacznego rozstrzygnięcia ani w doktrynie, ani w orzecznictwie ${ }^{136}$ i zdecydowanie wykracza poza ramy niniejszego opracowania. Niemniej jednak bliski jest mi pogląd, że ,jedynie wskazanie w wyroku sądu karnego, iż obowiązek naprawienia szkody nałożony został przez sąd w całości, wyklucza dochodzenie dalszych roszczeń na drodze procesu cywilnego"137. Racjonalne

130 Por. wyrok SN z dnia 4 marca 2003 r., II KK 127/02, KZS 2003, z. 7-8, poz. 18.

131 Por. postanowienie SN z dnia 4 lutego 2009 r., V KK 410/2008, OSNK 2009, poz. 322.

132 Tak A. Marek, Kodeks karny. Komentarz, s. 164 (Nb 9).

133 Por. W. Wróbel, A. Zoll, Polskie prawo karne..., s. 463.

134 M. Szewczyk, [w:] A. Zoll (red.), Kodeks karny..., s. 644 (Nb 25); Ł. Twarowski, Charakter prawny obowiazku naprawienia szkody - uwagi krytyczne, [w:] Z. Ćwiąkalski, G. Artymiak (red.), Karnomaterialne i procesowe aspekty naprawienia szkody w świetle kodyfikacji karnych z 1997 r. i propozycji ich zmian, Oficyna a Wolters Kluwer business, Warszawa 2010, s. 115-117.

135 OSNKW 2001, nr 1-2, poz. 2.

136 Por. przegląd dorobku orzeczniczego dokonany przez M. Rogalskiego, Dochodzenie roszczeń majątkowych a powaga rzeczy osądzonej, [w:] Z. Ćwiąkalski, G. Artymiak (red.), Karnomaterialne i procesowe aspekty..., s. 362-376.

137 Ł. Twarowski, Charakter prawny..., [w:] Z. Ćwiąkalski, G. Artymiak (red.), Karnomaterialne i procesowe aspekty..., s. 114. 
wydaje się przy tym twierdzenie Sądu Najwyższego, że „kwestia związania sądu cywilnego ustaleniem przez sąd karny wysokości szkody powinna być rozstrzygana w zależności od tego, czy ustalona wysokość szkody stanowi niezbędny element stanu faktycznego przestępstwa przypisanego oskarżonemu. Nie wiąże sądu cywilnego ustalenie sądu karnego co do wysokości szkody, jeśli: nie stanowi niezbędnego elementu stanu faktycznego przestępstwa, lecz ma jedynie charakter posiłkowy, stanowi wprawdzie niezbędny element stanu faktycznego przestępstwa, lecz ma charakter ocenny"138.

Sam ustawodawca przesądził jedynie, że dla nałożenia obowiązku naprawienia szkody nie mają przy tym znaczenia przepisy Kodeksu cywilnego dotyczące przedawnienia (art. $46 \S 1$ in fine).

Do rozważenia pozostaje także inna dolegliwość majątkowa dla sprawcy przestępstwa antymonopolowego, jaką jest przepadek korzyści pochodzących choćby pośrednio z przestępstwa, przewidziany w art. 45 kk. Przepadek następuje na rzecz Skarbu Państwa, nie można orzec go wówczas, gdy korzyść została zwrócona pokrzywdzonemu lub innej uprawnionej osobie. Za korzyść taką można byłoby uznać przysporzenie majątkowe w postaci np. zwiększonych dochodów menadżerów związanych ze wzrostem obrotów spowodowanym działalnością kartelu cenowego, czy premie uzyskane w związku z realizacją zmów kartelowych. W doktrynie przyjmuje się, że przepadkowi podlega tylko korzyść bezpośrednia, a nie np. pożytki uzyskane wskutek zainwestowania na giełdzie ${ }^{139}$. Podkreślenia wymaga, że art. $45 \mathrm{kk}$ przewiduje domniemanie, że mienie, które sprawca objął we władanie w czasie popełnienia przestępstwa lub po jego popełnieniu (do chwili wydania chociażby nieprawomocnego wyroku) stanowi korzyść uzyskaną z popełnienia przestępstwa; domniemanie to dotyczy jednak wyłącznie korzyści znacznej wartości - w doktrynie wskazuje się, że dla określenia owej „znacznej wartości” należy posiłkować się definicją mienia znacznej wartości z art. $115 \S 5 \mathrm{kk}^{140}$ (tj. wartość powyżej 200 tys. zt).

W odniesieniu do przestępstw monopolizacji rynku zastosowanie mogłyby znaleźć również przewidziane w Kodeksie karnym środki probacyjne, tj. warunkowe umorzenie postępowania karnego, warunkowe zawieszenie orzeczonej kary oraz warunkowe przedterminowe zwolnienie, z których dwa

138 Wyrok SN z dnia 17 czerwca 2005 r., III CK 642/2004, LexPolonica nr 1825404.

139 Tak A. Marek, Kodeks karny. Komentarz, Wyd. 5., Lex a Wolters Kluwer business, Warszawa 2010, s. 158 (Nb 5); B. Zygmont, Konfiskata mienia a przepadek korzyści majątkowej, Prok. i Pr. 2001, nr 11, s. 29-30.

140 Tak A. Marek, Kodeks karny. Komentarz, s. 160 (Nb 11); W. Wróbel, A. Zoll, Polskie prawo karne..., s. 461. 
pierwsze uznawane są w doktrynie za środki karne ${ }^{141}$. Zastosowanie środków probacyjnych byłoby szczególnie wskazane w przypadku procedury leniency.

\subsection{Wzajemne oddziaływanie sankcji antymonopolowych nakładanych w trybie administracyjnoprawnego i karnoprawnego egzekwowania reguł ochrony konkurencji}

Na wstępie należy zaznaczyć, że niewłaściwym byłoby określenie sygnalizowanego w tytule podrozdziału problemu jako wzajemnego oddziaływania administracyjnych i karnych sankcji antymonopolowych, a to ze względu na to, że przedmiotem rozważań będą w istocie korelacje między typowymi sankcjami karnymi a sankcjami, nakładanymi co prawda przez organy, którym z reguły przypisywany jest status organów administracyjnych, ale wykazującymi naturę sankcji prawnokarnych.

Do rozstrzygnięcia pozostają następujące obszary konfliktów: nałożenie administracyjnej kary pieniężnej na przedsiębiorcę i nałożenie grzywny (jako sankcji karnej) na przedsiębiorcę; nałożenie administracyjnej kary pieniężnej na przedsiębiorcę i nałożenie sankcji karnej na osobę zarządzającą przedsiębiorstwem. Istotnym problemem w pierwszym ze wskazanych obszarów pozostaje problem sankcjonowania przestępstw antymonopolowych przedsiębiorstw, które wystąpiły z wnioskami o leniency. Potencjalny zbieg administracyjnej kary pieniężnej nałożonej przez organ ochrony konkurencji i grzywny nałożonej z tytułu przestępstwa antymonopolowego nie jest możliwy, jako że ewidentnie godziłby w zasadę ne bis in idem. Teza ta będzie prawdziwa o tyle, o ile karze pieniężnej nałożonej przez organ antymonopolowy przypiszemy charakter sankcji karnej142.

Możliwym jest natomiast nałożenie sankcji administracyjnej w postaci kary pieniężnej na przedsiębiorcę i jednoczesne pociągnięcie do odpowiedzialności karnej osoby fizycznej zaangażowanej w zarządzanie przedsiębiorstwem - nie zachodzi bowiem w tym przypadku tożsamość karanych

141 Tak A. Marek, Kodeks karny. Komentarz, s. 130-131 (Nb 2).

142 W świetle wyroku TS z dnia 5 czerwca 2012 r. w sprawie C-489/10 Łukasz Bonda (dotąd niepubl.) należy stwierdzić, że do naruszenia zasady ne bis in idem nie dochodzi w przypadku zbiegu sankcji administracyjnej i sankcji karnej, przy czym kluczowym elementem dla klasyfikacji obydwu sankcji jest cel ustanawiających je regulacji i przewidzianych przez nią sankcji (w przywołanej sprawie przedmiotem oceny był art. 138 ust. 1 akapity drugi i trzeci rozporządzenia Rady (WE) nr 1973/2004 z dnia 29 października 2004 r. ustanawiającego szczegółowe zasady stosowania rozporządzenia Rady (WE) nr 1782/2003 w sprawie systemów wsparcia przewidzianych w tytułach IV i IVa tego rozporządzenia oraz wykorzystania gruntów zarezerwowanych do produkcji surowców (Dz. U. L 345/1). 
podmiotów (nałożone sankcje oddziałują na różne podmioty, w związku z czym realizują również nieco odmienne funkcje, nie ma wówczas mowy o pogwałceniu zasady ne bis in idem).

Obawy o to, że istnienie odpowiedzialności karnej za naruszenie zakazu karteli zachwieje skutecznością programu leniency są znacznie bardziej uzasadnione niż podobne obawy związane z prywatnym egzekwowaniem prawa ochrony konkurencji. W przypadku odpowiedzialności karnej mamy do czynienie $\mathrm{z}$ jej nieuchronnością, przyznanie przez przedsiębiorstwo (na potrzeby postępowania przed organem ochrony konkurencji), że uczestniczy w porozumieniu ograniczającym konkurencję nie może pozostać bez reakcji organów publicznych zobligowanych do pociągania podmiotów do odpowiedzialności karnej. W związku z prywatnym egzekwowaniem zakazu karteli pozostaje zawsze margines niepewności co do tego, czy jakieś podmioty, i ewentualnie w jakiej skali, rzeczywiście wystąpią do sądów cywilnych $\mathrm{z}$ roszczeniami przeciwko przedsiębiorstwom uczestniczącym w programie leniency. Uzasadnione wydaje się rozwiązanie, aby przystąpienie do programu leniency gwarantowało brak odpowiedzialności karnej (indywidualnej i/lub korporacyjnej) - takie „ustępstwo” podyktowane jest w pierwszej kolejności potrzebą zapewnienia pożądanej efektywności publicznego trybu egzekwowania zakazu antykonkurencyjnych praktyk, jednak skuteczność publicznego trybu oddziałuje również na efektywność trybu prywatnoprawnego (w interesie którego nie leży bynajmniej zniechęcanie przedsiębiorców do leniency); pośrednio zatem jest to również rozwiązanie sprzyjające budowaniu zrównoważonego modelu funkcjonowania publicznego i prywatnego trybu egzekwowania prawa ochrony konkurencji. Należy podkreślić, że w związku $\mathrm{z}$ istnieniem sankcji indywidualnych (bez względu na ich stricte karny lub administracyjno-karny charakter), coraz częściej programy typu leniency kierowane są nie tylko do przedsiębiorców („korporacyjne leniency”), ale także do osób fizycznych (,indywidualne leniency”). W piśmiennictwie podkreśla się, że istnienie indywidualnego leniency, tj. rozwiązań prawnych, zgodnie z którymi współpraca osób fizycznych (nie przedsiębiorców) z organem ochrony konkurencji pozwala im uniknąć sankcji indywidualnych (stricte karnych czy administracyjno-karnych), nie tylko motywuje przedsiębiorców do korzystania z korporacyjnego leniency, ale także podwyższa koszty funkcjonowania kartelu (zmniejszając tym samym jego „opłacalność”)143.

Akceptując możliwość wyłączenia odpowiedzialności prawnokarnej wobec pracownika przedsiębiorcy włączającego się w program korporacyjnego lub indywidualnego leniency i jednocześnie biorąc pod uwagę zróżni-

143 F. Thépot, Leniency and Individual Liability..., s. 234-239. 
cowany wymiar „bezkarności” różnych uczestników leniency (od całkowitego darowania kary pieniężnej po jej stosunkowe obniżenie), należy rozważyć, w jakim zakresie podmiotowym i przedmiotowym konieczne jest zagwarantowanie zwolnienia z prawnokarnej odpowiedzialności osobistej. Powstaje pytanie choćby o to, czy zwolnienie z odpowiedzialności powinno dotyczyć wszystkich pracowników, którzy przez czas trwania praktyki ograniczającej konkurencję angażowali się w jej funkcjonowanie lub co najmniej tolerowali jej istnienie. M. Król-Bogomilska, odnosząc się do propozycji UOKiK co do wyłączenia stosowania art. 305 kk w sytuacji, gdy Prezes UOKiK darowałby lub zmniejszył karę pieniężną dla osoby fizycznej, która dopuściła do zaangażowania się przedsiębiorcy w praktykę ograniczającą konkurencję, słusznie podkreśliła, że konieczne jest sprecyzowanie na czym ma polegać wyłączenie odpowiedzialności karnej, ponieważ „w prawie karnym zaniechanie ukarania może przybierać różne postaci”144. W tym kontekście zasadne staje się również pytanie o to, jaki powinien być zakres wyłączenia odpowiedzialności karnej wobec osób, którym darowano karę i osób, wobec których ta kara była jedynie zmniejszona (oczywistym wydaje się - choćby w świetle zasady proporcjonalności - że zakres wyłączenia nie może być w takich dwóch przypadkach identyczny).

Konieczność zwolnienia z odpowiedzialności karnej uczestników programów leniency została rozpoznana w wielu porządkach prawnych. W Stanach Zjednoczonych funkcjonuje program Amnesty Plus, który zwalnia z odpowiedzialności karnej osoby, które już w toku postępowania karnego przekazały Antitrust Division informacje o innym kartelu (działającym na innym rynku). Amnestia może być udzielona tylko warunkowo, co podnosi efektywność programu, ponieważ wymusza określone, zgodne z oczekiwaniami organu, działania przedsiębiorców. W Wielkiej Brytanii osoba, która przyznaje się do udziału w kartelu, wspólpracuje z OFT w czasie prowadzonego postępowania, wycofała się z prac kartelu w momencie ujawnienia informacji organowi, może liczyć na wydanie przez OFT tzw. „listu o nieoskarżalności” (no-action letter), o ile nie nakłaniała ona innych przedsiębiorstw do udziału w kartelu (przy czym spełnienie wskazanych warunków jedynie uprawdopodabnia otrzymanie „listu o nieoskarżalności”). Skutkiem wydania listu przez

144 M. Król-Bogomilska, Uwagi do projektu założeń do projektu ustawy o zm. ustawy o ochronie konkurencji i konsumentów z dnia 15 maja 2012 r. ogtoszonych na stronie Urzędu Ochrony Konkurencji i Konsumentów ( $w$ zakresie dotyczacym problematyki kar i polityki tagodzenia kar) (pismo z dnia 5 czerwca 2012 r.), dostępne pod adresem: http://legislacja.rcl.gov. $\mathrm{pl} /$ docs $/ / 1 / 43452 / 43453 / 43456 /$ dokument40047.pdf?lastUpdateDay=03.08.12\&lastUpdate Hour $=4 \% 3$ A06\&userLogged $=$ false $\&$ date $=$ Sunday $\% 2 C+5+$ August +2012 (5.08.2012). 
OFT jest to, że jego adresat nie może być pociągnięty do odpowiedzialności karnej z tytułu popełnionego przestępstwa kartelowego ${ }^{145}$.

Warto w tym miejscu odnotować pogląd, że istnienie sankcji karnych zwłaszcza indywidualnych, w pewnym sensie pozwala na przywrócenie właściwej roli leniency - A. Riley zwraca uwagę na to, że np. Komisja Europejska (ale może to dotyczyć także organów krajowych) stała się zakładniczką sukcesu programu leniency, a przedsiębiorstwa uwzględniają możliwość korzystania z leniency w szacowaniu „opłacalności” karteli ${ }^{146 .}$

\subsection{Sankcje w prywatnoprawnym trybie egzekwowania zakazów praktyk ograniczających konkurencję - uwagi wstępne}

W piśmiennictwie podkreśla się, że prawo cywilne posługuje się pojęciem sankcji dość sporadycznie, nazywając raczej konsekwencje zachowań niezgodnych z normami cywilnymi za pomocą terminów opisowych ${ }^{147}$. Prawo cywilne operuje sankcjami w wielu postaciach, takich jak: odpowiedzialność cywilna, odpowiednie ukształtowanie (przekształcenie, rozwiązanie) stosunku prawnego, sankcja nieważności, przymusowe wykonanie zobowiązania, przymusowe ustalenie treści prawa oraz inne (np. nakaz złożenia oświadczenia nie będącego oświadczeniem woli) ${ }^{148}$. Sama możliwość dochodzenia roszczeń z tytułu naruszenia zakazów praktyk ograniczających konkurencję na drodze prywatnoprawnej wywodzona jest przez przedstawicieli doktryny przede wszystkim z faktu istnienia „obciążenia” tych zakazów sankcją nieważności bezpośrednio w ustawach antymonopolowych. Argument ten sprawdza się w pełni w odniesieniu do polskiej uokik, która w art. 6 ust. 2 przewiduje nieważność porozumień ograniczających konkurencję, zaś w art. 9 ust. 2 nieważność praktyk nadużywania pozycji dominującej. Podobne rozwiązania przyjęte zostały w wielu europejskich ustawach antymonopolowych. Wprowadzenie sankcji nieważności do ustawy o ochronie konkurencji „oznacza uruchomienie mechanizmu prawnego unieważniania czynności prawnych,

145 Por. sekcja 190(4) Enterprise Act 2002.

146 A. Riley, The Modernisation of EU Anti-Cartel Enforcement: Will the Commission Grasp the Opportunity?, CEPS Special Report, January 2010, dostępny pod adresem: www.ceps. eu/ceps/download/2834.

147 A. Gryniuk, Przymus prawny..., s. 41.

148 Tak A. Stelmachowski, Zarys teorii prawa cywilnego, Wyd. Prawnicze PWN, Warszawa 1998, s. 212-213. 
co niewątpliwie podnosi skuteczność rozwiązań prawnych chroniących konkurencję (...)"149.

Natomiast prawodawca unijny zastrzegł nieważność jedynie dla porozumień ograniczających konkurencję (art. 101 ust. 2 TFUE), nie przewidując takiej sankcji dla zakazanego nadużycia pozycji dominującej. Niemniej jednak orzecznictwo oraz doktryna „przeniosły” sankcję nieważności z art. 101 ust. 2 TFUE także na grunt art. 102 TFUE - pogląd ten obecnie wydaje się nie budzić większych kontrowersji.

Umiejscowienie przepisów ustanawiających sankcję nieważności w ustawach antymonopolowych niewątpliwie podkreśla prywatnoprawne egzekwowanie prawa konkurencji, niemniej jednak - w moim przekonaniu - w systemie polskiego prawa cywilnego fakt ten ma znaczenie drugorzędne. Sankcja nieważności przewidziana w art. 6 ust. 2 i art. 9 ust. 2 uokik jest bowiem klasyczną sankcją cywilnoprawną i nie różni się ona od sankcji nieważności przewidzianej w Kodeksie cywilnym. Pogląd taki w polskiej literaturze wyraził m.in. P. Podrecki ${ }^{150}$, K. Kowalik-Bańczyk ${ }^{151}$, W. Szydło. Ten ostatni twierdzi nawet, że sankcja nieważności wyrażona w przepisach ustawy o ochronie konkurencji i konsumentów ma jedynie „walor informacyjny", istotny z punktu widzenia przedsiębiorców dopuszczających się naruszeń i osób trzecich, oraz „walor wyjaśniający, gdyż w sposób jednoznaczny rozstrzyga wszelkie ewentualne wątpliwości w tym względzie" 152 .

S. Gronowski uważał z kolei, że nieważność ustanowiona w przepisach ustawy antymonopolowej stanowi „samoczynny mechanizm przeciwdziałania czynnościom prawnym sprzecznym z ustawą"153 (co wskazywałoby na jej odmienność od sankcji ustanowionej w kc), choć autor ten przyznawał jednocześnie, że rozstrzygnięcie przyjęte w ustawie jest „zbieżne z rozwiązaniami znanymi już na gruncie prawa cywilnego" 154 . Zdecydowanym przeciwnikiem uznania nieważności praktyk antymonopolowych za sankcję cywilnoprawną był natomiast T. Ławicki, który zaoponował „przeciwko stanowisku SN, który w swej tezie alternatywnie wymienia przesłanki nieważności umowy,

149 K. Strzyczkowski, Nowe prawo konkurencji. Uwagi o projekcie ustawy o ochronie konkurentów i konsumentów, PUG 2000, nr 9, s. 4-5.

150 P. Podrecki, Porozumienia monopolistyczne..., s. 187.

151 K. Kowalik-Bańczyk, Sadowe stosowanie unijnego prawa konkurencji, [w:] A. Wróbel (red.), Stosowanie prawa Unii Europejskiej przez sądy. Tom 1, LEX a Wolters Kluwer business, Warszawa 2010, s. 797.

152 W. Szydło, Nieważność czynności prawnych będących przejawem nadużycia przez przedsiębiorce pozycji dominującej, MoP 2010, nr 4.

153 S. Gronowski, Polskie prawo antymonopolowe..., s. 169.

154 Ibidem. 
cytując przepis ustawy (art. 8 ust. 2) oraz k.c. (art. 58)"155, stwierdzając jednocześnie, że „sankcja nieważności zawarta w art. 8 ust. 2 ustawy jest co prawda zbieżna $\mathrm{z}$ rozwiązaniem znanym na gruncie prawa cywilnego (art. 58 k.c.), ale nie jest z nią tożsama"156. Autor ten równocześnie uznawał możliwość dochodzenia „odszkodowania w postępowaniu antymonopolowym", ale w oparciu o reguły ogólnie przyjęte w prawie cywilnym, uznając, że „nie ma podstaw, by twierdzić, że zadziałanie sankcji nieważności (...) daje legitymację do dochodzenia odszkodowania"157.

Nietrafny wydaje mi się również pogląd B. Turno, który uważa, że „cywilnoprawna sankcja nieważności ma więc zastosowanie zarówno w przypadku publiczno-, jak i prywatnoprawnego egzekwowania przestrzegania prawa konkurencji”158; sankcja nieważności pozostaje właściwa wyłącznie dla prywatnego modelu egzekwowania prawa ochrony konkurencji - fakt, że została ona umiejscowiona w ustawie o ochronie konkurencji nie zmienia jej czysto prywatnoprawnego charakteru.

W konsekwencji uznania sankcji nieważności w uokik za sankcję cywilnoprawną należy przyjąć, że w braku odpowiednich przepisów uokik możliwe byłoby wywiedzenie nieważności z art. 58 § 1 kc: źródłem nieważności antykonkurencyjnej czynności prawnej może być zarówno sprzeczność z ustawą, jak i nielegalności jego causa, rozumianego jako gospodarcza funkcja porozumienia ${ }^{159}$. A. Stawicki podkreśla z kolei, że nieważność porozumienia ograniczającego konkurencję nie oznacza automatycznej nieważności umów zawieranych przez strony antykonkurencyjnego porozumienia i osoby trzecie. Autor ten podkreśla, że strony takiej umowy mogą podnosić jej nieważność z powołaniem się na art. $58 \S 2 \mathrm{kc}$, „należy bowiem uznać, że zawarcie takiej umowy jest sprzeczne z zasadami współżycia społecznego"160.

Jak słusznie uznał SAM, ustawa antymonopolowa jest jedną $\mathrm{z}$ tych ustaw, do których odsyła art. $353^{1} \mathrm{kc}$, określając granice swobody umów ${ }^{161}$, w związku z czym nieważność należy łączyć przede wszystkim z naruszeniem

155 T. Ławicki, Glosa do wyroku SN z dnia 22 lutego 1994 r., I CRN 238/93, PiP 1995, nr 7, s. 102.

156 Ibidem.

157 T. Ławicki, Ustawa o przeciwdziataniu praktykom monopolistycznym. Komentarz, Wydawnictwo Prawnicze PWN, Warszawa 1998, s. 48.

158 B. Turno, Leniency - program tagodzenia kar..., s. 198.

159 M. Libertini, M. R. Maugeri, Infringment of competition law and invalidity of contracts, European Review of Contract Law 2005, nr 2, s. 254. Por. także P. Machnikowski, [w:] E. Gniewek (red.), Kodeks cywilny. Komentarz, C. H. Beck, Warszawa 2011, s. 138 $(\mathrm{Nb} 12)$.

160 A. Stawicki, [w:] A. Stawicki, E. Stawicki (red.), Ustawa..., s. 271.

161 Wyrok SAM z dnia 6 września 1993 r., XVII Amr 26/93, OG 1993, Nr 4, poz. 86. 
imperatywnej normy prawa publicznego - pogląd ten zachowuje aktualność także w odniesieniu do uokik oraz art. 101 i 102 TFUE. Dodatkowo, przypisanie „tradycyjnego” charakteru cywilnoprawnego sankcji nieważności wzmacnia równocześnie - przynajmniej w warunkach polskich - obciążenie sankcją nieważności także praktyk naruszających zakaz zawarty $\mathrm{w}$ art. 102 TFUE (mimo braku bezpośredniego ustanowienia tej negatywnej konsekwencji prawnej w treści Traktatu). Należy jednak zauważyć, że w doktrynie wyrażany jest pogląd przypisujący nieważności przewidzianej w art. 101 ust. 2 TFUE charakter autonomicznego pojęcia prawa unijnego (tak twierdzi A. Komninos ${ }^{162}$; również w polskiej literaturze P. Podrecki zajął stanowisko, zgodnie z którym wzmiankowany przepis ,pełni nie tylko funkcję sankcji, ale wprowadza też do porządków krajowych wspólne pojęcie nieważności"163). Pogląd ten nie zasługuje jednak na aprobatę w sytuacji, gdy pojęcie nieważności nabiera konkretnego znaczenia dopiero w kontekście zastosowania prawa krajowego. Sytuacja ta może jednak zmienić się wówczas, gdy UE zdecyduje się na przyjęcie przepisów harmonizujących niektóre aspekty dochodzenia roszczeń z tytułu naruszenia zakazów praktyk ograniczających konkurencję.

\subsection{Nieważność czynności prawnych naruszających zakazy praktyk ograniczających konkurencję}

\subsubsection{Przedmiot nieważności}

Sankcja nieważności może dotykać wyłącznie czynności prawnych, nie zaś czynności faktycznych nie obejmujących oświadczeń woli - pogląd ten jest powszechnie akceptowany w doktrynie prawa cywilnego ${ }^{164}$. Nieważność nie dotyka zatem wszystkich porozumień ograniczających konkurencję, ale tylko tych (w praktyce - większości), które przyjęły formę porozumienia sensu stricto (umowy pisemnej lub ustnej) bądź uchwały lub innego aktu związków przedsiębiorców lub ich organów statutowych, tj. porozumień w znaczeniu nadanym przez art. 4 pkt 5 lit. a) i c) uokik. Nieważność nie może natomiast odnosić się do uzgodnień (faktycznych) w rozumieniu art. 4 pkt 5 lit. b) uokik - taki pogląd w polskiej literaturze podzielili m.in. T. Skoczny

162 A. Komninos, „Transient” and „transitional” voidness of anti-competitive agreements: a nonissue and an issue, E.C.L.R. 2007, vol. 28(8), s. 446.

163 P. Podrecki: Porozumienia monopolistyczne $i$ ich cywilnoprawne skutki, ZNUJ PWiOWI, Kraków 2000, s. 156.

164 Por. m.in.: P. Machnikowski, [w:] E. Gniewek (red.), Kodeks cywilny..., s. 138 (Nb 9). 
i W. Szpringer ${ }^{165}$ oraz P. Podrecki ${ }^{166}$; odmienny pogląd na tę kwestię prezentowali zaś S. Gronowski ${ }^{167}$ i E. Modzelewska-Wąchal ${ }^{168}$; niektórzy autorzy zwracają uwagę jedynie na fakt, że orzekanie w sprawach porozumień zawartych $\mathrm{w}$ formie uzgodnionych praktyk „,z punktu widzenia dowodowego może rodzić poważne trudności”, nie wyłączając jednak uzgodnień z zakresu sankcji nieważności ${ }^{169}$.

Polski ustawodawca w art. 6 ust. 2 uokik nieprecyzyjnie zatem określa przedmiot sankcji nieważności jako „porozumienia, o których mowa w ust. 1", skoro porozumieniami takimi są zarówno umowy i uchwały związków przedsiębiorców, jak i uzgodnienia. Prawodawca unijny był w tym przypadku bardziej precyzyjny i ograniczył w art. 101 ust. 2 TFUE sankcję nieważności do porozumień (umów) i decyzji związków przedsiębiorstw.

Analogicznie za nieważne uznane mogą być jedynie te praktyki nadużywania pozycji dominującej, które materializują się poprzez czynności prawne.

Jak trafnie zauważa T. Eilmansberger, oddziaływanie sankcji nieważności jest ograniczone właśnie ze względu na to, że nie wszystkie praktyki angażują czynności prawne (z tego powodu nieważność nie dotyczy np. najpoważniejszych karteli) ${ }^{170}$.

Nieważnością objęte są te czynności prawne, które spełniają przesłanki zakazów praktyk ograniczających konkurencję i jednocześnie nie korzystają z wyłączeń spod zakazu ani jako porozumienia de minimis (art. 7 uokik), ani jako wyjątki legalne na zasadzie samooceny realizacji przesłanek $\mathrm{z}$ art. 8 ust. 1 uokik ${ }^{171}$ lub art. 101 ust. 3 TFUE, ani na zasadzie wyłączeń grupowych na podstawie rozporządzeń Rady Ministrów lub Rady (Komisji). Sankcja nieważności nie powinna dotykać również tych praktyk nadużywania pozycji dominującej, które korzystają z orzeczniczego wyłączenia (orzeczniczej racjonalizacji) zakazu nadużywania siły rynkowej z pomocą doktryn obronnych stosowanych $\mathrm{w}$ ramach art. 9 uokik lub art. 102 TFUE (obiektywnego uzasadnienia, doktryny efektywnościowej czy doktryny sprostania konkurencji).

165 T. Skoczny, W. Szpringer, Zakaz porozumień..., s. 45

166 P. Podrecki, Porozumienia monopolistyczne..., s. 189-190.

167 S. Gronowski, Polskie prawo antymonopolowe..., s. 169.

168 E. Modzelewska-Wąchal, Ustawa..., s. 87.

169 Tak: C. Banasiński, E. Piontek (red.), Ustawa..., s. 220.

170 T. Eilmansberger, Green Paper on Damages Actions for Breach of the EC Antitrust Rules and Beyond: Reflections on the Utility and Feasibility of Stimulating Private Enforcement Through Legislative Actions, CMLR 2007, vol. 44(2), s. 433.

171 Tak C. Banasiński, E. Piontek (red.), Ustawa..., s. 222. 
Objęcie sankcją nieważności czynności prawnych stanowiących porozumienie ograniczające konkurencję lub nadużycie pozycji dominującej jest oczywiste, wynika wprost z przepisów (w przypadku porozumień ograniczających konkurencji) lub wykładni systemowej. Spory w doktrynie budzi natomiast problem nieważności innych umów powiązanych $\mathrm{z}$ zakazaną czynnością antykonkonurencyjną. Do umów takich, które mogą być określone jako umowy pochodne, należą m.in. zawierane przez przedsiębiorców-uczestników kartelu umowy sprzedaży, w których stosowana jest cena uzgodniona przez kartel, czy też umowy sprzedaży zawierane przez dystrybutorów doświadczających ze strony dostawcy-przedsiębiorcy dominującego cen nadmiernie wygórowanych. Za objęciem umów pochodnych sankcją nieważności przemawiałaby konieczność wyeliminowania z obrotu wszelkich następstw antykonkurencyjnych zachowań przedsiębiorstw, przeciwko - zasada (wartość) pewności obrotu ${ }^{172}$. Przyznanie priorytetowego znaczenia pewności obrotu skutkuje jednak tym, że praktyki uzgodnione pozostają praktycznie poza oddziaływaniem sankcji nieważności. Jeśli bowiem przyjmujemy, że umowy pochodne wobec czynności prawnych nie mogą być - w imię pewności obrotu - uznane za nieważne, taki sam model należy zastosować wobec umów będących pochodnymi uzgodnień. Brak nieważności umów pochodnych może być jednak zrównoważony poprzez przyznanie nabywcom pośrednim możliwości dochodzenia roszczeń odszkodowawczych od podmiotów dopuszczających się praktyk ograniczających konkurencję $1^{173}$.

Przepisy ustaw antymonopolowych, w tym polskie i unijne przepisy, nie rozstrzygają o stosowaniu sankcji wobec umów tego rodzaju, orzecznictwo i doktryna w poszczególnych krajach różnie odnosi się do tej kwestii. W doktrynie i orzecznictwie niemieckim wyróżnia się umowy następcze (niem. Folgerverträge, ang. follow-on contract) i wykonawcze (niem. Ausführungsverträge). Pierwsza $\mathrm{z}$ tych kategorii obejmuje umowy zawierane przez bezpośredniego uczestnika praktyki ograniczającej konkurencję z osobami trzecimi, niepowiązanymi z czynnością prawną stanowiącą antykonkurencyjną praktykę. Umowy tego rodzaju nie są $\mathrm{z}$ reguły dotknięte sankcją

172 Nawet przedstawiciele doktryny opowiadający się za przyznaniem pierwszoplanowej roli zasadzie pacta sunt servanda nie odmawiają racjonalności argumentowi, że ochrona konkurencji wymagałaby objęcia sankcją nieważności także umów będących następstwem czynności prawnych naruszających zakaz antykonkurencyjnych praktyk por. m.in. M. Gustafsson, F. Hoseinian, Private enforcement of EC competition law: Swedish Supreme Court judgment on the validity of 'follow-on' contracts, E.C.L.R. 2006, vol. 27(1), s. 8-9.

173 Szerzej na temat nabywców pośrednich - zob. rozdział II, pkt 4.3.2.2. 
nieważności - wartością nadrzędną staje się pewność obrotu ${ }^{174}$. P. Podrecki uważa natomiast, że umowy następcze mogą być dotknięte sankcją nieważności, o ile „wpływ tych umów na konkurencję ma charakter negatywny" 175 - pogląd ten nie broni się o tyle, że pośredni negatywny wpływ na konkurencję należy przypisać w zasadzie każdej umowie następczej, jako że zawiera ona uzgodnienia stanowiące rezultat zachowań antykonkurencyjnych; jeśli natomiast umowa następcza sama w sobie negatywnie wpływa na konkurencję (ogranicza konkurencję), może ona samoistnie stać się przedmiotem nieważności. Umowy wykonawcze zawierane są między uczestnikiem (uczestnikami) antykonkurencyjnej czynności prawnej (czynności głównej) a osobami trzecimi, które jednak przyczyniły się do dokonania tej czynności. Umowy te $\mathrm{z}$ reguły są objęte sankcją nieważności, szczególnie wówczas, gdy służą bezpośrednio osiągnięciu niedozwolonego celu ${ }^{176}$. W orzecznictwie francuskim za nieważne uznaje się wszystkie umowy pochodne, bez względu na ich status ${ }^{177}$. Orzecznictwo włoskie natomiast $\mathrm{z}$ reguły odmawia nieważności umowom pochodnym ${ }^{178}$, podobne doświadczenia w odniesieniu do umów następczych ma orzecznictwo szwedzkie ${ }^{179}$.

Problem objęcia sankcją nieważności umów pochodnych ma istotny wymiar praktyczny, możliwe jest bowiem wskazanie pewnej korelacji między potencjalną nieważnością a dopuszczalnością odszkodowań następczych (ang. pass-on damages).

\subsubsection{Charakter nieważności}

Nieważność praktyk ograniczających konkurencję jest nieważnością ipso iure $^{180}$, co S. Gronowski wywodzi z przyjęcia, w przypadku praktyk ograniczających konkurencję, zasady zakazu jako podstawowej zasady ochrony

174 M. Libertini, M. R. Maugeri, Infringement..., s. 259; V. Emmerich, Prawo antymonopolowe, [w:] M. A. Dauses (red.), Prawo gospodarcze Unii Europejskiej, C. H. Beck, Warszawa 1999, s. 729.

175 P. Podrecki, Porozumienia monopolistyczne..., s. 166.

176 P. Podrecki, Porozumienia monopolistyczne..., s. 167; V. Emmerich, Prawo antymonopolowe, [w:] M. A. Dauses (red.), Prawo gospodarcze..., s. 729.

177 Wyrok Cour de Cassastion z dnia 24 września 2000 r., „European Commercial Cases” 2001, s. 140, podaję za: M. Libertini, M. R. Maugeri, Infringement..., s. 260.

178 M. Libertini, M. R. Maugeri, Infringement..., s. 260.

179 Wyrok szwedzkiego Sądu Najwyższego z dnia 23 grudnia 2004 r., T2280/02, Boliden Mineral/Fortum.

180 Por. m.in. wyrok SN z dnia 2 marca 2006 r., III CSK 83/05 (LEX nr 369165), gdzie SN stwierdza: „czynności prawne będące następstwem takich bezprawnych zachowań przedsiębiorców dominujących są nieważne z mocy prawa”. Tak również m.in. Z. Radwański, 
konkurencji181. O sankcji nieważności nie mogą orzekać organy ochrony konkurencji182; nie można zatem domagać się stwierdzenia nieważności (czy przesądzenia o niej) czynności prawnej w decyzji Prezesa UOKiK ${ }^{183}$.

Potwierdzenia nieważności mogą dokonać wyłącznie sądy powszechne184, w systemie polskiego prawa procesowego w trybie art. $189 \mathrm{kpc}^{185}$. Stwierdzenie nieważności przez sąd ma charakter wyłącznie deklaratoryjny186; nie jest ono uzależnione od istnienia uprzedniej decyzji organu ochrony konkurencji ${ }^{187}$.

W piśmiennictwie z zakresu prawa cywilnego ugruntowany był pogląd, że sąd uwzględnia nieważność z urzędu ${ }^{188}$, jednak w świetle obecnych regulacji Kodeksu postępowania cywilnego, zwłaszcza zasady prawdy formalnej, bardziej trafne wydaje się stanowisko, zgodnie z którym „obowiązek uwzględnienia nieważności przez sąd z urzędu w każdym stadium ewentualnego procesu, nie może być ujmowany jako cecha charakterystyczna bezwzględ-

[w:] Z. Radwański (red.), System prawa prywatnego. Prawo cywilne - część ogólna, Tom 2, C. H. Beck, Warszawa 2008, s. 432 (Nb 7).

181 S. Gronowski, Glosa do postanowienia SN z 27.10.1995, III CZP 135/95, OSP 1996, nr 6, poz. 112.

182 Por. art. 1 ust. 1 rozporządzenia 1/2003.

183 Por. wyrok SAM z dnia 17 stycznia 1996 r., XVII Amr 54/95, Wokanda 1997, nr 4, s. 52. Por. także T. Ławicki, Ustawa o przeciwdziałaniu..., s. 47 („Brak jest zatem podstaw do zamieszczania w sentencji decyzji Prezesa Urzędu Ochrony Konkurencji i Konsumentów rozstrzygnięcia w przedmiocie nieważności umowy").

184 Por. art. 6 rozp. 1/2003.

185 Tak również m.in. S. Gronowski, Polskie prawo antymonopolowe..., s. 170; M. K. Kolasiński, Obowiązek wspótpracy gospodarczej w prawie antymonopolowym, TNOiK, Toruń 2009, s. 77-79.

186 W uchwale z dnia 23 lipca 2008 r., III CZP 52/08, SN stwierdził, że z art. 9 ust. 3 „nie wynika, że przesłanką nieważności czynności prawnej jest stwierdzenie nadużycia pozycji dominującej ostateczną decyzją Prezesa UOKiK. Jest to rozwiązanie konsekwentne, gdyż naruszenie zakazu jest zdarzeniem niezależnym od decyzji, która ma w tym zakresie charakter deklaratywny". Taki pogląd jest też powszechnie prezentowany przez doktrynę - zob. m.in. C. Banasiński, E. Piontek (red.), Ustawa ..., s. 218; M. Król-Bogomilska, Kary pieniężne..., s. 37; R. Poździk, Glosa do uchwaty SN z 23 lipca 2008 r., sygn. III CZP 52/08, OSP 2009, nr 7-8, s. 605.

187 Problemowi relacji między rozstrzygnięciami sądowymi i decyzjami organów ochrony konkurencji poświęcony jest rozdział VI. Por. także R. Trzaskowski, Kompetencja sądu do ustalania nieważności czynności prawnych będacych przejawem nadużywania pozycji dominującej oraz nieważności porozumień ograniczających konkurencję, Palestra 2009, nr 9-10, s. 235-243.

188 Z. Radwański, Prawo cywilne - część ogólna, C. H. Beck, Warszawa 2007, s. 339 (Nb 771). Tak również E. Wojtaszek, Ochrona konkurencji a swoboda kontraktowania $w$ umowach franchisingu, PiP 1996, nr 10, s. 24. 
nej nieważności”189. Słusznie zatem Z. Radwański opatruje stwierdzenie, że sąd $\mathrm{z}$ urzędu uwzględnia nieważność czynności prawnej dodatkowymi zastrzeżeniami: „po pierwsze sąd zawsze bierze pod uwagę stan faktyczny przedstawiony przez strony (poza okolicznościami notoryjnymi). Z urzędu obowiązany jest więc oceniać ważność czynności prawnej tylko na tej podstawie”; „po drugie strona nie jest pozbawiona możliwości powoływania się na nieważność czynności prawnej, jednak nie stanowi to koniecznej przesłanki uznania jej za nieważną" ${ }^{190}$. Niemniej jednak względy chociażby praworządności przemawiają za tym, aby nieważność była uwzględniana przez sąd na każdym etapie postępowania.

Uwzględnienie z urzędu nieważności czynności prawnej dotyczy czynności prawnych naruszających zakazy praktyk ograniczających konkurencję zawartych zarówno w prawie krajowym, jak i prawie Unii Europejskiej. Problem uwzględniania przez sądy z urzędu naruszenia prawa unijnego był co prawda w przeszłości przedmiotem ożywionej debaty, jednak obecnie jak się wydaje - został on już rozstrzygnięty, dominującym stanowiskiem stało się obligatoryjne wzięcie pod uwagę przez sąd zarzutu naruszenia prawa UE191. Część przedstawicieli doktryny obowiązek stosowania art. 101 i 102 TFUE wywodzi wprost $z$ art. 6 rozporządzenia $1 / 2003^{192}$.

Sąd może stwierdzić nieważność czynności prawnej także pośrednio, w związku z rozpatrywaniem innych roszczeń (np. odszkodowawczych) wynikających z kwestionowanej czynności prawnej193. Zarzut nieważności może być wykorzystywany aktywnie jako „miecz”, gdy dochodzi się własnych roszczeń przeciw uczestnikom zakazanego porozumienia lub pasywnie jako „tarcza”, kiedy nieważność powoływana jest w celu obrony przed roszczeniami innego podmiotu ${ }^{194}$. Inaczej mówiąc, ustalenie nieważności

189 M. Gutowski, Nieważność czynności prawnej, C. H. Beck, Warszawa 2006, s. 444.

190 Z. Radwański, [w:] Z. Radwański (red.), System prawa prywatnego. Prawo cywilne - część ogólna, Tom 2, C. H. Beck, Warszawa 2008, s. 432 (Nb 8).

191 Por. C-295-298/04 Manfredi, pkt 31; C-126/97 Eco Swiss, pkt 39 i 40); „nieważność, na którą mogą powołać się wszyscy, wiąże sąd (...)" (C-295/04 do C-298/04 Manfredi, pkt 57); w polskiej doktrynie pogląd taki wyrażają m.in. M. Bernatt, Prywatny model ochrony konkurencji oraz jego realizacja w postępowaniu przed sadem krajowym [w:] E. Piontek (red.), Nowe tendencje w prawie konkurencji UE, Warszawa 2008, s. 323; K. Kowalik-Bańczyk, Uwzględnianie przez sąd z urzędu zarzutów opartych na prawie wspólnotowym, EPS 2007, nr 12, s. 10-20.

192 Tak: C. Banasiński, E. Piontek (red.), Ustawa..., s. 220; P. Podrecki, Civil Actions in the Context of Competition Restricting Practices under Polish Law, YARS 2009, vol. 2(2), s. 79.

193 S. Gronowski, Polskie prawo antymonopolowe..., op. cit., s. 169.

194 H. Van den Heuvel, Civil Law Consequences of Violation of the Antitrust Provisions of the Rome Treaty, American Journal of Comparative Law 1963, vol. 12(2), s. 172. Por. rozdział III, pkt 4.3.1. 
porozumienia może być dokonane przez sąd w sposób bezpośredni (gdy strona mająca $\mathrm{w}$ tym interes prawny domaga się ustalenia istnienia lub nieistnienia stosunku prawnego lub prawa) bądź pośredni (gdy okoliczności dotyczące nieważności umowy ujawniają się w postępowaniu związanym $\mathrm{z}$ roszczeniami z tej umowy).

Nieważność może być źródłem roszczenia o zwrot świadczenia spełnionego w wykonaniu nieważnej czynności prawnej, roszczenia odszkodowawczego opartego na culpa in contrahendo oraz roszczenia o ustalenie nieważności czynności prawnej195. Jednocześnie w wyroku z dnia 2 lipca 2009 r., III SK 10/09196, SN podkreślił, że „nieuzasadniony jest zarzut naruszenia art. $387 \S 1$ k.c. oraz art. 8 ust. 3 ustawy [uokik z 2000 r. - przyp. aut.] poprzez uznanie, że umieszczenie w umowie najmu (...) zobowiązania tożsamego ze stwierdzoną praktyką, nie jest równoznaczne ze zobowiązaniem do świadczenia niemożliwego, a tym samym skutkującym nieważnością postanowienia. Okoliczność, że zgodnie z art. 8 ust. 3 ustawy czynności prawne będące przejawem nadużycia pozycji dominującej są nieważne $\mathrm{z}$ mocy prawa nie ma wpływu na ocenę zachowania przedsiębiorcy z punktu widzenia przepisów ustawy, w szczególności jej art. 102”.

Nieważności jako sankcji za naruszenie zakazów praktyk ograniczających konkurencję przypisuje się charakter bezwzględny, co powoduje, że wywiera ona ex tunc197 skutek erga omnes (wszyscy mogą się na nią powołać) ${ }^{198}$. Czynności prawne dotknięte nieważnością nie mogą podlegać konwalidacji, traktowane są jako nieistniejące. Bezwzględna nieważność oznacza bezskuteczność czynności prawnej199. Nie można dochodzić wykonania takiej czynności prawnej przed sądem; umowy dotknięte sankcją nieważności nie wywołują skutków między stronami i nie można się na nie powołać

195 M. Gutowski, Nieważność czynności prawnej, C. H. Beck, Warszawa 2006, s. 449.

196 OSNP 2011, nr 7-8, poz. 116.

197 Tak również: C. Banasiński, E. Piontek (red.), Ustawa..., s. 218, 295; M. Kozak, Private enforcement of competition rules under Community and Polish law - comments after accession, International Business Law Journal 2005, no. 3, s. 382. Inaczej R. Janusz, M. Sachajko, T. Skoczny, Nowa ustawa o ochronie konkurencji i konsumentów, KPPubl. 2001, nr 3 - autorzy twierdzili, że sankcja nieważności przewidziana w ustawie o ochronie konkurencji i konsumentów (z 2000 r.) wywiera skutki ex ante.

s. 380. Por. P. Machnikowski, [w:] E. Gniewek (red.), Kodeks cywilny..., s. 137 (Nb 5).

198 M. Gutowski, Nieważność czynności..., s. 443; Z. Radwański, [w:] Z. Radwański (red.), Kodeks cywilny..., s. 432 (Nb 9). Pogląd o uznaniu nieważności czynności prawnych stanowiących praktykę antykonkurencyjną za skuteczną erga omnes (w świetle polskiej ustawy antymonopolowej) neguje M. Lewandowski, Sankcja nieważności w ustawie antymonopolowej - problematyka kompetencji organów $w$ przedmiocie ustalania naruszenia zakazów antymonopolowych, PPH 2012, nr 2, s. 36.

199 P. Podrecki, Porozumienia monopolistyczne..., s. 174. 
wobec osób trzecich. Za bezwzględnym charakterem nieważności przemawia także okoliczność, że ustawodawca nie przewidział typowej dla nieważności względnej możliwości wzruszenia czynności prawnej200.

Bezwzględny charakter nieważności jest powszechnie uznawany przez polską doktrynę 201 i orzecznictwo ${ }^{202}$. Podobne stanowisko w odniesieniu do sankcji nieważności, na którą wskazuje art. 101 ust. 2 TFUE, zajmował także Trybunał Sprawiedliwości m.in. w wyrokach w sprawach 22/71 Béguelin I 203; 319/82 Société de Ventes de Ciments et Bétons de L'Est SA p. Kerpen \& Kerpen GmbH i Co. KG. ${ }^{204}$; C-453/99 Couarge $^{205}$; C-295/04 do C-298/04 Manfredi206.

Uznanie nieważności czynności prawnej za bezwzględną powoduje, że niemożliwą do zaakceptowania na gruncie polskiego prawa cywilnego jest koncepcja „ważności tymczasowej” (provisional validity), stosowana w początkach funkcjonowania Wspólnot Europejskich przez Trybunał Sprawiedliwości ${ }^{207}$, czy koncepcja „nieważności przejściowej” (transient nullity) wypracowana $\mathrm{w}$ orzecznictwie brytyjskim, a oparta na założeniu, że nieważność czynności prawnych naruszających zakazy praktyk ograniczających konkurencję może mieć charakter dynamiczny. Niezgodność zachowania przedsiębiorstw z zakazami praktyk ograniczających konkurencję może wynikać nie tylko z umyślnego zachowania graczy rynkowych, ale także z sytuacji rynkowej - np. zakaz nadużywania pozycji dominującej znajduje

200 Tak E. Wojtaszek, Ochrona konkurencji..., s. 24.

201 Por. C. Banasiński, E. Piontek (red.), Ustawa..., s. 295; M. Gutowski, Nieważność czynności..., s. 392 i n.; W. Szydło, Nieważność czynności...; R. Poździk, Glosa do uchwaty SN z 23 lipca 2008 r., s. 605; E. Wojtaszek, Ochrona konkurencji..., s. 24.

202 Tak m.in. postanowienie SN z dnia 27 października 1995 r., III CZP 135/95, OSP 1996, nr 6, poz. 112.

203 Wyrok Trybunału z dnia 25 listopada 1971 r. w sprawie C-22/71 Béguelin Import Co. v S.A.G.L. Import Export (Zb. Orz. 1971, s. 00949), pkt 29.

204 Wyrok Trybunału z dnia 14 grudnia 1983 r. w sprawie C-319/82 319/82 Société de Ventes de Ciments et Bétons de L'Est SA p. Kerpen \& Kerpen GmbH i Co. KG (Zb. Orz. 1983, s. 04173), pkt 11 .

205 Wyrok w sprawie Courage, pkt 22.

206 Wyrok w sprawie Manfredi, pkt 57.

207 Zgodnie z tą koncepcją sądy krajowe miały powstrzymać się od oceny ważności porozumień tak długo, jak długo Komisja nie wyraziła negatywnej opinii o porozumieniu - dotyczyło to głównie porozumień zawartych przed wejściem w życie pierwszego rozporządzenia wdrażającego ówczesny art. 85 i 86 - rozporządzenia 17/62. O ewolucji i tej koncepcji w prawie UE piszę nieco szerzej w komentarzu do art. 101 ust. 2 TFUE [w:] A. Wróbel, K. Kowalik-Bańczyk, M. Szwarc-Kuczer (red.), Komentarz do Traktatu o funkcjonowaniu Unii Europejskiej. Tom II, LEX a Wolters Kluwer business, Warszawa 2012, s. 269-270. 
zastosowanie tak długo, jak długo przedsiębiorca zajmuje taką pozycję na rynku, porozumienia ograniczające konkurencję nie będą podlegać zakazowi tak długo, jak długo nie spełniają przesłanek bagatelności. Zmiana okoliczności rynkowych może zatem prowadzić do tego, że praktyka, która początkowa była całkowicie legalna, zyskuje w pewnym momencie niedozwolony charakter; możliwa jest również sytuacja odwrotna: praktyka dozwolona wskutek zmiany uwarunkowań gospodarczych zaczyna podlegać zakazowi praktyk ograniczających konkurencję. W pierwszej z wymienionych sytuacji należy przyjąć, że praktyka staje się nieważna $\mathrm{z}$ chwilą, w której zaczyna ona spełniać przesłanki zakazu porozumień ograniczających konkurencję 208 (jakkolwiek ustalenie takiego momentu może nastręczać istotnych trudności); nie można uznać praktyki za nieważną ze skutkiem retroaktywnym. Stanowisko takie wydaje się możliwe do zaakceptowania z punktu widzenia dogmatyki prawa cywilnego.

Jednakże w wyroku w sprawie Passmore v. Morland \& Ors English \& Wales Court of Appeal stanął na stanowisku, zgodnie z którym nieważność porozumienia „znika” z chwilą, gdy praktyka przestaje spełniać przesłanki zachowania zakazanego. W takiej sytuacji dochodzi zatem do konwalidacji czynności prawnej dotkniętej w przeszłości sankcją nieważności - akceptacja takiego poglądu oznacza zatem pozbawienie nieważności charakteru bezwzględnego, w zamian zaś - przypisanie jej charakteru względnego. Chociaż wyrok w sprawie Passmore spotkał się z krytyką ze strony doktryny (A. Komninos ${ }^{209}$, M. Skowrońska ${ }^{210}$ ), to argumentacji brytyjskiego sądu nie można odmówić pewnej słuszności - jest to argumentacja pragmatyczna, ściśle wiążąca stosowaną sankcję ze specyfiką naruszenia. Niemniej jednak koncepcja przejściowej nieważności wydaje się nie do pogodzenia z zasadą bezwzględnej nieważności antykonkurencyjnych czynności prawnych, akceptowaną nie tylko przez sądy krajowe, ale także Trybunał Sprawiedliwości211. Co prawda w orzeczeniu w sprawie C-279/06 CEPSA Trybunał, jak się wydaje, dopuścił możliwość konwalidacji porozumień, następującej wskutek zmiany treści rozporządzenia wyłączającego - sytuacja ta pozostaje jednak

208 Tak również M. Skowrońska, [w:] A. Wróbel, K. Kowalik-Bańczyk, M. Szwarc-Kuczer (red.), Traktat ustanawiający Wspólnotę Europejska. Komentarz, Tom 2, LEX a Wolters Kluwer business, Warszawa 2009, s. 373-374.

209 A. Komninos, „Transient” and „transitional” voidness..., s. 445-450.

210 M. Skowrońska, [w:] A. Wróbel, K. Kowalik-Bańczyk, M. Szwarc-Kuczer (red.), Traktat..., s. 374.

211 Por. wyrok TS z dnia 11 września 2008 r. w sprawie C-279/06 CEPSA Estaciones de Servicio SA v LV Tobar e Hijos SL (Zb. Orz. 2008, s. I-06681), pkt 73-74. 
odmienna, jako że konwalidacja następuje wskutek zmiany stanu prawnego, a nie stanu faktycznego ${ }^{212}$.

\subsubsection{Zakres nieważności}

Czynności prawne mogą być nieważne w całości (nieważność całkowita) lub „w odpowiedniej części” (nieważność częściowa). Zdaniem SN okoliczności, w których umowy są całkowicie lub częściowo nieważne są „to sytuacje odmienne, zarówno z punktu widzenie przyczyn, jak i skutków" (wyrok SN z dnia 28 kwietnia 2004 r., III CK 521/02, niepubl.). Rozróżnienie to jest istotne ze względu na gospodarcze znaczenie sankcji nieważności, której celem nie jest wyeliminowanie czynności prawnej jako takiej z obrotu, ale ograniczenie jej negatywnych (w tym przypadku antykonkurencyjnych) skutków. Wyodrębnienie nieważności całkowitej i częściowej znajduje także swoje uzasadnienie w art. $58 \S 3 \mathrm{kc}$.

Nieważność może mieć charakter częściowy jedynie wówczas, gdy kwestionowane postanowienie da się wyodrębnić z całości czynności prawnej (umowy) bez uszczerbku dla jej istoty gospodarczej i prawnej, a zatem gdy sankcją objęte są elementy nieistotne umowy. Nieważność całkowita odnosić się będzie zatem do istotnych postanowień umowy (essentialia negotii). Pogląd ten został wielokrotnie potwierdzony zarówno w polskim, jak i unijnym orzecznictwie 213 oraz w literaturze ${ }^{214}$.

Dla oceny możliwości występowania nieważności częściowej i całkowitej przydatne może być zastosowanie podziału klauzul na zakazane i niedozwolone, wykorzystywanego w niektórych regulacjach wyłączających grupowo porozumienia spod zakazu porozumień ograniczających konkurencję. Przykładowo, rozporządzenie ustanawiające wyłączenie grupowe dla porozumień wertykalnych (obecnie rozporządzenie 330/2010) zawiera katalogi

212 Więcej miejsca poświęcam tej kwestii w komentarzu do art. 101 ust. 2 TFUE [w:] A. Wróbel, K. Kowalik-Bańczyk, M. Szwarc-Kuczer (red.), Komentarz..., s. 270-271; zob. także P. Giudici: The CEPSA Case, European Review of Contract Law 2009, nr 2, s. 164.

213 Por. m.in. wyrok Trybunału z dnia 30 czerwca 1966 r. w sprawie 56/65 Sóciété Technique Miniére v. Maschinenbau Ulm GmbH (Zb. Orz. 1966, s. 00235); zob. także wyrok Trybunału z dnia 13 lipca 1966 r. w połączonych sprawach 56/64 i 58/64 Consten GmbH Und Grunding-Verkaufs-GmbH v. Komisja (Zb. Orz. 1966, s. 00299); 319/82 Société de Ventes de Ciments et Bétons de L'Est SA p. Kerpen \& Kerpen GmbH i Co. KG, pkt 11-12; C-279/06 CEPSA, pkt 78.

214 Tak: C. Banasiński, E. Piontek (red.), Ustawa..., s. 295; P. Machnikowski, [w:] E. Gniewek (red.), Kodeks cywilny..., s. 141 (Nb 36). 
dwojakiego rodzaju klauzul: „czarnych”, zakazanych (najpoważniejszych ograniczeń konkurencji, powodujących automatyczną nieważność całego porozumienia; np. art. 4 rozporządzenie 330/2010) oraz niedozwolonych (klauzul sprzecznych co prawda $\mathrm{z}$ art. 101 ust. 1 TFUE, których usunięcie „sanuje” jednak pozostałą część porozumienia; np. art. 5 rozp. 330/2010). W konsekwencji porozumienie zawierające najpoważniejsze ograniczenia konkurencji, wskazane w rozporządzeniach wyłączających jako klauzule zakazane („,czarne”), w całości dotknięte jest sankcją nieważności ${ }^{215}$; porozumienia zawierające klauzule niedozwolone pozostają ważne, za wyjątkiem wzmiankowanego postanowienia.

Ocena możliwości wyodrębnienia pojedynczych klauzul dotkniętych nieważnością należy każdorazowo do sądu orzekającego w danej sprawie. Niemniej jednak aktualny wydaje się apel Trybunału Sprawiedliwości do Komisji, aby ta w swoich decyzjach albo wyraźnie stwierdzała, które klauzule podlegają zakazowi z (obecnego) art. 101 ust. 1 TFUE, albo precyzowała w uzasadnieniu decyzji dlaczego kwestionowane klauzule nie mogą zostać wyodrębnione z całości porozumienia (56/64 i 58/64 Consten \& Grundig). Takie zalecenie może być kierowane także wobec krajowych organów ochrony konkurencji, w tym Prezesa UOKiK.

\subsubsection{Roszczenia o ustalenie istnienia lub nieistnienia stosunku prawnego}

Roszczenie to, które może być realizowane na podstawie art. 189 kpc, określane jest również jako roszczenie o ustalenie nieważności czynności prawnej216. W ramach powództwa opartego na art. $189 \mathrm{kpc}$ nie jest możliwe ustalenie faktów, ta podstawa prawna służy ustaleniu stosunku prawnego lub prawa, przy czym przedmiotem ustalenia mogą być te „prawa i stosunki, dla których właściwa jest droga procesu cywilnego"217, w tym kwestia nieważności umowy.

Warunkiem skorzystania z roszczenia opartego na art. $189 \mathrm{kpc}$ jest wykazanie interesu prawnego w ustaleniu konkretnego stosunku prawnego lub konkretnego prawa. $\mathrm{Z}$ tego powodu niektórzy przedstawiciele doktryny za

215 Por. wyrok Trybunału z dnia 30 listopada 2006 r. w połączonych sprawach C-376/05 i C-377/05 Brünsteiner GmbH and Autohaus Hilgert GmbH v. Bayerische Motorenwerke $A G(B M W)$ (Zb. Orz. 2006, s. I-11383), pkt 50.

216 Tak M. Gutowski, Nieważność czynności..., s. 473.

217 A. Zieliński, [w:] A. Zieliński (red.), Kodeks postępowania cywilnego. Komentarz, C. H. Beck, Warszawa 2012, s. 353 (Nb 3). Por. także B. Czech, [w:] K. Piasecki (red.), Kodeks postępowania cywilnego. Komentarz do art. 1-366, C. H. Beck, Warszawa 2010, s. 1001 (Nb 5). 
niedopuszczalne przyjmują powództwo z art. $189 \mathrm{kpc}$, jeśli istnieje możliwość wytoczenia powództwa o świadczenie - uznaje się bowiem, że brak jest wówczas interesu prawnego, ponieważ ustalenie istnienia lub nieistnienia stosunku prawnego jest wówczas tylko przesłanką uwzględnienia roszczenia o świadczenie. A. Zieliński przypisuje roszczeniu o ustalanie charakter prewencyjny, wynikający z interesu prawnego powodu; „interes ten $z$ reguły odpada, gdy prawo powoda zostało już naruszone $\mathrm{i}$ istnieje możliwość dochodzenia świadczenia wynikającego z naruszenia"218. Okoliczność ta mogłaby znacząco ograniczać możliwość skorzystania z powództwa przewidzianego $\mathrm{w}$ art. $189 \mathrm{kpc} \mathrm{w}$ przypadku naruszeń prawa ochrony konkurencji. Niemniej jednak w wyroku z dnia 2 lutego 2006 r. (II CK 395/05) SN uznał, że interesu prawnego w żądaniu ustalenia stosunku prawnego nie można zakwestionować, gdy ma ono znaczenie zarówno dla obecnych, jak i przyszłych (możliwych), ale obiektywnie prawdopodobnych stosunków prawnych i praw (sytuacji prawnej) podmiotu występującego z żądaniem ustalenia. $\mathrm{W}$ istocie $\mathrm{w}$ przypadku naruszeń zakazu praktyk ograniczających konkurencję, zwłaszcza jeśli naruszenie trwa, niekoniecznie możliwe będzie wniesienie roszczenia o świadczenie, np. roszczenia odszkodowawczego ze względu na nieznany rozmiar szkody. Pogląd o rozszerzonym stosowaniu art. 189, nie ograniczonym wyłącznie do funkcji prewencyjno-wychowawczej, wyrazili m.in. T. Żyznowski219 i B. Czech ${ }^{220}$.

Interes prawny postrzegany jest jako przesłanka merytoryczna powództwa o ustalenie. Kategoria interesu prawnego interpretowana jest szeroko: interes prawny może mieć charakter majątkowy lub niemajątkowy. W sytuacji, gdy postępowanie antymonopolowe w sprawach praktyk ograniczających konkurencję może być wszczynane na wniosek, a nie wyłącznie z urzędu, zastosowanie znajduje stanowisko Sądu Najwyższego, zgodnie z którym „interes prawny w rozumieniu art. 189 kpc jest kategorią obiektywną i nie występuje w takiej sytuacji, gdy stan niepewności u powoda jest wywołany przez składanie wniosków o wszczęcie postępowania administracyjnego"221.

218 A. Zieliński, [w:] A. Zieliński (red.), Kodeks postępowania cywilnego..., s. 359 (Nb 63). Inaczej B. Czech, który stwierdza, że „zasady, że powództwo o ustalenie nie jest dopuszczalne, gdy w konkretnej sytuacji można wytoczyć powództwo o świadczenie, nie można stosować rygorystycznie, lecz należy kierować się względami celowości i ekonomii procesowej" - B. Czech, [w:] K. Piasecki (red.), Kodeks postępowania cywilnego..., s. 1005 $(\mathrm{Nb} 25)$.

219 T. Żyznowski, [w:] H. Dolecki, T. Wiśniewski (red.), Kodeks postępowania cywilnego. Komentarz, Tom I, LEX a Wolters Kluwer business, Warszawa 2011, s. 694 (Nb 3).

220 B. Czech, [w:] K. Piasecki (red.), Kodeks postępowania cywilnego..., s. 1003 (Nb 15).

221 Wyrok SN z dnia 24 marca 1993 r., I CRN 141/93, niepubl., cytuję za: A. Zieliński, [w:] A. Zieliński (red.), Kodeks postępowania cywilnego..., s. 355 ( $\mathrm{Nb} 28)$. 
W orzecznictwie przyjęto również, że interes prawny nie istnieje, gdy powód może żądać świadczenia bądź na drodze sądowej, bądź w postępowaniu administracyjnym ${ }^{222}$ - analogicznie można byłoby przyjąć, że powództwo $\mathrm{z}$ art. $189 \mathrm{kpc}$ zostanie oddalone, jeśli powód ma możliwość złożenia wniosku o wszczęcie postępowania antymonopolowego ${ }^{223}$. Choć celem takiego postępowania nie jest samo w sobie ustalenie nieważności czynności prawnej, to jednak stwierdzenie naruszenia zakazu praktyki ograniczającej konkurencję jest jednoznaczne z nieważnością czynności prawnej stanowiącej istotę takiej praktyki. Uwzględniając jednak okoliczność, że organy ochrony konkurencji mogą odmówić wszczęcia postępowania z powodu niespełnienia przesłanki interesu publicznego, co nie przekreśla możliwości stwierdzenia naruszenia zakazu na drodze prywatnoprawnej, analogia tego rodzaju nie może być w moim przekonaniu - zastosowana.

Interes prawny leżący u podstaw powództwa opartego na art. $189 \mathrm{kpc}$ wyraża się w usunięciu niepewności stanu prawnego 224 - o takim stanie niepewności co do nieważności czynności prawnej stanowiącej potencjalną praktykę ograniczającą konkurencję nie można mówić wówczas, gdy organ ochrony konkurencji wydał rozstrzygnięcie uznające praktykę za sprzeczną z art. 6 lub 9 uokik bądź art. 101 lub 102 TFUE. Należy zatem przyjąć, że w odniesieniu do naruszenia reguł konkurencji roszczenie o ustalenie nieważności czynności wnoszone będzie jako roszczenie samoistne, zwłaszcza jeśli przyjmiemy prejudycjalny charakter rozstrzygnięć organów ochrony konkurencji. Jeśli bowiem istnieje już decyzja organu stwierdzająca naruszenie zakazu praktyki ograniczającej konkurencję, roszczenie o ustalenie nieważności czynności prawnej, której niezgodność z prawem została potwierdzona w decyzji, jest w zasadzie bezprzedmiotowe. Jak orzekł SN w wyroku z dnia 15 marca 2002 r. (II CKN 919/99), w przypadku, gdy dojdzie już do naruszenia prawa, w związku z którym powodowi służy roszczenie o świadczenie (...), wyłączona jest możliwość skutecznego wystąpienia z powództwem o ustalenie, skoro sfera podlegająca ochronie jest w takiej sytuacji szersza, a rozstrzygnięcie o różnicy zdań w stanowiskach stron nabiera charakteru przesłankowego.

„Wyrok uwzględniający powództwo o ustalenie korzysta z powagi rzeczy osądzonej, wskutek czego w razie wytoczenia powództwa o świadczenie

222 Wyrok SN z dnia 21 stycznia 1998 r., II CKN 572/97; orzeczenie SN z dnia 5 maja 2000 r., IV CKN 686/00; orzeczenie SN z dnia 3 listopada 2000 r., IV CKN 146/00, niepubl.

223 Zwolennikiem takiego poglądu wydaje się być M. K. Kolasiński, Obowiązek wspótpracy gospodarczej..., s. 78-79.

224 Uchwała SN z dnia 13 kwietnia 2002 r., III CZP 17/81, OSNC 1981, nr 9, poz. 169. 
$\mathrm{z}$ tego stosunku prawnego, wszelkie zarzuty pochodzące $\mathrm{z}$ okresu przed wydaniem wyroku ustalającego są niedopuszczalne"225.

\subsection{Roszczenie odszkodowawcze z tytułu naruszenia zakazów praktyk ograniczających konkurencję}

\subsubsection{Uwagi wstępne}

Roszczenia odszkodowawcze w polskim prawie cywilnym mogą być realizowane w ramach odpowiedzialności kontraktowej (art. 471 i n. kc) oraz odpowiedzialności z tytułu czynów niedozwolonych (art. 415 i n. kc). Ten ostatni reżim wydaje się mieć podstawowe znaczenie w przypadku naruszenia zakazów praktyk ograniczających konkurencję, choćby dlatego, że wiele podmiotów poszkodowanych wskutek antykonkurencyjnych praktyk (np. konkurenci) nie jest powiązanych z uczestnikami praktyk żadnymi umowami, które mogłyby stać się podstawą odpowiedzialności kontraktowej. Nie można przy tym wykluczyć realizacji odpowiedzialności kontraktowej (o ile istnieją odpowiednie podstawy prawne) ${ }^{226}$. Powstanie obowiązku naprawienia szkody warunkowane jest wystąpieniem trzech przesłanek: szkody (bezprawnej), faktu, z którym wiąże się obowiązek odszkodowawczy (czyn niedozwolony lub niewykonanie bądź nienależyte wykonanie umowy), oraz związku przyczynowego między nimi. Druga $\mathrm{z}$ wymienionych przesłanek może mieć różną treść, co związane jest z tym, że w niektórych przypadkach wykazanie odpowiedzialności wymaga dowiedzenia winy, w innych zaś wina nie jest niezbędnym elementem odpowiedzialności z tytułu czynów niedozwolonych. Nie ma wątpliwości co do tego, że odpowiedzialność na zasadzie winy stanowi podstawową zasadę odpowiedzialności w polskim systemie prawa cywilnego (na co wskazuje brzmienie art. $415 \mathrm{kc}$ ), podczas gdy odpowiedzialność na zasadzie ryzyka oraz na zasadzie słuszności pełnią funkcję uzupełniającą 227. Przesłanki te mogą ulegać pewnej modyfikacji w przypadku odpowiedzialności kontraktowej, o czym będzie jeszcze mowa w dalszej części niniejszego rozdziału.

Udowodnienie przesłanek odpowiedzialności odszkodowawczej w kontekście naruszeń zakazów praktyk ograniczających konkurencję rodzi pewne

225 B. Czech, [w:] K. Piasecki (red.), Kodeks postępowania cywilnego..., s. 1026 (Nb 110).

226 Por. pk 7.7.2. w niniejszym rozdziale.

227 W. Czachórski, Zobowiazania. Zarys wyktadu, Wydawnictwa Prawnicze PWN, Warszawa 1995, s. 146-147. 
trudności i wyzwania związane z interpretacją klasycznych przesłanek odpowiedzialności odszkodowawczej.

W doktrynie wskazuje się na trojaką (kompensacyjna, penalna, wychowawczo-prewencyjna) lub czworaką (obok wymienionych, także funkcja repartycyjna ${ }^{228}$ ) funkcję odpowiedzialności odszkodowawczej, nie ma jednak zgody co do tego, która z tych funkcji przeważa ${ }^{229}$. Funkcji kompensacyjnej przypisuje się rolę wyrównania uszczerbku majątkowego, przywrócenia równowagi majątkowej. Funkcja prewencyjna (sensu stricto) ukierunkowana jest na oddziaływanie na konkretną osobę lub na ogół społeczeństwa (funkcja prewencyjno-wychowawcza) ${ }^{230}$. Funkcja represyjna oznacza ujmowanie obowiązku naprawienia szkody jako kary nakładanej na dłużnika. Funkcja repartycyjna polega na rozłożeniu ekonomicznego ciężaru naprawienia szkody na szerszą grupę społeczną; najlepszy przykład odpowiedzialności repartycyjnej stanowi odpowiedzialność ubezpieczeniowa. Funkcji repartycyjnej nie można przypisać odpowiedzialności za naruszenie zakazów praktyk ograniczających konkurencję.

\subsubsection{Odpowiedzialności kontraktowa uczestników porozumienia}

Co do zasady wzajemne zobowiązania stron z umów naruszających zakazy praktyk ograniczających konkurencję, jako dotknięte sankcją nieważności, nie mogą być egzekwowane. P. Podrecki wskazuje na niedopuszczalność roszczeń odszkodowawczych w oparciu o reżim odpowiedzialności kontraktowej między stronami porozumień 231 . Ten sam autor wyklucza również w zasadzie możliwość powoływania się przez uczestników porozumienia na bezprawność deliktową, argumentując, że stan bezprawności jest wynikiem wspólnego działania stron porozumienia, nie może być zatem podstawą ochrony praw i interesów którejkolwiek ze stron ${ }^{232}$. P. Podrecki dopuszcza jedynie możliwość odwołania się do konstrukcji culpa in contrahendo jako ewentualnej podstawy roszczeń deliktowych między stronami porozumienia ${ }^{233}$. Autor ten wyprowadzał taką odpowiedzialność z art. 387 § 2 kc (pierwotna niemożliwość świadczenia) ${ }^{234}$. Pogląd ten był jednak formułowany przed wejściem w życie ustawy z dnia

228 M. Kaliński, [w:] A. Olejniczak (red.) System prawa prywatnego. Prawo zobowiazań - część ogólna, Tom 6, C. H. Beck, Warszawa 2009, s. 68 (Nb 55).

229 A. Stelmachowski, Zarys teorii..., s. 213.

230 Por. M. Kaliński, [w:] A. Olejniczak (red.), System prawa prywatnego..., s. 72 (Nb 64).

231 P. Podrecki, Porozumienia monopolistyczne..., s. 227.

232 Ibidem, s. 228.

233 Ibidem, s. 228-230.

234 Tak również M. Gutowski, Nieważność czynności..., s. 463. 
14 lutego 2003 r. wprowadzającej nowe brzmienie art. 72 kc - obecnie również ten przepis normuje zasadę winy w kontraktowaniu. Wydaje się, że ta podstawa prawna dla odpowiedzialności z tytułu winy w kontraktowaniu jest znacznie bardziej adekwatna dla praktyk ograniczających konkurencję, ponieważ art. $72 \S 2 \mathrm{kc}$ odnosi się do „stanów faktycznych, w których jedna ze stron negocjacji wie o przesłance nieważności umowy, lecz innej niż objęta zakresem normy z art. 387 kc" - przesłanką tą może być oczywiście nieważność z perspektywy zakazów antykonkurencyjnych praktyk z uokik lub TFUE. W myśl art. 72 § 2 kc, jeśli strona negocjacji prowadzi je niezgodnie z dobrymi obyczajami (np. ukrywa rzeczywisty cel umowy, jakim jest zakazane działanie antykonkurencyjne, co można postrzegać jako wprowadzenie w błąd), istnieje możliwość wystąpienia z roszczeniem odszkodowawczym. W piśmiennictwie przeważający wydaje się pogląd, że zakres tego roszczenia ograniczony jest do tzw. ujemnego interesu umownego.

Stanowiska wykluczającego odpowiedzialność kontraktową uczestników porozumienia nie można jednak uznać za dominujące. M. Bernatt, odwołując się do orzeczenia Trybunału Sprawiedliwości w sprawie Courage, wyróżnia czwartą przesłankę odpowiedzialności odszkodowawczej, która jak podkreśla - odnosi się „tylko do odpowiedzialności pomiędzy uczestnikami porozumienia, tj. odpowiedzialności kontraktowej"235. Przesłanką tą jest znacząca odpowiedzialność sprawcy (kontrahenta poszkodowanego) za zaistniałe naruszenie 236 .

\subsubsection{Odpowiedzialność deliktowa z tytułu naruszenia zakazów praktyk ograniczających konkurencję}

\subsubsection{Wina jako przesłanka odpowiedzialności z tytułu czynów niedozwolonych w kontekście naruszeń zakazów antykonkurencyjnych praktyk}

W piśmiennictwie wskazuje się, że w europejskich (kontynentalnych) porządkach prawnych istnieją dwa sposoby formułowania przesłanek odpowiedzialności cywilnej: pierwszy z nich zakłada wyodrębnianie obok winy przesłanki bezprawności czynu, drugi - opiera się na ogólnym pojęciu winy, przy czym obejmuje ona element obiektywny i subiektywny (ten sposób jest właściwy m.in. dla prawa polskiego i francuskiego) ${ }^{237}$. Odpowiedzialność

235 M. Bernatt, Prywatny model..., [w:] E. Piontek (ed.), Nowe tendencje..., s. 335.

236 Por. pkt 36 wyroku w sprawie Courage.

237 A. Stelmachowski, Zarys teorii..., s. 216. Por. także White Paper Staff Working Paper, pkt 163; B. Nowak-Chrząszczyk, Roszczenie odszkodowawcze w postępowaniu $w$ sprawie 
cywilna $\mathrm{z}$ tytułu własnych czynów niedozwolonych w formule przewidzianej w art. 415 kc opiera się na zasadzie winy.

Pojęcie winy nie zostało zdefiniowane w Kodeksie cywilnym, niemniej jednak polska doktryna powszechnie przyjmuje, że składa się na nią bezprawność postępowania jako element obiektywny oraz podmiotowa, subiektywna wadliwość zachowania się sprawcy jako element subiektywny238. Bezprawność postępowania oznacza, że zachowanie sprawcy (zobowiązanego) musi naruszać jakieś reguły postępowania, nie tylko te określone w prawie powszechnie obowiązującym, ale także poprzez zasady współżycia społecznego ${ }^{239}$. Nie budzi wątpliwości, że naruszenie zakazów praktyk ograniczających konkurencję z art. 6 i 9 uokik oraz art. 101 i 102 TFUE realizuje przesłankę bezprawności.

Subiektywny element winy obejmuje „niewłaściwość zachowania się sprawcy związaną z momentem przewidywania i momentem woli. Stawiamy sprawcy zarzut, że podjął i wykonał niewłaściwą decyzję, a w określonych sytuacjach, że nie uczynił tego, co należało, choć mógł był i powinien" 240 . Występowanie tego elementu jako przesłanki odpowiedzialności odszkodowawczej w przypadku praktyk antykonkurencyjnych jest co najmniej dyskusyjne. O ile niewątpliwym jest, że kartele cenowe, kontyngentowe czy podziałowe, tj. praktyki postrzegane jako zakazane per se, są powoływane za wolą uczestniczących przedsiębiorców, o tyle np. niektóre praktyki mogą ziścić się niezależenie od woli przedsiębiorcy - może się zdarzyć, że wskutek zmiany stosunków rynkowych porozumienie de minimis straci status porozumienia bagatelnego lub określony przedsiębiorca uzyska pozycję dominującą ze względu na wycofanie się konkurenta $\mathrm{z}$ rynku, w konsekwencji czego dotychczasowe legalne praktyki rynkowe - bez udziału woli - staną się bezprawne. Niekoniecznie zatem w odniesieniu do wszystkich rodzajów praktyk ograniczających konkurencję możliwa wydaje się akceptacja odpowiedzialności na zasadzie winy, niemniej jednak zasada ta sprawdza się w przypadku karteli241.

W doktrynie prawa ochrony konkurencji powszechnie przyjmuje się, że naruszenie zakazów praktyk ograniczających konkurencję ma charakter czysto obiektywny, jest niezależne od elementu subiektywnego.

o naruszenie wspólnotowego prawa konkurencji, [w:] E. Piontek (red.), Nowe tendencje..., s. 380-381.

238 Tak m.in. W. Czachórski, Zobowiazania..., s. 148-149; W. Dubis, [w:] E. Gniewek (red.), Kodeks cywilny..., s. 706 (Nb 9).

239 Tak W. Czachórski, Zobowiazania..., s. 149.

240 W. Czachórski, Zobowiązania..., s. 149.

241 P. Podrecki, Porozumienia monopolistyczne..., s. 264. 
Należy rozważyć trzy stanowiska wobec powyższego problemu. Pierwsze $\mathrm{z}$ nich opiera się na odrzuceniu przekonania o całkowicie obiektywnym charakterze naruszeń zakazów praktyk ograniczających konkurencję i przypisaniu przedsiębiorcom podejmującym praktykę co najmniej winy nieumyślnej w postaci niedbalstwa. Wymaga to jednak akceptacji poglądu, że nieprzestrzeganie zakazów praktyk ograniczających konkurencję stanowi przejaw braku należytej staranności przedsiębiorcy; należy wówczas przyjąć, że miernikiem staranności przedsiębiorcy jest wzorzec przedsiębiorcy przestrzegającego zakazów praktyk ograniczających konkurencję. Przyjęcie tego stanowiska wydaje się akceptowalne zwłaszcza w świetle normatywnej teorii winy, której zastosowanie zaciera w zasadzie granice między niedbalstwem a bezprawnością 242 .

Drugie stanowisko przewiduje odrzucenie możliwości korzystania z roszczeń cywilnoprawnych opartych na reżimie odpowiedzialności z tytułu czynów niedozwolonych w tych przypadkach, gdy nie jest możliwe dowiedzenie winy pozwanego (pozwanych). Należy zastrzec, że akceptacja tego stanowiska nie będzie bynajmniej pozbawiała zainteresowanych powodów możliwości dochodzenia roszczeń w ramach prywatnego egzekwowania prawa ochrony konkurencji, ale będzie wymagała oparcia roszczeń na innej podstawie prawnej niż art. $415 \mathrm{kc}$ - do dyspozycji pozostaje roszczenie z tytułu bezpodstawnego wzbogacenia (art. $405 \mathrm{kc})^{243}$ oraz roszczenia przewidziane w ustawie o zwalczaniu nieuczciwej konkurencji, dla których realizacji nie jest konieczne dowiedzenie winy.

Trzecie stanowisko zakłada przyjęcie, że odpowiedzialność odszkodowawcza za naruszenie zakazów praktyk ograniczających konkurencję jest odpowiedzialnością niezależną od winy, odpowiedzialnością na zasadzie ryzyka. Można założyć, że naruszenie zakazów praktyk ograniczających konkurencję stanowi pewne ryzyko prowadzenia działalności gospodarczej. Istota odpowiedzialności na zasadzie ryzyka sprowadza się do tego, że „do powstania obowiązku naprawienia szkody wina osoby, która za szkodę odpowiada, nie jest potrzebna. Wystarczy samo powstanie szkody, stanowiące następstwo zdarzenia, z którym ustawa łączy ową zaostrzoną odpowiedzialność"244. Realizacja takiego podejścia do odpowiedzialności odszkodowawczej w ramach prywatnego egzekwowania prawa ochrony konkurencji wymagałaby jednak interwencji ustawodawcy, gdyż przypadki odpowiedzialności na zasadzie ryzyka muszą być wyraźnie określone w ustawie. P. Podrecki słusznie

242 Z. Banaszczyk, [w:] K. Pietrzykowski (red.), Kodeks cywilny. Komentarz. Tom I, C. H. Beck, Warszawa 1999, s. 930 (Komentarz do art. 415, Nb 18).

243 Por. pkt 7.8.4. w niniejszym rozdziale.

244 J. Winiarz, Obowiazek naprawienia szkody, Wydawnictwa Prawnicze, Warszawa 1970, s. 39. 
podnosi, że przyjęcie odpowiedzialności sprawców praktyk ograniczających konkurencję na zasadzie ryzyka „byłoby w pewnym sensie zbieżne” z ukształtowaniem zasad odpowiedzialności w ustawach (przepisach) z zakresu prawa ochrony konkurencji245.

Stanowisko zaprezentowane powyżej (jako trzecie) można powiązać z widocznym, zwłaszcza w orzecznictwie Trybunału Sprawiedliwości, przekonaniem, że naruszenia zakazów praktyk ograniczających konkurencję są same w sobie na tyle poważne, że eliminują konieczność dowiedzenia winy 246 . Przekonanie to stanowi prawdopodobnie źródło przedstawionej przez Komisję w Białej księdze propozycji, aby zwolnienie się z odpowiedzialności odszkodowawczej związanej z naruszeniem zakazów antykonkurencyjnych praktyk możliwe było jedynie w sytuacji, gdy naruszenie nastąpiło pod wpływem usprawiedliwionego błędu (excusable error) ${ }^{247}$, przy czym błąd „uznaje się za usprawiedliwiony, jeśli osoba działająca racjonalnie i z zachowaniem wysokiego standardu staranności nie mogła być świadoma, że dane postępowanie ograniczało konkurencję"248.

\subsubsection{Związek przyczynowy jako przesłanka odpowiedzialności z tytułu czynów niedozwolonych w kontekście naruszeń zakazów antykonkurencyjnych praktyk}

Zagadnienie definiowania związku przyczynowego znacznie wykracza nie tylko poza ramy niniejszego opracowania, ale poza ramy nauki prawa w ogóle. Najogólniej przyjmuje się, że związek przyczynowy między jakimś zdarzeniem a szkodą zachodzi wówczas, gdy bez zdarzenia początkowego nie nastąpiłby wynik ostateczny w postaci szkody 249 . W doktrynie prawa cywilnego związek przyczynowy wyjaśniany jest przede wszystkim przez teorię równowartości przyczyn lub teorię adekwatnej przyczynowości, za przejaw tej ostatniej uznaje się art. $361 \S 1 \mathrm{kc}^{250}$.

245 P. Podrecki, Porozumienia monopolistyczne..., s. 264.

246 White Paper Commission Staff Working Paper, pkt 170.

247 Niektórzy autorzy wskazują, że należałoby wskazać więcej niż jedną okoliczność zwolnienia $\mathrm{z}$ odpowiedzialności - por. P. Voet van Vormizeele, The fault requirement in European private antitrust litigation and compliance programmes as exculpating or mitigating factor, G.C.L.R. 2010, vol. 3(1), s. 4.

248 Biała księga, pkt 2.4. (s. 7-8). Por. także White Paper Commission Staff Working Paper, pkt $176-179$.

249 Tak W. Czachórski, Zobowiazania..., s. 155.

250 J. Winiarz, Obowiazek naprawienia..., s. 28. Tak również K. Dubis, [w:] E. Gniewek (red.), Kodeks cywilny..., s. 571 (Nb 5). 
Związek przyczynowy stanowi zarówno podstawę odpowiedzialności, jak i wyznacza granicę odpowiedzialności odszkodowawczej251, jego oddziaływanie limituje sam ustawodawca poprzez art. $361 \S 1 \mathrm{kc}$ ograniczający odpowiedzialność do adekwatnego związku przyczynowego, czyli do normalnych następstw działania i zaniechania, z którego szkoda wynikła. Za normalne następstwa danej przyczyny uważane są takie, których prawdopodobieństwo powstania każdorazowo zwiększa się poprzez zaistnienie przyczyny 252 .

P. Podrecki uważa jednak, że w przypadku porozumień ograniczających konkurencję (a pogląd ten można śmiało rozciągnąć także na nadużywanie pozycji dominującej) korzystanie $\mathrm{z}$ dyrektywy zawartej w art. $361 \S 1 \mathrm{kc}$ jest niewystarczające ${ }^{253}$. W istocie szczególnych trudności może nastręczać odróżnienie tych negatywnych skutków rynkowych, które stanowią realne następstwo praktyki, od skutków, które zaistniałyby także w braku antykonkurencyjnej praktyki. Problematyczne może być również ustalenie związku przyczynowego między działaniem lub zaniechaniem stanowiącym antykonkurencyjną praktykę a szkodą odczuwalną dla uczestników rynku działających na szczeblu odległym od szczebla, na którym funkcjonuje przedsiębiorca dopuszczający się praktyki (przedsiębiorcy pośrednio poszkodowani), czy wreszcie - szkodą odczuwalną dla konsumentów. Niektórzy przedstawiciele doktryny wprost postulują badanie w kontekście związku przyczynowego „skutku naruszenia prawa konkurencji w postaci szkód poniesionych przez pośrednich odbiorców dóbr czy usług, w tym konsumentów"254.

Niemniej jednak również TS wskazywał na potrzebę wykazania związku przyczynowego między szkodą a praktyką ograniczającą konkurencję w przypadku dochodzenia roszczeń z tytułu naruszenia z zakazów z art. 101 lub 102 TFUE $^{255}$.

\subsubsection{Szkoda antymonopolowa}

\subsection{Pojęcie szkody antymonopolowej}

Celem wystąpienia $\mathrm{z}$ roszczeniem odszkodowawczym jest uzyskanie świadczeń pieniężnych rekompensujących szkodę powstałą wskutek naruszenia zakazów praktyk ograniczających konkurencję. Kodeks cywilny nie zawiera definicji „szkody”, prawnicze rozumienie tego pojęcia jest zbliżone

251 M. Kaliński, [w:] A. Olejniczak (red.), System prawa prywatnego..., s. 122 (Nb 100).

252 M. Kaliński, [w:] A. Olejniczak (red.), System prawa prywatnego..., s. 127 (Nb 103).

253 P. Podrecki, Porozumienia monopolistyczne..., s. 272.

254 M. Bernatt, Prywatny model..., [w:] E. Piontek (red.), Nowe tendencje..., s. 335.

255 Wyrok TS w sprawach połączonych od C-295/04 do C-298/04 Manfredi, pkt 61 i 63. 
do pojęcia potocznego, jednocześnie podkreśla się, że w doktrynie i orzecznictwie istnieją znaczące rozbieżności co do zakresu pojęcia „szkody”256, choć większość autorów jest zgodna co do tego, że pojęcie to odnosi się wyłącznie do sfery majątkowej257. Przykładowo, J. Winiarz definiuje „szkodę” jako różnicę między stanem majątkowym poszkodowanego, a stanem, jaki by w jego majątku istniał, gdyby to zdarzenie nie nastąpiło 258 . Niektórzy autorzy - m.in. A. Szpunar 259 i Z. Radwański ${ }^{260}$ - włączali w definicję „szkody” element braku woli poszkodowanego co do powstania szkody, co jednak spotyka się z uzasadnioną krytyką ${ }^{261}$.

W odniesieniu do prywatnego egzekwowania prawa konkurencji zasadne staje się pytanie o to, czy tradycyjne cywilistyczne ujęcie szkody jest wystarczające w kontekście odpowiedzialności z tytułu czynów niedozwolonych, wynikającej z naruszenia zakazów praktyk ograniczających konkurencję, czy też szkoda antymonopolowa (antitrust harm; antitrust injury) nie powinna być identyfikowana jako samoistna kategoria szkody, wykazująca pewne specyficzne cechy. Jednym z zasadniczych problemów definiowania szkody w sprawach cywilnych związanych ze stosowaniem zakazów praktyk ograniczających konkurencję jest wyznaczenie granicy między szkodą powstałą z antykonkurencyjnych zachowań a „szkodami”, jakich przedsiębiorcy (rzadziej: inne podmioty) doznają wskutek normalnej walki konkurencyjnej (tj. zachowań nie naruszających zakazów praktyk ograniczających konkurencję), np. wskutek intensyfikacji konkurencji.

Dorobek doktryny i orzecznictwa europejskiego i krajowego w zakresie definiowania szkody antymonopolowej jako szczególnego rodzaju szkody pozostaje stosunkowo ograniczony ${ }^{262}$, pewnych wskazówek może dostarczać jednak dorobek orzecznictwa i doktryny amerykańskiej. W wyroku w spra-

256 Z. Banaszczyk, [w:] K. Pietrzykowski (red.), Kodeks cywilny..., s. 791 (Komentarz do art. 361, $\mathrm{Nb} 24)$.

257 Inaczej W. Czachórski, który definiował szkodę jako „uszczerbek, który dotyka poszkodowanego, zarówno o charakterze majątkowym, jak i niemajątkowym”, przy czym autor ten zaznaczał, że „pewne unormowania specjalne odnoszą się jednak do uszczerbku niemajątkowego, zwanego także krzywdą” - W. Czachórski, Zobowiązania..., s. 75.

258 J. Winiarz, Obowiazek naprawienia..., s. 21.

259 A. Szpunar, Zakres obowiazku naprawienia szkody, PiP 1960, z. 1, s. 29 i d.

260 Z. Radwański, Prawo zobowiazań, Warszawa 1986, s. 76.

261 Z. Banaszczyk, [w:] K. Pietrzykowski (red.), Kodeks cywilny..., s. 792 (Komentarz do art. 361, $\mathrm{Nb} 27)$.

$262 \mathrm{~W}$ polskim piśmiennictwie problematykę tę podją D. Miąsik, Wtasność intelektualna a szkoda dla konkurencji w prawie UE, Zeszyty CEN 2012, z. 25. 
wie Brunswick ${ }^{263}$ sąd najwyższy US stwierdził, że „szkoda antymonopolowa to taka szkoda, której wystąpieniu zapobiec miało prawo antymonopolowe i która wynika z nielegalnego zachowania pozwanego". Istota wypracowanej w sprawie Brunswick doktryny szkody antymonopolowej (antitrust injury doctrine) polega na tym, że kwestią pierwszoplanową w postępowaniach sądowych nie jest to, czy pozwany wyrządził szkodę powodowi, ale to, czy potencjalna szkoda $\mathrm{w}$ dostatecznym stopniu odzwierciedla negatywny wpływ zachowania pozwanego na konkurencję; innymi słowy doktryna szkody antymonopolowej przewiduje, że szkodę ponosi nie tylko powód, ale także konkurencja ${ }^{264}$, szkoda odczuwalna jest zatem w dwóch płaszczyznach (interes prywatny, interes publiczny). Doktryna ta pozwoliła wyeliminować sytuacje, w których samo stwierdzenie naruszenia prawa konkurencji było wystarczającą przesłanką do uzyskania potrójnego odszkodowania, co należy oceniać negatywnie z punktu widzenia kształtowania efektywnych relacji rynkowych ${ }^{265}$.

W wyroku w sprawie $A R C O^{266}$ amerykański sąd najwyższy uściślił, że szkoda antymonopolowa wynika z ograniczenia lub eliminacji konkurencji na rynku, nie zaś jedynie z naruszenia zasad funkcjonowania rynku, ponieważ „każde naruszenie prawa antymonopolowego może być postrzegane jako «zakłócenie» (ang. disrupt) lub «zniekształcenie» (ang. distort) konkurencji”, w innym przypadku nie istniałoby naruszenie. W tym miejscu - jak słusznie wskazuje C. A. Jones - ujawnia się istotna rozbieżność między amerykańskim i europejskim prawem konkurencji, polegająca na tym, że art. 101 i 102 TFUE (oraz wzorowane na nich przepisy krajowe, takie jak art. 6 i 9 uokik) wymieniają zniekształcenie konkurencji jako „delikt antymonopolowy” na równi z ograniczeniem i eliminacją konkurencji. Według C. A. Jonesa jest to okoliczność uniemożliwiająca import doktryny szkody antymonopolowej na grunt europejskiego (i wzorowanego na nim krajowego) prawa konkurencji ${ }^{267}$.

263 Brunswick Corp. v. Pueblo Bowl-O-Mat, Inc., 429 US 489 (1977). Sprawa ta dotyczyła szkody wynikłej z naruszenia sekcji 7 Clayton Act (zakaz fuzji wywierających negatywny wpływ na rynek).

264 K. S. Marshall, The Economics of Competitve Injury, [w:] K. S. Marshall (red.), The Economics of Antitrust Injury and Firm-Specific Damages, Tucson 2008, s. 3.

265 Tak: W. H. Page, Antitrust Damage and Economic Efficiency: An Approach to Antitrust Injury, The University of Chicago Law Review 1980, vol. 47(3), s. 468; J. M. Jacobson, T. Greer, Twenty-One Years of Antitrust Injury: Down the Alley with Brunswick v. Pueblo Bowl-O-Mat, Antitrust Law Journal 1998, vol. 66, s. 273 i n.

266 ARCO - Atlantic Richfield Co. V. USA Petroleum Co., 495 US 328 (1990).

267 C. A. Jones, Private enforcement of antitrust law in the EU, UK and USA, Oxford 2005, s. 193. 
Przyjmując, że doktryna szkody antymonopolowej byłaby trudna do zaakceptowania w europejskim (i krajowym) prawie konkurencji, należałoby rozważyć recepcję stanowiska wypracowanego przez sąd najwyższy USA w wyroku w sprawie Cargill268, zgodnie z którym szkoda antymonopolowa definiowana jest w sposób negatywny - nie jest nią szkoda poniesiona wskutek intensyfikacji konkurencji.

Koncepcja wypracowana w orzeczeniu w sprawie Cargill mogłaby zostać zaakceptowana w polskim orzecznictwie. Obecnie jednak w Polsce pojęcie szkody antymonopolowej jest obce zarówno ustawodawcy, jak i orzecznictwu, a nawet piśmiennictwu (żaden $\mathrm{z}$ autorów podnoszących problematykę prywatnego egzekwowania prawa ochrony konkurencji nie posługuje się tym pojęciem). W istocie trudno znaleźć argumenty przemawiające za klasyfikowaniem szkody z tytułu naruszenia zakazów praktyk ograniczających konkurencję jako odrębnego rodzaju (kategorii) szkód cywilnych, zwłaszcza wówczas, gdy nie istnieją żadne specjalne unormowania dotyczące prywatnego egzekwowania prawa ochrony konkurencji. W polskim systemie prawnym szkody wywołane praktykami antykonkurencyjnymi pozostają zatem „normalnymi” szkodami cywilnymi.

\subsection{Zakres szkody antymonopolowej}

W kategoriach prawnych elementy szkody antymonopolowej, tak jak każdej innej szkody cywilnoprawnej, stanowią: szkoda rzeczywista (damnum emergens) oraz utracone korzyści (lucrum cessans), a ewentualnie także odsetki. W polskim porządku prawnym zakres odszkodowania obejmujący stratę i utracone korzyści wyznacza art. 361 § 2 kc. Rzeczywistą szkodę stanowi uszczerbek na majątku określonej osoby, natomiast utrata korzyści oznacza, że nie doszło do zwiększenia majątku, które nastąpiłoby, gdyby nie doszło do naruszenia. Odsetki powinny natomiast służyć „naprawie szkodliwych skutków wynikających z czasu, jaki upłynął od momentu szkody spowodowanej naruszeniem" 269 . W doktrynie i orzecznictwie panuje zgoda co do tego, że odszkodowania w ramach prywatnego egzekwowania prawa konkurencji powinny obejmować tak rozumianą szkodę, bez względu na to,

268 Cargill, Inc. v. Monfort of Colorado, Inc.

269 Por. Projekt - Wskazówki Komisji. Ustalanie wysokości szkody w dochodzeniu roszczeń odszkodowawczych z tytułu naruszenia art. 101 lub 102 TFUE - dokument przygotowany został przez DG ds. Konkurencji, dostępny pod adresem: http://ec.europa.eu/competition/ consultations/2011_actions_damages/draft_guidance_paper_pl.pdf; dalej jako: projekt Wskazówki Komisji. Ustalanie wysokości szkody..., pkt 17. Por. wyrok Trybunału z dnia 2 sierpnia 1993 r. w sprawie C-271/91 Marshall (Zb. Orz. 1993, s. I-4367), pkt 31; wyrok TS w połączonych sprawach od C-295/04 do C-298/04 Manfredi, pkt 97. 
czy chodzi o szkodę wynikającą z naruszenia prawa krajowego, czy prawa unijnego. W odniesieniu do tego ostatniego TS w wyroku w połączonych sprawach od C-295/04 do 298/04 Manfredi stwierdzit, że żądanie, aby wielkość odszkodowania obejmowała zarówno rzeczywiste szkody (damnum emergens), jak i utracone korzyści (lucrum cessans) oraz zapłatę odsetek, jest zgodne z zasadą skuteczności prawa unijnego ${ }^{270}$; stanowisko takie popiera również Komisja ${ }^{271}$. Zdaniem Trybunału, wykluczenie utraconych korzyści z wartości szkody mogłoby „uczynić faktycznie niemożliwym naprawienie szkody”272. Zapłatę odsetek natomiast TS uznał wprost za „niezbędny składnik odszkodowania"273.

Włączenie w pojęcie szkody (choćby w sensie prawnym) utraconego zysku pozwala na objęcie statusem poszkodowanych nie tylko rzeczywistych, ale także potencjalnych konkurentów lub kontrahentów podmiotów dopuszczających się naruszenia. Nawet firmy nieobecne na rynku w czasie trwania naruszenia, ale wskutek jego istnienia wykluczone z rynku, mogą dochodzić utraconych zysków, jeśli będą w stanie wykazać wystarczający związek przyczynowo-skutkowy między wykluczeniem a poniesioną szkodą274. Kategoria lucrum cessans może obejmować straty określane w literaturze jako utracony zysk (ang. lost profit), utracony dorobek (ang. lost wealth), czy utracone okazje (ang. lost opportunity). W przypadku szkody odniesionej przez przedsiębiorców (konkurentów lub kontrahentów) w sensie ekonomicznym utracony zysk może być identyfikowany ze szkodą w postaci utraconego wolumenu.

Postać, jaką przybiera szkoda antymonopolowa, zależy w dużej mierze od rodzaju praktyki ograniczającej konkurencję stanowiącej jej źródło. W literaturze ekonomicznej wskazuje się na dwie kategorie najczęściej występujących szkód: zawyżone ceny (ang. overcharges) ${ }^{275}$ oraz tzw. efekt utraconego

\footnotetext{
270 Wyrok w połączonych sprawach od C-295/04 do C-298/04 Manfredi, pkt 95.

271 Biała księga, pkt 2.5. (s. 8).

272 Pkt 66 wyroku. Por. wyrok Trybunału z dnia 5 marca 1996 r. w sprawach połączonych C-46/93 i 48/93 Brasserie du Pecheur S.A. p. Germany oraz $R$ p. Secretary of State for Transport, ex parte Factortame Ltd. i inni (Zb. Orz. 1996, s. I-1029), pkt 87, oraz wyrok TS z dnia 8 marca $2001 \mathrm{r}$. w sprawach połączonych C-397/98 i C-410/98 Metallgesellschaft $i$ in. (Zb. Orz. 2001, s. I-1727), pkt 91.

273 Pkt 97 wyroku. Por. wyrok w sprawie C-271/91 Marshall, pkt 31.

274 Quantifying antitrust damages. Towards non-binding guidance for courts (study prepared for the European Commission by Oxera and multijurisdictional team of lawyers led by Dr A. Komninos), grudzień 2009, s. 20 (dokument dostępny pod adresem: http://ec.europa. eu/competition/antitrust/actionsdamages/quantification_study.pdf); dalej jako raport Oxera.

$275 \mathrm{~W}$ polskim tłumaczeniu projektu wskazówek Komisji w sprawia ustalania wysokości szkody... zawyżone ceny (overcharges) określane są jako „nadmierne obciążenia”. Por. także projekt - Wskazówki Komisji. Ustalanie wysokości szkody..., pkt 117-141.
} 
wolumenu (ang. lost volume), określany także jako spadek wartości sprzedaży ${ }^{276}$. Obydwie kategorie szkód mogą być wynikiem zarówno karteli, jak i jednostronnych praktyk wykluczających. Z kolei Komisja Europejska wyodrębnia dwie zasadnicze kategorie szkód ${ }^{277}$ : te wynikłe z naruszeń podmiotów wykorzystujących (indywidualnie lub zbiorowo) swoją władzę rynkową do podwyższania cen ${ }^{278}$ oraz te wynikające z naruszeń polegających na wykluczaniu innych podmiotów z rynku lub ograniczających udział w nim²79.

Najbardziej klasyczną szkodę antymonopolową, wynikającą z karteli poziomych, stanowi cena zawyżona (nadmiernie „obciążona”) (ang. overcharges), czyli różnica między ceną konkurencyjną (tj. tą, stosowaną w warunkach nieistnienia kartelu, np. po jego zakończeniu) a ceną kartelową ${ }^{280}$ - badania ekonomistów wskazują, że średnio takie zawyżenie wynosi od 13-16\%281 poprzez $18-20 \% 282$ do nawet $28 \% 283$ ceny kartelowej. Na marginesie należy zauważyć, że wartości wskazywane przez ekonomistów jako nadwyżkowe są jednak wyższe niż progi przyjęte dla domniemania szkody antymonopolowej w ustawodawstwie węgierskim oraz w amerykańskim prawie miękkim (wzmiankowane powyżej). W przypadku praktyk wykluczających szkoda w postaci zawyżonej ceny sprowadza się do zawyżenia marży.

Szkoda w postaci utraconego wolumenu obrazowana jest ilością towarów, których klienci nie kupią ze względu na cenę stosowaną wskutek praktyki ograniczającej konkurencję (bez względu na to, czy wynika ona z działalności kartelowej czy z nadużywania pozycji dominującej). Utracony wolumen może wynikać z utraty klientów - dzieje się tak np. wówczas, gdy stosowanie cen drapieżnych przez dominanta wyklucza możliwość konkurowania z nim na poziomie sprzedaży hurtowej lub detalicznej284 bądź w przypadku

\footnotetext{
276 Por. projekt - Wskazówki Komisji. Ustalanie wysokości szkody..., pkt 155-159.

277 Projekt - Wskazówki Komisji. Ustalanie wysokości szkody..., pkt 18.

278 Szerzej: projekt - Wskazówki Komisji. Ustalanie wysokości szkody..., pkt 108-159.

279 Szerzej: projekt - Wskazówki Komisji. Ustalanie wysokości szkody.., pkt 160-196.

280 Takie stanowisko wyraził Landgericht Dortmund w wyroku z dnia 1 kwietnia 2004 r. w sprawie 13 O 55/02 Kart (Kartel witaminowy).

281 Badania OECD 2002.

282 Na średnią wartość 20\% nadwyżki wskazują badania Connora i Lande (Cartel Overcharges and Optimal Cartel Fines, [w:] S. W. Waller (red.), Issues in Competition Law and Policy, volume 3, ABA Section of Antitrust Law, 2008, s. 2203-18); na 18\% - bazujące na tych badaniach, aczkolwiek przy zmienionej próbie - badania przeprowadzone przez Oxera na potrzeby raportu z 2009 r. (zob. raport Oxera, s. 91).

283 R. A. Posner, Antitrust Law, 2nd edition, The University of Chicago Press 2001.

284 Por. np. wyrok Corte d'Appello di Roma z dnia 20 stycznia 2003 r. w sprawie Albacom S.p.A. $i$ inni v. Telecom Italia S.p.A.
} 
praktyki polegającej na odmowie dostaw, kontraktowania czy dostępu do urządzenia kluczowego.

Wskazane powyżej kategorie szkód poddają się, choć nie bez pewnych przeszkód, kwantyfikacji, podczas gdy szkody antymonopolowe wynikające z praktyk (zwłaszcza eksploatacyjnych) o charakterze pozacenowym z trudem mogą być ujmowane ilościowo i/lub wartościowo (przykładem takiej szkody jest obniżenie jakości ${ }^{285}$ ).

Jeśli jednak porozumienie zostało zawarte, ale nie zostało $\mathrm{w}$ żaden sposób wdrożone, to jego uczestnicy będą podlegali sankcjom w trybie publicznego egzekwowania konkurencji, natomiast - przyjmując, że niewdrożenie porozumienia jest równoznaczne z brakiem szkody - nie będzie możliwości orzeczenia o odszkodowaniach; w ramach trybu prywatnoprawnego porozumienie takie zostanie objęte tylko sankcją nieważności. Badania ekonomiczne wskazują, że możliwe, choć rzadkie (ok. 7\%) ${ }^{286}$ są również sytuacje, w których realizowana zmowa kartelowa nie spowodowała żadnego zawyżenia ceny287; również w takich przypadkach - kiedy nie wystąpi szkoda rzeczywista (ani utracone korzyści) - nie będzie możliwe uzyskanie odszkodowania, mimo stwierdzenia naruszenia publicznego prawa konkurencji.

\subsection{Uwagi ogólne o sposobach naprawienia szkody}

Naprawienie szkody może polegać na przywróceniu stanu poprzedniego lub zapłacie odpowiedniej sumy pieniężnej (art. $363 \S 1 \mathrm{kc}$ ). Wskazane sposoby naprawienia szkody mają realizować podstawową funkcję odpowiedzialności odszkodowawczej, jaką jest funkcja kompensacyjna ${ }^{288}$. W wielu wypadkach przywrócenie stanu poprzedniego albo w ogóle nie jest możliwe z przyczyn faktycznych lub prawnych, albo pociąga ze sobą nadmierne trudności lub koszty dla zobowiązanego, albo też nie będzie (np. ze względu na upływ czasu) realizowało interesu poszkodowanego ${ }^{289}$. Wybór sposobu

285 Raport Oxera, s. 17.

286 Raport Oxera, s. 90. Autorzy raportu powołują się na wyniki badań przeprowadzonych przez J. M. Connor i R. H. Lande i zaprezentowanych [w]: How High Do Cartels Raise Prices? Implications for Reform of the AntitrustSentencing Guidelines, American Antitrust Institute Working Paper No. 01-04, April 2005.

287 Raport Oxera, s. 88.

288 Z. Banaszczyk, [w:] K. Pietrzykowski (red.), Kodeks cywilny..., s. 807 (Komentarz do art. 363, Nb 1).

289 Problematyka restytucji naturalnej omówiona jest nieco szerzej w pkt 7.8.3. w niniejszym rozdziale. 
naprawienia szkody należy jednak do poszkodowanego, co w piśmiennictwie postrzegane jest jako przejaw ochrony jego interesów 290 .

Jeśli chodzi o świadczenia pieniężne, to art. $363 \$ 2 \mathrm{kc}$ przyjmuje zasadę, że wysokość odszkodowania w pieniądzu powinna być ustalona według cen z daty ustalenia odszkodowania, co stanowi odzwierciedlenie zasady pełnej kompensacji szkody. Ustalając wysokość odszkodowania, należy uwzględniać ceny rynkowe ${ }^{291} \mathrm{z}$ dnia zamknięcia rozprawy, po którym dochodzi do wydania wyroku ${ }^{292}$. Szereg szczegółowych wskazówek co do ustalania wielkości szkody przynosi również orzecznictwo. Przykładowo, w odniesieniu do wysokości odszkodowania, jaka miałaby pokryć utracone korzyści, w wyroku z dnia 22 października 2010 r., III CSK 333/2009, SN stwierdził, że „(...) ustalając rozmiar utraconych korzyści należy mieć na uwadze, że chodzi o korzyści, które poszkodowany mógłby osiągnąć. Ustalając zakres należnego odszkodowania należy brać pod uwagę nie moment, w którym zdarzenie szkodzące naruszyło sferę interesów poszkodowanego, ale uwzględniać również warunki, jakie ukształtowały się po zajściu zdarzenia wyrządzającego szkodę, które doprowadziły do tego, że nie mógł on osiągnąć określonych korzyści" 293 .

Jedynie gdy jest to uzasadnione „szczególnymi okolicznościami”, można przyjąć inną miarodajną chwilę ustalenia odszkodowania. Szczególne okoliczności „zachodzą, jeżeli przyjęcie ceny z daty ustalenia odszkodowania powodowałoby albo pokrzywdzenie, albo bezpodstawne wzbogacenie poszkodowanego"294. W wyroku z dnia 24 września 2010 r., IV CSK 78/10295, SN odrzucił możliwość traktowania jako „szczególne okoliczności” takiego wzrostu cen, który - choć znaczący - był jedynie wynikiem gry rynkowych sił podaży i popytu.

Wskazane zasady, wynikające z art. 363 kc, a uszczegółowione w orzecznictwie, odnoszą się również do prywatnego egzekwowania prawa konkurencji.

290 Z. Banaszczyk, [w:] K. Pietrzykowski (red.), Kodeks cywilny..., s. 807 (Komentarz do art. $363, \mathrm{Nb} 2)$.

291 Tak T. Wiśniewski, [w:] S. Dmowski, M. Sychowicz, H. Ciepła, K. Kołakowski, T. Wiśniewski, C. Żuławska, J. Gudowski, G. Bieniek, Komentarz do kodeksu cywilnego. Księga trzecia. Zobowiazania, LexisNexis, Warszawa 2011 (Komentarz do art. 363, Nb 11).

292 Tak SN w wyroku z dnia 11 lutego 2010 r., I CSK 262/2009, LexPolonica nr 2573531.

293 Wyrok SN z dnia 22 października 2010 r., III CSK 333/2009, LexPolonica nr 2550996.

294 Wyrok SN z dnia 4 lutego 2005 r., I CK 569/2004, LexPolonica nr 2252722.

295 Wyrok SN z dnia 24 września 2010 r., IV CSK 78/2010, LexPolonica nr 3034470. 


\subsection{Ustalanie wysokości szkody antymonopolowej}

Inaczej niż w postępowaniu przed publicznymi organami ochrony konkurencji, w postępowaniu przed sądem cywilnym nie wystarczy wykazanie, że zachowanie przedsiębiorcy narusza zakaz praktyk ograniczających konkurencję i w ten sposób wywołuje „szkodę antymonopolową” - na takim stwierdzeniu można poprzestać w publicznym trybie egzekwowania prawa konkurencji, gdzie organy ochrony konkurencji wskazują, jakiego rodzaju zachowanie przedsiębiorcy (przedsiębiorców) pozostaje w sprzeczności z zakazami praktyk ograniczających konkurencji (a więc wskazują sam fakt powstania szkody dla konkurencji i jednocześnie interesu publicznego ${ }^{296}$ ), publiczne organy ochrony konkurencji nie są natomiast zobowiązane do szacowania szkody powstałej w wyniku zakazanych zachowań297. W sprawach toczących się przed sądami cywilnymi konieczność określenia charakteru szkody i jej wymiaru dotyczy wszystkich ograniczeń konkurencji, także tych, które - jak kartele cenowe - uznawane są za zakazane per se, choćby w tym sensie - na gruncie prawa polskiego i unijnego - że nie wymagają one od organów ochrony konkurencji wykazania antykonkurencyjnych skutków ${ }^{298}$.

Udowodnienie istnienia szkody jest nierozerwalnie związane ze wskazaniem jej rozmiaru, co dopiero otwiera drogę do uzyskania odszkodowania. Problemy z wyznaczeniem wysokości szkody antymonopolowej wskazywane są w doktrynie jako jedna z podstawowych przeszkód dla rozwoju prywatnego egzekwowania prawa ochrony konkurencji w Europie. Problemy związane z obliczaniem wielkości szkody antymonopolowej są jedynie pochodną trudności w zdefiniowaniu samej szkody antymonopolowej. Jak słusznie stwierdza Komisja w projekcie wskazówek w sprawie ustalania wysokości szkody w dochodzeniu roszczeń odszkodowawczych z tytułu naruszenia art. 101 lub 102 TFUE, „nie jest możliwe ustalenie jednej <<prawdziwej>> wartości poniesionej szkody. Przeprowadza się jedynie najlepsze szacunki, bazując na założeniach i przybliżeniach"299. Jeśli natomiast chodzi o metodologię wyznaczania rozmiaru szkody (i w konsekwencji odszkodowania), to

296 Por. rozdział IV, pkt 4.1.

297 A. P. Komninos uważa, że nakładanie takiego obowiązku na organy antymonopolowe realizowałoby co prawda dobre intencje, ale byłoby wadliwe - tenże, Relationship between Public and Private Enforcement: quod Dei Deo, quod Caesaris Caesari (referat wygłoszony na konferencji Integrating public and private enforcement of competition law: Implications for courts and agencies, Florencja, 17-18 czerwca 2011 r.), dostępny pod adresem: http:// papers.ssrn.com/sol3/papers.cfm?abstract_id=1870723, s. 23.

298 Takie stanowisko zajął również amerykański sąd najwyższy w przywołanym powyżej wyroku w sprawie $A R C O$.

299 Projekt - wskazówki Komisji. Ustalanie wysokości szkody..., pkt 14. 
nie wydaje się, aby prawo antymonopolowe generowało więcej problemów niż chociażby prawo zwalczania nieuczciwej konkurencji, egzekwowane niejako „naturalnie” na drodze sądowej, czy szkody wynikające z naruszenia zakazu konkurencji wynikającego ze stosunku zatrudnienia.

Również w celu wyznaczenia rozmiaru szkód antymonopolowych należy odnieść się do podstawowych metod obliczania szkód w prawie cywilnym, tj. metody dyferencyjnej i metody obiektywnej. Ta ostatnia „polega na ustaleniu wysokości szkody w odniesieniu do konkretnego dobra”, metoda ta „abstrahuje od skutków, jakie zdarzenie szkodzące wywołuje w całym majątku poszkodowanego"300. Metoda dyferencyjna polega na porównaniu aktualnego stanu majątku poszkodowanego z hipotetycznym stanem jego majątku, jaki istniałby, gdyby nie nastąpiło zdarzenie szkodzące ${ }^{301}$. Metodę dyferencyjną uznaje się za bardziej przydatną dla wyznaczenia ustalenia szkody w obu postaciach (strata i utracone korzyści), stąd należy ją uznać za właściwą także dla wyznaczania rozmiaru szkód antymonopolowych.

Proces obliczania szkody obejmuje zatem dwa etapy: pierwszy z nich wymaga stworzenia kontrafaktu (ang. contrafactual scenario lub 'but for' scenario), tj. odtworzenia stanu, jaki istniałby wówczas, gdyby nie doszło do naruszenia zakazu praktyk ograniczających konkurencję. Na tym etapie niezbędne jest określenie charakteru naruszenia (rodzaju praktyki ograniczającej konkurencję), a tym samym - rodzaju szkody, kręgu i statusu podmiotów potencjalnie dotkniętych szkodą, a także charakterystyki rynku (rynków), na którym szkoda zaistniała (np. czy jest to tzw. nowy rynek (ang. new market) czy rynek dojrzały). Realizacja tego etapu polega na tym, że - przykładowo - naruszenie w postaci stosowania cen drapieżnych wymaga wskazania akceptowalnego („legalnego”) poziomu cen.

Drugi etap polega na określeniu ostatecznej wartości szkody (odszkodowania) poprzez np. wskazanie czasu, w jakim występowała szkoda (przykładowo: jaki rozmiar ma szkoda, jeśli cena kartelowa stosowana była przez trzy lata).

Dla obliczania szkody antymonopolowej przydatne może być wykorzystanie modeli i metod ekonomicznych. Nauki ekonomiczne wypracowały ich wiele, problematyczny może być natomiast dobór modelu (metody) do określonej sytuacji. W sztandarowym europejskim studium nad kalkulowaniem rozmiarów szkód antymonopolowym, przygotowanym na zlecenie Komisji Europejskiej w grudniu 2009 r. (raport Oxera), ekonomiczne

300 Z. Banaszczyk, [w:] K. Pietrzykowski (red.), Kodeks cywilny..., s. 794 (Komentarz do art. $361, \mathrm{Nb} 34$ i 35$)$.

301 Ibidem, s. 794 (Komentarz do art. 361, Nb 35). 
ramy obliczania odszkodowań zostały sklasyfikowane na trzech poziomach: podejścia (ang. approach), rodzaju danych wykorzystywanych do wyznaczenia kontrafaktu (ang. basis for contrafactual), technik (ang. techniques) ${ }^{302}$. Autorzy raportu zidentyfikowali trzy podejścia do obliczania szkód antymonopolowych, w ramach których stosowane są szczegółowe modele i metody kalkulowania odszkodowań303.

Podejście komparatystyczne (ang. comparator-based approach) ${ }^{304}$ polega na porównywaniu rynków produktowych i geograficznych ${ }^{305}$, porównywaniu w czasie (przed i w czasie naruszenia ${ }^{306}$, przed i po naruszeniu ${ }^{307}$, w czasie i po naruszeniu ${ }^{308}$ ) lub porównywaniu różnic ${ }^{309}$, przy wykorzystaniu m.in. metody interpolacji ${ }^{310}$, regresji ${ }^{311}$ lub porównywania danych uśrednionych; cechą charakterystyczną tego podejścia jest bazowanie na danych empirycznych.

Podejście właściwe dla analizy finansowej (ang. financial-analysis-based approach $)^{312}$ polega na konstruowaniu kontrafaktów np. poprzez ocenę

302 Raport Oxera, s. V.

303 Wskazane w dalszych rozważaniach przykłady orzeczeń sądów krajowych są zaczerpnięte z raportu Oxera.

304 Szerzej: raport Oxera, pkt 3.3.-3.5. (s. 46-62) oraz projekt - Wskazówki Komisji. Ustalanie wysokości szkody..., pkt 28-62.

305 Por. np. wyrok madryckiego sądu handlowego z dnia 11 listopada 2005 r. w sprawie Conduit Europe, S.A. v. Telefónica de España S.A.U., gdzie rozstrzygnięcie zostało oparte na porównaniu hiszpańskiego i brytyjskiego rynku usług telekomunikacyjnych, co pozwoliło określić utracone korzyści wskutek stosowania praktyki eksploatacyjnej przez firmę Telefónica.

306 Por. wyrok Corte d'Appello di Milano z dnia 10 grudnia 2004 r. w sprawie INAZ Paghe srl v. Associazione Nazionale dei Consulenti del Lavoro.

307 W wyroku Corte d'Appello di Roma z dnia 20 stycznia 2003 r. Albacom S.p.A. i inni v. Telecom Italia S.p.A, gdzie operator telekomunikacyjny został zobowiązany do naprawienia szkody wynikającej z jego praktyki stosowania nieuczciwych cen, sąd do porównania sytuacji rynkowej wykorzystał dane o liczbie umów zawartych z klientami Telecom Italia $\mathrm{w}$ czasie trwania antykonkurencyjnej praktyki oraz poziom udziału w rynku konkurentów wykluczonych wskutek tej praktyki; wysokość odszkodowania sąd obliczył poprzez podzielenie liczby kontraktów przez wartość udziałów w rynku dla poszczególnych przedsiębiorców telekomunikacyjnych.

308 Por. np. wyrok Landesgericht für Zivilrechtssachen Graz z dnia 17 sierpnia 2007 r. w sprawie Bundesarbeitskammer v. Powerdrive Fahrschule Andritz GmbH - sąd dokonał porównania cen kursów jazdy samochodem w czasie funkcjonowania kartelu oraz po jego ustaniu.

309 Technika ta opiera się na założeniu, że niedające się wyjaśnić różnice stanowią rezultat zaistniałego naruszenia.

310 Por. projekt - Wskazówki Komisji. Ustalanie wielkości szkody..., pkt 57-62.

311 Por. projekt - Wskazówki Komisji. Ustalanie wielkości szkody..., pkt 63-79.

312 Szerzej: raport Oxera, pkt 3.6.-3.7. (s. 62-75). 
poprawy lub pogorszenia sytuacji finansowej powodów ${ }^{313}$ lub pozwanych ${ }^{314}$, bądź poprzez ocenę i porównywanie kosztów produkcji i marży produktów ${ }^{315}$. Prowadzenie analiz tego typu wymaga wykorzystania różnych czynników finansowych, takich jak np. wskaźnik inflacji czy opodatkowanie dochodów/przychodów.

Podejście oparte na strukturze rynkowej (ang. market-structure-based approach $)^{316}$ wykorzystuje dorobek industrial organisation w zakresie oceny relacji konkurencyjnych w różnych modelach konkurencji (od monopolu po konkurencję doskonałą), poprzez np. wykorzystanie modelu Cournota ${ }^{317}$; podejście to charakteryzuje się wykorzystaniem zarówno modeli teoretycznych, jak i szacunków empirycznych.

Wyliczenie rozmiaru szkody antymonopolowej powinno uwzględniać nie tylko statyczne, ale także długoterminowe dynamiczne skutki antykonkurencyjnych praktyk, takie jak spadek (wzrost) poziomu innowacyjności czy pogorszenie (poprawę) efektywności ${ }^{318}$.

Wybór określonego modelu stanowi zawsze pewne arbitralne rozstrzygnięcie, o tyle istotne, że może ono wywierać wpływ na ostateczny wynik sprawy (wielkość odszkodowania). Każda z metod wyliczania szkód ma swoje wady i zalety, stąd żadna nie powinna być „rekomendowana per $s e " 319$. Nie sposób jednak nie zauważyć, że stosowanie teorii czy szkół ekonomicznych podlega pewnym okresowym „modom” (częściowo związanym z rozwojem nauk ekonomicznych ${ }^{320}$ ), choć wybór metody ustalenia wysokości odszkodowania może być również podyktowany dostępnością określonych dowodów 321 .

313 Por. np. wyrok Cour d'Appel de Versailles z dnia 24 czerwca 2004 r. w sprawie Verimedia v SA Mediametrie, SA Secodip, GIE Audipub, w której wykluczone z rynku przedsiębiorstwo wskazywało na utracone korzyści poprzez odniesienie ich do swojej sytuacji finansowej.

314 Por. np. wyrok duńskiego sądu najwyższego (Højesteret) z dnia 20 kwietnia 2005 r. w sprawie UFR 2005.2171H, GT Linien $A / S$ (wcześniej GT Link $A / S$ ) v. De Danske Statsbaner DSB and Scandlines $A / S$ (wcześniej DSB Rederi $A / S$ ).

315 Por. projekt - Wskazówki Komisji. Ustalanie wielkości szkody..., pkt 94-100.

316 Szerzej: raport Oxera, pkt 3.8. (s. 76-86) oraz. projekt - Wskazówki Komisji. Ustalanie wielkości szkody..., pkt 86-93.

317 Por. Concord Boat Corporation v. Brunswick Corporation, 207 F.3d 1039 (8th Cir. 2000), Decision: March 24th 2000.

318 Raport Oxera, s. 15.

319 N. Frank, R. P. Lademann, Economic Evidence in Private Damage Claims: What Lessons Can Be Learned from the German Cement Cartel Case?, Journal of Competition Law \& Economics 2010, vol. 1(4), s. 366.

320 Por. Projekt - Wskazówki Komisji. Ustalanie wysokości szkody..., pkt 9.

321 Projekt - Wskazówki Komisji. Ustalanie wysokości szkody..., pkt 7. 
Ostateczna decyzja co do doboru metod będzie należała do sądu, niemniej jednak w praktyce stosowanie skomplikowanych modeli ekonomicznych przez sędziów może okazać się trudne. Można przyjąć, że na wybór modelu wpływa nie tylko posiadany przez sędziów zasób wiedzy, w jaki sposób wyliczyć rozmiar szkody antymonopolowej przy pomocy określonego modelu, ale także adekwatność określonego modelu lub metody do danego typu „deliktu antymonopolowego”, czy wreszcie - dostępność informacji i danych (finansowych, rynkowych). Jak podkreślają H. W. Friederiszick i L.-H. Röller, sędziowie powinni poszukiwać „kompromisu” między dokładnością (trafnością) ustaleń a ich praktycznością 322.

Sam fakt, że sędziowie zakładają istnienie szkody antymonopolowej np. w przypadku karteli, wynikać może jedynie z doświadczenia życiowego (niem. Lebenserfahrung) - potwierdzają to przede wszystkim wyroki sądów niemieckich, m.in. w sprawie kartelu witaminowego ${ }^{323}$ i cementowego $^{324}$. Stanowisko sądów co do występowania szkody antymonopolowej może być oparte również na domniemaniach legalnych. Warto podkreślić, że również art. $361 \S 2 \mathrm{kc}$ zezwala na modyfikację standardowego zakresu naprawienia szkody przewidzianego w tym przepisie, co otwiera furtkę do ewentualnego ustanowienia domniemania prawnego zakresu odszkodowania np. w ustawie o ochronie konkurencji i konsumentów. Jak dotąd jedynie ustawodawca węgierski zdecydował się na wprowadzenie do ustawy o ochronie konkurencji przepisu stanowiącego, że powód, który udowodni zaangażowanie pozwanego w kartel (typu hard core) może opierać się na możliwym do podważenia domniemaniu, że „naruszenie oddziaływało na wartość odzwierciedlająca do $10 \%$ ceny, o ile nic innego nie zostanie udowodnione" 325 . Podobny zapis, również odwołujący się do $10 \%$, istnieje w wytycznych o karaniu wydanych przez amerykańską Sentencing Commission ${ }^{326}$. Z kolei sąd włoski

322 H. W. Friederiszick, L.-H. Röller, Quantification of harm in damages actions for antitrust infringements: insights from German cartel cases, Journal of Competition Law \& Economics 2010, vol. 6(3), s. 595-618.

323 Wyrok Landgericht Dortmund z dnia 1 kwietnia 2004 r. w sprawie 13 O 55/02 Kart (Kartel witaminowy).

324 Wyrok Oberlandesgericht Düsseldorf z dnia 28 czerwca 2005 r. KRB 2/05 Berliner Transportbeton $I$.

325 Competition Act (as amended, 2008), Hungary, Section 88/C. Por. C. I. Nagy, The new Hungarian rules on damages caused by horizontal hardcore cartels: presumed price increase and limited protection for whistleblowers - an analytical introduction, E.C.L.R 2011, vol. 32(2), s. 68.

326 US Sentencing Commission Guidelines for the United States Courts, 18 U.S. C.18 U.S.C. Section 2R1.1, Bid-rigging, Price-fixing or Market-allocation Agreements Among Competitors, Application Note 3. 
w sprawie kartelu ubezpieczeniowego uznał założenie o 20-procentowej nadwyżce ceny kartelowej327 za „zwykłe domniemanie” (wł. prezencione semplice) w rozumieniu art. 2727 włoskiego kodeksu cywilnego. Krytycy ustanowienia domniemania wysokości szkody w przepisach podkreślają, że regulacja taka może przynieść odwrotny od zamierzonego skutek - ze względu na ograniczenia co do wysokości odszkodowania może ona zniechęcać potencjalnych powodów do występowania na drogę sądową ${ }^{328}$.

W sytuacji, gdy sąd ma trudność z określeniem dokładnej wysokości szkody (i co za tym idzie - odszkodowania), prawo prywatne daje wszak sądom możliwość opierania się na domniemaniach czy orzekania na zasadzie słuszności (ex aeqo et bono) - włoski sąd najwyższy uznał nawet jej wykorzystanie w sytuacji, gdy poszkodowani w kartelu ubezpieczeniowym nie byli w stanie udowodnić precyzyjnej wysokości zawyżenia ceny za „książkowy przykład zastosowania zasady słuszności" 329 . Należy również odnotować pogląd, że w odniesieniu do tej części odszkodowania, która ma odzwierciedlać utracony zysk, sądy stosują nieco mniej restryktywne standardy dowodowe ${ }^{330}$. Wreszcie, sądy mogą korzystać z pomocy ekspertów, choć tutaj może pojawić się wątpliwość co do tego, czy powinni być to biegli wyznaczani przez sąd, czy raczej eksperci „dostarczani” przez strony 331 .

Biorąc pod uwagę brak przygotowania (czy raczej brak doświadczenia) sędziów do obliczania rozmiarów szkód antymonopolowych, można zaakceptować potrzebę wydania przez organ ochrony konkurencji wytycznych dotyczących obliczania wysokości odszkodowań. Dokument taki miałby oczywiście status „miękkiego prawa” - inaczej mógłby być postrzegany jako niedopuszczalna próba ograniczania autonomii sądów - i powinien mieć charakter wyjaśniający, wspomagający, a nie dyrektywy - w praktyce miałoby to przejawiać się we wskazaniu w nim wachlarza możliwych rozwiązań

327 Wyrok Giudice di Pace di Bitonto z dnia 21 maja 2007 r. w sprawie Vincenzo Manfredi v. Lloyd Adriatico Assicurazioni $\operatorname{SpA}$.

328 Tak R. Noble, S. Pilsbury, Is 10 per cent the answer? The role of legal presumptions in private competition litigation, G.C.L.R. 2008, vol. 1(3), s. 132.

329 Wyrok Corte di Cassazione z dnia 17 lutego 2007 r. w sprawie Fondiaria SAI SpA v. Nigriello. Por. M. Carpagnano, Competition Law Litigation: The Italian Perspective (1990-2010), [w:] L. A. Velasco i inni (red.), Private enforcement of competition law, Valladolid 2011, s. 97. Por. także art. 1226 włoskiego kodeksu cywilnego.

330 Por. stanowisko Sądu w wyroku z dnia 27 listopada 2007 r. w połączonych sprawach T-3/00 and T-337/04 Athanasios Pitsiorlas v. Rada i Europejski Bank Centralny (Zb. Orz. 2007, II-4779).

331 A. I. Gavil, The challanges of economic proof in a decentralized and privatized European competition policy system: lessons from the American perspective, Journal of Competition Law and Economics 2007, vol. 4(1), s. 185-197. 
w zakresie wyznaczania wielkości odszkodowania, nie zaś jednoznacznego określenia sposobu kalkulowania odszkodowań. Takie rozwiązanie przyjęła Komisja, ujawniając w czerwcu 2011 r. (do konsultacji publicznych) projekt wskazówek w sprawie ustalania wysokości szkody w dochodzeniu roszczeń odszkodowawczych z tytułu naruszenia art. 101 lub 102 TFUE ${ }^{332}$. Wydanie ewentualnych wytycznych w sprawie obliczania odszkodowań przez Komisję Europejską należy przy tym postrzegać jako absolutnie wystarczające, nie ma już potrzeby opracowywania takiego dokumentu przez organy krajowe - mechanizm powstawania szkód antymonopolowych nie różni się przecież w zależności od tego, czy stosujemy prawo unijne, czy prawo krajowe. Ograniczeniem ewentualnej inicjatywy ustawodawcy krajowego w zakresie ustalania wielkości odszkodowań za szkody antymonopolowe pozostaje zasada skuteczności i zasada równoważności ${ }^{333}$.

\subsection{Okoliczności modyfikujące wysokość odszkodowania}

Odpowiedzialność odszkodowawcza w polskim systemie prawnym opiera się na zasadzie pełnego odszkodowania - zasada ta doznaje jednak kilku ograniczeń, które w piśmiennictwie klasyfikuje się w trzech grupach ${ }^{334}$. Po pierwsze odstępstwa od zasady pełnego odszkodowania wynikają z adekwatnego związku przyczynowego (ograniczenie naprawienia szkody do normalnych następstw zdarzenia). Po drugie ograniczenia mogą być wprowadzone przez przepisy szczególne. Po trzecie możliwe jest skorzystanie przez sąd z ius moderandi, wynikającego m.in. z przyczynienia się poszkodowanego do powstania szkody, przewidzianego w art. $362 \mathrm{kc}^{335}$. Usytuowanie art. $362 \mathrm{kc}$ jednoznacznie wskazuje na to, że miarkowanie wysokości odszkodowania ze względu na przyczynienie się poszkodowanego jest możliwe zarówno w reżimie odpowiedzialności kontraktowej, jak i z tytułu czynów niedozwolonych. Artykuł $362 \mathrm{kc}$ wskazuje na dwa stany faktyczne: przyczynienie się do powstania szkody oraz przyczynienie się do zwiększenia już powstałej szkody. W doktrynie prawa cywilnego rozumienie pojęcia „przyczynienia się poszkodowanego" do powstania szkody budzi liczne kontrowersje.

332 Projekt - Wskazówki Komisji. Ustalanie wysokości szkody... Konsultacje publiczne trwały w okresie od dnia 17 czerwca do 30 września 2011 r.

333 Por. projekt - Wskazówki Komisji. Ustalanie wysokości szkody..., pkt 2.

334 Z. Banaszczyk, [w:] K. Pietrzykowski (red.), Kodeks cywilny..., s. 795 (Komentarz do art. 361, $\mathrm{Nb} \mathrm{38).}$

335 Inaczej M. Kaliński, który jedynego przypadku iuris moderandi w polskim prawie cywilnym upatruje w art. $440 \mathrm{kc}$ - por. tenże, [w:] A. Olejniczak (red.), System prawa prywatnego..., s. $200(\mathrm{Nb} \mathrm{186)}$. 
K. Zagrobelny wyróżnił cztery stanowiska rozstrzygające ten problem ${ }^{336}$. Zgodnie z pierwszym $\mathrm{z}$ nich (L. Longchamps de Berier) przyczynienie się poszkodowanego do szkody następuje wówczas, gdy jego zachowanie pozostaje w adekwatnym związku przyczynowym ze szkodą. Drugie stanowisko (T. Dybowski) zakłada, że o przyczynieniu możemy mówić wtedy, gdy zachowanie się poszkodowanego jest obiektywnie naganne (quasi-bezprawne). W myśl trzeciego ze stanowisk (A. Ohanowicz) obniżenie odszkodowania należnego poszkodowanemu jest możliwe tylko w sytuacji postawienia mu zarzutu subiektywnego zawinienia. Czwarte ze stanowisk (A. Szpunar) przewiduje, że określając przyczynienie się poszkodowanego do powstania szkody, należy uwzględniać zasadę odpowiedzialności - jeśli jest to zasada winy, konieczne jest ustalenie winy poszkodowanego.

W związku z naruszeniem zakazów praktyk ograniczających konkurencję, $\mathrm{z}$ przyczynieniem się poszkodowanego mamy do czynienia w porozumieniach, rzadziej do sytuacji takiej może dojść przy nadużywaniu pozycji dominującej, choć i tego nie należy wykluczać.

Dochodzenie roszczeń przez strony porozumień naruszających zakazy praktyk ograniczających konkurencję może budzić wątpliwości ze względu na zasadę, że nikt nie może osiągać korzyści z naruszenia przez siebie prawa. Jednakże Trybunał Sprawiedliwości w orzeczeniu w sprawie C-435/99 Courage uznał, że prawo unijne nie stoi na przeszkodzie regulacjom krajowym zezwalającym na to, aby strona zakazanego porozumienia dochodziła roszczeń odszkodowawczych od drugiej strony umowy, przy poszanowaniu zasady równoważności oraz skuteczności ${ }^{337}$, a także przy zachowaniu zasady, że ochrona praw gwarantowanych przez prawo unijne nie może prowadzić do bezpodstawnego wzbogacenia uprawnionych ${ }^{338}$. Oceniając ewentualne przyczynienie się poszkodowanego do powstałej szkody należy, zgodnie ze wskazówkami Trybunału, uwzględnić siłę przetargową stron (ang. bargaining power) oraz zachowanie stron umowy339. Przede wszystkim należy wziąć pod uwagę to, czy strona umowy naruszającej zakaz porozumień ograniczających konkurencję znalazła się w położeniu znacząco gorszym niż inne strony, tj. takim, które ograniczało lub nawet eliminowało możliwość negocjowania warunków umowy, a przez to także możliwość zachowania pozwalającego na uniknięcie szkody lub zmniejszenie jej zakresu ${ }^{340}$. Nie-

336 K. Zagrobelny, [w:] E. Gniewek (red.), Kodeks cywilny. Komentarz, C. H. Beck, Warszawa 2011, s. 583-584 (Nb 4-5).

337 Wyrok w sprawie C-435/99 Courage, pkt 31.

338 Wyrok w sprawie C-435/99 Courage, pkt 30.

339 Wyrok w sprawie C-435/99 Courage, pkt 32.

340 Wyrok w sprawie C-435/99 Courage, pkt 33. 
mniej jednak, nawet jeśli pozycja strony umowy była rzeczywiście istotnie gorsza w przedstawionym powyżej rozumieniu, a nawet gdy umowa została zawarta w warunkach przymusu ekonomicznego (np. nieprzystąpienie do kartelu mogło spowodować wykluczenie z rynku), nie można przyjąć, że słabszy podmiot nie przyczynił się do powstania szkody, choć modyfikacja wysokości odszkodowania powinna być w takim wypadku jedynie symboliczna (ograniczenie wysokości odszkodowania w myśl art. 362 kc powinno być „odpowiednie”). Stanowisko takie podyktowane jest spotykanym w literaturze cywilistycznej poglądem, że przyczynienie się poszkodowanego ,jest obiektywną przesłanką, powodującą obniżenie wysokości odszkodowania, zupełnie niezależną od tego, czy poszkodowany «przyczynił się» w sposób zawiniony lub niezawiniony, byle między zachowaniem się poszkodowanego a powstałą szkodą istniał normalny związek przyczynowy"341. Takie stanowisko określa się jako „formułę czysto kauzalną”, której słabością - według T. Pajora - jest brak rozróżnienia między przyczynieniem się poszkodowanego do powstania szkody a współsprawstwem ${ }^{342}$. Ten sam autor słusznie podkreśla, że poszkodowany nie odpowiada za szkodę, nawet jeśli ją spowodował ${ }^{343}$.

W piśmiennictwie w obszarze prawa cywilnego wskazuje się jednak również na inne - normatywne - ujęcie przyczynienia się do powstania, zgodnie z którym kształtowanie obowiązku odszkodowawczego w świetle art. 362 kc powinno uwzględniać - jak chce ustawodawca - wszystkie „okoliczności”, wśród których należy wyróżnić te istotne dla naruszeń zakazów antykonkurencyjnych praktyk, tj. ,porównanie winy obu stron, porównanie ciężaru i roli naruszenia przez strony obowiązujących reguł postępowania (bezprawności), czy wreszcie motywów ich postępowania"344. W konsekwencji określenie faktu i stopnia przyczynienia się poszkodowanego do powstania

341 J. Winiarz, Obowiazek naprawienia..., s. 98. Inaczej Z. Banaszczyk, który twierdzi, że wina poszkodowanego stanowi podstawowe kryterium miarkowania odszkodowania Z. Banaszczyk, [w:] K. Pietrzykowski (red.), Kodeks cywilny..., s. 804 (Komentarz do art. $362, \mathrm{Nb} 16)$.

342 T. Pajor, Uwagi o przyczynieniu się poszkodowanego do powstania szkody, [w:] M. PyziakSzafnicka (red.), Odpowiedzialność cywilna. Księga pamiatkowa ku czci Profesora Adama Szpunara, Zakamycze, Kraków 2004, s. 160. Za taką formułą opowiada się natomiast K. Zagrobelny, [w:] E. Gniewek (red.), Kodeks cywilny..., s. 584 (Nb 6).

343 T. Pajor, Uwagi o przyczynieniu się..., [w:] M. Pyziak-Szafnicka (red.), Odpowiedzialność cywilna..., s. 161.

344 Z. Banaszczyk, [w:] K. Pietrzykowski (red.), Kodeks cywilny..., s. 804 (Komentarz do art. 362, Nb 14). Do zwolenników normatywnego ujęcia przyczynienia się do szkody zalicza się również A. Szpunara - por. T. Pajor, Uwagi o przyczynieniu się..., [w:] M. Pyziak-Szafnicka (red.), Odpowiedzialność cywilna..., s. 156. 
szkody wymaga analiz ad casu. W przypadku potencjalnych praktyk antykonkurencyjnych pod uwagę należy wziąć choćby to, czy np. producent ukształtował warunki obowiązujące w sieci dystrybucji w ten sposób, że naruszały zakazy praktyk ograniczających konkurencję.

Innej możliwości zmniejszenia odszkodowania lub nawet zwolnienia się $\mathrm{z}$ obowiązku naprawienia szkody można upatrywać w kontrzarzucie przerzucania nadmiernych obciążeń (zawyżonych cen) na podmioty działające na innych szczeblach obrotu niż sprawca (sprawcy) naruszenia zakazów praktyk ograniczających konkurencję. Jeśli bezpośredni kontrahent uczestników kartelu (nabywca bezpośredni) nabywa produkt po zawyżonej cenie ustalonej przez kartel, prawdopodobnym jest, że następnie sprzeda ten produkt swoim dalszym kontrahentom lub konsumentom (nabywcy pośredni) również po zawyżonej cenie, „odsuwając” w ten sposób od siebie szkodę. W takich okolicznościach przerzucenie przez poszkodowanego obciążenia na inny podmiot może być podnoszone przez pozwanego jako okoliczność eliminująca lub co najmniej łagodząca jego odpowiedzialność za szkodę. $\mathrm{W}$ terminologii angielskiej kontrzarzut tego rodzaju określany jest jako pass-on defence, w języku polskim określa się go jako „zarzut przerzucania obciążeń" 345 . W literaturze przedmiotu o przerzucaniu nadmiernych obciążeń mówi się przede wszystkim w kontekście karteli ${ }^{346}$, jednak ten sam mechanizm może zadziałać w przypadku praktyki nadużywania pozycji dominującej - bardziej adekwatne wydaje się mówienie o przerzucaniu nadmiernych obciążeń w kontekście praktyk cenowych, bez różnicowania na praktyki wielo- $\mathrm{i}$ jednostronne.

Dopuszczalność zarzutu przerzucenia obciążeń rekomendowała Komisja w Białej księdze ${ }^{347}$. Skuteczność korzystania z obrony opartej na zarzucie przerzucania nadmiernych obciążeń zależy od zasad odpowiedzialności cywilnej przewidzianych w określonym porządku prawnym. Można założyć, że transferowanie obciążeń na nabywców pośrednich stanowi okoliczność wymagającą miarkowania wysokości odszkodowania - rozwiązanie to jest możliwe w sytuacji, gdy na nabywców pośrednich przerzucono jedynie część zawyżonej ceny, a także wówczas, gdy przerzucenie zawyżonych cen spowodowało spadek wielkości sprzedaży (wskutek zmniejszenia popytu na droższy

345 Por. projekt - Wskazówki Komisji. Ustalanie wysokości szkody..., pkt 145 lit. a).

346 Por. m.in. F. Verboven, T. van Dijk, Cartel damages claims and the passing-on defense, Journal of Industrial Economics 2009, vol. 57(3), s. 451-497; M. Hellwig, Private damages claims and the passing on defense in horizontal price-fixing cases: an economist's perspective, Preprints of the Max Planc Institute for Research on Collective Goods, No. 2006, 22 (dostępne pod adresem: http://www.econstor.eu/bitstream/10419/26906/1/521158958.PDF).

347 Biała księga, pkt 2.6. (s. 9). 
produkt) - na ten ostatni efekt zwraca się powszechnie uwagę w literaturze ekonomicznej. Całkowite zwolnienie się z odpowiedzialności w oparciu o zarzut przerzucania nadmiernych obciążeń jest mało prawdopodobne, szkoda wyrządzona przez praktyki cenowe nie zanika przecież, ale ujawnia się (jest odczuwalna) w innych, pośrednich relacjach rynkowych. W istocie jednak, jeśli producentowi uda się dowieść, że dystrybutorzy transferowali obciążenia cenowe na konsumentów, może liczyć na to, że konsumenci nie wystąpią z roszczeniami, bądź też ich skala (jeśli nie skorzystają z instrumentów grupowego dochodzenia roszczeń) będzie znacznie mniejsza niż w przypadku podmiotów profesjonalnych ${ }^{348}$. Skorzystanie z kontrzarzutu przerzucenia obciążeń wydaje się mało prawdopodobne wówczas, gdy bezpośredni klient podmiotu dopuszczającego się praktyki ograniczającej konkurencję wykorzystuje produkty będące przedmiotem praktyk cenowych do konkurowania na rynku niższego szczebla - w takiej sytuacji mało prawdopodobnym jest, aby doszło do transferowania nadmiernych obciążeń ${ }^{349}$. Przerzucanie obciążeń jest natomiast stosunkowo wysoce prawdopodobne w sytuacji, gdy wszystkie przedsiębiorstwa na rynku niższego szczebla padają ofiarą praktyk antykonkurencyjnych ${ }^{350}$.

Należy podkreślić, że w świetle polskiej doktryny prawa cywilnego możliwość „przerzucenia” szkody na inny podmiot niż bezpośredni wierzyciel należy oceniać bardzo sceptycznie. Dominujący wydaje się pogląd, że „poszkodowanym może być w zasadzie tylko wierzyciel, nie są nim osoby trzecie, w szczególności jego wierzyciele, choćby ponieśli uszczerbek"351.

\subsection{Rodzaje odszkodowań}

Innym, obok definiowania i obliczania szkody antymonopolowej, problemem prywatnego egzekwowania prawa konkurencji pozostaje wybór „filozofii” naprawiania szkody antymonopolowej, tj. odpowiedź na pytanie, czy odszkodowanie powinno odzwierciedlać wyłącznie wartość poniesionej szkody (bez względu na sposób jej określenia), czy też może powinno ono przyjąć postać odszkodowania przykładowego (ang. exemplary damages) ${ }^{352}$,

348 Rewersem problemu modyfikacji wielkości odszkodowania ze względu na transferowanie nadmiernych obciążeń jest możliwość występowania z roszczeniami bezpośrednio przez nabywców pośrednich - ten problem omówiony został w rozdziale IV, pkt 4.3.2.2.

349 Projekt - Wskazówki Komisji. Ustalanie wysokości szkody..., pkt 149.

350 Projekt - Wskazówki Komisji. Ustalanie wysokości szkody..., pkt 150.

351 M. Kaliński, [w:] A. Olejniczak (red.) System prawa prywatnego..., s. 48 (Nb 37).

352 Dla określenia odszkodowania przykładowego używa się również pojęcia „nawiązka”, co jednak nie wydaje się właściwe ze względu na to, że termin ten ma przypisane znaczenie w prawie karnym - por. art. $47 \mathrm{kk}$. 
bądź odszkodowania represyjnego (ang. punitive damages) ${ }^{353}$. Ten ostatni typ odszkodowania odzwierciedlony jest w koncepcji wielokrotnych odszkodowań, takich jak amerykańska zasada potrójnego odszkodowania (ang. treble damages). Akceptacja koncepcji wielokrotnych odszkodowań wymaga nie tylko stwierdzenia, czy jest to możliwe w określonym systemie prawnym (kulturze prawnej), ale także decyzji, czy wielokrotne odszkodowania miałyby stosować się do wszystkich, czy tylko do wybranych kategorii praktyk ograniczających konkurencję.

Chociaż doktryna posługuje się zarówno pojęciem odszkodowań przykładowych, jak i odszkodowań represyjnych, to w istocie są to pojęcia tożsame ${ }^{354}$. Wywodzą się one z prawa precedensowego (pojawiły się w Anglii w latach 60-tych XVII w.) ${ }^{355}$ i jako takie są obce europejskiej kontynentalnej kulturze prawnej hołdującej zasadzie pełnego odszkodowania odzwierciedlającego rzeczywistą wartość szkody i odmawiającej sankcjom cywilnym funkcji stricte prewencyjnej i odstraszającej (choć pośrednio kompensacja pełni taką funkcję). Odszkodowania przykładowe i represyjne przewidują kompensowanie szkody w wysokości większej niż jej rzeczywisty rozmiar, pierwszoplanowym zadaniem odszkodowań tego rodzaju pozostaje zapobieganie działaniom antykonkurencyjnym poprzez odstraszanie (ang. deterrence). Stosowanie odszkodowań tego rodzaju powiązane jest $\mathrm{z}$ teorią optymalnego odstraszania (ang. optimal deterrence). Odszkodowania przykładowe i represyjne mogą przyjąć postać odszkodowań wielokrotnych (ang. multiple damages) ${ }^{356}$. Odszkodowania wielokrotne spełniają swoją rolę

$353 \mathrm{~W}$ polskiej literaturze punitive damages określane jest również jako „odszkodowanie karne" - por. E. Bagińska, Odszkodowania karne (punitive damages) w prawie amerykańskim, PiP 2003, nr 6, s. 79 i n.; R. Molski, Prywatnoprawna ochrona konkurencji $w$ amerykańskim prawie antytrustowym, KPP 2005, nr 3, s. 765 i n. W pkt. 32 preambuły rozporządzenia (WE) 864/2007 pojęcie exemplary damages tłumaczone jest jako „odszkodowanie o charakterze kary”, zaś punitive damages jako „odszkodowanie o skutku odstraszającym”. Wydaje się jednak, że bardziej adekwatne byłoby odwrócenie tych tłumaczeń i określanie punitive damages jako odszkodowania o charakterze kary, zaś exemplary damages jako odszkodowania o skutku odstraszającym.

354 Tak: V. Wilcox, Punitive Damages in England [w:] H. Koziol, V. Wilcox (red.), Punitive Damages: Common Law and Civil Law Perspectives, Wien 2009, s. 7. Orzecznictwo brytyjskie preferuje jednak pojęcie exemplary damage - tak H. Brook, A Brief Introduction: The Origins of Punitive Damages, [w:] H. Koziol, V. Wilcox (red.), Punitive Damages..., s. 1.

$355 \mathrm{Na}$ temat historycznych korzeni odszkodowań represyjnych i przykładowych - zob. cyt. powyżej artykuł H. Brooka.

356 Inny pogląd reprezentuje w polskiej doktrynie R. Molski, który uważa, że odszkodowanie wielokrotne nie jest formą odszkodowania represyjnego - R. Molski, Prywatnoprawna ochrona konkurencji..., s. 773-774. Niemniej jednak w tej samej publikacji autor, rozważając efektywność potrójnych odszkodowań w amerykańskim prawie antytrustowym często 
w odniesieniu do tych praktyk, których wykrywanie jest stosunkowo trudne, czyli przede wszystkim karteli ${ }^{357}$. Jeśli prawdopodobieństwo wykrycia kartelu wynosi ok. 30\%, optymalne odszkodowanie powinno wynosić co najmniej trzykrotność wyrządzonej szkody358; można przyjąć, że odszkodowania te mają na celu zrekompensowanie szkody w szerszym, ponadindywidualnym wymiarze (czyli także w stosunku do sprawców, których nie zdołano pociągnąć do odpowiedzialności). W doktrynie zwraca się uwagę na fakt, że w przypadku praktyk innych niż zmowy kartelowe - zwłaszcza praktyk jednostronnych - odszkodowania wielokrotne (jako przykładowe i represyjne) mogą wywrzeć nadmiernie odstraszający efekt, blokując nawet intensywną konkurencję cenową 359 . Na efektywność odszkodowań wielokrotnych wskazuje się również w doktrynie w przypadkach, gdy koszty dochodzenia roszczeń są stosunkowo wysokie.

Problem odszkodowań represyjnych i przykładowych pojawił się w europejskiej debacie nad prywatnym egzekwowaniem prawa konkurencji głównie za sprawą amerykańskiej instytucji potrójnego odszkodowania (ang. treble damages), przewidzianej $\mathrm{w}$ federalnym prawie antytrustowym (15 U.S.C. $\S 15)$, a stanowiącej jeden z najważniejszych i - jak podkreśla R. Molski ${ }^{360}$ - unikalny środek ochrony konkurencji na drodze cywilnoprawnej. Jego zastosowanie polega na tym, że poszkodowanemu przysługuje rekompensata w wysokości trzykrotności poniesionego uszczerbku, powiększonego o koszty procesowe. W doktrynie podkreśla się, że trzykrotność odszkodowania ma często w praktyce charakter iluzoryczny, bo realna wysokość odszkodowania zazwyczaj zbliża się do faktycznej wysokości szkody lub nawet jest od niej niższa, m.in. ze względu na to, że sądy amerykańskie nie

odwołuje się do argumentów właściwych bezpośrednio dla odszkodowań represyjnych (karnych), co - w moim przekonaniu - osłabia tezę o rozłączności pojęć odszkodowania wielokrotnego i odszkodowania represyjnego.

357 Inaczej C. A. Jones, Private Enforcement in Europe: A Policy Analysis and Reality Check, World Competition 2004, vol. 27(1), s. 18.

358 A. Renda, J. Peysner, A. J. Riley, B. J. Rodger, R. J. Van den Berg, S. Keske, R. Pardolesi, L. R. Camili, P. Caprile, Making antitrust damages more effective in the European Union: welfare impact and potential scenarios, Report for the European Commission, Brussels, Rotterdam, Rome, December 2007 (raport dostępny pod adresem: http://ec.europa.eu/ competition/antitrust/actionsdamages/files_white_paper/impact_study.pdf), cz. II, s. 193. W tym samym raporcie przywołuje się pogląd doktryny, zgodnie z którym przyjmowane w orzecznictwie amerykańskim potrójne odszkodowanie stanowi wartość dalece zbyt małą, aby osiągnąć poziom optymalnego odstraszania - por. przypis 358, cz. III, s. 194.

359 Making antitrust damages more effective in the European Union, cz. II, s. 194, 195. Kwestie te szeroko analizuje E. D. Cavanagh, Detrebling antitrust damages in monopolization cases, Antitrust Law Journal 2009, vol. 76(1), s. 97 i n.

360 R. Molski, Prywatnoprawna ochrona konkurencji..., s. 770. 
orzekają o odsetkach za okres od popełnienia czynu skutkującego szkodą do momentu wydania wyroku ${ }^{361}$.

Nawiązując, jak się wydaje, do rozwiązań amerykańskich w Zielonej księdze w sprawie odszkodowań Komisja Europejska przedstawiła do rozważenia - jako opcję 16 - możliwość przyznawania odszkodowań wielokrotnych (podwójnych; ang. double damages) w przypadku poziomych porozumień kartelowych. Odszkodowania takie mogłyby być stosowane automatycznie, warunkowo lub pozostawione decyzji sądu 362 . Akceptacji odszkodowań wielokrotnych potencjalnie mogłoby sprzyjać pozytywne stanowisko Trybunału Sprawiedliwości, który przychylił się do dopuszczalności odszkodowań represyjnych i przykładowych w wyrokach w sprawach: Brasserie du Pécheur (pkt 90) oraz Manfredi. W tym ostatnim wyroku TS wywiódł dopuszczalność odszkodowań przykładowych bezpośrednio z zasady równoważności (ekwiwalentności), co w praktyce oznacza, że możliwość orzekania o odszkodowaniach wielokrotnych miałaby wynikać wyłącznie z prawa krajowego, czemu prawo unijne nie może się sprzeciwiać363. Jednocześnie TS zastrzegł, że „prawo wspólnotowe nie stoi na przeszkodzie temu, by sądy krajowe czuwały nad tym, żeby ochrona praw zagwarantowanych przez wspólnotowy porządek prawny nie prowadziła do bezpodstawnego wzbogacenia osób, którym te prawa przysługują" 364 - wypowiedź tę można potraktować jako przejaw jedynie umiarkowanego entuzjazmu Trybunału wobec odszkodowań represyjnych ${ }^{365}$. Dodatkowym problemem w skali europejskiej może być uznawalność wyroków zasądzających odszkodowania przykładowe i represyjne w tych państwach członkowskich, gdzie taki sposób naprawiania szkód nie jest dopuszczalny ${ }^{366}$.

361 Ibidem. Szerzej zjawisko to analizuje R. H. Lande, Are Antitrust 'Treble' Damages Really Single Damages?, Ohio State Law Journal 1993, vol. LIV, s. 118. Por. także C.A. Jones, Private enforcement of antitrust law..., Oxford 2005, s. 230.

362 Por. Zielona księga, pkt 2.3./Pytanie E/Opcja 16.

363 Por. White Paper Comission Staff Working Paper, pkt 190 (s. 57).

364 Pkt 94 i 99 wyroku. Por. także wyroki Trybunału: z dnia 4 października 1979 r. w sprawie 238/78 Ireks-Arkady v. Rada i Komisja (Zb. Orz. 1979, s. 2955), pkt 14; z dnia 21 września 2000 r. w sprawach połączonych C-441/98 i C-442/98 Michaïlidis (Zb. Orz. 1998, s. I-7145), pkt 3; z 20 września 2001 r. w sprawie C-453/99 Courage Ltd p. Crehan (Zb. Orz. 2001, s. I-6297), pkt 30.

365 Por. M. Carpagnano, Private Enforcement of Competition Law Arrives in Italy: Analysis of the Judgement of the European Court of Justice in Joined Cases C-295-298/04 Manfredi, The Competition Law Review 2006, vol. 3(1), s. 71. Por. także White Paper Comission Staff Working Paper, pkt 189 (s. 57).

366 Problem ten omawia M. Danov, Awarding exemplary (or punitive) antitrust damages in ec competition cases with an international element - the Rome II Rregulation and the Commission's White Paper on Damages, E.C.L.R. 2008, vol. 29(7), s. 430-436. Autor ten 
W rzeczywistości odszkodowanie przykładowe wprost przewidziane jest jedynie w irlandzkim prawie ochrony konkurencji (sekcja 14(5) Competition Act), choć nie jest to często stosowany środek. W orzeczeniu w sprawie Donovan v. Electricity Supply Board ${ }^{367}$ sąd potwierdzi1, że badanie motywów lub intencji podmiotu naruszającego reguły konkurencji ma znaczenie tylko wówczas, gdy pojawia się kwestia przykładowych odszkodowań ${ }^{368}$.

W Wielkiej Brytanii to dorobek orzeczniczy wskazuje, w jakich sytuacjach roszczenia mogą być zaspokojone za pomocą odszkodowań przykładowych ${ }^{369}$. Za jedną z takich sytuacji uznaje się okoliczność, w której pozwany podejmuje naganne działanie „z premedytacją”, licząc na osiągnięcie zysków przewyższających potencjalne odszkodowanie należne powodowi. Takie zachowania mogą być powiązane z naruszeniami zakazów praktyk ograniczających konkurencję.

W wielu opracowaniach wskazuje się, że odszkodowania przykładowe mogą być zasądzane także na Cyprze ${ }^{370}$, jednak praktyka nie dostarcza takich przykładów.

W zdecydowanej większości państw członkowskich UE odszkodowania represyjne i przykładowe nie są akceptowane jako sprzeczne z porządkiem publicznym. W przypadku sporów transgranicznych możliwe jest powołanie się na klauzulę porządku publicznego, która przewidziana jest nie tylko w krajowych ustawach z zakresu prawa międzynarodowego prywatnego, ale także w art. 26 rozporządzenia (WE) nr 864/2007 Parlamentu Europejskiego i Rady z dnia 11 lipca 2007 r. dotyczącego prawa właściwego dla zobowiązań pozaumownych (Rzym II), zezwala jednak państwom członkowskim na wyłączenie stosowania prawa obcego, jeśli jest ono „w sposób oczywisty niezgodne z porządkiem publicznym państwa siedziby sądu”. W pkt. 32 preambuły do tego rozporządzenia prawodawca unijny wskazał, że klauzula ta może być zastosowana w szczególności, gdy prawo obce przewiduje przyznanie „w nadmiernej wysokości odszkodowania mającego charakter kary

twierdzi, że jest to problem na tyle doniosły, że uzasadnia podjęcie przez Unię Europejską inicjatywy legislacyjnej w zakresie odszkodowań przykładowych i represyjnych (s. 435).

367 Donovan v. Electricity Supply Board [1997] 3 IR 573, s. 585.

368 Raport nt. Irlandii towarzyszący Raportowi Ashursta, s. 15-16 (dostępny pod adresem: http://ec.europa.eu/competition/antitrust/actionsdamages/national_reports/ireland_ en.pdf).

369 Por. wyrok w sprawie Rookesg v. Barnard [1964] AC 1129, HL, gdzie sąd sformułował zasady dopuszczalności odszkodowań przykładowych.

370 Por. Raport Ashursta, pkt G(a)(vi), s. 84 i towarzyszący mu raport krajowy nt. Cypru (Executive summary and overview of the national report for Cyprus), s. 3 (dostępny pod adresem: http://ec.europa.eu/competition/antitrust/actionsdamages/executive_summaries/ cyprus_en.pdf). 
[represyjnego - przyp. aut.] lub odszkodowania o skutku odstraszającym [przykładowego - przyp. aut.]”. Praktyce znane są przypadki, kiedy sądy w państwach członkowskich UE (m.in. w Niemczech) ${ }^{371}$ powoływały się na względy porządku publicznego, odmawiając wykonania wyroków sądów amerykańskich zasądzających odszkodowania represyjne; należy jednak odnotować, że hiszpański sąd najwyższy zezwolił na wykonanie orzeczenia sądu amerykańskiego, w którym zasądzono potrójne odszkodowanie ${ }^{372}$, zaś w projekcie nowelizacji francuskiego kodeksu zobowiązań znalazł się zapis dopuszczający odszkodowania represyjne ${ }^{373}$.

Zaproponowana przez Komisję w Zielonej księdze koncepcja podwójnego odszkodowania spotkała się z generalną krytyką - zdecydowanie przeciw odszkodowaniom represyjnym wypowiedziały się m.in. Bundeskartellamt (s. 6), brytyjski departament handlu i przemysłu (s. 14-15), fińskie ministerstwo handlu i przemysłu (s. 5), litewska rada konkurencji (s. 3), norweskie ministerstwo administracji rządowej i reform (s. 4), rumuńska rada konkurencji (s. 9) ${ }^{374}$. Nawet irlandzki organ ochrony konkurencji (Irish Competition Authority) nie wyraził poparcia dla koncepcji podwójnego odszkodowania (s. 7), zaś brytyjski Office of Fair Trading opowiedział się jedynie przeciwko obligatoryjnemu stosowaniu podwójnych odszkodowań, pozostawiając sądom uznanie w tym zakresie, z tym jednak zastrzeżeniem, że sądy nie mogłyby orzekać wielokrotnego odszkodowania wobec przedsiębiorców przystępujących do programu łagodzenia kar (s. 11).

W konsekwencji wyników konsultacji publicznych Zielonej księgi, ostatecznie w Białej księdze Komisja Europejska zdecydowanie porzuciła koncepcję podwójnego odszkodowania jako elementu europejskiego systemu prywatnoprawnego egzekwowania reguł konkurencji. Stanowisko to należy w pełni zaaprobować375.

371 Znane są przypadki, kiedy sądy w państwach członkowskich UE powoływały się na względy porządku publicznego, odmawiając wykonania wyroków sądów amerykańskich zasądzających odszkodowania represyjne - przykłady takie przytacza H. Koziol, Punitive Damage: Admission into the Seventh Legal Heaven or Eternal Damnation? Comparative Reports and Conclusions, [w:] H. Koziol, V. Wilcox (red.), Punitive Damages..., s. 276.

372 Miller Import Corp. v. Alabastres Alfredo, S.L., STS, 13 listopada 2001 (Exequàtur No. 2039/1999) - por. J. Y. Gotanda, Charting Developments Concerning Punitive Damages: Is the Tide Changing?, Columbia Journal of Transnational Law 2007, vol. 4/3, s. 521-522.

373 Podaję za: J. Y. Gotanda, Charting Developments..., s. 517-518.

374 Polski rząd w ogóle nie wypowiedział się w swojej opinii na temat proponowanej przez Komisję opcji 16, przewidującej podwójne odszkodowanie.

375 Inaczej w polskim piśmiennictwie: M. K. Kolasiński, Odpowiedzialność cywilna za szkody powstałe w wyniku naruszenia wspólnotowych zakazów praktyk ograniczajacych konkurencje 
Możliwe jest wyodrębnienie trzech podstawowych argumentów przemawiających za dopuszczalnością odszkodowań przykładowych i represyjnych w ramach prywatnego egzekwowania prawa ochrony konkurencji. Pierwszym z nich jest fakt, że odszkodowania takie mogą być postrzegane jako zachęta dla występowania z powództwami cywilnymi z tytułu naruszenia zakazów praktyk ograniczających konkurencję ${ }^{376}$. W taki sposób do odszkodowań tego rodzaju odnosili się autorzy Raportu Ashursta377, towarzyszącego Zielonej księdze w sprawie roszczeń odszkodowawczych. Drugi argument związany jest z postrzeganiem odszkodowań przykładowych i represyjnych jako środków wzmacniających efektywność egzekwowania prawa ochrony konkurencji.

Bardziej przekonujące wydają mi się jednak argumenty przemawiające za wykluczeniem możliwości stosowania odszkodowań przykładowych i represyjnych. Pierwszy z nich stanowi sprzeczność z przyjętymi w systemach prawa stanowionego (czyli w większości państw członkowskich UE) zasadami odpowiedzialności cywilnej - dopuszczalność wielokrotnych odszkodowań oznaczałaby konieczność wprowadzenia w większości systemów prawnych (także polskim) nowych, rewolucyjnych regulacji cywilnoprawnych. Poszanowanie kontynentalnej tradycji prawniczej, acz niepozbawione znaczenia, nie wydaje się jednak kluczową kwestią, dużo istotniejszym argumentem przeciwko wprowadzaniu (bądź ugruntowywaniu) odszkodowań przykładowych i represyjnych jest ich hybrydowa natura, łącząca elementy odpowiedzialności cywilnej i karnej. Sankcje o wyraźnym charakterze represyjnym i prewencyjnym powinny pozostać właściwe dla publicznego trybu egzekwowania prawa konkurencji, podczas gdy środki ochrony prawnej właściwe dla trybu prywatnego powinny zachować charakter kompensacyjny i restytucyjny ${ }^{378}$. Potwierdzenie takiego stanowiska odnaleźć można nawet w orzecznictwie brytyjskim, w którym odszkodowania przykładowe i represyjne są wszak ugruntowane. W orzeczeniu w sprawie Devenish Nutrition Limited \& the Others v. Sanofi Avensis SA France \& Others ${ }^{379}$ High Court of Justice stwierdzit, że przyznawanie odszkodowania przykładowego w sprawie, w której na pozwanego została już nałożona sankcja przez Komisję

i nadużywania pozycji dominujacej, PPH 2007, nr 11, s. 22. Autor ten widzi dla odszkodowań wielokrotnych „silne uzasadnienie funkcjonalne”.

376 Tak również: E. D. Cavanagh, Detrebling antitrust damages..., s. 97.

377 Por. Raport Ashursta, pkt III(e), s. 130.

378 M. Hazelhorst, Private Enforcement of EU Competition Law: Why Punitive Damages Are a Step Too Far, ERPL 2010, nr 4, s. 767-768.

379 Wyrok High Court of Justice, Chancery Division, z dnia 19 października 2007, [2007] EWHC 2394 (Ch.). 
należałoby traktować jako naruszenie zasady ne bis in idem ${ }^{380}$. Również wśród przedstawicieli doktryny z krajów anglosaskich coraz częściej spotykana jest krytyka odszkodowań represyjnych i przykładowych ${ }^{381}$, zwłaszcza w odniesieniu do praktyk innych niż kartele cenowe i podziałowe ${ }^{382}$ - wsłuchanie się w te głosy powinno być również częścią europejskiej i krajowej debaty nad tą kwestią.

Mimo że odszkodowania represyjne i przykładowe są co do zasady obce regułom odpowiedzialności odszkodowawczej w kontynentalnych systemach prawnych, to również w polskim systemie prawnym można zidentyfikować ich przejawy. Najbardziej oczywiste przejawy odszkodowania represyjnego (wielokrotnego) odnaleźć można w ustawie Prawo autorskie, w której przewidziano roszczenia o zapłatę sumy pieniężnej w wysokości stanowiącej wielokrotność (dwu- lub trzykrotność) stosownego wynagrodzenia, w zależności od stopnia winy [art. 79 ust. 1 pkt 3 lit. b) ustawy Prawo autorskie]. Krytycznie na temat tego rozwiązania wypowiadali się nie tylko przedstawiciele doktryny (m.in. P. Podrecki, który wskazał, że szczególnie nagannym jest uznanie winy za element przesądzający o kolejnej wielokrotności wynagrodzenia ${ }^{383}$ ), ale i Sąd Najwyższy, który stwierdził, że „regulacja ta wywołuje zastrzeżenia, zarówno w kontekście dyrektywy nr 2004/48/WE (...), jak również w kontekście trwale ukształtowanego, także w porządku krajowym, modelu odpowiedzialności odszkodowawczej"384. Rolę odszkodowania przykładowego można przypisać roszczeniom publikacyjnym oraz roszczeniom o zapłatę pewnej sumy na cele społeczne, przewidzianym w polskiej ustawie o zwalczaniu nieuczciwej konkurencji385. Jeśli przyjąć, że odszkodowaniem przykładowym jest każde, które wykracza poza kom-

380 Na sprzeczność odszkodowań represyjnych z regułą ne bis in idem wskazała także w opinii do Zielonej księgi w sprawie odszkodowań m.in. Association Française des Entreprises Privées, s. 9 (dokument dostępny pod adresem: http://ec.europa.eu/competition/antitrust/ actionsdamages/white_paper_comments/afep_en.pdf).

381 Por. m.in. D. B. Dobbs, Ending Punishments in „Punitive” Damages: Detterence-Measured Remedies, Alabama Law Review 1988/1989, vol. 40, s. 831; A. J. Sebok, Punitive Damages: From Myth to Theory, Iowa Law Review 2007, vol. 92, s. 957.

382 E. D. Cavanagh, Detrebling antitrust damages..., s. 97. W przypadku praktyk monopolizacyjnych (sekcja 2 Aktu Shermana) autor proponuje przynajmniej zastąpienie systemu obligatoryjnych potrójnych odszkodowań możliwością przyznawania odszkodowań wielokrotnych na zasadzie dyskrecjonalnej.

383 P. Podrecki, Środki ochrony..., s. 300.

384 Wyrok SN z dnia 21 października 2011 r., IV CSK 133/2011, OSNC 2012, Nr 5, poz. 62.

385 Raport Ashursta, pkt G(a)(vi), s. 84. Por. pkt 7.8.6. w niniejszym rozdziale. 
pensację finansową dla poszkodowanego, to należałoby zgodzić się z taką tezą 386 .

Koncepcja odszkodowań represyjnych narusza - moim zdaniem - równowagę między prywatnym a publicznym egzekwowaniem prawa konkurencji, stąd w zrównoważonym modelu współfunkcjonowania obydwu trybów nie powinno być miejsca na sankcje tego rodzaju, zwłaszcza jeśli publiczny system ochrony konkurencji obejmuje również sankcje karne.

\subsection{Inne roszczenia cywilnoprawne}

\subsubsection{Uwagi wstępne}

Sankcja nieważności nie jest jedyną sankcją cywilnoprawną za naruszenie zakazów praktyk ograniczających konkurencję, choć - przynajmniej w Polsce i UE - jest ona jedyną wynikającą wprost z przepisów antymonopolowych i implikuje zastosowanie niektórych pozostałych sankcji pośrednich. Naruszenia zakazów praktyk ograniczających konkurencję mogą uruchomić różnorodne roszczenia cywilnoprawne: roszczenia negatoryjne, roszczenia windykacyjne $\mathrm{i}$ inne. Pierwsza $\mathrm{z}$ wymienionych kategorii obejmuje roszczenia służące likwidacji stanu niezgodności z prawem ochrony konkurencji, podczas gdy roszczenia kompensacyjne są ukierunkowane na pokrycie uszczerbku w majątku poszkodowanego wskutek zaistniałego naruszenia zakazów praktyk ograniczających konkurencję 387.

W debatach nad prywatnym egzekwowaniem prawa konkurencji zdecydowanie najwięcej miejsca poświęca się roszczeniom odszkodowawczym - dobitnie wynika to choćby z dokumentów Komisji Europejskiej, która problematyce odszkodowań wydaje się dawać absolutne pierwszeństwo (na co wskazuje m.in. tytuł Białej księgi - w sprawie roszczeń o naprawienie szkody wynikłej z naruszenia wspólnotowego prawa ochrony konkurencji ${ }^{388}$. Niemniej jednak należy podkreślić, że również Europejski Trybunał Spra-

386 Niemniej jednak polski raport autorstwa A. Lisieckiej, K. Wójcik, T. Wardyńskiego i K. Filińskiego towarzyszący Raportowi Ashursta nie klasyfikuje takich roszczeń jako represyjnych/przykładowych (dokument dostępny pod adresem: http://ec.europa.eu/competition/ antitrust/actionsdamages/national_reports/poland_en.pdf).

387 P. Podrecki, Civil Law Actions..., s. 83.

$388 \mathrm{O}$ tym, że roszczenia również inne niż odszkodowawcze realizują założenia prywatnego egzekwowania prawa konkurencji mówi także White Paper Staff Working Paper, jednak i ten dokument koncentruje się wyłącznie na roszczeniach odszkodowawczych - por. White Paper Staff Working Paper, s. 7 (przypis 5). 
wiedliwości kilkakrotnie opowiadał się za możliwością stosowania roszczeń innych niż odszkodowawcze w sytuacjach naruszenia traktatowych zakazów praktyk ograniczających konkurencję 389 .

Choć roszczenia odszkodowawcze (kompensacyjne) zapewne najpełniej realizują cele prywatnego egzekwowania prawa ochrony konkurencji - mogą one potencjalnie realizować funkcję nie tylko represyjną, ale także prewencyjną (odstraszającą), również inne rodzaje roszczeń mogą doskonale owe zadania wypełniać, zakładając, że tak publiczne, jak i prywatne egzekwowanie prawa konkurencji jest zorientowane na przywrócenie stanu zgodności z prawem. Nie wszystkie naruszenia zakazów antykonkurencyjnych prowadzą do powstania rzeczywistych szkód, dla niektórych antykonkurencyjnych praktyk (np. praktyk dyskryminacyjnych) bardziej adekwatne mogą być roszczenia o zaniechanie (zanim powstaną szkody) bądź co najmniej ustalenia samego faktu naruszenia. Nie sposób również ignorować faktu, że dochodzenie roszczeń innych niż odszkodowawcze jest - w porównaniu z tymi ostatnimi - znacznie mniej kosztowne. Atrakcyjność korzystania z nich zależy jednak także od sprawności aparatu sądowego, zwłaszcza od czasu oczekiwania na rozpatrzenie sprawy.

Deprecjonowanie roszczeń cywilnoprawnych innych niż kompensacyjne można postrzegać jako osłabienie idei prywatnego egzekwowania prawa konkurencji. Słusznie podkreśla się jednak w piśmiennictwie, że roszczeniami o charakterze niekompensacyjnym nie będą zainteresowani konsumenci, którzy po pierwsze często nie wiedzą, że są „ofiarami” naruszenia prawa, zaś po drugie zazwyczaj wchodzą oni w relacje z określonym przedsiębiorcą (naruszającym reguły konkurencji) tylko raz, stąd nie zależy im na doprowadzeniu do ustania naruszenia. Roszczenia o charakterze niekompensacyjnym mogą natomiast pozostawać w kręgu zainteresowania organizacji konsumenckich ${ }^{390}$.

Warto zwrócić uwagę na różnice terminologiczne, jakie pojawiają się w piśmiennictwie dotyczącym prywatnego egzekwowania prawa konkurencji, a wynikają z fundamentalnych rozbieżności systemów prawnych: common law oraz prawa kontynentalnego. Systemy prawa cywilnego w Europie kontynentalnej oparte są na koncepcji roszczeń (claim), wspieranych punktowymi interwencjami sądu w postaci zarządzeń (tymczasowych), natomiast w common law kluczowym pojęciem ochrony prawnej jest „środek” zakazowy

389 Por. wyrok SPI z dnia 18 września 1992 r. w sprawie T-24/90 Automec Srl. v. Komisja Wspólnot Europejskich (Zb. Orz. 1992, s. II-2223), pkt 50 (w wyroku tym chodziło o nakaz zawarcia umowy).

390 C. Cauffman, Injunctions at the Request of Third Parties in EU Competition Law, Maastricht European Private Law Institute, Working Paprt No. 2011/05, s. 27. 
lub zapobiegawczy (remedy), który może być zarówno środkiem interwencji trwałej (permanent), jak i tymczasowej (interim). W systemie anglosaskim środki te, inne niż roszczenia kompensacyjne, objęte są wspólną kategorią pojęciową injunctive relief. Osadzenie, na potrzeby niniejszej rozprawy, rozważań nad relacjami między publicznym i prywatnym egzekwowaniem prawa ochrony konkurencji w systemie prawa polskiego wymaga naturalnie posługiwania się nomenklaturą typową dla systemów prawnych Europy kontynentalnej, choć w rozważaniach nad roszczeniami cywilnoprawnymi wykorzystane będzie również piśmiennictwo autorów poruszających się w systemie common law.

\subsubsection{Roszczenie o zaniechanie}

Roszczenie o zaniechanie należy do kategorii roszczeń negatoryjnych, niemajątkowych ${ }^{391}$. Określane jest ono także jako roszczenie zakazowe, którego zasadniczą rolą jest przywrócenie stanu zgodności z prawem - z tego względu roszczenie to ma charakter pierwotny wobec roszczeń kompensacyjnych - jak również zapobieżenie niedopuszczalnym działaniom na przyszłość. W przypadku antykonkurencyjnych praktyk zgodność z prawem będzie oznaczała prowadzenie działalności gospodarczej z poszanowaniem zakazów praktyk ograniczających konkurencję wynikających z art. 6 i 9 uokik oraz art. 101 i 102 TFUE.

Podstawą roszczenia o zaniechanie może być art. 18 ust. 1 pkt 1 uznk bądź art. $439 \mathrm{kc}$, regulujący roszczenie zapobiegawcze, a postrzegany w literaturze jako pierwowzór roszczenia o zaniechanie w systemie ochrony przewidzianym w ustawie o zwalczaniu nieuczciwej konkurencji ${ }^{392}$. W piśmiennictwie wskazuje się jednak na zróżnicowany zakres ochrony na wskazanych podstawach: szerszy w przypadku ustawy o zwalczaniu nieuczciwej konkurencji i węższy w przypadku Kodeksu cywilnego. Skorzystanie z roszczenia o zaniechanie na podstawie art. 18 ust. 1 pkt 1 uznk warunkowane jest wykazaniem naruszenia, że działanie pozwanego wypełnia wszystkie przesłanki czynu nieuczciwej konkurencji, nie ma natomiast obowiązku wykazania szkody. Ochrona udzielona w ramach uznk „,nie powinna być zawężona do zabezpieczenia majątkowych interesów przedsiębiorcy, ale wszelkich interesów doniosłych gospodarczo (...)"393.

391 Postanowienie Sądu Najwyższego z dnia 8 marca 2007 r., III CZ 12/2007, OSNC 2008, nr 2, poz. 26.

392 Tak J. Rasiewicz, [w:] M. Zdyb, M. Sieradzka (red.), Ustawa o zwalczaniu nieuczciwej konkurencji. Komentarz, Wolters Kluwer, Warszawa 2011, s. 734.

393 Tak J. Rasiewicz, [w:] M. Zdyb, M. Sieradzka (red.), Ustawa..., s. 738. 
W przypadku roszczenia opartego na art. $439 \mathrm{kc}$, obok wykazania deliktu (roszczenie to nie może być wykorzystane w stosunkach obligacyjnych ${ }^{394}$ ), konieczne jest dowiedzenie zagrożenia szkodą w rozumieniu Kodeksu cywilnego (uszczerbek majątkowy), stan zagrożenia kwalifikuje omawiane roszczenie jako roszczenie o charakterze prewencyjnym ${ }^{395}$. Wystąpienie szkody jest w wysokim stopniu prawdopodobne, a zagrożenie szkodą „bezpośrednie, a jednocześnie skonkretyzowane w danych okolicznościach i w odniesieniu do szkód określonego typu"396.

Na powodzie występującym z roszczeniem o zaniechanie - bez względu na podstawę prawną - ciąży obowiązek udowodnienia faktu naruszenia. Wystąpienie $\mathrm{z}$ roszczeniem o zaniechanie na podstawie art. 18 ust. 1 pkt 1 uznk nie wymaga dowiedzenia winy; w piśmiennictwie spotyka się również pogląd uniezależniający realizację roszczenia z art. $439 \mathrm{kc}$ od przesłanki winy oraz bezprawności. M. Safjan twierdzi, że „sama zgodność określonej działalności gospodarczej z obowiązującym prawem, nie będzie zatem przeszkodą do wytoczenia powództwa prewencyjnego"397 - zagadnienie to nie ma jednak znaczenia dla prywatnego egzekwowania prawa konkurencji, gdyż roszczenie to będzie stosowane wyłącznie w przypadkach, gdy doszło do działania bezprawnego (sprzecznego z zakazami z art. 6 lub 9 uokik bądź art. 101 lub 102 TFUE). W przypadku roszczeń następczych dowiedzenie faktu naruszenia jest zadaniem o tyle prostym, że faktu tego dowodziłaby (a w sytuacji braku prejudycjalności co najmniej uprawdopodabniałaby) decyzja uznająca określone zachowanie za ograniczające konkurencję. Jednakże istnienie decyzji stwierdzającej antykonkurencyjną praktykę oznacza, że powód został już zobowiązany do zaniechania sprzecznego z prawem działania (i z dużym prawdopodobieństwem tego działania zaniechał), co z kolei czyni roszczenie o zaniechanie bezzasadnym. Należy zatem przyjąć, że $z$ roszczeniami tego rodzaju powodowie będą występowali wtedy, gdy organ ochrony konkurencji nie wydał jeszcze decyzji stwierdzającej naruszenia. W sytuacji zbiegu postępowania antymonopolowego i sądowego zawieszenie postępowania przez sąd jest - ze względu na istotę roszczenia - mało

394 Tak W. Dubis, [w:] E. Gniewek (red.), Kodeks cywilny..., s. 798 (Nb 6).

395 Tak W. Dubis, [w:] E. Gniewek (red.), Kodeks cywilny..., s. 797 (Nb 1).

396 G. Bieniek, [w:] S. Dmowski, M. Sychowicz, H. Ciepła, K. Kołakowski, T. Wiśniewski, C. Żuławska, J. Gudowski, G. Bieniek, Komentarz do kodeksu cywilnego. Księga trzecia. Zobowiazania. Tom I, Wyd. Prawnicze LexisNexis, Warszawa 2011 (LexPolonica Maxima 2011).

397 Tak M. Safjan, [w:] K. Pietrzykowski (red.), Kodeks cywilny. Komentarz. Tom I, C. H. Beck, Warszawa 1999, s. 439 (Nb 6). 
prawdopodobne, zaś ze względu na sankcję zaniechania (stosowaną przez organ ochrony konkurencji) - całkowicie nieefektywne.

Uprawnieni występują z roszczeniami o zaniechanie $\mathrm{z}$ reguły niezwłocznie po naruszeniu (dowiedzeniu się o fakcie naruszenia), przy czym skutki praktyk antykonkurencyjnych mogą być widoczne na rynku i odczuwalne dla uprawnionych do wniesienia roszczenia w perspektywie czasowej odległej od podjęcia antykonkurencyjnych działań przez pozwanego. P. Podrecki słusznie podkreśla, że wystąpienie $\mathrm{z}$ roszczeniem o zaniechanie po dłuższym okresie tolerowania antykonkurencyjnych zachowań powinno być uwzględniane przy określaniu ewentualnego zabezpieczenia tymczasowego w sprawie, nie może natomiast stanowić przesłanki uznania roszczenia za niezasadne 398 .

Treścią roszczenia o zaniechanie na podstawie art. 18 ust. 1 pkt 1 uznk jest żądanie wydania zakazu kontynuowania konkretnego zachowania sprzecznego z zakazem praktyk ograniczających konkurencję. E. Nowińska i M. du Vall wskazują przy tym, że „powód powinien określić zakaz tak szeroko, jak tylko na to pozwalają okoliczności konkretnego przypadku (a zatem - jak najmniej kazuistycznie)" ${ }^{399}$. Roszczenie na podstawie art. 18 uznk może być przedstawione wówczas, gdy doszło już do naruszenia, istnieje możliwość jego ponowienia albo też realna obawa wystąpienia naruszenia ${ }^{400}$. Co do tej ostatniej sytuacji nie ma zgody w doktrynie, czy rzeczywiście możliwe jest żądanie zaniechania działań polegających na przygotowaniu do popełnienia czynu nieuczciwej konkurencji, jako że art. 18 uznk nie gwarantuje expressis verbis ochrony prewencyjnej (jak czyni to np. art. 285 ustawy Prawo własności przemysłowej). E. Nowińska i M. du Vall uznali, że dla wystąpienia z roszczeniem o zaniechanie nie wystarcza ewentualne zagrożenie (chociażby realne) popełnienia czynu nieuczciwej konkurencji ${ }^{401}$. Wydaje się, że w przypadku praktyk ograniczających konkurencję zidentyfikowanie działań polegających na przygotowaniu się do zakazanej praktyki będzie nastręczać znaczących trudności - za czynności przygotowawcze można byłoby uznać np. zawarcie umowy ustanawiającej kartel, jednak w świetle prawa ochrony konkurencji już sama taka czynność - zorientowana na ograniczenie konkurencji, bez konieczności osiągnięcia antykonkurencyjnego celu - stanowi działanie zakazane.

Analizując treść żądań powodów można wskazać, przykładowo, że jeśli praktyką ograniczającą konkurencję jest porozumieniem cenowym, powód

398 P. Podrecki, Środki ochrony..., s. 190.

399 E. Nowińska, M. du Vall, Komentarz..., (Komentarz do art. 18, Nb 11).

400 P. Podrecki, Środki ochrony..., s. 201; J. Rasiewicz, [w:] M. Zdyb, M. Sieradzka (red.), Ustawa..., s. 735.

401 E. Nowińska, M. du Vall, Komentarz..., (Komentarz do art. 18, Nb 10). 
powinien żądać zaprzestania stosowania cen ustalonych przez kartel lub narzuconych w ramach porozumienia wertykalnego. Od uczestników porozumienia kontyngentowego można żądać zaniechania realizacji ustaleń związanych z kontrolą produkcji lub sprzedaży, zaś od uczestników porozumienia podziałowego - zaniechania podziału rynku poprzez przystąpienie do obsługi wszystkich klientów, niezależnie od terytorium, asortymentu czy ich statusu podmiotowego. Problematyczne może być jednak występowanie $\mathrm{z}$ roszczeniem o zaniechanie $\mathrm{w}$ przypadku nadużycia pozycji dominującej poprzez narzucanie nieuczciwych cen - zakaz stosowania cen na określonym poziomie (uznanym za nieuczciwy) nie będzie równoznaczny z nakazem stosowania cen w wysokości „uczciwej”.

Z kolei - jak podkreśla się w piśmiennictwie - treścią żądania opartego na art. $439 \mathrm{kc}$ jest zobowiązanie do „podjęcia środków, które mogłyby odwrócić stan istniejącego zagrożenia" 402 , co w wielu sytuacjach będzie równoznaczne z zakazem kontynuowania działań antykonkurencyjnych.

Odrębną kwestię problemową stanowi możliwość modyfikowania przez sąd treści żądania powoda co do zachowania pozwanego w sytuacji, gdy samo żądanie zaniechania jest co do swej istoty zasadne. P. Podrecki, powołując się na analogię z orzecznictwem Sądu Najwyższego w sprawach dotyczących naruszeń dóbr osobistych, stoi na stanowisku, że modyfikacje takie powinny być dopuszczalne bez uznawania ich za orzekanie ponad żądanie pozwu ${ }^{403}$. Stanowisko to wydaje się trafne.

Należy również odnotować pogląd, zgodnie z którym „w przypadkach szczególnych sąd powinien zastosować - na zasadzie analogii - przepis art. 320 k.p.c. i oznaczyć terminy, w których pozwany powinien zaniechać niedozwolonych działań" 404.

Atrakcyjność roszczeń o zaniechanie potwierdza praktyka niemiecka ${ }^{405}$.

\subsubsection{Roszczenie o przywrócenie stanu poprzedniego. Roszczenie o usunięcie skutków naruszenia}

Do roszczeń restytucyjnych, które mogą być wykorzystane w sytuacji naruszenia zakazów praktyk ograniczających konkurencję, należy zaliczyć roszczenie o przywrócenie stanu poprzedniego (restitutio in integrum), oparte na art. $363 \S 1 \mathrm{kc}$ oraz roszczenie o usunięcie skutków naruszenia, oparte

\footnotetext{
402 M. Safjan, [w:] K. Pietrzykowski (red.), Kodeks cywilny..., s. 440 (Nb 8).

403 P. Podrecki, Srodki ochrony..., s. 196.

404 E. Nowińska, M. du Vall, Komentarz..., (Komentarz do art. 18, Nb 12).

405 Por. statystyki zaprezentowane przez S. Peyer, Injunctive relief..., s. 6.
} 
na art. 18 ust. 1 pkt 2 uznk. E. Nowińska i M. du Vall wyrazili pogląd, że „zakres znaczeniowy pojęcia «usunięcie skutków» jest zbliżony do pojęcia «przywrócenie stanu poprzedniego»"406, natomiast P. Podrecki podkreśla, że te dwa roszczenia mogą być wobec siebie konkurencyjne, ,jeśli na tle okoliczności stanu faktycznego doszło do wyrządzenia szkody" 407.

Wystąpienie z roszczeniem o usunięcie skutków naruszenia na podstawie art. 18 ust. 1 pkt 2 uznk wymaga wykazania bezprawności działania naruszyciela, nie ma natomiast ani obowiązku dowiedzenia winy ${ }^{408}$, ani też obowiązku wykazania szkody (wystarczające jest zagrożenie interesu). Konieczne jest natomiast wykazanie związku przyczynowego między czynem bezprawnym a skutkami, które mają zostać usunięte. W piśmiennictwie podnosi się, że wystąpienie z roszczeniem o usunięcie skutków wymaga, aby skutki czynu istniały w dacie orzekania ${ }^{409}$. W odniesieniu do roszczeń związanych z praktykami ograniczającymi konkurencję istotnych trudności może nastręczać określenie tych skutków dla konkurencji i pozycji rynkowej powoda, które są rezultatem niedozwolonych działań i tych skutków, które stanowią wynik normalnej (niezakłóconej) rywalizacji rynkowej.

Zastosowanie art. $363 \S 1 \mathrm{kc}$ wymaga natomiast dodatkowo dowiedzenia istnienia szkody.

Artykuł $363 \S 1 \mathrm{kc}$ przewiduje dwa równorzędne sposoby naprawienia szkody: przywrócenie stanu poprzedniego (restytucja naturalna) oraz zapłatę odpowiedniej sumy pieniężnej. Restytucja naturalna „polega na kompensacji szkody w drodze zastąpienia lub naprawienia naruszonego dobra poszkodowanego lub też usunięcia ujemnych skutków naruszenia jego konkretnego interesu (...)" ${ }^{\prime 10}, \mathrm{w}$ tym „,szeroko pojętego interesu ekonomicznego 411 ”. Za klasyczne formy restytucji naturalnej uznaje się naprawienie uszkodzonej rzeczy, dostarczenie odpowiedniej ilości rzeczy w zamian za rzeczy zniszczone, czy zwrot rzeczy zabranej. Żadna $\mathrm{z}$ tych form nie ma możliwości zaistnienia $\mathrm{w}$ odniesieniu do szkód wywołanych praktykami ograniczającymi konkurencję, które jako takie nie są ukierunkowane na wyrządzenie szkody w sferze materialnej (majątkowej) sensu stricto. W przypadku naruszeń zakazów praktyk ograniczających konkurencję nie można zatem mówić o dosłownym odtworzeniu stanu sprzed wyrządzenia szkody, ale raczej o „stworzeniu takiego stanu gospodarczego, jaki by istniał gdyby nie

406 E. Nowińska, M. du Vall, Komentarz..., (Komentarz do art. 18, Nb13).

407 P. Podrecki, Środki ochrony..., s. 203-204.

408 Tak E. Nowińska, M. du Vall, Komentarz..., (Komentarz do art. 18, Nb 14).

409 Tak J. Rasiewicz, [w:] M. Zdyb, M. Sieradzka (red.), Ustawa..., s. 742.

410 Z. Banaszczyk, [w:] K. Pietrzykowski (red.), Kodeks cywilny. Komentarz..., s. 809.

411 J. Rasiewicz, [w:] M. Zdyb, M. Sieradzka (red.), Ustawa.., s. 742. 
nastąpiło zdarzenie szkodzące" 412 . W istocie zatem w niektórych przypadkach usunięcie skutków naruszenia można kwalifikować jako przywrócenie stanu poprzedniego; w takich przypadkach może dojść do zbiegu roszczeń $\mathrm{z}$ art. 18 ust. 1 pkt 2 uznk i art. $363 \S 1 \mathrm{kc}$. Akceptując takie szerokie rozumienie restytucji naturalnej, można przyjąć, że wystąpienie z roszczeniem opartym na art. $363 \S 1 \mathrm{kc}$ (ale i na podstawie art. 18 ust. 1 pkt 2 uznk) byłoby możliwe np. w przypadku praktyk dyskryminacyjnych, np. kolektywnego bojkotu lub dyskryminacji przez dominanta, gdy dyskryminacja polegała na odmowie kontraktowania/dostaw - powód mógłby wówczas żądać zawarcia umowy/dokonania dostaw czy np. wykonania na jego rzecz określonych usług 413 . W odniesieniu do praktyk kontyngentowych (ograniczanie ilości produktów dostarczanych na rynek) roszczenie restytucyjne mogłoby zmierzać do uzyskania przez powoda żądanej ilości produktów (przy czym owa żądana ilość musi być racjonalna, możliwa do wytworzenia przez pozwanego/pozwanych). Kres praktyce podziału rynku może położyć zobowiązanie do zaopatrywania określonego rynku terytorialnego lub asortymentowego bądź zaopatrywanie określonych grup klientów przez danego uczestnika porozumienia. Wydawałoby się, że restytucję naturalną należy traktować jako podstawową formę naprawienia szkody, jednak w wielu przypadkach - i dotyczy to zwłaszcza szkód wywołanych „deliktami antymonopolowymi" - przywrócenie stanu poprzedniego - nawet we wskazanym powyżej rozumieniu - nie jest możliwe. Przykładowo, przywrócenie stanu poprzedniego nie będzie możliwe, jeśli praktyka ograniczająca konkurencję przyjęła formę porozumienia przetargowego.

W piśmiennictwie podkreśla się, że wybór sposobu naprawienia szkody należy do poszkodowanego, a jedynie w przypadku jego opieszałości uprawnienie to przechodzi na zobowiązanego ${ }^{414}$. Jeśli ze względów faktycznych (charakter praktyki anykonkurencyjnej) lub prawnych (np. poszkodowany zakończył prowadzenie działalności gospodarczej) nie jest możliwe przywrócenie stanu poprzedniego, art. $363 § 1$ kc daje możliwość żądania zapłaty odpowiedniej sumy pieniężnej.

412 Z. Banaszczyk, [w:] K. Pietrzykowski (red.), Kodeks cywilny. Komentarz..., s. 809. Por. także T. Wiśniewski, [w:] S. Dmowski, M. Sychowicz, H. Ciepła, K. Kołakowski, T. Wiśniewski, C. Żuławska, J. Gudowski, G. Bieniek, Komentarz do kodeksu cywilnego..., (Komentarz do art. 363, $\mathrm{Nb} 2$ ).

413 Por. K. Zagrobelny, [w:] E. Gniewek (red.), Kodeks cywilny..., s. 588-589 (Nb 12).

414 Tak m.in.: Z. Banaszczyk, [w:] K. Pietrzykowski (red.), Kodeks cywilny. Komentarz..., s. 807; T. Wiśniewski, [w:] S. Dmowski, M. Sychowicz, H. Ciepła, K. Kołakowski, T. Wiśniewski, C. Żuławska, J. Gudowski, G. Bieniek, Komentarz do kodeksu cywilnego..., (Komentarz do art. 363, $\mathrm{Nb} 1)$. 
W doktrynie i orzecznictwie ${ }^{415}$ słusznie podkreśla się - i pogląd ten można odnieść zarówno do roszczeń o przywrócenie stanu poprzedniego, jak i roszczeń o usunięcie skutków naruszenia - że powód może żądać podjęcia tylko takich działań, które są adekwatne do zaistniałych negatywnych skutków zachowania powoda 416 . W szczególności roszczenie o usunięcie skutków naruszenia nie może być wykorzystane w celu wyrządzenia pozwanemu uszczerbku majątkowego (np. poprzez zbyt wysokie koszty działań restytucyjnych) bądź uzyskania nieuzasadnionej przewagi konkurencyjnej. W razie niespełnienia przesłanki adekwatności sąd zachowuje prawo częściowego oddalenia roszczenia lub zmiany zakresu czynności żądanych od pozwanego.

\subsubsection{Roszczenie z tytułu bezpodstawnego wzbogacenia}

Wśród roszczeń dostępnych dla podmiotów poszkodowanych naruszeniem zakazów praktyk ograniczających konkurencję, obok roszczeń odszkodowawczych, najczęściej wymienia się roszczenia z tytułu bezpodstawnego (nieuzasadnionego, niesłusznego) wzbogacenia. Możliwość zastosowania roszczeń tego rodzaju w przypadku spraw związanych z naruszeniem zakazów praktyk ograniczających konkurencję znalazła potwierdzenie również w orzecznictwie 417 .

W doktrynie prawa cywilnego podkreśla się, że fakt uzyskania kosztem innej osoby jakiejś korzyści majątkowej bez należytego usprawiedliwienia prawnego stanowi samoistne źródło zobowiązania418. Zwrot korzyści „ma na celu przywrócenie między stronami równowagi majątkowej, naruszonej bezpodstawnym uzyskaniem korzyści" 419 . Podstawę prawną zobowiązania stanowi art. $405 \mathrm{kc}$. Roszczenie o wydanie bezpodstawnie uzyskanych korzyści przewidziane jest również w art. 18 ust. 1 pkt 5 uznk - w przepisie tym ustawodawca odwołał się do zasad ogólnych, zatem dorobek orzecznicy i piśmienniczy odnoszący się do art. 405 kc znajduje zastosowanie rów-

415 Wyrok SA w Poznaniu z dnia 10 października 2005 r., I ACa 221/05, podaję za: J. Rasiewicz, [w:] M. Zdyb, M. Sieradzka (red.), Ustawa..., s. 743.

416 Por. m.in. J. Rasiewicz, [w:] M. Zdyb, M. Sieradzka (red.), Ustawa ..., s. 743.

417 Por. m.in. J. Rasiewicz, [w:] M. Zdyb, M. Sieradzka (red.), Ustawa ..., s. 743.

418 P. Podrecki, Środki ochrony..., s. 203; orzeczenie SN z dnia 7 listopada 1997 r., II CKN 424/97, OSN 1998, Nr 5, poz. 77; W. Czachórski, Zobowiqzania. Zarys wyktadu, Wydawnictwa Prawnicze PWN, Warszawa 1995, s. 131.

419 W. Czachórski, Zobowiazania..., s. 132. Tak również E. Łętowska, Bezpodstawne wzbogacenie, C. H. Beck, Warszawa 2000, s. 2; P. Mostowik, [w:] A. Olejniczak (red.) System prawa prywatnego..., s. 217 ( $\mathrm{Nb} 14)$. 
nież w przypadku oparcia roszczenia na art. 18 ust. 1 pkt 5 uznk ${ }^{420}$. Nie zasługuje na aprobatę, przytoczone przez J. Rasiewicz stanowisko z niepublikowanego orzeczenia Sądu Apelacyjnego w Poznaniu (I ACa 819/07)421, zgodnie z którym „roszczenie o wydanie uzyskanych korzyści stanowi samodzielną podstawę odpowiedzialności, różni się od bezpodstawnego wzbogacenia ( $\mathrm{z}$ art. $405 \mathrm{i} \mathrm{n}$. kc). Nie ma zatem podstaw odmawiać uwzględnienia roszczenia o ich wydanie $\mathrm{z}$ uwagi na fakt, że powód nie wykazał swojego zubożenia".

Powstanie zobowiązania $\mathrm{z}$ bezpodstawnego wzbogacenia wymaga spełnienia trzech przesłanek: wzbogacenia po jednej stronie i zubożenia po drugiej422, związku przyczynowego między nimi (przy czym nie jest to „klasyczny" związek przyczynowy, w którym mamy do czynienia z przyczyną i jej skutkiem, ale sytuacja, w której „między zubożeniem i wzbogaceniem musi zachodzić tego rodzaju zależność, aby można uznać, że są to dwie strony tego samego przesunięcia jakiejś wartości $\mathrm{z}$ jednego majątku do drugiego" 423 ) oraz uzyskania korzyści bez postawy prawnej. Jeśli roszczenie $z$ tytułu bezpodstawnego wzbogacenia zostało wniesione na podstawie art. 18 ust. 1 pkt 5 uznk, dodatkowo konieczne jest wykazanie popełnienia czynu nieuczciwej konkurencji - E. Nowińska i M. du Vall wskazują, że ta przesłanka na gruncie art. 18 ust. 1 pkt 5 uznk zastępuje przesłankę braku podstawy prawnej przewidzianą $\mathrm{w}$ art. $405 \mathrm{kc}^{424}$.

W przypadku praktyk antykonkurencyjnych wzbogacenie będzie polegać przede wszystkim na zwiększeniu aktywów wzbogaconego poprzez uzyskanie przez niego korzyści, które powinny były wejść do majątku zubożonego ${ }^{425}$. Wzbogaceniem będzie zatem „uzyskanie korzyści gospodarczych kosztem utraty części lub całości rynku” przez zubożonego ${ }^{426}$. Z kolei zubożeniem będzie głównie „utrata korzyści z gospodarczego wykorzystywania (...) pozy-

420 Tak również E. Nowińska, M. du Vall, Komentarz..., (Komentarz do art. 18, Nb 34); P. Mostowik, [w:] A. Olejniczak (red.) System prawa prywatnego..., s. 271 (Nb 85).

421 Wyrok SA w Poznaniu z dnia 7 listopada 2007 r., I ACa 819/07, niepubl., podaję za: J. Rasiewicz, [w:] M. Zdyb, M. Sieradzka (red.), Ustawa..., s. 763 (Komentarz do art. 18, $\mathrm{Nb}$ 47).

422 K. Pietrzykowski uznaje te zdarzenia za dwie odrębne przesłanki - K. Pietrzykowski, [w:] K. Pietrzykowski (red.), Kodeks cywilny..., s. 897 (Komentarz do art. 405 KC, Nb 3).

423 Wyrok SN z dnia 2 sierpnia 2007 r., V CSK 152/2007, Orzecznictwo Sądów w sprawach Gospodarczych 2008, nr 12, poz. 98, s. 3.

424 E. Nowińska, M. du Vall, Komentarz..., (Komentarz do art. 18, Nb 34).

425 K. Pietrzykowski, [w:] K. Pietrzykowski (red.), Kodeks cywilny..., s. 898 (Komentarz do art. $405 \mathrm{KC}, \mathrm{Nb} 5)$.

426 J. Rasiewicz, [w:] M. Zdyb, M. Sieradzka (red.), Ustawa..., s. 765 (Komentarz do art. 18, $\mathrm{Nb} 48)$. 
cji rynkowej" 427 . W orzecznictwie za wzbogacenie uznane zostały koszty sfinansowania przez odbiorcę energii budowy urządzeń energetycznych, następnie połączonych $\mathrm{w}$ sposób stały $\mathrm{z}$ siecią przedsiębiorstwa energetycznego, które dopuściło się praktyk monopolistycznych ${ }^{428}$. Inaczej niż w przypadku roszczenia o wydanie uzyskanych korzyści w prawie własności intelektualnej, gdzie - jak twierdzi P. Podrecki - oceniana jest tylko wartość wzbogacenia ${ }^{429}$, roszczenia wynikające $\mathrm{z}$ antykonkurencyjnych praktyk muszą uwzględniać również wskazanie zakresu zubożenia. Przesłankę braku podstaw prawnych dla uzyskania korzyści w literaturze rozumie się przede wszystkim jako brak podstawy prawnej w rozumieniu braku causa czynności prawnej, W. Czachórski podkreśla przy tym, że „rozciąga się to i na sytuacje, w których inne ewentualne roszczenia cywilnoprawne zawodzą, a mimo to istnieje $\mathrm{z}$ jednej strony wzbogacenie, a $\mathrm{z}$ drugiej zubożenie niczym nie usprawiedliwione" 430 . Twierdzenie to wydaje się szczególnie aktualne w przypadku roszczeń związanych z naruszeniem zakazów praktyk ograniczających konkurencję. Stanowisko to jest również zgodne z tezą wyroku Sądu Najwyższego z dnia 15 września 1945 r., C.I. 116/45431, w myśl której „pozew, oparty na niesłusznym wzbogaceniu, może mieć miejsce nie tylko wówczas, gdy nie ma innego środka do odzyskania doznanego uszczerbku majątkowego, lecz także wtedy, gdy inne środki połączone są z większymi trudnościami" "432. Sąd Najwyższy w wyroku z dnia 7 listopada 1997 r., II CKN 424/97 stanął również na stanowisku, zgodnie z którym jeśli umowa jest nieważna ze względu na naruszenie zakazu praktyk ograniczających konkurencję, to „odpadła podstawa prawna uzyskania korzyści majątkowej przez pozwanego i otworzyła się droga do dochodzenia roszczenia na podstawie art. 405 i nast. kc". M. Lemkowski w glosie do przywołanego orzeczenia

427 J. Rasiewicz, [w:] M. Zdyb, M. Sieradzka (red.), Ustawa..., s. 765 (Komentarz do art. 18, $\mathrm{Nb} 48)$.

428 Orzeczenie SN z dnia 7 listopada 1997 r., II CKN 424/97, OSN 1998, Nr 5, poz. 77. glosa M. Lemkowskiego, Monitor Prawniczy nr 13/2001. Por. także wyrok SN z dnia 9 października 1998 r., III CKN 641/97, OSNC 1999, nr 3 poz. 61.

429 P. Podrecki, Środki ochrony..., s. 360.

430 W. Czachórski, Zobowiązania..., s. 133.

431 Orzeczenie SN z dnia 15 września 1945 r., C.I. 116/45, LexPolonica nr 362180. Por. także m.in. wyrok SN z dnia 18 stycznia 2002 r., I CKN 810/99, LexPolonica nr 384087; wyrok SN z dnia 2 sierpnia 2007 r., V CSK 152/2007; wyrok SN z dnia 7 maja 2009 r., IV CSK 27/2009, LexPolonica nr 2030983.

432 Por. także uchwałę SN z dnia 27 kwietnia 1995 r., III CZP 46/95, OSN 1998, nr 7-8, poz. 114. Przytoczone stanowisko Sądu Najwyższego określa się jako „pośrednie” między tymi poglądami doktryny, które określają roszczenie z art. $405 \mathrm{KC}$ jako autonomiczne i jako subsydiarne - por. P. Mostowik, [w:] A. Olejniczak (red.) System prawa prywatnego..., s. 251 ( $\mathrm{Nb} 61)$. 
stwierdził jednak, że skoro decyzja organu ochrony konkurencji ma charakter deklaratywny, to „mamy do czynienia nie tyle z odpadnięciem podstawy prawnej świadczenia, ale z jej brakiem od samego początku" 433 .

Obowiązek zwrotu obejmuje zarówno samą korzyść, jak i związane z nią pożytki cywilne lub naturalne ${ }^{434}$. Zwrot korzyści powinien być co do zasady dokonany w naturze, jednakże jeśli nie jest to możliwe ze względu na charakter korzyści (a tak dzieje się w przypadku antykonkurencyjnych praktyk), dopuszcza się zwrot wartości korzyści (art. 405 in fine) $)^{435}$ - w takiej sytuacji obowiązek zwrotu korzyści powstaje $\mathrm{z}$ chwilą uzyskania jej przez wzbogaconego ${ }^{436}$, jednak ,zasądzeniu podlega zwrot aktualnego wzbogacenia, przez co należy rozumieć, zgodnie z art. 405 k.c. w zw. z art. 316 k.p.c. i stosowanym w drodze analogii art. $363 \S 2$ k.c., zwrot wzbogacenia istniejącego w chwili wyrokowania"437. Zgodnie ze stanowiskiem SN sformułowanym w wyroku z dnia 13 maja 1988 r., III CRN 83/88438, jeśli wzbogacenie polegało na uzyskaniu sumy pieniężnej, zobowiązany powinien zwrócić świadczenie pieniężne przeliczone zgodnie z zasadą ekwiwalentności. Jeśli strata zubożonego jest większa niż korzyść wzbogaconego (może się tak zdarzyć w sytuacji, gdy wskutek antykonkurencyjnej praktyki dominant przejmuje część rynku swoich konkurentów, oferując ceny niższe, nawet drapieżne, w stosunku do cen poszkodowanych konkurentów), przedmiotem obowiązku zwrotu jest zawsze wartość mniejsza ${ }^{439}$.

Okolicznością przemawiającą za wykorzystaniem roszczenia z bezpodstawnego wzbogacenia w przypadku naruszeń zakazów antykonkurencyjnych praktyk jest uniezależnienie zaspokojenia tego roszczenia od dowiedzenia spełnienia przesłanki winy czy nawet przesłanki zaistnienia naruszenia prawa - w wyroku z dnia 12 marca 2004 r., II CK 53/2003440, SN stwierdził, że

433 M. Lemkowski, Glosa do wyroku SN z 7.11.1997 r., II CKN 424/97, OSNC Nr 5/1997, poz. 77, MoP 2001, nr 13.

434 Tak m.in. K. Pietrzykowski, [w:] K. Pietrzykowski (red.), Kodeks cywilny..., s. 898 (Komentarz do art. 405 KC, Nb 11); K. Kołakowski, [w:] S. Dmowski, M. Sychowicz, H. Ciepła, K. Kołakowski, T. Wiśniewski, C. Żuławska, J. Gudowski, G. Bieniek, Komentarz do kodeksu cywilnego..., (Komentarz do art. 405, $\mathrm{Nb} 8$ ).

435 Por. wyrok SN z dnia 18 stycznia 2002 r., I CKN 810/99, LexPolonica nr 384087.

436 Tak K. Pietrzykowski, [w:] K. Pietrzykowski (red.), Kodeks cywilny..., s. 898 (Komentarz do art. $405 \mathrm{KC}, \mathrm{Nb}$ 14).

437 Wyrok SN z dnia 7 maja 2009 r., IV CSK 27/2009, LexPolonica nr 2030983.

438 Wyrok SN z dnia 13 maja 1988 r., III CRN 83/88, OSNCP 1989, nr 5, poz. 84, OSPiKA 1989, nr 7-12, poz. 149; PiP 1990, nr 5, s. 114.

439 Por. orzeczenie SN z dnia 24 października 1974 r., II CR 542/74, OSP 1976, nr 6, poz. 115. Por. także K. Pietrzykowski, [w:] K. Pietrzykowski (red.), Kodeks cywilny..., s. 898, (Komentarz do art. $405 \mathrm{KC}, \mathrm{Nb} 15$ ).

440 Wyrok SN z dnia 12 marca 2004 r., II CK 53/2003, LexPolonica nr 1546866. 
dla zastosowania art. $405 \mathrm{kc}$ nie jest konieczne stwierdzenie, że pozwany (wzbogacony) dopuścił się wobec powoda (zubożonego) praktyki monopolistycznej (stanowiącej niejako źródło wzbogacenia).

Z kolei pewną słabością może być to, że art. 409 kc przewiduje wygaśnięcie obowiązku zwrotu korzyści, jeśli zobowiązany „zużył ją lub utracił w taki sposób, że nie jest już wzbogacony" (tzw. zużycie konsumpcyjne ${ }^{441}$ ), ciężar dowodu spoczywa na wzbogaconym. W przypadku roszczeń związanych $z$ antykonkurencyjnymi praktykami rynkowymi ryzyko zaistnienia takiej sytuacji (tj. niemożności zwrotu korzyści) może wystąpić w przypadku, gdy przedsiębiorcy bezpodstawnie wzbogaconemu uda się dowieść, że uzyskane wskutek praktyki korzyści transferował na innych przedsiębiorców w łańcuchu dostaw (argument $\mathrm{z}$ obszaru pass-on defence). W piśmiennictwie z zakresu prawa cywilnego wyraża się jednak pogląd, że w takiej sytuacji to „obdarowana” osoba trzecia (tj. osoba, na rzecz której transferowano korzyści) będzie zobowiązana do wydania uzyskanej korzyści ${ }^{442}$.

Zgodnie $\mathrm{z}$ wolą ustawodawcy obowiązek zwrotu korzyści nie istnieje jednak wówczas, gdy wzbogacony powinien był liczyć się z obowiązkiem zwrotu. Biorąc pod uwagę fakt, że praktyki antykonkurencyjne mogą być dokonywane „nieumyślnie”, wzbogacony niekoniecznie musi mieć świadomość bezpodstawnego uzyskania korzyści - akceptacja takiej tezy uniemożliwiałaby zwolnienie się przez podmiot dopuszczający się antykonkurencyjnych praktyk od obowiązku zwrotu korzyści. Niemniej jednak w piśmiennictwie obecny jest pogląd, zgodnie z którym „powinność” liczenia się z obowiązkiem zwrotu korzyści oznacza również sytuację, w której wzbogacony „był subiektywnie przekonany, że korzyść mu się należy, chociaż na podstawie okoliczności sprawy obiektywnie powinien był liczyć się z obowiązkiem zwrotu"443; pogląd ten znalazł potwierdzenie również w orzecznictwie ${ }^{444}$. $\mathrm{Z}$ taką sytuacją możemy mieć do czynienia w przypadku praktyk antykonkurencyjnych, przytoczone stanowisko doktryny pozwoliłoby wyeliminować ryzyko możliwości powołania się na art. $409 \mathrm{kc}$ w sprawach związanych $\mathrm{z}$ bezpodstawnym wzbogaceniem $\mathrm{z}$ tytułu praktyk antykonkurencyjnych.

441 Tak K. Kołakowski, [w:] S. Dmowski, M. Sychowicz, H. Ciepła, K. Kołakowski, T. Wiśniewski, C. Żuławska, J. Gudowski, G. Bieniek, Komentarz do kodeksu cywilnego..., (Komentarz do art. 409, Nb 1).

442 Tak P. Księżak, Bezpodstawne wzbogacenie. Komentarz, C. H. Beck, Warszawa 2007, s. 145 ( $\mathrm{Nb} \mathrm{6)}$.

443 K. Pietrzykowski, [w:] K. Pietrzykowski (red.), Kodeks cywilny..., s. 907 (Komentarz do art. $409 \mathrm{KC}, \mathrm{Nb} 5)$.

444 Wyrok SN z dnia 2 marca 2010 r., II PK 246/2009, LexPolonica nr 2396930. 
Oceniając możliwości dochodzenia roszczeń na podstawie art. $405 \mathrm{kc}$, nie należy również ignorować faktu, że zgodnie $\mathrm{z}$ art. 414 kc możliwy jest zbieg roszczenia $\mathrm{z}$ art. $405 \mathrm{kc}$ oraz innych roszczeń związanych z naprawieniem szkody - w praktyce, co potwierdza orzecznictwo ${ }^{445}$, uprawnionemu (tj. powodowi, a nie pozwanemu ${ }^{446}$ ) przysługuje wybór podstawy prawnej roszczeń kierowanych przeciwko podmiotom dopuszczającym się antykonkurencyjnych praktyk. O pewnej modyfikacji tego stanowiska można byłoby mówić ewentualnie w odniesieniu do roszczeń, z jakimi miałaby wystąpić strona umowy naruszającej zakaz porozumień ograniczających konkurencję lub podmiot będący stroną umowy z dominantem rynkowym, którego zachowanie naruszało zakaz nadużywania pozycji dominującej. Jak podkreślił SN w uchwale z dnia 19 sierpnia 2009 r., III CZP 58/2009447, „powszechnie przyjęte jest stanowisko, że roszczenie kondycyjne jest wykluczone, gdy istnieje wyraźnie ustawowo sprecyzowane co do treści roszczenie o wykonanie zobowiązania”. Jednocześnie w tej samej uchwale SN uznał, że art. 18 uznk (w tym ust. 1 pkt 5) należy traktować jako regulację szczególną wobec przepisów kc, a więc mimo istnienia stosunku zobowiązaniowego między stronami „można dochodzić zwrotu bezpodstawnie uzyskanych korzyści na podstawie art. 18 ust. 1 pkt 5 u.z.n.k., bez potrzeby rozważania kwestii nieważności umowy".

\subsubsection{Roszczenie publikacyjne}

Kategoria roszczeń publikacyjnych obejmuje roszczenia o złożenie oświadczenia o odpowiedniej treści i roszczenia o opublikowanie treści wyroku. Roszczenia te postrzegane są przez doktrynę jako szczególna forma usunięcia skutków naruszenia (niedozwolonych działań) ${ }^{448}$, stąd zaliczane są do roszczeń negatoryjnych.

Artykuł 18 ust. 1 pkt 3 uznk przewiduje roszczenie o złożenie jednokrotnego lub wielokrotnego oświadczenia odpowiedniej treści i w odpowiedniej formie (na koszt pozwanego). Sąd Najwyższy przypisał temu roszczeniu

445 Por. wyrok SN z dnia 19 października 2007 r., II PK 74/2007, OSNP 2008, nr 23-24, poz. 349; wyrok SN z dnia 2 sierpnia 2007 r., V CSK 152/2007.

446 P. Księżak, Bezpodstawne wzbogacenie..., s. 127-128 (Nb 17-18), s. 269 (Nb 13).

447 Uchwała SN z dnia 19 sierpnia 2009 r., III CZP 58/2009, OSNC 2010, nr 3, poz. 37.

448 Tak E. Nowińska, M. du Vall, Komentarz..., (Komentarz do art. 18, Nb 19); E. Wojcieszko-Głuszko, Roszczenie o złożenie oświadczenia w sprawie nieuczciwej konkurencji, [w:] E. Nowińska, M. du Vall (red.), Księga pamiątkowa ku czci Profesora Janusza Szwaji, ZNUJ-PIPWI 2004, z. 88, s. 218-219. 
charakter roszczenia majątkowego ${ }^{449}$, jednak w piśmiennictwie nie ma co do tego zgody 450 .

W doktrynie wskazuje się na kompensacyjną, ale także prewencyjną i wychowawczą rolę roszczeń publikacyjnych ${ }^{451}$, wyklucza się natomiast ich funkcję represyjną ${ }^{452}$. Roszczenie publikacyjne może dopełniać skutki innych nakazów czy zakazów ${ }^{453}$, E. Wojcieszko-Głuszko kwalifikuje je nawet jako skonkretyzowaną postać roszczenia o usunięcie skutków niedozwolonych działań $^{454}$ (obydwa roszczenia oparte są na tych samych przesłankach ${ }^{455}$ ). Jednocześnie podkreśla się również informacyjną rolę roszczeń publikacyjnych jako „środka działającego na świadomość klienteli i jej wybory znajdujące odbicie w stosunkach majątkowych” 456 oraz środka, który „umożliwia przywrócenie równowagi rynkowej poprzez skorygowanie błędnych informacji funkcjonujących w świadomości klientów i przedsiębiorców" 457 .

W przypadku praktyk antykonkurencyjnych roszczenie publikacyjne może być wykorzystane jako jeden ze środków przywrócenia pozycji rynkowej powoda - oświadczenie o dopuszczeniu się praktyki przez określony podmiot pozwoli wyjaśnić opinii publicznej powody gorszej kondycji rynkowej przedsiębiorcy i może skłonić klientów do powrotu. Rola roszczeń publikacyjnych związanych z praktykami zakazanymi przez ustawę o ochronie konkurencji i konsumentów będzie jednak znacznie mniejsza niż w przy-

449 Por. postanowienie SN z dnia 8 marca 2007 r., III CZ 12/2007, OSNC 2008, nr 2, poz. 26; wyrok Sądu Najwyższego z dnia 9 stycznia 2008 r., II CSK 363/2007, LexPolonica nr 1798171.

450 Przegląd stanowisk doktryny w tej kwestii szeroko prezentuje E. Wojcieszko-Głuszko, Roszczenie o ztożenie oświadczenia..., [w:] E. Nowińska, M. du Vall (red.), Księga pamiątkowa..., s. 220-224. S. Dudzik i R. Skubisz, powołując się na orzecznictwo Sądu Najwyższego (m.in. wyrok SN z dnia 24 listopada 2009 r., V CSK 71/09, Legalis) stoją na stanowisku, że wszystkie roszczenia z art. 18 uznk mają charakter majątkowy - S. Dudzik, R. Skubisz, [w:] J. Szwaja (red.), Ustawa o zwalczaniu nieuczciwej konkurencji. Komentarz, C.H. Beck, Warszawa 2012, s. 848-849 (Wprowadzenie do komentarza do art. 18, $\mathrm{Nb}$ 9).

451 Tak P. Podrecki, Środki ochrony..., s. 447.

452 J. Rasiewicz, [w:] M. Zdyb, M. Sieradzka (red.), Ustawa..., s. 746 (Komentarz do art. 18, $\mathrm{Nb} 23)$.

453 E. Nowińska, M. du Vall, Komentarz..., (Komentarz do art. 18, Nb 22).

454 E. Wojcieszko-Głuszko, Roszczenie o złożenie oświadczenia..., [w:] E. Nowińska, M. du Vall (red.), Księga pamiątkowa..., s. 218.

455 J. Rasiewicz, [w:] M. Zdyb, M. Sieradzka (red.), Ustawa..., s. 746 (Komentarz do art. 18, $\mathrm{Nb} 24)$.

456 E. Nowińska, M. du Vall, Komentarz..., (Komentarz do art. 18, Nb 22). Por. także wyrok SA w Warszawie z dnia 7 listopada 2007 r., I ACa 334/2007, LexPolonica nr 1668514.

457 J. Rasiewicz, [w:] M. Zdyb, M. Sieradzka (red.), Ustawa..., s. 746 (Komentarz do art. 18, $\mathrm{Nb} 22)$. 
padku roszczeń wynikających z tych czynów nieuczciwej konkurencji, które szczególnie uderzają $\mathrm{w}$ dobra niematerialne, takie jak renoma przedsiębiorcy, czy też roszczeń publikacyjnych związanych z naruszeniami praw własności intelektualnej. W piśmiennictwie dominuje zresztą pogląd, że roszczenie publikacyjne może być wniesione tylko wówczas, gdy powstały skutki nadające się do usunięcia w ten sposób ${ }^{458}$ - nie będzie takich skutków w każdym przypadku antykonkurencyjnych praktyk.

Żądanie złożenia oświadczenia powinno wskazywać konkretną treść oświadczenia, miejsce i zasięg publikacji, a także terminy i częstotliwość publikacji 459 . W orzecznictwie w odniesieniu do roszczeń publikacyjnych postuluje się, aby osoba domagająca się ochrony ściśle określiła treść oświadczenia, którego złożenia domaga się, a „powód (...) nie może ograniczyć się do ogólnego domagania się «podania faktycznych źródeł i prawdziwych faktów», nie może bowiem pozostawiać sformułowania oświadczenia sądowi. To konkretna treść postulowanego przez stronę oświadczenia poddana jest osądowi organu orzekającego. Sąd może ingerować w treść oświadczenia jedynie poprzez ograniczenie jego zakresu lub konkretnych sformułowań, uwzględniając wówczas żądanie jedynie w określonej części (zakresie). Natomiast brak sformułowania treści oświadczenia, którego złożenia strona domaga się, oznacza brak możliwego do uwzględnienia żądania” (wyrok SN z dnia 22 grudnia 1997 r., II CKN 546/97460). W piśmiennictwie wyrażane są jednak również poglądy o potrzebie rezygnacji „z tak zawyżonych standardów wobec żądania pozwu" - nie jest konieczne, aby powód formułował dokładną treść oświadczenia, za wystarczające można uznać „określenie jej w sposób dostateczny", z jednoczesnym przyznanie sądom kompetencji do modyfikowania proponowanej treści oświadczenia ${ }^{461}$.

W przypadku roszczeń związanych z praktykami antykonkurencyjnymi treść świadczenia powinna obejmować przede wszystkim dokładne określenie istoty zakazanego działania, np. poprzez cytowanie klauzul umownych naruszających art. 6 lub 9 uokik bądź art. 101 lub 102 TFUE. Możliwe wydaje się również włączenie do treści takiego oświadczenia informacji o decyzji organów ochrony konkurencji stwierdzających określoną praktykę

458 J. Rasiewicz, [w:] M. Zdyb, M. Sieradzka (red.), Ustawa..., s. 747 (Komentarz do art. 18, $\mathrm{Nb} 24)$.

459 Tak P. Podrecki, Środki ochrony..., s. 454.

460 Wyrok SN z dnia 22 grudnia 1997 r., II CK 546/97, OSNC 1998, nr 7-8, poz. 119, glosa J. Wiercińskiego, PiP 1999, nr 3, s. 98. Por. także wyrok SN z dnia 5 stycznia 2005 r., IV CK 413/2004, LexPolonica nr 2120684.

461 E. Wojcieszko-Głuszko, Roszczenie o złożenie oświadczenia..., [w:] E. Nowińska, M. du Vall (red.), Księga pamiątkowa..., s. 237. 
(co będzie możliwe tylko w przypadku roszczeń następczych), natomiast niewłaściwe byłoby zamieszczenie w oświadczeniu informacji o toczącym się, a nie zakończonym, postępowaniu antymonopolowym.

Wyznaczając miejsce i zasięg publikacji w przypadku roszczeń związanych z praktykami antykonkurencyjnymi, należy uwzględnić wymiar rynku właściwego zarówno produktowo, jak i geograficznie. Rynek właściwy produktowo może być wskazówką dla wyboru mediów, w jakich powinno być publikowane oświadczenie (np. w przypadku, gdy praktyka dotyczyła szczebla hurtowego rynku odpowiednim miejscem publikacji będą media branżowe, natomiast gdy praktyka dotyczyła detalicznego szczebla rynku zamierzony skutek może być osiągnięty dzięki publikacji w mediach ogólnodostępnych). Wymiar geograficzny rynku właściwego pozwoli z kolei zdecydować o tym, czy publikacja powinna nastąpić w mediach o zasięgu lokalnym, regionalnym, czy też ogólnokrajowym.

\subsubsection{Roszczenie o zasądzenie odpowiedniej kwoty na cel społeczny związany ze wspieraniem kultury polskiej lub ochroną dziedzictwa narodowego}

Roszczenie o zasądzenie odpowiedniej kwoty na cel społeczny związany ze wspieraniem kultury polskiej lub ochroną dziedzictwa narodowego pełni funkcję represyjną, utożsamiane jest z nawiązką ${ }^{462}$ („pokutnym” ${ }^{463}$ ). Tym samym roszczenie to wychodzi poza klasyczne funkcje sankcji cywilnoprawnych, wprowadzając element odpowiedzialności quasi-karnej; w literaturze nawiązkę określa się niekiedy jako „sankcję o charakterze pośrednim między karą a egzekucją" 464 . Z tych względów istnienie tego roszczenia w katalogu $\mathrm{z}$ art. 18 uznk spotkało się z krytyką niektórych przedstawicieli doktryny ${ }^{465}$, choć J. Rasiewicz upatruje w nim dodatkowego instrumentu kompensacji szkód wynikłych z czynów nieuczciwej konkurencji, co zdaniem tej autorki jest szczególnie istotne w sytuacji, gdy wykazanie szkody lub wzbogacenia/ zubożenia w przypadku czynów nieuczciwej konkurencji jest nadmiernie utrudnione ${ }^{466}$. Odmienne stanowisko zajęli E. Nowińska i M. du Vall, którzy stwierdzili, że przepis art. 18 ust. 1 pkt 6 uznk „nie powinien być trakto-

462 E. Nowińska, M. du Vall, Ustawa..., (Komentarz do art. 18, Nb 39).

463 Tak J. Szwaja, K. Jasińska, [w:] J. Szwaja (red.), Ustawa.., s. 893 i n. (Komentarz do art. $18, \mathrm{Nb}$ 124-134).

464 A. Redelbach, S. Wronkowska, Z. Ziembiński, Zarys teorii..., s. 92.

465 J. Szwaja, K. Jasińska, [w:] J. Szwaja (red.), Ustawa..., s. 895 (Komentarz do art. 18, $\mathrm{Nb}$ 131); E. Nowińska, M. du Vall, Ustawa..., (Komentarz do art. 18, Nb 39).

466 J. Rasiewicz, [w:] M. Zdyb, M. Sieradzka (red.), Ustawa..., s. 767 (Komentarz do art. 18, $\mathrm{Nb} 53)$. 
wany jako surogat odszkodowania w tych sytuacjach, w których bądź do wyrządzenia szkody nie doszło, bądź też dochodzenie roszczeń odszkodowawczych jest wyłączone ze względu na to, że powód należy do kategorii wskazanych w art. 19 ust. 1 pkt 2 (a zatem nie mógł ponieść szkody)"467.

Przesłanką wniesienia roszczenia o zasądzenie odpowiedniej kwoty na wskazany cel jest wina, co wynika wprost z treści art. 18 ust. 1 pkt 6 uznk. Stopień winy (może być nią także lekkomyślność lub niedbalstwo) powinien mieć wpływ na wysokość zasądzonej kwoty. W orzecznictwie wskazuje się przy tym, że „winę” w kontekście art. 18 ust. 1 pkt 6 uznk można przypisać nie tylko osobie fizycznej, ale i prawnej ${ }^{468}$. Roszczenie może być zasądzone wraz $\mathrm{z}$ innymi roszczeniami pieniężnymi z art. 18 ust. 1 pkt 4 i 5 uznk. Zasądzenie kwoty następuje na rzecz określonego podmiotu realizującego cele społeczne wskazane w art. 18 ust. 1 pkt 6 uznk.

Skorzystanie z roszczenia o zasądzenie odpowiedniej kwoty na cel społeczny będzie właściwe szczególnie w tych przypadkach, gdy dochodzi do pokrzywdzenia powoda. $\mathrm{Z}$ tego powodu powolanie się na to roszczenie w sprawach praktyk zakazanych przez art. 6 lub 9 uokik bądź ich odpowiedniki w Traktacie o funkcjonowaniu UE wydaje się mało prawdopodobne, acz niewykluczone. Roszczenie o zasądzenie odpowiedniej kwoty na cel społeczny może być odpowiednim środkiem prywatnoprawnego egzekwowania prawa konkurencji w odniesieniu do porozumień o antykonkurencyjnym celu, które jednak nie zostały zrealizowane (a zatem w sferze realnej nie zaistniała szkoda).

\subsection{Wzajemna „zaliczalnośćc sankcji nałożonych w ramach publicznego i prywatnego trybu egzekwowania zakazów praktyk ograniczających konkurencję}

Analiza sankcji, jakie mogą być stosowane w ramach publicznego i prywatnego trybu egzekwowania zakazów praktyk ograniczających konkurencję, rodzi naturalne pytanie o potencjalne wzajemne oddziaływanie tych sankcji,

467 E. Nowińska, M. du Vall, Ustawa..., (Komentarz do art. 18, Nb 39). Por. także wyrok SA w Szczecinie z dnia 4 lipca 2007 r., I ACa 400/2007, LexPolonica nr 2400537, gdzie sąd stwierdził, że „obowiązek uiszczenia na wskazany cel społeczny kwoty (...) nie stanowi jednak odszkodowania za spowodowaną czynem nieuczciwej konkurencji szkodę, lecz ma charakter jedynie represyjno-prewencyjny".

468 Wyrok SA w Warszawie z dnia 11 grudnia 2008 r., I ACa 568/2008, LexPolonica nr 2413036. Inny pogląd, skrytykowany przez SA w przywołanym wyroku, prezentują E. Nowińska i M. du Vall, Ustawa..., (Komentarz do art. 18, Nb 37). 
ich wzajemną „zaliczalność” w poszczególnych trybach. Pytanie to staje się wysoce zasadne w sytuacji, gdy podstawowa sankcja cywilnoprawna (tj. sankcja nieważności) znajduje swoje uregulowanie - zresztą jako jedyny element z zakresu prywatnego egzekwowania prawa ochrony konkurencji - w publicznoprawnej regulacji ochrony konkurencji (art. 6 i 9 uokik, art. 101 TFUE). Takie usytuowanie sankcji cywilnoprawnej może rodzić uzasadnione podejrzenie, że sankcje obydwu trybów egzekwowania prawa ochrony konkurencji w jakiś sposób na siebie oddziałują. Warto podkreślić, że analiza wzajemnego wpływu sankcji nie może ograniczać się zresztą do dwupodziału: sankcje publicznoprawne i prywatnoprawne, ale powinna uwzględniać dodatkowo dwoistość sankcji publicznych, tj. sankcje administracyjne i sankcje karne. Podkreślenia wymaga okoliczność, że rozważania dotyczące wzajemnego oddziaływania sankcji dotyczą przede wszystkim sankcji o charakterze pieniężnym, tzn. kar pieniężnych nakładanych w trybie publicznoprawnym oraz odszkodowań zasądzanych w trybie prywatnoprawnym. Sankcje o charakterze niepieniężnym, takie jak np. nakaz zaniechania naruszenia w trybie publicznoprawnym, mogą co najwyżej oddziaływać na potencjalne sankcje cywilnoprawne w ten sposób, że uczynią bezprzedmiotowymi (pod warunkiem ich wykonania przez naruszycieli) niektóre roszczenia (np. o zaniechanie naruszenia).

W ramach rozważań nad „zaliczalnością” należy określić, na czym może polegać wzajemne oddziaływanie sankcji (pieniężnych) obydwu trybów. Biorąc pod uwagę wpływ sankcji publicznych na prywatne, można przyjąć następujące warianty oddziaływania:

1) wariant maksymalistyczny: nałożenie (podstawowej, „standardowej”) kary pieniężnej w ramach trybu publicznego (bez względu na to, jaki charakter - administracyjny czy karny - jej przypisujemy) eliminuje możliwość przyznania odszkodowania w trybie prywatnoprawnym (można bowiem wyjść z założenia, że sankcja publiczna „konsumuje” sankcję prywatną, nadmierne obciążenie sankcjami pieniężnymi może prowadzić do znaczącego pogorszenia sytuacji przedsiębiorcy-sprawcy naruszenia, a nawet jego upadłości);

2) wariant pośredni: modyfikacje wysokości kary pieniężnej wynikające z zastosowania programu lagodzenia lub darowania kar, bądź związane $\mathrm{z}$ ugodami (dobrowolnym poddaniem się karze) prowadzą do modyfikacji wysokości odszkodowania lub zasad odpowiedzialności cywilnej (np. zniesienie odpowiedzialności solidarnej uczestników porozumienia ograniczającego konkurencję);

3) wariant zerowy: ani nałożenie kary pieniężnej w trybie publicznoprawnym, ani jakiekolwiek jej modyfikacje nie wpływają w żaden sposób na sankcje stosowane $\mathrm{w}$ trybie prywatnoprawnym. 
Analiza możliwości wzajemnego oddziaływaniu sankcji cywilnych na sankcje publiczne skłania do wyodrębnienia następujących wariantów:

1) wariant maksymalistyczny: naprawienie szkody spowodowanej praktyką antykonkurencyjną eliminuje możliwość zastosowania sankcji publicznoprawnych;

2) wariant pośredni: naprawienie szkody wywołanej praktyką antykonkurencyjną może stanowić okoliczność łagodzącą karę pieniężną nakładaną w trybie publicznoprawnym;

3) wariant zerowy: naprawienie szkody wywołanej naruszeniem zakazu praktyki ograniczającej konkurencję nie wpływa w żaden sposób na nałożenie sankcji w trybie publicznoprawnym.

Jak wskazują zidentyfikowane powyżej warianty wzajemnego wpływu sankcji w prywatnym i publicznym trybie egzekwowania prawa ochrony konkurencji, rozstrzygnięcie kwestii zaliczalności sankcji jest możliwe w oparciu o dwa stanowiska. Pierwsze z nich zakłada, że sankcje prywatnego i publicznego trybu egzekwowania prawa konkurencji są całkowicie autonomiczne. Sankcje cywilne nie oddziałują na sankcje publiczne ani też odwrotnie. Drugie stanowisko przewiduje, że sankcje nałożone w jednym trybie są w pewnym zakresie uwzględniane w drugim trybie egzekwowania zakazów antykonkurencyjnych praktyk - do rozważenia w tym wypadku pozostaje to, czy „przenikanie” sankcji działa w obie strony (z trybu publicznego do prywatnego i na odwrót) oraz jaki jest jego zakres.

Zdecydowana większość systemów prawnej ochrony konkurencji, w tym polski porządek prawny, hołduje pierwszemu ze wskazanych stanowisk, utrzymując całkowitą autonomię sankcjonowania naruszeń zakazów praktyk ograniczających konkurencję w ramach publicznego i prywatnego prawa ochrony konkurencji. Jest to stanowisko najbardziej pożądane z punktu widzenia „czystości” podsystemu prawa: prawa publicznego i prawa prywatnego. Rozwiązanie to wpisuje się w model całkowitej niezależności (rozłączności) publicznego i prywatnego trybu egzekwowania prawa ochrony konkurencji, a koresponduje z nim zidentyfikowany powyżej wariant zerowy wzajemnego oddziaływania sankcji. Z kolei opisany powyżej wariant maksymalistyczny mieści się w modelu całkowitej zależności obydwu trybów egzekwowania zakazów praktyk ograniczających konkurencję (zastosowanie sankcji w jednym z trybów kasuje możliwość stosowania sankcji w drugim).

Poszukiwanie zrównoważonego modelu współistnienia obydwu trybów egzekwowania prawa konkurencji wymaga jednak co najmniej podjęcia rozważań nad możliwością realizacji drugiego ze wskazanych stanowisk, tj. wzajemnego uwzględniania sankcji prywatnych i publicznych. Rozważania te należy rozpocząć od próby odpowiedzi na pytanie, czemu miałaby służyć 
wzajemna zaliczalność sankcji obu trybów. W pierwszej kolejności na zagadnienie to trzeba spojrzeć $\mathrm{z}$ punktu widzenia zasady ne bis in idem, która zakłada zbędność orzekania po raz drugi w tej samej sprawie ze względu na niestosowanie podwójnego karania tej samej osoby za ten sam czyn; zasada ta jest właściwa przede wszystkim dla sankcji publicznoprawnych, stąd rozważenie jej zastosowania (a w konsekwencji ewentualnie naruszenia) odnosi się do tych sankcji, które mają charakter represyjny ${ }^{469}$. Na poziomie europejskim zasada ne bis in idem wyrażona jest w art. 4 Protokołu nr 7 do Konwencji o ochronie praw człowieka i podstawowych wolności, sporządzonego 22 listopada $1984 \mathrm{r}$. w Strasburgu 470 oraz - na poziomie unijnym - w Karcie praw podstawowych; również TS uznał ją w licznych wyrokach za podstawową zasadę prawa Unii Europejskiej471. W polskim porządku prawnym zasada ne bis in idem wyrażona jest w art. 17 § 1 Kodeksu postępowania karnego; w orzecznictwie polskiego Trybunału Konstytucyjnego zasada ta wywodzona jest „z zasady demokratycznego państwa prawnego (art. 2 Konstytucji) oraz ze standardu sprawiedliwej procedury sądowej, stanowiącej jeden $\mathrm{z}$ elementów prawa do sądu (art. 45 ust. 1 Konstytucji)" ${ }^{472}$. Zasadę ne bis in idem wywodzi się ponadto z art. 30 Konstytucji ${ }^{473}$.

469 Poza zakresem niniejszego opracowania pozostają kwestie stosowania zasady ne bis in idem w odniesieniu do postępowań prowadzonych równocześnie w oparciu o przepisy TFUE i przepisy krajowe oraz postępowań prowadzonych przez organy ochrony konkurencji w różnych państwach członkowskich - na ten temat szerzej w polskim piśmiennictwie: P. Rosiak, The ne bis in idem Principle in Proceedings Related to Anti-Competitive Agreements in EU Competition Law, YARS 2012, vol. 5(6), s. 111-135; R. Stefanicki, Zasada ne bis in idem $w$ procesie wykonywania prawa konkurencji, PPH 2012, nr 8, s. 21-27; K. Kowalik-Bańczyk, Problematyka ochrony praw podstawowych $w$ sprawach z zakresu ochrony konkurencji, Zeszyt 39, Centrum Europejskie Natolin 2010, s. 68-71; A. Sakowicz, Zasada ne bis in dem w prawie karnym, Temida 2, Białystok 2011, s. 295-301; w piśmiennictwie zagranicznym m.in.: F. Louis, G. Accardo, Ne Bis in Idem, Part 'Bis', World Competition 2011, vol. 34(1), s. 97-112; G. Di Federico, EU Competition Law and the Principle of Ne Bis in Idem, European Public Law 2011, vol. 17(2), s. 241-260; W. P. J. Wils, The Principle of the Ne Bis in Idem in EC Antitrust Enforcement: A Legal and Economic Analysis, World Competition 2003, vol. 26(2), s. 131-148.

470 Dz. U. $2003 \mathrm{Nr}$ 42, poz. 364.

471 Por. m.in. wyroki TS: z dnia 5 maja 1966 r. w sprawach połączonych 18/65 i 35/65 Gutmann v. Komisja EWEA (Zb. Orz. 1965, s. 149), pkt 172; z dnia 15 października 2002 r. w sprawach połączonych C-238/99P, C-244/99 P, C-245/99 P, C-247/99 P, od C-250/99 P do C-252/99 P i C-254/99 P Limburgse Vinyl Maatschappij $i$ in. v. Komisja (Zb. Orz. 2002, s I-8375), pkt 59; z dnia 29 czerwca 2006 r. w sprawie C-308/04 P SGL Carbon v. Komisja (Zb. Orz. 2006, s. I-5977), pkt 26.

472 Wyrok TK z dnia 15 kwietnia 2008 r., P 26/06.

473 Tak A. Sakowicz, Zasada ne bis in idem..., s. 57-60. 
W rozważanym kontekście aplikowanie zasady ne bis in idem miałoby polegać na wykluczeniu możliwości dwukrotnego stosowania sankcji o charakterze represyjnym wobec tego samego przedsiębiorcy naruszającego zakazy antykonkurencyjnych praktyk. Powyżej, w podrozdziale poświęconym rodzajom odszkodowań była już mowa o jednym takim przypadku, tj. zasądzaniu odszkodowań represyjnych w sytuacji, gdy uprzednio organ ochrony konkurencji nałożył karę pieniężną na uczestnika porozumienia ograniczającego konkurencję - brytyjski sędzia Lewison słusznie upatruje w takim przypadku naruszenia zasady ne bis in idem. Jeśli roszczeniu publikacyjnemu przypiszemy funkcję represyjną, również należałoby uznać, że jeśli roszczenie takie miałoby być zasądzone wobec podmiotu, na który organ ochrony konkurencji nałożył już karę pieniężną, to mamy do czynienia $\mathrm{z}$ naruszeniem omawianej zasady. Jednakże ze względu na fakt, że roszczenie publikacyjne nie jest ukierunkowane na pozyskanie świadczenia pieniężnego (wykluczam sytuacje, gdy chodzi o publikację w bardzo drogim medium) i obok funkcji represyjnej można mu przypisać także funkcję usuwania skutków naruszenia, zasądzenia tego roszczenia nie należy postrzegać jako naruszenia zasady ne bis in idem, jeśli na określony podmiot została nałożona już kara w postępowaniu antymonopolowym.

Skoro możliwe jest odwołanie do zasady ne bis in idem w odniesieniu do sankcji cywilnych o represyjnym charakterze, tym bardziej zasada ta powinna się stosować do obydwu rodzajów sankcji trybu publicznego, tj. sankcji karnych i tych sankcji administracyjnych, które realizują cele represyjne (kar pieniężnych). Zastosowanie omawianej zasady w tym przypadku jest nawet mniej kontrowersyjne ze względu na podzielany przez wielu przedstawicieli doktryny i orzecznictwo pogląd o prawnokarnym charakterze kar pieniężnych nakładanych przez organy ochrony konkurencji. Należy przy tym zaznaczyć, że zasada ne bis in idem znajdzie zastosowanie tylko wobec kar pieniężnych za naruszenie przepisów materialnych, nigdy zaś - w odniesieniu do kar w celu przymuszenia (okresowych kar pieniężnych) ${ }^{474}$, które nawet wobec jednego adresata mogą być nakładane wielokrotnie.

Penalizując zakazy praktyk ograniczających konkurencję, ustawodawcy winni uwzględniać zasadę ne bis in idem. Do naruszenia omawianej zasady nie dojdzie, jeśli sankcje administracyjne za samo naruszenie zakazów nakładane są $\mathrm{z}$ reguły na przedsiębiorców (przedsiębiorstwa), będących osobami prawnymi, podczas gdy sankcje karne dotykają osób fizycznych zaangażowanych $\mathrm{w}$ kierowanie przedsiębiorstwem ${ }^{475}-\mathrm{w}$ takiej sytuacji

\footnotetext{
474 Tak również M. Sachajko, Istota i charakterystyka..., s. 65.

475 Por. pkt 7.3.2.1. w niniejszym rozdziale.
} 
trudno mówić o spełnieniu jednego z warunków stosowania zasady ne bis in idem, jakim jest tożsamość podmiotu, na który nakładane są sankcje; sytuacja ta komplikuje się jednak wówczas, gdy przedsiębiorcą, na którego została nałożona (administracyjna) kara pieniężna, jest osoba fizyczna (która jednocześnie może kierować przedsiębiorstwem) lub gdy - obok sankcji karnych - na osobę fizyczną (kierującą przedsiębiorstwem) można nałożyć również administracyjną karę pieniężną. W polskim piśmiennictwie w odniesieniu do podobnych co do istoty sytuacji zbiegu kar pieniężnych za naruszenia proceduralne (za nieudzielenie informacji na żądanie lub udzielenia informacji nieprawdziwych lub wprowadzających w błąd, tj. kar przewidzianych w art. 106 ust. 2 pkt $2 \mathrm{i} \mathrm{w}$ art. 108 ust. 1 pkt 3 uokik) wyrażano rozbieżne poglądy co do zasadności uwzględniania reguły ne bis in idem; zdecydowanie za niestosowaniem podwójnego karania opowiada się M. Król-Bogomilska ${ }^{476}$, A. Stawicki ${ }^{477}$; możliwość podwójnego karania dopuszcza natomiast K. Kohutek ${ }^{478}$.

W kontekście omawianej reguły należy również postawić pytanie o to, czy jeśli w postępowaniu cywilnym zasądzone zostało odszkodowanie represyjne, organ ochrony konkurencji posiada nadal kompetencje do nałożenia kary pieniężnej. „Zaliczenie” sankcji cywilnoprawnych nawet o represyjnym charakterze na rzecz kary administracyjnej o stricte represyjnym charakterze nie wydaje się jednak uzasadnione. Obowiązek zapłaty odszkodowania, nawet jeśli ma ono charakter represyjny, nie ma jednak charakteru publicznoprawnego, podczas gdy zasada ne bis in idem odnosi się właśnie do takich (tj. publicznoprawnych) sankcji ${ }^{479}$. Całkowite pozbawienie organu ochrony konkurencji możliwości realizacji swoich funkcji stanowiłoby istotne osłabienie publicznego trybu ochrony konkurencji - inaczej niż w przypadku postępowań sądowych, gdzie obok odszkodowań represyjnych możliwe jest zastosowanie „zwykłych” odszkodowań, odzwierciedlających normalną wielkość szkody, organy ochrony konkurencji nie posiadają (obok kar pieniężnych) dodatkowych możliwości represji wobec naruszycieli zakazów praktyk ograniczających konkurencję.

Wzajemnemu oddziaływaniu sankcji obydwu trybów można przypisać również pewne znaczenie dla efektywności całego systemu egzekwowania zakazów praktyk ograniczających konkurencję. Podkreślenia wymaga okoliczność, że wzajemna zaliczalność sankcji oznacza faktyczne transferowanie

476 M. Król-Bogomilska, [w:] T. Skoczny, A. Jurkowska, D. Miąsik (red.), Ustawa..., s. $1625-1626(\mathrm{Nb} 62)$.

477 A. Stawicki, [w:] A. Stawicki, E. Stawicki (red.), Ustawa..., s. 1196.

478 K. Kohutek, [w:] K. Kohutek, M. Sieradzka, Ustawa..., s. 1039.

479 Tak A. Sakowicz, Zasada ne bis in idem..., s. 300. 
funkcji jednego trybu do drugiego. W umiarkowanym zakresie transfer ten może, jak się wydaje, służyć zapewnieniu optymalnej efektywności kompleksowego systemu prawnej ochrony konkurencji. To właśnie motywacja efektywnościowa zdaje się leżeć u podstaw szczegółowych rozwiązań prawnych dotyczących uwzględniania sankcji publicznych w trybie prywatnego egzekwowania prawa ochrony konkurencji w tych systemach prawnych, które takie rozwiązania przyjęły. Według mojej najlepszej wiedzy, jeśli ustawodawcy decydują się na wprowadzenie przepisów umożliwiających zaliczanie sankcji jednego trybu w drugim trybie egzekwowania zakazów antykonkurencyjnych praktyk, to oddziaływanie sankcji jest jednokierunkowe i sprowadza się do wpływu sankcji publicznych na sankcje i zakres odpowiedzialności w ramach prywatnego egzekwowania prawa ochrony konkurencji.

Umiarkowany zakres transferu funkcji trybu publicznego do trybu prywatnego (i odwrotnie) poprzez sankcje jest właściwy dla zidentyfikowanego powyżej, pośredniego wariantu wzajemnego oddziaływania sankcji. W przypadku wpływu sankcji publicznych na prywatne wariant taki może mieć miejsce w sytuacji, gdy aktywność samego sprawcy naruszenia prowadzi do zmniejszenia kary pieniężnej nakładanej w trybie publicznego egzekwowania zakazu porozumień ograniczających konkurencję (zarówno bowiem program leniency, jak i ugody są z reguły dostępne tylko dla uczestników porozumień ograniczających konkurencję, nie dla przedsiębiorców nadużywających pozycji dominującej). W zamian za umożliwienie (jak w leniency) bądź ułatwienie (jak w leniency i w postępowaniu ugodowym) przeprowadzenia postępowania antymonopolowego przedsiębiorcom naruszającym zakaz antykonkurencyjnych porozumień zmniejszona zostaje kara lub następuje jej całkowite darowanie - ratio legis tych rozwiązań jest wzmocnienie efektywności publicznego trybu egzekwowania prawa ochrony konkurencji. Skuteczność tego instrumentu może być jednak umniejszona lub nawet zniweczona wskutek tego, że przyspieszenie i ułatwienie postępowania antymonopolowego przed publicznym organem ochrony konkurencji równocześnie stwarza możliwości łatwiejszego dochodzenia roszczeń na drodze prywatnoprawnej, co z kolei może blokować chęć przedsiębiorców do współpracy z organami antymonopolowymi, czy to w ramach leniency, czy postępowań ugodowych - tym samym zagrażając skutecznemu egzekwowaniu prawa konkurencji. W celu zapobieżenia temu negatywnemu efektowi, proponuje się, aby złagodzenie sankcji w trybie publicznym pociągało za sobą również złagodzenie sankcji w trybie prywatnym. To ostatnie może polegać na zmniejszeniu wysokości odszkodowania, do zapłaty którego zobowiązani są uczestnicy porozumienia ograniczającego konkurencję lub na zniesieniu zasady odpowiedzialności solidarnej uczestników porozumienia, z korzyścią dla wnio- 
skodawcy leniency ${ }^{480}$. Rozwiązanie takie może stać jednak w sprzeczności z podstawową dla wielu porządków prawnych zasadą pełnego odszkodowania, ponadto „przerzuca” koszty skutecznej interwencji publicznej na podmioty prywatne. Argumenty te straciłyby nieco na znaczeniu jedynie wówczas, gdyby przyjąć, że pozwany, który od wnioskodawcy o leniency otrzymał obniżone odszkodowanie, nadal ma prawo ubiegać się o pozostałą część odszkodowania (tj. pokrywającą szkodę w całości) od pozostałych uczestników kartelu. Jednak i to rozwiązanie ma swoje wady: w przypadku niewypłacalności innych uczestników kartelu, powód pozbawiony będzie możliwości uzyskania pełnego odszkodowania, a dodatkowo sytuacja taka godzi w zasadę solidarnej odpowiedzialności uczestników kartelu. Inna propozycja uzależniająca zakres odpowiedzialności odszkodowawczej od wniosku leniency przewiduje ograniczenie odpowiedzialności przedsiębiorcy, który skutecznie wnioskował o leniency jedynie do roszczeń jego własnych bezpośrednich i pośrednich nabywców, co de facto oznacza również zniesienie odpowiedzialności solidarnej członków kartelu ${ }^{481}$. Za wyłączeniem przedsiębiorstwa, któremu darowano karę, spod obowiązku ponoszenia odpowiedzialności solidarnej opowiedział się m.in. brytyjski OFT 482 .

Reguła obniżonego odszkodowania i/lub wyłączenia wnioskodawcy leniency z solidarnej odpowiedzialności uczestników kartelu pogłębiałaby zatem różnicę w sytuacji prawnej wnioskodawcy o leniency oraz pozostałych uczestników karteli, co mogłoby wpływać na nadużywanie programów darowania i łagodzenia kar ze względu na ich większą atrakcyjność. Obniżone odszkodowania dla wnioskodawców leniency stanowią przykład rozwiązania, w ramach którego zasady odpowiedzialności cywilnej (prywatnego egzekwowania prawa konkurencji) ulegałyby ograniczeniu (modyfikacji) w zamian za korzyści, jakie odnosiłby publiczny tryb egzekwowania prawa konkurencji. Modyfikacje te wydają się zbyt daleko idące, a punkt ciężkości korelacji

480 Rozwiązanie takie przewidziano m.in. w prawie węgierskim, gdzie przedsiębiorca uczestniczący w programie leniency jako tzw. whistleblower jest zobowiązany do zapłaty odszkodowania tylko o tyle, o ile uzyskanie pełnego odszkodowanie nie jest możliwe od pozostałych uczestników kartelu - por. C.I. Nagy, The new Hungarian rules..., s. 66-67; G. Bacher, Hungary: Limitation of liability of the leniency applicant and calculation of amount of damages in the new Hungarian legislation, G.C.L.R. 2008, vol. 1(2), s. R30-32.

481 Commission staff working paper accompanying the Green Paper, pkt 236. Szerzej: C. Cauffman, The Interaction of Leniency Programmes and Actions for Damages, The Competition Law Review 2011, vol. 7(2), s. 210-213.

482 Private action in competition law: effective redress for consumer and business, Discussion paper, OFT, April 2007, pkt 3.7. Zwolennikami takiego rozwiązania są również: R. Nazzini, A. Nikpay, Private Actions in EC Competition Law, Competition Policy International 2008, vol. 4(2), s. 136. 
prywatnego i publicznego egzekwowania prawa konkurencji nazbyt przesunięty w stronę trybu publicznego, niemniej jednak rozwiązanie co do obniżonych odszkodowań znajduje swoich zwolenników (w Białej księdze Komisja podtrzymała propozycję rozwiązania polegającego na zawężeniu odpowiedzialności wnioskodawcy leniency do bezpośrednich i pośrednich nabywców $\left.{ }^{483}\right)$. W polskiej literaturze przeciwko temu rozwiązaniu zdecydowanie opowiedział się S. Sołtysiński, argumentując, że „pozbawienie wierzycieli roszczeń odszkodowawczych przez ustawodawcę byłoby aktem podobnym do wywłaszczenia i mogłoby nastąpić tylko za odszkodowaniem"484. Ten sam autor dopuszcza jednocześnie możliwość ograniczenia odszkodowania uczestników programu leniency tylko do damnum emergens. W literaturze obcej przeciwko temu rozwiązaniu opowiedział się m.in. W. P. J. Wils ${ }^{485}$, w polskiej - M. K. Kolasiński ${ }^{486}$.

Analogicznym rozwiązaniem w obszarze oddziaływania sankcji trybu prywatnego na sankcje trybu publicznego byłoby przyjęcie rozwiązania, zgodnie z którym dobrowolne naprawienie szkody przez sprawcę naruszenia (voluntary compensation) byłoby samoistnym warunkiem obniżenia wysokości kary pieniężnej nakładanej w trybie administracyjnym lub - jak np. w Stanach Zjednoczonych - byłoby jednym $\mathrm{z}$ warunków uczestnictwa w leniency (jeden z sześciu warunków realizacji leniency jeszcze przed wszczęciem dochodzenia przez DOJ wymaga, aby ,jeśli to możliwe, dokonać restytucji na rzecz poszkodowanych”487). Takie „uzależnienie” jednego ze środków publicznego egzekwowania prawa konkurencji od realizacji elementów jego prywatnego egzekwowania należy oceniać jako pozytywny przykład związania obydwu trybów z korzyścią dla każdego z nich. Zasadniczych trudności (i kontrowersji) można jednak upatrywać w szczegółowej regulacji dotyczącej zakresu dobrowolnych odszkodowań jako warunku złagodzenia kary pieniężnej -

483 Commission Staff working paper accompanying White Paper, pkt 304-306. Przeciwnikiem wykluczenia odpowiedzialności solidarnej uczestników kartelu był również Parlament Europejski - por. rezolucja z dnia 26 marca 2009 r. w sprawie Białej księgi, (2008/254(INI).

484 S. Sołtysiński, $Z$ doświadczeń programu leniency w Brukseli $i w$ Warszawie, [w:] C. Banasiński (red.), Prawo konkurencji - stan obecny oraz przewidywane kierunki zmian, UOKiK, Warszawa 2006, s. 47.

485 W. P. J. Wils, The Relationship Between Public Antitrust Enforcement and Private Actions for Damages, World Competition 2009, vol. 32(1); tekst dostępny także pod adresem: http://papers.ssrn.com/sol3/papers.cfm?abstract_id=1296458, s. 30-32.

486 M. K. Kolasiński, Wspólnotowa polityka zwalniania z grzywien i zmniejszania ich wysokości $w$ sprawach kartelowych po reformie z 2006 r. EPS 2008, nr 6, s. 29.

487 US Department of Justice, Corporate Leniency Policy (10 sierpnia 1993 r.), dostępne pod adresem: http://www.justice.gov/atr/public/guidelines/0091.pdf. 
podstawowe pytania, jakie nasuwają się w tym kontekście, to pytania o to, czy dobrowolna kompensacja powinna być skierowana do wszystkich poszkodowanych przez kartel (przy czym liczba poszkodowanych w wielu przypadkach będzie raczej niemożliwa do ustalenia) lub czy kompensacja powinna być skierowana do określonego kręgu poszkodowanych (np. tylko nabywców bezpośrednich). Słusznie podkreśla się przy tym w piśmiennictwie, że rzeczywiste korelacje między leniency a prywatnoprawnym egzekwowaniem reguł konkurencji są trudne do oceny w warunkach słabego rozwoju tego trybu egzekwowania zakazu porozumień ograniczających konkurencję ${ }^{488}$.

Podsumowując należy stwierdzić, że sankcje prywatnego i publicznego trybu egzekwowania prawa konkurencji mogą ewentualnie na siebie oddziaływać w celu wzmocnienia efektywności jednego z trybów egzekwowania zakazów antykonkurencyjnych praktyk (faktycznie chodzi o tryb publiczny) tylko wówczas, gdy są to sankcje realizujące podstawowe i „czyste” funkcje każdego z trybów, tj. funkcję kompensacyjną w przypadku trybu prywatnego oraz funkcję represyjną w przypadku trybu publicznego - w innym razie istnieje ryzyko pogwałcenia zasady ne bis in idem.

\subsection{Uwagi końcowe}

W powyższych rozważaniach na uwagę zasługuje fakt, że w publicznym i prywatnym trybie egzekwowania zakazów praktyk ograniczających konkurencję można zaobserwować nakładanie się funkcji stosowanych sankcji (czy szerzej - funkcji odpowiedzialności). Naturalnie, w każdym z tych trybów można wskazać funkcję wiodącą - w modelu publicznym jest nią funkcja represyjna oraz prewencyjna, natomiast $\mathrm{w}$ modelu prywatnym - funkcja kompensacyjna. Nie sposób jednak nie zauważyć, że również w publicznym trybie egzekwowania prawa ochrony konkurencji mogą pojawić się elementy kompensacyjne - może się tak zdarzyć w przypadku odpowiedniego ukształtowania środków zaradczych, natomiast $\mathrm{w}$ trybie prywatnym mogą pojawić się elementy prewencji i represji (realizowane np. poprzez odszkodowanie represyjne). Zbieżność funkcji sankcjonowania w publicznym i prywatnym trybie egzekwowania zakazów antykonkurencyjnych praktyk jest do pewnego stopnia uzasadniona - w każdym $\mathrm{z}$ trybów realizowane są przecież te same normy materialne. Przyjęcie założenia o konieczności i potrzebie współistnienia obydwu modeli egzekwowania prawa konkurencji wyklucza jednak - moim zdaniem - konieczność powielania funkcji sankcji wykorzystywanych

488 B. Turno, Leniency - program tagodzenia kar..., s. 332. 
w każdym z nich. Zrównoważony model egzekwowania prawa konkurencji wymaga, aby segment publiczny realizował funkcje represyjne, a prywatny - funkcje kompensacyjne, jedynie funkcja prewencyjna wydaje się wspólna dla obydwu trybów, jako że może ona współistnieć tak z funkcją represyjną, jak i kompensacyjną ${ }^{489}$ (bez pogwałcenia jednak zasady restytucji).

Pożądanym stanem jest takie współistnienie sankcji trybu publicznego i trybu prywatnego, aby każdy z nich co do zasady samodzielnie realizował swoje podstawowe funkcje, a podmioty zainteresowane egzekwowaniem zakazów praktyk ograniczających konkurencję miały poczucie efektywności sankcji i środków ochrony prawnej, z których korzystają. Zrównoważony model egzekwowania prawa ochrony konkurencji nie powinien natomiast opierać się na „dowartościowywaniu” sankcji jednego trybu względem sankcji drugiego trybu w celu zapewnienia skuteczności materialnych norm prawa ochrony konkurencji. Za sprzeczną z założeniami zrównoważonego modelu egzekwowania prawa ochrony konkurencji należy uznać sytuację, w której np. karom pieniężnym przypisuje się rolę „tym bardziej istotną” ze względu na to, że „ograniczone zastosowanie mają inne instrumenty, które mogą służyć realizacji tego samego celu. Przykładowo, przepisy prawa polskiego z drobnymi wyjątkami nie przewidują odpowiedzialności karnej za naruszenie przepisów ustawy, roli prewencyjnej nie odgrywa także ryzyko związane z możliwością kierowania przeciwko naruszycielom roszczeń odszkodowawczych, bowiem sprawy tego typu nie są w naszym kraju powszechne, a dochodzenie tego typu roszczeń jest utrudnione" 490.

489 Tak K. Zagrobelny, [w:] E. Gniewek (red.), Kodeks cywilny..., s. 576 (Nb 30).

490 A. Stawicki, [w:] A. Stawicki, E. Stawicki (red.), Ustawa..., s. 1161. 



\section{Rozdział VIII}

\section{W kierunku zrównoważonego publiczno-prywatnego modelu egzekwowania zakazów praktyk ograniczających konkurencję w Polsce}

\subsection{Aktualny model egzekwowania zakazów antykonkurencyjnych praktyk w Polsce}

Polskie orzecznictwo i doktryna zaakceptowały współistnienie prywatnego i publicznego trybu egzekwowania zakazów praktyk ograniczających konkurencję (choć ściślej należałoby mówić o akceptacji sądowego trybu dochodzenia roszczeń), więc polski model można uznać za kompleksowy (zintegrowany).

Obecnie wspólistnienie submodeli egzekwowania reguł konkurencji w Polsce oparte jest na zasadzie dekomplementarności, przynajmniej w wymiarze formalnym - nie istnieją bowiem żadne unormowania wskazujące na wzajemne zależności (subsydiarne lub komplementarne) publicznego i prywatnego trybu egzekwowania prawa ochrony konkurencji. Pewien wyjątek w polskim modelu stanowi kwestia prejudycjalnego statusu ostatecznej decyzji Prezesa UOKiK, która została rozstrzygnięta w orzecznictwie (jak się wydaje, w sposób powszechnie akceptowany) - przyjęte rozwiązanie skłania do kwalifikowania relacji między publicznym a prywatnym trybem egzekwowania zakazów antykonkurencyjnych praktyk jako opartych (choć wyłącznie w tym aspekcie) na zasadzie subsydiarności względnej (pozaformalnej). Relacja tego typu może się rozwijać, tj. może obejmować także inne aspekty egzekwowania prawa, jednak wymaga to aktywności sądów. O tę ostatnią zaś trudno, skoro - m.in. ze względu na brak ustawodawstwa „zachęcającego" do wyboru drogi sądowej - liczba spraw z zakresu prywatnego egzekwowania reguł konkurencji jest marginalna. 
W przypadku unijnego prawa ochrony konkurencji - w braku uregulowań na poziomie ponadnarodowym i jednocześnie w sytuacji, gdy dochodzenie roszczeń odbywa się na podstawie przepisów proceduralnych państw członkowskich - trudno mówić o kompleksowym modelu egzekwowania reguł konkurencji. Spodziewana dyrektywa w sprawie prywatnego egzekwowania reguł konkurencji (jeśli ostatecznie w ogóle zostanie przyjęta) będzie prawdopodobnie kształtowała te relacje na zasadzie komplementarności.

Dekomplementarny (co do zasady) charakter aktualnego modelu egzekwowania reguł ochrony konkurencji nie pozwala na kwalifikowanie polskiego modelu jako modelu zrównoważonego. Dla stworzenia takiego modelu za niezbędne uważam stworzenie ram prawnych dla prywatnego egzekwowania reguł konkurencji i/lub - przynajmniej w niektórych obszarach - zmianę bądź odpowiednie ukształtowanie praktyki orzeczniczej.

\subsection{Potrzeba regulacji prywatnego egzekwowania zakazów antykonkurencyjnych praktyk?}

Dyskusja nad potrzebą (koniecznością) wprowadzenia regulacji poświęconych prywatnemu egzekwowaniu reguł konkurencji była bardzo żywa na poziomie unijnym, natomiast nie odnotowano jej właściwie w Polsce - autorzy podejmujący problematykę sądowego dochodzenia roszczeń z tytułu naruszenia reguł konkurencji zazwyczaj poprzestają na krytyce istniejących rozwiązań prawnych z perspektywy ich adaptowalności dla trybu prywatnego egzekwowania reguł konkurencji, nie proponując pozytywnych rozwiązań1.

Prowadzone w poprzednich rozdziałach książki rozważania prowadzą do wniosku, że w polskim systemie prawnym istnieją instrumenty, które mogą być wykorzystane dla dochodzenia roszczeń związanych $\mathrm{z}$ naruszeniami zakazów antykonkurencyjnych praktyk - możliwości takie stwarza Kodeks cywilny, ustawa o zwalczaniu nieuczciwej konkurencji (a zdaniem, niektórych autorów także ustawa o przeciwdziałaniu nieuczciwym praktykom rynkowym), ustawa o dochodzeniu roszczeń w postępowaniu grupowym, a w warstwie stricte proceduralnej - Kodeks postępowania cywilnego. Instrumenty takie istnieją, ale moim zdaniem nie są one dla prywatnego egzekwowania reguł konkurencji wystarczająco efektywne (pod pojęciem efektywności rozumiem możliwość skutecznego dochodzenia roszczeń z tytułu naruszenia

1 Por. np. O. Filipowski, Sytuacja konsumenta na rynku cementu w świetle decyzji Prezesa Urzędu Ochrony Konkurencji i Konsumentów w sprawie kartelu cementowego, PPP 2010, nr 11, s. 67-68. 
zakazów antykonkurencyjnych praktyk na drodze sądowej, przy czym skuteczność oznacza w tym przypadku merytoryczne rozpatrzenie sprawy przez sąd, bez względu na wynik sporu). Brak tak rozumianej efektywności znajduje odzwierciedlenie w bardzo małej liczbie spraw z zakresu prywatnego egzekwowania reguł konkurencji. Jasne (w miarę możliwości) określenie przez ustawodawcę zasad dochodzenia roszczeń z tytułu antykonkurencyjnych praktyk na drodze sądowej dawałoby szanse na intensyfikację prywatnego egzekwowania reguł konkurencji i przełamanie całkowitej dominacji publicznego trybu egzekwowania zakazów antykonkurencyjnych praktyk. Niestety, doświadczenia innych państw (np. Szwecji ${ }^{2}$ ) wskazują, że przyjęcie regulacji poświęconej prywatnemu egzekwowaniu reguł konkurencji (a więc potwierdzenie expressis verbis możliwości dochodzenia roszczeń) niekoniecznie automatycznie przekłada się na rozwój prywatnego trybu egzekwowania reguł konkurencji.

Wzmocnienie pozycji sądowego dochodzenia roszczeń wynikających $\mathrm{z}$ antykonkurencyjnych praktyk uważam za najważniejszy argument przemawiający za potrzebą wprowadzenia regulacji poświęconych prywatnemu egzekwowaniu reguł konkurencji. Za inny argument może być uznana „specyfika” prawa ochrony konkurencji, przejawiająca się przede wszystkim w ekonomicznej istocie spraw z tego zakresu. Argument ten ma swoje uzasadnienie - rzeczywiście już sama wykładnia poszczególnych przesłanek zakazów praktyk ograniczających konkurencję (choćby przesłanki „nadużywania" pozycji dominującej z art. 9 uokik lub art. 102 TFUE) może nastręczać istotnych trudności, nie mówiąc już o właściwych dla ścieżki sądowej kwestiach, takich jak np. obliczanie szkody antymonopolowej. Uwzględniając te trudności, trzeba jednak zaznaczyć, że z podobnymi problemami boryka się praktyka sądowa również w innych obszarach prawa, także pokrewnych prawu ochrony konkurencji, takich jak choćby stosowanie ustawy o zwalczaniu nieuczciwej konkurencji.

Argumentem przemawiającym przeciwko przyjmowaniu specjalnych regulacji poświęconych prywatnemu egzekwowaniu reguł konkurencji pozostaje istnienie zarówno reguł ogólnych dochodzenia roszczeń na drodze sądowej, jak i - ewentualnie - innych regulacji, które mogą subsydiarnie być wykorzystywane przy prywatnym egzekwowaniu zakazów antykonkurencyjnych praktyk.

Na marginesie należy zaznaczyć, że obok argumentów przemawiających za lub przeciw regulacji prywatnego egzekwowania zakazów praktyk ogra-

2 H. Andersson, E. Legnerfalt, Sweden - one step ahead in private enforcement?, G.C.L.R. 2009, vol. 2(1), s. 60-66. 
niczających konkurencję, wspólnych dla unijnego i krajowego porządku prawnego, można zidentyfikować argumenty właściwe tylko dla prawa unijnego. Jednym $\mathrm{z}$ nich jest negowanie potrzeby przyjmowania instrumentu unijnego ze względu na oczekiwanie, że kształtowanie odpowiednich reguł krajowych nastąpi pod wpływem orzecznictwa Trybunału Sprawiedliwości. W moim przekonaniu, jest to jednak mało prawdopodobne - jak wskazuja dotychczasowe doświadczenia, znaczna pozostaje liczba kwestii nierozstrzygniętych w orzecznictwie, a kluczowych dla sądowego dochodzenia roszczeń z tytułu naruszenia reguł konkurencji; wyroki Trybunału Sprawiedliwości nie zawsze oferują jednoznaczne rozstrzygnięcia, co bynajmniej nie zmniejsza „obszaru niepewności” dla potencjalnych zainteresowanych występowaniem na ścieżkę sądową. Przeciwnicy przyjmowania specjalnych regulacji unijnych dla prywatnego egzekwowania reguł konkurencji przekonywali również, że nieuzasadnione jest takie uprzywilejowanie prawa konkurencji wobec innych dziedzin prawa. Argument ten wydaje się jednak o tyle nietrafny, że - jak słusznie zauważa A. P. Komninos - w ostatnich dwóch dekadach w Unii Europejskiej mamy do czynienia z procesem intensyfikacji wydawania aktów prawa wtórnego poświęconych środkom ochrony i procedurom w różnych szczegółowych dziedzinach prawa, takich jak np.: ochrona konsumentów, zamówienia publiczne, nieuczciwe praktyki rynkowe czy handel elektroniczny $^{3}$ (regulacje te znajdują odzwierciedlenie także w prawie krajowym).

\subsection{Najważniejsze rozwiązania legislacyjne zmierzające do budowy zrównoważonego modelu egzekwowania zakazów antykonkurencyjnych praktyk (postulaty de lege ferenda)}

Punktem wyjścia dla ustawodawcy planującego regulowanie prywatnego egzekwowania prawa ochrony konkurencji powinno być przyjęcie określonej aksjologii całego modelu egzekwowania przepisów tego obszaru prawa. Dla budowy modelu zrównoważonego pożądane są wartości wskazane w początkowej fazie rozważań nad współistnieniem trybów egzekwowania reguł konkurencji, tj. efektywność prawa konkurencji, spójność (stosowania/praktyki) prawa ochrony konkurencji oraz równość prywatnego i publicznego trybu egzekwowania zakazów antykonkurencyjnych praktyk. Wartości te - stosowane wobec całego modelu - mogą być uzupełnione o inne, właściwe

3 A. P. Komninos, EC Private Antitrust Enforcement. Decentralised Application of EC Competition Law by National Courts, Hart Publishing, Oxford and Portland, Oregon 2008, s. $142-144$. 
dla poszczególnych aspektów prywatnego egzekwowania reguł konkurencji. Za taką „inną” (cząstkową) wartość można uznać np. pewność prawa jako zasadę rządzącą współoddziaływaniem rozstrzygnięć trybu publicznego i trybu prywatnego, prowadzącą do przyjęcia regulacji o związaniu sądów decyzjami organów ochrony konkurencji (nawet jeśli regulacja taka ogranicza autonomię prywatnego egzekwowania reguł konkurencji i narusza równość obydwu trybów).

Podejmując decyzję o wprowadzeniu regulacji dotyczącej prywatnego egzekwowania reguł konkurencji, ustawodawca staje również przed problemem umiejscowienia nowych przepisów. Potencjalnie mogą one znaleźć się w Kodeksie postępowania cywilnego, ustawie o ochronie konkurencji i konsumentów czy ustawie o zwalczaniu nieuczciwej konkurencji (w grę może wchodzić również ustawa o przeciwdziałaniu nieuczciwym praktykom rynkowym). Mało prawdopodobne (według mojej najlepszej wiedzy - niepraktykowane nigdzie w świecie) wydaje się przyjęcie odrębnej ustawy poświęconej prywatnemu egzekwowaniu reguł konkurencji. Możliwe jest natomiast przyjęcie rozwiązania, które będzie przewidywało różne dla konsumentów i przedsiębiorców umiejscowienie przepisów ustanawiających zasady prywatnego egzekwowania prawa ochrony konkurencji (np. w uznk - dla przedsiębiorców oraz w ustawie o nieuczciwych praktykach rynkowych - dla konsumentów). Takie rozwiązanie przyjęte przez polskiego ustawodawcę w odniesieniu do ochrony przed nieuczciwymi praktykami rynkowymi, jednak spotkałoby się zapewne z krytyką doktryny. Krytykując rozdzielenie między dwiema regulacjami ochrony konsumentów i przedsiębiorców przed nieuczciwymi praktykami rynkowymi, J. Szwaja i A. Tischner słusznie wskazali, że sytuacja, w której „ocena aktów nieuczciwej konkurencji między przedsiębiorcami (...) może się (...) odbywać bez względu na interes konsumentów” jest „wadliwa gospodarczo i szkodliwa społecznie. W ten sposób może dojść do niepożądanego utrwalenia się różnych standardów oceny zachowań nieuczciwych"4. Pogląd ten z powodzeniem można odnieść również do naruszeń zakazów praktyk ograniczających konkurencję. W moim przekonaniu, najbardziej naturalnym miejscem dla przepisów o prywatnym egzekwowaniu zakazów antykonkurencyjnych praktyk pozostaje ustawa o ochronie konkurencji i konsumentów, przy czym poszerzenie zakresu tego aktu o aspekty sądowego dochodzenia roszczeń z tytułu naruszenia zakazów antykonkurencyjnych praktyk należałoby postrzegać jako kolejny

4 J. Szwaja, A. Tischner, Dokad zmierza prawo zwalczania nieuczciwej konkurencji?, [w:] J. Barta, A. Matlak (red.), Prawo wtasności intelektualnej wczoraj, dziś i jutro, PIPWI UJ, Oficyna a Wolters Kluwer business, Kraków 2007, z. 100, s. 506. 
argument przemawiający za rozdzieleniem regulacji poświęconej ochronie konkurencji i regulacji poświęconych ochronie konsumentów.

Inną fundamentalną kwestią niezbędną do rozstrzygnięcia przez ustawodawcę jest problem uwzględniania interesu prywatnego w ramach publicznego trybu egzekwowania reguł konkurencji i odwrotnie (uwzględniania interesu publicznego w trybie prywatnego egzekwowania reguł konkurencji). W zrównoważonym modelu egzekwowania reguł konkurencji publiczny tryb realizacji zakazów praktyk ograniczających konkurencję powinien ograniczać się do uwzględniania wyłącznie interesu publicznego - właściwe wydaje się rozwiązanie polegające na „zamknięciu” postępowania antymonopolowego dla podmiotów prywatnych (w tym sensie, że nie mogą one być takimi inicjatorami postępowań, których wnioski byłyby wiążące dla organu ochrony konkurencji) i przyznanie tej kompetencji wyłącznie organowi ochrony konkurencji. Podmiotom prywatnym należałoby pozostawić rolę jedynie subsydiarną, wspomagającą realizację interesu publicznego, a polegającą na dostarczaniu informacji o podejrzeniach praktyk ograniczających konkurencję. Jest to rozwiązanie, któremu odpowiadają co prawda obecne regulacje polskiej ustawy o ochronie konkurencji i konsumentów, nie oznacza to jednak, że - biorąc pod uwagę inne czynniki legislacyjne i pozalegislacyjne - rozwiązanie to zapewnia funkcjonowanie zrównoważonego modelu egzekwowania reguł konkurencji. Przyjęcie czysto urzędowego trybu wszczynania postępowań antymonopolowych gwarantowałoby osiągnięcie takiego celu wówczas, gdyby realizacja interesów prywatnych w postępowaniu sądowym była efektywna, w tym łatwo dostępna i stosunkowo mało kosztowna (zarówno pod względem finansowym, jak i czasowym). W celu zapewnienia efektywności realizacji interesu prywatnego pożądane byłoby wprowadzenie do ustawodawstwa przepisu określającego choćby w sposób generalny, wzorowany na rozwiązaniu niemieckim, kategorię podmiotów dysponujących legitymacją czynną w zakresie dochodzenia roszczeń z tytułu naruszenia reguł konkurencji, wraz z otwartym egzemplarycznym wyliczeniem poszczególnych rodzajów legitymowanych podmiotów (np. konsumenci, konkurenci itp.). Niezbędne jest, w moim przekonaniu, także ustawowe rozstrzygnięcie o dopuszczalności dochodzenia roszczeń przez tzw. nabywców pośrednich oraz - konsekwentnie - zagwarantowanie możliwości korzystania z zarzutu przerzucania obciążeń (pass-on defence). Dostrzegając ułomność takich rozstrzygnięć, uważam je za konieczny element „ośmielania” podmiotów prywatnych do występowania $\mathrm{z}$ roszczeniami z tytułu naruszenia zakazów antykonkurencyjnych praktyk. Nie widzę natomiast potrzeby wprowadzania odrębnych regulacji dotyczących dochodzenia roszczeń grupowych w sprawach z obszaru ochrony konkurencji - zakładam, że gdyby powstała regu- 
lacja odnosząca się do prywatnego egzekwowania reguł konkurencji, to jej przepisy należałoby traktować jako lex specialis wobec ustawy o dochodzeniu roszczeń w postępowaniu grupowym.

Póki żadna ze wskazanych powyżej regulacji nie funkcjonuje, a realizacja interesów prywatnych w postępowaniu sądowym stanowi tylko teoretyczną modalność, należy lepiej zadbać o realizację interesu prywatnego (aczkolwiek rozumianego jako element składowy interesu publicznego) w ramach publicznego trybu egzekwowania reguł konkurencji. Postulowana zmiana miałaby polegać na nałożeniu na Prezesa UOKiK obowiązku informowania zawiadamiających o wynikach wszystkich postępowań wszczętych wskutek otrzymanego przez organ zawiadomienia. Obecnie art. 86 uokik zobowiązuje Prezesa UOKiK ogólnikowo do poinformowania o sposobie załatwienia sprawy, co wydaje się dalece niewystarczające (o czym świadczą kierowane przez zawiadamiających do WSA skargi, w których zarzucają oni Prezesowi UOKiK niedopełnienie obowiązku informowania o skutkach zawiadomienia wykraczających dalej niż wszczęcie postępowania wyjaśniają$\left.\operatorname{cego}^{5}\right)$. Należałoby również wprowadzić przepis precyzujący zasady kontroli sądowej nad aktywnością bądź brakiem aktywności Prezesa UOKiK w tej dziedzinie. Artykuł 86 uokik nie przewiduje - w moim przekonaniu słusznie - możliwości wystąpienia do SOKiK w sprawie bezczynności organu lub ze skargą na pismo wystosowane przez organ do zawiadamiającego, natomiast sądy administracyjne konsekwentnie uznają się za niewłaściwe i odmawiają traktowania takich pism jako „czynności” w rozumieniu art. 3 $\S 2$ ust. 4 ustawy z dnia 30 sierpnia 2002 r. Prawo o postępowaniu przed sądami administracyjnymi 6 . Rozwiązania te uznaję za istotne dla realizacji interesu prywatnego przede wszystkim dlatego, że pochodząca od Prezesa UOKiK informacja dotycząca postawy organu wobec podejrzenia praktyki ograniczającej konkurencję może potencjalnie wpłynąć na decyzję zawiadamiającego co do realizacji interesu prywatnego na drodze cywilnoprawnej (informacja o wszczęciu postępowania antymonopolowego może zdecydować o tym, że podmiot prywatny podejmie przygotowania do wystąpienia na drogę sądową, słusznie sądząc, że jeśli Prezes UOKiK wszczyna postępowanie prawdopodobieństwo uznania działania przedsiębiorcy za antykonkurencyjną praktykę jest stosunkowo wysokie; informacja taka może wpłynąć również na to, że podmiot prywatnie zacznie poszukiwać innych niż ustawa o ochronie konkurencji i konsumentów podstaw prawnych do realizacji swojego indywidualnego interesu). Proponowanych rozwiązań nie należy

\footnotetext{
Por. postanowienie WSA w Warszawie z dnia 6 lipca 2011 r., VI SA/WA 1131/11.
}

6 Dz. U. Nr 153, poz. 1270 ze zm. 
postrzegać jako powrotu do wnioskowego trybu wszczynania postępowań antymonopolowych - zawiadomienia nadal miałyby status niewiążących, natomiast obowiązki Prezesa UOKiK - charakter stricte informacyjny, całkowicie wykluczam możliwość weryfikowania stanowiska organu pod względem merytorycznym ${ }^{7}$.

Jeśli chodzi o prejudycjalny status decyzji Prezesa UOKiK, to nawet jeśli w zakresie pryncypiów (tj. braku uzależnienia drogi sądowej od uprzedniej decyzji organu antymonopolowego oraz związanie sądu istniejącą decyzją ostateczną) obecna linia orzecznicza jest zadowalająca, to stworzenie stabilnego modelu współistnienia publicznego i prywatnego egzekwowania zakazów antykonkurencyjnych praktyk wymagałoby podjęcia konkretnych rozwiązań legislacyjnych. De lege ferenda należałoby postulować wprowadzenie do uokik przepisu wzorowanego na art. 16 ust. 1 rozporządzenia 1/20038, co pozwoliłoby uniknąć ewentualnych zmian linii orzeczniczej. Przepisy tego rodzaju obowiązują przecież w wielu krajowych systemach prawnych, w tym m.in. w Niemczech ${ }^{9}$ i Wielkiej Brytanii ${ }^{10}$. Wielu przedstawicieli polskiej doktryny słusznie wskazuje na brak podstaw prawnych dla prejudycjalnego charakteru decyzji organu ochrony konkurencji jako jedną z istotnych barier i trudności prywatnego egzekwowania prawa konkurencji11; wprowadzenie odpowiedniej podstawy prawnej w pełni uzasadniałoby również używanie pojęcia „Związania sądów” przez decyzje Prezesa UOKiK.

Organom ochrony konkurencji należałoby umożliwić występowanie w postępowaniach sądowych w roli amicus curiae. De lege ferenda należałoby zatem postulować wprowadzenie do Kodeksu postępowania cywilnego przepisu wzorowanego na obecnym art. 63, który pozwalałby krajowemu organowi ochrony konkurencji przedstawiać sądom istotne dla sprawy

7 Por. postanowienie WSA w Warszawie z dnia 3 czerwca 2011 r., VII SA/Wa9/11.

8 Postulat uregulowania przez ustawodawcę „kwestii prejudycjalności rozstrzygnięć organu antymonopolowego" był formułowany w piśmiennictwie już wiele lat temu, tuż po uchwaleniu ustawy o ochronie konkurencji i konsumentów w 2000 r. - por. R. Janusz, M. Sachajko, T. Skoczny, Nowa ustawa o ochronie konkurencji i konsumentów, KPPubl. 2001, nr 3.

9 Par. 33(4) niemieckiej ustawy kartelowej przewiduje związanie niemieckich sądów ostatecznymi decyzjami organów ochrony konkurencji i sądów zarówno niemieckich, jak i z innych państw członkowskich (oraz decyzjami Komisji Europejskiej).

10 Sections 47A(9), 47B(5), 58 and 58A of the Competition Act 1998.

11 E. Rumak, P. Sitarek, Polish Leniency Programme and Its Intersection with Private Enforcement of Competition Law, YARS 2009, vol. 2(2), s. 117; M. K. Kolasiński, Odpowiedzialność cywilna za szkody powstałe $w$ wyniku naruszenia wspólnotowych zakazów stosowania praktyk ograniczajacych konkurencję i nadużywania pozycji dominującej, PPH 2007, nr 11, s. 20-21. 
informacje i opinie. Ponadto kompetencja do występowania przed sądami cywilnymi powinna być expressis verbis wymieniona w przepisie uokik, formułującym katalog zadań Prezesa UOKiK. Co do sposobu przekazywania przez organy ochrony konkurencji opinii i informacji, to na wzór art. 15 ust. 3 rozp. 1/2003 należałoby postulować możliwość przekazywania uwag z urzędu na piśmie oraz za zgodą sądu - ustnie. Jeśli chodzi o zakres przedmiotowy, to możliwe byłoby skorzystanie ze znanego $\mathrm{z}$ art. $63 \mathrm{kpc}$ sformułowania o ,istotnym poglądzie dla sprawy”, co pozwoliłoby na przedstawianie uwag organu zarówno co do prawa, jak i co do faktów. Dla zapewnienia właściwego funkcjonowania omawianej instytucji procesowej uzasadnione byłoby wprowadzenie obowiązku sądów w zakresie informowania Prezesa UOKiK o wniesionych pozwach, związanych z egzekwowaniem zakazów praktyk ograniczających konkurencję - pozwoliłoby to Prezesowi UOKiK na rzeczywiste korzystanie z możliwości włączenia się do postępowania w roli przyjaciela sądu.

Sądy również powinny mieć możliwość zwracania się do Prezesa UOKiK o opinię w rozpatrywanej przez siebie sprawie. Opinie przyjaciela sądu mogą być narzędziem wspierającym prawidłową ocenę materiału dowodowego. Wprowadzenie regulacji tego rodzaju uważam za uzasadnione $\mathrm{z}$ punktu widzenia funkcjonowania zrównoważonego współistnienia publicznego i prywatnego trybu egzekwowania prawa ochrony konkurencji nawet biorąc pod uwagę fakt, że praktyczne znaczenie art. 15 rozp. 1/2003 okazało się niewielkie. W sprawozdaniu $\mathrm{z}$ funkcjonowania rozp. 1/2003 podkreślono, że - chociaż w okresie sprawozdawczym (tj. między 1 maja 2004 r. a 1 maja 2009 r.) Komisja tylko dwukrotnie podjęła decyzję o złożeniu uwag jako amicus curiae, to „zainteresowane podmioty wezwały Komisję do częstszego stosowania tego instrumentu i należy rozważyć, w jaki sposób powinno się rozwinąc tę praktykę"12; w 2010 r. Komisja podjęła trzy interwencje na podstawie art. 15 ust. 3 rozp. 1/2003, choć wszystkie one dotyczyły spraw z udziałem krajowych organów ochrony konkurencji, tj. z zakresu publicznego egzekwowania prawa konkurencji13. Za wprowadzeniem regulacji dotyczącej amicus curiae przemawiają natomiast argumenty prawnoporównawcze: niektóre państwa członkowskie, w tym Grecja, Niemcy, Portugalia i Węgry, zdecydowały o przyjęciu odpowiednich regulacji, wzorowanych na art. 15 rozp. 1/2003 lub wdrażających ten artykuł.

12 Komunikat Komisji do Parlamentu Europejskiego i Rady: Sprawozdanie z funkcjonowania rozporządzenia nr 1/2003 (SEK(2009)574), Bruksela, dnia 29 kwietnia 2009, $\operatorname{KOM}(2009) 206$ wersja ostateczna, pkt 35.

13 Pkt 109 Commission Staff Working Paper Accompanying the Report from the Commission on Competition Policy 2010, COM(2011) 328 final. 
W odniesieniu do dostępności dowodów, zrównoważony model egzekwowania prawa konkurencji wymaga zapewnienia regulacji, które umożliwiałyby udostępnianie dowodów zgromadzonych w postępowaniu antymonopolowym na potrzeby postępowania sądowego; autonomia publicznego trybu egzekwowania zakazów praktyk ograniczających konkurencję powinna doznać w tym wypadku ograniczenia - przemawia za tym racjonalne wykorzystanie zasobów znajdujących się w posiadaniu administracji publicznej.

Istnieje natomiast potrzeba wprowadzenia przepisów, które w bezpośredni sposób pozwolą na wykorzystanie w postępowaniu cywilnym dowodów zgromadzonych w postępowaniu antymonopolowym. Obecnie istniejące instrumenty $\mathrm{w}$ zasadzie na to nie pozwalają lub pozwalają $\mathrm{w}$ bardzo ograniczonym zakresie. Przepis art. $248 \S 1 \mathrm{kpc}$ nie wydaje się w tym zakresie wystarczającym narzędziem przede wszystkim dlatego, że udostępnienie akt uzależnia od aktywności sądu (choć możliwej do podjęcia także na wniosek stron). Za konieczne dla rozwoju prywatnego egzekwowania prawa ochrony konkurencji uważam wprowadzenie przepisu, który nakazywałby organowi ochrony konkurencji (Prezesowi UOKiK) udostępnienie akt postępowania antymonopolowego na potrzeby postępowania cywilnego na wniosek stron. Bowiem, nawet jeśli w sytuacji, gdy organ ochrony konkurencji wydał decyzję uznającą praktykę za ograniczającą konkurencję, nie istnieje potrzeba udowodnienia samego naruszenia (gdy charakter decyzji jest prejudycjalny), to szczegóły postępowania antymonopolowego mogą być kluczowe np. dla ustalenia wielkości szkody.

Przepis taki powinien być zawarty w Kodeksie postępowania cywilnego bądź w ustawie o ochronie konkurencji konsumentów. Spod obowiązku udostępnienia należy wyłączyć dokumenty i informacje udostępnione w ramach procedur leniency. Jeśli chodzi o inne ograniczenia dostępu do akt, to mogą być one inspirowane rozwiązaniami przyjętymi w ustawie o ochronie konkurencji i konsumentów w odniesieniu do ograniczeń dostępu do akt postępowania antymonopolowego. Należałoby jednak rozważyć wprowadzenie do art. 73 (np. do ust. 2) uokik wyraźnego wyłączenia zakazu wykorzystywania informacji uzyskanych $w$ toku postępowania przed Prezesem UOKiK w postępowaniach związanych $\mathrm{z}$ sądowym dochodzeniem roszczeń z tytułu naruszenia zakazu antykonkurencyjnych praktyk.

Nie jestem natomiast zwolenniczką wprowadzenia do procedury cywilnej instytucji ujawniania dowodów między stronami (w jej postaci znanej z prawa amerykańskiego) jako niemal całkowicie obcej polskiej kulturze prawnej. Argument przeciwko wprowadzaniu regulacji służących disclosure stanowi, w moim przekonaniu, także okoliczność, że ustawodawca zdecydował się na likwidację postępowania odrębnego w sprawach gospodarczych, 
co należy odczytywać jako odejście od procedur i uregulowań specyficznych dla określonych kategorii spraw (a taki charakter miałaby regulacja dotycząca ujawniania dowodów w cywilnych sprawach antymonopolowych). Gdyby jednak ustawodawca zdecydował o wprowadzeniu przepisów, które $\mathrm{w}$ aspekcie dowodowym miałyby ułatwic prywatne egzekwowanie prawa ochrony konkurencji, to należałoby przyjąc model „sądocentryczny”, charakteryzujący się cechami wskazanymi w Białej księdze przez Komisję ${ }^{14}$.

Istotnym obszarem wspólistnienia publicznego i prywatnego egzekwowania reguł konkurencji pozostaje (ewentualna) zależność zakresu odpowiedzialności odszkodowawczej od uczestnictwa pozwanych w programie darowania lub łagodzenia kar. Ograniczenie wysokości odszkodowania w sytuacji, gdy pozwany skutecznie współpracował z organem ochrony konkurencji w ramach leniency, uważam za nadmierne ustępstwo na rzecz publicznego egzekwowania reguł konkurencji. Budując zrównoważony model egzekwowania reguł konkurencji, należy rozróżniać rozwiązania, które nie pozwalają jedynie na osłabienie atrakcyjności leniency (za takie rozwiązanie można uznać ograniczenie dostępu do dowodów zebranych w związku z leniency) oraz rozwiązania, które - dodatkowo - mają na celu zwiększenie atrakcyjności programu leniency (takie jak oddziaływanie na zakres odpowiedzialności odszkodowawczej). W obydwu przypadkach dochodzi do „uprzywilejowania” publicznego trybu egzekwowania reguł konkurencji względem trybu prywatnego (poprzez ograniczenie praw powodów), jednak w moim przekonaniu, wprowadzanie środków czyniących leniency bardziej atrakcyjnym odebrałoby zintegrowanemu modelowi egzekwowania reguł konkurencji pożądany, zrównoważony charakter. Ustawodawca powinien zastosować jedynie te środki, które nie powodują osłabienia efektywności leniency poprzez prywatne egzekwowanie reguł konkurencji.

Nie są natomiast pożądane ani przepisy ani praktyka orzecznicza wymagające, aby w decyzji organu ochrony konkurencji obligatoryjnie znalazło się określenie wielkości szkody (i w jego następstwie - określenie wysokości odszkodowania) ${ }^{15}$. W tym wypadku publiczny tryb egzekwowania reguł konkurencji w zbyt szerokim zakresie przejmowałby funkcje właściwe dla sądowego trybu egzekwowania reguł konkurencji przez podmioty prywatne.

Obszarem całkowitej „autonomii” publicznego i prywatnego trybu egzekwowania zakazów praktyk ograniczających konkurencję powinny, moim

14 Por. rozdział V, pkt 5.5.

15 Tak również P. Collins, Interaction between public enforcement and private damages actions: competition authorities' perspective, Valladolid, 14 października 2010 r. (wystąpienie Chairman of Office of Fair Trading, dostępne pod adresem: http://www.oft.gov.uk/shared_oft/ speeches/689752/speech1210.pdf, s. 5). 
zdaniem, pozostać terminy przedawnienia: wszczęcia postępowania przed organem ochrony konkurencji i roszczeń cywilnoprawnych. Upływ terminu przedawnienia „ścigania” przez organ antymonopolowy będzie oczywiście wpływał na możliwość sądowego dochodzenia roszczeń z tytułu naruszenia zakazu antykonkurencyjnych praktyk - nie uniemożliwiając co prawda prywatnego egzekwowania zakazów, ale czyniąc je trudniejszym z tego względu, że po upływie terminu przedawnienia przewidzianego w art. 93 uokik nie jest możliwe wszczęcie postępowania antymonopolowego w sprawie praktyk ograniczających, prowadzące do wydania decyzji o statusie prejudykatu w postępowaniu sądowym.

Przedstawione powyżej postulaty wskazują, że model egzekwowania reguł konkurencji określony jako „zrównoważony” w istocie nie zapewnia bezwzględnej równości obydwu trybów egzekwowania reguł konkurencji, ale zakłada pewną supremację submodelu publicznego egzekwowania zakazów antykonkurencyjnych praktyk nad submodelem prywatnego dochodzenia roszczeń. Należy przy tym zaznaczyć, że zrównoważony model egzekwowania reguł konkurencji budowany jest w warunkach, w których publiczne egzekwowanie reguł konkurencji ma charakter nadrzędny, jeśli chodzi o zapobieganie (odstraszanie) naruszeniom zakazów antykonkurencyjnych praktyk, zaś tryb prywatny - tam, gdzie chodzi o kompensację skutków naruszenia tych zakazów. Zapewnienie całkowitej równości obydwu trybom egzekwowania zakazów prowadziłoby w moim przekonaniu do „paraliżowania” w wielu sytuacjach funkcji poszczególnych trybów (zwłaszcza funkcji trybu publicznego). Aby uniknąć takiej sytuacji konieczne jest zapewnienie marginesu wzajemnych ustępstw obydwu trybów - fakt, że proponuję więcej takich ustępstw ze strony prywatnego trybu egzekwowania reguł konkurencji (na rzecz trybu publicznego) stanowi naturalną konsekwencję publicznoprawnego rodowodu zakazów praktyk ograniczających konkurencję. Postulat tworzenia zrównoważonego modelu egzekwowania reguł konkurencji ma jednakże niwelować skutki zasady, zgodnie z którą zwiększona efektywność publicznego egzekwowania reguł konkurencji raczej utrudnia niż ułatwia prywatne egzekwowanie zakazów antykonkurencyjnych praktyk ${ }^{16}$.

16 Por. S. Kon, A. Bancroft, Aspects of the complementary roles of public and private enforcement of $U K$ and EU antitrust law: an enforcement deficit?, G.C.L.R. 2008, vol. 1(1), s. 23. 


\subsection{Uwagi końcowe}

Zapewnienie funkcjonowania zintegrowanego i zrównoważonego modelu egzekwowania zakazów antykonkurencyjnych praktyk (a także szerzej reguł konkurencji w ogóle) można postrzegać jako jedno z najważniejszych wyzwań współczesnego prawa ochrony konkurencji. Polski ustawodawca nie wydaje się jednak dostrzegać wagi omawianego zagadnienia, co w połączeniu z ubogą praktyką sądową sprawia, że w Polsce brakuje pozytywnego klimatu dla sądowego dochodzenia roszczeń z tytułu naruszenia praktyk ograniczających konkurencję. Sceptycznie odnoszę się do możliwości rozwoju prywatnego egzekwowania reguł konkurencji - nie wydaje się to możliwie w sytuacji braku regulacji prawnych poświęconych choćby wybranym aspektom sądowego dochodzenia roszczeń w sprawach z zakresu ochrony konkurencji. Co więcej, równie sceptycznie oceniam możliwości przyjęcia takiej regulacji - w Polsce rezygnacja ze specjalnego trybu dla spraw gospodarczych zapowiada wręcz odwrotną tendencję legislacyjną, niewykorzystaną szansę na wprowadzenie odpowiednich regulacji stanowiła również zaproponowana przez UOKiK w maju 2012 r. znacząca nowelizacja ustawy o ochronie konkurencji i konsumentów.

Właściwe ukształtowanie relacji między prywatnym i publicznym trybem egzekwowania reguł ochrony konkurencji należy postrzegać jako istotne także dlatego, że obecnie w Polsce relacje te odnoszą się do dychotomicznego (administracyjno-cywilnego) modelu egzekwowania reguł konkurencji. Tymczasem zauważalne w całym świecie tendencje do kryminalizacji prawa ochrony konkurencji (widoczne także w propozycjach nowelizacji ustawy o ochronie konkurencji i konsumentów) zaprowadzą nas zapewne do trychotomicznego modelu egzekwowania reguł konkurencji, który to model nie będzie już opisywany jako publiczno-prywatny, ale jako model oparty na trzech filarach: administracyjnym, karnym, cywilnym. Taki rozwój będzie wymagał ponownego redefiniowania wzajemnych zależności - tym razem nie tylko w odniesieniu do relacji publiczno-prywatnych, ale także wewnątrz submodelu publicznego. 



\section{Źródła}

\section{Literatura}

Adamczak-Retecka M, Odpowiedzialność odszkodowawcza jednostki za naruszenie prawa wspólnotowego, IWEP, Warszawa 2010.

Adamczak-Retecka, Ubi ius, ibi remedium? czyli: odpowiedzialność jednostki za naruszenia prawa wspólnotowego $w$ świetle orzeczenia Trybunatu Sprawidliwości w sprawie C-453/99 Courage Ltd., Gdańskie Studia Prawnicze 2005, Tom XIV.

Adamiak B., Borkowski J., Postępowanie administracyjne i sqdowoadministracyjne, Warszawa 2008.

Adamski D., How wide is "the widest possibile"?Judicial interpretation of the exceptions of the right of access to official documents revisted, CMLR 2009, vol. 46(2).

Akińcza J., Dopuszczalność dowodzenia z urzędu w zwiazku z wystapieniem prekluzji dowodowej, Glosa 2007, $\mathrm{nr} 4$.

Albors-Llorens A., Courage v. Crehan: Judicial Activism or Consistent Approach?, The Cambridge Law Journal 2002, vol. 61(1).

Aleksandrowicz T. R., Komentarz do ustawy o dostępie do informacji publicznej, LexisNexis, Warszawa 2002.

Andersson H., Legnerfalt E., Sweden - one step ahead in private enforcement?, G.C.L.R. 2009, vol. 2(1).

Andriychuk O., Can We Protect Competition Without Protecting Consumers?, The Competition Law Review 2009, vol. 6(1).

Anthony G., UK Public Law and European Law, Hart Publishing, Oxford and Portland, Oregon 2002.

Areeda P. E., Hovenkamp H., Antitrust Law: An Analysis of Antitrust Principles and Their Application, Aspen Publishers, Nowy Jork 1992.

Bacher G., Hungary: Limitation of liability of the leniency applicant and calculation of amount of damages in the new Hungarian legislation, G.C.L.R. 2008, vol. 1(2).

Bagińska E., Odszkodowania karne (punitive damage) w prawie amerykańskim, $\mathrm{PiP}$ 2003, nr 6. 
Baker D. I., The Use of Criminal Law Remedies to Deter and Punish Cartels and Bid-Rigging, George Washington Law Review 2001, vol. 69.

Banasiński C., Piontek E. (red.), Ustawa o ochronie konkurencji i konsumentów. Komentarz, Wyd. LexisNexis, Warszawa 2009.

Banasiński C., Konstytucyjne podstawy ustroju gospodarczego, [w:] Banasiński C., Gronkiewicz-Waltz H., Pawłowicz K., Szafrański D., Wierzbowski M., Wyrzykowski M., Prawo gospodarcze. Zagadnienia administracyjnoprawne, Warszawa 2003.

Banasiński C., Publicznoprawne aspekty ochrony konkurencji, [w:] Banasiński C., Gronkiewicz-Waltz H., Pawłowicz K., Szafrański D., Wierzbowski M., Wyrzykowski M., Prawo gospodarcze. Zagadnienia administracyjnoprawne, Warszawa 2003.

Bator A., Gromski W., Kozak A., Kaźmierczyk S., Pulka Z., Wprowadzenie do nauk prawnych. Leksykon tematyczny, Wyd. Prawnicze LexisNexis, Warszawa 2006.

Beaton-Wells C., Haines F., Making Cartel Conduct Criminal: A Case-Study of Ambiguity in Controlling Business Behaviour, Australian and New Zealand Journal of Criminology 2009, vol. 42(2).

Beatson J., "Public" and "Private" in English Administrative Law, LQR 198710334.

Berger D., Bernstein R., An Analytical Framework for Antitrust Standing, Yale Law Review 1977, vol. 86.

Bernaczyk M., Jabłoński M., Praktyczne problemy wdrażania ustawy o dostępie do informacji publicznej. Komercjalizacja informacji publicznej, elektroniczna Administracja 2007, nr 1.

Bernard K. S., Private antitrust litigation in the European Union - why does the EC want to embrace what the US FTC is trying to avoid?, G.C.L.R. 2010, vol. 3(2).

Bernatt M., Can the Right To Be Heard Be Respected without Access to Information about the Proceedings? Deficiencies of National Competition Procedure, YARS 2012, vol. 5(6).

Bernatt M., Glosa do wyroku w sprawie Manfredi, [w:] Jurkowska-Gomułka A. (red.), Orzecznictwo sadów wspólnotowych w sprawach konkurencji w latach 2004-2009, Oficyna a Wolters Kluwer business, Warszawa 2010.

Bernatt M., Gwarancje proceduralne w sprawach z zakresu ochrony konkurencji $i$ regulacji, majacych charakter karny $w$ świetle EKPCz - glosa do wyroku SN z 14.04.2010 r., EPS 2011, nr 6.

Bernatt M., Opinia przyjaciela sadu jako pomocnicza instytucja prawna $w$ orzecznictwie sadów polskich, [w:] Bojarski Ł. (red.), Sprawny sąd. Zbiór dobrych praktyk. Część druga, Warszawa 2008.

Bernatt M., Prywatny model ochrony konkurencji oraz jego realizacja w postepowaniu przed sądem krajowym, [w:] Piontek E. (red.), Nowe tendencje w prawie konkurencji UE, Oficyna a Wolters Kluwer business, Warszawa 2008.

Bernatt M., Sprawiedliwość proceduralna w postępowaniu przed organem ochrony konkurencji, Wyd. Naukowe WZ UW, Warszawa 2011.

Bernatt M., Skoczny T., Publicznoprawne wdrażanie regut konkurencji w Polsce. Czas na zmiany?, [w:] Gronkiewicz-Waltz H.,. Jaroszyński K. (red.), Europeizacja publicznego prawa gospodarczego, C. H. Beck, Warszawa 2011. 
Będkowski-Kozioł M., Prywatne wdrażania prawa antymonopolowego w RFN - uwagi na tle regulacji siódmej noweli kartelowej, PUG 2007, nr 12.

Blicharz R., Kania M., Klauzula interesu publicznego w publicznym prawie gospodarczym, PUG 2010, nr 5.

Blachnio-Parzych A., The Nature of Resposibility of An Undertaking in Antitrust Proceeding and the Concept of 'Criminal Charge' in the Jurisprudence of the European Court of Human Rights, YARS 2012, vol. 5(6).

Błachucki M., Właściwość sq̨dów administracyjnych i sq̨ów powszechnych $w$ sprawach antymonopolowych, [w:] Błachucki M., Górzyńska T. (red.), Aktualne problemy rozgraniczenia wtaściwości sądów administracyjnych i powszechnych, Naczelny Sąd Administracyjny, Warszawa 2011.

Błachucki M., Jóźwiak S., Sankcje strukturalne w prawie antymonopolowym jako sankcje administracyjne, [w:] Stahl M., Lewicka R., Lewicki M. (red.), Sankcje administracyjne, LEX a Wolters Kluwer business, Warszawa 2011.

Błaszyńska A., Zakres podmiotowy prawa do informacji publicznej, PPP 2010, nr 6. Boge U., Ost K., Up and running or is it? Private enforcement - the situation in Germany and policy perspectives, E.C.L.R. 2006, vol. 27(4).

Bojarski T., Polskie prawo karne. Zarys części ogólnej, LexisNexis, Warszawa 2008. Boskovits K., Modernization and the Role of National Courts: Institutional Choices, Power Relations, and Substantive Implications, [w:] Kokkoris I., Lianos I. (red.), The reform of EC competition law: new challenges, Kluwer Law International 2009.

Broniewicz W., Postepowanie cywilne $w$ zarysie, LexisNexis, Warszawa 1996.

Brook H., A Brief Introduction: The Origins of Punitive Damages, [w:] Koziol H., Wilcox V. (red.), Punitive Damages: Common Law and Civil Law Perspectives, Wien 2009.

Burzyński P., Ustawowe określenie sankcji karnej, Oficyna a Wolters Kluwer business, Warszawa 2008.

Buxbaum H. L., German Legal Culture and the Globalization of Competition Law: A Historical Perspective on the Expansion of Private Antitrust Enforcement, Berkeley Journal of International Law 2005, vol. 23(2).

Calvani T., Calvani T. H., Cartel sanctions and deterrence, Antitrust Bulletin 2011, vol. 56(2).

Calkins S., Summary Judgment, Motions to Dismiss, and Other Examples of Equilibrating Tendencies in the Antitrust System, Georgetown Law Journal 1986, vol. 74.

Carpagnano M., Competition Law Litigation: The Italian Perspective (1990-2010), [w:] Velasco San Pedro L. A., Alonso Ledesma C., Echebarria Saenz J.A., Herrero Suarez C., Gutierrez Gilsanz J. (red.), Private enforcement of competition law, Lex Nova, Valladolid 2011.

Carpagnano M., Private Enforcement of Competition Law Arrives in Italy: Analysis of the Judgement of the European Court of Justice in Joined Cases C-295-298/04 Manfredi, The Competition Law Review 2006, vol. 3(1).

Cartels: Sanctions against Individuals, OECD Journal of Competition Law and Policy 2007, vol. 9(3). 
Cauffman C., Injunctions at the Request of Third Parties in EU Competition Law, Maastricht European Private Law Institute, Working Paprt No. 2011/05.

Cauffman C., The Interaction of Leniency Programmes and Actions for Damages, The Competition Law Review 2011, vol. 7(2).

Cavanagh E. D., Detrebling antitrust damages in monopolization cases, Antitrust Law Journal 2009, vol. 76(1).

Cengiz F., Passing-On Defense and Indirect Purchaser Standing in Actions for Damages against the Violations of Competition Law: What Can EC Learn from US?, ESRC Centre for Competition Policy and School of Law, University of East Anglia, CCP Working Paper 2007, No. 21.

Coffee J. C., "No Soul To Damn: No Body To Kick": An Unscndalized Inquiry into the Problem of Corporate Punishment, Michigan Law Review 1981, vol. 79.

Collin P. H., Bartnicki K., Stownik prawa (angielsko-polski, z indeksem polsko-angielskim), Wyd. Wilga, Warszawa 2001.

Connor J. M., Lande R. H., How High Do Cartels Raise Prices? Implications for Reform of the AntitrustSentencing Guidelines, American Antitrust Institute Working Paper No. 01-04, April 2005.

Cook C. J., Private Enforcement of EU Competition Law in Member State Courts: Experience to Date and the Path Ahead, Competition Policy International 2008, vol. 4(2).

Cook Ch., Piergiovanni M., Implications of settling an EU cartel investigation for a prospective civil damages defendant: bad or good?, G.C.L.R. 2011, vol. 4(2).

Coulson E., We will not have to wait long to see what a national court - in this case, the English High Court - makes of the Pfleiderer decisions, Competition Law Insight, 20 września 2011.

Cupa B., Scattered Damages: A comparative Law Study About the Enforcement Deficit of Low-Value Damages and the Class Action Approach, ERPL 2012, vol. 2.

Curtis M. E., McNally J., The Classic Cartel - Hatchback Sentence, The Competition Law Review 2007, vol. 4(1).

Czachórski W., Zobowiąania. Zarys wyktadu, Wydawnictwa Prawnicze PWN, Warszawa 1995.

Danov M., Awarding exemplary (or punitive) antitrust damages in ec competition cases with an international element - the Rome II Rregulation and the Commission's White Paper on Damages, E.C.L.R. 2008, vol. 29(7),

Dawn O., Common Values and the Public-Private Divide, Butterworths, London, Edinburgh, Dublin 1999.

Di Federico G., EU Competition Law and the Principle of Ne Bis in Idem, European Public Law 2011, vol. 17(2).

Dmowski S., Sychowicz M., Ciepła H., Kołakowski K., Wiśniewski T., Żuławska C., Gudowski J., Bieniek G., Komentarz do kodeksu cywilnego. Księga trzecia. Zobowiąania, LexisNexis, Warszawa 2011.

Dobbs D.B., Ending Punishments in „Punitive” Damages: Detterence-Measured Remedies, Alabama Law Review 1988/1989, vol. 40.

Dolecki H., Postępowanie cywilne. Zarys wyktadu, wyd. 3, LexisNexis, Warszawa 2007. 
Dolecki H., Wiśniewski T. (red.), Kodeks postępowania cywilnego. Komentarz. Tom I, LEX a Wolters Kluwer business, Warszawa 2011.

Dubisz S. (red.), Uniwersalny stownik języka polskiego. Tom 1, Wyd. Naukowe PWN, Warszawa 2003.

Dutch Court of Appeal rules that director may be personally liable for company's competition fine, G.C.L.R. 2010, vol. 3(4).

Ehlermann C. D., Atanasiu I. (red.), European Competition Law Annual 2001: Effective Private Enforcement of EC Antitrust Law, Hart Publishing, OxfordPortland-Oregon 2003.

Ehlermann C. D., Atanasiu I. (red.), European Competition Law Annual 2000: The Modernisation of EC Antitrust Policy, Hart Publishing, Oxford and Portland, Oregon 2001.

Eilmansberger T., Green Paper on Damages Actions for Breach of the EC Antitrust Rules and Beyond: Reflections on the Utility and Feasibility of Stimulating Private Enforcement Through Legislative Actions, CMLR 2007, vol. 44(2).

Eilmansberger T., The relationship between rights and remedies in EC law: In search of the missing link, CMLR 2004, vol. 41(5).

Emmerich V., Prawo antymonopolowe, [w:] Dauses M. A. (red.), Prawo gospodarcze Unii Europejskiej, C. H. Beck, Warszawa 1999.

Ereciński T. (red.), Kodeks postępowania cywilnego. Komentarz. Tom 1, LexisNexis, Warszawa 2007.

Ezaki S., Motoyoshi T., Moussis V., Recent trends in private antitrust litigation in Japan, G.C.L.R. 2010, vol. 3(1).

Filar M. (red.), Kwaśniewski Z., Kala D., Komentarz do ustawy o odpowiedzialności podmiotów zbiorowych za czyny zabronione pod groźba kary, TNOiK, Toruń 2003.

Filipek J., Sankcja prawna w prawie administracyjnym, PiP 1963, z. 12.

Filipowski O., Sytuacja konsumenta na rynku cementu w świetle decyzji Prezesa Urzędu Ochrony Konkurencji i Konsumentów w sprawie kartelu cementowego, PPP 2010, nr 11.

Fisse B., The Australian Cartel Criminalisation Proposals: An Overview and Critique, The Competition Law Review 2007, vol. 4(1).

Floriańczyk M., Wolność gospodarcza a konkurencja, [w:] Szwajdler W., Nowicki H. (red.), Konstytucyjna zasada wolności gospodarczej, TNOiK, Toruń 2009.

Foer A. E, Schultz E. P., Will Two Roads Still Diverge? Private Enforcement of Antitrust Law Is Getting Harder in the United States. But Europe May Be Making It Easier, G.C.L.R. 2011, vol. 4(3).

Frank N., Lademann R. P., Economic Evidence in Private Damage Claims: What Lessons Can Be Learned from the German Cement Cartel Case?, Journal of Competition Law \& Economics 2010, vol. 1(4).

Friederiszick H. W., Röller L.-H., Quantification of harm in damages actions for antitrust infringements: insights from German cartel cases, Journal of Competition Law \& Economics 2010, vol. 6(3).

Gal M. S., Monopoly Pricing as an Antitrust Offense in the U.S. and the EC: Two Systems of Belief About Monopoly?, Antitrust Bulletin 2004, vol. 49. 
Gamble R., "Speaking (formally) with the enemy" - cartel settlements evolve, E.C.L.R. 2011, vol. 32(9).

Gavil A. I., State Indirect Purchaser Actions, Proposal for a Reform, OECD Journal: Competition Law and Policy 2009, vol. 11(2).

Gavil A.I., The challanges of economic proof in a decentralized and privatized European competition policy system: lessons from the American perspective, Journal of Competition Law and Economics 2007, vol. 4(1).

Gerber D., Private enforcement of competition law: a comparative perspective, [w:] Möllers T. M. J., Heinemann A. (red.), The Enforcement of Competition Law in Europe, Cambridge University Press 2009.

Giannakopoulos T. K., Safeguarding Companies' Rights in Competition and AntiDumping/Anti-Subsidies Proceedings, Kluwer Law International 2011.

Giezek J., Kardas P., Konstrukcja dziatania na szkodę spótki handlowej oraz przestepstwa stanowiace jej odpowiednik - projekt nowelizacji, Palestra 2011, nr 1-2.

Giezek J., Łabuda G., System sankcji w ustawie o odpowiedzialności podmiotów zbiorowych za czyny zabronione pod groźba kary, Prok. i Pr 2004, nr 11-12.

Ginsburg D. H., Comparing Antitrust Enforcement in the United States and Europe, Journal of Competition Law and Economics 2005, vol. 1(3).

Giudici P., The CEPSA Case, European Review of Contract Law 2009, nr 2.

Gniewek E. (red.), Kodeks cywilny. Komentarz, C. H. Beck, Warszawa 2011.

Goddin G., Recent Judgments Regarding Transparency and Access to Documents in the Field of Competition Law: Where Does the Court of Justice of the EU Strike the Balance?, Journal of European Competition Law \& Practice 2011, vol. 2(1).

Gordon J., Stownik terminologii prawniczej i gospodarczej (polsko-angielski, angielsko-polski), Wyd. Poltext, Warszawa 2008.

Gotanda J. Y., Charting Developments Concerning Punitive Damages: Is the Tide Changing?, Columbia Journal of Transnational Law 2007, vol. 4/3.

Górniok O., Czyny karalne przewidziane w Kodeksie spótek handlowych (Tytut V), [w:] Górniok O. (red.), Prawo karne gospodarcze, C. H. Beck, Warszawa 2003.

Górniok O., Pojęcie karnego prawa gospodarczego i jego szczególne problemy, [w:] Górniok O. (red.), Prawo karne gospodarcze, C. H. Beck, Warszawa 2003.

Grasso R., The E.U. Leniency Program and U.S. Civil Discovery Rules: A Fraternal Fight?, Michigan Journal of International Law 2008, vol. 29(1).

Green J., McCall I., Leniency and civil claims. Should leniency programmes extend to private actions?, Competition Law Insights, 28 July 2009.

Gromadzki C., Glosa do wyroku z dnia 12 grudnia 2000 r. (V CKN 175/00), PS 2003, nr 3.

Gronowski S., Glosa do postanowienia SN z dnia 27 października 1995 r., III CZP 135/95, OSP 1996, nr 6, poz. 112.

Gronowski S., Polskie prawo antymonopolowe. Zarys wykładu, Wyd. Zrzeszenia Prawników Polskich, Warszawa 1998.

Gryniuk A., Przymus prawny. Studium socjologiczno-prawne, Wyd. UMK, Toruń 1994 
Grzybowski S. (red.), System prawa cywilnego. T. I. Część ogólna, Wyd. PAN, Ossolineum 1985.

Gustafsson M., Hoseinian F., Private enforcement of EC competition law: Swedish Supreme Court judgment on the validity of 'follow-on' contracts, E.C.L.R. 2006, vol. 27(1).

Gutowski M., Nieważność czynności prawnej, C. H. Beck, Warszawa 2006.

Hakopian G., Criminalization of EU Competition Law Enforcement - A Possibility after Lisbon?, The Competition Law Review 2010, vol. 7(1).

Hanausek S., „Zwiąanie” sadu cywilnego decyzja administracyjna, SC 1974, t. XXIII. Hansberry-Bieguńska D., Poland, [w:] Gotts I. K. (red.), The Private Competition Enforcement Review, 4. ed., Law Business Research, London 2011.

Harlow C., "Public" and "Private" Law: Definition Without Distinction, Modern Law Review 1980, vol. 43(3).

Harris R. G., Sullivan A., Passing on the Monopoly Overcharge: A Comprehensive Policy Analysis, University of Pennsylvania Law Review 1980, vol. 128.

Hauser R., Niewiadomski Z., Wróbel A. (red.), System prawa administracyjnego. Instytucje prawa administracyjnego. Tom 1, C. H. Beck, Warszawa 2010.

Hazelhorst M., Private Enforcement of EU Competition Law: Why Punitive Damages Are a Step Too Far, ERPL 2010, nr 4.

Hellwig M., Private damages claims and the passing on defense in horizontal pricefixing cases: an economist's perspective, Preprints of the Max Planc Institute for Research on Collective Goods, No. 2006, 22.

Hempel R., Access to DG Competition's files: an analysis of recent EU court case law, E.C.L.R. 2012, vol. 33(4).

Hughes P., The Enforcement of Private Actions for Breaches of EC Competition Law - The Role of the Shareholder under English Law, The Competition Law Review 2006, vol. 3(1).

Ioannidou M., Enhancing the Consumer's Role in EU Private competition Law Enforcement: A Normative and Practical Approach, The Competition Law Review 2011, vol. 8(1).

Iwulski J., Zwiąanie sadu powszechnego decyzja administracyjna na przykładzie decyzji dotyczacej stwierdzenia choroby zawodowej, MoP 1995, nr 3.

Jacobson J. M., Greer T., Twenty-One Years of Antitrust Injury: Down the Alley with Brunswick v. Pueblo Bowl-O-Mat, Antitrust Law Journal 1998, vol. 66.

Jakubecki A. (red.). Kodeks Postępowania Cywilnego. Komentarz, Oficyna a Wolters Kluwer business, Warszawa 2008.

Jakubecki A., Kontradyktoryjność a poznanie prawdy $w$ procesie cywilnym $w$ świetle zmian Kodeksu postępowania cywilnego, PS 1998, nr 10.

Jakubecki A., Prejudycjalność w postępowaniu cywilnym, NP 1982, nr 7-8.

Jamróz A., Wprowadzenie do prawoznawstwa, Wyd. Prawnicze LexisNexis, Warszawa 2008.

Janusz R., Sachajko M., Skoczny T., Nowa ustawa o ochronie konkurencji i konsumentów, KPPubl. 2001, nr 3.

Jaroch W., Przestępstwa $w$ systemie zamówień publicznych, Prok. i Pr. 2004, nr 4. 
Jarosz M., Stownik wyrazów obcych, Wyd. Europa, Wrocław 2001.

Jarosz-Żukowska M., Charakter $i$ znaczenie wolności $i$ praw jednostki wyrażonych $w$ Rozdziale I Konstytucji RP, [w:] Jabłoński M. (red.), Wolności i prawa jednostki w Konstytucji RP. Tom 1 (Idee $i$ zasady przewodnie konstytucyjnej regulacji wolności i praw jednostki w RP), C. H. Beck, Warszawa 2010.

Jaśkowska M., Dostęp do informacji publicznej w świetle orzecznictwa Naczelnego Sądu Administracyjnego, Toruń 2002.

Jaworski T., Radzimierski P., Ustawa o dochodzeniu roszczeń w postępowaniu grupowym. Komentarz, C. H. Beck, Warszawa 2010.

Jendrośka J., Stoczkiewicz M., Ustawa o dostępie do informacji publicznej a regulacje szczegótowe, PiP 2003, nr 6.

Jestaedt T., Derenne J., Ottervanger T., Study on the enforcement of State aid law at national level, Publications Office, Luxembourg 2006.

Jędrzejewska M., Grzegorczyk P., Weitz K., Ereciński T., Gudowski J., Kodeks postepowania cywilnego. Komentarz, LexisNexis, Warszawa 2012.

Jodłowski J., Resich Z., Postępowanie cywilne, PWN, Warszawa 1979.

Jones C.A., Private enforcement of antitrust law in the EU, UK and USA, Oxford 2005,

Jones C. A., Private Antitrust Enforcement in Europe: A Policy Analysis and Reality Check, World Competition 2004, vol. 27(1).

Jones C., Sharpston E., Beyond Delimitis: Pluralism, Illusions, and Narrow Constructionism in Community Antitrust Litigation, Columbia Journal of European Law 1996/97, vol. 3.

Jurkowska A., Antitrust Private Enforcement - Case of Poland, YARS 2008, vol. 1(1).

Jurkowska A., Glosa do uchwaty SN z 23.07.2008 r., III CZP 52/08, EPS 2010, nr 5.

Jurkowska A., Glosa do wyroku w sprawie Courage, [w:] Jurkowska A., Skoczny T. (red.), Orzecznictwo sądów wspólnotowych $w$ sprawach konkurencji $w$ latach 1964-2004, Oficyna a Wolters Kluwer business, Warszawa 2007.

Jurkowska A., O „prywatyzacji” prawa wspólnotowego i jej skutkach, EPS 2006, nr 9.

Jurkowska A., Perspektywy prywatnego wdrażania prawa ochrony konkurencji w Polsce na tle doświadczeń Wspólnoty Europejskiej, PUG 2008, nr 1.

Jurkowska A., Prywatnoprawne wdrażanie wspólnotowego prawa konkurencji, Zeszyty CEN (Zeszyt 19), Centrum Europejskie Natolin, Warszawa 2004.

Jurkowska A., Miąsik D., Skoczny T., Szydło M., Nowa uokik z 2007 r. - kolejny krok $w$ kierunku doskonalenia podstaw publicznoprawnej ochrony konkurencji $w$ Polsce, PUG 2007, nr 4.

Jurkowska A., Skoczny T., Wytaczenia grupowe spod zakazu porozumień ograniczajacych konkurencję we wspólnotowym i polskim prawie ochrony konkurencji, [w:] Jurkowska A., Skoczny T. (red.), Wytaczenia grupowe spod zakazu porozumień ograniczających konkurencję we Wspólnocie Europejskiej i w Polsce, Wyd. Naukowe WZ UW, Warszawa 2008.

Jurkowska-Gomułka A., Odpowiedzialność prawnokarna menadżerów za antykonkurencyjne praktyki przedsiębiorców, [w:] Księga jubileuszowa z okazji 40-lecia Wydziału Zarzadzania UW, Wyd. Naukowe WZ UW, Warszawa 2012. 
Jurkowska-Gomułka A., Między efektywnościa walki z kartelami a efektywnościa dochodzenia roszczeń z tytułu naruszenia art. 101 ust. 1 TFUE - glosa do wyroku TS z 14.06.2011 r. w sprawie C-360/09 Pfleiderer AG v. Bundeskartellamt, EPS 2012, nr 7.

Jurkowska-Gomułka A., Skoczny T., Wspólne reguły konkurencji Unii Europejskiej, IWEP, Warszawa 2010.

Kamińska I., Rozbicka-Ostrowska M., Ustawa o dostępie do informacji publicznej. Komentarz praktyczny, LexisNexis, Warszawa 2008.

Kardas P., Działania na szkodę spótki - konkretne czy abstrakcyjne narażenie na niebezpieczeństwo, PiP 2006, nr 6.

Karon D. R., Your Honor, Tear Down that Illinois Brick Wall!: The National Movement Towards Indirect Purchaser Antitrust Standing and Consumer Justice, William Mitchell Law Review 2004, vol. 30.

Kloub J., White Paper on Damage Actions For Breach of the EC Antitrust Rules: Plea For a More Holistic Approach to Antitrust Enforcement, European Competition Journal 2009, vol. 5(2).

Kmieciak Z., Postępowanie $w$ sprawach ochrony konkurencji a koncepcja procedury hybrydowej, PiP 2002, nr 4.

Kmieciak Z., Skuteczność regulacji administracyjnoprawnej, Łódź 1994.

Knysiak-Molczyk H., Prawo do informacji w postępowaniu administracyjnym, sadowo-administracyjnym oraz $w$ ustawie o dostępie do informacji publicznej, PPP 2010, nr 3.

Kociubiński J., Arbitraż w europejskim prawie konkurencji - zarys problemu, Kwartalnik ADR 2012, nr 2.

Kohutek K., Komentarz do rozporzadzenia Rady (WE) nr 1/2003 z dnia 16 grudnia $2002 r$. $w$ sprawie wprowadzenia $w \dot{z} y c i e$ regut konkurencji ustanowionych $w$ art. 81 i 82 Traktatu (Dz.U.UE.L.03.1.1), LEX/el 2006.

Kohutek K., Naruszenie interesu publicznego a naruszenie konkurencji (na tle praktyk rynkowych dominantów), PiP 2010, nr 7.

Kohutek K., Sieradzka M., Ustawa o ochronie konkurencji i konsumentów. Komentarz, LEX a Wolters Kluwer business, Warszawa 2008.

Kolasiński M. K., Obowiazek wspótpracy gospodarczej w prawie antymonopolowym, TNOiK, Toruń 2009.

Kolasiński M. K., Odpowiedzialność cywilna za szkody powstate w wyniku naruszenia wspólnotowych zakazów stosowania praktyk ograniczajacych konkurencję i nadużywania pozycji dominujacej, PPH 2007, nr 11.

Kolasiński M. K., Wspólnotowa polityka zwalniania $z$ grzywien $i$ zmniejszania ich wysokości w sprawach kartelowych po reformie z 2006 r., EPS 2008, nr 6.

Kolasińki M. K., A. Kustra, Konstytucyjne standardy ochrony przedsiębiorcy a środki zaradcze we wspólnotowym prawie konkurencji, EPS 2008, nr 5

Kolber J., Zasady stosowania prawa konkurencji UE przez sąy arbitrażowe, Kwartalnik ADR 2012, nr 3.

Kołodziej A., Roszczenie informacyjne w prawie wtasności intelektualnej, [w:] Nowińska E., du Vall M. (red.), Księga pamiatkowa ku czci Profesora Janusza Szwaji, ZNUJ-PIPWI UJ 2004, z. 88. 
Komninos A. P., EC Private Antitrust Enforcement. Decentralised Application of EC Competition Law by National Courts, Hart Publishing, Oxford and Portland, Oregon 2008.

Komninos A. P., Effect of Commission decisions on private antitrust litigation: setting the story straight, CMLR 2007, vol. 44(10).

Komninos A. P., New Prospects For Private Enforcement of EC Competition Law: Courage v. Crehan and the Community Right To Damages, CMLR 2002, vol. 39.

Komninos A. P., „Transient” and „transitional” voidness of anti-competitive agreements: a non-issue and an issue, E.C.L.R. 2007, vol. 28(8).

Kon S., Bancroft A., Aspects of the complementary roles of public and private enforcement of UK and EU antitrust law: an enforcement deficit?, G.C.L.R. 2008, vol. 1(1).

Korybski A., Leszczyński L., Pieniążek A., Wstęp do prawoznawstwa, Morpol, Lublin 2000.

Kosikowski C., Polskie publiczne prawo gospodarcze, PWN, Warszawa 1998.

Kosikowski C., Publiczne prawo gospodarcze Polski i Unii Europejskiej, LexisNexis, Warszawa 2005.

Kowalik-Bańczyk K., Prawo do obrony w unijnych postępowaniach antymonopolowych. W kierunku unifikacji standardów proceduralnych w Unii Europejskiej, LEX a Wolter Kluwer business, Warszawa 2012.

Kowalik-Bańczyk K., Problematyka ochrony praw podstawowych $w$ unijnych postępowaniach $w$ sprawach z zakresu ochrony konkurencji, Zeszyty CEN (nr 39), Natolin 2010.

Kowalik-Bańczyk, Procedural Autonomy of Member States and the EU Rights of Defence in Antitrust Proceedings, YARS 2012, vol. 5(7).

Kowalik-Bańczyk K., Sądowe stosowanie unijnego prawa konkurencji, [w:] Wróbel A. (red.), Stosowanie prawa Unii Europejskiej przez sady. Tom 1, Wolters Kluwer, Warszawa 2010.

Kowalik-Bańczyk K., Uwzględnianie przez sąd z urzędu zarzutów opartych na prawie wspólnotowym, EPS 2007, nr 12.

Kozak M., Private enforcement of competition rules under Community and Polish law - comments after accession, International Business Law Journal 2005, no. 3.

Koziol H., Punitive Damage: Admission into the Seventh Legal Heaven or Eternal Damnation? Comparative Reports and Conclusions [w:] Koziol H., Wilcox V. (red.), Punitive Damages: Common Law and Civil Law Perspectives, Wien 2009.

Krajewska E., Settlement $w$ świetle doświadczeń europejskich - w poszukiwaniu najlepszych rozwiazań, iKAR 2012, nr 4(1).

Krasnodębska-Tomkiel M., Czas na zmiany $w$ prawie antymonopolowym, iKAR 2012, nr 1(1).

Król-Bogomilska M., Kary pieniężne - główne kierunku ewolucji w okresie 20 lat rozwoju polskiego prawa antymonopolowego, EPS 2010, nr 5.

Król-Bogomilska M., Kary pieniężne naktadane na przedsiębiorców w świetle polskiego $i$ wspólnotowego prawa konkurencji, SE 1998, nr 3. 
Król-Bogomilska M., Kary pieniężne $w$ prawie antymonopolowym, KiK, Warszawa 2001.

Król-Bogomilska M., Standards of Entrepreneur Rights in Competition Proceedings - a Matter of Administrative or Criminal Law, YARS 2012, vol. 5(6).

Król-Bogomilska M., Zmiany $w$ systemie orzekania kar pieniężnych $w$ polskim prawie antymonopolowym po przystapieniu Polski do Unii Europejskiej, Studia Iuridica 2006, z. XLVI.

Księżak P., Bezpodstawne wzbogacenie. Komentarz, C. H. Beck, Warszawa 2007.

Kubiak A., Koncepcja umowy administracyjnej (na tle projektu Przepisów ogólnych prawa administracyjnego), PiP 2009, nr 4.

Lande R. H., Are Antitrust 'Treble' Damages Really Single Damages?, Ohio State Law Journal 1993, vol. LIV.

Lande R. H., Davis J. P., Benefits from Private Antitrust Enforcement: An Analysis of Forty Cases, University of San Franciso Law Review 2008, vol. 42.

Lande R. H., Davis P. J., Comparative Deterrence from Private Enforcement and Criminal Enforcement of the U.S. Antitrust Laws, University of San Francisco School of Law Legal Studies Research Paper Series No. 2010-17.

Landes W. M., Posner R., Should Indirect Purchasers Have Standing to Sue Under the Antitrust Laws? An Economic Analysis of the Rule of Illinois Brick, University of Chicago Law Review 1979, vol. 46.

Lave J. M., Umbrella standing: the tradeoff between plaintiff suit and speculative claims, Antitrust Bulletin 2003, vol. 48(1).

Lemkowski M., Glosa do wyroku SN z 7.11.1997 r., II CKN 424/97, OSNC Nr 5/1997, poz. 77, MoP 2001, nr 13.

Lenaerts K., Some Thoughts on Evidence and Procedure in European Community Competition Law, Fordham International Law Journal 2007, vol. 30(5).

Leszczyński L., Zagadnienia teorii stosowania prawa. Doktryna i tezy orzecznictwa, Zakamycze, Kraków 2004.

Lewandowski M., Sankcja nieważności w ustawie antymonopolowej - problematyka kompetencji organów $w$ przedmiocie ustalania naruszenia zakazów antymonopolowych, PPH 2012, nr 2.

Lewicki M., Pojęcie sankcji prawnej w prawie administracyjnym, PiP 2002, nr 8.

Lewisch P., Enforcement of antitrust law: the way from criminal individual punishment to semi-penal sanctions in Austria, [w:] Cseres K. J., Schinkel M. P, Vogelaar F. O. W. (red.), Criminalization of Competition Law Enforcement: Economic And Legal Implications For The EU Member States, Edward Elgar Publishing 2006.

Libertini M., Maugeri M. R., Infringment of competition law and invalidity of contracts, European Review of Contract Law 2005, nr 2.

Louis F., Accardo G., Ne Bis in Idem, Part 'Bis', World Competition 2011, vol. 34(1).

Łaszczyca G., Pojęcie zagadnienia wstępnego w kodeksie postępowania administracyjnego, PiP 2002, nr 7.

Ławicki T., Glosa do wyroku SN z 22 lutego 1994 r., I CRN 238/93, PiP 1995, nr 7.

Ławicki T., Ustawa o przeciwdziataniu praktykom monopolistycznym. Komentarz, Wydawnictwo Prawnicze PWN, Warszawa 1998. 
Łętowska E., Bezpodstawne wzbogacenie, C. H. Beck, Warszawa 2000.

Łętowski J., W sprawie granicy między prawem publicznym a prywatnym, [w:] Kordasiewicz B., Lętowska E. (red.), Prace z prawa cywilnego wydane dla uczczenia pracy naukowej Profesora Józefa Stanistawa Piatowskiego, Ossolineum, Wrocław 1985.

Mak Ch., Rights and remedies. Article 47 EUCFR and Effective Judicial Protection in European Private law Matters, Amsterdam Law School Research Paper No. 2012-88, Centre for the Study of European Contract Law Working Paper Series No. 2012-11.

Manowska M. (red.), Kodeks postępowania cywilnego. Komentarz. Tom 1, LexisNexis, Warszawa 2011.

Marcos F., Sánchez Graells A., Damages for breach of the EC antitrust rules: harmonising Tort Law through the back door?, Revista Para El Análisis del Derecho 2008, nr 1.

Marek A., Kodeks karny. Komentarz, Wyd. 5., Lex a Wolters Kluwer business, Warszawa 2010.

Marek A., Naprawienie szkody wyrzadzonej przestęstwem. Refleksje na tle projektu kodyfikacji karnej, [w:] Waltoś S. (red.), Problemy kodyfikacji prawa karnego. Księga ku czci Prof. M. Cieślaka, Kraków 1993.

Marshall K. S., The Economics of Competitve Injury, [w:] Marshall K. S. (red.), The Economics of Antitrust Injury and Firm-Specific Damages, Tucson 2008.

Massey P., Criminal Sanctions for Competition Law: A Review of Irish Experiences, The Competition Law Review 2004, vol. 1(1).

Materna G., Pojęcie przedsiębiorcy w polskim i europejskim prawie ochrony konkurencji, Oficyna a Wolters Kluwer business, Warszawa 2009.

Materna G., Ograniczenie prawa wgladu do materiatu dowodowego w postepowaniach przed Prezesem UOKiK, PPH 2008, nr 4.

McAfee R. P., Mialon H. M., Mialon, S. H. Private v. Public Antitrust Enforcement: A Strategic Analysis, Journal of Public Economics 2008, vol. 92(10-11).

McCarthy E. J., Seador G. S., Price Ch. R. (red.), Indirect Puchaser Lawsuites. A State-by-State Survey, Chicago 2010.

Mehta K., Centella M. L. T., Settlement procedure in EU cartel cases, Competition Law International, June 2008.

Mezei P., Wanted: Antitrust Criminals. Criminalization of Cartel law with a special view to Hungary, New Journal of European Criminal Law 2011, vol. 2.

Miąsik D., Controlled Chaos with Consumer Welfare as the Winner - a Study of the Goals of Polish Antitrust Law, YARS 2008, vol. 1(1).

Miąsik D., Wtasność intelektualna a szkoda dla konkurencji w prawie UE, Zeszyty CEN 2012, z. 25.

Miąsik D., Zasada efektywności, [w:] Wróbel A. (red.), Stosowanie prawa Unii Europejskiej przez sady. Tom I, wyd. 2, Lex a Wolters Kluwer business, Warszawa 2010.

Michalak A., Przeciwdziałanie nieuczciwym praktykom rynkowym. Komentarz, C. H. Beck, Warszawa 2008.

Miller N. H., Strategic Leniency and Cartel Enforcement, American Economic Review 2009, vol. 99. 
Miller S. M., Nordlander K., Owens J. C., U.S. Discovery of European Union and U.S. Leniency Applications and Other Confidential Investigatory Materials, CPI Antitrust Journal, marzec 2010(1).

Miwa Y., Ramseyer M., Toward a Theory of Jurisdictional Competition: the Case of the Japanese FTC, Journal of Competition Law and Economics 2005, vol. 1(2).

Molski R., Prywatnoprawna ochrona konkurencji $w$ amerykańskim prawie antytrustowym, KPP 2005, z. 3.

Molski R., Sankcje penalne $w$ prawie kartelowym, [w:] Z. Ofiarski (red.), Księga jubileuszowa z okazji 15-lecia Wydziatu Prawa i Administracji Uniwersytetu Szczecińskiego, Wyd. Naukowe USz, Szczecin 2004.

Morawski L., Wstęp do prawoznawstwa, TNOiK, Toruń 2005.

Moshel W., Fines in European competition law, E.C.L.R. 2011, vol. 32(7).

Motta M., Settlements in cartel cases, [w:] Ehlerman C. D., Marquis M. (red.), European Competition Law Annual 2008: Antitrust Settlements under EC Competition Law, Hart Publishing, Oxford and Portland 2009.

Möllers T. M. J., Heinemann A. (red.), The Enforcement of Competition Law in Europe, Cambridge University Press 2009.

Myrczek E., Dictionary of Law Terms. English-Polish. Polish-English, C. H. Beck, Warszawa 2005.

Nagy C. I., The new Hungarian rules on damages caused by horizontal hardcore cartels: presumed price increase and limited protection for whistleblowers - an analytical introduction, E.C.L.R 2011, vol. 32(2).

Namysłowska-Gabrysiak B., Odpowiedzialność karna osób prawnych, C. H. Beck, Warszawa 2003.

Nazzini R., Nikpay A., Private Actions in EC Competition Law, Competition Policy International 2008, vol. 4(2).

Noble R., Pilsbury S., Is 10 per cent the answer? The role of legal presumptions in private competition litigation, G.C.L.R. 2008, vol. 1(3).

Nowak-Chrząszczyk B., Roszczenie odszkodowawcze $w$ postępowaniu $w$ sprawie o naruszenie wspólnotowego prawa konkurencji, [w:] E. Piontek (red.), Nowe tendencje $w$ prawie konkurencji UE, Oficyna a Wolters Kluwer business, Warszawa 2008.

Nowak-Gruca A., Roszczenie informacyjne w ustawie - Prawo wtasności przemystowej $w$ świetle ekonomicznej analizy prawa, MoP 2008, nr 15.

Nowińska E., du Vall M., Komentarz do ustawy o zwalczaniu nieuczciwej konkurencji, LexisNexis, Warszawa 2010.

Nowińska E., Zakaz nieuczciwych praktyk rynkowych (art. 3 u.p.n.p.r.) i klauzula generalna nieuczciwych praktyk rynkowych (art. 4 u.p.n.p.r), [w:] Nowińska E., Kasprzycki D. (red.), Nieuczciwe praktyki rynkowe. Ocena regulacji, Wyd. Uniwersytetu Jagiellońskiego, Kraków 2012.

O'Kane M., The Law of Criminal Cartels, Oxford 2009.

Ochendowski E., Moc wiążaca aktu administracyjnego, RPEiS 1968, z. 1.

Ochendowski E., Postępowanie administracyjne ogólne, egzekucyjne i sądowoadministracyjne, TNOiK, Toruń 2005. 
Odudu O., Developing private enforcement in the EU: Lessons from the Roberts Court, Antitrust Bulletin 2008, vol. 53(4).

Olejniczak A. (red.) System prawa prywatnego. Prawo zobowiazań - część ogólna, Tom 6, C. H. Beck, Warszawa 2009.

Ożga E., The Great Dictionary of Law and Economics, Vol. I. English-Polsih, C. H. Beck, Warszawa 2006.

Ożga E., Stownik terminologii prawniczej. Część 2 angielsko-polska, Oficyna Wydawnicza Branta, Bydgoszcz 2002.

Page W.H., Antitrust Damage and Economic Efficiency: An Approach to Antitrust Injury, The University of Chicago Law Review 1980, vol. 47(3).

Page W. H., Policy choices in defining the measure of antitrust damages, OECD Journal: Competition Law and Policy 2009, vol. 2.

Pajor T., Uwagi o przyczynieniu się poszkodowanego do powstania szkody, [w:] Pyziak-Szafnicka M. (red.), Odpowiedzialność cywilna. Księga pamiątkowa ku czci Profesora Adama Szpunara, Zakamycze, Kraków 2004.

Parlak S., Passing-On Defence and Indirect Purchaser Standing: Should the Passing-On Defence Be Rejected Now the Indirect Purchaser Has Standing After Manfredi and the White Paper of the European Commission?, World Competition 2010, vol. 33(1).

Paulis E., De Smijter E., Enhanced enforcement of the EC competition rules since 1 May 2004 by the Commission and the NCA's. The Commission's view (paper for the IBA Conference on the Antitrust Reform in Europe, 9-11 March 2005).

Pawłusiewicz K., Brożek B., Prawo karne w świetle ekonomicznej teorii prawa (Uwagi krytyczne), PiP 2002, nr 10.

Pérez Carillo F., Access to documents and transparency: elements to facilitate damages actions arising from competition law infringements in the European Union, [w:] Velasco San Pedro L. A., Alonso Ledesma C., Echebarria Saenz J. A., Herrero Suarez C., Gutierrez Gilsanz J. (red.), Private enforcement of competition law, Lex Nova, Valladolid 2011.

Petrasincu A., Discovery revisited - the impact of the US discovery rules on the European Commission's leniency programme, E.C.L.R. 2011, vol. 32(7).

Piasecki K. (red.), Kodeks Postępowania Cywilnego. Komentarz do art. 1-366. Tom 1, wyd. 5, C. H. Beck, Warszawa 2010.

Piasecki K., Postępowanie sporne rozpoznawcze w sprawach cywilnych, C. H. Beck, Warszawa 2010.

Pieńkoś J., Polsko-angielski stownik prawniczy, Zakamycze, Kraków 2002.

Pietrzykowski K. (red.), Kodeks cywilny. Komentarz. Tom I, C. H. Beck, Warszawa 1999.

Piskorz-Ryń A., Dostęp do informacji publicznej - zasady konstrukcyjne ustawy, KPPubl. 2002, nr 4.

Piszcz A., Kilka uwag do projektu zatożeń ustawy o zmianie ustawy o ochronie konkurencji i konsumentów, iKAR 2012, nr 2(1).

Piszcz A., Uwagi do Wyjaśnień $w$ sprawie wydawania decyzji zobowiazujacej $w$ sprawach praktyk ograniczajacych konkurencje oraz praktyk naruszajacych zbiorowe interesy konsumentów, iKAR 2012, nr 4(1). 
Piszcz A., Still-unpopular Sanctions: Developments in Private Antitrust Enforcement in Poland After the 2008 White Paper, YARS 2012, vol. 5(7).

Piszcz A., Wybrane problemy zwiazane ze stosowaniem prawa antymonopolowego Unii Europejskiej przez sądy krajowe, [w:] N. Szczęch (red.), Księga Jubileuszowa z okazji 5-lecia Wydziału Prawa Wyższej Szkoty Menedżerskiej w Legnicy „Ius est ars boni et aequi”, Legnica 2010.

Pitofsky R., Arbitration and Antitrust Enforcement, The Arbitration Journal 1975, vol. 25(1).

Pniewska M., Problematyka charakteru prawnego odpowiedzialności podmiotów zbiorowych za czyny zabronione pod groźba kary w prawie polskim, Studia IuridicaToruniensia 2006, Tom VI.

Podrecki P., Civil Law Actions in the Context of Competition Restricting Practices Under Polish Law, YARS 2009, vol. 2(2).

Podrecki P., Porozumienia monopolistyczne $i$ ich cywilnoprawne skutki, Zakamycze, Kraków 2000.

Podrecki P., Środki ochrony praw wtasności intelektualnej, LexisNexis, Warszawa 2010

Polden D. J., Antitrust Standing and the Rule Against Resale Price Maintanance, Cleveland State Law Review 1989, vol. 37(2).

Polinsky A.M., Schavell S., The Theory of Public Enforcement of Law, Discussion Paper No. 529, Harvard Law School, 10/2005.

Posner R.A., Antitrust Law, 2nd edition, The University of Chicago Press 2001.

Postulski W., Zasada efektywnej ochrony praw wspólnotowych, [w:] Wróbel A. (red.), Stosowanie prawa Unii Europejskiej przez sądy, Zakamycze, Kraków 2005.

Postulski W., Jednolite $i$ efektywne stosowanie prawa wspólnotowego przed sadami państw członkowskich, Przegląd Sądowy 2002, nr 6.

Poździk R., Glosa do uchwaty SN z 23 lipca 2008 r., sygn. III CZP 52/08, OSP 2009, nr 7-8.

Półtorak N., Odpowiedzialność odszkodowawcza państwa w prawie Wspólnot Europejskich, Zakamycze, Kraków 2002.

Prechal S., de Leeuw M.E., Transparency: A General Principle of EU Law?, [w:] Bernitz U., Nergelius J., Cardner C. (red.), General Principles of EU Law in a Process of Development, Kluwer Law International 2008.Prejs E., Udostepnianie danych osobowych internatów dla celów postępowania cywilnego - glosa do wyroku ETS z 29.01.2008 r. w sprawie C-275/06 Productores de Música de España (Promusicae) v. Telefónica de España SAU, EPS 2009, nr 4.

Pruś P., Stefańska E., Sieńko M., Tomaszewski K., Radwan M., Manowska M., Kodeks postępowania cywilnego. Komentarz, LexisNexis, Warszawa 2011.

Quoos M. A., Ograniczenia dotyczace powotywania twierdzen, zarzutów i dowodów na gruncie systemu prekluzji $w$ procesie cywilnym (cz. 2), Palestra 2007, nr 1-2.

Radwański Z., Prawo cywilne- część ogólna, C. H. Beck, Warszawa 2007.

Radwański Z. (red.), System prawa prywatnego. Prawo cywilne - część ogólna, Tom 2, C. H. Beck, Warszawa 2008.

Rajski J., Rola sądów arbitrażowych w procesie postęujacej europeizacji prawa kontraktów, e-Przegląd Arbitrażowy 2011, nr 4. 
Redelbach A., Wronkowska S., Ziembiński Z., Zarys teorii państwa i prawa, Wyd. Naukowe PWN, Warszawa 1992.

Reich N., Horizontal liability in EC law: hybridization of remedies for compensation in case of breaches of EC rights, CMLR 2007, vol. 44(3).

Reich N., The "Courage” Doctrine: Encouraging or Discouraging Antitrsut Injuries?, CMLR 2005, vol. 42(1).

Rejdak M., Pietkiewicz P., Ustawa o dochodzeniu roszczeń w postępowaniu grupowym. Komentarz, LexPolonica 2011.

Richards S., Thevarajaha S., Liability of directors under competition law, E.C.L.R. 2012, vol. 33(1).

Richman B. D., Murray Ch. R., Rebuilding Illinois Brick: A Functionalist Approach to the Indirect Purchaser Rule, Southern California Law Review 2007, vol. 81.

Rizutto F., Does the European Community have legal competence to harmonise national procedural rules governing private actions for damages from infringements of European Community antitrust rules?, G.C.L.R. 2009, vol. 2(1).

Rizutto F., The private enforcement of European Union competition law: what next?, G.C.L.R. 2010, vol. 3(2).

Rizutto F., The procedural implication of Pfleiderer for the private enforcement of European Union competition law in follow-up actions for damages, G.C.L.R. 2011, vol. 4(3).

Roach K., Trebilcock M.J., Private enforcement of competition laws, Osgoode Hall Law Journal 1996, vol. 34(3).

Rodger B. J., MacCulloch A., Community Competi tion Law Enforcement Deregulation and Re-regulation: The Commision, National Authorities and Private Enforcement, Columbia Journal of European Law 1998, vol. 4.

Rodziewicz J., Prejudycjalność w postępowaniu cywilnym, Arche, Gdańsk 2000.

Rogalski M., Dochodzenie roszczeń majątkowych a powaga rzeczy osadzonej, [w:] Ćwiąkalski Z., Artymiak G. (red.), Karnomaterialne i procesowe aspekty naprawienia szkody $w$ świetle kodyfikacji karnych z 1997 r. i propozycji ich zmian, Oficyna a Wolters Kluwer business, Warszawa 2010.

Romanowski M., Dziatanie na szkodę spótki - uwagi po uchyleniu art. 585 k.s.h., PPH 2012, nr 4.

Rosenberg D., Sullivan J. P., Coordinating Private Class Action and Public Agency Enforcement of Antitrust Law, The Harvard John M. Olin Discussion Paper Series (No. 523), 08/2005.

Rosiak P., The ne bis in idem Principle in Proceedings Related to Anti-Competitive Agreements in EU Competition Law, YARS 2012, vol. 5(6).

Rother Ch., Staebe E., Private antitrust damage claims in Germany - legal foundation and recent trends, G.C.L.R. 2012, vol. 5(1).

Róziewicz-Ładoń K., Postępowanie przed Prezesem Urzędu Ochrony Konkurencji $i$ Konsumentów $w$ zakresie przeciwdziatania praktykom ograniczajacym konkurencje, LEX a Wolters Kluwer business, Warszawa 2011.

Rumak E., Sitarek P., Polish Leniency Programme and its Intersection with Private Enforcement of Competition Law, YARS 2009, vol. 2(2). 
Rylski P., Dziatanie sądu z urzędu a faktyczna podstawa wyroku cywilnego, Oficyna a Wolters Kluwer business, Warszawa 2009.

Rypina M., Wierzbowski M., Umowa z organem $w$ postępowaniu administracyjnym, PiP 2010, nr 4.

Sachajko M., Istota i charakterystyka prawna antymonopolowych kar pieniężnych, RPEiS 2002, nr 1.

Sachajko M., Administracyjna kara pieniężna jako element systemu sankcjonowania naruszeń wspólnotowych oraz polskich zakazów praktyk ograniczających konkurencję, [w:] Banasiński C., Kępiński M., Popowska B., Rabska T. (red.), Aktualne problemy polskiego i europejskiego prawa ochrony konkurencji, UOKiK, Warszawa 2006.

Sakowicz A., Zasada ne bis in dem w prawie karnym, Temida 2, Białystok 2011.

Samuel G., Public and Private Law: A Private Lawyer's Response, Modern Law Review 1983, vol. 46(5).

Sarkowicz R., Stelmach J., Teoria prawa, Wyd. UJ, Kraków 1998.

Schepel H., The Enforcement of EC Law in Contractual Relations: Case Studies in How Not to "Constitutionalize" Private Law, ERPL 2004, vol. 5.

Schinkel M. P., Rüggeberg J., Consolidating Antitrust Damages in Europe: A Proposal for Standing in Line with Efficient Private Enforcement, Amsterdam Center for Law and Economics, Working Paper No. 2006-04.

Schinkel M. P., Tuinstra J., Rüggeberg J., Illinois Walls: how barring indirect purchaser suits facilitates collusion, RAND Journal of Economics 2008, vol. 39(3).

Segal I. R., Whinston M., Public v. Private Enforcement of Antitrust Law: A Survay, Stanford Law and Economics Olin Working Paper No. 335.

Seidler G. L., Groszyk H., Malarczyk J., Pieniążek A., Wstęp do nauki o państwie i prawie, Morpol, Lublin 2000.

Shavell S., The Optimal Structure of Law Enforcement, Journal of Law and Economics 1993, vol. XXXVI.

Sebok A. J., Punitive Damages: From Myth to Theory, Iowa Law Review 2007, vol. 92.

Sibiga G., Dostęp do informacji publicznej a prawa do prywatności jednostki i ochrony jej danych osobowych, Sam. Teryt. 2003, nr 11.

Sibiga G., Wtaściwość sądów administracyjnych i powszechnych w sprawach z zakresu dostępu do informacji publicznej, [w:] Błachucki M., Górzyńska T. (red.), Aktualne problemy rozgraniczenia wtaściwości sądów administracyjnych i powszechnych, Naczelny Sąd Administracyjny, Warszawa 2011.

Sieradzka M., Dochodzenie roszczeń odszkodowawczych z tytułu naruszenia unijnego i krajowego prawa konkurencji (część I i II), PUG 2012, nr 1 i 2.

Sieradzka M., Dochodzenie roszczeń za naruszenie unijnych $i$ krajowych reguta konkurencji a kwestie prejudycjalności rozstrzygnięć organów ochrony konkurencji, PPH 2010, nr 12.

Sieradzka M., Glosa do uchwaty SN z dnia 8 kwietnia 2010 r., III SZP 1/10, PUG 2011, nr 5.

Sieradzka M., Pozew grupowy jako instrument prywatnoprawnej ochrony interes konsumentów z tytułu naruszenia regut konkurencji, LEX a Wolters Kluwer business, Warszawa 2012. 
Sieradzka M., Ustawa o dochodzeniu roszczeń w postępowaniu grupowym. Komentarz, Oficyna a Wolters Kluwer business, Warszawa 2010.

Silton H. M., Davis C. S., Levisohn D., Pfleiderer AG v. Bundeskartellamt: A Step Forward in Efforts to Obtain Discovery from European Commission Antitrust Proceedings, Westlaw Journal Antitrust, 2011, vol. 19(6).

Sitniewski P., Ustawa o dostępie do informacji publicznej. Komentarz, Presscom, Wrocław 2011.

Skoczny T., Instytucjonalne modele wdrażania regut konkurencji na świecie - wnioski dla Polski, RPEiS 2011, z. 2.

Skoczny T., Konsekwencje przysztego systemu stosowania art. 81 i 82 TWE dla prawa i orzecznictwa $w$ zakresie ochrony konkurencji w Polsce (cz. II), PUE 2001, nr 5.

Skoczny T., Stosowanie wspólnotowych regut konkurencji - także w Polsce - po 1 maja 2004 r., KPPubl. 2004, z. 2.

Skoczny T., Janusz R., Postępowanie antymonopolowe jako szczególne postępowanie administracyjne, [w:] Instytucje wspótczesnego prawa administracyjnego. Księga jubileuszowa prof. zw. dra hab. Józefa Filipka, Kraków 2001.

Skoczny T., Jurkowska A., Miąsik D. (red.), Ustawa o ochronie konkurencji i konsumentów. Komentarz, C. H. Beck, Warszawa 2009.

Skubisz R., Roszczenie o udzielenie informacji w prawie wtasności przemystowej (w świetle dyrektywy $n r$ 2004/48 i prawa polskiego), [w:] Gudowski J., Weitz K. (red.), „Aurea praxis, aurea theoria”. Ksiega pamiatkowa ku czci Profesora Tadeusza Erecińskiego. Tom 2, LexisNexis, Warszawa 2011.

Skupiński J., Odpowiedzialność podmiotów zbiorowych na tle ustawy z dnia 28 października 2002 roku (próba zarysu problematyki), [w:] Aktualne problemy prawa i procesu karnego; ksiega ofiarowana Profesorowi Janowi Grajewskiemu, Gdańskie Studia Prawnicze, 2003, t. XI.

Slater D., Thomas S., Waelbroeck D., Competition law proceedings before the European Commission and the right to a fair trial: no need for reform?, European Competition Journal 2009, vol. 5(1).

Stownik prawniczy polsko-angielski, Wyd. Polskiej Akademii Nauk, Ossolineum, Wrocław 1986.

Smyczyński T., Skutki cywilnoprawne aktu administracyjnego, Nowe Prawo 1971, nr 1.

Sobczak K., Prawne instrumenty polityki antymonopolowej, PUG 1989, nr 4.

Soltesz U., Due process and judicial review - mixed signals from Luxembourg in cartel cases, E.C.L.R. 2012, vol. 33(5).

Soltesz U., Von Kockritz Ch., EU cartel settlements in practice - the future of EU cartel law enforcement?, E.C.L.R. 2011, vol. 32(5).

Sołtysiński S., Sankcje w ustawie o przeciwdziałaniu praktykom monopolistycznym w gospodarce narodowej, RPEiS 1987, z. 4.

Sołtysiński S., $Z$ doświadczeń programu leniency $w$ Brukseli $i w$ Warszawie, [w:] Banasiński C. (red.), Prawo konkurencji - stan obecny oraz przewidywane kierunki zmian, UOKiK, Warszawa 2006.

Soyez V., What the international legal community think about the European Commission's White Paper?, G.C.L.R. 2008, vol. 1(3). 
Sproul G., UK courts rule out recovery of competition penalties from directors and employees, G.C.L.R. 2011, vol. 4(2).

Stahl M., Sankcje administracyjne - problemy węztowe, [w:] Stahl M., Lewicka R., Lewicki M. (red.), Sankcje administracyjne, LEX a Wolters Kluwer business, Warszawa 2011.

Stankiewicz R., Likwidacja procedur hybrydowych - krok $w$ dobrym kierunku czy szkodliwy dogmatyzm?, [w:] Błachucki M., Górzyńska T. (red.), Aktualne problemy rozgraniczenia właściwości sądów administracyjnych $i$ powszechnych, Naczelny Sąd Administracyjny, Warszawa 2011.

Stankiewicz R., O konieczności zwiększenia partycypacji podmiotów trzecich w postępowaniu antymonopolowym, iKAR 2012, $\mathrm{nr} 2$.

Stankiewicz R., Kilka uwag o istocie administracyjnej kary pieniężnej z tytułu zwtoki w wykonaniu orzeczenia Prezesa UOKiK (art. 107 ustawy antymonopolowej), [w:] Stahl M., Lewicka R., Lewicki M. (red.), Sankcje administracyjne, LEX a Wolters Kluwer business, Warszawa 2011.

Stankiewicz R., Pawełczyk M., Ochrona tajemnicy przedsiębiorstwa w postępowaniu antymonopolowym, Radca Prawny 2005, nr 5.

Stawecki T., Winczorek P., Wstęp do prawoznawstwa, C. H. Beck, Warszawa 1996.

Stawicki A., Competence of Common Courts in Poland in Competition Matters, YARS 2012, vol. 5(6).

Stawicki A., Poland, [in:] G. Blanke, R. Nazzini (red.), International Competition Litigation: A Multi-jurisdictional Handbook, Kluwer Law International BV 2012.

Stawicki A., Stawicki E. (red.), Ustawa o ochronie konkurencji i konsumentów. Komentarz, LEX a Wolters Kluwer business, Warszawa 2011.

Stefanicki R., Ochrona konsumenta w prawie konkurencji (wybrane zagadnienia), [w:] M.B. Król (red.), Wzmocnienie roli obywateli. Polityka Unii Europejskiej dotyczaca ochrony konsumentów, Fundacja dla Uniwersytetu Jagiellońskiego, Kraków 2012.

Stefanicki R., Prywatnoprawne środki dochodzenia odszkodowania z tytutu naruszenia przez przedsiębiorców prawa konkurencji, [w:] Prawo handlowe XXI wieku. Czas stabilizacji, ewolucji czy rewolucji. Księga jubileuszowa Profesora Józefa Okólskiego, Wolters Kluwer Polska - LEX, Warszawa 2010.

Stefanicki R., Ustawa o przeciwdziataniu nieuczciwym praktykom rynkowym. Komentarz, LexisNexis, Warszawa 2009.

Stefanicki R., Zasada ne bis in idem $w$ procesie wykonywania prawa konkurencji, PPH 2012, nr 8.

Stefaniuk M., Zasady wymierzania kar pieniężnych $w$ polskim prawie antymonopolowym, [w:] Stahl M., Lewicka R., Lewicki M. (red.), Sankcje administracyjne, LEX a Wolters Kluwer business, Warszawa 2011.

Steinle Ch., Hattass J., The tide has turned: private enforcement of competition law in Germany, G.C.L.R. 2008, vol. 1(1).

Stelmachowski A., Zarys teorii prawa cywilnego, Wyd. Prawnicze PWN, Warszawa 1998.

Stephan A., How Dishonesty Killed the Cartel Offence, Criminal Law Review 2011, vol. 6 . 
Strzyczkowski K., Nowe prawo konkurencji. Uwagi o projekcie ustawy o ochronie konkurencji i konsumentów, PUG 2000, nr 9.

Stürner R., Duties of Disclosure and Burden of Proof in the Privte Enforcement of European Competition Law, [w:] Basedow J. (red.), Private Enforcement of Competition Law, Kluwer Law International 2007.

Suderow J., Access to evidence in European Commission proceedings and the limits established by its leniency programmes, [w:] Velasco San Pedro L. A., Alonso Ledesma C., Echebarria Saenz J.A., Herrero Suarez C., Gutierrez Gilsanz J. (red.), Private enforcement of competition law, Lex Nova, Valladolid 2011.

Swora M., Trela A., Amicus curiae w postepowaniu antymonopolowym?, Administracja. Teoria-Dydaktyka-Praktyka 2006, nr 1(2).

Sylwestrzak D., Postępowanie przed Prezesem Urzędu Ochrony Konkurencji i Konsumentów, PUG 2002, nr 9.

Syp Sz., O odpowiedzialności osób fizycznych $w$ polskim prawie konkurencji - de lege lata $i$ de lege ferenda, iKAR 2012, $\mathrm{nr} 4$ (1).

Szpunar M., Odpowiedzialność podmiotu prywatnego z tytutu naruszenia prawa wspólnotowego, Oficyna a Wolters Kluwer Business, Warszawa 2008.

Szpunar A., Zakres obowiazku naprawienia szkody, PiP 1960, nr 1.

Szpunar M., Stosowanie prawa konkurencji UE przez sądy arbitrażowe, [w:] Okólski J. (red.), Księga pamiatkowa 60-lecia Sadu Arbitrażowego przy Krajowej Izbie Gospodarczej, LexisNexis, Warszawa 2010.

Szustakiewicz P., Postępowanie $w$ spawie bezczynności w zakresie udzielania informacji publicznej w orzecznictwie sądów administracyjnych, PPP 2012, nr 6.

Szustakiewicz P., Ustawa o zamówieniach publicznych a przestępstwo utrudniania przetargu, Prok. i Prawo 2004, nr 2.

Szustakiewicz P., Zasady ustawy o dostęie do informacji publicznej, Jurysta 2002, nr 1.

Szwaja J. (red.), Ustawa o zwalczaniu nieuczciwej konkurencji. Komentarz, C. H. Beck, Warszawa 2012.

Szwaja J., Tischner A., Dokąd zmierza prawo zwalczania nieuczciwej konkurencji?, [w:] Barta J., Matlak A. (red.), Prawo wtasności intelektualnej wczoraj, dziś i jutro, PIPWI UJ, Oficyna a Wolters Kluwer business, Kraków 2007, z. 100.

Szwarczyk M., Michalska-Warias A., Piórkowska-Flieger J., Bojarski T. (red.), Kodeks karny. Komentarz, LexPolonica Maxima/2011.

Szydło M., Swoboda dziatalności gospodarczej, C. H. Beck, Warszawa 2005.

Szydło W., Nieważność czynności prawnych będacych przejawem nadużycia przez przedsiębiorce pozycji dominujacej, MoP 2010, nr 4.

Taggart M., 'The Peculiarities of the English': Resisting the Public/Private Law Distinction, [w:] Craig P., Rawlings R. (red.), Law and Administration in Europe. Essays in Honour of Carol Harlow, Oxford University Press 2003.

Targosz T., Ustawa o przeciwdziałaniu nieuczciwym praktykom rynkowym - model ochrony, zasady, zakres ochrony, implikacje dla systemu prawa konkurencji $i$ konsumentów, [w:] Nowińska E., Kasprzycki D. (red.), Nieuczciwe praktyki rynkowe. Ocena regulacji, Wyd. Uniwersytetu Jagiellońskiego, Kraków 2012. 
Terhechte J. P., Enforcing European Competition Law - Harmonizing Private and Public Approaches in a More Differentitated Enforcement Model, [w:] Basedow J., Terhechte J. P., Tichy L. (red.), Private enforcement of competition law, Nomos, 2010.

Thépot F., Leniency and Individual Liability: Openining the Black Box of the Cartel, The Competition Law Review 2011, vol. 7(2).

Tischner A., Harmonizacja prawa polskiego $z$ wymogami dyrektywy $w$ sprawie egzekwowania praw wtasności intelektualnej - cz. I, MoP 2005, nr 13.

Tischner A., Miejsce implementacji dyrektywy 2005/29/WE do prawa polskiego, [w:] Nowińska E., Kasprzycki D. (red.), Nieuczciwe praktyki rynkowe. Ocena regulacji, Wyd. Uniwersytetu Jagiellońskiego, Kraków 2012.

Tischner A., Targosz T., Dostosowanie polskiego prawa wtasności intelektualnej do wymogów prawa wspólnotowego. Uwagi na tle projektu z dnia 24 maja $2006 \mathrm{r}$. ustawy o zmianie ustawy o prawie autorskim i prawach pokrewnych oraz o zmianie innych ustaw, [w:] Matlak A. (red.), Zagadnienia prawa autorskiego, PIPWI UJ, Oficyna a Wolters Kluwer business, Kraków 2007.

Trzaskowski R., Kompetencja sądu do ustalania nieważności czynności prawnych będacych przejawem nadużywania pozycji dominujacej oraz nieważności porozumień ograniczających konkurencję, Palestra 2009, nr 9-10.

Turno B., Leniency - program tagodzenia kar pieniężnych $w$ polskim prawie ochrony konkurencji, LEX a Wolters Kluwer business, Warszawa 2013.

Turno B., Model sądowej kontroli decyzji Prezesa Urzędu Ochrony Konkurencji i Konsumentów, PiP 2012, nr 10.

Twarowski A., Odpowiedzialność za naruszenia zwiazane z udzielaniem zamówień publicznych - zagadnienia ogólne, Prawo Zamówień Publicznych 2006, nr 4.

Twarowski Ł., Charakter prawny obowiqzku naprawienia szkody - uwagi krytyczne, [w:] Ćwiąkalski Z., Artymiak G. (red.), Karnomaterialne i procesowe aspekty naprawienia szkody $w$ świetle kodyfikacji karnych z 1997 r. i propozycji ich zmian, Oficyna a Wolters Kluwer business, Warszawa 2010.

Tyszkiewicz L., Hoc S., Wąsek A., Filipkowski W., Siwik Z., Kulik M., Bojarski M., Radecki W., Hofmański P., Sienkiewicz Z., Wilk L., Górniok O., Filar M., Kalitowski M., Paprzycki L. K., Pływaczewski E., Stefański R. A., Kodeks karny. Komentarz, LexiNexis, Warszawa 2010.

Ulasiewicz M., Ograniczenia dostępu do informacji publicznej - zagadnienia wybrane, PPP 2010, nr 9.

Ulasiewicz M., Pojęcie i rodzaj informacji publicznej, PPP 2009, nr 11.

Van Den Bergh R., Keske S., Private Enforcement of European Competition Law: Quo Vadis?, European Review of Contract Law 2007, nr 4.

Van den Heuvel H., Civil Law Consequences of Violation of the Antitrust Provisions of the Rome Treaty, American Journal of Comparative Law 1963, vol. 12(2).

Vandenborre I., The confidentiality of EU Commission cartel records in civil litigation: the ball is in the EU court, E.C.L.R. 2011, vol. 32(3).

Vandenborre I., Thomas S. B., European Court of Justice provides limited guidance on the disclosure of leniency documents, E.C.L.R. 2011, vol. 32(10). 
Van Dijk T., Verboven F., Implementing the passing-on defence in cartel damages actions, G.C.L.R. 2010, vol. 3(3).

Van Gerven W., Of Rights, Remedies and Procedures, CMLR 2000, vol. 37(3).

Van Gerven W., Substantive Remedies for the Private Enforcement of EC Antitrust Rules Before National Courts, [w:] Ehlermann C. D., Atanasiu I. (red.), European Competition Law Annual 2001: Effective Private Enforcement of EC Antitrust Rules, Hart Publishing, Oxford, Portland, Oregon 2003.

Van Gerven W., Private Enforcement of EC Competition Rules in the ECJ - Courage v. Crehan and the Way Ahead, [w:] Basedow J. (red.), Private Enforcement of EC Competition Law, Kluwer Law International 2007.

Verboven F., van Dijk T., Cartel damages claims and the passing-on defense, Journal of Industrial Economics 2009, vol. 57(3).

Voet van Vormizeele P., The fault requirement in European private antitrust litigation and compliance programmes as exculpating or mitigating factor, G.C.L.R. 2010, vol. 3(1).

Wagner von-Papp F., What If All Bid-Riggers Went To Prison and Nobody Noticed? Criminal antitrust law enforcement in Germany, [w:] Beaton-Wells C., Ezrachi A. (red.), Criminalising Cartels: Critical Studies of International Regulatory Movement, Hart Publishing, Oxford 2010.

Waller S. W., Towards a Constructive Public-Private Partnership to Enforce Competition Law, World Competition 2006, vol. 29(3).

Waller S. W. (red.), Issues in Competition Law and Policy, volume 3, ABA Section of Antitrust Law, 2008.

Waltoś S., O odpowiedzialności karnej podmiotów zbiorowych, Edukacja Prawnicza 2003, nr 12.

Werden G. J., Hammond S. D., Barnett B. A., Deterrence and detection of cartels: using all the tools and sanctions, Antitrust Bulletin 2011, vol. 56(2).

Whelan P., A Principled Argument for Personal Criminal Sanctions As Punishment under EC Cartel Law, The Competition Law Review 2007, vol. 4(1).

Whish R., Competition Law, 5th ed., LexisNexis Butterworths 2003.

White S., Rights of defence in administrative investigations: access to the file in EC investigations, Review of European Administrative Law 2009, vol. 2(1).

Wilcox V., Punitive Damages in England [w:] Koziol H., Wilcox V. (red.), Punitive Damages: Common Law and Civil Law Perspectives, Wien 2009.

Wilczyńska A., Interes publiczny $w$ prawie stanowionym $i$ orzecznictwie Trybunatu Konstytucyjnego, PPH 2009, nr 6.

Wils W. P. J., Is Criminalization of EU Law The Answer, World Competition 2005, vol. 28(2).

Wils W. P. J., Should Private Antitrust Enforcement Be Encouraged in Europe?, World Competition 2003, vol. 26(3).

Wils W. P. J., The Optimal Enforcement of EC Antitrust Law, Kluwer Law International, 2002.

Wils W. P. J., The Principle of the Ne Bis in Idem in EC Antitrust Enforcement: A Legal and Economic Analysis, World Competition 2003, vol. 26(2). 
Wils W. P. J., The Relationship Between Public Antitrust Enforcement and Private Actions for Damages, World Competition 2009, vol. 32(1).

Wilsher D., Reconciling the public and private dimensions of competition litigation in the European Union, G.C.L.R. 2011, vol. 4(2).

Wincenciak M., Sankcje $w$ prawie administracyjnym $i$ procedura ich wymierzania, Oficyna a Wolters Kluwer business, Warszawa 2008.

Winczorek P., Komentarz do Konstytucji Rzeczpospolitej Polskiej z dnia 2 kwietnia 1997 r., Liber, Warszawa 2000.

Winiarz J., Obowiazek naprawienia szkody, Wydawnictwa Prawnicze, Warszawa 1970.

Włodarska-Dziurzyńska K., Sankcje w prawie konsumenckim na przykładzie wybranych umów, LexisNexis, Warszawa 2008.

Wojcieszko-Głuszko E., Roszczenie o złożenie oświadczenia $w$ sprawie nieuczciwej konkurencji, [w:] Nowińska E., du Vall M. (red.), Księga pamiątkowa ku czci Profesora Janusza Szwaji, ZNUJ-PIPWI 2004, z. 88.

Woodgate T., I. Filippi, The decision that binds: follow on actions for competition damages after Enron, E.C.L.R. 2012, vol. 33(4).

Woods D., Private Enforcement of Antitrust Rules - Modernization of EU Rules and the Road Ahead, Loyola Consumer Law Review 2004, vol. 16(4).

Woolf H., Public Law - Private Law. Why the Divide? Personal View, Public Law 1986.

Wojtaszek E., Ochrona konkurencji a swoboda kontraktowania $w$ umowach franchisingu, PiP 1996, nr 10.

Wojtczak D. E., Zwalczanie zmów przetargowych w Polsce, PiP 2010, nr 7.

Wright K., European Commission opinions to national courts in antitrust cases: consistent application and the judicial-administrative relationship, ESRC Centre for Competition Policy Working Paper Series 2008/24.

Wróbel A., Kowalik-Bańczyk K., Szwarc-Kuczer M. (red.), Traktat o funkcjonowaniu Unii Europejskiej. Komentarz. Tom II, LEX a Wolters Kluwer business, Warszawa 2012.

Wróbel A., Kowalik-Bańczyk K., Szwarc-Kuczer M. (red.), Traktat ustanawiający Wspólnote Europejska. Komentarz, Tom II, LEX a Wolters Kluwer business, Warszawa 2009.

Wróbel W., Zoll A., Polskie prawo karne. Część ogólna, Znak, Kraków 2010.

Wróblewski J., Wstęp do prawoznawstwa (wyd. IV rozszerzone), Wyd. Uniwersytetu Łódzkiego, Łódź 1984.

Wróblewski J., Sądowe stosowanie prawa, PWN, Warszawa 1972.

Wurmnest W., A New Era for Private Antitrust Litigation in Germany? A Critical Appraisal of the Modernized Law againts Restraints of Competition, German Law Journal 2005, vol. 6(8).

Wyrzykowski M., Pojęcie interesu spotecznego w prawie administracyjnym, Wyd. Uniwersytetu Warszawskiego, Warszawa 1986.

Zdyb M., Sieradzka M. (red.), Ustawa o zwalczaniu nieuczciwej konkurencji. Komentarz, LEX a Wolters Kluwer business, Warszawa 2011.

Zekos G. I., Antitrust/Competition Arbitration in EU verus U.S. Law, Journal of International Arbitration 2008, vol. 25(1). 
Zieliński A. (red.), Kodeks Postępowania Cywilnego. Komentarz, C. H. Beck, Warszawa 2011.

Zientara A., Przestępstwo nadużycia zaufania z art. 296 kodeksu karnego, Oficyna a Wolters Kluwer business, Warszawa 2010.

Zimmermann J., Prawo administracyjne, Oficyna a Wolters Kluwer, Warszawa 2010.

Zoll A. (red.), Kodeks karny. Czesść ogólna. Komentarz, LEX a Wolters Kluwer business, Warszawa 2007.

Zygmont B., Konfiskata mienia a przepadek korzyści majątkowej, Prok. i Pr. 2001, nr 11.

Żurawik A., Klauzula interesu publicznego w prawie gospodarczym krajowym $i$ unijnym, EPS 2013, nr 1.

Żurawik A., Problem publicyzacji prawa prywatnego $w$ kontekście ustrojowym, PiP 2010, nr 5.

Inne (raporty, sprawozdania, materiały konferencyjne, itp.)

An Antitrust Primer for Federal Law Enforcement Personnel, Antitrust Division, U.S. Department of Justice, August 2003 (revised April 2005) (dokument dostępny pod adresem: http://www.justice.gov/atr/public/guidelines/209114.htm).

Antitrust Division Manual, 4th edition, September 2008.

Barnett T. O (Assistant Attorney General, Antitrust Division, U.S. Department of Justice), Criminal Enforcement of Antitrust Laws: The U.S. Model, Fordham Competition Law Institute's Annual Conference on International Antitrust Law and Policy, New York, 14 września 2006 r., dostępne pod adresem: http://www. justice.gov/atr/public/speeches/218336.htm

Collins P., Interaction between public enforcement and private damages actions: competition authorities' perspective, Valladolid, 14 października 2010 r. (wystąpienie Chairman of OFT, dostępne pod adresem: http://www.oft.gov.uk/shared_oft/ speeches/689752/speech1210.pdf).

Commission Staff Working Papier accompanying the Communication from the Commission to the European Parliament and Council - Report on the functioning of Regulation 1/2003, COM(2009)206 final.

Criminal Enforcement. Fines and Jail Charts 2000-2011, US Department of Justice Antitrust Division (dokument dostępny pod adresem: http://www.justice.gov/atr/ public/criminal/264101.html).

Decyzja Europejskiego Rzecznika Praw Obywatelskich z dnia 6 kwietnia 2010 r. zamykającej postępowanie w sprawie skargi 3699/2006/ELB przeciwko Komisji (dokument dostępny pod adresem: http://www.ombudsman.europa.eu/cases/ decision.faces/en/4752/html.bookmark).

Hammonnd A., Penrose R., Proposed criminalization of cartels in the UK, Office of Fair Trading, November 2001.

Hess B., Pfeiffer T., Mertens M., Sabanogullari L., Evaluation of contributions to the public consultation and hearing: „Towards a Coherent European Approach to Collective Redress”, Study JUST/2010/JCIV/CT/0027/A4, 2011. 
Jenny F., Deterrence and Compliance. The Organisational Dimension of Implementing Competition Law (wystąpienie na 14th Annual Irish European Law Forum, Dublin 23 marca 2012 r.; dokument dostępny pod adresem: http://www.tca. ie/images/uploaded/documents/2012-03-23\%20Jenny\%20-\%20Deterrence $\% 20$ and $\% 20$ compliance- $\% 20$ The $\% 20$ organisational $\% 20$ dimension $\% 20$ of $\% 20 \mathrm{imple}-$ menting\%20competition\%20law\%20-\%20slides.pdf).

Komninos A. P., Relationship between Public and Private Enforcement: quod Dei Deo, quod Caesaris Caesari (referat wygłoszony na konferencji Integrating public and private enforcement of competition law: Implications for courts and agencies, Florencja, 17-18 czerwca 2011 r.), dostępny pod adresem: http://papers.ssrn. com/sol3/papers.cfm?abstract_id $=1870723$.

Kovacic W. E., Private Participation in the Enforcement of Public Competition Law (referat wygłoszony na: British Institution of International \& Comparative Law Third Annual Conference on International and Comparative Competition Law: The Transatlantic Antitrust Dialogue, Londyn, maj 2003); tekst dostępny pod adresem: http://www.ftc.gov/speeches/other/030514biicl.shtm.

Kubas A., Kos R., Opinia w sprawie projektu ustawy o dochodzeniu roszczeń w postępowaniu grupowym (druk sejmowy 1829), 20.10.2009 r.

Lipski J., Opinia prawna $w$ sprawie projektu ustawy o dochodzeniu roszczeń $w$ postępowaniu grupowym [druk sejmowy nr 1829], 21 maja 2009 r.

Montt P., Cartel Enforcement and Leniency Programmes: The Experience of Chile, wrzesień 2010, dokument dostępny pod adresem: http://www.ucl.ac.uk/laws/conferences/latin-america/montt_ucl_sept2010.pdf.

Private action in competition law: effective redress for consumer and business, Discussion paper, OFT, April 2007.

Private action in competition law: effective redress for consumer and business. Recommendations from the OFT, November 2007.

Proponowane przez UOKiK $i$ inne pożadane zmiany $w$ ustawie o ochronie konkurencji z 2007 r. Opinia Grupy Roboczej ds. nowelizacji uokik z 2007 r. przy Centrum Studiów Antymonopolowych i Regulacyjnych (CARS UW), Warszawa, czerwiec 2012, (dokument dostępny pod adresem: http://www.cars.wz.uw.edu.pl/doradztwo/pdf/Opinia_GR_CARS-fin.pdf).

Quantifying Antitrust Damages. Towards non-binding guidance for courts. Study prepared for the European Commission, December 2009, Publication Office of the European Union, Luxembourg 2010.

Recomendation Concerning Effective Action Against Hard Core Cartels, OECD Council 1998.

Renda A., Peysner J., Riley A. J., Rodger B. J., Van den Berg R. J., Keske S., Pardolesi R., Camili L. R., Caprile P., Making antitrust damages more effective in the European Union: welfare impact and potential scenarios, Report for the European Commission, Brussels, Rotterdam, Rome, December 2007 (dokument dostępny pod adresem: http://ec.europa.eu/competition/antitrust/actionsdamages/files_white_paper/impact_study.pdf) 
Resolution of the Meeting of Heads of the European Competition Authorities of 23 May 2012 - Protection of leniency material in the context of civil damages actions (dokument dostępny pod adresem: http://ec.europa.eu/competition/ecn/ leniency_material_protection_en.pdf).

Riley A., The Modernisation of $\bar{E} U$ Anti-Cartel Enforcement: Will the Commission Grasp the Opportunity?, CEPS Special Report, January 2010.

Sprawozdanie z wdrożenia w Polsce dyrektywy 2004/48/WE Parlamentu Europejskiego i Rady z dnia 29 kwietnia 2004 r. w sprawie egzekwowania praw własności intelektualnej, Ministerstwo Kultury i Dziedzictwa Narodowego, Warszawa, kwiecień 2009 (dokument dostępny pod adresem: http://www.mkidn.gov. $\mathrm{pl} /$ media/docs/enforcement_sprawozdanie_przyjete_przez_KERM.pdf

US Sentencing Commission Guidelines for the United States Courts, 18 U.S. C. Waelbroeck D., Slater D., Evan-Shoshan G., Study on the conditions of claims for damages in case of infringement of EC competition rules. Comparative report, 31 sierpnia 2004 (dokument dostępny pod adresem: http://ec.europa.eu/competition/antitrust/actionsdamages/comparative_report_clean_en.pdf.

Waszkiewicz R., Postępowanie grupowe (class action) w systemie polskiego postępowania cywilnego - aspekty praktyczne (niepublikowane materiały z konferencji „Pozwy grupowe - kolejny krok w kierunku wzmocnienia ochrony konsumentów", Warszawa, 22 kwietnia 2010 r.).

White Paper: A World Class Comeptition Regime, Department of Trade and Industry (Cm5233), 2001 (dokument dostępny pod adresem: http://www.iiiglobal. org/component/jdownloads/finish/389/1401.html).

Wincenciak M., Funkcje sankcji we wspólnotowym prawie ochrony konkurencji, s. 6 (tekst dostępny pod adresem: http://www.law.muni.cz/sborniky/Days-of-publiclaw-doplnek/files/pdf/Wincenciak.pdf).

Wiseman A.M., Protection of Confidentiality: a U. S. Perspective (materiał przedstawiony na Global Competition Review Competition Litigation Conference, 4 października 2011 r., niepubl.).

2009 update of the 2006 Study on the enforcement of State aid law at national level (dostępny pod adresem: http://ec.europa.eu/competition/state_aid/studies_reports/enforcement_study_2009.pdf).

Akty prawne i dokumenty towarzyszące (w tym akty niewiążace i projekty aktów prawnych)

\section{Polska}

Konstytucja Rzeczypospolitej Polskiej z dnia 2 kwietnia 1997 r. (Dz. U. 1997 Nr 78, poz. 483, zm.: Dz. U. 2006 Nr 200, poz. 1471; Dz. U. 2009 Nr 114, poz. 946$)$.

Ustawa z dnia 17 grudnia 2009 r. o dochodzeniu roszczeń w postępowaniu grupowym (Dz. U. $2010 \mathrm{Nr}$ 7, poz. 44).

Ustawa z dnia 23 sierpnia 2007 r. o przeciwdziałaniu nieuczciwym praktykom rynkowym (Dz. U. 2007 Nr 171, poz. 1206). 
Ustawa z dnia 16 lutego 2007 r. o ochronie konkurencji i konsumentów (Dz. U. $2007 \mathrm{Nr} 50$, poz. 331 ze zm.).

Ustawa z dnia 29 lipca 2005 r. o obrocie instrumentami finansowymi (Dz. U. $\mathrm{Nr}$ 183, poz. 1538 ze zm.).

Ustawa z dnia 27 maja 2004 r. o funduszach inwestycyjnych (Dz. U. 2004 Nr 146, poz. 1546).

Ustawa z dnia 22 maja 2003 r. o działalności ubezpieczeniowej (Dz. U. Nr 124, poz. 1151 ze zm.).

Ustawa z dnia 28 października 2002 r. o odpowiedzialności podmiotów zbiorowych za czyny zabronione pod groźbą kary (test jedn. Dz. U. z 2012 r., poz. 768, 769 i 1193).

Ustawa z dnia 30 sierpnia 2002 r. - Prawo o postępowaniu przed sądami administracyjnymi (Dz. U. Nr 153, poz. 1270 ze zm.).

Ustawa z dnia 6 września 2001 r. o dostępie do informacji publicznej (Dz. U. 2001 Nr 112, poz. 1198 ze zm.).

Ustawa z dnia 27 lipca 2001 r. - Prawo o ustroju sądów powszechnych (Dz. U. $2001 \mathrm{Nr} 98$, poz. 1070 ze zm.).

Ustawa z dnia 15 grudnia 2000 r. o ochronie konkurencji i konsumentów (tekst jedn. Dz. U. 2005 Nr 244, poz. 2080 ze zm.).

Ustawa z dnia 15 września 2000 r. - Kodeks spółek handlowych (Dz. U. 2000 Nr 94, poz. 1037 ze zm.).

Ustawa z dnia 30 czerwca 2000 r. - Prawo własności przemysłowej (tekst jedn. Dz. U. 2003 Nr 119, poz. 1117 ze zm.).

Ustawa z dnia 29 sierpnia 1997 r. - Prawo bankowe (tekst jedn. Dz. U. 2002 $\mathrm{Nr} 72$, poz. 665 ze zm.).

Ustawa z dnia 6 czerwca 1997 r. - Kodeks karny (Dz. U. 1997 Nr 88, poz. 553 ze $\mathrm{zm}$.).

Ustawa z dnia 19 czerwca 1995 r. o statystyce publicznej (Dz. U. 1995 Nr 88, poz. 439 ze zm.).

Ustawa z dnia 4 lutego 1994 r. Prawo autorskie (tekst jedn. Dz. U. 2006 Nr 90, poz. 631 ze zm.).

Ustawa z dnia 16 kwietnia 1993 r. o zwalczaniu nieuczciwej konkurencji (tekst jedn. Dz. U. 2003 Nr 153, poz. 1503 ze zm.).

Ustawa z dnia 22 stycznia 1991 r. o ochronie informacji niejawnych (tekst jedn. Dz. U. $2005 \mathrm{Nr}$ 196, poz. 1631 ze zm.).

Ustawa z dnia 24 lutego 1990 r. o przeciwdziałaniu praktykom monopolistycznym i ochronie konsumentów (tekst jedn. Dz. U. $1999 \mathrm{Nr}$ 52, poz. 547 ze $\mathrm{zm}$.).

Ustawa z dnia 24 maja 1989 r. o rozpoznawaniu przez sądy spraw gospodarczych (Dz. U. 1989 Nr 33, poz. 125 ze zm.).

Ustawa z dnia 17 listopada 1964 r. - Kodeks postępowania cywilnego (Dz. U. $1964 \mathrm{Nr}$ 43, poz. 296 ze zm.).

Ustawa z dnia 23 kwietnia 1964 r. - Kodeks cywilny (Dz. U. 1964 Nr 16, poz. 93 ze zm.). 
Ustawa z dnia 14 czerwca 1960 r. - Kodeks postępowania administracyjnego (tekst jedn. Dz. U. 2000 Nr 98, poz. 1071 ze zm.).

Dekret Prezydenta Rzeczypospolitej z dnia 27 listopada 1935 r. w sprawie zmiany ustawy z dnia 28 marca 1933 r. o kartelach (Dz. U. $1935 \mathrm{Nr} 86$, poz. 529).

Ustawa z dnia 28 marca 1933 r. o kartelach (Dz. U. 1933 Nr 31, poz. 270).

Rozporządzenia Rady Ministrów z dnia 30 marca 2011 r. w sprawie wyłączenia niektórych rodzajów porozumień wertykalnych spod zakazu porozumień ograniczających konkurencję (Dz. U. 2011 Nr 81, poz. 441).

Rozporządzenie Rady Ministrów z dnia 26 stycznia 2009 r. w sprawie trybu postępowania w przypadku wystąpienia przedsiębiorców do Prezesa Urzędu Ochrony Konkurencji i Konsumentów o odstąpienie od wymierzania kary pieniężnej lub jej obniżenie (Dz. U. 2009 Nr 20, poz. 109).

Rozporządzenia Rady Ministrów z dnia 30 lipca 2007 r. w sprawie wyłączenia niektórych rodzajów porozumień dotyczących transferu technologii spod zakazu porozumień ograniczających konkurencję (Dz. U. 2007 Nr 137, poz. 963).

Wyjaśnienia Prezesa UOKiK w sprawie ustalania wysokości kar pieniężnych za stosowanie praktyk ograniczających konkurencję (Dz. Urz. UOKiK $2009 \mathrm{Nr} 1$, poz. 1).

Wyjaśnienia w sprawie wydawania decyzji zobowiązującej w sprawach praktyk ograniczających konkurencję oraz praktyk naruszających zbiorowe interesy konsumentów (Dz. Urz. UOKiK 2012 Nr 1, poz. 2).

Projekt ustawy o zmianie ustawy o ochronie konkurencji i konsumentów przedstawiony w dniu 21 listopada $2012 \mathrm{r}$.

Projekt założeń projektu ustawy o zmianie ustawy o ochronie konkurencji i konsumentów (projekt z dnia 15 maja 2012 r.).

\section{Unia Europejska}

Traktat o funkcjonowaniu Unii Europejskiej (wersja skonsolidowana: Dz. Urz. 2012 C 326).

Rozporządzenie Komisji (UE) nr 1218/2010 z dnia 14 grudnia 2010 r. w sprawie stosowania art. 101 ust. 3 Traktatu o funkcjonowaniu Unii Europejskiej do niektórych kategorii porozumień specjalizacyjnych (Dz. Urz. UE 2010 L 335/43).

Rozporządzenie Komisji (UE) nr 1217/2010 z dnia 14 grudnia 2010 r. w sprawie stosowania art. 101 ust. 3 Traktatu o funkcjonowaniu Unii Europejskiej do niektórych kategorii porozumień badawczo-rozwojowych (Dz. Urz. UE 2010 L 335/36).

Rozporządzenie Komisji (UE) nr 330/2010 z dnia 20 kwietnia 2010 r. w sprawie stosowania art. 101 ust. 3 Traktatu o funkcjonowaniu Unii Europejskiej do kategorii porozumień wertykalnych i praktyk uzgodnionych (Dz. Urz. UE 2011 L 102/1).

Rozporządzenie Komisji nr 773/2004 z dnia 7 kwietnia 2004 r. w sprawie prowadzenia przez Komisję postępowań zgodnie z art. 81 i art. 82 Traktatu WE (Dz. Urz. UE 2004 L 123/18). 
Rozporządzenie Komisji (WE) nr 772/2004 z dnia 7 kwietnia 2004 r. w sprawie stosowania art. 81 ust. 3 Traktatu do kategorii porozumień o transferze technologii (Dz. Urz. UE 2004 L 123/11).

Rozporządzenie Rady (WE) nr 1/2003 z dnia 16 grudnia 2002 r. w sprawie wprowadzenia w życie reguł konkurencji ustanowionych w art. 81 i 82 Traktatu (Dz. Urz. UE 2003 L 1/1).

Rozporządzenie (WE) nr 1049/2001 Parlamentu Europejskiego i Rady z dnia 30 maja 2001 r. w sprawie publicznego dostępu do dokumentów Parlamentu Europejskiego, Rady i Komisji (Dz. Urz. WE 2001 L 145/43).

Rozporządzenie Rady (WE) nr 44/2001 z dnia 22 grudnia 2000 r. w sprawie jurysdykcji i uznawania orzeczeń sądowych oraz ich wykonywania w sprawach cywilnych i handlowych (Dz. Urz. WE 2001 L 12/1).

Dyrektywa 2005/29/WE Parlamentu Europejskiego i Rady z dnia 11 maja 2005 r. dotycząca nieuczciwych praktyk handlowych stosowanych przez przedsiębiorstwa wobec konsumentów na rynku wewnętrznym oraz zmieniająca dyrektywę Rady 84/450/EWG, dyrektywy 97/7/WE, 98/27/WE i 2002/65/WE Parlamentu Europejskiego i Rady oraz rozporządzenie (WE) nr 2006/2004 Parlamentu Europejskiego i Rady (Dz. Urz. UE 2005 L 149/22).

Dyrektywa 2004/48/WE Parlamentu Europejskiego i Rady z dnia 29 kwietnia 2004 r. w sprawie egzekwowania praw własności intelektualnej (Dz. Urz. UE 2004 L 157/45).

Dyrektywa 2003/98/WE Parlamentu Europejskiego i Rady z dnia 17 listopada 2003 r. w sprawie ponownego wykorzystywania informacji sektora publicznego (Dz. Urz. UE 2003 L 345/90).

Dyrektywa 85/374/EWG z dnia 25 lipca 1985 r. w sprawie zbliżenia przepisów ustawowych, wykonawczych i administracyjnych Państw Członkowskich dotyczących odpowiedzialności za produkty wadliwe (Dz. Urz. EWG 1985 L 210/29).

Zawiadomienie Komisji w sprawie najlepszych praktyk w zakresie prowadzenia postępowań w związku z art. 101 i 102 TFUE (Dz. Urz. UE 2011 C 308/6).

Opinia Europejskiego Komitetu Ekonomiczno-Społecznego w sprawie Białej Księgi w sprawie roszczeń o naprawienie szkody wynikłej z naruszenia wspólnotowego prawa ochrony konkurencji, COM(2008)165 final (Dz. Urz. UE 2009 C 228/6).

Komunikat Komisji w sprawie egzekwowania prawa dotyczącego pomocy państwa przez sądy krajowe (Dz. Urz. UE 2009 C 85/01).

Komunikat Komisji do Parlamentu Europejskiego i Rady: Sprawozdanie z funkcjonowania rozporządzenia $\mathrm{nr}$ 1/2003 (SEK(2009)574), Bruksela, dnia 29 kwietnia 2009, KOM(2009) 206 wersja ostateczna.

Rezolucja Parlamentu Europejskiego z dnia 26 marca 2009 r. w sprawie białej księgi w sprawie roszczeń o naprawienie szkody wynikłej z naruszenia wspólnotowego prawa ochrony konkurencji (2008/2154(INI)).

Zielona księga w sprawie dochodzenia zbiorowych roszczeń konsumentów $\operatorname{KOM}(2008) 794$ wersja ostateczna, Bruksela, dnia 27.11.2008 r.

Zawiadomienie Komisji w sprawie środków zaradczych dopuszczalnych na mocy rozporządzenia Rady (WE) nr 139/2004 i rozporządzenia Komisji (WE) nr 802/2004 (Dz. Urz. UE 2008 C 267/1). 
Obwieszczenia Komisji w sprawie prowadzenia postępowań ugodowych w związku z przyjęciem decyzji na mocy art. 7 i 23 rozporządzenia Rady (WE) nr 1/2003 w sprawach kartelowych (Dz. Urz. UE 2008 C 167/1). Opinia Europejskiego Komitetu Ekonomiczno-Społecznego w sprawie definicji roli i systemu powództw zbiorowych w dziedzinie wspólnotowego prawa konsumenckiego (Dz. Urz. UE 2008 C 162/1).

Opinia Europejskiego Komitetu Ekonomiczno-Społecznego w sprawie: Regulacja konkurencji a ochrona konsumentów, INT/280 CESE 949/2006 (Dz. Urz. UE 2006 C 309/1).

Obwieszczenie Komisji w sprawie zwalniania z grzywien i zmniejszania grzywien w sprawach kartelowych (Dz. Urz. UE 2006 C 298/17).

Obwieszczenie Komisji dotyczące zasad dostępu do akt Komisji w sprawach na mocy art. 81 i 82 Traktatu WE, art. 53, 54 i 57 Porozumienia EOG oraz rozporządzenia Rady (WE) nr 139/2004 (Dz. Urz. UE 2005 C 325/07).

Commission Notice on the co-operation between the Commission and the courts of the EU Member States in the application of Articles 81 and 82 EC) (OJ 2004 C 101/54).

Commission Notice - Guidelines on the effect on trade concept contained in Articles 81 and 82 of the Treaty (OJ 2004 C 101/86).

Biała księga w sprawie roszczeń o naprawienie szkody wynikłej z naruszenia wspólnotowego prawa ochrony konkurencji, \{SEC(2008) 404SEC (2008) 405SEC (2008) 406\}.

Commission staff working paper accompanying the White paper on damages actions for breach of the EC antitrust rules $\{\mathrm{COM}(2008) 165$ final $\}$ \{SEC (2008) 405\} \{SEC (2008) 406\}/* SEC/2008/0404 final *

Commission staff working document accompanying the White paper on damages actions for breach of the EC antitrust rules - Impact assessment $\{\mathrm{COM}(2008)$ 165 final $\}\{\operatorname{SEC}(2008) 404\}\{\operatorname{SEC}(2008) 406\} / *$ SEC/2008/0405 final *

Rezolucja Parlamentu Europejskiego z dnia 25 kwietnia 2007 r. w sprawie Zielonej Księgi dotyczącej roszczeń o odszkodowanie za stosowanie praktyk ograniczających konkurencję i nadużywanie pozycji dominującej (2006/2207 (INI)).

Zielona księga - Roszczenia o odszkodowanie za stosowanie praktyk ograniczających konkurencję i nadużywanie pozycji dominującej, KES(2005) 1732; COM/2005/672 wersja ostateczna.

Commission Staff Working Paper. Annex to the Green Paper Damages actions for breach of the EC antitrust rules, $\operatorname{COM}(2005) 672$ final.

Projekt - Wskazówki Komisji. Ustalanie wysokości szkody w dochodzeniu roszczeń odszkodowawczych z tytułu naruszenia art. 101 lub 102 TFUE

Inne

Konwencja o ochronie praw człowieka i podstawowych wolności sporządzona w Rzymie dnia 4 listopada 1950 r. (Dz. U. 2003 Nr 42, poz. 364). 


\section{Orzecznictwo}

Unia Europejska

Wyrok Trybunału z dnia 6 listopada 2012 r. w sprawie C-199/11 Europese Gemeenschap v. Otis $N V$ i inni (dotąd niepubl.).

Wyrok Trybunału z dnia 5 czerwca 2012 r. w sprawie C-489/10 Eukasz Bonda (dotąd niepubl.)

Wyrok Sądu z dnia 15 grudnia 2011 r. w sprawie T-437/08 CDC Hydrogene Peroxide v. Komisja (dotąd niepubl.).

Wyroku Trybunału z dnia 21 lipca 2011 r. w sprawie C-506/08 P Królestwo Szwecji v. MyTravel i Komisja (niepubl.).

Wyrok Trybunału z dnia 14 czerwca 2011 r. w sprawie C-360/09 Pfleiderer AG v. Bundeskartellamt (dotąd niepubl.).

Wyrok Trybunału z dnia 3 maja 2011 r. w sprawie C-375/09 Prezes UOKiK v. Tele 2 (dotąd niepubl.).

Wyrok Sądu z dnia 15 grudnia 2010 r. w sprawie T-141/08 E.ON v. Komisja (Zb. Orz. 2010, s. 5761).

Wyrok Trybunału z dnia 10 grudnia 2010 r. w połączonych sprawach T-494/08 do T-500/08 i T-509/08 Ryanair v. Komisja (Zb. Orz. 2010, s. II-5723).

Wyrok Trybunału z dnia 7 grudnia 2010 r. w sprawie C-439/08 VEBIC (Zb. Orz. 2010, s. I-12471).

Wyrok Trybunału z dnia 29 czerwca 2010 r. w sprawie C-139/07 Komisja v. Technische Glaswerke Ilmenau (Zb. Orz. 2010, s. I-05885).

Wyrok Trybunału z dnia 11 czerwca 2009 r. w sprawie C-429/07 Inspecteur van de Belastingdienst v. X BV (Zb. Orz. 2009, s. I-04833).

Wyrok Trybunału z dnia 11 września 2008 r. w sprawie C-279/06 CEPSA Estaciones de Servicio $S A$ v. LV Tobar e Hijos SL (Zb. Orz. 2008, s. I-06681).

Wyrok Trybunału z dnia 29 stycznia 2008 r. w sprawie C-275/06 Productores de Música de España (Promusicae) v. Telefónica de España SAU (Zb. Orz. 2008, I-00271).

Wyrok SPI z dnia 27 listopada 2007 r. w połączonych sprawach T-3/00 i T-337/04 Athanasios Pitsiorlas v. Rada i Europejski Bank Centralny (Zb. Orz. 2007, II-4779).

Wyrok Trybunału z dnia 7 czerwca 2007 r. w sprawach połączonych od C-222/05 do C-225/05 van der Weerd $i$ in. (Zb. Orz. 2007, s. I-4233).

Postanowienie prezesa SPI z dnia 3 maja 2007 r. w sprawie T-12/07 R Polimeri Europa v. Komisja.

Wyrok SPI z dnia 14 grudnia 2006 r. w sprawie T-237/02 Technische Glaswerke Ilmenau (Zb. Orz. 2006, s. II-05131).

Wyrok Trybunału z dnia 30 listopada 2006 r. w połączonych sprawach C-376/05 i C-377/05 Brünsteiner GmbH and Autohaus Hilgert GmbH v. Bayerische Motorenwerke $A G(B M W)$ (Zb. Orz. 2006, s. I-11383).

Wyrok Trybunału z dnia 7 września 2006 r. w sprawie C-526/04 Laboratoires Boiron $S A$ v. Urssaf (Zb. Orz. 2006, s. I-07529). 
Wyrok Trybunału z dnia 13 lipca 2006 r. w połączonych sprawach C-295-298/04 V. Manfredi v. Lloyd Adriatico Assicurazioni SpA, Antonio Cannito v. Fondiaria Sai SpA, Nicolò Tricarico, Pasqualina Murgolo v. Assitalia SpA (Zb. Orz. 2006, s. I-06619).

Wyrok Trybunału z dnia 29 czerwca 2006 r. w sprawie C-308/04 P SGL Carbon v. Komisja (Zb. Orz. 2006, s. I-5977).

Wyrok Trybunału z dnia 28 czerwca 2005 r. w sprawach połączonych C-189/02 P, C-202/02 P, C-205/02 P do C-208/02 P oraz C-213/02 P Dansk Rørindustri A/S v. Komisja (Zb. Orz. 2005, s. I-5425).

Wyrok SPI z dnia 13 kwietnia 2005 r. w sprawie T-2/03 Verein für Konsumenteninformation v. Komisja (Zb. Orz. 2005, s. II-1121).

Wyrok Trybunału z dnia 15 października 2002 r. w sprawach połączonych C-238/99 P, C-244/99 P, C-245/99 P, C-247/99 P, od C-250/99 P do C-252/99 P i C-254/99 P Limburgse Vinyl Maatschappij $i$ in. v. Komisja (Zb. Orz. 2002, s. I-8375).

Wyrok Trybunału z dnia 20 września $2001 \mathrm{r}$. w sprawie C-453/99 Courage Ltd v. Bernard Crehan and Bernard Crehan v. Courage Ltd and Others (Zb. Orz. 2001, s. I-06297).

Wyrok Trybunału z dnia 8 marca 2001 r. w sprawach połączonych C-397/98 i C-410/98 Metallgesellschaft $i$ in. (Zb. Orz. 2001, s. I-1727).

Wyrok Trybunału z dnia 14 grudnia 2000 r. w sprawie C-344/98 Masterfoods Ltd i HB Ice Cream Ltd oraz Ice Cream Ltd i Masterfoods Ltd (Zb. Orz. 2000, s. I-11369).

Wyrok Trybunału z dnia 21 września 2000 r. w sprawach połączonych C-441/98 i C-442/98 Michailidis (Zb. Orz. 1998, s. I-7145).

Wyrok Trybunału z dnia 8 lipca 1999 r. w sprawie C-199/92 P Hüls $A G$ v. Komisja (Zb. Orz. 1999, s. I-4287).

Wyrok Trybunału z dnia 1 czerwca 1999 r. w sprawie C-126/97 Eco Swiss China Time Ltd v. Benetton International NV (Zb. Orz. 1999, s. I-03055).

Wyrok Trybunału z dnia 10 lipca 1997 r. w sprawie C-261/95 Palmisani (Zb. Orz. 1997, s. I-4025).

Wyrok SPI z dnia 14 listopada 1996 r. w sprawie Tetra Pak International SA v. Komisja Wspólnot Europejskich (Zb. Orz. 1996, s. II-05951).

Wyrok SPI z dnia 18 września 1996 r. T-353/94 Postbank v. Komisja (Zb. Orz. 1996, s. II-921).

Wyrok Trybunału z dnia 5 marca $1996 \mathrm{r}$. w połączonych sprawach C-46/93 i C-48/93 Brasserie du Pecheur SA v. Bundesrepublik Deutschland (Zb. Orz. 1996, s. I-1029).

Wyrok Trybunału z dnia 6 kwietnia 1995 r. w sprawie C-310/93P BPB Industries and British Gypsum (Zb. Orz 1995, I-865).

Wyrok Trybunału z dnia 13 kwietnia 1994 r. w sprawie C-128/92 H.J. Banks \& Company Limited v. British Coal Corporation (Zb. Orz. 1994, s. I-01209).

Wyrok Trybunału z dnia 2 sierpnia 1993 r. w sprawie C-271/91 Marshall (Zb. Orz. 1993, s. I-4367).

Wyrok SPI z dnia 1 kwietnia 1993 r. w sprawie T-65/89 BPB Industries and British Gyspsum v. Komisja (Zb. Orz. 1993, II-389). 
Wyrok SPI z dnia 17 września 1992 r. w sprawie T-24/90 Automec v. Komisja (Zb. Orz. 1992, s. II-0223).

Wyrok Trybunału z dnia 25 lipca 1991 r. w sprawie C-221/89 Queen v. Secretary of State for Transport, ex parte Factortame Limited (Zb. Orz. 1991, s. I-3095).

Wyrok Trybunału z dnia 28 lutego 1991 r. w sprawie C-234/89 Stergios Delimitis v. Henninger Bräu $A G$ (Zb. Orz. 1991, s. I-935).

Wyrok Trybunału z dnia 19 listopada $1990 \mathrm{r}$. w połączonych sprawach C-6/90 i C-9/90 Andrea Francovich i Danila Bonifaci i inni v. Republika Wtoska (Zb. Orz. 1991, s. I-05357).

Wyrok Trybunału z dnia 11 kwietnia 1989 r. w sprawie 66/86 Ahmed Saeed Flugreisen and Silver Line Reisebüro GmbH v Zentrale zur Bekämpfung unlauteren Wettbewerbs e.V. (Zb. Orz. 1989, s. 00803).

Wyrok Trybunału z dnia 14 grudnia 1983 r. w sprawie C-319/82 319/82 Société de Ventes de Ciments et Bétons de L'Est SA v. Kerpen \& Kerpen GmbH i Co. KG (Zb. Orz. 1983, s. 04173).

Wyrok Trybunału z dnia 9 listopada 1983 r. w sprawie C-199/82 Amministrazione delle Finanze dello Stato v SpA San Giorgio (Zb. Orz. 1983, s. 3595).

Wyrok Trybunału z dnia 4 grudnia 1979 r. w sprawie C-68/79 Hans Just I/S v. Danish Ministry for Fiscal Affairs (Zb. Orz. 1980, s. 501).

Wyrok Trybunału z dnia 4 października 1979 r. w sprawie 238/78 Ireks-Arkady v. Rada i Komisja (Zb. Orz. 1979, s. 2955).

Wyrok Trybunału z dnia 9 marca 1978 r. w sprawie 106/77 Amministrazione delle Finanze dello Stato v Simmenthal SpA (Zb. Orz. 1978, s. 00629).

Wyrok Trybunału z dnia 30 czerwca 1974 r. w sprawie 127/73 Belgische Radio en Televisie v. SV SABAM and NV Fonior (Zb. Orz. 1974, s. 00051).

Wyrok Trybunału z dnia 25 listopada 1971 r. w sprawie C-22/71 Béguelin Import Co. v. S.A.G.L. Import Export (Zb. Orz. 1971, s. 00949).

Wyrok Trybunału z dnia 13 lipca 1966 r. w połączonych sprawach 56/64 i 58/64 Consten GmbH Und Grunding-Verkaufs-GmbH v. Komisja (Zb. Orz. 1966, s. 00299).

Wyrok Trybunału z dnia 30 czerwca 1966 r. w sprawie 56/65 Sóciété Technique Miniére v. Maschinenbau Ulm GmbH (Zb. Orz. 1966, s. 00235).

Wyrok Trybunału z dnia 5 maja $1966 \mathrm{r}$. w sprawach połączonych 18/65 i 35/65 Gutmann v. Komisja EWEA (Zb. Orz. 1966, s. 149).

Decyzja Komisji C (2006) 1766 wersja ostateczna z dnia 3 maja 2006 r. dotycząca postępowania na mocy art. 81 [WE] i art. 53 porozumienia o EOG (sprawa COMP/F/38.620 - Nadtlenek wodoru i nadboran sodu).

Decyzja Komisji 2004/138/WE z dnia 11 czerwca 2002 r. w sprawie postępowania na podstawie art. 81 WE (Banki austriackie -,klub Lombard”) (Dz. Urz. UE 2004 L 56/1).

\section{Polska}

Wyrok TK z dnia 19 stycznia 2010 r., SK 35/2008, OTK ZU 2010/1A, poz. 2.

Wyrok TK z dnia 15 kwietnia 2008 r., P 26/06.

Wyrok TK z dnia 3 listopada 2004 r., K 18/03, Dz. U. 2004 Nr 243, poz. 2442. 
Wyrok TK z dnia 27 lipca 2004 r., SK 9/2003, OTK ZU 2004/7A, poz. 71. Wyrok TK z dnia 14 czerwca 2004 r., SK 21/2003, OTK ZU 2004/6A, poz. 56. Wyrok TK z dnia z 29 kwietnia 2003 r., SK 24/2002, OTK ZU 2003/4A, poz. 33. Wyrok TK z dnia 10 lipca 2000 r., SK 12/99, LexPolonica nr 347787, OTK 2000, nr 5, poz. 143 .

Wyrok SN z dnia 25 maja 2012 r., I CSK 498/2011, LexPolonica nr 3880826. Wyrok SN z dnia 17 listopada 2011 r., III CSK 30/11.

Wyrok SN z dnia 4 listopada 2011 r. I CSK 796/2010, LexPolonica nr 3882091. Wyrok SN z dnia 28 października 2011 r., III KK 266/2011, LexPolonica nr 3047452. Wyrok SN z dnia 15 czerwca 2011 r., V CSK 382/10, niepubl. Postanowienie SN z dnia 12 maja 2011 r., III CSK 238/10, niepubl.

Wyrok SN z dnia 11 kwietnia 2011 r., V KK 27/2011, OSNKW 2011, nr 9, poz. 77. Wyrok SN z dnia 6 kwietnia 2011 r., V KK 15/2011, OSNKW 2011, nr 8, poz. 72. Wyrok SN z dnia 26 stycznia 2011 r., II KK 214/2010, OSP 2012, nr 1, poz. 5. Wyrok SN z dnia 11 stycznia 2011 r., I PK 152/10, niepubl.

Wyrok SN z dnia 28 października 2010 r., II CSK 191/2010, OSNC 2011, nr 6, poz. 71 .

Wyrok SN z dnia 22 października 2010 r., III CSK 333/2009, LexPolonica nr 2550996. Wyrok SN z dnia 30 września 2010 r., I CSK 680/09, Lex nr 622200.

Wyrok SN z dnia 24 września 2010 r., IV CSK 78/2010, LexPolonica nr 3034470. Wyrok SN z dnia 21 września 2010 r., III SK 8/10, OSN 2012 nr 3-4, poz. 52. Wyrok SN z dnia 6 maja 2010 r., II CSK 602/09, Lex nr 585768.

Wyrok SN z dnia 14 kwietnia 2010 r., III SK 1/10, Lex nr 577853.

Uchwała SN z dnia 8 kwietnia 2010 r., III SZP 1/10.

Wyrok SN z dnia 2 marca 2010 r., II PK 246/2009, LexPolonica nr 2396930. Wyrok SN z dnia 11 lutego 2010 r., I CSK 262/2009, LexPolonica nr 2573531. Wyrok SN z dnia 10 lutego 2010 r., V CSK 269/09, OSNC 2010, nr 9, poz. 127. Wyrok SN z dnia 15 stycznia 2010 r., I CSK 199/09, niepubl.

Wyrok SN z dnia 20 sierpnia 2009 r., II CSK 166/09, Rejent 2010, nr 7-8, poz. 178. Wyrok SN z dnia 19 sierpnia 2009 r., III SK 5/09, OSNP 2011, nr 9-10, poz. 144. Wyrok SN z dnia 7 lipca 2009 r., V KK 82/2009, OSNWSK 2009, poz. 1455. Wyrok SN z dnia 7 maja 2009 r., IV CSK 27/2009, LexPolonica nr 2030983. Wyrok SN z dnia 16 kwietnia 2009 r. I CSK 24/2009, OSP 2011, nr 1, poz. 12. Wyrok SN z dnia 19 lutego 2009 r., III SK 31/2008, LexPolonica nr 2302381. Postanowienie SN z dnia 4 lutego 2009 r., V KK 410/2008, OSNK 2009, poz. 322. Wyrok SN z dnia 14 stycznia 2009 r., V KK 245/2008, OSNK 2009, poz. 164. Wyrok SN z dnia 7 stycznia 2009 r., III SK 16/2008, OSNP 2010, nr 13-14, poz. 177. Wyrok SN z dnia 11 grudnia 2008 r., IV CSK 302/08.

Wyrok SN z dnia 14 listopada 2008 r., V KK 256/2008, OSNK 2008, poz. 2298. Wyrok SN z dnia 16 października 2008 r. III SK 2/2008, LexPolonica nr 2551023. Wyrok SN z dnia 3 października 2008 r., I CSK 62/08, Lex nr 470020.

Uchwała SN z dnia 23 lipca 2008 r., III CZP 52/08, OSNC 2009, nr 7-8, poz. 107. Wyrok SN z dnia 10 czerwca 2008 r., I UK 376/07, OSNP 2009, nr 21-22, poz. 295. 
Wyrok SN z dnia 5 czerwca 2008 r., III SK 40/07, OSNP 2009, nr 19-20, poz. 272. Wyrok SN z dnia 17 kwietnia 2008 r., I CSK 79/08.

Wyrok SN z dnia 9 stycznia 2008 r., II CSK 363/2007, LexPolonica nr 1798171.

Wyrok SN z dnia 19 października 2007 r., II PK 74/2007, OSNP 2008, nr 23-24, poz. 349.

Wyrok SN z dnia 23 października 2007 r., IIII CSK 107/08, niepubl.

Uchwała SN z dnia 7 października 2007 r., OSN Izba Cywilna 2008, nr 3, poz. 30.

Wyrok SN z dnia 4 października 2007 r., V CSK 188/07, Lex nr 485901.

Wyrok SN z dnia 2 sierpnia 2007 r., V CSK 152/2007, Orzecznictwo Sądów w sprawach Gospodarczych 2008, nr 12, poz. 98.

Uchwała SN z dnia 26 kwietnia 2007 r., I KZP 7/2007, OSNKW 2007, nr 5, poz. 38. Wyrok SN z dnia 19 kwietnia 2007 r., I CSK 27/07, Biuletyn SN 2007, nr 11.

Postanowienie SN z dnia 8 marca 2007 r., III CZ 12/2007, OSNC 2008, nr 2, poz. 26. Wyrok SN z dnia 5 stycznia 2007 r., III SK 17/2006, LexPolonica nr 2025330.

Wyrok SN z dnia 30 maja 2006 r., I CSK 85/2006, OSP 2008, nr 5, poz. 55.

Wyrok SN z dnia 2 marca 2006 r., I CSK 83/05, Lex nr 369165.

Wyrok SN z dnia 22 lutego 2006 r., III CK 341/05, OSNC 2006, nr 10, poz. 174. Postanowienie SN z dnia 12 stycznia 2006 r., II CK 335/05, MP 2006, nr 3, poz. 115. Wyrok SN z dnia 20 grudnia 2005 r., III CK 121/05, niepubl.

Wyrok SN z dnia 15 grudnia 2005 r., V CK 400/05, OSP 2006, nr 11, poz. 127. Uchwała SN z dnia 7 lipca 2005 r., IV CK 12/05, niepubl.

Wyrok SN z dnia 17 czerwca 2005 r., III CK 642/2004, LexPolonica nr 1825404.

Wyrok SN z dnia 4 lutego 2005 r., I CK 569/2004, LexPolonica nr 2252722.

Wyrok SN z dnia 5 stycznia 2005 r., IV CK 413/2004, LexPolonica nr 2120684.

Wyrok SN z dnia 19 listopada 2004 r., V CK 251/04, Lex nr 172465.

Wyrok SN z dnia 28 lipca 2004 r. III CK 29 6/03, Biuletyn SN 2005, nr 1, s. 11.

Wyrok SN z dnia 12 marca 2004 r., II CK 53/2003, LexPolonica nr 1546866.

Wyrok SN z dnia 13 lutego 2004 r., IV CK 24/03, OSNC 2004, nr 3, poz. 45.

Wyrok SN z dnia 18 września 2003 r., I CK 81/02.

Wyrok SN z dnia 27 sierpnia 2003 r., I CKN 527/10, Lex nr 137525.

Wyrok SN z dnia 27 sierpnia 2003 r., I CKN 185/03, Dz. Urz. UOKiK 2004 nr 1. Wyrok SN z dnia 27 sierpnia 2003 r., I CKN 523/01, LexPolonica nr 362988.

Wyrok SN z dnia 24 lipca 2003 r., I CKN 496/2001, Dz. Urz. UOKiK 2004 nr 1, poz. 283.

Uchwała SN z dnia 12 marca 2003 r., III CZP 85/02, OSN 2003, nr 10, poz. 129. Wyrok SN z dnia 4 marca 2003 r., II KK 127/02, KZS 2003, z. 7-8, poz. 18.

Wyrok SN z dnia 16 maja 2002 r., IV CKN 1071/00, OSNC 2003, nr 9, poz. 120. Uchwała SN z dnia 13 kwietnia 2002 r., III CZP 17/81, OSNC 1981, nr 9, poz. 169. Wyrok SN z dnia 5 marca 2002 r., I CZ 4/2002, LexPolonica nr 394322.

Wyrok SN dnia 28 stycznia 2002 r., I CKN 112/99, OSNC 2002, nr 11, poz. 144. Wyrok SN z dnia 18 stycznia 2002 r., I CKN 810/99, LexPolonica nr 384087.

Wyrok SN z dnia 11 lipca 2001 r., V CKN 406/00, Prok. i Pr. 2002, nr 4.

Wyrok SN z dnia 29 maja 2001 r., I CKN 1217/98, OSNC 2002, nr 1, poz. 13.

Wyrok SN z dnia 2 lutego 2001 r., IV CKN 255/2000, OSNC 2001, nr 9, poz. 137. 
Uchwała z dnia 13 grudnia 2000 r., I KZP 40/2000, OSNKW 2001, nr 1-2, poz. 2. Wyrok SN z dnia 12 grudnia 2000 r., V CKN 175/00, OSP 2001, nr 7-8, poz. 116 Wyrok SN z dnia 6 grudnia 2000 r., II UKN 118/00, OSNP 2002, nr 15, poz. 363. Wyrok SN z dnia 3 listopada 2000 r., IV CKN 146/00, niepubl.

Wyrok SN z dnia 30 czerwca 2000 r., III CKN 268/00, OSNC 2001, nr 1, poz. 10. Uchwała SN z dnia 19 maja 2000 r., III CZP 4/00, OSNC 2000, nr 11, poz. 195. Wyrok SN z dnia 5 maja 2000 r., IV CKN 686/00.

Wyrok SN z dnia 8 lutego 2000 r., V KKN 557/99, Prok. i Pr. 2000, nr 9, poz. 9. Wyrok SN z dnia 24 listopada 1999 r., I CKN 223/98, Wokanda 2000, nr 3, s. 7. Wyrok SN z dnia 15 września 1999 r., III CKN 606/99.

Postanowienie SN z dnia 21 maja 1999 r., III CKN 244/98, OSP 1999, nr 12, poz. 222. Wyrok SN z dnia 9 października 1998 r., III CKN 641/97, OSNC 1999, nr 3 poz. 61. Wyrok SN z dnia 7 października 1998 r., II UKN 246/98, OSNAPiUS 1999, nr 20, poz. 660.

Wyrok SN z dnia 25 marca 1998 r., II CKN 656/97, OSNC 1998, nr 12, poz. 208. Wyrok SN z dnia 21 stycznia 1998 r., II CKN 572/97.

Wyrok SN z dnia 22 grudnia 1997 r., II CK 546/97, OSNC 1998, nr 7-8, poz. 119. Orzeczenie SN z dnia 7 listopada 1997 r., II CKN 424/97, OSN 1998, nr 5, poz. 77. Wyrok SN z dnia 7 listopada 1997 r., III CKN 244/07, OSNC 1998, nr 3, poz. 52. Wyrok SN z dnia 24 kwietnia 1996 r., I CRN 49/96, OSNCP 1996, nr 9, poz. 124. Postanowienie SN z dnia 27 października 1995 r., III CZP 135/95, OSP 1996 r., nr 6, poz. 112 .

Uchwała SN z dnia 27 kwietnia 1995 r., III CZP 46/95, OSN 1998, nr 7-8, poz.114. Wyrok SN z dnia 9 listopada 1994 r., III CRN 36/94, OSNC 1995, nr 3, poz. 54. Uchwała SN z dnia 16 czerwca 1994 r., II PZP 4/94, MP 1995, nr 3, s. 73.

Uchwała SN z dnia 23 marca 1993 r., II PZP 1/93, OSNCP 1993, nr 12, poz. 211. Wyrok SN z dnia 27 września 1991 r., III CZP 90/91, OSNCP 1992, nr 5, poz. 72. Wyrok SN z dnia 29 maja 1991 r., III CRN 120/91, OSNCP 1992, z. 5, poz. 87.

Wyrok SN z dnia 13 maja 1988 r., III CRN 83/88, OSNCP 1989, nr 5, poz. 84, OSPiKA 1989, nr 7-12, poz. 149; PiP 1990, nr 5, s. 114.

Orzeczenie SN z dnia 18 listopada 1982 r., III CZP 26/82, OSNCP 1983, nr 5-6, poz. 64.

Wyrok SN z dnia 27 listopada 1978 r., III CRN 238/78, LexPolonica nr 321537.

Orzeczenie SN z dnia 3 lutego 1976 r., II CR 732/75, OSNCP 1976, nr 12, poz. 263.

Orzeczenie SN z dnia 24 października 1974 r., II CR 542/74, OSP 1976, nr 6, poz. 115.

Wyrok SN z dnia 8 marca 1974 r., II CR 1/74.

Wyrok SN z dnia 18 listopada 1970 r., I PR 385/69, Lex nr 6822.

Wyrok SN z dnia 18 września 1969 r., II CR 308/69, OSNC 1970, nr 7-8, poz. 130. Wyrok SN z dnia 14 kwietnia 1965 r., I PR 88/65, OSNCP 1966, nr 2, poz. 23. Orzeczenie SN z dnia 12 maja 1964 r., II CR 185/64, OSNCP 1965, nr 3, poz. 41. Orzeczenie SN z dnia 26 czerwca 1963 r., II PR 282/62, RPEiS 1964, nr 3. Orzeczenie SN z dnia 19 lipca 1962 r., II PR 203/62, OSNC 1963 nr 7-8, poz. 165. Orzeczenie SN z dnia 17 kwietnia 1962 r., 4 CR 796/61, RPEiS 1963, nr 2, s. 356. 
Orzeczenie SN z dnia 27 marca 1962 r., IV CR 672/61, SOP 1965 z. 1, poz. 3. Orzeczenie SN z dnia 2 stycznia 1962 r., 4 CR 445/61, OSNCP 1963, nr 4, poz. 82. Orzeczenie SN z dnia 15 września 1945 r., C.I. 116/45, LexPolonica nr 362180.

Wyrok NSA z dnia 17 czerwca 2011 r., I OSK 490/01. Wyrok NSA z dnia 16 kwietnia 2010 r., I OSK 83/10. Wyrok NSA z dnia 16 marca 2010 r., I OSK 1715/09. Wyrok NSA z dnia 28 października 2009 r., I OSK 485/09.

Postanowienie NSA z dnia 23 września 2009 r., I OSK 1165/09.

Wyrok NSA z dnia 19 sierpnia 2009 r., I OSK 683/09.

Wyrok NSA z dnia 18 kwietnia 2008 r., I FSK 526/2007, LexPolonica nr 2492026. Wyrok NSA z dnia 20 marca 2008 r., II GSK 459/07.

Wyrok NSA z dnia 16 listopada 2007 r., II OSK 1523/06.

Wyrok NSA z dnia 19 września 2007 r., I OSK 1992/06.

Wyrok NSA z dnia 13 marca 2007 r., I OSK 243/07, niepubl.

Wyroki NSA z dnia10 stycznia 2007 r., I OSK 50/06, niepubl.

Wyrok NSA z dnia 11 maja 2006 r., II OSK 812/05, Lex nr 236465.

Wyrok NSA z dnia 11 grudnia 2002 r., II SA 2867/02, Wokanda 2003, nr 6, s. 33.

Wyrok SA w Warszawie z dnia 4 lipca 2012 r., VI ACa 202/12.

Postanowienie SA w Krakowie z dnia 7 grudnia 2011 r., I ACz 1235/2011, LexPolonica nr 3034141.

Wyrok SA z dnia 11 lutego 2011 r., VI ACa 1078/2010, LexPolonica nr 2614075. Wyrok SA w Warszawie z dnia 22 września 2010 r., VI ACa 181/2010, LexPolonica nr 2389682.

Wyrok SA w Warszawie z dnia 25 listopada 2009 r., VI Aca 422/09, niepubl.

Wyrok SA w Warszawie z dnia 11 grudnia 2008 r., I ACa 568/2008, LexPolonica nr 2413036.

Wyrok SA w Warszawie z dnia 28 listopada 2008 r., II AKa 361/08, LexPolonica nr 2061139, Prok. i Pr. - wkł. 2009, nr 10, poz. 35.

Wyrok SA w Warszawie z dnia 7 listopada 2007 r., I ACa 334/2007, LexPolonica nr 1668514.

Wyrok SA w Szczecinie z dnia 4 lipca 2007 r., I ACa 400/2007, LexPolonica nr 2400537.

Wyrok SA w Warszawie z dnia 29 czerwca 2007 r., VI ACa 1222/2006, Dz. Urz. UOKiK $2007 \mathrm{Nr}$ 4, poz. 48.

Wyrok SA w Warszawie z dnia 22 czerwca 2007 r., VI ACa 8/07, niepubl.

Wyrok SA w Katowicach z dnia 27 października 2005 r., II AKa 88/05, Prok. i Pr. 2006, nr 7-8, poz. 28.

Wyrok SA w Warszawie z dnia 11 marca 1998 r., II Aka 247/97, OSA 1999, nr 3, poz. 25.

Wyrok SOKiK z dnia 10 czerwca 2010 r., XVII Ama 124/2009, LexPolonica nr 3072420. 
Postanowienie SOKiK z dnia 22 czerwca 2006 r., XVII Amz 67/05, niepubl. Postanowienie SOKiK z dnia 30 maja 2006 r., XVII Amz 21/06, niepubl. Wyrok SOKiK z dnia 29 maja 2006 r., XVII Ama 9/05, Dz. Urz. UOKiK 2006 $\mathrm{Nr} 4$, poz. 58 .

Wyrok SOKiK z dnia 4 maja 2006 r., XVII Ama 119/04, LexPolonica nr 1402240. Wyrok SOKiK z dnia 21 marca 2005 r., XVII Ama 16/2004, Dz. Urz. UOKiK $2005 \mathrm{Nr} 2$, poz. 27.

Postanowienia SOKiK z dnia 19 kwietnia 2004 r., XVII Amz 4/04, niepubl. Postanowienie SAM z dnia 28 listopada 2001 r., XVII Amz 14/01, niepubl.

Wyrok SAM z dnia 21 listopada 2001 r., XVII Ama 2/2001, Dz. Urz UOKiK 2002 Nr 1, poz. 47.

Wyrok SAM z dnia 8 października 2001 r., XVII Ama 113/00, niepubl.

Wyrok SAM z dnia 5 września 2001 r., XVII Ama 103/00, Dz. Urz. UOKiK 2001 Nr 3, poz. 125.

Wyrok SAM z dnia 21 października 1998 r., XVII Ama 50/98, Lex nr 56137.

Postanowienie SAM z dnia 15 maja 1996 r., XVII Amz 1/96, Wokanda 1997, nr 10, s. 55.

Wyrok SAM z dnia 17 stycznia 1996 r., XVII Amr 54/95, Wokanda 1997, nr 4, S. 52.

Wyrok SAM z dnia 29 grudnia 1993 r., XVII Amr 42/93, Wokanda 1994, nr 5.

Wyrok SAM z dnia 6 września 1993 r., XVII Amr 26/93, OG 1993, nr 4, poz. 86.

Wyrok SAM z dnia 24 stycznia 1991 r., Amr 8/90, Wokanda 1992, nr 2

Postanowienie WSA w Warszawie z dnia 6 lipca 2011 r., VI SA/WA 1131/11.

Postanowienie WSA w Warszawie z dnia 3 czerwca 2011 r., VII SA/Wa 9/11.

Postanowienie WSA w Warszawie z dnia 9 marca 2011 r., VII SA/Wa 47/11.

Wyrok WSA w Warszawie z dnia 16 listopada 2009 r., II SA/Wa 1197/09.

Wyrok WSA w Warszawie z dnia 14 lutego 2008 r., II SA/Wa 1927/07.

Wyrok WSA w Krakowie z dnia 8 lutego 2008 r., II SA/Kr 942/07.

Wyrok WSA we Wrocławiu z dnia 22 listopada 2006 r., IV SA/Wr 712/06.

Wyrok WSA w Lublinie z dnia 16 grudnia 2005 r., II SAB/Lu 74/05.

Wyrok WSA w Poznaniu z dnia 5 kwietnia 2005 r., IV SA/Po 1541/04, niepubl.

Wyrok WSA w Rzeszowie z dnia 4 sierpnia 2004 r., II SAB/Rz 26/04, niepubl.

USA

In re City of New York, 607 F.3d. 923, 945 (2d. Cir. 2010).

JLM Industries v. Stolt Nielsen SA, 387 F.3d 163 (2nd Cir. 2004).

In re Vitamin Cartel Litigation, Misc. No. 99-197 (THF) \& MDL. No. 1285, 2002 U.S. Dist.

Gardner v. Parker [2002] 2 AC 1.

Johnson v. Gore Wood \& Co. [2001] 1 All ER 481.

Miller Import Corp. v. Alabastres Alfredo, S.L., STS, 2001 (Exequàtur No. 2039/1999).

Kotam Electronic, Inc. v. JBL Consumer Products Inc. 93 F.3d 724 (11th Cir. 1996). ARCO - Atlantic Richfield Co. V. USA Petroleum Co., 495 US 328 (1990).

Shearson/American Express v. McMahon 482 U.S. 220 (1987). 
Mitsubishi Motors v. Soler Chrysler Plymouth 473 U.S. 614, 105 S. Ct. 3346 (1985). Associated General Contractor of California v. California State Council of Carpenters, 459 US 519 (1983).

In re Coordinated Pretrial Proceedings in Petroleum Products Antitrust Litigation, $691 \mathrm{~F} 2 \mathrm{~d}$ (9th Cir 1982).

Prudential Insurance Co. Ltd. v. Newman Industries Ltd. [1982] 1 Ch 204.

Blue Shield of Virginia v. McCready, 457 US 465 (1982).

Chrysler Corp. v. Fedders Corp., 643 F 2d 1229, 1235 (6th Cir. 1979), 454 US 893 (1981).

In re Uranium Antitrust Litig., 480 F. Supp. 1138, 1155 (N.D. III.1979).

Mid-West Paper Product Co. v. Continental Group Inc., 596 F 2d. (1979)

Reiter v. Sonotone Corp., 442 U.S. 330, 343-344 (1979).

Brunswick Corp. v. Pueblo Bowl-O-Mat Inc., 429 US 477 (1977).

Illinois Brick Co.v. Illinois, 431 US 720 (1977).

Burch v. Goodyear Tire \& Rubber Co., 554 F 2d 633 (4th Cir. 1977).

Cromar Co. v. Nuclear Materials \& Equipment Corp., 543 F 2d 501 (3 ${ }^{\text {rd }}$ Cir. 1976).

Malamud v. Sinclair Oil Corp., 521 F 2d 1142 (6 ${ }^{\text {th }}$ Cir. 1975).

Hawaii v. Standard Oil Co., 405 US 251, 264 (1972).

American Safety Equip. Corp. v. J.P. Maguire \& Co., 391 F. 2d 821 (2d Cir. 1968).

Perma Life Mufflers Inc. v. International Parts Corp., 392 U.S. 134 (1968).

Hanover Shoe, Inc. v. United Shoe Machinery Corp., 392 US 481 (1968).

Melrose Realty Co. v. Loew's Inc., 234 F 2d 518 (3d Cir.), 352 US 890 (1956).

Karseal v. Richifield Oil Corp. 221 F 2d 358 (9th Cir. 1955).

Harrison v. Paramount Pictures, 115 F Supp. 312 (ED Pa. 1953), 211 F 2d 405 (3d Cir.), 348 US 828 (1954).

Conference of Studio Unions v. Loew's, Inc. 193 F 2d 51, 54 (9th Cir. 1951), 342 US 919 (1952).

Georgia v. Pennsylvania R. Co., 324 US 439 (1945).

Gerli v. Silk Association of America, 36 F 2d 956 (1929).

Loeb v. Eastman Kodak Co. 183 F 704 (3d Cir. 1910).

Wielka Brytania

English Welsh \& Scottish Railway v Enron Coal Services Limited (ECSL) [2011] EWCA Civ 2.

National Grid Electr. Transimission Plc. v. ABB Ltd. \& Ors, [2011] EWHC (ch) 1717, [9].

Safeway Stores Ltd v Twigger [2010] EWCA Civ 1472; [2011] Bus. L.R. 1629 (CA (Civ Div)).

Enron Coal Services Ltd (In Liquidation) v English Welsh \& Scottish Railway Ltd [2009] CAT 36.

Norris v. Government of the United States [2008] UKHL 16, [2008] 2 WLR 673.

Devenish Nutrition Limited \& the Others v. Sanofi Avensis SA France \& Others Wyrok High Court of Justice, Chancery Division, z dnia 19 października 2007, [2007] EWHC 2394 (Ch.). 
Donovan v. Electricity Supply Board [1997] 3 IR 573.

Iberian UK Ltd. v. BPB Indus. PLC et al. [1996] C.M.L.R. 601.

Anton Piller v. Manufctoring Processes [1979] Ch 55 (CA).

Europejski Trybunał Praw Człowieka

Wyrok ETPC z dnia 27 września 2011 r. w sprawie Menarini przeciwko Włochom, nr 43509/08.

Wyrok ETPC z dnia 21 lutego 1984 r. w sprawie Öztürk przeciwko Niemcom, nr 8544/79.

Wyrok ETPC z dnia 8 czerwca 1976 r. w sprawie Engel $i$ inni przeciwko Holandii, nr 5100/71. 


\section{Dotychczasowe publikacje Programu Wydawniczego CARS}

(www.cars.wz.uw.edu.pl/ksiazki.html)

A. Bolecki, Wymiana informacjimiędzy konkurentamiw ocenie organów ochrony konkurencji, Warszawa 2013.

T. Skoczny, Zgody szczególne w prawie kontroli koncentracji, Warszawa, 2012.

Yearbook of Antitrust and Regulatory Studies, 2012, Vol. 5(7).

Yearbook of Antitrust and Regulatory Studies, 2011, Vol. 5(6).

E.D. Sage, European Audiovisual Sector: Where business meets society's needs, Warszawa, 2011.

M. Bernatt, Sprawiedliwość proceduralna w postępowaniu przed organem ochrony konkurencji, Warszawa, 2011.

Yearbook of Antitrust and Regulatory Studies, 2011, Vol. 4(5).

S. Piątek, Sieci szerokopasmowe w polityce telekomunikacyjnej, Warszawa, 2011.

Yearbook of Antitrust and Regulatory Studies, 2011, Vol. 4(4).

Ustugi portów lotniczych w Unii Europejskiej i Polsce II - wybrane zagadnienia. Praca zbiorowa pod red. F. Czernickiego, T. Skocznego, Warszawa, 2011.

Yearbook of Antitrust and Regulatory Studies, 2010, Vol. 3(3).

Ustugi portów lotniczych $w$ Unii Europejskiej $i$ w Polsce a prawo konkurencji i regulacje lotniskowe. Praca zbiorowa pod red. F. Czernickiego, T. Skocznego, Warszawa, 2010.

M. Bernatt, Spoteczna odpowiedzialność biznesu. Wymiar konstytucyjny i międzynarodowy, Warszawa, 2009.

Yearbook of Antitrust and Regulatory Studies, 2009, Vol. 2(2).

Sprawa Microsoft - stadium, przypadku. Prawo konkurencji na rynkach nowych technologii, pod red. D. Miąsika, T. Skocznego, M. Surdek, Warszawa, 2008.

Wytaczenia grupowe spod zakazu porozumień ograniczających konkurencję we Wspólnocie Europejskiej i w Polsce, pod red. A. Jurkowskiej, T. Skocznego, Warszawa, 2008.

Yearbook of Antitrust and Regulatory Studies, 2008, Vol. 1(1).

S. Piątek, Regulacja rynków telekomunikacyjnych, Warszawa, 2007. 


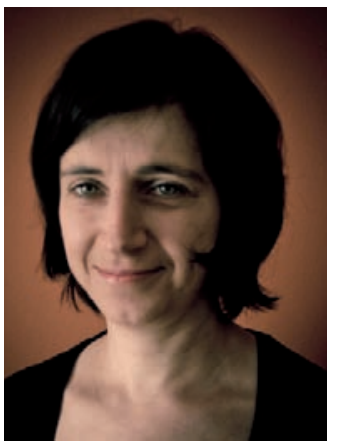

\section{Agata Jurkowska-Gomułka}

Doktor nauk prawnych, adiunkt w Zakładzie Europejskiego Prawa Gospodarczego WZ UW, członek zwyczajny CARS. Specjalizuje się w polskim i europejskim prawie ochrony konkurencji. Jest autorem wielu publikacji z tego zakresu w periodykach naukowych i pracach zbiorowych. Współredaktor komentarza do ustawy o ochronie konkurencji i konsumentów (C.H. Beck 2009). Członek zespołów redakcyjnych: anglojęzycznego Yearbook of Antitrust and Regulatory Studies i polskojęzycznego internetowego Kwartalnika Antymonopolowego i Regulacyjnego.

\section{Z recenzji wydawniczych:}

Książka Agaty Jurkowskiej-Gomułki stanowi pierwsze, kompleksowe studium zależności pomiędzy publicznym (administracyjnym i karnym) a cywilnym wdrażaniem reguł konkurencji w Polsce. [...] Autorka stawia trafną tezę, że publiczne i prywatne egzekwowanie zakazów praktyk ograniczających konkurencje powinno być oparte na modelu zrównoważonego współistnienia i podejmuje próbę programowania takiegoż modelu. $W$ tym celu autorka analizuje deficyty polskiego modelu ochrony konkurencji nawiązując obszernie do rozwiązań przyjętych w innych, także pozaeuropejskich porządkach prawnych. [...] Ogromnym walorem monografii jest jej interdyscyplinarność. Autorka kompetentnie bada nie tylko instytucje materialne i procesowe prawa ochrony konkurencji, ale także prawa cywilnego i prawa karnego [...].

Prof. UW dr hab. Tadeusz Skoczny Wydział Zarządzania UW

Niewątpliwym atutem monografii jest uwzględnienie szerszego kontekstu normatywnego problemów prawnych istotnych dla przedmiotu badań oraz wyjaśnianie - w wyznaczonym przez tytuł monografii zakresie - interakcji między instytucjami prawa antymonopolowego a innymi dziedzinami prawa. Autorka umiejętnie prowadzi czytelnika przez, niekiedy zawiłe, meandry przepisów z dziedzin, które na pierwszy rzut oka nie mają nic wspólnego z prawem antymonopolowym. Autorka nie ogranicza się do analizy samego orzecznictwa i poglądów piśmiennictwa stricte antymonopolowego oraz polemiki z wyrażonymi w nich tezami, lecz obszernie korzysta z dorobku innych dziedzin prawa.

Monografię cechuje bardzo wysoki poziom warsztatu naukowego. [...] Recenzowana praca niewątpliwie trafi do kanonu polskiego piśmiennictwa antymonopolowego. Ułatwi znacząco dalsze teoretyczne badania nad prawem ochrony konkurencji, jak i praktyczne stosowanie jego reguł.

Prof. INP PAN dr hab. Dawid Miąsik Instytut Nauk Prawnych PAN 
